UNIVERSIDADE DE SÃO PAULO

FACULDADE DE ECONOMIA, ADMINISTRAÇÃO E CONTABILIDADE

DEPARTAMENTO DE ADMINISTRAÇÃO

PROGRAMA DE PÓS-GRADUAÇÃO EM ADMINISTRAÇÃO

IZABEL CRISTINA NOGUEIRA SEABRA

EMPREENDEDORISMO SOCIAL E SUSTENTABILIDADE FINANCEIRA: Uma proposta de modelo analítico para reservas extrativistas do Bioma Amazônia. 


\section{IZABEL CRISTINA NOGUEIRA SEABRA}

EMPREENDEDORISMO SOCIAL E SUSTENTABILIDADE FINANCEIRA: Uma proposta de modelo analítico para reservas extrativistas do Bioma Amazônia.

Tese apresentada ao Programa de PósGraduação em Administração do Departamento de Administração da Faculdade de Economia, Administração e Contabilidade da Universidade de São Paulo, como requisito parcial para obtenção do título de Doutora em Ciências.

Orientadora: Prof ${ }^{\mathrm{a}} \mathrm{Dr}^{\mathrm{a}}$ Graziella Maria Comini

\section{Versão Corrigida}

(versão original disponível na Biblioteca da Faculdade de Economia, Administração e Contabilidade)

São Paulo

2021 
Prof. Dr. Vahan Agopyan

Reitor da Universidade de São Paulo

\section{Prof. Dr. Fábio Frezatti}

Diretor da Faculdade de Economia, Administração e Contabilidade

\section{Prof. Dr. Moacir de Miranda Oliveira Junior}

Chefe do Departamento de Administração

Prof. Dr. Eduardo Kazuo Kayo

Coordenador do Programa de Pós-Graduação em Administração 


\section{Ficha Catalográfica}

Autorizo a reprodução e divulgação total ou parcial deste trabalho, por qualquer meio convencional ou eletrônico, para fins de estudo e pesquisa, desde que citada a fonte.

Catalogação na publicação

Serviço de Biblioteca e Documentação

Universidade de São Paulo

Seabra, Izabel Cristina Nogueira.

Empreendedorismo Social e Sustentabilidade Financeira: uma proposta de modelo analítico para reservas extrativistas do Bioma Amazônia. / Izabel Cristina Nogueira Seabra. São Paulo, 2021.

$280 \mathrm{p}$.

Tese (Doutorado) - Universidade de São Paulo, 2021.

Orientadora: Graziella Maria Comini.

1. Sustentabilidade financeira. 2. Reservas extrativistas. 3. Empreendedorismo Social. 4. Bioma Amazônia. 5. Comunidades extrativistas. I. Universidade de São Paulo. Faculdade de Economia, Administração e Contabilidade. 


\title{
EMPREENDEDORISMO SOCIAL E SUSTENTABILIDADE FINANCEIRA: Uma proposta de modelo analítico para reservas extrativistas do Bioma Amazônia.
}

Tese apresentada ao Programa de PósGraduação em Administração do Departamento de Administração da Faculdade de Economia, Administração e Contabilidade da Universidade de São Paulo, como requisito parcial para obtenção do título de Doutor em Ciências.

Data da Defesa: 04/11/2021

\section{Banca Examinadora}

\author{
Prof $^{\mathrm{a}} \mathrm{Dr}^{\mathrm{a}}$ Graziella Maria Comini \\ FEA/USP - Orientadora \\ Prof $^{\mathrm{a}}$ Dr $^{\mathrm{a}}$ Rosa Maria Fischer \\ FEA/USP \\ Prof $^{\text {a }}$ Dr $^{\text {a }}$ Gimima Beatriz Melo da Silva \\ UEA/AM \\ Prof $^{\mathrm{a}}$ Dr $^{\mathrm{a}}$ Perla Calil Pongeluppe Wadhy Rebehy \\ FEA/USP - Orientadora
}


Aos meus amores,

Ângela Seabra, Brena Gomes Maia, Isaías Seabra e Soraia Seabra (in praesentia)

À minha mãe Alzira Nogueira Seabra

(in memoriam)

Dedico. 


\section{AGRADECIMENTOS}

Agradeço à minha instituição Universidade Estadual do Amazonas-UEA, especialmente ao Reitor Dr. Cleinaldo de Almeida Costa e, ao Professor Dr. Paulo César Diniz, pela idealização e realização do DINTER USP-UEA;

Agradeço à Universidade de São Paulo-USP, especialmente aos professores Dr. Jacques Marcovitch e Dr. Moacir de Miranda Oliveira Junior, que possibilitaram a realização do DINTER USP-UEA;

Agradeço a todos os professores do DINTER USP-UEA, pelos ensinamentos e desafios impostos ao longo das disciplinas ministradas;

Agradeço a todos os colegas de turma do DINTER USP-UEA, em especial ao amigo de longas jornadas, Manoel Rodrigues Terceiro Neto, in memoriam;

Agradeço a colega de turma do DINTER USP-UEA, Vivian Silva Lima Marangoni, amiga e psicóloga, que muito contribuiu para a manutenção do meu controle emocional nos momentos mais difíceis vividos durante a Pandemia da COVID-19;

Agradeço ao Centro de Empreendedorismo Social e Administração em Terceiro Setor-CEATS, especialmente a professora Dra. Rosa Maria Fischer, pelas reuniões que possibilitaram discussões e sinergias de ideias que fortaleceram $o$ desenvolvimento da pesquisa;

Agradeço aos amigos Alex Monte, Raylene Sena, Lúcia Puga e Gimima Silva, pelas discussões e estímulo durante a jornada;

Agradeço a Secretaria Estadual do Meio Ambiente-SEMA, em especial ao gestor da Reserva Estadual Canutama, Altemar Lopes, pelo apoio durante a pesquisa de campo, e ao líder da comunidade São Jerônimo, Elias Andrade Duarte, pelo acolhimento durante a estadia da equipe de pesquisa no interior da Resex;

Agradeço às minhas assistentes de pesquisa, Brena Maia e Ângela Seabra, que enfrentaram comigo o desafio de visitar comunidades extrativistas de difícil acesso, que exigiram longas caminhadas nas 'beiradas' do Rio Purus e debaixo do Sol inclemente da Amazônia;

Especial agradecimento à professora e orientadora Dra. Graziella Maria Comini, que me apresentou o empreendedorismo social, foi responsável pelo redirecionamento da pesquisa, e me ensinou a pensar em ações econômicas de impacto social positivo que possam solucionar problemas sociais com foco na criação de renda e melhoria da qualidade de vida de populações vulneráveis. 
"O conhecimento nos faz responsáveis"

(Ernesto Che Guevara) 


\section{RESUMO}

SEABRA, Izabel Cristina Nogueira. Empreendedorismo social e sustentabilidade financeira: uma proposta de modelo analítico para reservas extrativistas do Bioma Amazônia. 2021. Tese (Doutorado) - Programa de Pós-Graduação em Administração (PPGA), Universidade de São Paulo, Faculdade de Economia, Administração e Contabilidade. São Paulo, 2021.

A pesquisa desta tese foi desenvolvida junto a comunidades de uma reserva extrativista (Resex), localizada no Bioma Amazônia. O objetivo principal foi estruturar mecanismo que possibilite a mensuração e o monitoramento da sustentabilidade financeira de reservas extrativistas. Além da revisão da literatura relacionada ao tema, foram realizadas entrevistas com extrativistas, gestor e autoridade pública locais, como também foram analisados dados de 2019 e 2020, relativos à produção e venda dos produtos comercializados pela Resex Canutama, foco desta pesquisa. A partir da análise da base de dados, foi criado um sistema de informações web (SIW), que é apoiado no conceito de acesso universal, ou seja, disponível a qualquer plataforma ou dispositivo conectado à internet, de fácil usabilidade. O 'SIW Resex Canutama' é um modelo para acompanhamento e avaliação das atividades produtivas de reservas extrativistas, levando em conta características de cada espaço territorial produtivo. Associado ao 'Radar de Sustentabilidade Financeira', que é representado por uma escala de $0 \%$ a $100 \%$ e baseado em onze parâmetros de avaliação, o SIW mensurou o desempenho da produção, renda e liderança de cada uma das 16 comunidades e 22 localidades pesquisadas. De acordo com esse modelo desenvolvido, a Resex Canutama ainda não alcançou a sustentabilidade financeira, visto que os seus resultados referentes a 2019 e 2020 foram $20,59 \%$ e $26,82 \%$, respectivamente. Essa baixa performance corrobora a fragilidade do cenário observado, ressaltando graves desigualdades econômicas e financeiras das comunidades e localidades. A gestão precária, a falta de suporte do Poder público, a forte concentração das vendas da extração da castanha (principal produto da Resex), além da carência de registro de dados produtivos, para dar suporte ao planejamento e tomada de decisões, provoca forte desequilíbrio em termos de produção e receita, sobretudo nos resultados individuais, de cada comunidade e localidade. O estudo possibilitou ainda compreender o modo de vida dos comunitários e conhecer suas necessidades e dificuldades para manter o sustento das famílias, tendo que, ao mesmo tempo, cumprir as regras estabelecidas para aqueles que residem e exploram áreas com proteção ambiental. Foi possível identificar as carências estruturais e logísticas para exercer a atividade extrativista e, desta forma, os impedimentos para alcançar sustentabilidade financeira, seja por comunidade/localidade, seja para toda a Resex. Some-se a isso, os problemas causados pelas ilegalidades ambientais ocorridas constantemente no Bioma, notadamente desmatamento e queimadas (intensas, no período de realização da coleta de dados para esta pesquisa). Considerando os propósitos e expectativas desde sua concepção, pôde-se constatar que, mesmo depois de quase trinta anos da criação da primeira Reserva Extrativista, houve poucas ações significativas e efetivas, no sentido de gerar melhorias e bem-estar duradouros às famílias e proteger os recursos ambientais daquelas áreas.

Palavras-chave: Sustentabilidade financeira. Reservas extrativistas. Empreendedorismo Social. Bioma Amazônia. Comunidades extrativistas. Extrativismo. Desenvolvimento sustentável. 


\begin{abstract}
SEABRA, Izabel Cristina Nogueira. Social Entrepreneurship and Financial Sustainability: a proposal for an analytical model for extractive reserves in the Amazon Biome. 2021. Tese (Doutorado) - Programa de Pós-Graduação em Administração (PPGA), Universidade de São Paulo, Faculdade de Economia, Administração e Contabilidade. São Paulo, 2021.
\end{abstract}

The research of this thesis was developed with the communities of an extractive reserve (Resex) located at Amazon Biome. The main goal was structure mechanism that enables measurement and the monitoring of the financial sustainability of the extractive reserves.

Besides the literature's review of related to the theme, were conducted interviews with extractivists, manager and local public authority, as well were analyzed data from 2019 to 2020, related to the production and sale of the marketed products by Resex Canutama, focus on this research. From the analysis of the base of data, was created a system of informations web (WIS), supported by the concept of universal access, that is, available to any platform or device connected to internet, with simple usability. The 'WIS Resex Canutama' is a model for monitoring and evaluating productive activities of extractive reserves, considering the characteristics of each productive territorial space. Associated with the Financial Sustainability Radar, which is represented by a scale of $0 \%$ to $100 \%$ and based on eleven evaluation parameters, the SIW measured the performance of production, income and leadership of each of the 16 communities and 22 localities researched. According to this model developed, the Resex Canutama has not yet achieved financial sustainability, since its results for 2019 and 2020 were 20,59\% and 26,82\%, respectively. This low performance corroborates the fragility of the observed scenario, with serious economic and financial inequalities of the communities and localities. The poor management, the lack of public power support, the strong concentration of sales from nut extraction (main product of Resex), in addition to the lack of productive data recording, to support planning, and decisions making, causes a strong imbalance in terms of production and revenue, specially in individual results of each community and locality. The study also maked it possible to understand the way of life of the community members and to know their needs and difficulties to support their families, having that, at the same time, fulfill the commitments established for those who reside and explore areas with environmental protection. It was possible identify the structurals and logistics deficiencies to practice extractive activity and, in this way, the impediments to achieving financial sustainability, whether for community/locality or for the entire Resex. Add to that, the problems caused by environmental illegalities occurred constantly in the Biome, notably deforestation and fires (intense during the period of data collection of this research). Considering the purposes and expectations since its conception, it can be seen that, even after almost thirty years of creation of the first Extractive Reserve, there were few significant and effective actions, in order to generate improvements and lasting well-being to the families and protecting the environmental resources of those areas.

Keywords: Financial Sustainability. Extractive Reserves. Social Entrepreneurship. Amazon Biome. Extractive Communities. Extractivism. Sustainable Development. 


\section{LISTA DE FIGURAS}

Figura 1- Foto de uma comunidade na Resex Médio Purus - Amazonas ...................................................... 23

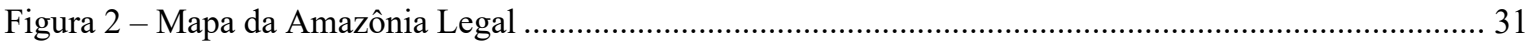

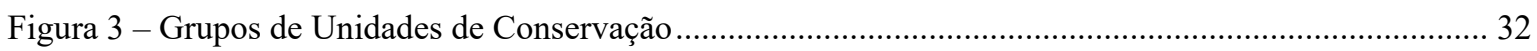

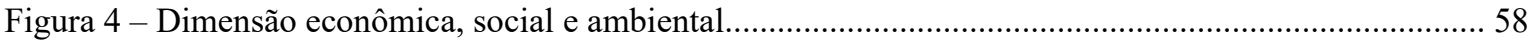

Figura 5 - Mapa de calor das ocorrências de desmatamento identificadas na Amazônia Legal Brasileira..... 64

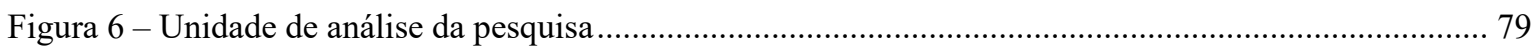

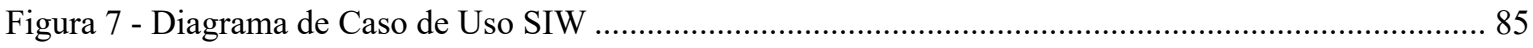

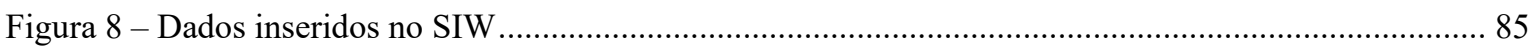

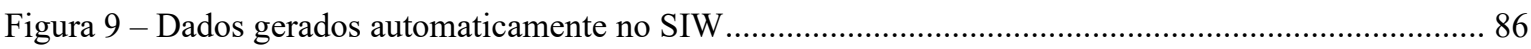

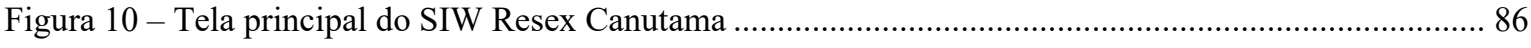

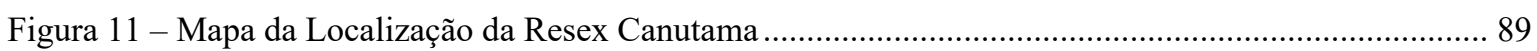

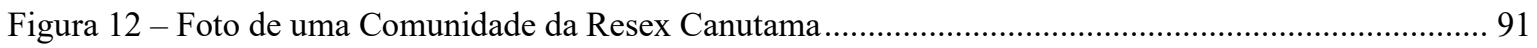

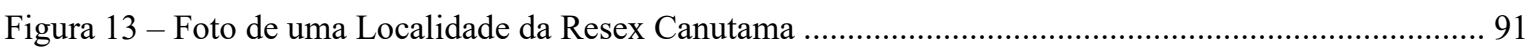

Figura 14 - Gráfico da participação dos produtos mais vendidos - Resex Canutama (2019) .........................113

Figura 15 - Gráfico da participação da produção nas Comunidades-Resex Canutama (2020).......................119

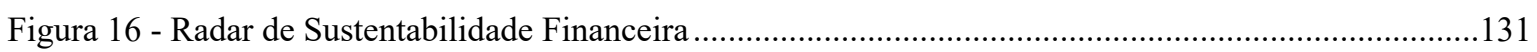

Figura 17 - Radar de Sustentabilidade Financeira da Resex Canutama (2019-2020) ....................................133

Figura 18 - Radar de Sustentabilidade Financeira das Comunidades (2019-2020) ………………………....134

Figura 19 - Radar de Sustentabilidade Financeira das Localidades (2019-2020) .........................................137

Figura 20 - Fotos dos Principais Produtos vendidos na Resex Canutama ......................................................246

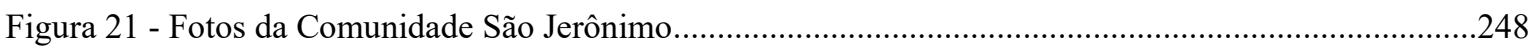

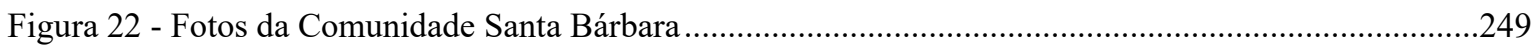

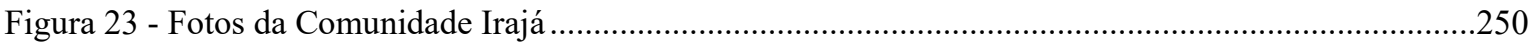

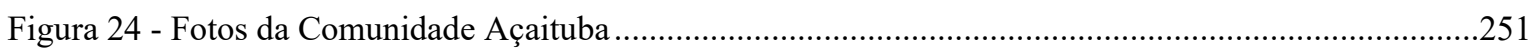

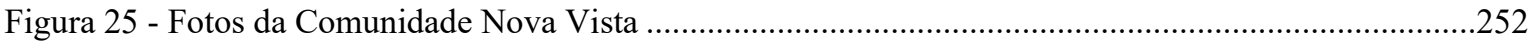

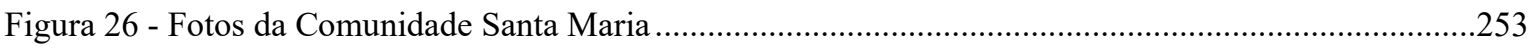

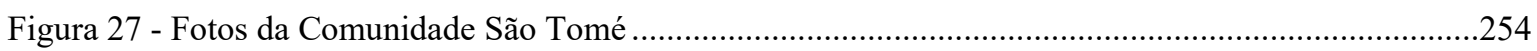

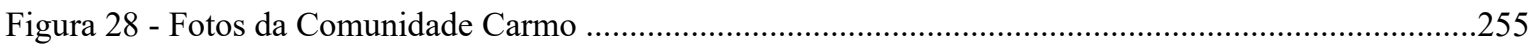

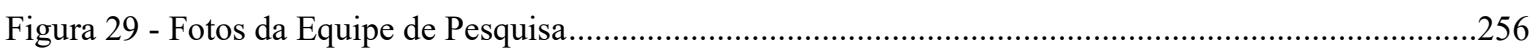




\section{LISTAS QUADROS}

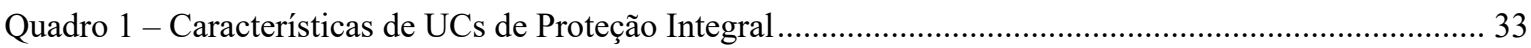

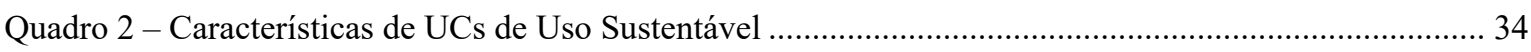

Quadro 3 - Comparativo entre os relatórios Meadows X Brundtland............................................................ 52

Quadro 4 - Objetivos do Desenvolvimento Sustentável - Agenda 2030 ........................................................... 53

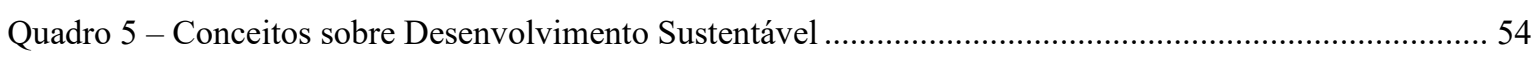

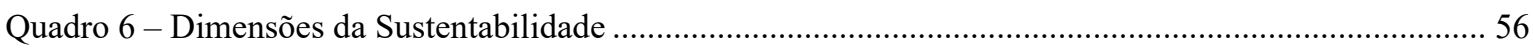

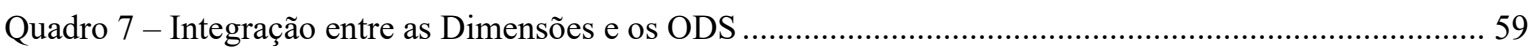

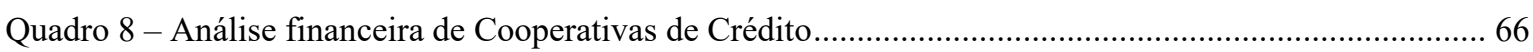

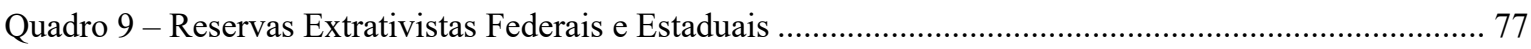

Quadro 10 - Dados gerais para Avaliação da Comunidade Nova Vista (2019-2020)....................................169

Quadro 11 - Dados gerais para Avaliação da Comunidade Santa Bárbara (2019-2020) …………………....171

Quadro 12 - Dados gerais para Avaliação da Comunidade Bacadaru (2019-2020).......................................173

Quadro 13 - Dados gerais para Avaliação da Comunidade Açaituba (2019-2020) …………........................175

Quadro 14 - Dados gerais para Avaliação da Comunidade Fortaleza (2019-2020) .......................................177

Quadro 15 - Dados gerais para Avaliação da Comunidade Glória II (2019-2020) ........................................179

Quadro 16 - Dados gerais para Avaliação da Comunidade Sacado (2019-2020) ...........................................181

Quadro 17 - Dados gerais para Avaliação da Comunidade Irajá (2019-2020) ..............................................183

Quadro 18 - Dados gerais para Avaliação da Comunidade Santa Maria (2019-2020) ...................................185

Quadro 19 - Dados gerais para Avaliação da Comunidade Forte Veneza/Nova Colônia (2019-2020) ..........187

Quadro 20 - Dados gerais para Avaliação da Comunidade Santo Antônio do Apituã (2019-2020)..............189

Quadro 21 - Dados gerais para Avaliação da Comunidade São Jerônimo (2019-2020) ..................................191

Quadro 22 - Dados gerais para Avaliação da Comunidade Carmo (2019-2020)..........................................193

Quadro 23 - Dados gerais para Avaliação da Comunidade Boca do Gavião (2019-2020) .............................195

Quadro 24 - Dados gerais para Avaliação da Comunidade São Tomé (2019-2020) ......................................197

Quadro 25 - Dados gerais para Avaliação da Comunidade Capoeirinha (2019-2020) ..................................199

Quadro 26 - Dados gerais para Avaliação da Localidade Tororó-Paissé (2019-2020) ....................................202

Quadro 27 - Dados gerais para Avaliação da Localidade Mapiciari (2019-2020).........................................204

Quadro 28 - Dados gerais para Avaliação da Localidade Santana (2019-2020)..............................................206

Quadro 29 - Dados gerais para Avaliação da Localidade Vista Alegre (2019-2020) .....................................208

Quadro 30 - Dados gerais para Avaliação da Localidade Bom Sucesso (2019-2020)....................................210

Quadro 31 - Dados gerais para Avaliação da Localidade Santa Eugênia (2019-2020) ………………….......212

Quadro 32 - Dados gerais para Avaliação da Localidade Santa Cora (2019-2020).........................................

Quadro 33 - Dados gerais para Avaliação da Localidade Estirão do Açaituba (2019-2020)...........................216

Quadro 34 - Dados gerais para Avaliação da Localidade São Francisco (2019-2020) ...................................218

Quadro 35 - Dados gerais para Avaliação da Localidade Moará (2019-2020) ................................................220

Quadro 36 - Dados gerais para Avaliação da Localidade Macacoã (2019-2020) ……………………….......222 
Quadro 37 - Dados gerais para Avaliação da Localidade Paraíso (2019-2020)

Quadro 38 - Dados gerais para Avaliação da Localidade Samaumeira (2019-2020) .................................226

Quadro 39 - Dados gerais para Avaliação da Localidade Novo Intento (2019-2020) ................................228

Quadro 40 - Dados gerais para Avaliação da Localidade Nazaré (2019-2020) ........................................230

Quadro 41 - Dados gerais para Avaliação da Localidade Monte Sião (2019-2020)...................................232

Quadro 42 - Dados gerais para Avaliação da Localidade Espírito Santo (2019-2020)...............................234

Quadro 43 - Dados gerais para Avaliação da Localidade Arraial (2019-2020) ........................................236

Quadro 44 - Dados gerais para Avaliação da Localidade São José do Paraíso (2019-2020).........................238

Quadro 45 - Dados gerais para Avaliação da Localidade Sobradinho (2019-2020) ...................................239

Quadro 46 - Dados gerais para Avaliação da Localidade Concórdia (2019-2020).....................................240

Quadro 47 - Dados gerais para Avaliação da Localidade Conceição-Paissé (2019-2020) ...........................241 


\section{LISTAS TABELAS}

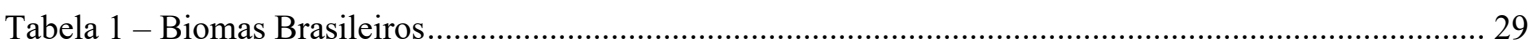

Tabela 2 - Reservas extrativistas Brasil - Bioma Amazônia .................................................................... 30

Tabela 3 - Taxa da distribuição do desmatamento por estado da ABL ................................................... 63

Tabela 4 - Amostra em relação a população total e residentes nas comunidades da Resex Canutama...........81

Tabela 5 - Número de famílias residentes e entrevistadas na Resex Canutama (outubro/2020)................... 82

Tabela 6 - Número de pessoas residentes e entrevistadas na Resex Canutama (outubro/2020) ....................82

Tabela 7 - Residentes das comunidades e localidades da Resex Canutama (2020) .................................... 90

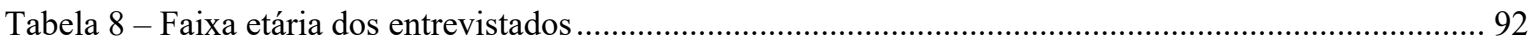

Tabela 9 - Tempo de residência dos entrevistados na Resex Canutama (2020) ......................................... 93

Tabela 10 - Participação dos produtos principais na produção da Resex Canutama (2010 a 2020) ..............115

Tabela 11 - Participação nas vendas dos principais produtos da Resex Canutama (2019/2020) ..................116

Tabela 12 - Resultados das Vendas da Resex Canutama (2019/2020) ......................................................117

Tabela 13 - Participação percentual da produção realizada nas Comunidades, ...........................................118

Tabela 14 - Participação percentual da produção realizada nas Localidades, ...........................................120

Tabela 15 - Resumo dos parâmetros de sustentabilidade financeira no SIW...............................................129

Tabela 16 - Valor e Participação percentual por local de produção na Resex Canutama (2019-2020) .........166

Tabela 17 - Valor e Participação percentual por produtos na produção da Resex Canutama (2019-2020) ...167

Tabela 18 - Sustentabilidade Financeira da Comunidade Nova Vista (2019-2020) .................................169

Tabela 19 - Produção na Comunidade Nova Vista (2019)..................................................................170

Tabela 20 - Produção na Comunidade Nova Vista (2020).................................................................170

Tabela 21 - Sustentabilidade Financeira da Comunidade Santa Bárbara (2019-2020)...............................171

Tabela 22 - Produção na Comunidade Santa Bárbara (2019) .................................................................172

Tabela 23 - Produção na Comunidade Santa Bárbara (2020) ....................................................................172

Tabela 24 - Sustentabilidade Financeira da Comunidade Bacadaru (2019-2020) ...................................173

Tabela 25 - Produção na Comunidade Bacadaru (2019) ...............................................................................174

Tabela 26 - Produção na Comunidade Bacadaru (2020) ........................................................................174

Tabela 27 - Sustentabilidade Financeira da Comunidade Açaituba (2019-2020) .....................................175

Tabela 28 - Produção na Comunidade Açaituba (2019) ............................................................................176

Tabela 29 - Produção na Comunidade Açaituba (2020) ...............................................................................176

Tabela 30 - Sustentabilidade Financeira da Comunidade Fortaleza (2019-2020) ...................................177

Tabela 31 - Produção na Comunidade Fortaleza (2019)..........................................................................178

Tabela 32 - Produção na Comunidade Fortaleza (2020)....................................................................178

Tabela 33 - Sustentabilidade Financeira da Comunidade Glória II (2019-2020) .......................................179

Tabela 34- Produção na Comunidade Glória II (2019) .............................................................................180

Tabela 35 - Produção na Comunidade Glória II (2020) .......................................................................180

Tabela 36 - Sustentabilidade Financeira da Comunidade Sacado (2019-2020) ..........................................181 
Tabela 37 - Produção na Comunidade Sacado (2019) ...............................................................................182

Tabela 38 - Produção na Comunidade Sacado (2020) ............................................................................ 182

Tabela 39 - Sustentabilidade Financeira da Comunidade Irajá $(2019-2020)$...........................................183

Tabela 40 - Produção na Comunidade Irajá (2019) ..............................................................................184

Tabela 41 - Produção na Comunidade Irajá $(2020)$................................................................................184

Tabela 42 - Sustentabilidade Financeira da Comunidade Santa Maria (2019-2020) ...............................185

Tabela 43 - Produção na Comunidade Santa Maria (2019) ........................................................................186

Tabela 44 - Produção na Comunidade Santa Maria (2020) .......................................................................186

Tabela 45 - Sustentabilidade Financeira da Comunidade Forte Veneza/Nova Colônia (2019-2020)............187

Tabela 46 - Produção na Comunidade Forte Veneza/Nova Colônia (2019) .................................................188

Tabela 47 - Produção na Comunidade Forte Veneza/Nova Colônia (2020) ...............................................188

Tabela 48 - Sustentabilidade Financeira da Comunidade Santo Antônio do Apituã (2019-2020) ...............189

Tabela 49 - Produção na Comunidade Santo Antônio do Apituã (2019)....................................................190

Tabela 50 - Produção na Comunidade Santo Antônio do Apituã (2020).....................................................190

Tabela 51 - Sustentabilidade Financeira da Comunidade São Jerônimo (2019-2020)................................191

Tabela 52 - Produção na Comunidade São Jerônimo (2019).........................................................................192

Tabela 53 - Produção na Comunidade São Jerônimo (2020) ...................................................................192

Tabela 54 - Sustentabilidade Financeira da Comunidade Carmo (2019-2020) ...........................................193

Tabela 55 - Produção na Comunidade Carmo (2019)..............................................................................194

Tabela 56 - Produção na Comunidade Carmo (2020) .........................................................................194

Tabela 57 - Sustentabilidade Financeira da Comunidade Boca do Gavião (2019-2020).............................195

Tabela 58 - Produção na Comunidade Boca do Gavião (2019) ................................................................196

Tabela 59 - Produção na Comunidade Boca do Gavião (2020) ................................................................196

Tabela 60 - Sustentabilidade Financeira da Comunidade São Tomé (2019-2020) .....................................197

Tabela 61 - Produção na Comunidade São Tomé (2019) ..........................................................................198

Tabela 62 - Produção na Comunidade São Tomé $(2020)$.............................................................................198

Tabela 63 - Sustentabilidade Financeira da Comunidade Capoeirinha (2019-2020)................................199

Tabela 64 - Produção na Comunidade Capoeirinha (2019) ...................................................................200

Tabela 65 - Produção na Comunidade Capoeirinha (2020) ….............................................................200

Tabela 66 - Sustentabilidade Financeira da Localidade Tororó-Paissé (2019-2020)...............................202

Tabela 67 - Produção na Localidade Tororó-Paissé (2019) ......................................................................203

Tabela 68 - Produção na Localidade Tororó-Paissé (2020) .......................................................................203

Tabela 69 - Sustentabilidade Financeira da Localidade Mapiciari (2019-2020) .....................................204

Tabela 70 - Produção na Localidade Mapiciari (2019) ................................................................................205

Tabela 71 - Produção na Localidade Mapiciari (2020)........................................................................205

Tabela 72 - Sustentabilidade Financeira da Localidade Santana (2019-2020) ........................................206

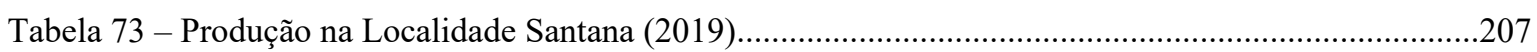

Tabela 74 - Produção na Localidade Santana (2020)..............................................................................207

Tabela 75 - Sustentabilidade Financeira da Localidade Vista Alegre (2019-2020)..................................208 
Tabela 76 - Produção na Localidade Vista Alegre (2019)

Tabela 77 - Produção na Localidade Vista Alegre (2020) .....................................................................209

Tabela 78 - Sustentabilidade Financeira da Localidade Bom Sucesso (2019-2020) .................................210

Tabela 79 - Produção na Localidade Bom Sucesso (2019)....................................................................211

Tabela 80 - Produção na Localidade Bom Sucesso (2020)........................................................................211

Tabela 81 - Sustentabilidade Financeira da Localidade Santa Eugênia (2019-2020) ................................212

Tabela 82 - Produção na Localidade Santa Eugênia (2019) ..................................................................213

Tabela 83 - Produção na Localidade Santa Eugênia (2020) .....................................................................213

Tabela 84 - Sustentabilidade Financeira da Localidade Santa Cora (2019-2020) ....................................214

Tabela 85 - Produção na Localidade Santa Cora (2019)..............................................................................215

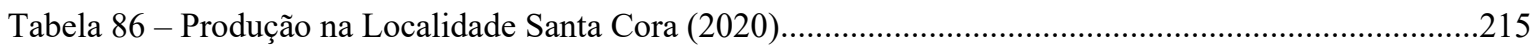

Tabela 87 - Sustentabilidade Financeira da Localidade Estirão do Açaituba (2019-2020) .........................216

Tabela 88 - Produção na Localidade Estirão do Açaituba (2020)..............................................................217

Tabela 89 - Sustentabilidade Financeira da Localidade São Francisco (2019-2020).................................218

Tabela 90 - Produção na Localidade São Francisco (2020)......................................................................219

Tabela 91 - Sustentabilidade Financeira da Localidade Moará (2019-2020)..............................................220

Tabela 92 - Produção na Localidade Moará (2020) ..................................................................................221

Tabela 93 - Sustentabilidade Financeira da Localidade Macacoã (2019-2020).........................................222

Tabela 94 - Produção na Localidade Macacoã (2020) ...........................................................................223

Tabela 95 - Sustentabilidade Financeira da Localidade Paraíso (2019-2020) ........................................224

Tabela 96 - Produção na Localidade Paraíso (2020) ..................................................................................225

Tabela 97 - Sustentabilidade Financeira da Localidade Samaumeira (2019-2020) .................................226

Tabela 98 - Produção na Localidade Samaumeira (2020) .....................................................................227

Tabela 99 - Sustentabilidade Financeira da Localidade Novo Intento (2019-2020) ...................................228

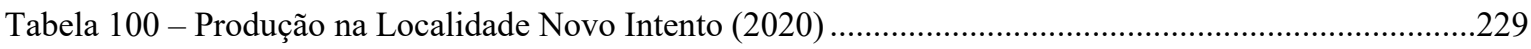

Tabela 101 - Sustentabilidade Financeira da Localidade Nazaré $(2019-2020)$...........................................230

Tabela 102 - Produção na Localidade Nazaré (2020) .............................................................................231

Tabela 103 - Sustentabilidade Financeira da Localidade Monte Sião (2019-2020)..................................232

Tabela 104 - Produção na Localidade Monte Sião (2020)....................................................................233

Tabela 105 - Sustentabilidade Financeira da Localidade Espírito Santo (2019-2020) ..............................234

Tabela 106 - Produção na Localidade Espírito Santo (2020).................................................................235

Tabela 107 - Sustentabilidade Financeira da Localidade Arraial (2019-2020).........................................236

Tabela 108 - Produção na Localidade Arraial (2020) ..........................................................................237

Tabela 109 - Sustentabilidade Financeira da Localidade São José do Paraíso (2019-2020) ........................238

Tabela 110 - Sustentabilidade Financeira da Localidade Sobradinho (2019-2020).................................239

Tabela 111 - Sustentabilidade Financeira da Localidade Concórdia (2019-2020) ...................................240

Tabela 112 - Sustentabilidade Financeira da Localidade Conceição-Paissé (2019-2020) ............................241 


\section{SUMÁRIO}

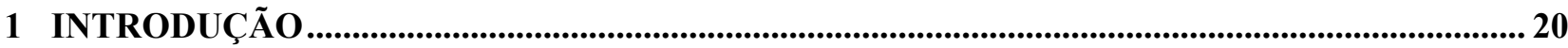

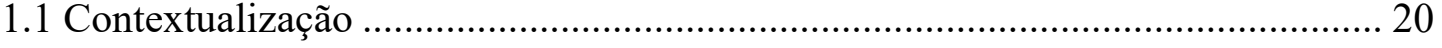

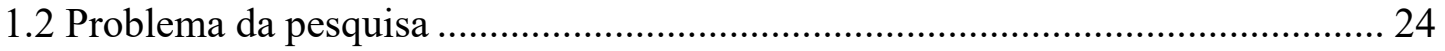

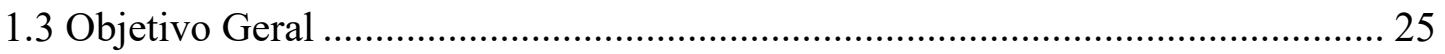

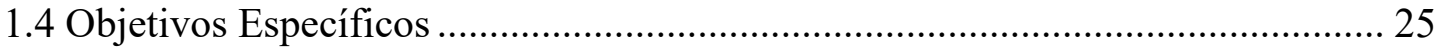

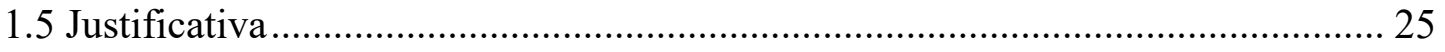

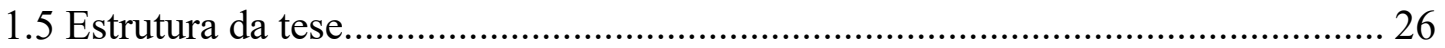

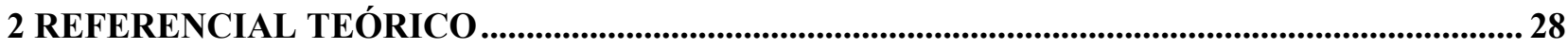

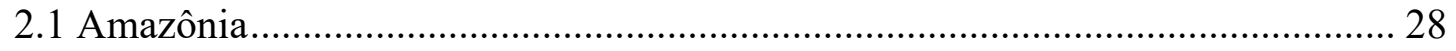

2.1.1 Bioma Amazônia .............................................................................. 29

2.1.2 Amazônia Legal................................................................................. 31

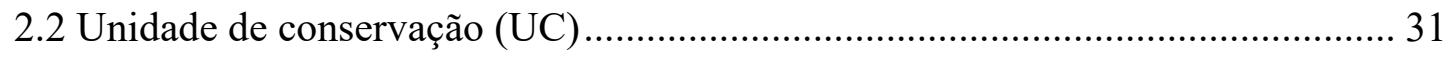

2.2.1 Sistema Nacional de Unidades de Conservação (SNUC)....................... 36

2.2.2 Projetos e Programas vinculados às Unidades de Conservação (UCs): . 37

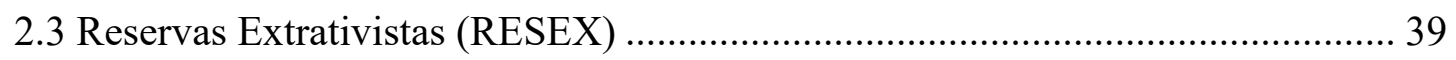

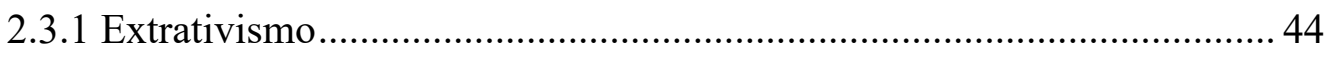

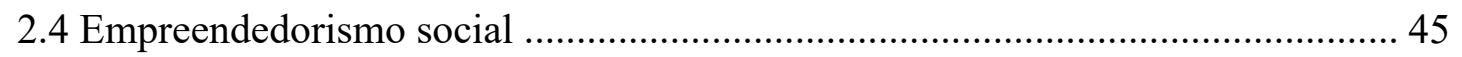

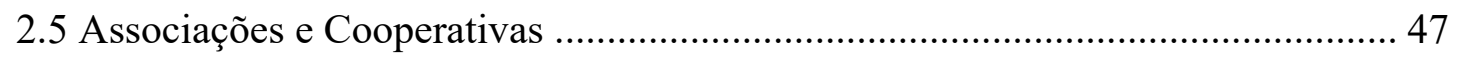

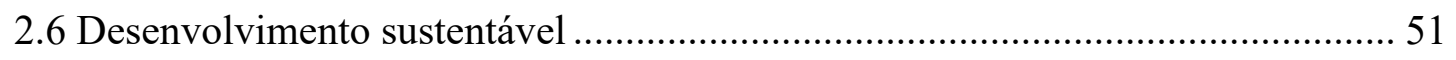

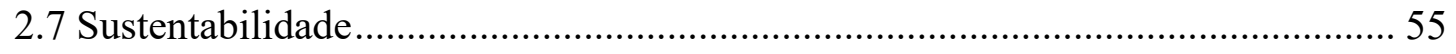

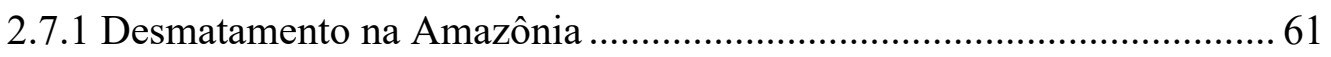

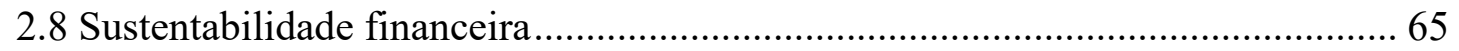

2.8.1 Sustentabilidade Financeira em Resex .............................................. 70

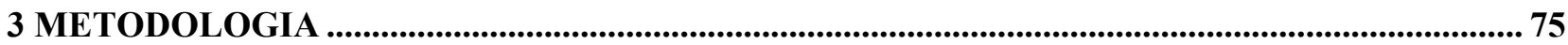

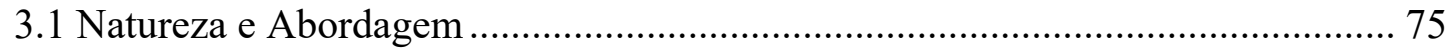

3.2 Estratégia e Técnicas de Pesquisa ………........................................................... 76

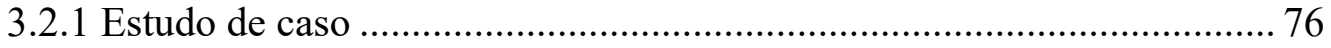

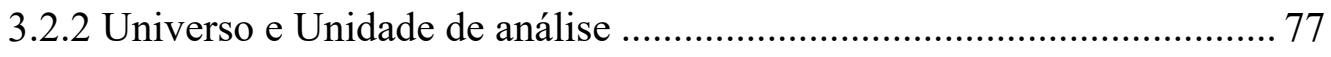




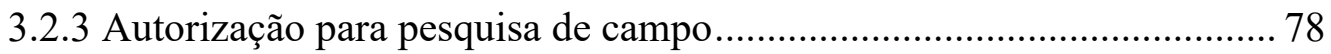

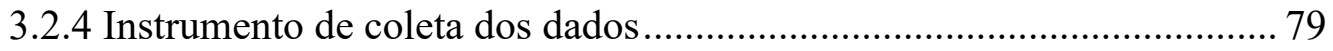

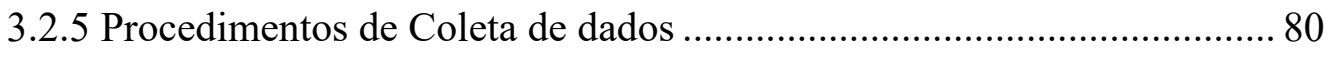

3.2.6 População pesquisada ......................................................................... 81

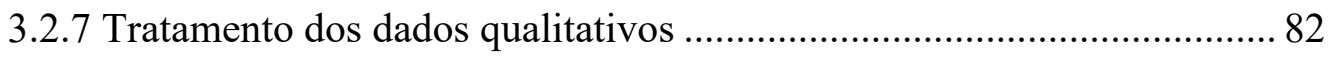

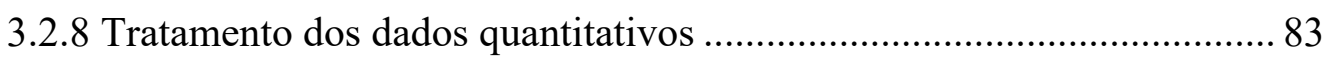

4 RESULTADOS

4.1 Aspectos gerais e perfil dos moradores

4.1.1 Criação e localização 89

4.1.2 Perfil dos moradores ..... 90

4.2 Experiência de vida do morador/produtor 95

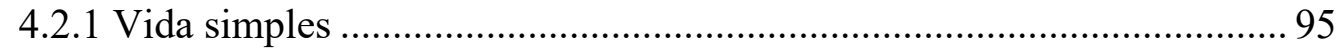

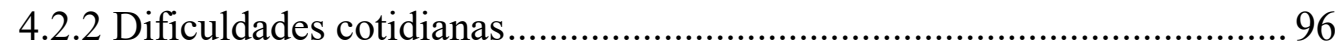

4.2.3 Líder com perfil de empreendedor social ........................................ 100

4.3 Conhecimento, gestão e expectativa sobre a Resex .......................................... 101

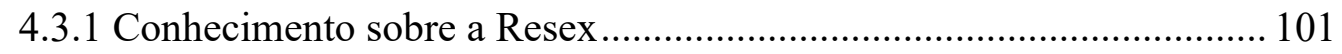

4.3.2 Mudanças decorrentes da criação da Resex........................................ 102

4.3.4 Gestão da Resex e participação dos comunitários ............................... 103

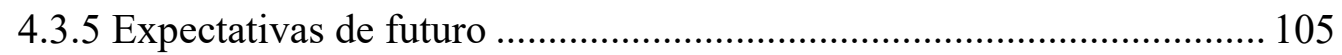

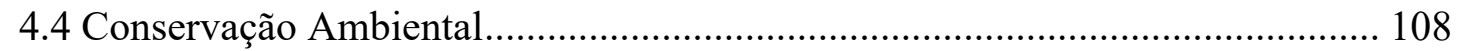

4.4.1 Conscientização e engajamento pela proteção ambiental..................... 108

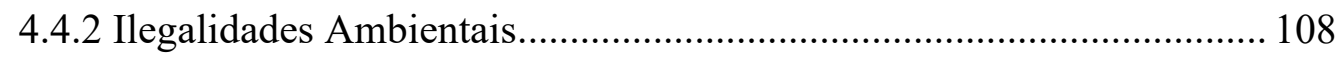

4.4.3 Fiscalização Ações preventiva.......................................................... 110

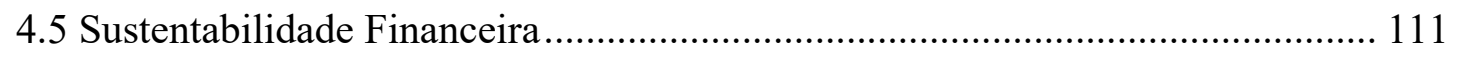

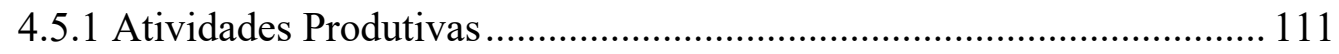

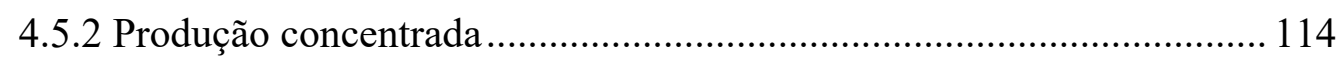

4.5.3 Excesso e escassez de produtos ....................................................... 120

4.5.4 Continuidade na atividade ............................................................... 121

4.5.5 Impacto da Covid-19 na Produção ..................................................... 122

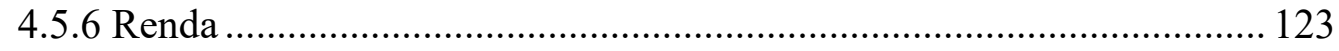

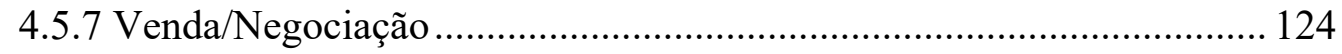

4.5.8 Dificuldades para manter a atividade ............................................. 125

4.6 Mensuração da Sustentabilidade Financeira ................................................... 127

4.6.1 Modelo analítico - Radar de Sustentabilidade Financeira .................. 128

4.6.2 Radar de Sustentabilidade Financeira Agregado Resex ...................... 132 
4.6.3 Radar de Sustentabilidade Financeira das Comunidades 134

4.6.4 Radar de Sustentabilidade Financeira das Localidades 137

4.6.5 Análise dos parâmetros em relação aos resultados apurados

5 CONSIDERAÇÕES FINAIS

5.1 Consecução dos objetivos propostos ……........................................... 142

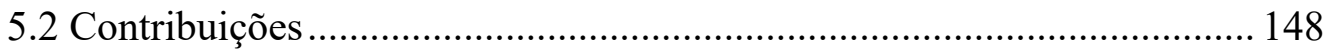

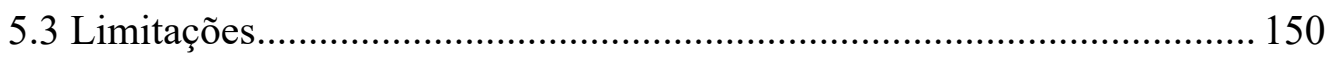

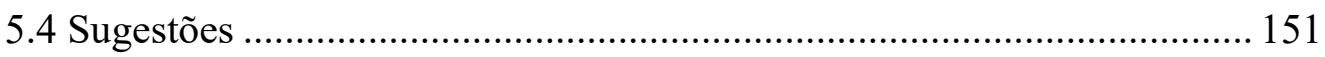

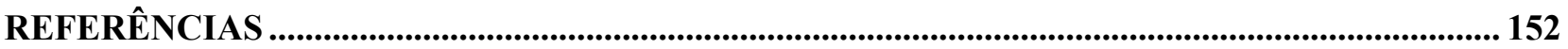

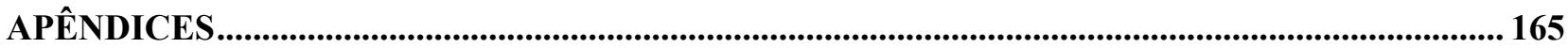

ANEXOS 


\section{INTRODUÇÃO}

\subsection{Contextualização}

O tema 'Desenvolvimento Sustentável' entrou na agenda do debate mundial no início da década de 1990, quando o mundo contemporâneo despertou para a preocupação com a conservação dos recursos naturais, de modo a permitir seu usufruto às gerações futuras. $O$ alerta, no entanto, se deu a partir do relatório do Clube de Roma, publicado em 1972, cujo teor advertia para o fato de que, mantido o ritmo do crescimento econômico e os atuais padrões de consumo, haveria, em curto prazo de tempo, o esgotamento dos recursos naturais, em consequência do trade-off entre desenvolvimento e preservação ambiental. Desde então, emergiu a cultura da consciência ecológica, que tem como principal desafio definir um novo estilo de vida e buscar soluções socialmente eficientes (EHLERS, 2017).

Um elemento crucial da discussão é a equidade intergerações, termo que entrou em pauta com o Relatório Brundtland (1987), que conceituou sustentabilidade como a capacidade de as gerações presentes atenderem suas necessidades, sem comprometer a capacidade de as gerações futuras atender as suas, o que cumpre os pressupostos de justiça e garantia do acesso das gerações futuras ao capital natural.

Em se tratando da agricultura, a questão da sustentabilidade adquiriu status de desafio, visto que a urgência de sistemas de produção sustentáveis surgiu das disfunções e externalidades negativas dos sistemas de produção propostos e difundidos nos processos de subordinação da agricultura aos setores industriais, de serviços e financeiros. Tais modelos foram denominados de 'revolução verde' e 'modernização da agricultura' (OLIVEIRA, 2016; ANTUNES, NASCIMENTO e QUEIROZ, 2017).

As proposições de modelos agrícolas sustentáveis, apesar de terem raízes no tempo histórico mais dilatado, na década de 1960, se firmaram a partir de questionamentos sobre os rumos que os países desenvolvidos e os organismos nacionais e internacionais de fomento destinavam ao crescimento da agricultura (EHLERS, 2017).

Segundo Conway (1993), o desenvolvimento da economia agrícola apresenta um conjunto de problemas, criados pela relação intrínseca entre agricultura e meio ambiente, que 
devem ser analisados sob o âmbito das múltiplas visões dos atores sociais envolvidos, sejam agricultores ou quaisquer dos profissionais relacionados com a questão. As várias dimensões se referem aos aspectos econômicos, sociais, ambientais, institucionais, científicos, éticos, e tantos outros, relacionados com a sustentabilidade. Finalmente, as escalas de análise abrangem os níveis espaciais que a questão pode atingir, do local ao regional, até ao global.

Nesse sentido, também são importantes os aspectos destacados por Sachs (1993; 2008), a fim de caracterizar o desenvolvimento sustentável de uma localidade/região/território. O autor refere à sustentabilidade social, tratada como uma finalidade precípua do desenvolvimento; à sustentabilidade econômica, tratada como uma necessidade, mas que pode causar transtornos ambientais; e à sustentabilidade ambiental, tratada como decorrência da sustentabilidade cultural e social.

O conceito de sustentabilidade financeira, derivado das definições de Sachs (1993) e Conway (1993), envolve várias dimensões e mantém como elemento comum a relação entre tempo e recursos. Os autores preconizam que as necessidades econômicas do presente devem ser supridas, sem comprometer o atendimento das necessidades econômicas futuras. Van Bellen (2004), por outro lado, tem como foco de análise a sustentabilidade nas empresas, considerando cinco perspectivas - econômica, social, ambiental, geográfica e cultural.

Para os fins desta pesquisa, o conceito específico de sustentabilidade financeira está associado à capacidade de determinada entidade econômica autoprover recursos financeiros para enfrentar contratempos decorrentes da sua exploração econômica, que se articula sobre a autonomia financeira, o equilíbrio do crescimento e o nível de negócio.

Nesse sentido, a autonomia e o equilíbrio financeiro são mensurados a partir da avaliação de indicadores que possam traduzir a situação econômico-financeira da entidade. A avaliação é realizada por meio dos dados extraídos dos demonstrativos contábeis financeiros, entre os quais os mais importantes são: o Balanço Patrimonial e o Demonstrativo do Resultado do Exercício (GITMAN, 2010; ROSS, WESTERFIELD, JORDAN e LAMB, 2013).

Estudos relacionados à análise com base em índices financeiros são usuais em pesquisas na área da Ciência Social Aplicada, e têm representado um termômetro para antecipar as condições futuras das organizações estudadas. Ao mesmo tempo, o papel da análise econômico-financeira é fundamental para o crescimento do cooperativismo, conforme demonstram Morozini, Olinquevitch e Hein (2006); Sabadin, Hoeltgebaum e Silveira (2008) Giacomin, Boetler, Fiabani e Sandi (2018). 
Em complemento, a Comissão Interministerial para a Preparação da Conferência da ONU sobre Meio Ambiente e Desenvolvimento - CIMA (1991) observa que os indicadores econômicos convencionais, utilizados na avaliação do setor agrícola, levam em conta os aspectos de mercado e rentabilidade. Entretanto, o conhecimento disponível atualmente já demonstra que outros fatores devem fazer parte dessa operação, dentre os quais destacam-se os custos associados aos impactos ambientais e à conservação ou reposição dos recursos de produção.

Desse modo, a partir dos levantamentos para o referencial teórico, verificou-se significativa frequência de estudos que relacionam a Amazônia com os conceitos de Desenvolvimento Sustentável e a dimensão econômica sendo estudada de forma macroeconômica (com análise de indicadores, por exemplo, do Produto Interno Bruto e/ou do Índice de Desenvolvimento Humano).

Até o presente momento não foram localizados estudos que aprofundassem análise da sustentabilidade financeira, com base em indicadores microeconômicos, dentro do contexto da dinâmica das atividades produtivas desenvolvidas por comunidades extrativistas localizadas no Bioma Amazônia. Daí a importância desta pesquisa, em mensurar a sustentabilidade financeira de comunidades extrativistas no Bioma Amazônia, uma vez que, a conservação da biodiversidade passa pela sustentabilidade das comunidades localizadas nas reservas extrativistas (VIANA, VACCARO e VENZKE, 2018).

Em que pese a importância da Amazônia, independentemente da preocupação ambiental exposta nos discursos de autoridades e ativistas, segundo Freitas (2005), Freitas e Castro Júnior (2004) e Castelani (2013) o Brasil ainda incorpora o pensamento ambiental sob o prisma dos neoclássicos, o que implica considerar os problemas ambientais como externalidades negativas, passíveis de correção pela superação das falhas de mercado, o que não há, portanto, qualquer choque com a política ambiental brasileira, que defende o modelo capitalista e nega qualquer travamento ou diminuição do crescimento econômico - as bases desse princípio já são praticadas pelo Brasil, mais por pressão externa pela preservação do que devido à consciência do problema.

O contexto do desenvolvimento econômico e social da região amazônica é reprimido pela forte concentração de renda e de riqueza; pela pequena densidade no mercado regional; pela escassez e irregularidade de suprimento de energia elétrica; pela fragilidade, diversidade e relativo desconhecimento dos distintos ecossistemas da região; e pela exploração predatória de recursos naturais (FREITAS, SILVA e MARMOZ, 2003). 
Esta pesquisa tem por unidade de estudo a dinâmica produtiva desenvolvida nos espaços territoriais (comunidades e localidades) legalmente denominados de reserva extrativista (identificado pela sigla Resex), localizadas dentro do Bioma Amazônia. Uma Resex é uma Unidade de Conservação de Uso Sustentável, área ou espaço territorial utilizada por populações extrativistas tradicionais, cuja subsistência baseia-se no extrativismo. A população residente nas Reservas Extrativistas é legalmente denominada 'Povos e comunidades tradicionais' (PCT), que possuem formas próprias de organização social, ocupam e usam territórios e recursos naturais da floresta (Lei 9.985, 2000; Decreto 6.040, 2007).

Uma única reserva extrativista abriga várias comunidades tradicionais, como por exemplo, a Reserva Extrativista do Médio Purus que está localizada no Bioma Amazônia, no estado do Amazonas, com 604.231,22 hectares, foi criada em 2008, compreende três municípios (Lábrea, Pauini e Tapauá) e possui 97 comunidades/localidades que abrigam cerca de 1.300 famílias, que, juntas, totalizam mais de 6.000 pessoas (ICMBio, 2017). A Figura 1 apresenta o registro fotográfico de uma das comunidades dentro da Resex Médio Purus.

Figura 1- Foto de uma comunidade na Resex Médio Purus - Amazonas

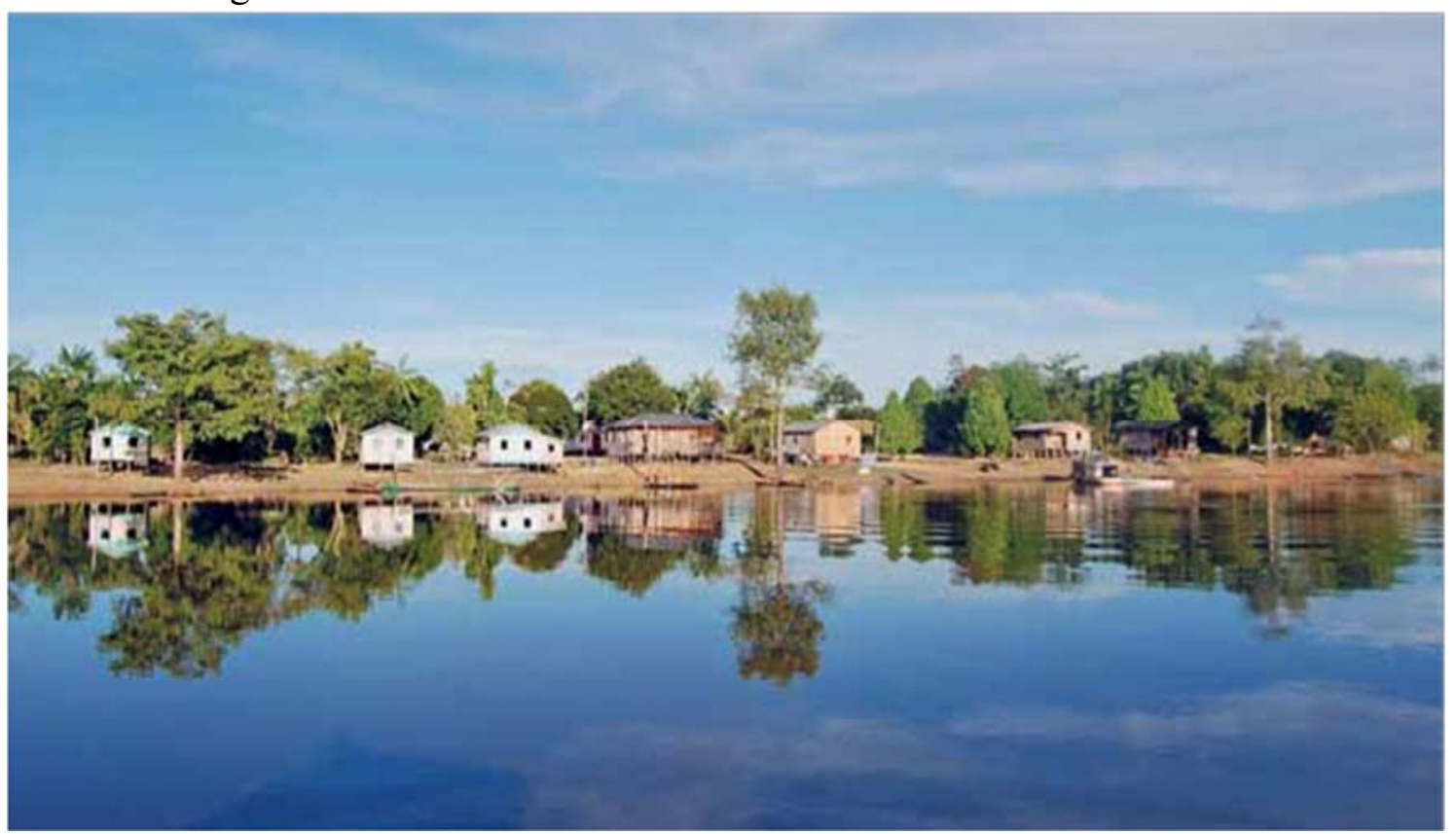

Fonte: Memorial da Luta pela Reserva Extrativista do Médio Purus em Lábrea-AM (ALEIXO, 2011)

Como resultado do movimento social da Amazônia ocidental, a criação de Reservas Extrativistas foi a maneira encontrada para garantir os direitos territoriais e ambientais das comunidades extrativistas. As Resex são uma forma de regularização da terra, reconhecendo os direitos de quem vive nela e utiliza os seus recursos para sobreviver - as comunidades 
tradicionais. Essas comunidades organizam-se em associações ou cooperativas, com o objetivo de implementar parcerias com o setor privado e público (ALEIXO, 2011).

Por um lado, a importância econômica que o Polo Industrial de Manaus (PIM) tem para a Amazônia é tão significativa que se converteu, nos últimos anos, em fonte de mais de $60 \%$ de todos os tributos federais arrecadados na região Norte (exceto Tocantins) do Brasil (RIVAS; MOTA; MACHADO, 2009, p. 26). De outro, a substancial importância e dependência do PIM também revela a premente necessidade de diversificação da matriz econômica do Estado, cuja discussão perpassa pelo conceito de Desenvolvimento Sustentável e, mais particularmente, pela manutenção da principal política ambiental no Brasil, o Sistema Nacional de Unidades de Conservação da Natureza - SNUC, que é responsável pela criação das Reservas Extrativistas.

Legalmente, as Resex representam a tentativa do governo em contemplar esta nova concepção dos problemas ambientais para a Amazônia, em que se busca uma gestão dos recursos naturais que considere as dimensões éticas, culturais e financeiras, objetivando o delineamento de uma política de desenvolvimento sustentável.

O desafio que se apresenta aos estudiosos é a busca da identificação e criação de modelos de políticas públicas e privadas que consigam harmonizar os conflitos naturais que surgem com os modelos econômicos de exploração da terra, a saber: (i) atividades econômicas já em andamento; e (ii) o uso futuro da floresta, consoante aos moldes do conceito de desenvolvimento sustentável, tendo compromisso sincrônico, com as demandas sociais atuais, e compromisso diacrônico, com as demandas sociais futuras (SACHS, 2002).

Nesse sentido, analisar e mensurar a situação financeira das comunidades extrativistas existentes nas Resex torna-se estratégico para garantir e consolidar uma das principais políticas de ocupação do território e de contenção do desmatamento florestal na Amazônia.

\subsection{Problema da pesquisa}

Decorrente do entrelaçamento entre: políticas públicas voltadas para o desenvolvimento sustentável na Amazônia; sustentabilidade financeira e empreendedorismo social local, surgiu o problema central desta pesquisa: identificar as condições financeiras de reservas extrativistas do Bioma Amazônia. 


\subsection{Objetivo Geral}

Estruturar mecanismo de mensuração e monitoramento da sustentabilidade financeira para o fortalecimento de reservas extrativistas do Bioma Amazônia.

\subsection{Objetivos Específicos}

a) Levantar e analisar as características e dinâmicas das atividades produtivas desenvolvidas nos espaços territoriais produtivos de uma reserva extrativista do Bioma Amazônia;

b) Propor instrumento que permita a mensuração e o monitoramento da sustentabilidade financeira de reservas extrativistas do Bioma Amazônia;

c) Mensurar as condições de sustentabilidade financeira existentes em comunidades extrativistas de uma reserva extrativista do Bioma Amazônia a partir do modelo analítico proposto.

\subsection{Justificativa}

A Amazônia e, mais particularmente, o Bioma Amazônia, se transformaram em ícones simbólicos para o equilíbrio ambiental do planeta. A amplitude do conhecimento e do 'desconhecimento' de seus recursos naturais, seus habitantes, suas políticas de uso da floresta, por si, legitima estudos e pesquisas.

O Brasil adotou uma política ambiental em que a criação de espaços territoriais voltados para o desenvolvimento sustentável é a principal estratégia para a contenção dos impactos ambientais e a preservação do Bioma Amazônia. A partir da década de 1980, foram criadas as Reservas Extrativistas como Unidades de Conservação de Uso Sustentável, que objetivam a implementação do uso equilibrado dos recursos naturais, voltados para a melhoria da qualidade de vida da presente geração, garantindo as mesmas possibilidades para as gerações futuras (Decreto 6.040, 2007).

A presente pesquisa se justifica pela necessidade de conhecimento das condições de sustentabilidade financeira das comunidades extrativistas localizadas no Bioma Amazônia, sobretudo as localizadas no estado do Amazonas. Pretende-se identificar oportunidades para a adoção de políticas públicas e iniciativas privadas na economia local, que possam fortalecer 
os mecanismos financeiros existentes, de forma a propiciar condições para que a população residente nas comunidades extrativistas melhore suas condições e expectativas socioeconômicas. As perspectivas de desenvolvimento sustentável devem ser voltadas para a garantia da qualidade de vida das pessoas, para a conservação dos recursos naturais para as gerações futuras e para a justiça social, na distribuição e na fruição dos bens criados pela humanidade (FISCHER e COMINI, 2012; DEES, 1998).

Como resultado da revisão bibliográfica, ficou evidente a carência de referências sobre a sustentabilidade financeira de comunidades extrativistas localizadas em Reservas Extrativistas - constatou-se que o vetor comumente estudado é o da conservação ambiental. Baseado nesse contexto, o intuito desta pesquisa é examinar o tema sob o ponto de vista da produção da comunidade, ou seja, estudar a dinâmica das atividades produtivas desenvolvidas nas comunidades.

A apresentação de propostas visando o fortalecimento da sustentabilidade financeira em comunidades economicamente vulneráveis, está inserida no conceito de desenvolvimento sustentável e converge para um dos eixos temáticos do mainstream mundial que gravita em torno das discussões que envolvem conservação ambiental e sustentabilidade, justamente para uma região crítica específica, a Amazônia. O fortalecimento das condições socioeconômicas das reservas extrativistas pode contribuir para a identificação e adoção de mecanismos que possibilitem frear o desmatamento e a degradação ambiental, além de reduzir a vulnerabilidade da população residente nessas comunidades.

\subsection{Estrutura da tese}

A presente tese está estruturada em cinco tópicos principais. O tópico 1 'Introdução' apresenta o contexto, o problema, os objetivos e a justificativa da pesquisa. O tópico 2 'Referencial Teórico' apresenta uma exposição teórica dos conceitos mais relevantes para o desenvolvimento do trabalho. O tópico 3 'Metodologia' aborda a natureza, procedimentos e técnicas utilizadas no estudo de caso. O tópico 4 'Resultados' expõe as análises e discussão dos resultados, bem como o modelo e aplicação do 'Radar de Sustentabilidade Financeira'. Por fim, o tópico 5 'Considerações Finais' apresenta em resumo, a consecução dos objetivos, as contribuições e limitações, bem como, sugestões de novas pesquisas.

Importante destacar que, depois da apresentação das 'Referências', nos 'Apêndices' são apresentados os dados gerais de produção e a apuração do Índice de Sustentabilidade de 
cada uma das dezesseis comunidades e vinte e duas localidades estudadas, o roteiro das entrevistas e o acervo fotográfico da pesquisa. 


\section{REFERENCIAL TEÓRICO}

\subsection{Amazônia}

A Amazônia refere-se à região norte da América do Sul, que abrange uma área total de 5,1 milhões de $\mathrm{km}^{2}$ do território nacional e onde está localizada a Floresta Amazônica. A maior parte da floresta está circunscrita a terras do Brasil, que detém 67\% da Amazônia, sendo o restante fragmentado entre Peru, Colômbia, Venezuela, Equador, Bolívia, Guiana, Suriname e Guiana Francesa (SUPERINTENDÊNCIA DO DESENVOLVIMENTO DA AMAZÔNIA [SUDAM], PRDA, 2020; MINISTÉRIO DO MEIO AMBIENTE [MMA], PROBIO 2004).

A Amazônia está localizada no estado do Amazonas, que é o estado com maior extensão territorial do Brasil $\left(1.559 .167 \mathrm{Km}^{2}\right)$, dos quais 97,09\% são de florestas naturais, que permanecem inalteradas (INSTITUTO BRASILEIRO DE GEOGRAFIA E ESTATÍSTICA [IBGE], 2020; PROJETO DE MAPEAMENTO ANUAL DO USO E COBERTURA DA TERRA NO BRASIL [MAPBIOMAS], 2019).

A Amazônia é um repositório de mais de centena de trilhões de toneladas de carbono, além de abrigar uma massa vegetal que libera milhões de litros de água para a atmosfera a cada segundo, bem como rios que formam a maior bacia hidrográfica, com maior volume de água doce existente no mundo. Nesse sentido, a Amazônia tem relevância significativa para a estabilidade ambiental do Planeta (MMA, 2002).

Essa abundância de recursos naturais propiciou desenvolvimento de diferentes formas de ocupação do território, o que destaca a Amazônia pela expressiva diversidade econômica, cultural e étnica, representada pelos povos indígenas e populações tradicionais - cerca de 180 povos indígenas, 1.206 comunidades remanescentes de quilombolas e milhares de comunidades de seringueiros, ribeirinhos, pescadores ou babaçueiros (SUDAM, PRDA, 2020).

A população da Amazônia soma mais de 25 milhões de pessoas e a taxa de crescimento demográfico ultrapassa a média de crescimento do restante do Brasil. Contudo, o padrão de crescimento não tem sido benéfico para o povo da Amazônia nem para a floresta não houve estímulo ao fortalecimento da economia, o padrão de vida da população não 
melhorou (98,5\% dos municípios da Amazônia apresentam condições de vida piores do que o verificado em outras regiões do País), além dos danos ambientais que comprometem inclusive as atividades agropecuárias, madeireiras e de mineração, que são apontadas como principais responsáveis pela degradação da floresta (ABRAMOVAY, 2019).

Relatório do IBGE (Brasil em Síntese, 2020) informa que entre os anos de 2016 e 2018, o território brasileiro foi atingido por algum tipo de mudança em cerca de 1\% na sua cobertura e uso da terra. Como observado em períodos anteriores, o que ocorre com mais frequência é a substituição das áreas de vegetação natural por áreas com intervenção humana, além do aumento de áreas agrícolas em regiões de pastagem.

Em complemento, Gomes et al. (2018) reforçam que a Amazônia brasileira é onde está localizada a maior floresta contígua remanescente do planeta, que sofre fortes pressões relativas ao desenvolvimento, ao mesmo tempo em que registra uma das maiores taxas de desmatamento do mundo. Abriga a maior porção de floresta tropical existente e a maior taxa absoluta de desmatamento, o que, contraditoriamente, faz com que o Brasil seja líder nessas duas modalidades: conservação e destruição dessas florestas.

\subsubsection{Bioma Amazônia}

Bioma é um conjunto de vida vegetal e animal, constituído pelo agrupamento de tipos de vegetação que são próximos e que podem ser identificados em nível regional, em condições de geologia e clima semelhantes e, historicamente, sofreram os mesmos processos de formação da paisagem, resultando em uma diversidade de flora e fauna própria (IBGE/Coordenação de Recursos Naturais e Estudos Ambientais, 2019). O Brasil possui seis biomas, como se verifica na Tabela 1, abaixo:

Tabela 1 - Biomas Brasileiros

\begin{tabular}{lcc}
\hline Biomas Brasileiros & Área Aproximada $\left(\mathbf{K m}^{2}\right)$ & Área / Total Brasil $\left(\mathbf{K m}^{2}\right)$ \\
\hline Amazônia & 4.212 .742 & $49,5 \%$ \\
Caatinga & 862.818 & $10,1 \%$ \\
Cerrado & 1.983 .017 & $23,3 \%$ \\
Mata Atlântica & 1.107 .419 & $13,0 \%$ \\
Pampa & 193.836 & $2,3 \%$ \\
Pantanal & 150.988 & $1,8 \%$ \\
\hline \multicolumn{1}{c}{ Total Brasil } & $\mathbf{8 . 5 1 0 . 8 2 0}$ & $\mathbf{1 0 0 \%}$ \\
\hline
\end{tabular}

Fonte: IBGE (2019) 
No Brasil, o Bioma Amazônia ocupa cerca de 49,5\% do território e abrange três regiões do País (Norte, Nordeste e Centro-Oeste). É o maior bioma do Brasil, onde crescem 2.500 espécies de árvores (ou um-terço de toda a madeira tropical do mundo), além de abrigar 30 mil espécies de plantas (das 100 mil espécies existentes na América do Sul) e deter 20\% das reservas de água doce do planeta. Seus recursos naturais - que, além da madeira, incluem enormes estoques de borracha, castanha, peixe e minérios - representam abundante fonte de riqueza natural (IBGE/Coordenação de Recursos Naturais e Estudos Ambientais, 2019).

A região também registra grande patrimônio cultural, com destaque para 0 conhecimento tradicional sobre os usos e a forma de explorar os recursos naturais, sem esgotá-los, nem destruir o habitat natural (IBGE/CNAE, 2019). Segundo Maciel et al. (2018), as populações tradicionais representam grupos de pequenos produtores, que foram atraídos por uma atividade econômica. Para esses comunitários, a natureza desempenha papel relevante na definição e desenvolvimento de modos de vida específicos que, normalmente, são sintonizados com as regras básicas do ecossistema da floresta.

O Estado do Amazonas concentra em torno de 17\% das reservas extrativistas do Bioma Amazônia, conforme Tabela 2:

Tabela 2 - Reservas extrativistas Brasil - Bioma Amazônia

\begin{tabular}{cccccr}
\hline $\begin{array}{c}\text { Reservas } \\
\text { Extrativistas }\end{array}$ & $\begin{array}{c}\text { Brasil } \\
\text { Quantidade }\end{array}$ & \multicolumn{2}{c}{ Bioma Amazônia } & \multicolumn{2}{c}{ Amazonas } \\
Quantidade & $\mathbf{\%}$ & Quantidade & $\mathbf{\%}$ \\
\hline Federais & 66 & 51 & $77 \%$ & 9 & $18 \%$ \\
Estaduais & 26 & 26 & $100 \%$ & 4 & $15 \%$ \\
\hline \multicolumn{1}{c}{ Total } & $\mathbf{9 2}$ & $\mathbf{7 7}$ & $\mathbf{8 4 \%}$ & $\mathbf{1 3}$ & $\mathbf{1 7 \%}$ \\
\hline
\end{tabular}

Fonte: Adaptado pela autora, com dados extraídos de Memorial Chico Mendes (2018)

Em parte do bioma Amazônia, onde ocorre grandes alterações na cobertura e uso da terra, as florestas perderam $27 \%$ das suas áreas para o avanço das pastagens com manejo. Considerando toda a extensão territorial brasileira, significa que, entre 2000 e 2018, houve redução de 7,6\% das áreas de vegetação florestal e de $10 \%$ da vegetação campestre (IBGE/Monitoramento da Cobertura e Uso da Terra do Brasil, 2020).

Diante das ameaças de degradação, somente sua importância socioambiental e seus potenciais não parecem ser suficientes para sustentar o futuro da Amazônia. Dados do Instituto Nacional de Pesquisas Espaciais - INPE (2020b), mostram que o desmatamento na região é alto, acelerado e crescente. No Amazonas, no primeiro semestre de 2021, o desmatamento já tinha consumido $11,28 \%$ daquele território. 


\subsubsection{Amazônia Legal}

A Amazônia Legal é um espaço territorial, criado pelo Governo Federal brasileiro em 1953, para designar a área da Floresta Amazônica (ou da Amazônia) que está localizada no Brasil. A área é administrada pela SUDAM e inclui os estados do Acre, Amapá, Amazonas, Pará, Rondônia, Roraima, Tocantins, Mato Grosso e parte do Maranhão. Sua superfície abrange cerca de cinco milhões de quilômetros quadrados $\left(5.020 .000 \mathrm{~km}^{2}\right)$, o que equivale a 58,96\% do território do Brasil (LEI COMPLEMENTAR 124, 2007), conforme demonstrado na Figura 2.

Figura 2 - Mapa da Amazônia Legal

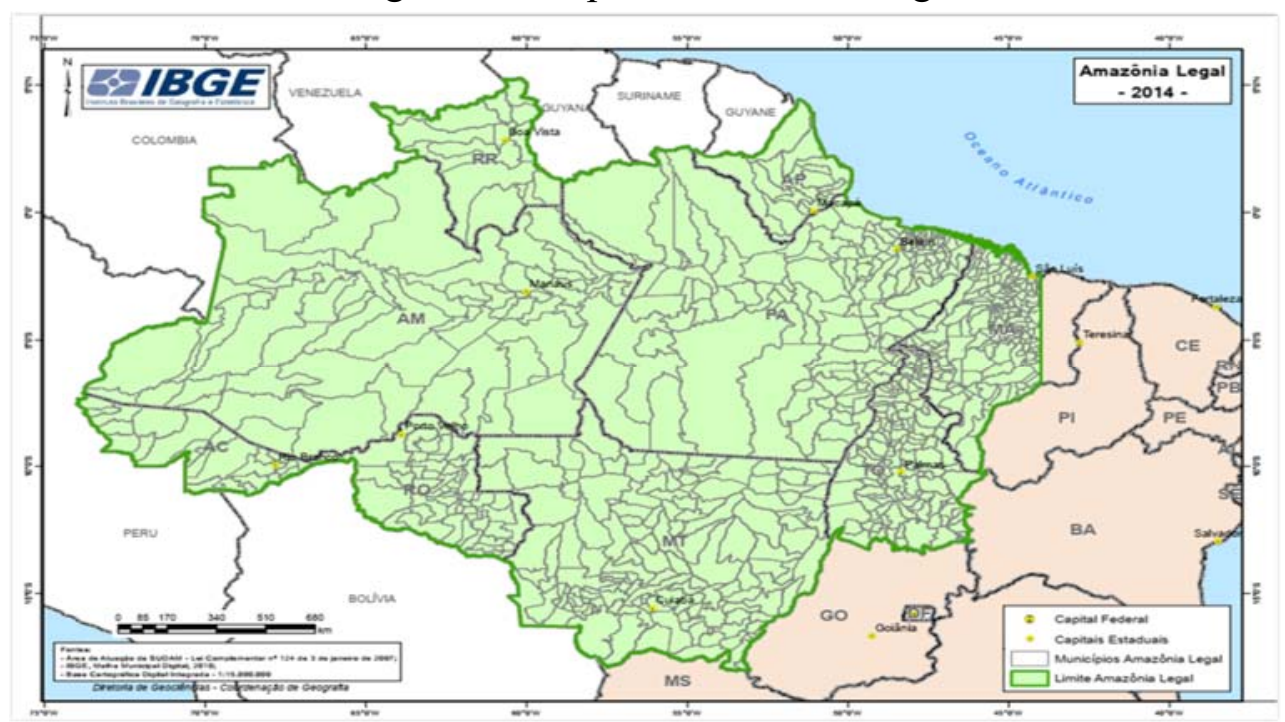

Fonte: IBGE (2014)

As áreas protegidas são instrumentos públicos que objetivam resguardar a integridade dos ecossistemas, nesse sentido, as Unidades de Conservação, que representam a principal estratégia de contenção do desmatamento e conservação ambiental na Amazônia são apresentadas a seguir.

\subsection{Unidade de conservação (UC)}

Unidades de Conservação (UCs) são espaços territoriais, incluindo seus recursos ambientais, com características naturais relevantes, que têm a função de assegurar a representatividade das diferentes populações, habitats e ecossistemas do território nacional, preservando o patrimônio biológico existente (Lei 9.985, 2000). 
Dividem-se em Unidades de Proteção Integral e Unidades de Uso Sustentável, conforme apresentado na Figura 3:

Figura 3 - Grupos de Unidades de Conservação

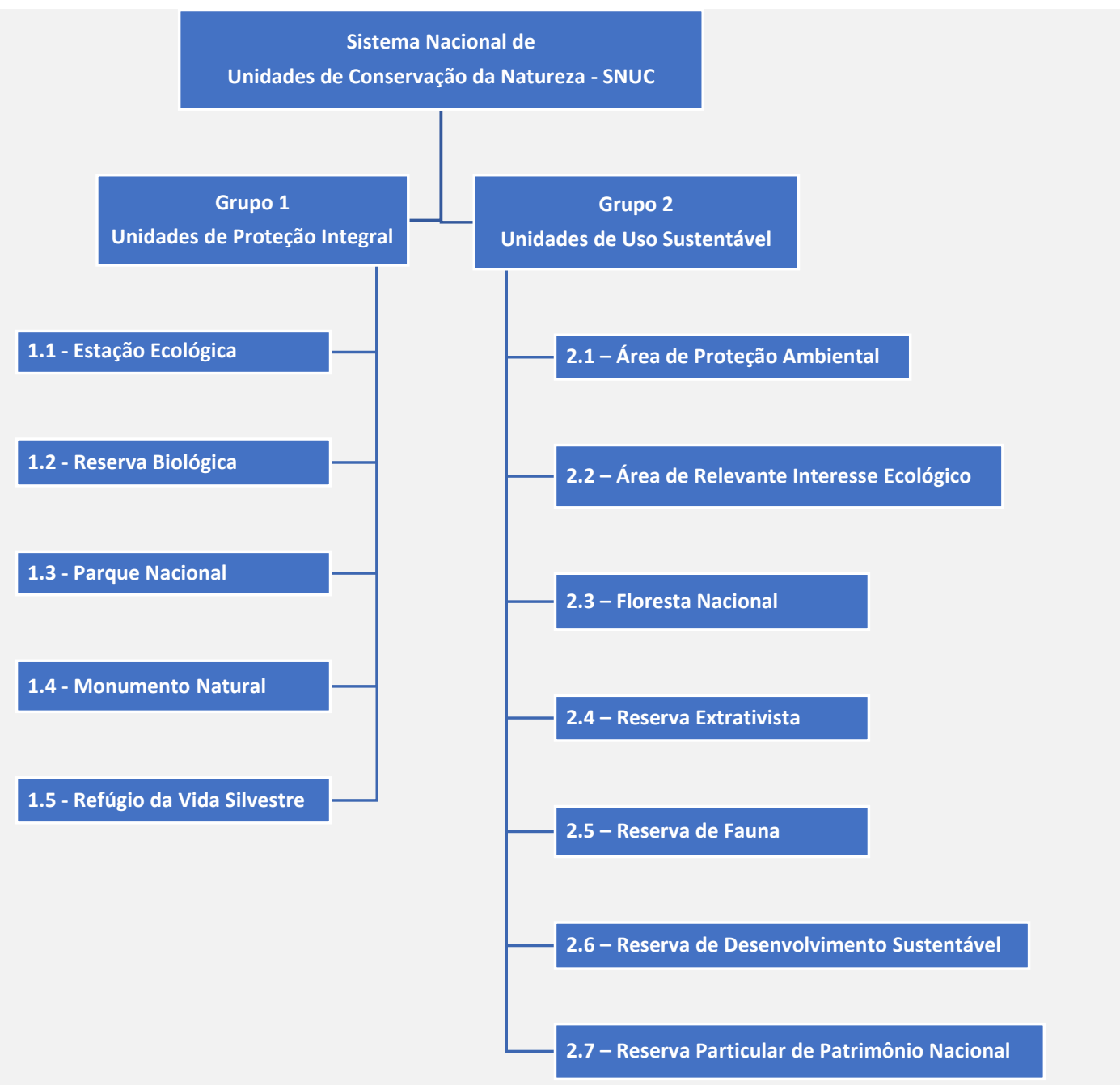

Fonte: Adaptado pela autora, com dados extraídos da Lei 9.985 (2000)

1) Unidades de Proteção Integral caracteriza-se por ser onde a proteção da natureza é o objetivo primordial, o que justifica as regras e normas mais restritivas. Nessas áreas é permitido apenas o uso indireto dos recursos naturais, quer dizer que não pressupõe consumo, coleta ou danos aos recursos naturais. Fazem parte deste grupo as estações ecológicas, as reservas biológicas, parques, monumentos naturais e refúgios de vida silvestre.

Segundo o SNUC, as Unidades de Conservação de Proteção Integral têm por objetivo preservar a natureza, sendo admitido apenas o uso indireto dos seus recursos naturais, com exceção dos casos previstos na Lei 9.985 (2000), que estabeleceu cinco tipos de unidades de conservação de proteção integral, administradas conforme as características em relação ao 
domínio da área territorial, população residente, visitação pública e pesquisa científica, como apresentadas no Quadro 1:

Quadro 1 - Características de UCs de Proteção Integral

\begin{tabular}{|c|c|c|c|c|}
\hline Categorias de UCs & Domínio & $\begin{array}{l}\text { População } \\
\text { residente }\end{array}$ & $\begin{array}{l}\text { Visitação } \\
\text { Pública }\end{array}$ & $\begin{array}{l}\text { Pesquisa } \\
\text { Científica }\end{array}$ \\
\hline Estação Ecológica & Público & $\begin{array}{c}\text { Não } \\
\text { permitida }\end{array}$ & \multirow{2}{*}{$\begin{array}{l}\text { Exclusivamente } \\
\text { com objetivo } \\
\text { educacional }\end{array}$} & \multirow{5}{*}{$\begin{array}{l}\text { Permitida } \\
\text { com } \\
\text { autorização } \\
\text { prévia. } \\
\text { Com normas } \\
\text { e restrições } \\
\text { pré- } \\
\text { estabelecidas }\end{array}$} \\
\hline Reserva Biológica & Público & $\begin{array}{c}\text { Não } \\
\text { permitida }\end{array}$ & & \\
\hline Parque Nacional & Público & $\begin{array}{c}\text { Não } \\
\text { permitida }\end{array}$ & \multirow{3}{*}{$\begin{array}{l}\text { Permitida sob } \\
\text { normas e } \\
\text { restrições }\end{array}$} & \\
\hline Monumento Natural & $\begin{array}{l}\text { Público e/ou } \\
\text { privado }\end{array}$ & Permitida & & \\
\hline $\begin{array}{l}\text { Refúgio da Vida } \\
\text { Silvestre }\end{array}$ & $\begin{array}{c}\text { Público e/ou } \\
\text { privado }\end{array}$ & Permitida & & \\
\hline
\end{tabular}

Fonte: Adaptado pela autora, com dados extraídos da Lei 9.985 (2000)

2) Unidades de Uso Sustentável são áreas em que é possível aliar conservação da natureza ao uso sustentável dos recursos naturais, ou seja, são permitidas atividades que coletem e usem recursos naturais, desde que respeitada a perenidade dos recursos ambientais renováveis e dos processos ecológicos. Compõem este grupo áreas de relevante interesse ecológico, floresta nacional, reservas de fauna, reservas de desenvolvimento sustentável, reservas extrativistas, Área de proteção Ambiental (APA) e Reserva Particular do Patrimônio Natural (RPPN).

De acordo com a Lei 9.985 (2000), uso sustentável é definido como sendo a exploração do ambiente, observando a garantia da perenidade dos recursos ambientais renováveis e dos processos ecológicos, mantendo a biodiversidade e os demais atributos ecológicos, de forma socialmente justa e economicamente viável.

O Ministério do Meio Ambiente (2020) acrescenta que as Unidades de Conservação são espaços territoriais, que se referem a seus recursos ambientais e características naturais relevantes, cuja função é garantir que amostras significativas e ecologicamente viáveis, representando as diversas populações, habitats e ecossistemas existentes no Brasil, sejam preservadas.

São áreas protegidas, sujeitas a normas e regras especiais e, desta maneira, as UCs proporcionam às populações tradicionais o uso sustentável dos recursos naturais, bem como propicia, às comunidades do entorno, a prática de atividades econômicas sustentáveis (MMA, 2020).

As UCs de Uso Sustentável são áreas territoriais de posse e uso, concedidas às populações tradicionais (LEI 9.985, 2000). A Lei estabeleceu sete tipos de Unidades de 
Conservação de Uso Sustentável, com as características em relação ao domínio da área territorial, população residente, visitação pública e pesquisa científica, conforme mostra o Quadro 2:

Quadro 2 - Características de UCs de Uso Sustentável

\begin{tabular}{|c|c|c|c|c|}
\hline Categorias de UCs & Domínio & $\begin{array}{c}\text { População } \\
\text { residente }\end{array}$ & $\begin{array}{c}\text { Visitação } \\
\text { Pública }\end{array}$ & $\begin{array}{c}\text { Pesquisa } \\
\text { Científica } \\
\end{array}$ \\
\hline Reserva de Fauna & Público & $\begin{array}{c}\text { Não } \\
\text { permitida }\end{array}$ & \multirow{5}{*}{$\begin{array}{l}\text { Permitida } \\
\text { sob } \\
\text { condições e } \\
\text { restrições } \\
\text { pré- } \\
\text { estabelecidas }\end{array}$} & \multirow{5}{*}{$\begin{array}{c}\text { Permitida } \\
\text { com } \\
\text { Autorização } \\
\text { prévia. } \\
\text { Com normas } \\
\text { e restrições } \\
\text { pré- } \\
\text { estabelecidas }\end{array}$} \\
\hline $\begin{array}{c}\text { Área de Proteção } \\
\text { Ambiental }\end{array}$ & $\begin{array}{c}\text { Público e/ou } \\
\text { privado }\end{array}$ & Permitida & & \\
\hline $\begin{array}{l}\text { Área de Relevante } \\
\text { Interesse Ecológico }\end{array}$ & $\begin{array}{c}\text { Público e/ou } \\
\text { privado }\end{array}$ & Permitida & & \\
\hline $\begin{array}{c}\text { Reserva Particular do } \\
\text { Patrimônio Natural }\end{array}$ & Privado & Permitida & & \\
\hline Floresta Nacional & Público & $\begin{array}{c}\text { Permitida } \\
\text { somente para } \\
\text { comunidades } \\
\text { e povos } \\
\text { tradicionais }\end{array}$ & & \\
\hline Reserva Extrativista & Público & \multirow{2}{*}{$\begin{array}{c}\text { Permitida } \\
\text { somente para } \\
\text { comunidades } \\
\text { e povos } \\
\text { tradicionais }\end{array}$} & \multirow{2}{*}{$\begin{array}{c}\text { Permitida, se } \\
\text { compatível } \\
\text { com o } \\
\text { interesse } \\
\text { local }\end{array}$} & \multirow{2}{*}{$\begin{array}{c}\text { Permitida e } \\
\text { incentivada, } \\
\text { com } \\
\text { autorização } \\
\text { prévia } \\
\end{array}$} \\
\hline $\begin{array}{c}\text { Reserva de } \\
\text { Desenvolvimento } \\
\text { Sustentável }\end{array}$ & Público & & & \\
\hline
\end{tabular}

Fonte: Adaptado pela autora, com dados extraídos da Lei 9.985 (2000)

Em todo o território nacional, são 2.446 Unidades de Conservação, sendo que, destas, $18,66 \%$ representam território continental e 26,46\% referem-se a área marinha protegida. Deste total, $31,77 \%$ são Áreas de Proteção Integral e 68,23\%, correspondem a UCs de Uso Sustentável (CNUC, 2019).

Abramovay (2019) enfatiza que diversas modalidades de áreas protegidas (reservas extrativistas, parques, territórios indígenas, florestas nacionais, além de outras) ocupam 50\% da Amazônia brasileira, e entre os anos 2003 e 2009, o Brasil representou 75\% das iniciativas de ampliação de áreas protegidas no mundo.

Pascuchi (2007) alerta que entre os desafios dos espaços territoriais especialmente protegidos está a definição de estratégias eficazes para a sua conservação ambiental, de acordo com a modalidade de conservação a que é destinado. Para a conservação dessas áreas, deve ser implementada uma sistemática que possibilite a continuidade dos processos que geram e proporcionam a manutenção dos recursos naturais - é importante que as políticas de conservação estejam conectadas com as políticas de desenvolvimento econômico e territorial do País.

Na década de 1980, a Política Nacional do Meio Ambiente no Brasil estabeleceu a criação de espaços territoriais e de seus recursos ambientais, especialmente protegidos pelo 
poder público (Lei 6.938, 1981). Uma das principais políticas públicas voltadas para o desenvolvimento sustentável na Amazônia foi a criação do Sistema Nacional de Unidades de Conservação da Natureza - SNUC (Lei 9.985, 2000).

Young e Medeiros (2018) ressaltam que as UCs representam tipicamente as áreas protegidas no Brasil e estão organizadas pelo Sistema Nacional de Unidade de Conservação (SNUC). Elas abrangem boa parte do território nacional, servindo de proteção para ecossistemas, espécies e meios de vida de populações tradicionais que habitam essas áreas.

As Unidades de Conservação representam um espaço territorial e seus recursos ambientais, incluindo as águas jurisdicionais, com características naturais relevantes. "São legalmente instituídos pelo Poder Público, com objetivos de conservação e limites definidos, sob regime especial de administração, ao qual se aplicam garantias adequadas de proteção" (Lei 9.985, 2000).

Em consenso com tratados internacionais, o Brasil integra o acordo que visa a fortalecer e ampliar o SNUC, cumprindo as metas definidas na COP-10, décima reunião das partes da Convenção das Nações Unidas sobre Diversidade Biológica. O compromisso dos signatários era implementar ações concretas no sentido de interromper a destruição da biodiversidade do planeta por meio, entre outras propostas, da ampliação da cobertura das áreas protegidas (YOUNG e MEDEIROS, 2018).

No que se refere à administração das UCs, estudo do Ministério do Meio Ambiente (MMA) identificou que tornar forte a organização social das comunidades de áreas protegidas é primordial para a gestão eficiente das Unidades de Conservação, ao mesmo tempo em que assegura, aos moradores, cidadania e participação nas decisões. Por isso, é importante que as estratégias de gestão contribuam para aperfeiçoar o processo de organização das famílias, bem como sua efetiva participação, pois, consequentemente, esta será a premissa básica para a melhoria das práticas de manejo sustentável dos recursos naturais e para a definição de parcerias de gestão, com vistas à sustentabilidade social e ambiental do território (MMA, 2018).

Baseado nisso, incentivar o manejo sustentável dos recursos naturais é fundamental para a gestão das UCs, o que exige trabalho conjunto de gestores e comunitários, reforçando a integração das atividades que geram renda para as famílias com a sustentabilidade ambiental da área protegida. Daí a relevância da junção dos saberes tradicionais dos moradores das Unidades de Conservação com o conhecimento técnico-científico dos demais participantes do Programa. Esse intercâmbio de experiências favorece a capacitação dos indivíduos e gera novos saberes a respeito do tema. Associado a isso, há evidências de que os projetos voltados 
para a formação, capacitação e organização comunitária contribuem sobremaneira para a melhoria das práticas de manejo dos recursos naturais, como também da gestão das UCs (MMA, 2018).

Igualmente, a não participação da comunidade no processo de gestão das UCs dificulta a percepção de apropriação e, por consequência, os moradores não se sentem responsáveis pelo projeto e, assim, não se empenham nas contrapartidas que lhes cabem (MMA, 2018).

Os tópicos seguintes apresentam o Sistema Nacional de Unidades de Conservação [SNUC] e os principais programas, projetos vinculados às Unidades de Conservação.

\subsubsection{Sistema Nacional de Unidades de Conservação (SNUC)}

É o sistema instituído pela Lei 9.985 (2000), que concentra informações de todas as UCs (federais, estaduais e municipais), possibilitando visão de conjunto das áreas naturais a serem preservadas. Além disso, a 'Lei do SNUC' estabeleceu mecanismos de regulamentação para a participação da sociedade na gestão das UCs, determinando a relação entre Estado, cidadãos e meio ambiente.

Na sua concepção, está previsto que o SNUC não somente viabilize a criação de UCs, mas também contribua para o seu planejamento e administração, de maneira integrada, assegurando representatividade para diferentes populações, habitats e ecossistemas em todo território nacional e nas águas jurisdicionais. Para tanto, a gestão do SNUC abrange os três níveis de governo - federal, estadual e municipal.

Outrossim, baseado na sua linha estratégica, o SNUC, possibilita aos tomadores de decisão das Unidades de Conservação atuarem no sentido de conservar os ecossistemas e a biodiversidade, gerar renda, emprego, desenvolvimento e, desse modo, melhorar significativamente a qualidade de vida das populações locais e do Brasil, de forma geral (Lei 9985, 2000).

$\mathrm{Na}$ percepção de Capelari (2017), a Lei que instituiu o SNUC garantiu a recategorização das áreas protegidas no Brasil, visto que as classifica em dois grandes grupos: proteção integral e uso sustentável. Enquanto o primeiro tem características preservacionista, não permitindo a intervenção humana nos seus recursos naturais, o segundo grupo estabelece condições para a compatibilização da conservação da natureza com o uso sustentável de parte dos seus recursos naturais. 


\subsubsection{Projetos e Programas vinculados às Unidades de Conservação (UCs):}

A Lei 9.985 (2000), que instituiu o SNUC, estabeleceu critérios e normas para a criação e gestão das Unidades de Conservação e, portanto, alguns programas/projetos e órgãos foram criados, a fim de dar suporte e acompanhar o desenvolvimento e desempenho das UCs. A seguir, a definição e objetivos de cada um deles:

\subsubsection{Programa Áreas Protegidas da Amazônia [ARPA]}

É um programa do governo federal, de longo prazo (2002-2039), que propõe a conservação de 600 mil km² de Unidades de Conservação (UCs) localizadas no bioma Amazônia, a partir da criação, concretização e sustentabilidade financeira permanente das UCs (MMA/ARPA, 2018).

O Programa foi lançado em 1998, formado por uma aliança entre o Fundo Mundial para a Natureza [World Wide Fund - WWF] e o Banco Mundial. Quando o governo brasileiro assumiu a gestão, houve também a adesão de outros parceiros e doadores, como o Fundo Global para o Meio Ambiente [GEF], além do governo da Alemanha. O objetivo desse esforço se resume em formar uma rede de unidades de conservação para proteger a biodiversidade da Amazônia (MMA/ARPA, 2018; WWF-Brasil, 2017).

A finalidade do ARPA é garantir recursos financeiros para a gestão das Unidades de Conservação, de modo a oferecer condições para o desenvolvimento sustentável na Amazônia, por meio da criação, expansão e fortalecimento das UCs (ARPA, 2014). Isso significa promover a conservação de amostra representativa da biodiversidade da Amazônia, dos ecossistemas e paisagens desse bioma, assim como a interação desses elementos com as comunidades humanas, de modo a contribuir para o seu desenvolvimento sustentável e manter os serviços ambientais nessas regiões (MMA/ARPA, 2018).

Dessa maneira, o Programa apoia comunidades locais, usuárias e beneficiárias das Unidades de Conservação, aplicando estratégias fortalecedoras do uso sustentável dos recursos naturais por estas comunidades (MMA/ARPA, 2018).

Estudo da WWF-Brasil (2017) indica que, em 15 anos de atuação, os resultados do ARPA são positivos, conseguindo superar transições políticas e institucionais, crises financeiras nacionais e globais, e todos os desafios de gerenciar e operar um programa dessa escala. Entretanto, o estudo alerta para a necessidade de encontrar condições para alcançar resultados mais robustos em algumas áreas, principalmente em planejamento de gestão, gestão participativa e compartilhada, estabelecimento de parcerias e de recursos públicos adicionais. 
2.2.2.2 Plano de Ação para a Prevenção e Controle do Desmatamento na Amazônia Legal [PPCDAM]

O Plano de Ação para a Prevenção e Controle do Desmatamento na Amazônia Legal (PPCDAM) foi criado, pelo governo federal, em 2003, e suas ações estratégicas abrangiam três eixos temáticos: ordenamento fundiário de territorial, monitoramento e controle e, por último, fomento às atividades sustentáveis. Em 2016, houve acréscimo de nova temática, a respeito de instrumentos econômicos e normativos (CAPELARI, 2017).

O propósito era controlar o desmatamento, atacando suas principais causas, tais como: ocupação irregular de terras públicas; crescimento desordenado da ocupação sobre a área de floresta; baixa gestão da malha fundiária; morosidade no licenciamento do desmatamento e dos planos de manejo; baixa eficácia da fiscalização e controle; pouca presença do Estado na Amazônia; sensação de impunidade administrativa e criminal relacionada ao desmatamento ilegal; baixo grau de responsabilização ambiental; baixa viabilidade da cadeia produtiva (que constitui alternativa ao desmatamento); expansão desordenada da agropecuária; baixa produção de madeireira sustentável; atividades produtivas dos assentamentos não compatíveis com a legislação ambiental; degradação florestal e do solo, dentre outros (CAPELARI, 2017).

Por isso, o cumprimento dos acordos internacionais de controle de desmatamento, firmados pelo Brasil nas conferências de clima, é um desafio que exigirá esforços de governos, autoridades, ambientalistas e diversos setores da sociedade.

\subsubsection{CNPT}

O Centro Nacional de Pesquisa e Conservação da Sociobiodiversidade Associada a Povos e Comunidades Tradicionais [CNPT] foi criado em 1992, como sendo uma unidade administrativa do IBAMA, que, originalmente, é o responsável pela implantação, consolidação e gestão das Reservas Extrativistas (UICN, 1995).

O CNPT foi criado com a finalidade de institucionalizar um formato de gestão específica para as Resex e seu propósito, a princípio, era "promover a elaboração, implantação e implementação de planos, programas e projetos e ações demandadas pelas populações tradicionais". À época, sua atuação compreendia a avaliação dos pleitos das populações, em conformidade com os recursos disponíveis, deixando a execução a cargo das entidades representativas dos beneficiários - contudo, o CNPT monitorava a aplicação dos recursos e avaliava os resultados (UICN, 1995). 
Em 2009, o CNPT foi incorporado à estrutura do ICMBio e, ainda que atuando exclusivamente na gestão das Resex, passou a se dedicar à promoção de pesquisas científicas em manejo e conservação de ambientes e territórios habitados por povos e comunidades tradicionais no que se refere aos seus conhecimentos, modos de organização social e formas de gestão dos recursos naturais, dando suporte ao manejo das Unidades de Conservação federais (MMA/SBF, 2009).

Sendo assim, os objetivos do CNPT passaram a ser direcionados para ações que visem possibilitar e incentivar a participação dos povos e comunidades tradicionais nas pesquisas e estudos desenvolvidos pelo Centro, relacionados à efetividade das Reservas Extrativistas. E as pesquisas, por sua vez, priorizam abordagens que contribuem para a conservação da biodiversidade e a melhoria da qualidade de vida dos povos e comunidades tradicionais (MMA/SBF, 2009).

\subsubsection{CNUC}

O Cadastro Nacional de Unidades de Conservação - CNUC é um sistema integrado de banco de dados virtual, contendo informações padronizadas das UCs administradas pelas três instâncias de governo (federal, estadual e municipal), como também por particulares (MMA/CNUC, 2021)

A mesma lei que instituiu o SNUC (Lei 9.985, Art. 50), estabeleceu que o MMA é o responsável por organizar e manter o CNUC, com a colaboração dos órgãos gestores da Federação, dos Estados e Municípios.

'Hospedado' no site do MMA, o CNUC disponibiliza mapas com características físicas, biológicas, turísticas, gerenciais, além de dados georreferenciados das Unidades de Conservação, permitindo que qualquer pessoa tenha acesso aos resultados das ações governamentais de proteção do patrimônio biológico nacional.

\subsection{Reservas Extrativistas (RESEX)}

As Reservas Extrativistas (Resex) estão intrinsecamente relacionadas com a ocupação da Amazônia, visto que, ainda no século XIX, milhares de famílias vindas do Nordeste se instalaram naquele território, a fim de trabalhar na extração da borracha, produto pelo qual havia alta e crescente demanda, por parte dos Estados Unidos e Europa. Foi o período denominado 'ciclo da borracha', cujo auge ocorreu na virada do século, sofrendo declínio em 1920, aproximadamente (UICN, 1995). 
Em 1990, foram criadas as primeiras Resex, atendendo a reivindicação de seringueiros para conter a exploração incessante de fazendeiros nos seringais do Acre. Foi uma tentativa de recuperar a cultura e costumes dos habitantes dessas áreas e, ao mesmo tempo, complementar atividades extrativistas, de roça e criação de pequenos animais. Também reforçava a proposta de uso racional da terra, mantendo os meios de vida dos moradores e as formas tradicionais de utilização dos recursos naturais (FREITAS et al., 2018).

Com visão semelhante, para Gomes et al. (2018) a implementação de Resex está associada a movimentos sociais, em diferentes estados e diferentes períodos. Portanto, os movimentos sociais estão interligados à agenda ambiental, em ampla escala, regional ou global. Na verdade, as discussões sobre o modelo das Resex adquiriram destaque devido à preocupação da comunidade internacional com relação a ações de ameaça à preservação da biodiversidade e à perda de florestas, ao contrário do propósito de sustentar os meios de subsistência locais.

Nesse contexto, a governança fundiária da região amazônica se apresenta como grande desafio, haja vista a sua dimensão, bem como as dificuldades de acompanhamento e fiscalização das diversas atividades e atores envolvidos com as instituições responsáveis pela gestão (MACIEL et al., 2018).

O Pará, com cerca de 5 milhões de hectares de área protegida, sob administração federal, é o estado que tem a maior quantidade de terra em reservas extrativistas. Comparativamente, o Amazonas tem 3,5 milhões hectares, seguido do Acre, com 2,7 milhões de hectares de Resex federais. Amazonas e Rondônia, os dois únicos com Resex estaduais, apresentam número semelhante de terras protegidas, em torno de 1 milhão de hectares (GOMES et al., 2018).

$\mathrm{O}$ principal marco legal associado às Reservas Extrativistas é o Decreto $\mathrm{n}^{\circ}$ 98.897/1990, que, em seu parágrafo único, definiu que Reservas Extrativistas “são espaços territoriais, considerados de interesse ecológico e social, as áreas que possuam características naturais ou exemplares da biota que possibilitem a sua exploração autossustentável, sem prejuízo da conservação ambiental".

No ano 2000, a Lei 9.985, que trata da implementação do Sistema Nacional de Unidades de Conservação da Natureza [SNUC], estabeleceu critérios e normas para a criação, implantação e gestão das unidades de conservação, definindo Reserva Extrativista (Resex) como sendo

“uma área utilizada por populações extrativistas tradicionais, cuja subsistência baseia-se no extrativismo e, complementarmente, na agricultura de subsistência e na criação de animais de pequeno porte, e tem como objetivos básicos proteger os 
meios de vida e a cultura dessas populações, e assegurar o uso sustentável dos recursos naturais da unidade" (Art. 18).

A mesma lei ainda estabeleceu que, assim como as Reservas de Desenvolvimento Sustentável - RDS (que fazem parte das UCs de Uso Sustentável), as Resex são classificadas como Unidades de Conservação de uso indireto, mantendo similaridade com as terras indígenas, pois são espaços territoriais demarcados, que têm como objetivo proporcionar sustentabilidade a populações humanas (PASCUCHI, 2007).

Nesse sentido, as Resex contribuem tanto para a conservação da biodiversidade quanto para a manutenção do estilo e modo de vida dos povos e comunidades tradicionais (CAPELARI, 2017). Young e Medeiros (2018) complementam que esta categoria de UC tem o objetivo de viabilizar o uso sustentável dos recursos naturais, ao mesmo tempo em que gera renda e emprego, combate ao desmatamento e protege a biodiversidade.

Na visão de Pascuchi (2007) o objetivo primordial das Resex é a conservação ambiental, de forma a proteger a diversidade biológica existente nessas áreas. Na sua origem, o propósito das Resex é de que, além do extrativismo, as populações residentes também exerçam a agricultura de subsistência e criação de animais de pequeno porte, bem como a exploração de madeira, de forma sustentável.

De acordo com Maciel et al. (2018), as Resex foram criadas a partir de proposta inovadora, tendo em vista a política fundiária, cujos objetivos estão voltados para solução de conflitos fundiários e política ambiental, obedecendo a preceitos de sustentabilidade para a preservação dos recursos naturais.

Pascuchi (2007) destaca ainda que as atividades praticadas por populações tradicionais e indígenas contribuem para a conservação do meio ambiente nas delimitações de seus territórios. Nesse contexto, as Reservas Extrativistas (Resex), as Reservas de Desenvolvimento Sustentável (RDS), bem como as terras indígenas têm a finalidade de manter o equilíbrio ecológico do meio ambiente, propiciando a subsistência física e cultural desses povos.

$\mathrm{Na}$ concepção de Gomes et al. (2018), as Resex foram lançadas como a maior estratégia de conservação da floresta, e, ao mesmo tempo, responsáveis por proporcionar retorno econômico sustentável para a população local. Dessa forma, o modelo se tornou base consistente nas políticas florestais brasileiras, enquanto evolui e diversifica significativamente, extrapolando o conceito original. Desde a implementação das primeiras Resex, ocorreram mudanças e, agora, o modelo abrange grande diversidade de grupos sociais, com variedade de sistemas de subsistência baseados na floresta, assim como diversos nichos ecológicos, estando sob contextos políticos diferentes, em níveis estaduais e federal. 
De acordo com Capelari (2017), a criação das Resex teve a finalidade de impedir o avanço do desmatamento, o que, de fato, ocorreu, embora as taxas de desmatamento nas áreas legalmente protegidas ainda sejam preocupantes. Tal situação sugere a necessidade de ações para melhorias da gestão e governança das Reservas Extrativistas.

Nas últimas décadas, observou-se aperfeiçoamento na governança ambiental no Brasil e a criação das Resex é representativa das mudanças da lei ambiental para a Amazônia brasileira. Com isso, houve maior investimento governamental na conservação da região, com adoção de políticas inovadoras, tanto em nível federal quanto estadual (GOMES et al., 2018).

O uso da área das Resex obedece a normas contidas no Plano de Manejo ou Plano de Gestão, que estabelece as zonas de proteção integral, a zona de amortecimento e a área de uso sustentável - esta última é onde a exploração de recursos ambientais é feita, seguindo critérios sustentáveis, havendo substituição da cobertura vegetal por espécies cultiváveis, quando possível. Dessa maneira, as Resex atuam como forma de conservação ambiental, fixando normas e restrições específicas às atividades humanas, objetivando reduzir os impactos negativos sobre a área demarcada (PASCUCHI, 2007).

Entretanto, é importante observar que as Reservas Extrativistas não são solução para os problemas de proteção ou de ocupação da Amazônia, sobretudo porque, por meio de projetos diversos (principalmente da agropecuária), grande parte da sua área já está tomada. Além de apenas $20 \%$ da superfície desse território estar apto para a implementação de Resex (UICN, 1995).

Corroborando essa percepção, Capelari (2017) reconhece que o cenário positivo começou a mudar em 2012 quando o Plano de Prevenção e Controle do Desmatamento na Amazônia Legal (PPCDAM) deixou de ter a sua execução integrada e eficiente e os principais mecanismos de coordenação e controle perderam força, fazendo com que, desde então, as taxas de desmatamento estejam aumentando gradativa e significativamente a cada ano, tornando o Brasil um dos países que mais desmatam no mundo.

Freitas et al. (2018) demonstram visão semelhante quando afirmam que a demarcação territorial para conservação não assegura melhoria nas condições de vida das famílias que vivem em áreas protegidas, sobretudo quando falta suporte governamental (em qualquer instância), seja por meio de alocação de recursos ou de fiscalização das infrações contra o meio ambiente. Assim, a conclusão do autor é de que o aumento da atividade agrícola e pecuária, ao mesmo tempo em que há diminuição do extrativismo, ocorre em função da ineficiência das ações do Estado. E, por consequência, o desmatamento prolifera, como 
também as necessidades básicas das famílias residentes (alimentação, vestuário, água potável, medicamentos, escola, transporte etc.) não são atendidas.

O que faz crer que a grande demanda social dos moradores, a baixa rentabilidade, os altos custos de manutenção, bem como o baixo investimento em infraestrutura difícultam - e até impedem - a sustentabilidade das Reservas Extrativistas (FREITAS et al., 2018).

Em consenso, Capelari (2017) ressalta que apesar de o extrativismo proporcionar muitos benefícios para seus adeptos e para a proteção das florestas tropicais, a constatação da realidade aponta que a atividade apenas mantém relações de subsistência, sem apresentar avanços significativos em melhoria de bem-estar e inclusão econômica das pessoas que a praticam.

Confirmando, Freitas et al. (2018) dizem que as Resex estão condicionadas ao mercado, já que valores e produtividade dos produtos florestais não têm a mesma competitividade que outros sistemas produtivos.

A percepção sobre a importância dos recursos da floresta pode ser caracterizada por meio da análise das escolhas e trocas dos meios de subsistência das famílias locais. A respeito disso, Camilotti et al. (2020) identificaram cinco fatores que, para os autores, permitem identificar a relação com os valores relevantes para os residentes, quais sejam: humano (conhecimento, habilidades); social (confiança, redes sociais; redes de segurança, participação em associações locais); físico (equipamentos, infraestrutura); financeiro (poupança, crédito, renda); e natural (acesso à terra e seus recursos).

Contudo, Gomes et al. (2018) chama atenção para o fato de que, apesar de as Resex terem alcançado expressivo protagonismo e permanecerem no centro das discussões sobre políticas de conservação ambiental no Brasil, ainda há desafios a serem enfrentados, especialmente no sentido de manter o combate contra as sucessivas pressões sobre o desenvolvimento da Amazônia. Por outro lado, os autores acreditam que o modelo das Reservas Extrativistas ainda são uma estratégia de conservação e desenvolvimento, que garante direito à terra às comunidades extrativistas e reprime o avanço do desmatamento na região.

Em concordância, Pascuchi (2007) entende que um dos desafios para os gestores dessas áreas protegidas, nas quais é permitida a presença humana, consiste na criação e implementação de estratégias de conservação ambiental adequadas às necessidades e à qualidade de vida dos moradores.

Nesse sentido, Gomes et al. (2018) defendem que, considerando que as Resex estiveram no centro dos debates a respeito de conservação do meio ambiente com base em 
pessoas, a atualização do significado das Resex já deveria ter sido feita, diante da sua importância para futuras discussões no contexto amplo do desenvolvimento regional e da conservação da Amazônia brasileira.

Em concordância, Cooper e Kainer (2018) ponderam que, no caso das Reservas Extrativistas, os meios de subsistência estão intrinsecamente relacionados à vida dos moradores, que serão afetados por qualquer projeto ou iniciativa que envolva intervenção na floresta. Portanto, são muitos os desafios da governança sustentável do uso de áreas protegidas, pois devem equilibrar ações no sentido de promover o bem-estar da comunidade, junto com a conservação da natureza.

\subsubsection{Extrativismo}

Conforme o SNUC, extrativismo é um sistema de exploração baseado na coleta e extração, de modo sustentável, de recursos naturais renováveis (Lei 9.985, 2000).

A atividade extrativista ocupa posição relevante na economia brasileira, remonta a exploração do pau-brasil, até os dias atuais, por meio da extração de diversos produtos, principalmente na região Norte do País. A maior parte do extrativismo ocorre nas Reservas Extrativistas (Resex), nas Reservas de Desenvolvimento Sustentável (RDS) e nas Florestas Nacional e Estadual (Flona e Flota), entre as quais se destacam as Resex, onde a prática é realizada por populações tradicionais, para subsistência (YOUNG e MEDEIROS, 2018).

Embora o extrativismo seja o principal fator para criação das Resex, no entanto, o que se verifica é que, comparativamente, a economia extrativista não tem sido suficiente para competir com a produção da agricultura e pecuária, sobretudo porque não supre as necessidades dos habitantes dessas comunidades (FREITAS et al., 2018; FREITAS e RIVAS, 2014).

Nesse sentido, estudo de Freitas et al. (2018) constatou que o extrativismo se tornou renda complementar à agricultura e à pecuária e, o que deveria ser atividade principal, transformou-se em secundária. Para o autor, o extrativismo é ineficiente e, cada vez mais, está perdendo competitividade para outras opções econômicas e para a migração rural-urbana.

Young e Medeiros (2018) também avaliam que a produção extrativista no Brasil tem sido reduzida expressivamente. Dados do IBGE (2016), apontam que no período entre 2011 e 2016, o volume da produção com extrativismo decresceu $30 \%$, estimando uma perda de R\$ 10,2 bilhões.

Paralelamente, Young e Medeiros (2018) afirmam que os recursos financeiros gerados com o extrativismo têm grande importância para as famílias que moram nas áreas de proteção, 
como também para as comunidades do entorno das Unidades de Conservação, o que, para os autores, corrobora a eficácia do modelo das UCs e do cumprimento das metas definidas pelo projeto da sua criação.

Há que se salientar que os benefícios propiciados pelas UCs são direcionados a comunidades localizadas em áreas distantes dos grandes centros urbanos, que, naturalmente, experimentam maior fragilidade econômica. Portanto, as atividades extrativistas geram impacto expressivo na composição da renda familiar dos envolvidos, evidenciando o aspecto de inclusão social da extração sustentável de produtos da floresta (YOUNG e MEDEIROS, 2018).

\subsection{Empreendedorismo social}

O empreendedorismo social é um conceito que emergiu em consonância com os negócios socioambientais, pois, simultaneamente, possuem propósitos sociais e ambientais. $\mathrm{O}$ termo tem sido utilizado para definir atividades inovadoras que criam valor, que têm como foco de atuação a sociedade e parcerias envolvendo comunidade, governo e setor privado (FISCHER, 2014; IIZUKA, 2014).

Fischer (2014) observa ainda que a nomenclatura adotada reflete a diversidade de objetivos e missões dos negócios sociais, mas ressalta que o conceito de negócio inclusivo está associado a geração de renda e a garantia de acesso a bens e serviços para população de baixa renda.

Outra definição atesta que empreendedorismo social integra conceitos econômicos e sociais, sob uma nova maneira de abordar problemas sociais recorrentes e, nesse contexto, desenvolve ações empreendedoras para solução dos problemas sociais vigentes, dando suporte cívico, político, ético moral e cultural (ÁVILA et al., 2014).

O conceito de negócios sociais defendido por Comini (2016) considera que os negócios sociais, principalmente ofertados por pequenas e médias empresas e cooperativas, possibilitam inserir a população de baixa renda e as minorias no mercado formal, mais em razão da proximidade e natureza do negócio em que atuam, do que pela intencionalidade de provocar impacto social positivo. Nessa perspectiva, a população vulnerável está na função de produtores, que é o formato organizacional comumente encontrado nas comunidades extrativistas, representados por cooperativas e/ou associações locais.

Complementando, Fischer (2014) e Iizuka (2014) afirmam que empreendimentos sociais se originam, principalmente, de iniciativas voltadas à geração de ocupação e renda 
para grupos sociais vulneráveis e com poucas possibilidades de inserção no mercado de trabalho formal. Portanto, as cooperativas e os arranjos produtivos comunitários são orientados pelos preceitos da Economia Solidária, com modelos de gestão compartilhada e processos decisórios participativos.

Em consenso, Freitas et al. (2017) argumenta que as cooperativas e/ou associações representam a única saída no sentido de gerar ocupação para a população residente em reservas extrativistas.

Fischer e Comini (2012) enfatizam que, para a garantia da qualidade de vida das pessoas, o desenvolvimento sustentável deve ser vinculado à conservação dos recursos naturais para as gerações futuras, assim como deve levar em consideração a justiça social na distribuição e na utilização dos bens criados pela humanidade. Para os autores, o associativismo e o cooperativismo são oriundos da perspectiva europeia, ou seja, estão relacionados à economia social e se concentram na produção econômica, gerando trabalho e renda para pessoas e grupos sociais economicamente vulneráveis.

De acordo com Dees (1998); Fischer e Comini (2012); Comini (2016), Ávila et al. (2014) e Freitas et al. (2017), o empreendedorismo social é caracterizado como sendo uma organização criada na comunidade e pela comunidade, tendo como objetivo principal a geração de valor social para os residentes desses locais.

Baseado nessa visão, é válido ressaltar que a integração da inovação, do empreendedorismo e das finanças deve levar em conta a divisão justa e equitativa dos benefícios para promover o desenvolvimento econômico e social, enquanto mantém a conservação dos recursos naturais locais. Ao mesmo tempo, uma abordagem inovadora por parte dos governos, o apoio ao empreendedorismo, o acesso a financiamentos verdes, além de uma gestão adaptativa, no modelo bottom-up, são os principais fatores do sucesso para a sustentabilidade dos negócios verdes (UNCTAD, 2017).

Acrescente-se a isso, engajamento dos governos, de organizações multilaterais e do setor privado, que são fundamentais para o sucesso dos negócios que envolvem biodiversidade. Da mesma forma que é essencial o envolvimento e engajamento das comunidades locais nas parcerias comerciais e de negócios, uma vez que é a base para gerar confiança entre as partes integrantes da cadeia de valor (UNCTAD, 2017).

Como exemplo, pode-se citar o Centro de Empreendedorismo da Amazônia, que atua na capacitação de empreendedores, cujo foco são negócios sustentáveis nas áreas florestal, de biodiversidade e de uso do solo. É uma associação da sociedade civil, sem fins lucrativos, com objetivo de promover e articular negócios sustentáveis na Amazônia (IMAZON, 2020). 
O Centro de Empreendedorismo também apoia programas de pré-aceleração e de aceleração, com o intuito de impulsionar negócios sustentáveis naquela região, principalmente na área rural, promovendo parcerias, com participação de agências de fomento, empresas privadas, universidades, organizações socioambientais, associações, cooperativas de pequenos produtores rurais, entre outros. Essas iniciativas contribuem para o desenvolvimento das cadeias locais de valor, de modo que possam operar efetivamente na redução do desmatamento, na melhoria do progresso social da região e no progresso das comunidades (IMAZON, 2020).

Contudo, o relatório das Nações Unidas (UN, 2019) denota preocupação com a realidade, porque, apesar de o crescimento econômico ter melhorado a renda significativamente (ainda que desigual, na comparação entre os países) e ter contribuído para o bem-estar humano, econômico e social, os efeitos para a sociedade e para o meio ambiente têm sido insustentáveis.

Modelos de empreendedorismo social, representados por entidades sem fins lucrativos que comumente atuam nas Reservas Extrativistas são Cooperativas e Associações, tema do tópico seguinte.

\subsection{Associações e Cooperativas}

Associações são entidades de direito privado, que constituem a união de pessoas que se organizam para fins não econômicos e são reguladas pela Lei 10.406, do Código Civil (Art. 53-61, 2002).

Pascuchi (2007) chama atenção para o fato de que as Associações contribuem para o desenvolvimento das atividades dos pequenos produtores, o que também melhora sua competitividade diante da concorrência. Ademais, essas entidades de classe locais costumam representar nichos de mercado, possibilitando a comercialização de produtos exóticos (como os produtos nativos da Amazônia), que oferecem atrativo extra, além de serem ambientalmente e socialmente diferenciados.

De acordo com estudo do Ministério do Meio Ambiente é necessário estimular a autonomia das organizações comunitárias, como forma de promover sua autogestão. Tal situação depende do fortalecimento das associações, que contribuem para que as organizações comunitárias alcancem independência ao longo do processo de consolidação das UCs e, consequentemente, é uma maneira de dar continuidade às ações iniciadas (BRASIL, 2018). 
Nesse sentido, pequenos produtores, quando associados, têm mais oportunidades de desenvolvimento das suas atividades diante da concorrência, pelo fato de que associações locais atendem nichos de mercado, oferecendo produtos diferenciados (PASCUCHI, 2007).

Cooperativa é uma associação de pessoas que, reciprocamente, se obrigam a contribuir com bens ou serviços para o exercício de uma atividade econômica, de proveito comum, sem objetivo de lucro.

São reguladas pela Lei 5.764 (Art. 4, 1971), possuem forma e natureza jurídica própria, de natureza civil, não sujeitas a falência, constituídas para prestar serviços aos associados, distinguindo-se das demais sociedades pelas seguintes características:

I- adesão voluntária, com número ilimitado de associados, salvo impossibilidade técnica de prestação de serviços;

II- variabilidade do capital social representado por quotas-partes;

III- limitação do número de quotas-partes do capital para cada associado, facultado, porém, o estabelecimento de critérios de proporcionalidade, se assim for mais adequado para o cumprimento dos objetivos sociais;

IV- incessibilidade das quotas-partes do capital a terceiros, estranhos à sociedade;

V- singularidade de voto, podendo as cooperativas centrais, federações e confederações de cooperativas, com exceção das que exerçam atividade de crédito, optar pelo critério da proporcionalidade;

VI- quórum para o funcionamento e deliberação da Assembleia Geral baseado no número de associados e não no capital;

VII- retorno das sobras líquidas do exercício, proporcionalmente às operações realizadas pelo associado, salvo deliberação em contrário da Assembleia Geral;

VIII- indivisibilidade dos fundos de Reserva e de Assistência Técnica Educacional e Social;

IX- neutralidade política e indiscriminação religiosa, racial e social; X- prestação de assistência aos associados e, quando previsto nos estatutos, aos empregados da cooperativa;

XI- área de admissão de associados limitada às possibilidades de reunião, controle, operações e prestação de serviços.

Especificamente nas cooperativas constituídas por extrativistas, podem ingressar pessoas jurídicas que pratiquem as mesmas atividades econômicas das pessoas físicas associadas ( $\$ 2^{\circ}$, Art. 29). 
Como afirma Menegário (2000), a cooperação sempre fez parte da sociedade. Teve origem a partir da necessidade de sobrevivência, fomentando o agrupamento de indivíduos, a fim de que, com suas ideias e trabalho, buscavam realizar seus objetivos.

Para Araújo (2011), os princípios cooperativistas determinam que a pessoa é o foco do benefício organizacional, o que torna o homem o objetivo e não os mecanismos de lucro.

No Brasil, o cooperativismo teve influência europeia, sobretudo do estado do Rio Grande do Sul, que, historicamente, abriga muitos imigrantes de países da Europa. O movimento cresceu, na medida em que as cidades e povoações foram se desenvolvendo e passaram a produzir mais (GIACOMIN, 2018).

Para a Organização das Cooperativas Brasileiras (OCB, 2020), cooperativa é uma organização em que os integrantes se unem em torno de um mesmo objetivo e todos são donos do próprio negócio. É um ciclo que proporciona ganhos para as pessoas, para o país e para o planeta.

Com visão semelhante, Giacomin (2018) argumenta que o cooperativismo contribui para o desenvolvimento econômico e social de um país, pois abrange todos os segmentos, direta ou indiretamente. Além disso, o cooperativismo se renova, principalmente em períodos de crise, quando as pessoas buscam amparo para enfrentar as dificuldades, tendo importância não somente na constituição jurídica, mas também no ato social.

Enquanto nas empresas tradicionais, as questões econômicas são prioritárias, no que se trata de gerenciamento e mensuração, já nos modelos de negócios com base social, as questões de desempenho econômico são focadas no ponto de vista da perenidade e equilíbrio. Neste caso, o pilar econômico é fundamental para o crescimento e perenidade da cooperativa e, por consequência, do associado (VIANA, VACCARO e VENZKE, 2018).

Para Naves (2007), as cooperativas de crédito rural dispõem de mecanismos e instrumentos operacionais que são mais adequados para a oferta de crédito, se comparadas a bancos comerciais. Isso, porque apresentam menos despesas operacionais, estão mais próximas do seu público-alvo, além de estarem em melhor posição para monitorar a aplicação dos recursos. Ademais, os custos de transação menores decorrem do fato de que essas cooperativas são constituídas pelos próprios produtores rurais da sua região de origem, que, além de donos, são os usuários dos serviços ofertados. Também porque os riscos com relação aos associados são menores, devido à forte presença de capital social, característica inerente a esse tipo de instituição (NAVES, 2007).

Em concordância, Ferreira, Gonçalves e Braga (2007) justificam que um dos motivos da eficiência das cooperativas é em razão da sua configuração societária e da estrutura de 
governança, pelo fato de que, nas cooperativas, os cooperados são donos e usuários do empreendimento.

Dessa forma, em se tratando de governança, a participação democrática é aspecto relevante nas cooperativas - os associados elegem um conselho dentre os seus membros, sendo que cada um tem direito a voto nas eleições para a diretoria e as decisões são compartilhadas (VIANA, VACCARO e VENZKE, 2018).

$\mathrm{Na}$ visão de Sabadin et al. (2008) ainda é importante atentar para o fato de que as cooperativas refletem o desenvolvimento dos setores da sua atuação e o que se observa é que o diferencial competitivo das empresas cooperativistas não se resume a somente uma característica. Daí a necessidade de conhecimento sobre as informações contábeis, pois a análise econômico-financeira é essencial para o crescimento do cooperativismo. Portanto, a necessidade de capacitação dos profissionais que atuam nesse segmento, a fim de que possam auxiliar o corpo diretivo no controle da empresa e na tomada de decisões gerenciais.

Viana, Vaccaro e Venzke (2018) complementam, ressaltando que, apesar de haver, por parte das cooperativas, grande preocupação com a sua viabilidade econômica, elas têm dificuldade para gerenciar os impactos econômicos indiretos, tais como a geração de renda e o impacto no desenvolvimento local.

Nesse sentido, a análise do desempenho econômico-financeiro das cooperativas deve levar em conta aspectos específicos, inerentes a essas entidades, portanto, a avaliação e acompanhamento do seu desempenho deve levar em conta as particularidades de cada caso (Carvalho, 2008).

Estudo de Viana, Vaccaro e Venzke (2018) constatou que, mesmo que se promova diversas práticas para incentivar o desenvolvimento sustentável por meio do cooperativismo nas comunidades em que atuam, não há gerenciamento formal, definição de metas e acompanhamento das atividades. É importante empreender esforços no sentido de estabelecer conexão entre cooperativismo e sustentabilidade - haverá benefícios para a sociedade e para as comunidades se as cooperativas e seus associados compreenderem a relevância de adotar valores e ações que os aproximem da sustentabilidade, tornando as cooperativas atuantes e promotoras do desenvolvimento sustentável.

Carvalho (2008) lembra que, em se tratando de cooperativas, a contabilidade tem importância significativa, uma vez que, além de dar suporte à gestão e às tomadas de decisão, contribui para a clareza e transparência das questões internas. Sendo assim, a disponibilização das demonstrações contábeis a todos os cooperados denota o caráter democrático e transparente do cooperativismo. 
De todo modo, em se tratando de florestas cogerenciadas, a relevância da perspectiva local é atingida somente quando os residentes dessas comunidades se envolvem formalmente nas decisões de gerenciamento dos recursos de todo o sistema (COOPER e KAINER, 2018).

\subsection{Desenvolvimento sustentável}

A terminologia 'desenvolvimento sustentável' entrou na agenda mundial a partir de alertas históricos ${ }^{1}$, a saber:

- 1972: Relatório 'Os Limites do Crescimento', também conhecido como Relatório Meadows, elaborado por pesquisadores do Clube de Roma, o relatório foi o principal objeto de discussão da Conferência das Nações Unidas sobre o Meio Ambiente - Conferência de Estocolmo, 1972.

- 1987: Relatório 'Nosso Futuro Comum', também conhecido como Relatório Brundtland, apresentado pela Comissão Mundial sobre Meio Ambiente e Desenvolvimento, foi o principal objeto de discussão da Conferência das Nações Unidas sobre o Meio Ambiente - denominada Cúpula da Terra (ou Rio-92), realizada no Rio de Janeiro, 1992.

A partir da Rio-92 foram elaborados dois importantes documentos: Agenda 21, assinado por 179 países, que pretendia ser um programa de ação (ou de intenções) abrangentes, com o objetivo de promover o 'novo' padrão de desenvolvimento, cuja essência era a sustentabilidade (ambiental). E no mesmo evento foi elaborada a 'Declaração do Rio sobre o Meio Ambiente', que estabeleceu 27 princípios envolvendo meio ambiente e desenvolvimento sustentável. O MMA (2019) definiu o documento Agenda $21^{(2)}$ como instrumento de planejamento para a construção de sociedades sustentáveis, em diferentes bases geográficas, que concilia métodos de proteção ambiental, justiça social e eficiência econômica.

\footnotetext{
${ }^{1}$ Todos os documentos históricos citados foram obtidos e podem ser recuperados no sítio eletrônico das Nações Unidades no Brasil - 'A ONU e o meio ambiente' (2020).

${ }^{2} \mathrm{O}$ documento denominado 'Agenda 21', contendo 40 capítulos, pode ser acessado, na íntegra e em português, no sítio eletrônico do Ministério do Meio Ambiente - 'Responsabillidade socioambiental' (2019). Disponível em: https://antigo.mma.gov.br/responsabilidade-socioambiental/agenda-21/agenda-21-global.html. Acessado em 12 jul. 2021
} 
O Quadro 3 apresenta resumo comparativo entre os relatórios:

Quadro 3 - Comparativo entre os relatórios Meadows X Brundtland

\begin{tabular}{|c|c|}
\hline Relatório Meadows & Relatório Brundtland \\
\hline Título: Os Limites do Crescimento & Título: Nosso Futuro Comum \\
\hline $\begin{array}{l}\text { Elaborado por equipe de pesquisadores do } \\
\text { MIT (Instituto de Tecnologia de } \\
\text { Massachusetts), sob a encomenda do Clube } \\
\text { de Roma. }\end{array}$ & $\begin{array}{l}\text { Elaborado por uma comissão da ONU, } \\
\text { composta por múltiplas nacionalidades. }\end{array}$ \\
\hline $\begin{array}{l}\text { Tese principal: colapso entre crescimento } \\
\text { populacional e recursos naturais (base na lei } \\
\text { da escassez de recursos). }\end{array}$ & $\begin{array}{l}\text { Tese principal: possibilidade de crescimento } \\
\text { econômico alinhado com a questão ambiental, } \\
\text { baseado no uso racional dos recursos, com } \\
\text { base nos preceitos de conservação, } \\
\text { preservação e proteção. }\end{array}$ \\
\hline $\begin{array}{l}\text { Apresentou como solução o conceito de } \\
\text { Crescimento Zero: congelar o crescimento, ou } \\
\text { seja, conter o crescimento econômico para } \\
\text { garantir a estabilização econômico-ecológica. }\end{array}$ & $\begin{array}{l}\text { Apresentou como solução o conceito de } \\
\text { Desenvolvimento Sustentável: acelerar o } \\
\text { crescimento com base tecnológica, utilizando } \\
\text { mecanismos de 'desenvolvimento limpo'. }\end{array}$ \\
\hline $\begin{array}{l}\text { Principais críticas: visão pessimista, caráter } \\
\text { catastrófico; subestimação do progresso } \\
\text { tecnológico; metodologia fraca e tendenciosa. }\end{array}$ & $\begin{array}{l}\text { Principais críticas: visão otimista, caráter } \\
\text { vago e difuso; utiliza o conceito como } \\
\text { artificio ideológico para atender à hegemonia } \\
\text { do neoliberalismo. }\end{array}$ \\
\hline Panorama mundial bipolar: Guerra Fria. & mundial multipolar: Globalização. \\
\hline
\end{tabular}

Fonte: Adaptado pela autora, com dados extraídos de Oliveira (2012)

São várias as conceituações de desenvolvimento sustentável e em que pese essa denominação ter sido apresentada anteriormente, em 1980, num trabalho intitulado "Estratégia de Conservação Mundial", no Programa das Nações Unidas para o Meio Ambiente, o termo se tornou público e reconhecido a partir do Relatório Brundtland, em 1987, no qual foi estabelecido que desenvolvimento sustentável é aquele que permite o atendimento das necessidades da geração presente, sem comprometer o atendimento das necessidades das gerações futuras (VAN BELLEN, 2004; BRUNDTLAND e KHALID, 1991).

No conceito apresentado no Relatório Brundtland, verifica-se intrínseca relação entre desenvolvimento sustentável, inclusão social e equidade social, pois estabelece dois conceitos-chave na sua definição. O primeiro - 'necessidades' - está vinculado às necessidades essenciais dos pobres, enquanto o segundo - 'limites' - diz respeito à imposição de que o estado da tecnologia e da organização social devem atender às necessidades presentes e futuras (FERREIRA PIMENTA E NARDELLI, 2016).

Mais tarde, o termo Desenvolvimento Sustentável foi oficialmente adotado pela ONU (2015), a partir dos seguintes eventos mundiais: 
- 2012: Conferência da ONU sobre Desenvolvimento Sustentável, no Rio de Janeiro, conhecida como Rio+20 que resultou no Relatório 'O Futuro Que Queremos'; e

- 2015: Cúpula das Nações Unidas sobre o Desenvolvimento Sustentável, em Nova York, evento em que 193 países adotaram a Agenda 2030, que elaborou um conjunto de 17 Objetivos de Desenvolvimento Sustentável, denominados de ODS, apresentados no Quadro 4, a seguir:

Quadro 4-Objetivos do Desenvolvimento Sustentável - Agenda 2030 17 Objetivos de Desenvolvimento Sustentável

Objetivo 1. Acabar com a pobreza em todas as suas formas, em todos os lugares.

Objetivo 2. Acabar com a fome, alcançar a segurança alimentar e melhoria da nutrição e promover a agricultura sustentável.

Objetivo 3. Assegurar uma vida saudável e promover o bem-estar para todos, em todas as idades.

Objetivo 4. Assegurar a educação inclusiva e equitativa e de qualidade, e promover oportunidades de aprendizagem ao longo da vida para todos.

Objetivo 5. Alcançar a igualdade de gênero e empoderar todas as mulheres e meninas.

Objetivo 6. Assegurar a disponibilidade e gestão sustentável da água e saneamento para todos.

Objetivo 7. Assegurar o acesso confiável, sustentável, moderno e a preço acessível à energia para todos.

Objetivo 8. Promover o crescimento econômico sustentado, inclusivo e sustentável, emprego pleno e produtivo e trabalho decente para todos.

Objetivo 9. Construir infraestruturas resilientes, promover a industrialização inclusiva e sustentável e fomentar a inovação em todas as suas formas, em todos os lugares.

Objetivo 10. Reduzir a desigualdade dentro dos países e entre eles.

Objetivo 11. Tornar as cidades e os assentamentos humanos inclusivos, seguros, resilientes e sustentáveis.

Objetivo 12. Assegurar padrões de produção e de consumo sustentáveis.

Objetivo 13. Tomar medidas urgentes para combater a mudança do clima e seus impactos.

Objetivo 14. Conservar e usar de forma sustentável os oceanos, mares e recursos marinhos para o desenvolvimento sustentável.

Objetivo 15. Proteger, recuperar e promover o uso sustentável dos ecossistemas terrestres, gerir de forma sustentável as florestas, combater a desertificação, deter e reverter a degradação da terra e deter a perda de biodiversidade.

Objetivo 16. Promover sociedades pacíficas e inclusivas para o desenvolvimento sustentável, proporcionar o acesso à justiça para todos e construir instituições eficazes, responsáveis e inclusivas em todos os níveis.

Objetivo 17. Fortalecer os meios de implementação e revitalizar a parceria global para o desenvolvimento sustentável.

Fonte: Adaptado pela autora, com dados extraídos de ONU (2015) 
A associação do conceito de desenvolvimento sustentável à questão social resultou em diversas concepções, sem consenso, sobre a terminologia 'sustentabilidade', o que, por consequência, gerou uma variedade de reflexões sobre os ODS (VAN BELLEN, 2004).

$\mathrm{Na}$ visão de Costanza (1991), o desenvolvimento sustentável apresenta relação dinâmica entre o sistema econômico e o sistema ecológico, sendo que a sustentabilidade significaria o equilíbrio entre os dois aspectos, de modo a assegurar que o crescimento e desenvolvimento da vida humana não destrua a diversidade, a complexidade e as funções do sistema ecológico.

Em se tratando de ambiente organizacional, destaque-se os três pilares do desenvolvimento sustentável, inseridos na pauta das discussões da Conferência das Nações Unidas em Joanesburgo em 2002 (conhecida como Rio+10) - o modelo, chamado Triple Bottom Line ${ }^{3}$, foi criado por Elkington (2001), a fim de medir a sustentabilidade em três aspectos: desempenho econômico, desempenho social e desempenho ambiental.

Em complemento, Froehlich (2014) resumiu as diferentes percepções conceituais de alguns autores, sobre as dimensões do desenvolvimento sustentável e/ou sustentabilidade, como mostra o Quadro 5, a seguir:

Quadro 5-Conceitos sobre Desenvolvimento Sustentável

\begin{tabular}{|l|l|}
\hline \multicolumn{1}{|c|}{ Conceitos } & \multicolumn{1}{|c|}{ Referência } \\
\hline $\begin{array}{l}\text { O desenvolvimento sustentável é um processo para alcançar o } \\
\text { desenvolvimento humano de forma inclusiva, equitativa, conectada, } \\
\text { segura e prudente. }\end{array}$ & $\begin{array}{l}\text { GLADWIN, T. N.; KRAUSE, } \\
\text { Tara-Shelomith; } \\
\text { KENNELLY, J. J. (1995) }\end{array}$ \\
\hline $\begin{array}{l}\text { O desenvolvimento sustentável pode ser interpretado como um } \\
\text { processo de mudança, em que a exploração de recursos, a direção dos } \\
\text { investimentos, a orientação do desenvolvimento tecnológico e as } \\
\text { alterações institucionais são realizadas de maneira consistente em } \\
\text { relação às necessidades atuais e futuras. }\end{array}$ & BANERJEE, S. B. (2002) \\
\hline $\begin{array}{l}\text { O conceito de sustentabilidade induz a um novo modelo de gestão de } \\
\text { negócios que leva em conta, no processo de tomada de decisão, além } \\
\text { da dimensão econômica, as dimensões social e ambiental. A empresa } \\
\text { sustentável é aquela que gera lucro para os acionistas, ao mesmo } \\
\text { tempo em que protege o meio ambiente e melhora a vida das pessoas } \\
\text { com quem mantém interações. }\end{array}$ & $\begin{array}{l}\text { SAVITZ, A. W.; WEBER, K. } \\
\text { (2007) }\end{array}$ \\
\hline
\end{tabular}

Fonte: Adaptado pela autora, com dados de Froehlich (2014, p. 156)

Os construtos 'sustentabilidade' e 'desenvolvimento sustentável' são polissêmicos, contemplam diversas interpretações e carecem de consolidação e aprimoramento conceitual (Freitas, 2003). Nesse sentido, Boff (2015) adverte para o uso político-econômico da

\footnotetext{
${ }^{3}$ As dimensões do Triple Bottom Line também são comumente denominadas de três Ps: person, planet e profits.
} 
expressão 'Desenvolvimento Sustentável', que está associado à perspectiva desenvolvimentista do capital baseado na satisfação das necessidades humanas, visão esta, ainda conservadora e apegada a um padrão de consumo específico.

Em seu livro mais recente, Elkington (2020) afirma que o modelo Triple Bottom Line está ultrapassado, sendo necessário uma abordagem mais abrangente, envolvendo questões sistêmicas, criando o conceito de 'cisne verde', uma espécie de espiral positivo que inicia uma profunda mudança de mercado catalisado por mudanças de paradigmas, modelos mentais, tecnologias, modelos de negócios e outros fatores-chaves.

Em seguida, são apresentadas considerações sobre o termo sustentabilidade, no que se refere ao meio ambiente, bem como outros conceitos relacionados.

\subsection{Sustentabilidade}

O conceito 'sustentabilidade' surgiu há quase três séculos, da percepção acerca da lei da escassez, conceito econômico básico que diz respeito a não existência quantitativa dos recursos para o atendimento das necessidades econômicas e do questionamento 'como administrar a escassez?'.

A expressão 'administração sustentável' foi utilizada em um tratado científico sobre a sustentabilidade das florestas com o título "Silvicultura Econômica", publicado em 1713, que foi traduzida pelos ingleses como "produção sustentável". A obra de Carl von Carlowitz influenciou grupos científicos, entre eles o Clube de Roma, que encomendou o Relatório 'Os Limites do Crescimento' na década de 1970, que, já naquela época, tratava do dilema entre o crescimento populacional acelerado, em face dos recursos naturais limitados (BOFF, 2015; ANTUNES e DE QUEIROZ, 2017).

Baseado em pesquisas bibliográficas constatou-se que os construtos de desenvolvimento sustentável e sustentabilidade, mesmo interdependentes, originam de fontes históricas semelhantes: década de 1970, com o Relatório 'Os Limites do Crescimento' também conhecido como Relatório Meadows; e década de 1980, com o Relatório 'Nosso Futuro Comum', ou Relatório Brundtland.

Pascuchi (2007) destaca que conservar o meio ambiente exige planejamento, a fim de assegurar suas potencialidades e sensibilidades e prevenir contra riscos e ameaças à qualidade de vida das sociedades humanas e demais formas de vida que devem ser preservadas. Assim, desenvolvimento sustentável diz respeito a ações e iniciativas com objetivo de manter os estoques 
de recursos renováveis e a qualidade ambiental, de forma que atenda às necessidades das gerações atuais e futuras.

O conceito sustentabilidade surgiu na Conferência das Nações Unidas, que ficou conhecida como Rio+10, ocorrida em 2002, na cidade de Joanesburgo (África). As conclusões do evento consolidaram a ideia de que os elementos qualificadores da sustentabilidade, ou as suas dimensões - social, econômica, ecológica e espacial -, não possuem hierarquia entre si (BODNAR, FREITAS e SILVA, 2016).

As publicações posteriores a esses marcos históricos, especificamente sobre a questão da sustentabilidade, foram tentativas de aprofundamento da terminologia e caracterização das suas dimensões. No Quadro 6, as referências associadas ao tema:

Quadro 6-Dimensões da Sustentabilidade

\begin{tabular}{|l|l|}
\hline \multicolumn{1}{|c|}{ Autores } & \multicolumn{1}{|c|}{ Dimensões } \\
\hline Sachs (1993) & $\begin{array}{l}\text { Econômica, Social, Ecológica, Cultural e } \\
\text { Espacial. }\end{array}$ \\
\hline OECD (1993) & $\begin{array}{l}\text { Econômica, Social, Ambiental e } \\
\text { Institucional. }\end{array}$ \\
\hline Elkington (1997) & Econômica, Social e Ambiental. \\
\hline Pawlowski (2008) & $\begin{array}{l}\text { Econômica, Social, Ambiental, Moral, } \\
\text { Legal, Técnica e Política. }\end{array}$ \\
\hline Agenda 2030 (2015) & Econômica, social e ambiental. \\
\hline Elkington (2020) & Ambiental, social e econômica. \\
\hline
\end{tabular}

Fonte: Adaptado pela autora, com dados extraídos de Froehlich (2014, p. 161).

Sachs (1993) definiu desenvolvimento sustentável como fim, e sustentabilidade, como meio, afirmando que todo planejamento, que pretende alcançar o desenvolvimento sustentável, deve analisar a sustentabilidade sob cada um destes aspectos:

1) Sustentabilidade Social: obtida a partir de processo de desenvolvimento sustentável, baseado na visão de uma sociedade 'boa', com maior equidade na distribuição de renda, de forma a reduzir o abismo entre os padrões de vida dos ricos e dos pobres.

2) Sustentabilidade Econômica: obtida a partir da criação de processo de alocação e gerenciamento eficientes dos recursos e de fluxo constante de investimentos públicos e privados, considerando ponto de vista macroeconômico.

3) Sustentabilidade Ecológica: obtida a partir do uso racional dos recursos naturais, o uso de mecanismos (novas tecnologias) que possam intensificar o uso potencial dos ecossistemas, com o mínimo de impacto aos sistemas de sustentação da vida, 
inclusive com a limitação do consumo de recursos renováveis e não renováveis, além da definição de normas de proteção ambiental.

4) Sustentabilidade Espacial: obtida a partir de configuração rural-urbana equilibrada, como também da melhor distribuição territorial de assentamentos humanos e atividades econômicas.

5) Sustentabilidade Cultural: obtida a partir de processos de modernização agrícola, que permitam manter a cultura local.

A esses aspectos, a Organização para Cooperação e Desenvolvimento Econômico [OCDE] inseriu a dimensão 'institucional', acrescentando transversalidade às demais, uma vez que abrange governos, legislação, organizações e sociedade civil (FROEHLICH, 2014).

Pawlowski (2008) acrescenta que, além das dimensões reconhecidas do desenvolvimento sustentável (ecológica, social e econômica), existem mais dimensões: a dimensão moral, fundada na responsabilidade da humanidade pela natureza e na crítica do poder tecnológico humano, destrutivo para a humanidade e para a natureza, o que conduz a reflexão sobre o direito universal à existência; a dimensão técnica, que surge do contraditório: se por um lado, o desenvolvimento de novas tecnologias (incluindo a própria indústria) contribui para a degradação do meio ambiente, é justamente no nível técnico que são implementadas estratégias fundamentais para a proteção ambiental.

Existe ainda a dimensão legal, intrínseca a todas que se referem ao desenvolvimento sustentável, porém é mais evidente na dimensão econômica, por exemplo, no que diz respeito à imposição de taxas e impostos, aplicados devido à descarga de poluentes no meio ambiente, que configura o princípio do 'poluidor-pagador' (PAWLOWSKI, 2008).

Nesse caso, a Política Nacional do Meio Ambiente determina medidas de conservação, melhoria e recuperação da qualidade ambiental favorável à vida, de maneira a garantir o desenvolvimento socioeconômico, a segurança nacional e a dignidade da vida humana (PASCUCHI, 2007).

Por fim, a dimensão política diz respeito à força e influência política na elaboração de estratégias de desenvolvimento sustentável em níveis mundial, regional e local (PAWLOWSKI, 2008).

Elkington (1997) apresentava sua versão da dimensão sustentável em que as empresas deveriam contribuir continuamente com a sustentabilidade pois necessitam de mercados estáveis e de habilidades tecnológicas, financeiras e gerenciais para atingirem um 
desenvolvimento sustentável. O autor enfatiza uma performance de integração entre a dimensão econômica, a dimensão social e a dimensão ambiental.

A versão mais atualizada do desenvolvimento sustentável de Elkington (2020) enfatizava a necessidade de uma visão sistêmica, em que a dimensão ambiental é a dimensão que engloba a dimensão social e econômica, ultrapassando a visão compartilhada entre as dimensões.

A Figura 4 apresenta a evolução das visões, em que na abordagem mais moderna, os negócios servem à sociedade e ambos estão contidos e dependem do meio ambiente, portanto, devem proteger e regenerar o ambiente natural, em seu sentido mais amplo (ELKINGTON, 2020).

Figura 4 - Dimensão econômica, social e ambiental

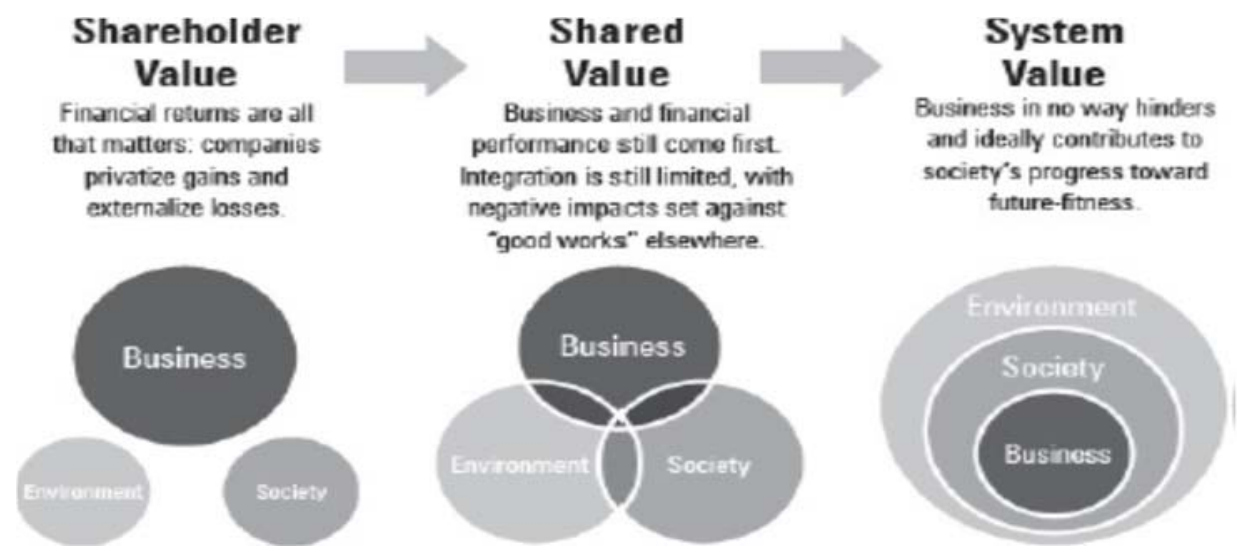

Fonte: Elkington (2020, página 135).

Em termos práticos, a $10^{\mathrm{a}}$ Conferência das Partes da Convenção sobre Diversidade Biológica [COP-10], ocorrida em Nagoya, cidade do Japão, previa que 17\% das áreas terrestres e de águas continentais, assim como $10 \%$ de áreas marinhas e costeiras, deveriam ser conservadas, utilizando sistemas de áreas protegidas, com gestão equitativa, com representatividade ecológica. No caso do Brasil, sabe-se que as metas não foram alcançadas e ainda será necessário implementar grandes esforços em vários biomas, onde a cobertura está longe do que foi estabelecido na 'Convenção de Nagoya' (YOUNG e MEDEIROS, 2018).

Nesse contexto, os dezessete Objetivos do Desenvolvimento Sustentável podem ser integrados às dimensões social, econômica e ambiental, permitindo uma rota para a conciliação entre os construtos de Desenvolvimento Sustentável e Sustentabilidade. O Quadro 7 apresenta uma proposta para essa integração: 
Quadro 7 - Integração entre as Dimensões e os ODS

\begin{tabular}{|c|c|}
\hline Dimensões & Objetivos de Desenvolvimento Sustentável \\
\hline Social & $\begin{array}{l}\text { Objetivo 1. Acabar com a pobreza em todas as suas formas, em todos os lugares. } \\
\text { Objetivo 2. Acabar com a fome, alcançar a segurança alimentar e melhoria da } \\
\text { nutrição e promover a agricultura sustentável. } \\
\text { Objetivo 3. Assegurar uma vida saudável e promover o bem-estar para todos, em } \\
\text { todas as idades. } \\
\text { Objetivo 4. Assegurar a educação inclusiva e equitativa e de qualidade, e promover } \\
\text { oportunidades de aprendizagem ao longo da vida para todos. } \\
\text { Objetivo 5. Alcançar a igualdade de gênero e empoderar todas as mulheres e } \\
\text { meninas. } \\
\text { Objetivo 7. Assegurar o acesso confiável, sustentável, moderno e a preço acessível } \\
\text { à energia para todos. } \\
\text { Objetivo 10. Reduzir a desigualdade dentro dos países e entre eles. } \\
\text { Objetivo 16. Promover sociedades pacíficas e inclusivas para o desenvolvimento } \\
\text { sustentável, proporcionar o acesso à justiça para todos e construir instituições } \\
\text { eficazes, responsáveis e inclusivas em todos os níveis. }\end{array}$ \\
\hline Econômica & $\begin{array}{l}\text { Objetivo 8. Promover o crescimento econômico sustentado, inclusivo e sustentável, } \\
\text { emprego pleno e produtivo e trabalho decente para todos. } \\
\text { Objetivo 9. Construir infraestruturas resilientes, promover a industrialização } \\
\text { inclusiva e sustentável e fomentar a inovação. } \\
\text { Objetivo 12. Assegurar padrões de produção e de consumo sustentáveis. } \\
\text { Objetivo 17. Fortalecer os meios de implementação e revitalizar a parceria global } \\
\text { para o desenvolvimento sustentável. }\end{array}$ \\
\hline Ambiental & $\begin{array}{l}\text { Objetivo 6. Assegurar a disponibilidade e gestão sustentável da água e saneamento } \\
\text { para todos. } \\
\text { Objetivo 11. Tornar as cidades e os assentamentos humanos inclusivos, seguros, } \\
\text { resilientes e sustentáveis. } \\
\text { Objetivo 13. Tomar medidas urgentes para combater a mudança do clima e seus } \\
\text { impactos. } \\
\text { Objetivo 14. Conservar e usar de forma sustentável os oceanos, mares e recursos } \\
\text { marinhos para o desenvolvimento sustentável. } \\
\text { Objetivo 15. Proteger, recuperar e promover o uso sustentável dos ecossistemas } \\
\text { terrestres, gerir de forma sustentável as florestas, combater a desertificação, deter e } \\
\text { reverter a degradação da terra e deter a perda de biodiversidade. }\end{array}$ \\
\hline
\end{tabular}

Fonte: Adaptado pela autora, com dados extraídos de ONU (2015)

Notadamente, as empresas demonstram dificuldade para aplicar os princípios da sustentabilidade no seu negócio, o contrário das cooperativas, que, em sua essência são voltadas para o desenvolvimento social e econômico de determinadas categorias profissionais, localidades/comunidades ou atividades, em muitos casos, associadas ao meio ambiente. Há grande convergência de temas entre cooperativismo e sustentabilidade e, por definição, o propósito das cooperativas é manter o equilíbrio entre o desenvolvimento econômico o bemestar da comunidade a que está vinculada (VIANA, VACCARO e VENZKE, 2018). 
Contudo, Viana, Vaccaro e Venzke (2018) alertaram para o fato de que, embora, no geral, a responsabilidade socioambiental seja considerada parte dos valores do cooperativismo, há visão contrária, dizendo que a relação é fraca. Nesse sentido, há que se registrar que, mesmo tendo forte ligação com o meio rural, as cooperativas podem enfrentar o dilema entre desenvolvimento rural e a preservação ambiental.

Em abordagem semelhante, a pesquisa de Castelani (2013), realizada na Amazônia, identificou situação igualmente contraditória entre o crescimento urbano e o desenvolvimento socioeconômico: se, por um lado, a urbanização e o crescimento da população pareceram promover progresso econômico em uma das regiões mais pobres do Brasil, por outro, isso também causou altos níveis de desmatamento local. A situação sugere que novas soluções para conservação da floresta precisam ser criadas e implementadas, em associação com políticas de conservação, tais como aumento de reservas legais ou a criação de parques nacionais ou outros tipos de áreas de conservação.

Castelani (2013) reforça o fato de que estudos tendem a priorizar a perspectiva das indústrias, levando em conta que a maioria das pesquisas aborda os incentivos fiscais que são oferecidos pelos governos locais, o que seria uma falha, porque deixam de considerar os efeitos do lado da demanda da economia. O autor acredita que a literatura deveria levar em conta os impactos no desenvolvimento local, o crescimento da demanda regional e outros aspectos derivados das solicitações de brasileiros e amazonenses no atual contexto, com intuito de dar tratamento apropriado ao relacionamento entre o desenvolvimento econômico e o desmatamento na região.

Em certa medida, estudo desenvolvido por Young e Medeiros (2018) coincide com essa visão, pois concluiu que, ao contrário da percepção de parcela da sociedade, as áreas destinadas à conservação não configuram entrave ao desenvolvimento econômico e social, já que, segundo os autores, essas áreas protegidas não são incompatíveis com outras atividades produtivas, tais como mineração, agropecuária ou geração de energia e, sim, proporcionam benefícios tangíveis para a sociedade.

Nos mesmos termos, Pascuchi (2007) argumenta que a inter e transdisciplinaridade entre as ciências tende a possibilitar a conservação ambiental e evitar a degradação da qualidade ambiental. Entre essas, está a economia, que pode promover adequação de práticas econômicas à sustentabilidade socioambiental, com vistas ao bem-estar humano. A autora defende que, como ciência, a economia pode possibilitar a coexistência entre desenvolvimento econômico e preservação do meio ambiente, adequando práticas econômicas à sustentabilidade ambiental. 
Dessa maneira, a conservação do meio ambiente não impede a paralisação das atividades econômicas, da mesma forma que a economia não ameaça os ecossistemas. Daí surgiu o conceito de desenvolvimento, que, de acordo com o Relatório Brundtland (1987), refere-se ao desenvolvimento que atende às necessidades atuais, sem comprometer a capacidade das gerações futuras de suprir suas próprias necessidades.

Nessa direção, o relatório das Nações Unidas (2019) refere a avanços com a adoção dos Objetivos de Desenvolvimento Sustentável -ODS - os dados do referido documento mostram que há países que incorporaram esses objetivos aos seus planos e estratégias nacionais e boa parte deles mencionou medidas efetivas para vincular os ODS aos seus orçamentos ou estavam considerando tal possibilidade. Também houve iniciativas direcionadas a questões ambientais, principalmente voltadas para as mudanças climáticas e uso sustentável do solo e oceanos.

Além disso, parcela significativa do setor privado se afastou dos modelos comuns de negócios, adotando ou reportando padrões de sustentabilidade. Paralelamente, cresce o envolvimento e mobilização da sociedade civil e organizações não governamentais em favor do desenvolvimento sustentável (ONU, 2019).

No entanto, o mesmo relatório faz ressalvas no sentido de que, apesar dos primeiros passos, o mundo ainda está longe de atingir as metas para cumprir os Objetivos que foram estabelecidos pela ONU em 2015. O sucesso limitado do progresso em direção aos ODS faz soar o alarme da comunidade internacional, porque muito mais ações precisam acontecer, com rapidez, a fim de viabilizar as transformações necessárias - por exemplo, políticas de impedimento devem ser revertidas ou modificadas, assim como os avanços recentes que promovem os ODS devem ser escalados de maneira acelerada (ONU, 2019).

\subsubsection{Desmatamento na Amazônia}

Capelari (2017) afirma que, desde a sua criação, as Unidades de Conservação (UCs) se tornaram a principal política de conservação da biodiversidade e de controle do desmatamento da Amazônia Legal e, de acordo com o autor, o desmatamento verificado fora dos limites das UCs tem sido maior do que o ocorrido dentro das áreas protegidas. Ainda assim, cabe ressaltar que, passados mais de 20 anos, as UCs (federais e estaduais) prevalecem como a mais importante iniciativa para conservação e controle das áreas protegidas daquele bioma.

Em oposição, Freitas et al. (2017), a partir de levantamento da produção científica sobre reservas extrativistas como modelo de política de conservação ambiental e desenvolvimento social, concluíram que a criação de Reservas Extrativistas (Resex) não reduz 
a degradação da floresta, portanto, segundo esses autores, não se pode associar as Resex a medidas de proteção ambiental, porque o modelo de gerenciamento do Estado é ineficiente, e as populações locais exploram a floresta para atendimento de necessidades básicas, na expectativa de garantir alimentação e o mínimo de serviços sociais.

Quando da criação das Resex, a expectativa era de que as instituições estatais implementariam projetos sociais (saúde, educação, aposentadoria, por exemplo) nas comunidades locais, além de outros incentivos ao processo de produção (crédito, assistência técnica, transporte, tecnologias), de forma a garantir o equilíbrio ambiental e melhoria nas condições de vida dos moradores. O que não ocorreu, visto que, decorridos quase trinta anos da criação das primeiras Resex, constata-se poucas iniciativas do governo federal no sentido de gerar melhorias e bem-estar às famílias e proteger os recursos ambientais nas áreas protegidas (FREITAS et al., 2018).

Além disso, segundo Castelani (2013), os modelos econômicos atuais sugerem que mercados maiores devem impor altos impactos sobre o desmatamento em determinada região, devido à substituição da cobertura florestal pelo uso do solo no desenvolvimento de atividades produtivas com o objetivo de atender tal demanda. Mercados localizados próximos da floresta, mesmo os menores, podem causar impactos significativos no desmatamento, já que, por conta do baixo custo de transporte e de venda dessas mercadorias, os produtos acabam sendo comercializados localmente, sem a exportação para áreas mais distantes. Dessa maneira, o autor depreende que é possível que mercados menores, e próximos, devam exercer tanto ou mais pressão ao desmatamento que os mercados maiores, mais distantes da floresta.

Em consenso, Camilotti et al. (2020) informam que vários estudos sobre a Amazônia descrevem uma ou mais dessas relações. Por exemplo, distância e tipo de acesso a centros urbanos talvez sejam o principal aspecto avaliado na definição das escolhas de meios de subsistência na região.

Outra questão discutida diz respeito à participação/inclusão dos moradores das comunidades nas decisões sobre a sua atividade. Uma das principais conclusões do estudo realizado por Cooper e Kainer (2018) foi a constatação da pouca ou nenhuma participação dos residentes na elaboração das regras e na governança dos programas de extração ou uso do solo das áreas protegidas. As autoras acreditam que mesmo um projeto de exploração legal da madeira, se planejado e implementado a partir das percepções dos residentes pode facilitar o desenvolvimento dos meios de subsistência, além de fomentar o empoderamento dos comunitários, ao invés de somente viabilizar renda adicional. No entanto, os produtores que não aderiram ao programa de extração de madeira alegaram que, mesmo com os benefícios 
previstos (renda e estradas), não eram suficientes para compensar o risco de acabar degradando as florestas e, por consequência, a garantia de seus meios de subsistência.

Sobre o mesmo contexto, Camilotti et al. (2020), acreditam que a avaliação a respeito da importância dos recursos da floresta depende de vários aspectos, desde a distância da localização das comunidades dos centros urbanos, facilidade de acesso a meios de transporte, assim como a idade e o gênero dos moradores. Outra explicação possível é o fato de que o valor da floresta em pé baixou e, sobretudo entre moradores fora das áreas protegidas, a tendência é optar por outras formas de uso do solo como maneira de não depender da floresta, o que, por consequência, faz aumentar o desmatamento na região. Para os moradores de áreas protegidas, os recursos da floresta são significativos para suas opções de meios de subsistência, funcionando como redes de segurança em períodos de escassez.

O reflexo dessa situação pode ser verificado com os dados coletados pelo Projeto de Monitoramento da Floresta Amazônica Brasileira por Satélite [PRODES] (2020a), associado ao INPE, que faz acompanhamento sistemático da taxa de desmatamento na Amazônia Legal Brasileira. Em 2019, verificou que houve concentração da degradação da floresta nos estados do Pará, Mato Grosso, Amazonas e Rondônia, que, juntos, representam 84,56\% de todo o desmatamento, conforme observado na Tabela 3 e no Mapa (FIGURA 3), a seguir.

Tabela 3 - Taxa da distribuição do desmatamento por estado da ABL

\begin{tabular}{|c|c|c|}
\hline Estado & PRODES $2019\left(\mathrm{Km}^{2}\right)$ & Contribuição (\%) \\
\hline Acre & 682 & $6,73 \%$ \\
\hline Amazonas & 1.434 & $14,16 \%$ \\
\hline Amapá & 32 & $0,32 \%$ \\
\hline Maranhão & 237 & $2,34 \%$ \\
\hline Mato Grosso & 1.702 & $16,80 \%$ \\
\hline Pará & 4.172 & $41,19 \%$ \\
\hline Rondônia & 1.257 & $12,41 \%$ \\
\hline Roraima & 590 & $5,82 \%$ \\
\hline Tocantins & 23 & $0,23 \%$ \\
\hline Amazônia Brasileira Legal (ABL) & 10.129 & $100 \%$ \\
\hline
\end{tabular}

Fonte: INPE, 2020a.

Por outro lado, Capelari (2017) relaciona alguns fatores que, na sua visão, podem ter contribuído para a redução do desmatamento na Amazônia Legal: i) criação de marcos legais e de estrutura de execução de políticas de proteção florestal; ii) mudanças no Código Florestal entre os anos 1980 e 1990 (restrições do uso do solo em áreas de florestas e definição mais assertiva dos termos 'reserva legal' e 'área de preservação permanente'); iii) promulgação da 
Lei de crimes ambientais (9.605/98); iv) Lei do SNUC (9.985/00); e x) 'Novo Código Florestal' (12.651/12). Mesmo assim, o autor destaca que as causas do desmatamento na Amazônia são bastante complexas e diversas, havendo muito a ser identificado e estudado.

Nesse sentido, o desmatamento no Brasil, sobretudo na Amazônia, tem sido objeto de muita avaliação e discussão, visto que as ações de degradação da floresta têm se sobressaído ante a sua proteção e preservação.

Relatório do MapBiomas (2020) confirma essa situação, informando que em 2019 os alertas de desmatamento originados no bioma Amazônia correspondiam a 63,2\% de toda a área monitorada, ou 770.148 hectares. O total da área desmatada no estado do Amazonas, em 2019, foi de 126 mil hectares. A Figura 5 apresenta os focos de calor das ocorrências.

Figura 5 - Mapa de calor das ocorrências de desmatamento identificadas na Amazônia Legal Brasileira

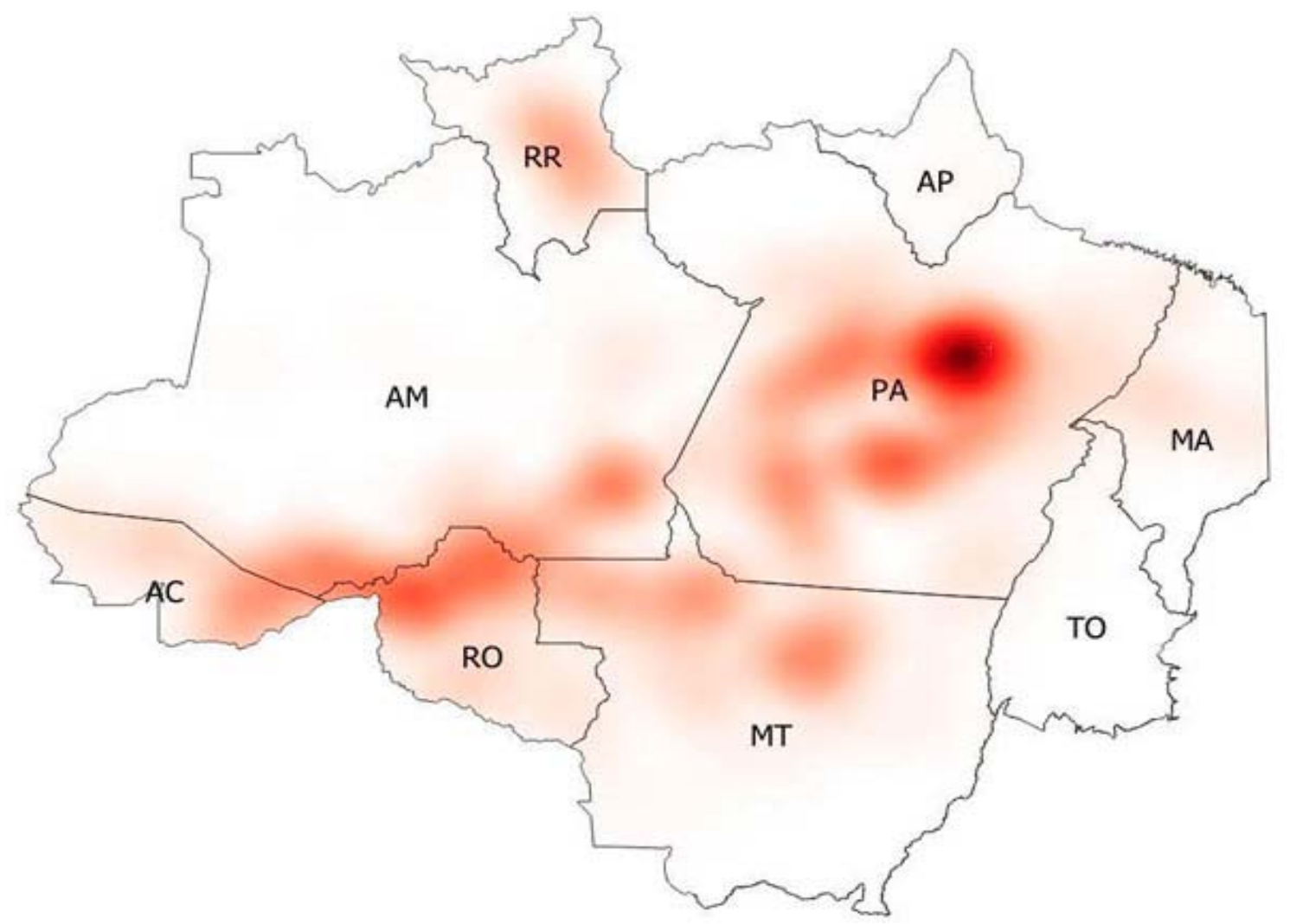

Fonte: INPE, 2020a.

Não bastasse, $92,6 \%$ do total das áreas desmatadas coincidem - completamente ou em parte - com áreas protegidas, sejam UCs $(12 \%)$, terras indígenas $(3,6 \%)$ ou imóveis rurais, constantes do Cadastro Ambiental Rural - CAR (77\%). Ainda, 55\% das áreas desmatadas sobrepõem, em algum grau, Áreas de Preservação Permanente (APP), Reserva Legal ou nascentes declaradas no CAR, portanto, são protegidas pelo Código Florestal. Esses números 
indicam que apenas $0,5 \%$ das áreas desmatadas atendem às regras de legalidade, o que, por sua vez, aponta nível de irregularidade do desmatamento no Brasil em mais de 99\% (MAPBIOMAS, 2020).

Nesse contexto, Capelari (2017) afirma que o desafio atual se torna cada vez maior, sobretudo porque, como se constata, os mecanismos de gestão ambiental, seja de comando e controle ou econômicos, não mostram efetividade. Dessa maneira, o autor indica duas alternativas possíveis para a redução do desmatamento: a criação de novos instrumentos ambientais ou a reavaliação dos instrumentos existentes, objetivando a sua adequação à situação do momento. $\mathrm{O}$ autor apresenta como principal instrumento ambiental o 'Acordo de Gestão', para servir de instrumento de gestão das Resex, o documento originalmente criado por uma instrução normativa do ICMBio, que tem por objetivo regular o uso dos recursos naturais e a ocupação do solo.

\subsection{Sustentabilidade financeira}

A avaliação da capacidade das empresas em se manterem no mercado não é preocupação recente, tendo em vista sua importância econômica para o desenvolvimento de um país. Dessa maneira, acredita-se que a sustentabilidade financeira guia a gestão das empresas à perpetuidade, já que representa a capacidade de cumprir as obrigações atuais, sem comprometer sua sobrevivência futura (BRANCO, 2013).

Outra definição diz que sustentabilidade financeira deriva da análise das demonstrações contábeis das organizações, análise de indicadores econômico-financeiros que comumente são divididas em duas categorias: análise financeira e análise econômica. A análise financeira informa a situação de liquidez e solvência das organizações, ou seja, sua capacidade financeira para pagamento das obrigações. Enquanto a análise econômica informa a capacidade de formação de riqueza e patrimônio (GITMAN, 2010; ROSS et al., 2013).

Segundo Meyer (2002), a sustentabilidade financeira de uma instituição/empresa pode ser medida em dois níveis: o primeiro se refere à sustentabilidade operacional, ou seja, quando a receita é suficiente para cobrir os custos de operação, como salários, suprimentos, perdas e outras despesas administrativas. O segundo, caracteriza a sustentabilidade financeira, que representa um patamar mais elevado, pois significa que, além dos custos operacionais, a instituição/empresa é capaz de cobrir custos de fundos e outros tipos de subsídios recebidos. 
Medir a sustentabilidade financeira requer manter a 'saúde' das contas, obedecendo práticas contábeis reconhecidas, com total transparência.

Em complemento, Brigham e Ehrhardt (2016) afirmam que o que caracteriza o valor de uma empresa é a sua capacidade de gerar fluxos de caixa no presente e no futuro, o que significa que, para ter valor para a organização, qualquer ativo financeiro precisa gerar fluxo de caixa. Sendo assim, o propósito da administração financeira é ganhar dinheiro ou agregar valor para os proprietários (ROSS et al., 2013).

Com base no levantamento bibliográfico, no Quadro 8 estão destacadas pesquisas realizadas com o tema 'Sustentabilidade Financeira'. As pesquisas chamaram atenção por terem adotado como objeto de estudo, a análise financeira de cooperativas - agrícolas/rurais ou de crédito -, que, indiretamente, está relacionada ao escopo deste projeto.

Quadro 8 - Análise financeira de Cooperativas de Crédito

\begin{tabular}{|c|c|}
\hline AUTOR & RESUMO DA PESQUISA \\
\hline $\begin{array}{c}\text { Menegário } \\
(2000)\end{array}$ & $\begin{array}{l}\text { Estudos com base em informações extraídas dos Balanços Patrimoniais e } \\
\text { Demonstrativo de Perdas e Sobras de } 31 \text { cooperativas agrícolas, localizadas no } \\
\text { estado de Paraná, utilizando indicadores econômico-financeiros para avaliação } \\
\text { financeira de cooperativas. Aplicação de análise tradicional e também modelos } \\
\text { econométricos. Conclusão: havia alto grau de endividamento e baixo grau de } \\
\text { sustentabilidade financeira. }\end{array}$ \\
\hline $\begin{array}{c}\text { Morozini, } \\
\text { Olinquevitch, e } \\
\text { Hein (2006) }\end{array}$ & $\begin{array}{l}\text { Testes em } 10 \text { cooperativas de crédito, apurando uma série de indicadores na análise } \\
\text { de balanços, com o intuito de selecionar os índices de maior relevância na análise de } \\
\text { solvência. Utilização de análise tradicional e aplicação da técnica estatística } \\
\text { descritiva. Conclusão: identificação de índices relevantes, a saber: participação de } \\
\text { capitais de terceiros; capital circulante líquido; liquidez geral; imobilização do } \\
\text { patrimônio líquido e giro do ativo. }\end{array}$ \\
\hline $\begin{array}{c}\text { Ferreira, } \\
\text { Gonçalves e } \\
\text { Braga (2007) }\end{array}$ & $\begin{array}{l}\text { Pesquisa sobre o desempenho de } 105 \text { cooperativas de crédito de Minas Gerais, } \\
\text { utilizando Análise Envoltória de Dados (DEA) e relatórios financeiros das } \\
\text { cooperativas estudadas. Conclusão: possibilidade de avaliar a situação financeira e a } \\
\text { eficiência das cooperativas de crédito, constatando que o monitoramento de } \\
\text { indicadores econômico-financeiro possibilita dimensionar a sustentabilidade desses } \\
\text { empreendimentos. }\end{array}$ \\
\hline Naves (2007) & $\begin{array}{l}\text { Estudo sobre a sustentabilidade financeira das cooperativas de crédito rural do } \\
\text { Estado de São Paulo, a partir do Balanço Patrimonial e do Demonstrativo de Perdas } \\
\text { e Sobras. Utilização de indicadores financeiros convencionais e um específico - } \\
\text { break-even sufficiency -, considerado determinante para aferir a sustentabilidade } \\
\text { financeira. }\end{array}$ \\
\hline
\end{tabular}


Continuação do Quadro 9 - Análise financeira de Cooperativas de Crédito

\begin{tabular}{|c|c|}
\hline AUTOR & RESUMO DA PESQUISA \\
\hline $\begin{array}{l}\text { Sabadin, } \\
\text { Hoeltgebaum e } \\
\text { Silveira (2008) }\end{array}$ & $\begin{array}{l}\text { Estudo sobre as tendências de desempenho das cooperativas do estado do Paraná, } \\
\text { Brasil, utilizando a análise de indicadores contábeis (Balanço Patrimonial e } \\
\text { Demonstrativo de Perdas e Sobras). Conclusão: identificação de variáveis } \\
\text { 'preditoras' da sustentabilidade financeira: eficiência econômico-financeira; } \\
\text { endividamento; tesouraria; capacidade operacional. }\end{array}$ \\
\hline Carvalho (2008) & $\begin{array}{l}\text { Pesquisa com o uso de indicadores de avaliação de desempenho de } 150 \text { cooperativas } \\
\text { agropecuárias de São Paulo, aplicando análise tradicional e testes estatísticos. A } \\
\text { análise foi aprofundada em } 3 \text { cooperativas, utilizando os indicadores de liquidez } \\
\text { corrente, liquidez geral, rotação de estoque, capital de terceiros/ativo total, margem } \\
\text { bruta, margem operacional, margem líquida, giro do ativo operacional, retorno sobre } \\
\text { o investimento e retorno do patrimônio líquido. }\end{array}$ \\
\hline $\begin{array}{c}\text { Leismann e } \\
\text { Carmona (2010) }\end{array}$ & $\begin{array}{l}\text { Análise da sustentabilidade financeira de } 1.470 \text { instituições brasileiras de } \\
\text { microfinanças, especificamente cooperativas de crédito singulares. Conclusão: } \\
\text { classificação das instituições em cinco níveis de sustentabilidade financeira - Índice } \\
\text { de Sustentabilidade Financeira Intrassetorial das Cooperativas de Crédito (Isif- } \\
\text { Créd). Utilização de escala de sustentabilidade (Precária; Baixa; Média; Alta; } \\
\text { Excelente). Aplicação da escala baseada em indicadores padronizados (Tamanho } \\
\text { (valor do ativo); Independência Financeira; Imobilização do Patrimônio Líquido; } \\
\text { Sobras/Patrimônio Líquido; Autossustentabilidade no Período). }\end{array}$ \\
\hline Araújo (2011) & $\begin{array}{l}\text { Análise de informações contábeis para determinar o risco de insolvência de } \\
\text { cooperativas de crédito, a partir de amostra com } 884 \text { organizações. Conclusão: } \\
\text { constatação da existência de influência significativa das seguintes características: } \\
\text { tipo de cooperativa; região de atuação e tamanho dos indicadores contábeis. }\end{array}$ \\
\hline $\begin{array}{l}\text { Machado e Mello } \\
\text { (2013) }\end{array}$ & $\begin{array}{l}\text { Pesquisa sobre solvência das cooperativas de crédito rural, a partir de extensa } \\
\text { revisão da literatura, com elaboração do histórico do período de } 1936 \text { a } 2012 \text { das } \\
\text { pesquisas realizadas no Brasil, que utilizaram indicadores econômico-financeiros } \\
\text { para avaliação da liquidez e da sustentabilidade financeira das organizações. }\end{array}$ \\
\hline $\begin{array}{c}\text { Viana, Vaccaro e } \\
\text { Venzke (2016) }\end{array}$ & $\begin{array}{l}\text { Diagnóstico de desempenho por meio da criação de framework da gestão de } \\
\text { sustentabilidade, considerando as especificidades de uma cooperativa de crédito. } \\
\text { Conclusão: da análise de } 95 \text { cooperativas, verificou-se que as cooperativas têm } \\
\text { ações esporádicas de sustentabilidade e que é necessária a adoção de indicadores e } \\
\text { processos de gerenciamento formais. }\end{array}$ \\
\hline $\begin{array}{l}\text { Giacomin et al. } \\
\qquad(2018)\end{array}$ & $\begin{array}{l}\text { Análise de gestão, baseada em indicadores econômicos e financeiros nas três } \\
\text { maiores cooperativas de Erechim, Rio Grande do Sul (Brasil). Foram utilizados os } \\
\text { seguintes indicadores para apuração, análise e testes estatísticos: liquidez corrente; } \\
\text { liquidez geral; liquidez seca; liquidez imediata; margem operacional; alavancagem } \\
\text { financeira; alavancagem operacional; margem líquida; retorno do patrimônio } \\
\text { líquido; participação do capital de terceiros; composição do endividamento e } \\
\text { imobilização do capital próprio. }\end{array}$ \\
\hline
\end{tabular}

Fonte: Elaborado pela autora.

A seguir, apresenta-se considerações baseadas no levantamento bibliográfico sobre o tema, decorrentes das pesquisas dos autores referenciados no Quadro 8 acima, e de outras fontes, também identificadas na literatura.

A maioria dos estudos sobre sustentabilidade estão relacionados sobretudo aos aspectos ambiental e social, mas também é citada como referência para definir situações de 
crescimento de longo prazo, também a capacidade para utilizar recursos em várias áreas, como agricultura, saúde, políticas públicas e organizações empresariais (BRANCO, 2013).

Branco (2013) enfatiza que, genericamente, o termo sustentabilidade está associado à responsabilidade organizacional com o meio ambiente, a sociedade e com acionistas (também referidos como stakeholders ou partes interessadas). E quando relacionado às empresas, a sustentabilidade contribui para redução de custos de capital, favorece a imagem institucional e satisfaz as demandas legais e de mercado.

Na visão de Barbieri (2010), a sustentabilidade de um negócio está baseada na sua capacidade de gerar recursos, remunerar a produção, repor ativos e ainda ter condições de investir, para manter a competitividade. Além desse conceito tradicional, destaque-se o modelo de organização inovadora sustentável, que busca vantagem competitiva desenvolvendo produtos, serviços, processos e negócios, novos ou modificados, com base nas dimensões social, ambiental e econômica.

Sabadin et al. (2008) acrescentam que, em mercados competitivos, a sobrevivência das empresas depende da compreensão dos seus objetivos, atividades e resultados. É importante entender a relação da empresa com os ambientes interno e externo em que atua, no que se refere ao contexto operacional, quanto ao estratégico.

Além disso, os acontecimentos no ambiente econômico, a busca por oportunidades, e os riscos inerentes, passaram a demandar mensuração e monitoramento constantes. Diante desse panorama, as demonstrações contábeis são os instrumentos para obtenção de dados e informações necessários para verificar o desempenho e 'saúde' financeira das empresas (SABADIN et al., 2008).

Sendo assim, a administração deve ter a contabilidade como principal instrumento para embasar a tomada de decisões, já que possibilita a identificação, o registro, a mensuração e análise e predição das circunstâncias econômicas que interferem no patrimônio de uma entidade. A falta de um sistema contábil eficiente, capaz de identificar oscilações da sua riqueza, pode prejudicar a continuidade de uma organização (SABADIN et al., 2008).

Estudo de Branco (2013) concluiu que, para uma empresa se manter no mercado por longo prazo, o primordial é estar preparada para enfrentar adversidades de fatores externos, desenvolver processos sucessórios adequados, bem como evitar situações que levem à sua mortalidade (por exemplo, alto endividamento, falta de rentabilidade).

Em concordância, Naves (2007) afirma que, para ser autossustentável, a empresa deve ser capaz de cobrir todos os seus custos e se manter no longo prazo - sua meta principal deve ser o gerenciamento de suas receitas e despesas. 
Ressalte-se, portanto, a importância de monitorar o desempenho das organizações, como forma de manter e assegurar a sua sustentabilidade (FERREIRA, GONÇALVES e BRAGA, 2007).

Com esses objetivos, o gestor tem à disposição várias ferramentas e indicadores, que auxiliam no estudo de viabilidade e sustentabilidade e propicia o desenvolvimento de um modelo próprio de gestão. Logo, é possível tomar decisões baseadas em fundamentação teórica, que, somada a expertise e conhecimento de mercado, podem definir o futuro da empresa (GIACOMIN, 2018).

Além dessas questões, Leismann e Carmona (2010) acrescentam que, principalmente para micro e pequenas empresas/entidades (incluídas as cooperativas), a sustentabilidade financeira depende da oferta de crédito, que, notadamente, impulsiona o desenvolvimento na maioria dos países. Para os autores, especialmente no Brasil, o desenvolvimento social e da economia (urbana e rural) depende da condição de propiciar a transferência de sobras de recursos de agentes econômicos que não pretendem investir para aqueles que têm projetos, mas não dispõem de recursos suficientes para viabilizá-los.

Machado e Mello (2013) concordam, defendendo que sobretudo as cooperativas rurais, por meio de políticas governamentais e oportunidade de crédito, exercem papel importante no desenvolvimento econômico e social, pela contribuição ao crescimento local, bem como pela inclusão financeira e social dos produtores rurais, já que proporcionam condições de permanência das famílias no campo.

É reconhecido que o crédito rural é fator importante para o desenvolvimento de produtores rurais, apesar do desequilíbrio na distribuição entre as regiões e classe de produtores brasileiras.

Historicamente, as regiões Norte e Nordeste são as que menos se beneficiam desse serviço, no entanto, verificou-se aumento na participação da Amazônia, em relação ao volume financeiro total de crédito, coincidindo com o deslocamento da agricultura e pecuária para a região Norte do Brasil.

Ainda que não esteja claro qual classe de produtor está sendo beneficiada, o fato é que, desde 2015, observa-se tendência de alta no crédito destinado à Região Norte, sendo que em 2018, a participação da região alcançou $18,53 \%$ do total de crédito distribuído no País - a Amazônia captou mais de R\$ 12 milhões do montante total distribuído por todas as regiões (R\$ 54.546 milhões). 


\subsubsection{Sustentabilidade Financeira em Resex}

Segundo a UNCTAD (2014), a subsistência está relacionada às capacidades, ativos (lojas, recursos, reivindicações, acesso) e atividades requeridas para enfrentar e se recuperar de situações de stress, ao mesmo tempo em que contribui para manter ou melhorar as capacidades e ativos. Assim, proporciona oportunidades para subsistência sustentável, inclusive por meio de outros meios de vida, em níveis local e global, em curto e longo prazos.

Em visão ampla, investir em áreas protegidas significa proporcionar retorno imediato para os brasileiros em geral, em termos de benefícios sociais e econômicos, visto que, por meio das UCs, é assegurada proteção de mananciais de água, que contribuem para regular o clima, conter erosões, ao mesmo tempo em que são ofertadas oportunidades de lazer, com apreciação de paisagens únicas, mantendo riquezas naturais e culturais, além de propiciar alternativas econômicas sustentáveis de desenvolvimento (MMA, 2020).

Dessa forma, políticas comerciais podem apoiar e promover a conservação e uso sustentável da biodiversidade, combatendo a superexploração, assim como podem viabilizar mudanças nos subsídios prejudiciais à biodiversidade (UNCTAD, 2017).

Para ser eficiente, a gestão das UCs depende sobretudo de aportes adequados e regulares de recursos financeiros e humanos. É o que possibilitará consolidação, manutenção e expansão do Sistema Nacional de Unidades de Conservação [SNUC], assim como a capacidade de o Brasil cumprir acordos e metas nacionais e internacionais de conservação do meio ambiente (MMA, 2020).

Coincidindo, a Conferência das Nações Unidas sobre Comércio e Desenvolvimento (UNCTAD, 2014), juntamente com as Iniciativas do Biocomércio [BTI], estabeleceu o termo 'biocomércio', que se refere às atividades relativas à coleta ou produção, transformação e comercialização de bens e serviços derivados da biodiversidade nativa (recursos genéticos, espécies e ecossistemas), conforme critérios de sustentabilidade ambiental, social e econômica.

As Iniciativas de Biocomércio da UNCTAD, junto com seus parceiros, têm desenvolvido cases de negócios, que demonstram que o comércio pode ser um incentivo positivo para melhorar a importância da biodiversidade em países em desenvolvimento, especialmente aqueles que abrigam grande riqueza de recursos naturais. O objetivo é gerar e valorizar a venda de produtos derivados da biodiversidade e sustentar meios de subsistência e incentivar a conservação da biodiversidade (UNCTAD, 2017).

Mas, como outras, as Iniciativas de Biocomércio dependem de estrutura política favorável e o envolvimento de vários atores, desde órgãos governamentais, do setor privado e 
da sociedade civil. É necessário, ainda, forte coordenação e regulamentação robusta, bem como requer políticas transversais, incluindo processos de planejamento e desenvolvimento, além de políticas econômicas, comerciais, ambientais e de consumo e produção sustentáveis (UNCTAD, 2017).

Em acordo, o Ministério do Meio Ambiente [MMA] estabeleceu como estratégia de sustentabilidade financeira, a reunião de esforços com o objetivo de criar e aperfeiçoar mecanismos para diagnosticar gaps de investimento no SNUC, calcular as contribuições econômicas das Unidades de Conservação (em funcionamento), além de sensibilizar os cidadãos e setor produtivo a respeito da relevância dessas áreas protegidas (MMA, 2020).

A intenção é concentrar esforços nas fontes de fomento do SNUC, cujas fontes são originadas principalmente de orçamento público e cobrança de ingresso de visitantes. Outros recursos - limitados -, destinados a unidades específicas, são provenientes de ações de compensação ambiental e de cooperação internacional.

Há ainda mecanismos com potencial de recursos para as unidades, mas dependem de critérios e procedimentos para seleção de projetos - por exemplo, fundo de áreas protegidas, concessões florestais, pagamento por serviços ambientais, aproveitamento de recursos genéticos, extrativismo e parcerias para a gestão das unidades. Outras maneiras que, indiretamente, podem contribuir para a ampliação e a consolidação do SNUC são o 'ICMS ecológico’ e o Fundo de Defesa dos Direitos Difusos (LEI 9.008, 1995).

Para o Ministério do Meio Ambiente, diante da complexidade da gestão financeira do SNUC, tanto para acesso a fontes de financiamento, quanto à limitação de disponibilização de recursos para manter seu funcionamento de forma adequada, o desafio está na formulação de políticas que conciliem a preservação ambiental e o uso sustentável dos recursos (MMA, 2020).

Corroborando esse contexto, estudo do MMA sobre a sustentabilidade financeira do SNUC deixou claro que as fontes tradicionais de financiamento das UCs, sobretudo as públicas, são essenciais, mas se mostraram insuficientes. Essa limitação orçamentária reduz a capacidade de gestão e proteção, da mesma forma que é um empecilho para a integração das UCs às dinâmicas econômicas do seu entorno. Além disso, considerando o longo prazo, a carência de recursos financeiros e humanos pode ameaçar a viabilidade dessas áreas (MMA, 2020). O que pode ser observado na distribuição dos recursos destinados ao MMA e outros ministérios, mostra a disparidade entre o orçamento da área ambiental e o das demais pastas.

Considerando que a área protegida pelo SNUC é de 1,5 milhão de $\mathrm{Km}^{2}$ do território brasileiro, incluindo UCs federais, estaduais e municipais, constata-se o grande desafio para 
um país com dimensões continentais e ampla diversidade de ecossistemas naturais e diferentes realidades econômicas, como o Brasil.

Análise de Freitas et al. (2018) confirma essa ideia, ressaltando que baixo investimento e equipe inexperiente para tratar questões complexas comprometem o bem-estar de famílias e da biodiversidade, além de, em certa medida, contribuir para o insucesso e colocar em risco o futuro do modelo de criação das reservas extrativistas.

Em visão ampliada, Young e Medeiros (2018) discutem a questão da deficiência de dados e informações sistematizadas acerca da efetividade da função das UCs no fornecimento de bens e serviços, que, de alguma forma, contribuem para o desenvolvimento econômico e social do Brasil.

Na tentativa de amenizar os efeitos dessas carências, foi criado o Sistema de Projeção de Investimentos Mínimos para a Conservação (IMC), uma ferramenta criada pelo Banco Mundial, que consiste em um conjunto de planilhas de cálculo com o objetivo de estimar os investimentos mínimos em infraestrutura e as despesas de custeio anuais para a gestão das UCs. A ferramenta é mais indicada para avaliar os investimentos mínimos necessários para um determinado grupo de UCs, mas também é possível analisar os gastos para apenas uma UC ou filtrar dados para recortes temáticos ou regionais, além de possibilitar projetar cenários futuros. Com ela, é possível detectar o nível de proteção da biodiversidade de cada país, com relação às UCs, como também pode determinar o número ideal de UCs, suficientes para proteger amostras de todos os ecossistemas e espécies nacionais, além de estimar investimento e custos, avaliando aspectos do tipo 'espécies ameaçadas', e variáveis econômicas (MMA, 2009).

Camilotti et al. (2020) contribuem, afirmando que recursos extrativos das florestas, sejam produtos madeireiros ou não, compõem a base dos meios de subsistência de várias populações da Amazônia. Dessa forma, o valor que as pessoas dão a um recurso pode revelar suas atitudes e decisões em torno da conservação ambiental e do uso das florestas e seus recursos. Nesse sentido, as mudanças nas práticas dos meios de subsistência (por falta ou por redução da abundância de alguns recursos da floresta) contribuem para a avaliação do valor que essas populações atribuem aos recursos da floresta, baseado nos seus usos e importância para a subsistência familiar.

O estudo de Camilotti et al. (2020) aponta que não é possível sobreviver somente com a renda derivada dos produtos extraídos da floresta, cujas vendas não são regulares e apenas complementam as necessidades de consumo das famílias. 
Cooper e Kainer (2018) também estudaram questão semelhante e constataram que há florestas de uso sustentável co-gerenciadas, que negociam direitos para extrair madeira, como maneira de equilibrar as necessidades da dinâmica do desenvolvimento, com metas, normas ou instituições de conservação estabelecidas, especificamente para gerar novas fontes de renda, baseadas na floresta. Ainda assim, no caso da extração de madeira, é certo que, mesmo com mecanismos e métricas de controle do desempenho e conservação de áreas protegidas, sabe-se que é inevitável que algum grau da integridade da floresta estará comprometido, qualquer que seja a quantidade de madeira extraída.

Biodiversidade e economia estão interligadas. O Banco de Desenvolvimento para a América Latina [CAF] estimou que 4\% do comércio internacional é originado de produtos e serviços relacionados à biodiversidade (UNCTAD, 2017).

Reforçando essa informação, Camilotti et al. (2020) constataram que a maioria das iniciativas de conservação na Amazônia brasileira faz uso e comercializa os recursos da floresta, associado à criação de reservas extrativistas. No entanto, o mesmo estudo apontou que, no geral, moradores da floresta (em áreas protegidas ou não) classificam como baixa a importância desses recursos naturais para geração de renda, o que indica que tal estratégia é limitada no que se refere ao objetivo de manutenção da floresta. Para os autores, somente quando a extração de recursos da floresta for economicamente compensadora, também será benéfico para a qualidade de vida da população dessas áreas, considerando o aumento de renda.

De todo modo, relatórios do governo federal destacam que as atividades econômicas sustentáveis desenvolvidas no ambiente das UCs têm papel fundamental na situação econômica das famílias, não somente no que se refere a questões financeiras da produção, mas também contribui para implementação de serviços e atividades de organização e envolvimento comunitário. Do mesmo modo, a formação de parcerias, a mobilização em torno de ajuda técnica e de comunicação fazem parte do apoio necessário à produção agroecológica nas Unidades de Conservação (MMA, 2018).

Portanto, as UCs não podem se privar de atividades econômicas, mesmo porque, uma das suas principais condições de conservação refere-se ao fato de abrigarem populações tradicionais (povos indígenas, comunidades ribeirinhas e extrativistas), cujas culturas materiais desenvolvidas demonstram que é possível compatibilizar o uso da floresta e sua preservação (ABRAMOVAY, 2019).

Maciel et al. (2018) apresentam outra situação, observando que, mesmo após mais de duas décadas da sua criação, mais da metade dos extrativistas da Resex Chico Mendes, no 
Acre, ainda não tem garantia de posse de terra. Para os autores, em termos econômicos, houve significativa redução da eficiência econômica e do nível de vida das famílias.

Ampliando a discussão das dificuldades para a sustentabilidade financeira das Resex, conforme o resultado da pesquisa de Cooper e Kainer (2018), com integrantes da Resex Chico Mendes, no estado do Acre, indicou que, após a regulamentação da extração de madeira em reservas extrativistas, a adesão de pequenos produtores da região foi influenciada pela situação econômica das famílias - os residentes locais com baixa condição econômica aderiram significativamente ao projeto $(73 \%)$, ao mesmo tempo em que a maioria daqueles com melhor condição econômica não quiseram fazer parte do programa (71\%). A principal justificativa dos apoiadores da regulamentação relacionava-se ao aspecto financeiro - $37 \%$ deste grupo. Entre os que não aderiram, 35\% se referiram a ativos naturais, ou seja, relacionados à natureza, ao meio ambiente em que vivem.

Outra situação verificada no estudo de Cooper e Kainer (2018) foi que algumas opções de uso do solo são percebidas pelos produtores locais como restritivas, o que torna mais atrativa a participação em projetos de extração de madeira, cuja remuneração é superior aos programas habituais (como os relacionados à castanha e pesca, ou da produção de farinha de mandioca), e é visto como melhor opção para reforço da renda familiar.

Por sua vez, o estudo de Maciel et al. (2018) constatou que, na última década, a renda gerada pela extração da borracha e da castanha do Pará atingiram seu limite por falta de inovação. No caso da castanha do Pará houve inovação, com a adoção de boas práticas de produção e beneficiamento, mas se mostrou insuficiente para aumentar a oferta e a qualidade do produto. Os autores complementam que esse tipo de situação está fazendo com que os produtores busquem, cada vez mais, alternativas de renda fora das unidades de conservação (inclusive trabalho assalariado), já que as atividades produtivas apresentam prejuízo, que se agrava com o tempo.

Ao mesmo tempo, as Resex também apresentam problemas para sua própria operacionalização, tais como: mercados limitados para produtos florestais, vulnerabilidade às oscilações de preços e altos custos de transação, bem como deficiência no gerenciamento, organização e transporte de produtos, agravadas pela ineficiência da atuação do poder público, o que dificulta ou impossibilita a autossuficiência econômica e, inevitavelmente, culmina em desestruturação social e econômica (FREITAS et al., 2017; MACIEL, CAVALCANTE FILHO e SOUZA, 2016; SILVA e MÜLLER, 2017). 


\section{METODOLOGIA}

A pesquisa é um processo, um procedimento racional e sistemático que proporciona respostas aos problemas, sobretudo quando não se dispõe de informações suficientes para responder aos problemas, ou, então, quando as informações disponíveis precisam ser adequadamente relacionadas aos problemas (GIL, 2002).

\subsection{Natureza e Abordagem}

Gil (2002) e Yin (2001) classificam as pesquisas em três grandes grupos: exploratórias, descritivas e explicativas.

Em relação ao objetivo geral proposto, esta pesquisa foi exploratória, pois teve como preocupação central a realização de uma análise preparatória de um assunto conhecido, mas pouco explorado no sentido de identificar os fatores que determinam ou que contribuem para a sustentabilidade financeira das comunidades extrativistas pesquisadas. Esta pesquisa buscou aprofundar o conhecimento da realidade para possibilitar estudos posteriores.

Sem embargo, a classificação da pesquisa em exploratória não exclui os demais tipos, pois não há rigorosa divisão nesta classificação, por seu termo, as pesquisas descritivas vão além da simples identificação da existência de relações entre variáveis, ela determina a natureza dessa relação, o que, de certa forma, aproxima da pesquisa explicativa. Por outro lado, há pesquisas que, embora definidas como descritivas - a partir de seus objetivos -, acabam contribuindo para proporcionar nova visão do problema, o que as aproxima das pesquisas exploratórias (GIL, 2008).

Nesse sentido, para este estudo de caso, é cabível também a classificação como descritiva, considerando a proposta para verificação da existência de relação entre as variáveis, de forma a avaliar a sustentabilidade financeira das comunidades e localidades existentes nas Resex e ainda apontar estratégias para seu fortalecimento. 
Em relação à natureza da pesquisa, esta proposta se enquadra como qualitativaquantitativa. Quantitativa, uma vez que utilizou estatística descritiva para analisar os dados da população e da produção de cada comunidade e/ou localidade da Resex Canutama; e qualitativa, porque envolveu dados descritivos e um processo de análise dedutiva por meio da análise de conteúdo dos dados coletados.

De acordo com Yin (2016) a pesquisa qualitativa possibilita estudos aprofundados a respeito de ampla variedade de temas, nos seus aspectos simples e cotidianos. Assim como permite abordar diferentes disciplinas das ciências sociais (sociologia, antropologia, ciência política, psicologia) e diferentes profissões (educação, administração, enfermagem, planejamento urbano, avaliação de programas).

Nesse sentido, o método qualitativo aplicado apresentou cinco características: i) o estudo do significado da vida das pessoas, como se apresenta na vida real; ii) a representação das opiniões e perspectivas das pessoas participantes da pesquisa; iii) a abrangência das condições contextuais em que as pessoas vivem; iv) as contribuições com revelações acerca de conceitos, existentes ou descobertos, que podem explicar o comportamento humano; v) a utilização de múltiplas fontes de evidência, ao invés de uma única fonte (YIN, 2016).

\subsection{Estratégia e Técnicas de Pesquisa}

A estratégia de pesquisa foi o estudo de caso, condizente com o problema proposto, uma vez que o objeto de análise são fenômenos contemporâneos inseridos em um contexto da vida real em que o pesquisador tem pouco ou nenhum controle, além de favorecer a compreensão das dinâmicas presentes em estruturas de análise únicas (YIN, 2001, p. 21).

Para Eisenhardt (1989) os estudos de caso são descrições ricas de eventos recentes, a partir dos quais pode haver desenvolvimento teórico indutivamente, com ênfase especial no contexto do mundo real, no qual fenômenos sociais complexos ocorrem.

\subsubsection{Estudo de caso}

O modelo de método de estudo de caso incorporado, foi o adequado para fins de suporte ao objetivo proposto, pois o estudo de caso incorporado, conforme Yin (2001), ocorre quando o estudo envolve mais de uma unidade de análise e, por isso, deve-se atentar para uma subunidade ou várias unidades incorporadas. Na pesquisa, a unidade de análise foi o espaço territorial denominado de Reserva Extrativista e as subunidades as comunidades extrativistas 
que compõem a Reserva Extrativista Estadual denominada de Resex Canutama, localizada no estado do Amazonas, no Bioma Amazônia

\subsubsection{Universo e Unidade de análise}

A delimitação das bases de investigação deste estudo baseou-se em um universo que compreende as Reservas Extrativistas federais e estaduais, localizadas no Bioma Amazônia, especificamente no estado do Amazonas, que totalizam treze reservas extrativistas ( 9 Federais e 4 Estaduais), conforme Quadro 9:

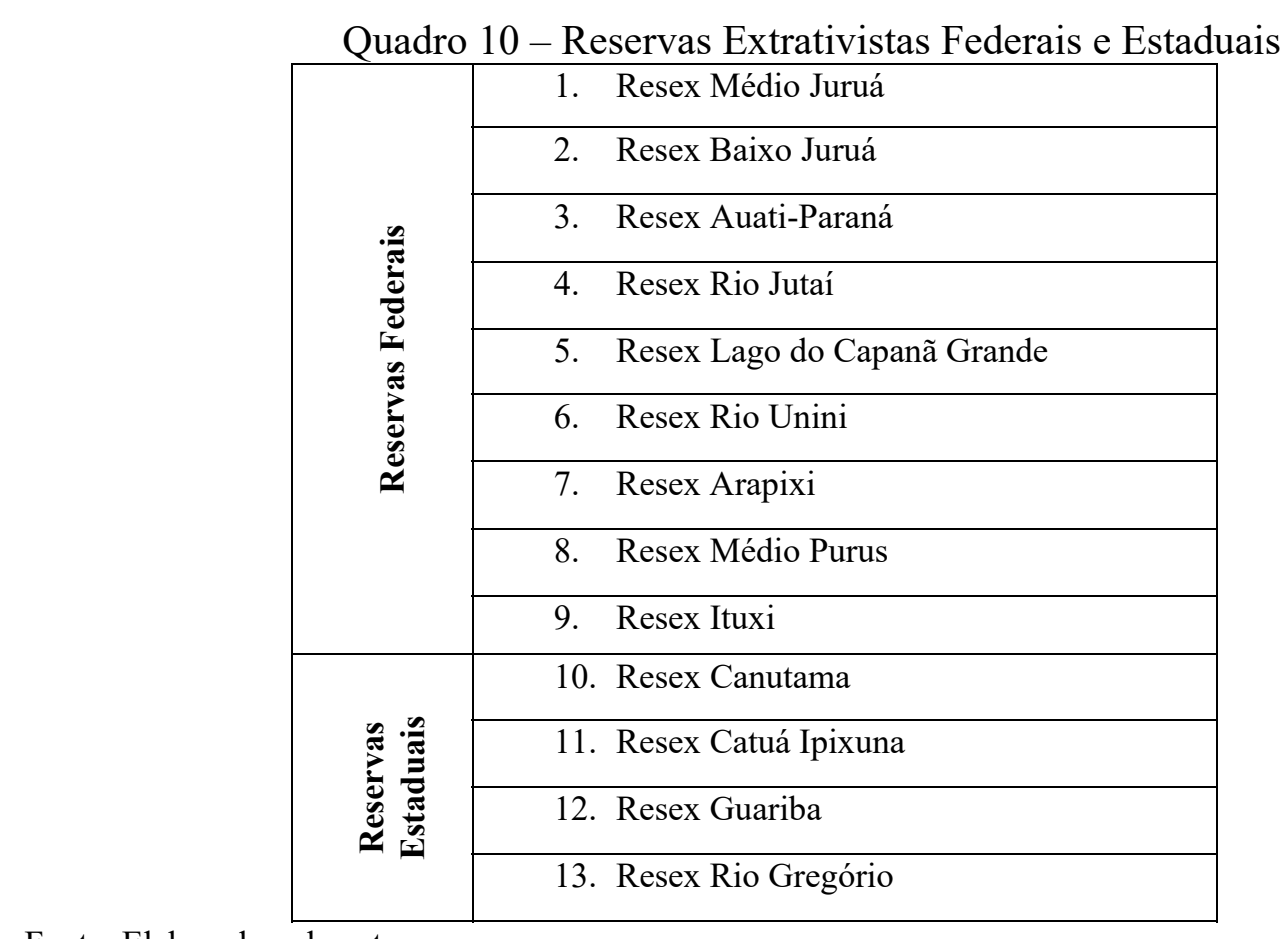

Fonte: Elaborado pela autora.

Dada a localização no Estado do Amazonas, a pesquisa concentrou-se, primeiramente, nas quatro reservas estaduais. Para a definição da unidade de análise foram considerados os dados secundários coletados no site da Secretaria de Estado de Meio Ambiente do Amazonas - SEMA, acrescidos de informações obtidas durante o processo de autorização. A seguir, são apresentadas as características das Reservas estaduais disponíveis para realização dos trabalhos, conforme dados da SEMA:

(a) Reserva Extrativista Canutama, criada em 2009, localizada nos Municípios de Canutama e Lábrea, com área de 197.986 hectares, com população estimada em 788 residentes, atividade econômica predominante o extrativismo da castanha e 
borracha e agricultura (Plano de Gestão da Reserva Extrativista Canutama, CEUC/SDS, 2014);

(b) Reserva Extrativista Catuá-Ipixuna, criada em 2003, localizada nos Municípios de Coari e Tefé, com área de 217.486 hectares, com população estimada em 1.457 residentes, com predominância da agricultura de subsistência e com poucos dados produtivos (Plano de Gestão da Reserva Extrativista Catuá-Ipixuna, CEUC/SDS, 2010);

(c) Reserva Extrativista Guariba, criada em 2005, localizada nos Municípios de Apuí e Novo Aripuanã, com área de 150.465 hectares, não há dados disponíveis do quantitativo da população residente, a Resex faz parte de um Mosaico de Unidades de Conservação do Apuí que tem como principais atividades econômicas a pecuária, exploração de pau-rosa e madeiras em geral (Plano de Gestão do Mosaico do Apuí, CEUC/SDS-WWF, 2010);

(d) Reserva Extrativista Rio Gregório, criada em 2007, localizada nos Municípios de Ipixuna e Eirunepé, com área de 305.268 hectares, com população estimada em 1.100 residentes, com poucos dados produtivos (Plano de Gestão da Reserva Extrativista Rio Gregório, CEUC/SDS, 2010).

Devido às restrições impostas pela pandemia da Covid-19, a unidade de análise escolhida foram as comunidades que fazem parte da Reserva Extrativista Estadual Canutama, que oferecia, à época, mais possibilidades de acesso e disponibilidade de informações cedidas pelo gestor da Resex.

\subsubsection{Autorização para pesquisa de campo}

A Carta de Apresentação para autorização da pesquisa foi apresentada para a Secretaria de Estado do Meio Ambiente (SEMA) no dia 03/02/2020. No dia 03/03/2020 foi autorizada visitas, pelo Departamento de Mudanças Climáticas e Gestão de Unidades de Conservação - DEMUC/SEMA, somente nas reservas extrativistas de Canutama; CatuáIpixuna e Rio Gregório, ( realização da pesquisa de campo). 
Conforme as instruções contidas na Autorização n 014/2020 - DEMUC/SEMA seria obrigatório o contato com o gestor da Resex, uma vez que o cronograma das visitas de campo deveria estar ajustado e em conformidade com a disponibilidade do gestor. Foi enviado e-mail para os gestores das três reservas, porém, somente houve retorno do gestor da Resex Canutama, Sr. Altemar Lopes.

A Reserva Extrativista Canutama possui 38 espaços territoriais, distribuídos em 16 Comunidades e 22 Localidades. O funil das etapas do estudo da unidade de análise está demonstrado na Figura 6 abaixo:

Figura 6 - Unidade de análise da pesquisa

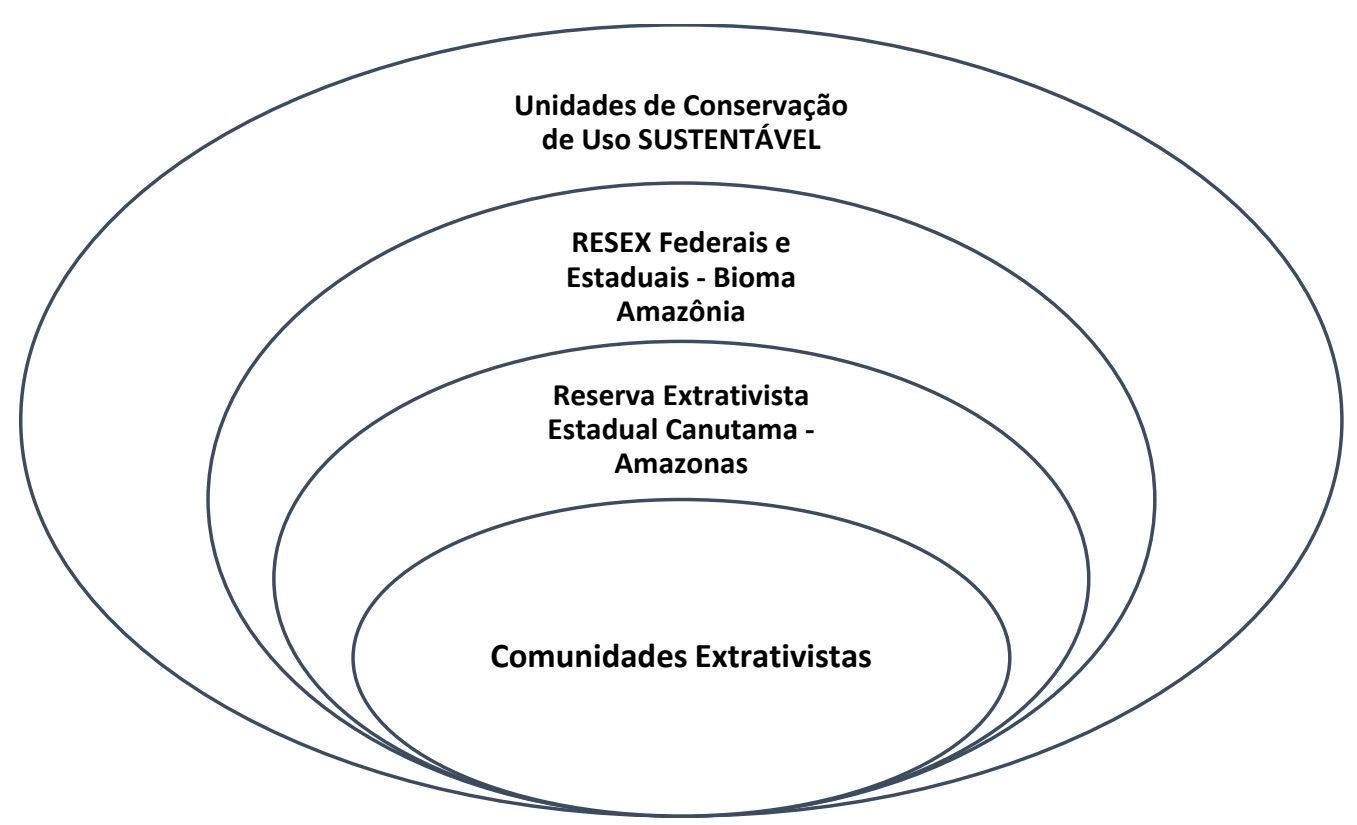

Fonte: Elaborado pela autora.

Para a abordagem quantitativa, a amostra se baseou na técnica não-probabilística e intencional, uma vez que a seleção da amostra dependeu de característica particular do universo: comunidades extrativistas acessíveis dentro da Reserva Canutama, única Resex disponível para visita conforme as regras impostas de SEMA (YIN, 2001; EISENHARDT, 1989).

\subsubsection{Instrumento de coleta dos dados}

Yin (2016) explica que em entrevistas qualitativas não há roteiro rígido, porque não há questionário com lista de perguntas e respostas pré-definidas, pelo contrário, o pesquisador 
não deve seguir conduta uniforme para todas as entrevistas, mas, sim, a partir da mentalização dos objetivos do estudo, verbalizar as abordagens (temas) de maneira diferente, conforme o contexto e o ambiente da entrevista. $\mathrm{O}$ autor reforça que, nesse método, a entrevista adota um modo conversacional, que levará à situação parecida com um relacionamento social, portanto, individualizada, para cada participante.

Para entrevistas não estruturadas não existem regras fixas, pois o desenvolvimento das perguntas depende do contexto da conversa, sendo que a sua condução e desenvolvimento fica a cargo do entrevistador. Contudo, é importante que, quanto possível, as perguntas sejam padronizadas, a fim de que as respostas obtidas possam ser comparadas entre si (GIL, 2008).

Dessa forma, para este estudo, foi elaborado um roteiro de abordagens semiestruturado, baseado nos objetivos propostos, respeitando o perfil dos entrevistados e prevendo as condições do ambiente em que vivem e considerando informações preliminares, obtidas nas primeiras coletas de dados secundários (APÊNDICE E - Roteiro das Entrevistas de Campo).

\subsubsection{Procedimentos de Coleta de dados}

A pesquisa de campo foi realizada na primeira quinzena de outubro de 2020, a equipe de coleta de dados e suporte foi formada por 3 pessoas: a pesquisadora doutoranda, uma assistente e uma enfermeira. A equipe de pesquisa saiu de Manaus para o município de Lábrea, onde se encontrou com mais duas pessoas: um piloto contratado para a lancha e o gestor da Resex.

O agendamento das entrevistas não seguiu o rito habitual (consulta, definição de data e horário etc.), devido às circunstâncias do local de moradia dos participantes - floresta amazônica. Os moradores foram informados, com antecedência, da visita da pesquisadora (e assistentes). As entrevistas foram realizadas em companhia do gestor da Resex, com todos os moradores que aceitaram participar do estudo (APÊNDICE F - Termo de Consentimento Livre e Esclarecido e Pós-Esclarecido).

A pesquisadora viajou com duas assistentes que ajudaram na realização das entrevistas. Elas foram devidamente treinadas e estavam cientes não somente das condições peculiares do ambiente/local das entrevistas, mas também do perfil dos entrevistados.

Em razão dessas circunstâncias, não houve definição antecipada da amostra. Foi possível realizar cinquenta entrevistas, com moradores de todas as oito Comunidades visitadas - no período em que ocorreram as entrevistas, as Localidades estavam desabitadas, o que impediu de haver representantes de parte desses grupos). Também foram entrevistados, o 
gestor da Resex, o presidente da Cooperativa, a presidente da associação dos agroextrativistas e o prefeito de Canutama.

Nesta mesma etapa do estudo, foi utilizada a técnica de observação participante, que é uma maneira valiosa de coletar dados, porque são os olhos e a percepção do próprio pesquisador que prevalecem, em vez de depender de filtros de relatos ou visão de outrem (YIN, 2016).

A pesquisadora e as assistentes atuaram como observadoras, momento em que notaram oportunidades para descobertas e conclusões. Foram feitos registros fotográficos e escritos, que, posteriormente e conforme a pertinência, se juntaram à análise dos dados adquiridos com as entrevistas.

Foi criado um site, totalmente gratuito, desenvolvido na base de dados da webnode para publicizar o relatório fotográfico da pesquisa. Acessar pelo link abaixo $(\mathrm{Ctrl}+$ clique para seguir o link):

\section{https://pesquisaizabelseabra.webnode.com}

\subsubsection{População pesquisada}

Em outubro de 2020 foram visitadas oito das dezesseis comunidades e realizadas 50 entrevistas com produtores extrativistas residentes na Resex Canutama. A pesquisa foi representativa de $29 \%$ e $21 \%$, respectivamente, em relação ao quantitativo de famílias residentes nas comunidades e ao total de famílias da Resex. A representatividade em relação ao número de pessoas residentes foi de $10 \%$ da população que vive nas comunidades e $7 \%$ do total da população residente na Resex Canutama. A Tabela 4 abaixo apresenta os dados:

Tabela 4 - Amostra em relação a população total e residentes nas comunidades da Resex Canutama

\begin{tabular}{lccccc}
\hline & $\begin{array}{c}\text { Amostra } \\
\text { pesquisada }\end{array}$ & $\begin{array}{c}\mathbf{N}^{\mathbf{0}} \text { de Residentes } \\
\text { em Comunidades }\end{array}$ & $\%$ & $\begin{array}{c}\mathbf{N}^{\mathbf{0}} \text { de } \\
\text { Residentes } \\
\text { na RESEX }\end{array}$ & $\%$ \\
\hline $\mathrm{N}^{\circ}$ de Famílias & 40 & 140 & $\mathbf{2 9 \%}$ & 191 & $\mathbf{2 1 \%}$ \\
$\mathrm{N}^{\circ}$ de Pessoas & 50 & 519 & $\mathbf{1 0 \%}$ & 688 & $\mathbf{7 \%}$ \\
\hline
\end{tabular}

Fonte: Elaborado pela autora.

Em relação ao quantitativo de famílias residentes e famílias entrevistadas, a pesquisa alcançou 40 de um total de 64 famílias residentes nas comunidades visitadas, atingindo uma proporção de $63 \%$ dos troncos familiares dessa população. A Tabela 5 apresenta os dados por comunidade visitada: 
Tabela 5 - Número de famílias residentes e entrevistadas na Resex Canutama (outubro/2020)

\begin{tabular}{lccc}
\multicolumn{2}{c}{ Comunidade Visitada } & \multicolumn{3}{c}{$\mathbf{N}^{\circ}$ de Famílias } \\
& Residentes & Entrevistadas & \% \\
\hline Santa Bárbara & 14 & 6 & $43 \%$ \\
Irajá & 12 & 5 & $42 \%$ \\
Carmo & 10 & 8 & $80 \%$ \\
São Jerônimo & 8 & 5 & $63 \%$ \\
Nova Vista & 8 & 6 & $75 \%$ \\
Santa Maria & 6 & 4 & $67 \%$ \\
Açaituba & 3 & 3 & $100 \%$ \\
São Tomé & 3 & 3 & $100 \%$ \\
\hline \multicolumn{1}{r}{ Total } & $\mathbf{6 4}$ & $\mathbf{4 0}$ & $\mathbf{6 3 \%}$ \\
\hline
\end{tabular}

Fonte: Elaborado pela autora.

Em relação ao quantitativo de pessoas residentes e pessoas entrevistadas, a pesquisa alcançou 50 de um total de 260 pessoas residentes nas comunidades visitadas, atingindo uma proporção de 19\% dessa população. A Tabela 6 apresenta os dados por comunidade visitada:

Tabela 6 - Número de pessoas residentes e entrevistadas na Resex Canutama (outubro/2020)

\begin{tabular}{|c|c|c|c|}
\hline \multirow{2}{*}{ Comunidade Visitada } & \multicolumn{3}{|c|}{$\mathrm{N}^{\circ}$ de Pessoas } \\
\hline & Residentes & Entrevistadas & $\%$ \\
\hline Irajá & 58 & 6 & $10 \%$ \\
\hline Santa Bárbara & 52 & 7 & $13 \%$ \\
\hline Nova Vista & 42 & 9 & $21 \%$ \\
\hline Carmo & 35 & 9 & $26 \%$ \\
\hline São Jerônimo & 30 & 5 & $17 \%$ \\
\hline Açaituba & 16 & 4 & $25 \%$ \\
\hline Santa Maria & 16 & 6 & $38 \%$ \\
\hline São Tomé & 11 & 4 & $36 \%$ \\
\hline Total & 260 & 50 & $19 \%$ \\
\hline
\end{tabular}

Fonte: Elaborado pela autora.

O acervo com o conteúdo das entrevistas, as entrevistas transcritas e as fotos estão disponíveis para acesso no Drive da USP. Disponível para acesso pelo link abaixo (Ctrl + clique para seguir o link):

https://drive.google.com/drive/folders/1fRjcmOUfS0fQV5gEqL9TAVUp4X3bPoLk?usp=sha $\underline{\text { ring }}$

\subsubsection{Tratamento dos dados qualitativos}

A abordagem qualitativa foi realizada a partir do método de "Análise de Conteúdo", desenvolvida por Lawrence Bardin (1977), cuja aplicação, de modo geral, é baseada no anseio da aplicação do rigor e na necessidade de descobrir e adivinhar, indo além das aparências. Pode ser aplicada em diversos discursos e a todas as formas de comunicação.

O método consistiu na organização dos em categorias de análise, que, ao final, possibilitam produzir análise dos resultados da coleta, utilizando inferências para explicar as 
premissas que originaram o estudo. As cinco categorias de análise estão apresentadas nos subitens do tópico 4 'Resultados'.

As diferentes etapas da análise de conteúdo utilizadas na pesquisa são descritas a seguir:

1) Pré-análise - fase de organização propriamente dita, que consistiu em sistematizar as ideias, com intuito de estabelecer um plano de análise, cujo objetivo foi, primordialmente, selecionar os dados submetidos à análise, formular hipóteses e elaborar indicadores para fundamentar a interpretação final.

2) Exploração do material - fase da administração sistemática dos dados organizados na pré-análise, por meio da codificação e enumeração dos dados, conforme as regras e necessidades estabelecidas anteriormente.

3) Tratamento dos resultados e a Interpretação - fase em que, de posse dos dados que foram tratados (significativos e válidos), foram propostas as inferências e interpretações relacionadas aos objetivos do estudo ou referentes a descobertas inesperadas.

\subsubsection{Tratamento dos dados quantitativos}

As características populacionais foram tratadas com base na estatística descritiva conforme Griffiths, Hill e Judge (1999) e Morttin e Bussab (2002), para facilitar a apresentação e interpretação dos dados.

As informações geradas na pesquisa de campo (dados primários e secundários) foram armazenados em um sistema de informações com o objetivo de inserção e geração de dados esquematizados e ordenados, para possibilitar a obtenção de informação e subsidiar análises.

O sistema de informações foi desevolvido com base na tecnologia web (Worl Wide Web), denominados de sistema de informações web (SIW), dentro do conceito de acesso universal, em que facilmente pode ser acessado de qualquer lugar ou plataforma, com qualquer sistema operacional de computador e ainda com qualquer navegador (NORIEGA, 2012).

A opção pelo desenvolvimento de um SIW foi devido a experiência da autora como professora de sistemas de informação na Universidade Estadual do Amazonas e também a oferta gratuita de softwares de código aberto na rede de internet.

Software de código aberto (do inglês open source software ou OSS) é um software para computador com o seu código fonte disponível e com uma licença de código aberto em que está concedido o direito de estudar, modificar e distribuir o software sem custos para 
qualquer pessoa e para qualquer finalidade. Geralmente é caracterizado por ter o conteúdo gerado pelo próprio usuário, o qual tem a possibilidade de reprogramar, reestruturar ou personalizar o programa de acordo com as suas necessidades (NORIEGA, 2012).

A linguagem utilizada para o desenvolvimento do sistema foi a PHP (Hypertext Preprocessor) que é uma linguagem de hipertexto ${ }^{4}$ com código aberto de uso geral, muito utilizada, e especialmente adequada para o desenvolvimento web em que o objetivo principal é permitir que as páginas sejam escritas mais rapidamente (MANUAL PHP, Versão Online 2020)

Estudos recentes demonstram que a maioria dos sistemas gerenciadores de conteúdo de código aberto estão implementados nesse tipo de linguagem. Uma das principais vantagens desses sistemas é que, como a maioria das pessoas domina o uso dos navegadores, a usabilidade dessas soluções é fácil para o público, sem a necessidade de um treinamento detalhado sobre como utilizar a aplicação (CHAGAS, CARVALHO e DA SILVA, 2018).

Para desenvolver o sistema de informações web com os dados da Resex Canutama (denominado de SIW Resex Canutama) foi utilizado o framework ${ }^{5}$ de desenvolvimento de sistema web disponibilizado gratuitamente pela empresa Cake Software Foundation, modelo CakePHP, que permite utilizar um editor online do GitHub, uma plataforma de hospedagem de código-fonte, que permitiu a contribuição de outros usuários no desenvolvimento deste sistema $\mathrm{web}^{6}$. O modelo utilizado para o desenvolvimento do software encontra-se disponível para acesso e leitura online no endereço https://book.cakephp.org/4/pt/index.html (CAKE PHP, Versão 4.X Online 2020).

O SIW Resex Canutama é um software de conteúdo hospedado na internet, onde foram inseridas informações gerais sobre cada uma das comunidades da Resex Canutama, para fins de gerar informações automáticas sobre a produção, inclusive com a possibilidade de exportação de relatórios por produto e por comunidade. O equipamento do usuário só necessita de um sistema operacional, um navegador e conexão com internet para acessar o sistema web, portanto, é um hardware de baixo custo (Manual PHP, Versão Online 2020).

O SIW Resex Canutama foi formatado com a sequência de inserção de dados apresentados no Diagrama de Caso de Uso conforme Figura 7:

\footnotetext{
${ }^{4}$ Hipertexto é um tipo de texto ao qual se agregam outros conjuntos de informação na forma de blocos de textos, palavras, imagens ou sons, cujo acesso se dá através de referências específicas, no meio digital denominadas hiperligações (Manual PHP, Versão Online 2020).

${ }^{5}$ Frameworks são modelos prontos usados pelos desenvolvedores para facilitar a criação de sistemas de forma mais ágil e prática. (Manual PHP, Versão Online 2020).

6 A plataforma digital GitHub possibilitou a colaboração gratuita de um programador de sistemas do setor privado, Alex Monte, que foi o responsável pela supervisão e ajustes do sistema web Resex Canutama.
} 
Figura 7 - Diagrama de Caso de Uso SIW

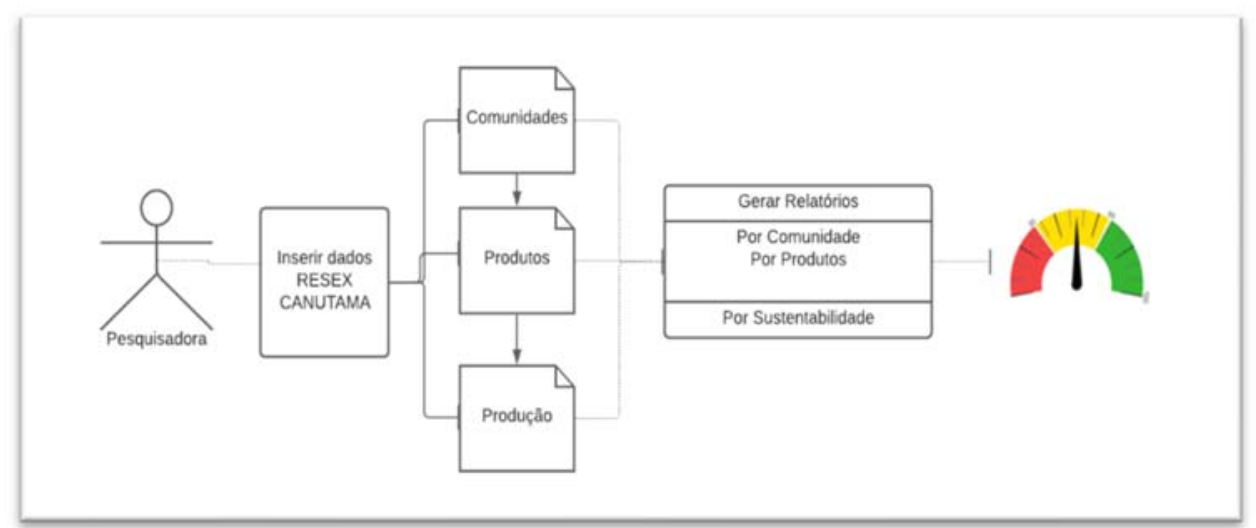

Fonte: Elaborado pela autora.

Para o Sistema de informações web foram criados três módulos para registros dos dados conforme detalhados na Figura 8:

Figura 8 - Dados inseridos no SIW

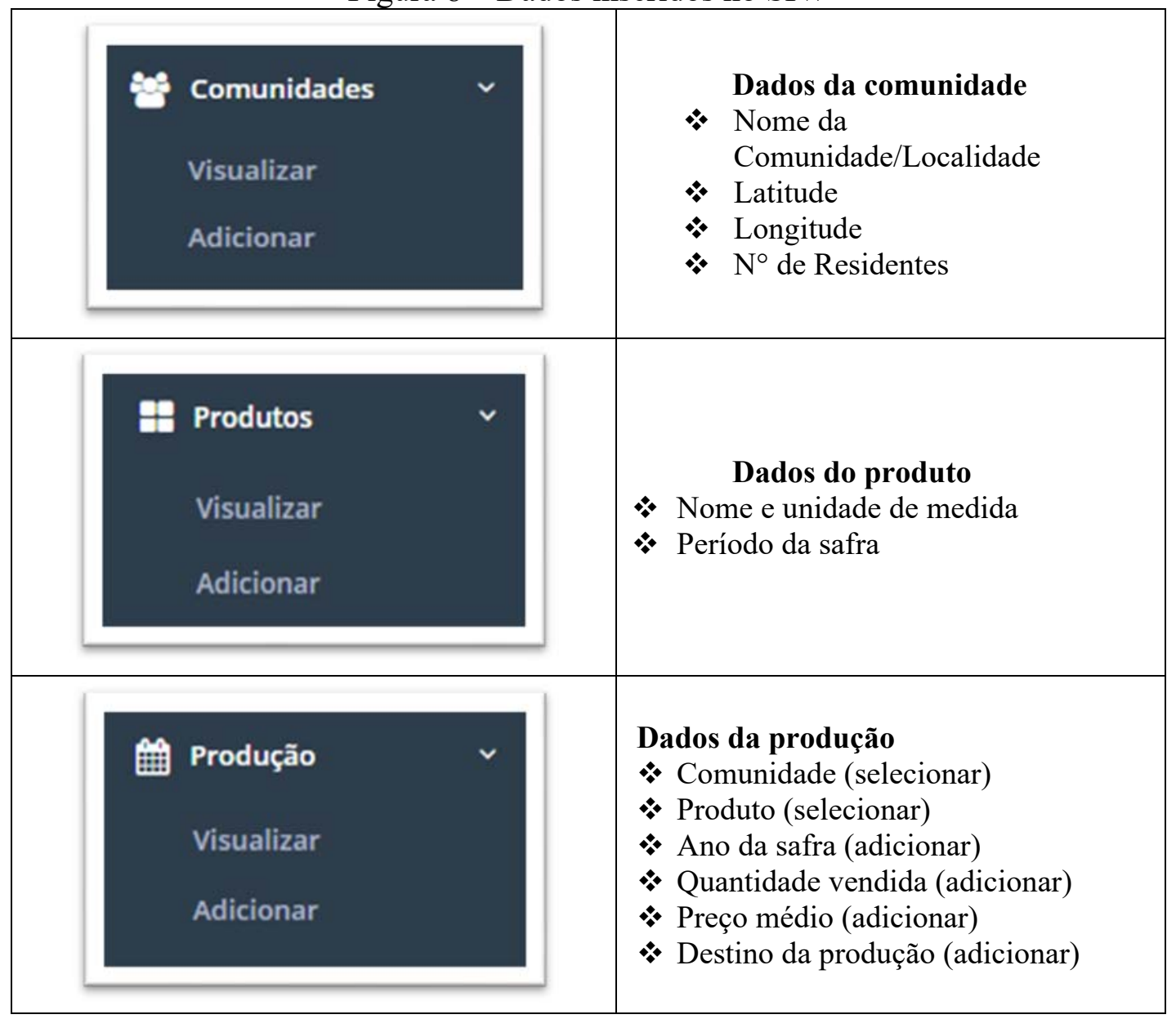

Fonte: Elaborado pela autora. 
O Sistema de informações web permite a geração de Relatórios automáticos, gerados a partir dos dados registrados nos módulos de 'Comunidades'; 'Produtos' e Produção', conforme detalhados na Figura 9:

Figura 9 - Dados gerados automaticamente no SIW

\begin{tabular}{|c|l|l|}
\hline 国 Relatórios & $\begin{array}{l}\text { Análise vertical e horizontal } \\
\text { Por Produtos } \\
\text { Por Produtos }\end{array}$ \\
Por Comunidades & $\begin{array}{l}\text { Por Sustentabilidade } \\
\text { Os dados dos produtos e/ou } \\
\text { comunidade são apresentados em } \\
\text { valores monetários permitindo a a a } \\
\text { comparação dos últimos dois anos. }\end{array}$ \\
\hline
\end{tabular}

Fonte: Elaborado pela autora.

A versão desenvolvida do SIW Resex Canutama é uma proposta de ferramenta para monitoramento e análise da produção da Resex e de cada uma das comunidades e/ou localidades, pode ser acessada no endereço eletrônico https://izabel.rsmtecnologia.com.br/ conforme $\underline{\text { APÊNDICE H }}$ - Instruções para acesso ao SIW Resex Canutama. A Figura 10 abaixo apresenta a tela principal do sistema:

Figura 10 - Tela principal do SIW Resex Canutama

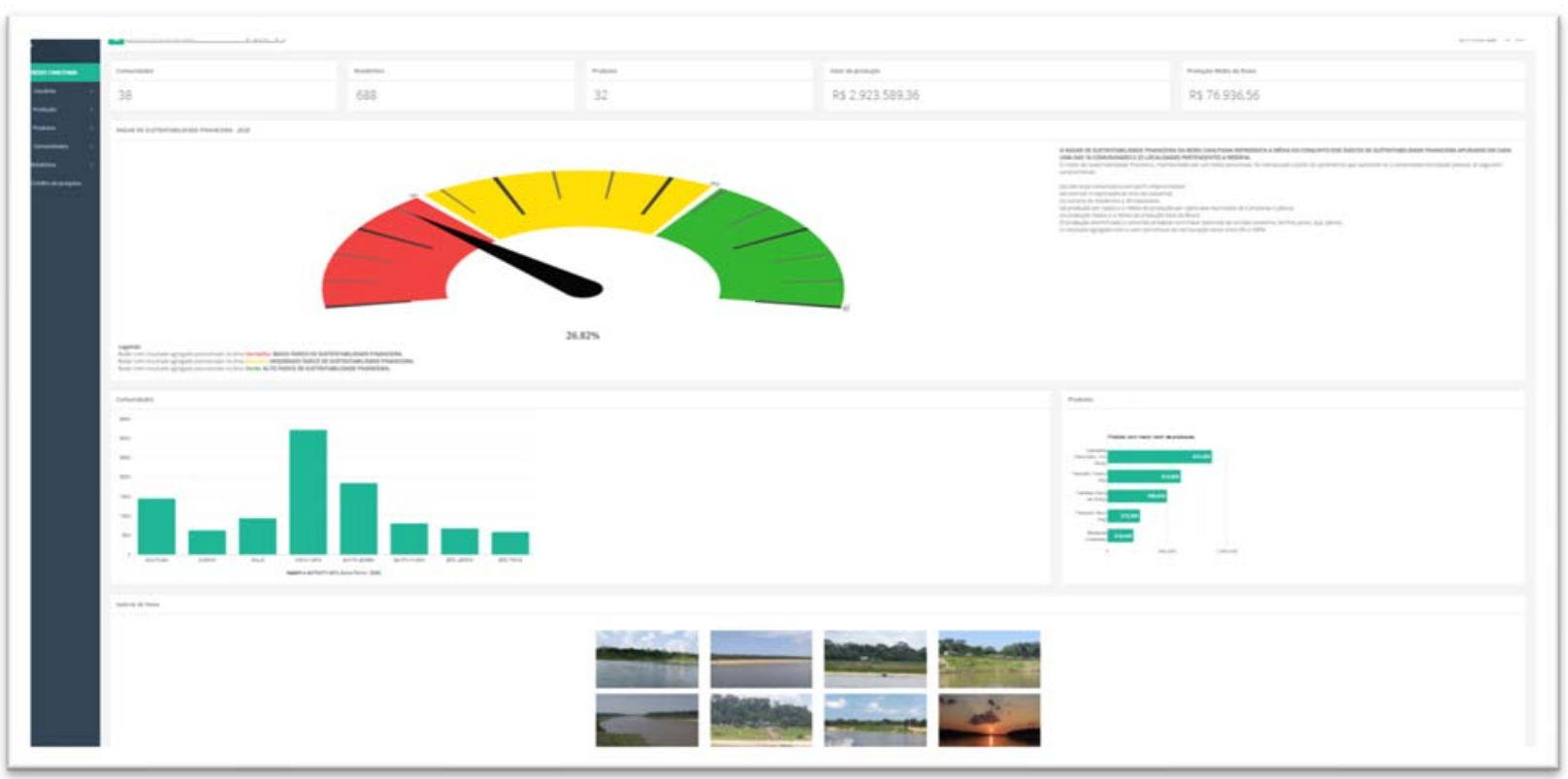

Fonte: SIW Resex Canutama. Disponível em: https://izabel.rsmtecnologia.com.br.

A partir das visitas in loco, das entrevistas realizadas e da percepção da dinâmica produtiva das comunidades extrativistas visitadas, foram identificados os parâmetros ou 
indicadores que serviram para avaliar e mensurar a sustentabilidade financeira em cada uma das comunidades/localidades da Resex Canutama.

A construção do modelo SIW não estava previsto inicialmente, surgiu em decorrência do desenvolvimento da pesquisa, portanto é considerado um produto da pesquisa (o modelo analítico proposto está apresentado no item $\underline{4.6 .1}$.) 


\section{RESULTADOS}

Nesta seção serão apresentados os resultados do estudo realizado conforme explicitado na metodologia.

A análise qualitativa, utilizou o método 'Análise de Conteúdo' procedendo ao detalhamento das abordagens contidas no roteiro de entrevistas, além de outras, que surgiram durante as conversas e que estão relatadas por serem relevantes para o entendimento do funcionamento da Resex Canutama, seus desdobramentos e consequências para a vida dos residentes e para o meio ambiente daquela área, além da conexão dessas questões com a sustentabilidade financeira da Resex. Esta etapa abrangeu oito comunidades (de um total de dezesseis) da Reserva Extrativista Canutama, situada na floresta amazônica, no estado do Amazonas. Os entrevistados foram moradores/produtores/extrativistas e lideranças locais.

Por sua vez, a análise quantitativa reuniu dados primários e secundários sobre a população residente e as atividades produtivas locais, possibilitando a análise da produção e vendas geradas pelas comunidades e localidades da Resex Canutama. Concomitantemente, os dados serviram de base para mensurar o status da sustentabilidade financeira das comunidades e localidades daquele território.

Desse modo, a análise dos resultados trata: i) dos aspectos gerais do perfil dos moradores da 'Reserva Extrativista Canutama'; ii) da 'Experiência de vida do morador/produtor'; iii) do conhecimento sobre o funcionamento, gestão e expectativa da Resex; iv) dos aspectos da 'Conservação Ambiental'; v) da 'Sustentabilidade Financeira' na Resex; e, por fim, vi) da 'Mensuração da Sustentabilidade Financeira' da Resex e das comunidades e localidades.

Os resultados não estão separados pelo método aplicado - qualitativo ou quantitativo, o que significa que, quando pertinente, dados qualitativos e quantitativos são apresentados conjuntamente, de forma a serem complementares para elucidar e responder aos objetivos propostos.

A seguir, os resultados. 


\subsection{Aspectos gerais e perfil dos moradores}

\subsubsection{Criação e localização}

A Resex Canutama foi criada pelo Decreto Estadual $n^{\circ} 28.421$, de 27 de março de 2009, está localizada entre o interflúvio Rio Purus - Rio Madeira nos municípios de Tapauá e Canutama, ambos pertencentes à Mesorregião do Sul Amazonense e Microrregião do Purus no Estado do Amazonas. Conforme o decreto, a Resex Canutama tem como objetivos proteger os meios de vida e garantir a utilização e a conservação dos recursos naturais renováveis que são tradicionalmente utilizados pelas comunidades residentes (Decreto 28421, 2009).

Figura 11 - Mapa da Localização da Resex Canutama

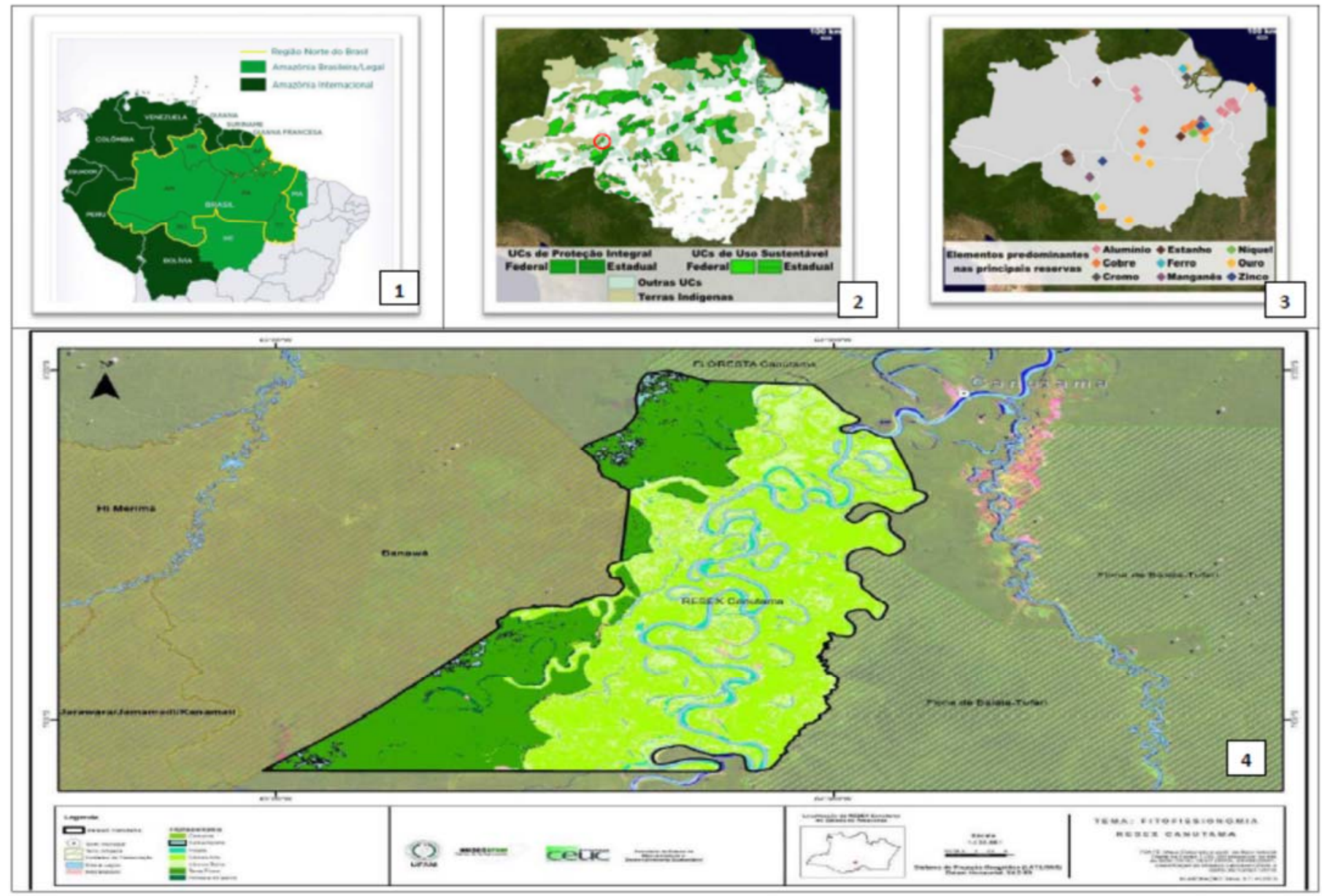

Legenda:

1 - Mapa da Amazônia Legal. Fonte https://www.todamateria.com.br/amazonia-legal/

2 - Mapa das UC's de Proteção Integral e UC's de Uso Sustentável. Fonte https://www.notasgeo.com.br

3 - Mapa dos Elementos Predominantes nas principais reservas. Fonte https://www.notasgeo.com.br

4 - Mapa da Resex Canutama - Área de Várzea e Terra Firme. Fonte Plano de Gestão CEUC, 2014

A Resex Canutama possui uma área aproximada de 197.986,50 hectares e limita-se ao norte com a Floresta Estadual Canutama, na porção nordeste com o Igarapé Paissé e um 
trecho do Rio Purus, na porção leste, é delimitado pela margem direita do Igarapé Cujubim e na porção sul é delimitado em linha reta até os limites da Terra Indígena Banawá que segue na porção oeste da Unidade. Na porção central é cortado pelo Rio Purus no sentido norte-sul. Encontram-se ainda na área do entorno o Rio Mucuim e a Unidade de Conservação Federal, Floresta Nacional de Balata-Tufari e a Reserva Extrativista Médio Purus.

A Figura 11 permite visualizar algumas características importantes da localização da Resex Canutama: o mapa 2 apresenta todas as UC's localizadas no estado do Amazonas; o mapa 3 apresenta a localização das principais reservas minerais na região Norte, e podemos constatar que a ausência de reservas de minérios dentro do estado do Amazonas pode ser um fator de retardo para o aumento do desmatamento nas proximidades das áreas das UC's (ver tópico 2.7.1).

\subsubsection{Perfil dos moradores}

A população da Resex Canutama compreende 688 pessoas residentes, que compõem 191 famílias. Em relação aos troncos familiares, 73\% das famílias residem em comunidades, totalizando 519 pessoas (as comunidades concentram 75\% das pessoas que residem na Resex Canutama). As famílias restantes moram em localidades. A Tabela 7, abaixo, resume esses dados comparativos entre comunidades e localidades:

Tabela 7 - Residentes das comunidades e localidades da Resex Canutama (2020)

\begin{tabular}{lccc}
\hline População residente & Comunidades & Localidades & Total Resex \\
\hline $\mathrm{N}^{\circ}$ de Famílias & $\mathbf{1 4 0}$ & $\mathbf{5 1}$ & $\mathbf{1 9 1}$ \\
$\mathrm{N}^{\circ}$ de Famílias (\%) & $73 \%$ & $27 \%$ & $100 \%$ \\
& & & \\
$\mathrm{~N}^{\circ}$ de Pessoas & $\mathbf{5 1 9}$ & $\mathbf{1 6 9}$ & $\mathbf{6 8 8}$ \\
$\mathrm{N}^{\circ}$ de Pessoas (\%) & $75 \%$ & $25 \%$ & $100 \%$ \\
\hline
\end{tabular}

Fonte: Elaborado pela autora.

As 'comunidades' são áreas com maior infraestrutura de desenvolvimento (escola, sede comunitária, igreja, campo de futebol) e concentram maior número de famílias e de pessoas residentes - em média, 32 pessoas residentes, distribuídas em nove famílias (Figura 12): 
Figura 12 - Foto de uma Comunidade da Resex Canutama

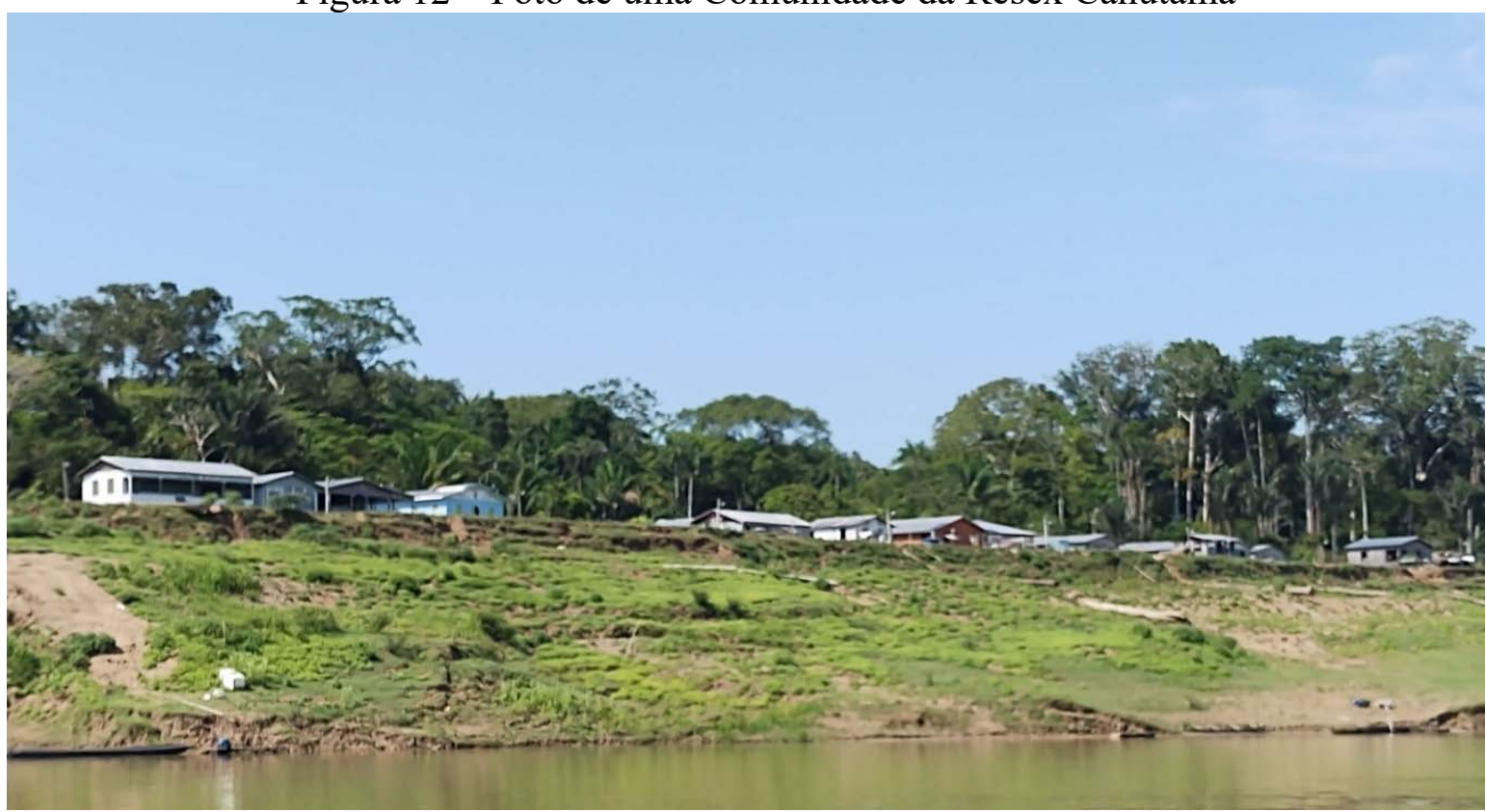

Fonte: Acervo da pesquisa.

As áreas denominadas 'localidades' representam pequenos grupos de pessoas, dentro das próprias comunidades, que mantêm relação de interdependência no que se refere à infraestrutura disponibilizada nas comunidades, possuem menor número de famílias e de pessoas residentes, em média são oito pessoas residentes distribuídas em duas famílias (Figura 13).

Figura 13 - Foto de uma Localidade da Resex Canutama

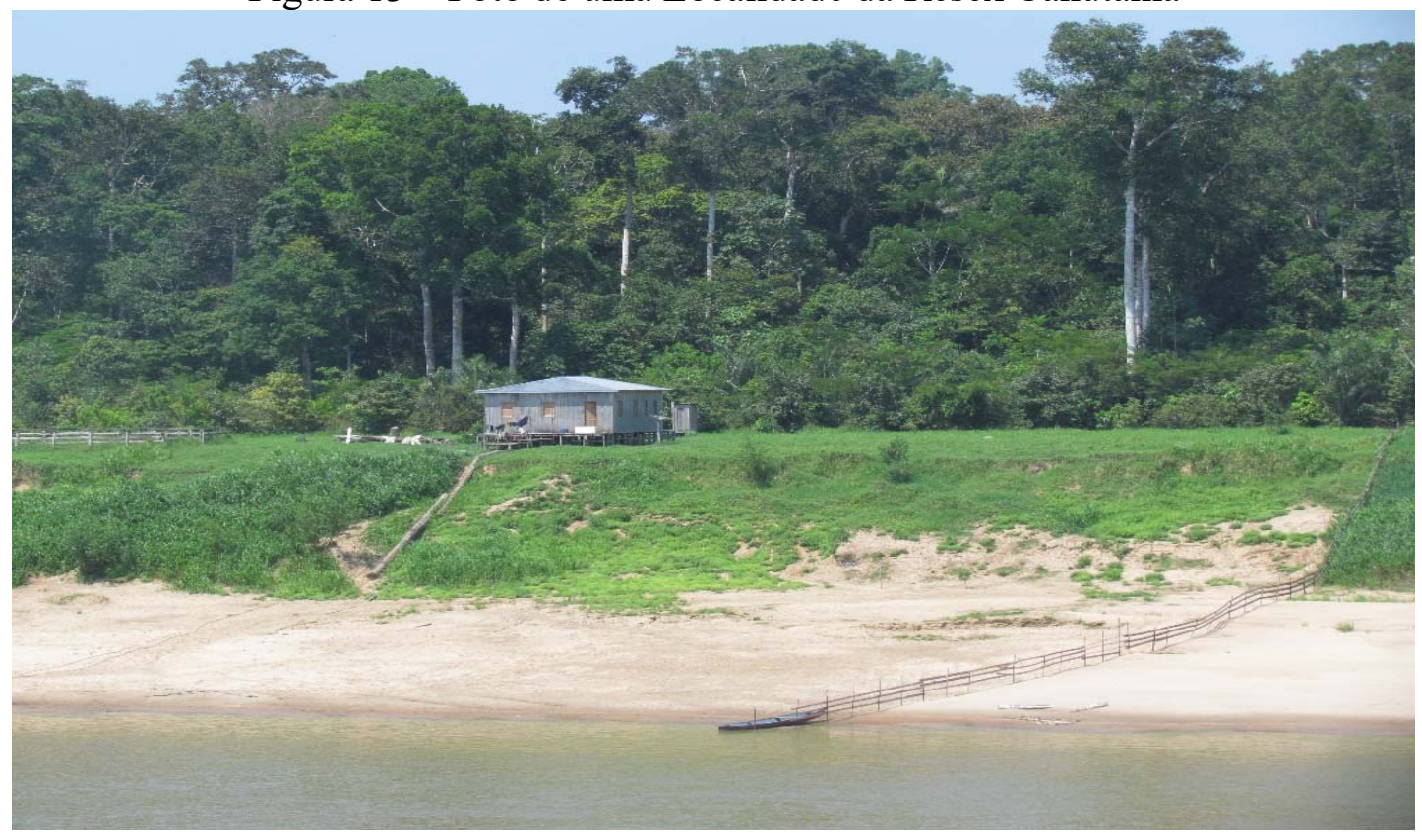

Fonte: Acervo da pesquisa. 
Apesar desse contingente expressivo de moradores, não há diferenças significativas de perfil entre os produtores das comunidades. Pode variar o tamanho das famílias ou número de moradores de cada local, assim como os alimentos que cultivam e/ou comercializam, mas a essência, tanto do modo de vida e da perspectiva de futuro, como da visão sobre questões relacionadas à Resex, é semelhante e se baseia na simplicidade, decorrente da falta de recursos (principalmente financeiros e estruturais) e de conhecimento e vivência de situações diversas daquelas típicas de quem vive em meio à maior reserva florestal do planeta.

As diferenças mais marcantes dizem respeito ao desempenho produtivo e financeiro de algumas comunidades em relação às demais, como será mostrado mais adiante, no tópico que avalia a sustentabilidade financeira das comunidades/localidades.

Os residentes da Resex Canutama representam famílias que, em sua maioria, já moravam naquele local antes da criação das Unidades de Conservação - UCs. São várias gerações que, com o passar do tempo, aumentam ou diminuem, conforme novas famílias se formam ou pessoas deixam as comunidades.

“Quando foi fundado essa... a Resex, eu já morava há muito tempo. Eu cheguei aqui meninozinho. Só aqui nessa praia, eu tô com mais de quarenta anos”. (Produtor - Comunidade Santa Bárbara)

Como mostra a Tabela 8 , as oito comunidades estudadas reúnem uma população predominantemente adulta (entre 21 e 50 anos), perfazendo $68 \%$ dos entrevistados. Ampliando-se esse grupo com os jovens (16 a 20 anos), verifica-se, entre os entrevistados, contingente expressivo de indivíduos em idade ativa, o que, em tese, favorece o desempenho produtivo e econômico da Reserva.

\begin{tabular}{|c|c|c|}
\hline \multicolumn{3}{|c|}{ Tabela 8 - Faixa etária dos entrevistados } \\
\hline \multirow[b]{2}{*}{ Faixa Etária } & \multicolumn{2}{|c|}{$\mathbf{N}^{0}$ de Moradores } \\
\hline & Valor Absoluto & $\%$ \\
\hline $16|-| 20$ & 3 & $6 \%$ \\
\hline $21|-| 30$ & 14 & $28 \%$ \\
\hline $31|-| 40$ & 9 & $18 \%$ \\
\hline $41|-| 50$ & 11 & $22 \%$ \\
\hline $51|-| 60$ & 7 & $14 \%$ \\
\hline 61 anos ou mais & 6 & $12 \%$ \\
\hline Total dos entrevistados & 50 & $100 \%$ \\
\hline
\end{tabular}

Fonte: Elabora pela autora. 
Os dados sobre o tempo de residência dos entrevistados revelam que 14\% residem na Resex em período igual ou menor que 10 anos. A maioria, 86\%, reside há mais de 20 anos, portanto, já eram moradores antes da criação da Resex Canutama. A Tabela 9, abaixo, ilustra essa situação:

Tabela 9 - Tempo de residência dos entrevistados na Resex Canutama (2020)

\begin{tabular}{cccccc}
\multicolumn{2}{c}{ Tempo de Residência } & \multicolumn{2}{c}{$\mathbf{N}^{\circ}$ de moradores } \\
Valor absoluto & $\%$ \\
\hline 1 & $-\mid$ & 10 & 7 & $14 \%$ \\
11 & $|-|$ & 20 & 7 & $14 \%$ \\
21 & $|-|$ & 30 & 16 & $32 \%$ \\
31 & $-\mid$ & 40 & 7 & $14 \%$ \\
41 & $-\mid$ & 50 & 11 & $22 \%$ \\
51 & $-\mid$ & 60 & 2 & $4 \%$ \\
\hline \multicolumn{3}{l}{ Total de entrevistados } \\
\hline
\end{tabular}

Fonte: Elabora pela autora.

Caso raro, a saída da Resex é motivada principalmente pela limitação de recursos para a sobrevivência das famílias e restrições de oferta de serviço educacional. Além da precariedade da estrutura física das escolas existentes (há comunidades sem escola), o nível escolar disponível se limita ao ensino fundamental.

Devido a isso, alguns jovens se mudam para municípios da área urbana, a fim de complementar os estudos, pelo menos o ensino médio. Essa não é uma situação preponderante, visto que poucas famílias têm condição financeira para arcar com despesas extras às já existentes. O mais comum é que os estudantes que saem para estudar fora, contam com um familiar que reside em alguma das cidades da região e que os acolhe durante o período de estudo.

Ao mesmo tempo, foi constatado que, na maior parte dos casos, as pessoas se contentam com o ensino ofertado na Resex e poucos demonstram interesse por novos aprendizados - apenas alguns chegaram ao ensino médio e não houve menção a alguém que tenha cursado ensino superior.

Essa é uma descoberta relevante do estudo, que corrobora o fato de que a maioria dos entrevistados gosta de viver na Resex, se contenta com a vida atual e não tem planos de deixar o local. São pessoas de hábitos muito simples, que vivem lá desde criança ou do nascimento entre a maior parcela dos entrevistados, não se percebeu, nem foi manifestada, ambição ou necessidade de viver em ambiente ou de forma diferente. Por outro lado, há quem queira 
deixar a Resex para avançar nos estudos - são poucos e, notadamente, jovens, ou pais, que desejam "um futuro melhor" para os filhos.

Também há os que foram embora (para outra comunidade ou "para a cidade"), mas retornaram ao seu local de origem, na maior parte dos casos, por não se adaptarem à agitação ("zuada", segundo o termo usual dos entrevistados) e custo de vida dos centros urbanos.

Nem todos os comunitários praticam extrativismo, principalmente porque, no geral, o local de coleta dos produtos mais vendidos não é próximo da moradia/comunidade (o que dificulta e encarece o processo de venda), e, para esses, a pesca não é opção. Ou ainda, para uma parcela desses casos, porque a escolha é apenas plantar para o sustento da família.

Devido a isso, a maioria dessas famílias precisa recorrer a programas sociais do governo (bolsa família, bolsa floresta e, no período em análise, ao auxílio emergencial) e, mesmo assim, não reclamaram ou demonstraram desejo de mudança quanto à sua situação.

A opção desses moradores, por permanecer no local, faz perceber que a Resex proporciona não somente a proteção das áreas de conservação ambiental e a subsistência das famílias residentes, mas também - talvez, para alguns, o mais importante - assegura moradia própria, oficializada por meio de Contrato de Concessão de Direito Real de Uso - $\mathrm{CCDRU}^{7}$ (ICMBio, 2019), sem ter que se submeter a qualquer tipo de trabalho e a exigências de grandes proprietários de terra, que, antes de a área se tornar reserva ambiental, tinham o poder de expulsar do território quem não obedecesse às suas regras.

Eu gosto do silêncio. É tão bom o silêncio. Na cidade é aquela zuada doida. Não gosto, não, da cidade. Eu vou a passeio, para fazer um trabalho..., mas para mim mesmo, [bom] é aqui mesmo. (Produtor - Comunidade Nova Vista)

[Morar na Resex] "Gosto. E não pretendo sair tão cedo. Eu acho aqui melhor que na cidade. Na cidade, todo dia precisa a gente estar gastando, né?”. (Produtor - Comunidade Santa Maria)

\footnotetext{
${ }^{7}$ CCDRU foi assinado pela Associação dos Agroextrativistas da Reserva de Canutama - ASARC
} 


\subsection{Experiência de vida do morador/produtor}

\subsubsection{Vida simples}

A vida dos moradores da Resex Canutama é bastante simples, assim como as próprias pessoas. São indivíduos que estudaram pouco (principalmente os mais velhos) e que, em sua maioria, sempre viveram na região, sem praticamente terem saído dali, ou, no máximo, já estiveram em Canutama ou Lábrea, os municípios mais próximos da Resex.

Pelos relatos, percebe-se que a simplicidade está relacionada com o contato com a natureza, na vivência de situações cotidianas, desde a facilidade de acesso a alimentos naturais (peixe, frutas, produção da própria farinha) até ao que se refere ao silêncio que a floresta proporciona (comparativamente aos centros urbanos próximos da Resex).

Apesar da vida modesta, alguns manifestaram desejo por itens de conforto, que, como dizem, são viáveis, mas o acesso a eles está condicionado à intervenção ou ajuda, sobretudo, das Prefeituras de Canutama ou de Lábrea. Ou dependem ainda da ação das lideranças e cooperativas e/ou associações locais.

As principais menções acerca de possíveis melhorias e/ou benefícios se referem à disponibilização de algum tipo de fonte de energia, que viabilizaria assistir TV e ter geladeira em casa. Também reivindicam sinal de internet (wifi), que melhoraria a comunicação da comunidade com serviços externos (saúde é o mais citado), como para ter informações frequentes e eficazes sobre a cotação dos produtos que comercializam.

Além disso, anseiam por um meio de transporte que seja adequado tanto para escoar a produção como para atender à alguma emergência da comunidade (socorrer algum morador doente, por exemplo).

Em se tratando da energia, a maioria das comunidades utiliza geradores, doados pela Prefeitura de Canutama, que também fornece certa quantidade de combustível (apesar de insuficiente para um mês inteiro).

É consenso que a energia solar é a mais adequada para a Resex, por ser 'limpa' e, portanto, associada à sustentabilidade ambiental, pressuposto primordial para áreas protegidas. Entretanto, é opção inacessível para a maioria das famílias, pelo alto custo. De todo modo, alguns moradores já possuem painéis solares em suas casas, adquiridos por conta própria. Outros, estão comprando, aos poucos (conforme a situação financeira), os equipamentos necessários para a instalação dos painéis. 
“Vai ali na beira do rio, pega um peixinho, come, né?”. (Produtor - Comunidade Açaituba)

\subsubsection{Dificuldades cotidianas}

Os principais problemas experimentados pelos moradores da Resex estão associados às dificuldades de acesso à região, tanto para sair quanto para chegar. Por estar localizada dentro da floresta, são poucos os recursos de infraestrutura que chegam ao local.

Não se espera ou é requerida estrutura de uma cidade (os moradores nem querem isso), mas, sim, iniciativas que atendam às necessidades básicas para o mínimo de assistência aos comunitários, tais como serviços de educação, saúde e fonte de energia. Um ou outro mencionou desejo por uma casa melhor do que a que possui.

São demandas previstas nos termos de criação das reservas extrativistas, cuja finalidade não é somente manter o equilíbrio ecológico do meio ambiente, mas também proporcionar a subsistência física e cultural, com retorno econômico para os habitantes desses territórios (Pascuchi, 2007; Gomes, 2018).

Em relação à infraestrutura: educação, saúde, fonte de energia e transporte, os entrevistados relatam os principais problemas vivenciados na Resex, a seguir detalhados.

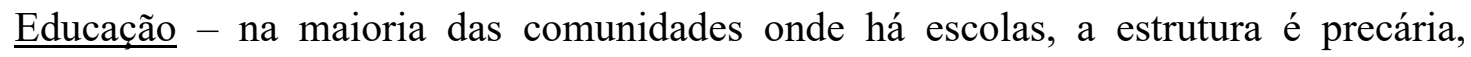
geralmente, se resume a uma sala de aula, cujos móveis (mesas dos alunos) estão em péssimas condições e são em número insuficiente para acomodar todos.

Independentemente disso, o problema maior está no fato de que o ensino é multisseriado, o que significa que a sala abriga alunos de vários e variados níveis de ensino, o que faz aumentar consideravelmente a quantidade de alunos em sala. Não bastasse, o mesmo professor tem que se desdobrar para orientar cada estudante nas suas necessidades (nível de ensino). É consenso que essa situação prejudica sobremaneira o aprendizado.

Além disso, o ensino é limitado ao nível fundamental, em consequência, os jovens precisam interromper os estudos ou se mudar para Canutama ou Lábrea (municípios mais próximos das comunidades), se quiserem completar pelo menos o ensino médio (Manaus também foi mencionado como destino, mas é opção pouco utilizada). Esses jovens vão sozinhos para a cidade, para morar com parentes, mas há pais que declararam intenção de se mudar junto com os filhos para que eles avancem nos estudos.

A preocupação com o "futuro dos filhos" é manifestada principalmente pelas mães, mas pelo menos um pai lamentou as limitações educacionais na Resex e se disse disposto a se mudar com a família, em função dos estudos dos filhos. Pais e jovens estudantes que pensam 
em sair da Reserva afirmaram que mudariam de ideia caso houvesse energia e atendimento educacional de qualidade.

"O futuro que eu quero dar pra minha filha é o que eu não tive. Principalmente, os estudos, né? É isso que eu quero dar para ela”.

(Produtora - Comunidade Açaituba)

"Quando eu vou pra cidade assim, eu fico doida pra vim embora. Aí eu tava dizendo pro meu marido, eu não sei se eu vou me acostumar lá. Porque Deus me livre, eu gosto daqui. [Se tivesse escola] Ficava. Ficava mesmo. Não ia, não".

(Produtora - Comunidade Nova Vista)

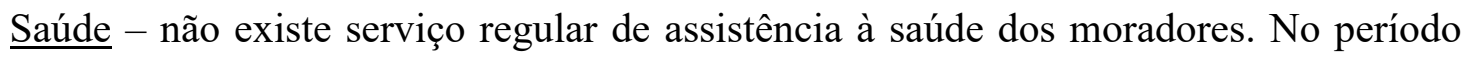
em análise, até visitas eventuais de profissionais de saúde à Resex não estavam ocorrendo mais. De acordo com depoimentos, agentes de saúde costumam visitar esporadicamente as comunidades, o que pode ocorrer a cada dois ou três meses ou uma vez por ano. O que não significa que os comunitários serão atendidos - alguns relataram que, pela rapidez da visita, a impressão é de que os profissionais param nas comunidades apenas para obter a assinatura de um morador, comprovando que "passaram por lá”.

Com essa situação, associada às dificuldades de acesso ao local, os moradores ficam sem assistência de serviços de saúde, seja para um simples curativo ou para atendimento de caso mais grave, por exemplo, que necessite recorrer a um hospital. O mesmo transtorno se repete para consultas médicas nos municípios vizinhos, pois, devido à distância e problemas para deslocamento (que é feito somente de barco), para atendimento médico, as pessoas são obrigadas a ficar na cidade mais de um dia, o que acarreta disponibilidade de tempo e dinheiro.

As informações a respeito de ações da Prefeitura local são confusas e desencontradas. $\mathrm{Na}$ época de realização desta pesquisa, havia expectativa de inauguração de uma Unidade Básica de Saúde (UBS) na Resex, como também houve menção à recente chegada de uma UBS móvel (embarcação), que visitaria as comunidades em determinados meses, mas não se sabia se o serviço seria permanente ou era uma iniciativa apenas para orientar sobre os procedimentos com relação à pandemia da Covid-19, que, no Brasil, estava em franca ascensão.

Diante disso, alguns tinham a percepção de que atendimento preventivo seria algo difícil de acontecer naquela região, portanto, os comunitários estarão sempre recebendo tratamento posterior às ocorrências e necessidades, tendo à frente as dificuldades logísticas e de infraestrutura já relatadas. 
"Muitas vezes por questão de saúde... Agora tá se resolvendo, porque a prefeitura tem essa UBS e tá vindo agora de dois em dois... três meses, tá vindo na zona rural”. (Gestor da

"Eu, por exemplo, eu tô aqui, não fui pra Lábrea, não fui pra Canutama, tô esperando médico, por exemplo. Médico cadê? Não existe. Esse prefeito aí mesmo não [visitou a Resex] ... Quatro ano já". (Produtor - Comunidade Irajá)

"Aí, uma Secretaria de Saúde, uma Prefeitura, fazer um mutirão, também, pô. Traz... tem um barco, traz um médico, traz assistente social, traz a saúde... Entendeu?” (Gestor da Resex)

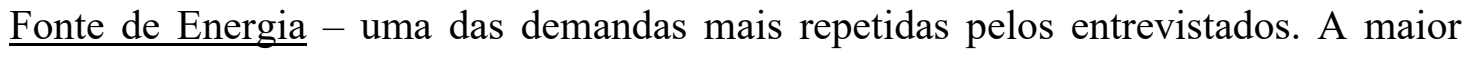
parte da energia utilizada é obtida a partir de geradores doados pela Prefeitura de Canutama, que também fornece certa quantidade de combustível (diesel).

Nas residências, a energia é utilizada especialmente para a iluminação à noite e assistir TV por algum tempo (nem todos tem TV em casa), mas um grupo de residentes também manifestou desejo de ter geladeira "para tomar uma água gelada" e armazenar alimentos.

No entanto, a necessidade premente de energia é para possibilitar comunicação com o exterior da Resex, principalmente para emergência médica e para verificar a cotação dos produtos comercializados pelos produtores locais.

A energia solar é vista como a mais adequada, porém o preço das placas é impeditivo para a maioria dos comunitários - alguns conseguiram adquirir o equipamento, outros, estão comprando aos poucos, na medida em que sua condição financeira permite.

"E eu acredito que a gente, pelo fato de morar dentro de uma Unidade de Conservação, se a gente tivesse uma energia limpa, tipo energia solar... Que, aliás eu até tenho uma placa aqui, mas ainda não tá bem arrumada minhas coisinhas aqui, pelo fato de a gente ter uma renda baixa e sai um pouco caro pra gente assim. $E u$, pelo menos, vivo feliz aqui dentro. Mas a gente tem sonho também, de ter uma casinha melhor, uma televisão, e tem que, muitas vezes, a gente não tem isso, porque a gente depende de prefeitura pra funcionar o motor de luz. Porque eles colocam o motor na comunidade e dão uma parte do diesel. E o diesel, o inflamável que eles dão, não é suficiente pra funcionar o mês todo". (Produtor - Comunidade São Jerônimo)

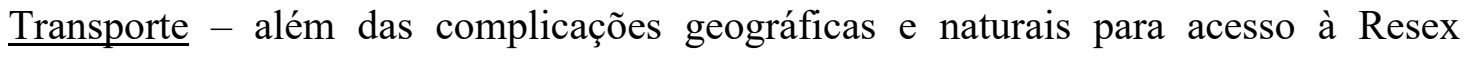
Canutama (estão no meio da floresta, margeados por um rio), os comunitários sofrem com a falta de transporte adequado (em tamanho e potência do motor) para os trajetos entre a Reserva e os centros urbanos mais próximos, tanto para escoar a produção, quanto para compras de alimentos ("rancho"), acessar serviços de saúde, entre outras necessidades. Esses 
deslocamentos são possíveis somente por embarcação fluvial, já que a Reserva é entrecortada pelo rio Purus.

Principalmente as comunidades mais distantes de Lábrea e Canutama, que estão no centro da Reserva, são as mais afetadas. Conforme relatos, há casos em que o doente "quando chega [a um posto de saúde ou hospital], já está morto".

A maioria das famílias possui uma embarcação para pequenos trajetos, mas nenhuma delas é considerada (pelos próprios donos) adequada, uma vez que são barcos (canoas) com muito tempo de uso e motor com baixa potência, além de serem pequenos e, portanto, com capacidade limitada para transporte da produção ou de pessoas.

Somado a esse panorama, o preço do combustível naquela região é bastante caro, o que inviabiliza ou restringe sobremaneira a saída da Resex, por qualquer motivo. Essa precariedade tem feito com que, cada vez mais, os produtores limitem a venda dos seus produtos, reduzindo a plantação ou extração, bem como a quantidade de produtos destinados à venda, tendo que entregar a colheita para os atravessadores, com o propósito de garantir a venda e não ter prejuízo ou ficar sem o recurso que sustenta suas famílias.

Os comunitários ressentem da ajuda da Prefeitura nesse sentido, que, em outra época, já disponibilizou embarcação para os deslocamentos, como também havia um barco vendendo alimentos básicos às comunidades, evitando a ida a Lábrea ou Canutama com esse intuito. Porém, a ação da Prefeitura de Canutama para atender a Resex não é regular e muda a cada eleição (há prefeitos que ajudam/ajudaram mais que outros).

Se tivesse um barco pra vender as coisas assim, né? Um barco pro cara vender. (Produtor - Comunidade Carmo)

Em resumo, os relatos sobre a experiência de vida do morador/produtor revelam que a vida na Resex é simples e os moradores não reclamam disso, mas ressentem do mínimo de facilidades para o dia a dia, como escola, posto de saúde e acesso facilitado ao centro urbano mais próximo. São resignados, mas demonstraram certo "cansaço" pelas dificuldades vividas e pela falta de assistência e de perspectivas -, seja do Poder público (Prefeitura, Governos Estadual e Federal) ou das Cooperativas e Associações existentes.

"Não tem energia, não tem um telefone, é difiço para gente, né? Um bocado da minha família foi embora já, por causa disso". (Produtora - Comunidade Nova Vista)

"É isso que eu falo aqui, quando eu tenho [adquiro] uma coisa, quer dizer, tá tudo aí. Eu não tenho nada de prefeito, não tenho nada de prefeitura. Eu tenho que dá meus pulo. Eu pego um peixe... quando vem um homem, aí eu vou ali, pego um peixe, vendo pra ele, guardo 
aquele dinheiro, vendo quatro melanciazinha, tem o dinheiro contado... Eu não paro de fazer isso". (Produtor - Comunidade Irajá)

\subsubsection{Líder com perfil de empreendedor social}

Nas comunidades visitadas, as entrevistas foram realizadas primeiramente com a pessoa identificada como 'líder' comunitário. Oito líderes foram entrevistados e todos relataram que, a liderança exige muito 'tempo' destinado para 'lutar' pela comunidade. Nesse sentido, essas lideranças, que agem como porta-vozes da comunidade e ocupam tais cargos de liderança em função de maior disponibilidade de tempo para se dedicar ao trabalho (SILVA, 2015).

Durante as entrevistas, foi realizada uma avaliação qualitativa para gerar dados para um dos parâmetros do modelo: Parâmetro - Líder comunitário com perfil empreendedor. Nessa avaliação, a pesquisadora buscou identificar o engajamento, a responsabilidade e a participação ativa voltada para os interesses da comunidade, uma vez que o perfil empreendedor, aqui é compreendido como um fator para o desenvolvimento comunitário (BOSE, 2012).

Uma das principais 'queixas' dos líderes é ausência de associações ou cooperativas 'fortes' atuando na área, uma vez que a organização comunitária é importante para o fortalecimento da economia da Resex, principalmente para inclusão de todos na produção e na renda das comunidades. Os relatos confirmam a ideia de que cooperativas e/ou associações representam uma alternativa capaz de gerar ocupação e renda para grupos sociais vulneráveis residente em reservas extrativistas (COMINI, 2016; FISCHER, 2014; IIZUKA, 2014; FREITAS et al., 2017).

Os relatos também evidenciaram uma deficiência na governança da Resex, os líderes não possuem conhecimento do volume de atividade geradas na Resex, que pode gerar dificuldades operacionais no sentido de coordenar a produção e vendas (SABADIN et. al. 2008).

Importa em ressaltar o protagonismo do líder da Comunidade Nova Vista, comunidade responsável por quase um terço do volume de recursos financeiros obtidos pela Resex Canutama. Foi o único líder que apresentou o Plano de Gestão e conhecimento de todas as atividades produtivas desenvolvidas. Possui uma história de engajamento na luta pela criação da Resex e preside a Associação dos Agroextrativistas da Reserva Extrativista de CanutamaASARC, criada em 2011 para atuar questões fundiárias. 


\subsection{Conhecimento, gestão e expectativa sobre a Resex}

\subsubsection{Conhecimento sobre a Resex}

A maior parte dos residentes não sabe detalhes acerca do funcionamento da Resex, principalmente sobre sua gestão ou sua representatividade com relação aos comunitários. As informações citadas pelos entrevistados dizem respeito ao propósito de proteção ambiental e, portanto, esta é a principal justificativa comentada pelos entrevistados para referirem ao efeito positivo da criação da Resex.

A falta de conhecimento sobre a gestão também é percebida quando se referem ao gestor da Resex. Somente os líderes entrevistados mencionaram às atividades realizadas pelo gestor da Resex, principalmente para indicá-lo como sendo a pessoa que recebe as denúncias de ilegalidades ambientais e toma as providências sobre as ocorrências. Além disso, outra atribuição mencionada sobre o gestor da Resex, seria a distribuição ocasional de sementes para as lavouras (ainda que não seja uma atividade regular).

Os entrevistados não responsabilizam o gestor da Resex ou associações e cooperativas, pela falta de estrutura do local e por outras dificuldades, pelo contrário, no geral, os problemas são imputados à prefeitura de Canutama, município ao qual pertence a Reserva. $\mathrm{O}$ fato de a Prefeitura disponibilizar (ainda que inconstantemente) combustível para os geradores de energia e para as embarcações dos produtores cria expectativa para outras necessidades e acaba por induzir à ideia de que a Prefeitura é o suporte a quem eles devem recorrer ou de quem devem reclamar.

Como não têm informações específicas sobre a administração da Resex e quais as possibilidades de sua representação em favor das comunidades, os moradores têm transferido suas queixas e reivindicações para o Poder público, no caso, a Prefeitura de Canutama.

Sobretudo no período em que esta pesquisa foi realizada, os comunitários enfrentavam muitas dificuldades e não havia ajuda - efetiva e frequente - de nenhuma das partes envolvidas/responsáveis pela Resex, seja da Prefeitura, da associação e da cooperativa, ONGs ou empresas apoiadoras. Além dos transtornos causados pelas restrições da pandemia da Covid-19, no que diz respeito à venda dos seus produtos, os moradores reclamaram, repetidamente, da deficiência de serviços básicos, tais como saneamento, atendimento de saúde, transporte e educação.

Por seu turno, a Prefeitura local se queixou da falta de "parceria" do governo federal "nós nos sentimos muito só" (na luta para preservar o bioma da floresta amazônica, sobretudo no que se refere à fiscalização). 
Levando em conta a necessidade de representatividade para as demandas dos produtores das áreas protegidas, estudo do Ministério do Meio Ambiente (MMA) ressaltou a importância de incentivar a autonomia das organizações comunitárias, a fim de promover sua autogestão. O que está condicionado ao fortalecimento das associações, como forma de propiciar a independência das organizações comunitárias e dar continuidade a iniciativas já existentes (BRASIL, 2018).

"Eu acredito que se eles... o Poder público tivesse mais presente aqui dentro da Resex seria bem melhor. Porque a gente também sente muito a ausência do Poder público aqui do município”. (Produtor - Comunidade São Jerônimo)

“[Ajuda] Algumas vezes. Com esse prefeito que tá no comando, ele manda o diesel. Já tava com três meses que não mandava. Agora, como chegou a política [período eleitoral], eles mandaram de volta o diesel. (Produtora - Comunidade Açaituba)

\subsubsection{Mudanças decorrentes da criação da Resex}

De acordo com os depoimentos, as mudanças positivas que a criação da Resex proporcionou estão relacionadas sobretudo à preservação da floresta. Os entrevistados têm dificuldade para verbalizar detalhadamente sobre os benefícios percebidos, devido à falta de conhecimento a respeito da gestão da Reserva ou porque, de maneira geral, não conseguem expressar claramente suas ideias e opiniões.

Por isso, se referem genericamente ao meio ambiente - "não teve mais desmatamento" - e sobre os benefícios aos moradores da Resex. Entretanto, baseado nos relatos, não é incorreto acrescentar um benefício direto aos comunitários: no que tange à segurança de ter uma moradia, sem dever obrigações a patrões e donos da terra. Este é motivo relevante para satisfação da população local e foi conquistado a partir da delimitação da área de proteção ambiental.

É verdade que há referências à tranquilidade do local, que condiz com o modo de vida dos comunitários, mas quando mencionam as condições de vida antes da criação da Resex ou das dificuldades financeiras para sustentar a família ou, ainda, do custo proibitivo (para eles) de se morar "na cidade" (centro urbano mais próximo), é que se percebe a importância, para os entrevistados, da garantia de ter onde morar.

Por outro lado, há reconhecimento de que, após a criação das reservas extrativistas, as comunidades residentes dessas áreas tiveram redução das opções de subsistência, por conta das restrições, já que as áreas com permissão de exploração são menos abrangentes, além de a extração de certos produtos estar vinculada a longos deslocamentos floresta adentro, o que 
aumenta o tempo de realização da tarefa (além do tempo de deslocamento, há o tempo para extração do produto) e encarece o processo de comercialização (local de extração é longe do rio, único caminho para escoar a produção).

Maciel et al. (2018) observou situação semelhante na Resex Chico Mendes, no Acre, onde houve significativa redução da eficiência econômica e do nível de vida das famílias. Verificou ainda que, na questão ambiental, houve diminuição das florestas e aumento do desmatamento e de pastagens para produção de gado.

"Eu acho que se não tivesse acontecido isso pra nós aqui, tava muito mais difícil. Porque antes de ser criada a Resex, era, digamos que as localidades eram divididas por dono, né, assim, patrão. E a gente não tinha... a gente morava de favor”.

(Produtor - Comunidade São Jerônimo)

\subsubsection{Gestão da Resex e participação dos comunitários}

No período de realização deste estudo, o gestor da Resex Canutama estava à frente da Reserva havia dez anos, sendo que, desde 2015, acumulava também a gestão de outra Unidade, o que, segundo ele, comprometia sua atuação, por conta da dificuldade para estar presente assiduamente nas duas áreas, até porque, em termos de localização, elas ficam em sentidos opostos. O que é agravado pela precariedade da estrutura para deslocamentos na região, que são realizados por barcos ou a pé, adentrando a floresta.

O gestor declarou não ter participado de treinamentos específicos para a função e que sua capacitação decorre da experiência anterior, como "gestor de Unidade de Conservação, cargo que ocupou por três anos. O tempo de atuação nas comunidades e na Resex, como um todo, proporcionou grande vivência administrativa, conhecimento facilmente perceptível nas suas manifestações e comentários. No entanto, o gestor revelou que recebeu, em caráter geral e não específico, orientações técnicas e gerenciais de órgãos governamentais e de instituições parceiras ou que apoiam a defesa da Amazônia e das áreas protegidas.

A experiência prática propiciou ao gestor saber dos trâmites que envolvem captação de recursos e execução de ações em favor da Resex, reclamou da falta de engajamento dos produtores, mas não relatou ter realizado atividades ou ações que estimulassem o engajamento dos moradores/produtores. Estes, por sua vez, pareceram inertes e/ou resignados com a situação atual e, de fato, não demonstraram conhecimento sobre as possibilidades de assistência que podem conquistar ou que têm direito, como também não demonstraram postura de engajamento, no sentido de se empenhar para implementar ações transformadoras e de melhoria das condições da população da Resex. 
Em contraponto, não se sabe se o comportamento dos produtores seria outro, caso tivessem recebido informações gerenciais, burocráticas ou administrativas, com relação à Resex e às condições para captação de recursos ou outro tipo de ajuda, a fim de melhorar o processo de venda dos seus produtos.

Nesse sentido, estudo de Cooper e Kainer (2018) constatou que há pouca, ou nenhuma, participação dos comunitários na elaboração das regras e na governança dos programas de extração ou uso do solo das áreas protegidas. A sua conclusão ressalta a importância de levar em conta as percepções dos residentes na tarefa de facilitar o desenvolvimento dos meios de subsistência, além de fomentar o empoderamento dos comunitários, ao invés de somente viabilizar renda adicional.

Paralelamente, a atuação de cooperativas e associações locais é praticamente nula, inclusive há produtores que nem sabem que existe uma entidade representativa da Resex, da mesma forma que não foi relatada nenhuma iniciativa em favor dos comunitários. Por isso houve poucas menções espontâneas a respeito da cooperativa e da associação existentes e, quem comentou, sugeriu que era preciso "ser paciente", aludindo ao ritmo da atuação dessas organizações. A opinião de alguns é que a cooperativa poderia ser uma aliada no processo de venda dos produtos da Resex, representando os produtores e/ou reivindicando, junto ao Poder Público, melhorias, seja na colheita (equipamentos, mínimo de estrutura para quem tem que ficar dias no meio da floresta), armazenamento, negociação (atravessadores), transporte.

Segundo relato do presidente da Cooperativa Mista Agroextrativa do Sardinha COOPMAS, criada em 2008, é única cooperativa que atua na Resex Canutama, a entidade está praticamente sem atividades a mais de 3 anos devido ausência de recursos e má gestão, apesar de ter estrutura para beneficiar castanha e açaí, não possui barco coletor e nem condições financeiras para adquirir a produção, relata que os produtores da reserva não tem interesse na cooperativa, devido a cooperativa não possuir recursos financeiros para pagar antecipado ou à vista pela produção, portanto, os produtores 'preferem' negociar diretamente com o atravessador.

A Resex Canutama possui duas associações, Associação dos Agroextrativistas da Reserva Extrativista de Canutama-ASARC, criada em 2011, que atua mais nas questões fundiárias, a Associação dos Produtores Agroextrativistas da Colônia do Sardinha-ASPACS, criada em 1998, que atua na coleta e comercialização de produtos da Resex. Conforme relatos da presidente da ASPACS, a associação trabalha com extração de óleos vegetais e agricultura familiar, mas não consegue acessar as comunidades mais distantes, devido à ausência de barco, só consegue fazer coletas nas comunidades mais próximas. A ASPARC está em 
situação financeira melhor, pois, conseguiu firmar contrato para fornecimento de manteiga de murumuru, porém, também enfrenta problemas financeiros e não possui condições para financiar produtores. A cooperativa COOPMAS e a associação ASPARC funcionam no mesmo local, e ambas enfrentam problemas de viabilidade econômica. A associação ASARC ainda não tem sede ( $\underline{\mathrm{ANEXO} \mathrm{B}}$ - Contrato da Associação: fornecimento de gordura de Murumuru)

Em contraponto, Viana, Vaccaro e Venzke (2018) ponderam que, mesmo que as cooperativas se preocupem com a sua viabilidade econômica, não é fácil, para elas, gerenciar os efeitos econômicos indiretos, tais como a geração de renda e o impacto no desenvolvimento local. Contudo, importante reforçar que, conforme os relatos, os produtores negam ou desconhecem qualquer iniciativa das entidades representativas estabelecidas na Resex.

De todo modo, esse panorama não favorece o desenvolvimento da Resex e afeta sua sustentabilidade financeira, porque o comprometimento dos governos, de organizações multilaterais e do setor privado é fundamental para o sucesso dos negócios que envolvem biodiversidade. Assim como é importante a participação e engajamento das comunidades locais nas parcerias comerciais e de negócios, pois essa relação é o que gera confiança entre as partes da cadeia de valor (UNCTAD, 2017).

\section{“[Ajuda da cooperativa] tá indo, né? Tem que ser paciente”. (Produtora - Comunidade Açaituba)}

"Eu acho que se tivesse um preço melhor, se tivesse tipo uma cooperativa para comprar as coisas pra gente, produto da gente aqui, eu acho que a gente viveria melhor”.

(Produtor - Comunidade São Jerônimo)

\subsubsection{Expectativas de futuro}

Segundo os relatos, os entrevistados esperam melhorias para suas vidas na Resex, especialmente na infraestrutura, que ajudará a desenvolver sua atividade produtiva e proporcionar mais conforto e facilidades para seu cotidiano. Também é consenso que a manutenção da fiscalização e os procedimentos de preservação ambiental são fatores preponderantes para a conservação da floresta e da própria Reserva.

No geral, os comunitários se sentem abandonados pelo Poder público, desde questões básicas, como serviços de educação, saúde, energia, saneamento, a situações mais complexas e fundamentais, como as relacionadas à comercialização da sua produção, que incluem a 
necessidade de transporte adequado e combustível, para que os próprios produtores possam levar os produtos aos compradores, sem a intermediação de atravessadores, situação que refletiria positivamente no valor de venda dos produtos.

Considerando esse panorama, pode-se dizer que o sentimento de abandono é legítimo, já que a criação das Resex previa que houvesse apoio efetivo das instituições estatais, com implementação de projetos sociais (saúde, educação, aposentadoria, por exemplo) nas comunidades locais, além de outros incentivos ao processo de produção (crédito, assistência técnica, transporte, tecnologias), de maneira a garantir o equilíbrio ambiental e melhorias nas condições de vida dos moradores. Todavia, o que se verifica é que, após quase trinta anos da criação das primeiras Resex, houve poucas iniciativas do governo federal no sentido de gerar melhorias e bem-estar às famílias e em favor dos recursos ambientais nas áreas protegidas (FREITAS et al., 2018; FREITAS e RIVAS, 2014).

Um pequeno grupo de comunitários se manifestou desanimado com o futuro da Resex e, consequentemente, com as implicações da situação atual para suas famílias. A questão da limitação do serviço educacional tem relevância significativa para esses entrevistados, mas observou-se que o principal motivo do desalento está associado às dificuldades para manter a subsistência das suas famílias.

Alguns produtores têm contratos fixos com a Prefeitura ou abastecem alguma escola com sua produção, mas a maioria dos residentes da Resex convive, a cada colheita/extração, com a incerteza acerca da venda da sua produção - devido às dificuldades de transporte, de baixa ou alta produção, os produtores têm que se sujeitar a um baixo valor de venda, para não voltarem para casa com os mesmos produtos (que apodrecerão), ou sem dinheiro. Ou há casos em que a decisão é por não colher a produção (“deixar perder”), pois, assim, o prejuízo é menor, segundo declarações. Há ainda os que, apesar dessas condições, se dão por satisfeitos pelo simples fato de conseguirem sustentar a família, sem precisar vender produtos da Resex (plantam para subsistência).

“Plantar pra que mais?” Porque tá invadido já, todo mundo planta uma coisa só [melancia]. Perderam muito, não tem pra quem vender... Aí não vai dá. Aí eu fiquei pensando: "O quê que eu vou fazer? Voltar a pescar de novo?” Outra briga. Eu já parei isso. Porque o cara sofre, também, demais. (Produtor - Comunidade Irajá)

"Se tivesse pra cá um comprador, né, só pra comprar os nossos... Os produto, né? A gente entregava o produto e recebesse logo o dinheiro. Como a castanha, até agora não recebemo um centavo da castanha. Não recebemo nem um centavo. Aí fica difiço, né, para gente. A gente não tem condições". (Produtora - Comunidade Nova Vista) 
"Melancia está aí, se estragando na praia. Ninguém vende não, tem demais na cidade. Tenta vender, é muito baratinho, é muita despesa".

(Produtora - Comunidade do Carmo)

Quanto ao propósito de preservação ambiental, os entrevistados acreditam na eficácia do papel da Resex para manter a área protegida, mas demonstraram preocupação com o que está por vir, considerando as frequentes ocorrências (no período em análise) de queimadas e desmatamento em UCs vizinhas.

De qualquer forma, como pondera Gomes et al. (2018), pelo fato de as Resex terem ocupado o centro dos debates a respeito de conservação do meio ambiente com base em pessoas, a atualização do significado e representatividade das Resex já deveria ter acontecido, se considerada sua importância para futuras discussões no contexto amplo do desenvolvimento regional e de conservação da Amazônia brasileira.

"O que gostaria que melhorasse era que olhasse mais pra gente, né? Porque tem muito... Assim, tão passando agora aí, pra retornar de novo, pode esquecer. Aí eu gostaria que eles viessem mais vezes, pra orientar a gente de alguma coisa, né? Porque isso é o principal disso acontecer. Aí vem uma vez por ano, quando vem. Aliás, quando vem. Não é nem toda vez que vem. Às vezes, quando vem, não para aqui, passa direto. Aí isso aí, pra mim, tem que melhorar mesmo" (Produtora- Comunidade Açaituba)

[Resex tem futuro?] “Tem. Se preservar mesmo, tem, né? Se não deixar invadir, né? Os de fora...” (Produtor - Comunidade Nova Vista)

Em resumo, a análise de conteúdo das entrevistas referente ao conhecimento do morador/produtor sobre a Resex Canutama revelou que na maioria dos casos, o conhecimento sobre a Resex se refere mais às exigências e restrições para o cuidado ambiental do território do que ao seu funcionamento em geral ou às condições para sua manutenção e que os comunitários sabem mais dos seus deveres do que dos direitos. Junto com a simplicidade do modo de vida e com relação a expectativas, talvez a falta de conhecimento aprofundado sobre a Resex (direitos, deveres, oportunidades), esteja inibindo ou dificultando o engajamento e motivação dos comunitários em ações de reivindicação e /ou de busca por melhores condições de vida na Resex. 


\subsection{Conservação Ambiental}

\subsubsection{Conscientização e engajamento pela proteção ambiental}

No geral, as melhorias observadas pelos entrevistados, após a criação da Resex, referem-se à proteção da área, ou seja, desde então, houve menos invasões, menos desmatamento, menos pesca ilegal - embora em algumas comunidades ainda ocorra ilegalidades, principalmente a pesca. Também houve comentários sobre o fato de que a Resex trouxe mais informações e orientações para os comunitários, principalmente acerca de formas de cultivo de alimentos, assegurando proteção ao meio ambiente.

Mesmo que não da forma ideal (porque as ilegalidades prosseguem), segundo os produtores, as Reservas Extrativistas têm contribuído ("é a saída") para a preservação do ecossistema da Amazônia.

Contudo, em se tratando de melhorias nas condições de vida das famílias residentes na Resex, os efeitos não são expressivos, haja vista que persistem as dificuldades para sobreviver e para vender seus produtos, apesar de que essa situação não tenha relação direta com a criação da Resex, pois era da mesma forma anteriormente.

Manifestações e relatos dos entrevistados demonstraram que eles estão cientes do seu papel no que diz respeito aos esforços para preservação daquela área de proteção ambiental, seja fazendo a sua parte, obedecendo às determinações dos órgãos oficiais e governamentais de conservação ambiental, seja fiscalizando a área da sua comunidade e denunciando qualquer ação de desrespeito e degradação do meio ambiente.

“Melhorou um pouco, por causa das invasões... que pararam mais, de invadir. Tinha muita [invasão]. Na madeira, ninguém mexeu mais, mas a pesca, ainda tem.

(Produtor - Comunidade Santa Maria)

\subsubsection{Ilegalidades Ambientais}

Ainda que as Resex tenham contido as investidas de infratores às áreas protegidas, as ilegalidades continuam acontecendo. Por isso, o repetido desrespeito às áreas protegidas alerta para a necessidade de fiscalização efetiva e constante.

Quando identificada, qualquer ilegalidade praticada dentro da Resex Canutama é rapidamente "denunciada" pelos moradores ao gestor ou lideranças locais, que se encarregam de advertir os infratores. Normalmente, há uma conversa de conscientização sobre a preservação dentro dos limites das UCs e das punições previstas e, conforme necessário, providencia-se a retirada dessas pessoas dos limites da Resex. 
Dois tipos de ilegalidades são as mais recorrentes:

Desmatamento - O desmatamento da floresta amazônica é uma realidade que faz parte da vida dos moradores da Resex e há muito tempo eles presenciam ou ouvem falar sobre essa situação. No entanto, sobretudo para os que já moravam na região antes da criação das reservas extrativistas, é notório que a delimitação de áreas com proteção ambiental fez reduzir a ação (pelo menos, a ostensiva) de degradação da floresta.

Os entrevistados afirmaram que as Resex são fundamentais para cumprir o objetivo de "parar de destruir o pau" indiscriminadamente. A opinião geral é que houve, de fato, controle do desmatamento, mas, em períodos recentes (inclusive durante a realização desta pesquisa), foi constatada intensa ocorrência de queimadas em áreas próximas aos limites da Resex Canutama - para desaprovação e indignação dos comunitários, que, notadamente, estão conscientes e engajados nas ações de preservação ambiental.

A percepção acerca do aumento de queimadas é confirmada por dados do INPE (2019), que, já em 2019, apontavam que o desmatamento na região amazônica era alto, acelerado e crescente. Entre os anos de 2008 e 2019, o desmatamento no estado do Amazonas tinha consumido $10,97 \%$ do território.

De acordo com os relatos, as queimadas, além de contribuir para o desflorestamento, provocam alterações no clima (aumento da temperatura, "chuva com água escurecida"), que afetam a saúde das pessoas e todo o ecossistema da região. A alta da temperatura, agravada pelas queimadas, prejudica a produção das comunidades, pois, com o "calor castigando", é mais difícil permanecer muito tempo na plantação ou na extração.

Depoimentos isolados davam conta de que em algumas comunidades tem havido ocorrências de desmatamento - "pouco, mas tem" - e os moradores atribuía]m a pessoas de fora da Resex.

"Eu era doidinho que transformasse em reserva, sabe? Porque o pessoal destruiu muito pau aqui, sem precisão. Porque quando entra em reserva, já tá dizendo, é reserva. É para o cara conservar, não é para ir tirando coisa. Que não tem precisão, né?’”.

(Produtor - Comunidade Santa Bárbara)

“De queimada, aqui, eu acredito que não chegou, não, ainda”.

(Produtor - Comunidade São Jerônimo)

[Queimadas] "Eu acho que é errado isso aí, de tarem fazendo isso aí. Por causa que isso jamais era pra tá acontecendo. Porque prejudica o ser humano, né? Tudo, aliás. Prejudica é todo mundo mesmo, até os animais, a vida das crianças. (Produtora - Comunidade Açaituba) 


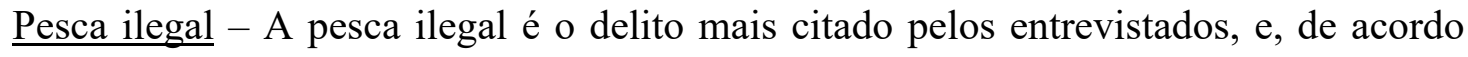
com depoimentos, na maioria dos casos, é cometido por pessoas que não são moradores da Resex. As principais ocorrências são a pesca em locais e épocas proibidas e o uso de artefatos de pesca considerados ilícitos em áreas de proteção ambiental. Em determinadas comunidades, foi vista derrubada de árvores "para secar pirarucu" e houve comentários sobre tartarugas capturadas no período da desova, sendo levadas para venda.

Tais situações causam indignação aos moradores não somente pela violação das normas estabelecidas para reservas extrativistas (há casos de espécies em extinção), mas também porque se sentem prejudicados, já que eles respeitam as regras e os infratores acabam tendo vantagens (em volume e qualidade dos produtos), o que faz parecer que a regulamentação que vale para os comunitários (que respeitam as regras de preservação), mas não vale para todos, pois os infratores não estão sendo punidos (principalmente se for levado em conta que as ocorrências são reincidentes). Há receio de que, em algum momento, faltará peixe para abastecer as famílias dessas comunidades, já que, muitas delas, pescam apenas para o próprio consumo. Apesar das denúncias, esses fatos têm se repetido.

"Mas a questão de outros crimes ambientais, tipo da pesca, a gente vê que tem pescadores aí que pesca com material que não é pra pescar, é proibido por lei. E a gente, que mora aqui dentro, a gente sente que... Malha miúda... A deles, leva tudo. E aqueles que eles acham que não dá para vender, é que eles jogam fora, porque estraga. Eu tô vendo que uma hora vai faltar [peixe]" (Produtor - Comunidade São Jerônimo)

“... Porque, às vezes, a gente pesca... é pouco, né? Eles que é direto, é inverno e verão, direto, direto, direto. Tanto faz inverno como no verão, eles tão lá dentro, acabando com tudo. Aí já faz falta [peixe] pra nós, né? Que nem nós fomo agora, os peixe até difiço entrar na 'maiadeira', porque solta até bomba lá dentro"

(Produtora - Comunidade Nova Vista)

\subsubsection{Fiscalização Ações preventiva}

$\mathrm{Na}$ maior parte dos casos a fiscalização é feita a partir de denúncias, pois, raramente ocorre o monitoramento chamado preventivo, segundo o gestor, por falta de funcionários/agentes e de transporte adequado para deslocamentos (nem sempre há combustível disponível, que é destinado, prioritariamente, ao atendimento de necessidades básica da população local, como o escoamento da produção e alguma emergência de saúde).

Em geral, as ações preventivas são realizadas quando "parceiros" da Resex se apresentam. IBAMA e ICMBio são os principais agentes governamentais que atuam nas Unidades de Conservação e Reservas Extrativistas, porém, a sua presença nas Resex não é 
constante, os relatos dão conta de que as visitas às comunidades locais acontecem somente quando precisam cumprir algum compromisso em Lábrea ou Canutama.

Invariavelmente, as denúncias de situações contra o meio ambiente se referem a pesca e/ou extração de madeira de forma ilegal e, conforme depoimentos, são atendidas prontamente, e com firmeza, pelo gestor da Resex, que acredita que a atenção deve ser constante - "a gente tem que se programar para vir em cima!".

“A gente era colocado por eles, pra trabalhar para eles e, quando a gente não fazia do jeito deles, a gente era expulso daquela localidade, pelo fato de não fazer da forma que ele queria.

Porque [agora], pelo fato de ser Unidade de Conservação, os títulos que tinha foram nulos. [...] Aí os patrões perderam a força. Até porque a maioria já nem morava mais aqui. Eles ficavam administrando de lá”. (Produtor - Comunidade São Jerônimo)

O estudo também evidenciou forte conscientização dos comunitários quanto à necessidade de proteção do meio ambiente, maiormente do local em que vivem. Para tanto, os moradores da Resex Canutama se manifestaram prontos e dispostos a denunciar qualquer ação de depredação ou violação das restrições daquela área protegida.

Em resumo, a análise de conteúdo referente à percepção do morador/produtor entrevistado sobre conservação revelou que a criação das Reservas Extrativistas contribuiu para a conscientização e engajamento dos comunitários nos esforços para preservar as áreas de proteção ambiental; os comunitários têm participação efetiva nas ações de preservação das áreas protegidas.

\subsection{Sustentabilidade Financeira}

\subsubsection{Atividades Produtivas}

As atividades produtivas realizadas na Resex Canutama são determinadas pela sazonalidade hídrica da região, que permite identificar dois períodos bem distintos para o desenvolvimento das atividades agrícolas e de extrativismo, período de seca e período de cheia.

No período de seca, a partir de julho o nível do Rio Purus começa a baixar, formando praias com solo fértil favorecendo o plantio. Nessa época, são basicamente realizadas as seguintes atividades econômicas: a agricultura de diversas culturas nas praias que são 
disponibilizadas a partir do fim do mês de julho até novembro, principalmente, melancia, feijão, jerimum, milho, macaxeira, batata-doce. A outra atividade importante é a pescaria.

No período da cheia ou enchente do Rio Purus as atividades são realizadas nas localidades distantes das margens dos rios, às atividades extrativistas são realizadas, predominam a extração de castanha e açaí, coleta de sementes de murumuru e andiroba.

Mesmo a região tendo períodos de chuva e seca claramente definidos (que determina o melhor momento para plantar e colher), a produção sofre com a ação de pragas e pássaros que destroem as plantações. Alguns reclamaram também de animais de vizinhos que costumam atacar as lavouras e comer os alimentos.

"Nesse período da seca trabalha mais com a agricultura, né? Aí no período da cheia é mais com extrativismo" (Produtor - Comunidade São Jerônimo)

Os principais alimentos cultivados são melancia, melão, macaxeira (mandioca), feijão, milho, maxixe, quiabo, jerimum (abóbora). Maior parte desses produtos são destinados à subsistência das famílias e o excedente, que é comercializado, não representa grande volume, pois a produção, de modo geral, é modesta, embora o valor obtido com a venda seja importante na composição da renda dos comunitários.

Ao todo, são 38 produtos decorrentes das atividades agrícolas e extrativistas na Resex. A castanha, principal produto extrativista da Resex, foi responsável em média por $34 \%$ do total das vendas realizadas no período de 2010 a 2020, enquanto a farinha de mandioca se destacou como o principal produto agrícola, que, no período, representou em média $18 \%$ do total das vendas de produtos da Resex Canutama (Figura 14). 
Figura 14 - Gráfico da participação dos produtos mais vendidos - Resex Canutama (2019)

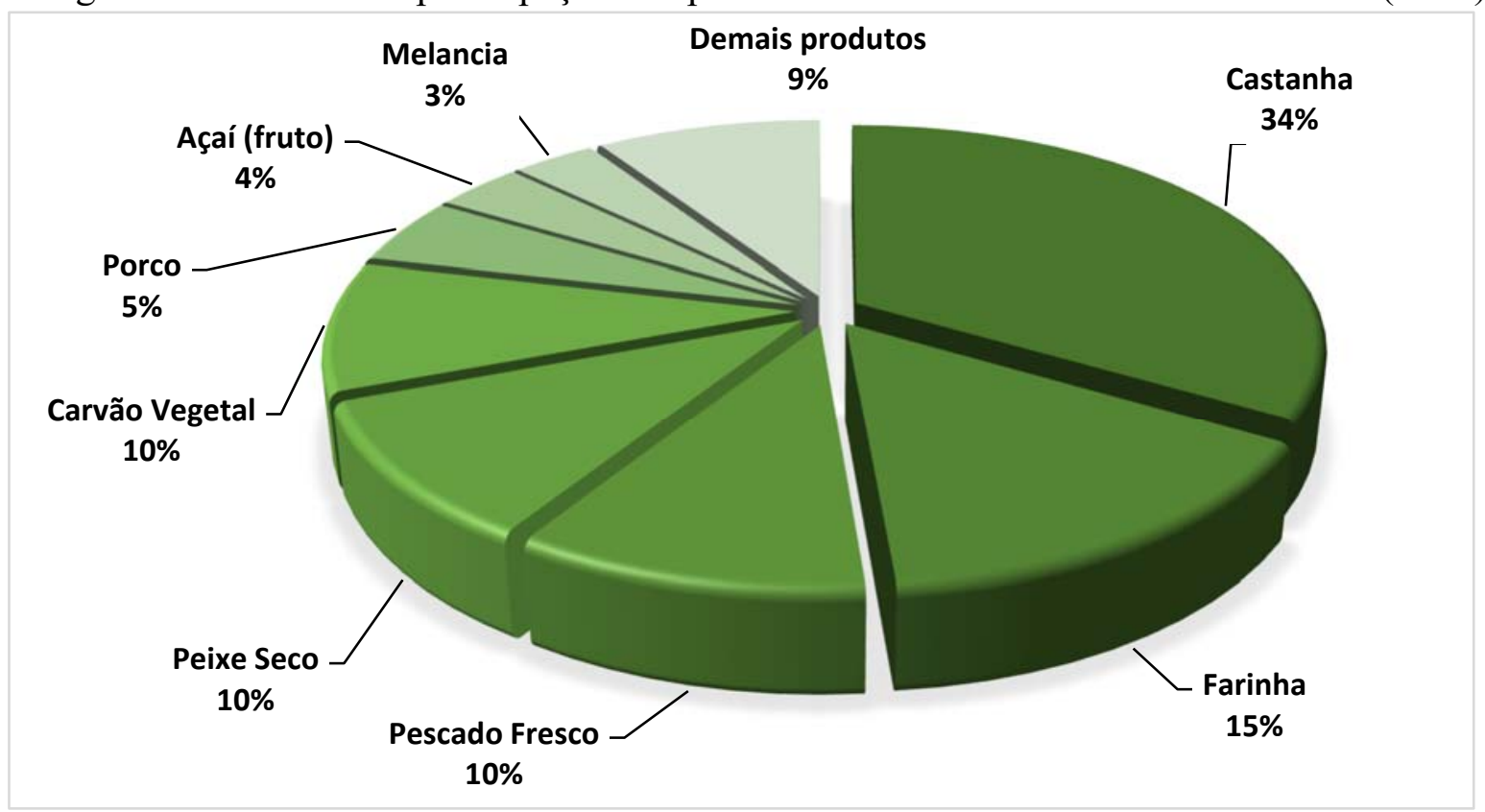

Fonte: Relatórios Gestão da Resex Canutama - adaptado pela autora.

Algumas lavouras (feijão, por exemplo) demandam mais trabalho, sobretudo na colheita, e dependem da participação de maior número de trabalhadores, o que nem sempre é possível. Normalmente, as famílias se juntam para a colheita e produção (no caso da farinha de mandioca), mas se alguém adoece ou se os filhos não ajudam, a execução da tarefa se torna difícil e acaba impactando a produção, a venda e, por consequência, o sustento das famílias. Para completar, pessoas idosas e as que já sentem no corpo os reflexos de uma "vida toda" dedicada à "roça", em algum momento, abandonam as atividades e, assim, reduzem as opções de mão-de-obra que propiciam obtenção de renda.

Do extrativismo, destacam-se castanha (carro-chefe da Reserva), pescado, açaí, murumuru e andiroba. Apesar de não atingir todas as comunidades e localidades da mesma forma, a castanha é o produto com peso mais significativo na renda da maioria das famílias da Resex Canutama.

Extraordinariamente, em alguma temporada (colheita) pode ocorrer de a farinha de mandioca, o pescado ou até a melancia, ser a principal fonte de renda.

“A minha roça eu só faço mesmo para despesa. Às vezes, nem dá. Isso aí é mais pra nós comer. Vendo mais algum litro, mas só aqui mesmo [na comunidade]”.

(Produtor - Comunidade Açaituba)

“Graças a Deus, não dá pra sobrar, mas, também, a gente não passa necessidade, não”. (Produtor - Comunidade Santa Maria) 
Nenhum dos produtores entrevistados planta com o objetivo de venda total da produção, pelo contrário, a maioria comercializa somente o que excede da produção para consumo próprio. Até porque a logística encarece sobremaneira a venda, especialmente porque os produtores não dispõem de transporte adequado (em tamanho, para armazenamento, e na potência do motor da embarcação) para fazer chegar os produtos aos compradores. Poucos levam diretamente seus produtos aos centros urbanos para vender, a opção mais usual é negociar com algum atravessador, o que provoca perdas consideráveis, pois além de pagarem pelo transporte, o preço oferecido pelos intermediários não é competitivo ("justo").

\subsubsection{Produção concentrada}

$\mathrm{Na}$ análise histórica dos dados agregados da produção vendida pela Resex Canutama no período de 2010 a 2020, chama atenção a representatividade da castanha, farinha e pescados fresco e seco nas vendas da Resex Canutama. Juntos, esses produtos significaram, em média, de $72,8 \%$ das vendas, durante a década analisada. Exclusivamente a castanha foi responsável por, em média, 34\% do volume das vendas totais.

Houve variações nos resultados gerais (década analisada), mas, à época da pesquisa, o produto mais vendido continuava sendo a castanha, apesar de ter perdido participação em 2020. Na segunda posição dos mais vendidos, a farinha de mandioca perdeu lugar para o pescado fresco, que vendeu em 2020 mais de 50\% do que foi comercializado no ano anterior.

Apesar de alguns dos produtos mais rentáveis da Resex (castanha, farinha, pescado fresco, pescado seco, açaí, porco, melancia) terem mudado de posição no ranking dos mais, ou menos, vendidos em 2019, eles se mantiveram entre os produtos com melhor desempenho em vendas em 2020.

Por outro lado, a avaliação individual (por produto) desses produtos mais vendidos (percentuais de participação 10\%, ou mais), mostra que as oscilações nos resultados das vendas se repetiram na última década, não havendo constância de queda ou de crescimento, ainda que em alguns anos tenha havido quedas bruscas ou crescimentos expressivos. Por exemplo, a venda de castanha caiu em 2015 e 2017, tendo recuperado o crescimento em 2018, voltando aos patamares da média; enquanto o pescado fresco repetiu bom nível de crescimento em 2015 e em 2020. Mesmo estando abaixo de patamar significativo, optou-se por manter explícitos na Tabela 4, os registros referentes às vendas de açaí, melancia, carvão vegetal e borracha, devido à sua representatividade no histórico de vendas da Resex - no caso 
do carvão vegetal e da borracha, é possível constatar o processo de decadência desses produtos ao longo dos anos.

A Tabela 10 ilustra os resultados da produção ao longo da última década. Nela, podese visualizar a participação, em percentual, de cada um dos principais produtos comercializados pelas Comunidades e Localidades da Resex Canutama entre os anos 2010 e 2020 .

Tabela 10 - Participação dos produtos principais na produção da Resex Canutama (2010 a 2020)

\begin{tabular}{|c|c|c|c|c|c|c|c|c|c|c|c|}
\hline \multirow{2}{*}{$\begin{array}{c}\text { Identificação do } \\
\text { Produto }\end{array}$} & \multicolumn{11}{|c|}{ Valor percentual por Ano (em \%) } \\
\hline & 2010 & 2011 & 2012 & 2013 & 2014 & 2015 & 2016 & 2017 & 2018 & 2019 & 2020 \\
\hline Castanha & $38 \%$ & $34 \%$ & $33 \%$ & $41 \%$ & $45 \%$ & $26 \%$ & $35 \%$ & $27 \%$ & $32 \%$ & $34 \%$ & $30 \%$ \\
\hline Farinha & $15 \%$ & $11 \%$ & $18 \%$ & $23 \%$ & $34 \%$ & $17 \%$ & $11 \%$ & $18 \%$ & $19 \%$ & $15 \%$ & $17 \%$ \\
\hline Pescado Fresco & $7 \%$ & $6 \%$ & $13 \%$ & $10 \%$ & $6 \%$ & $12 \%$ & $17 \%$ & $18 \%$ & $14 \%$ & $10 \%$ & $21 \%$ \\
\hline Peixe Seco & $16 \%$ & $12 \%$ & $14 \%$ & $3 \%$ & $\ldots$ & $6 \%$ & $4 \%$ & $15 \%$ & $5 \%$ & $10 \%$ & $9 \%$ \\
\hline Porco & $\ldots$ & $\ldots$ & $2 \%$ & $1 \%$ & $0,4 \%$ & $4 \%$ & $7 \%$ & $10 \%$ & $3 \%$ & $10 \%$ & $0,03 \%$ \\
\hline Açaí (fruto) & $\ldots$ & $\ldots$ & $1 \%$ & $0,50 \%$ & $0,2 \%$ & $2 \%$ & $3 \%$ & $3 \%$ & $6 \%$ & $5 \%$ & $5 \%$ \\
\hline Melancia & $6 \%$ & $5 \%$ & $5 \%$ & $7 \%$ & $\ldots$ & $12 \%$ & $7 \%$ & $5 \%$ & $8 \%$ & $4 \%$ & $7 \%$ \\
\hline Carvão Vegetal & $\ldots$ & $\ldots$ & $0,04 \%$ & $0,04 \%$ & $\ldots$ & $1 \%$ & $2 \%$ & $0,2 \%$ & $3 \%$ & $3 \%$ & $0,4 \%$ \\
\hline Borracha & $15 \%$ & $23 \%$ & $9 \%$ & $11 \%$ & $13 \%$ & $4 \%$ & $1 \%$ & $\ldots$ & $\ldots$ & $\ldots$ & $\cdots$ \\
\hline Demais produtos & $4 \%$ & $9 \%$ & $6 \%$ & $4 \%$ & $0 \%$ & $16 \%$ & $14 \%$ & $3 \%$ & $11 \%$ & $9 \%$ & $10 \%$ \\
\hline Total & $100 \%$ & $100 \%$ & $100 \%$ & $100 \%$ & $100 \%$ & $100 \%$ & $100 \%$ & $100 \%$ & $100 \%$ & $100 \%$ & $100 \%$ \\
\hline
\end{tabular}

Fonte: Elaborado pela autora, com base nos dados cedidos pelo gestor da Resex

Esse panorama instável parece evidenciar não somente incertezas dos mercados, mas, também, deficiências na governança da Resex. Como destacaram Sabadin et. al. (2008), para se manter em mercados competitivos, as empresas precisam ter ciência dos seus objetivos, atividades e resultados, bem como relacionar esses aspectos aos ambientes interno e externo em que atua, tanto no que diz respeito ao contexto operacional, quanto ao estratégico.

Notadamente nos dois últimos anos contabilizados, as oscilações nas vendas foram contundentes, como mostra, a seguir, a Tabela 11. Estão apresentados os dados comparativos referentes aos produtos cultivados/extraídos com mais representatividade nas vendas totais da Resex Canutama em 2019 e 2020, além da respectiva taxa de crescimento de um ano para outro. 
Tabela 11 - Participação nas vendas dos principais produtos da Resex Canutama (2019/2020)

\begin{tabular}{lcc|c}
\hline $\begin{array}{l}\text { Produto } \\
\text { E Unidade de Medida }\end{array}$ & $\begin{array}{c}\mathbf{2 0 1 9} \\
(\mathbf{\%})\end{array}$ & $\begin{array}{c}\mathbf{2 0 2 0} \\
\mathbf{( \% )}\end{array}$ & $\begin{array}{c}\text { Crescimento } \\
\mathbf{( \% )}\end{array}$ \\
\hline Castanha (Hectolitro; 100 litros) & $33,5 \%$ & $29,9 \%$ & $-13,10 \%$ \\
Farinha (Saca de 50Kg) & $15,2 \%$ & $17,0 \%$ & $9,17 \%$ \\
Pescado Fresco (Kg) & $10,3 \%$ & $21,0 \%$ & $98,15 \%$ \\
Pescado Seco (Kg) & $10,2 \%$ & $9,3 \%$ & $-11,31 \%$ \\
Porco (Unidade) & $9,5 \%$ & $0,0 \%$ & $-99,71 \%$ \\
Açaí Fruto (Lata 18Kg) & $4,9 \%$ & $5,0 \%$ & $-0,34 \%$ \\
Melancia (Unidade) & $3,6 \%$ & $7,5 \%$ & $101,06 \%$ \\
Carvão Vegetal (Saco 50Kg) & $3,4 \%$ & $0,4 \%$ & $-87,44 \%$ \\
Demais produtos & $9,3 \%$ & $9,8 \%$ & $2,83 \%$ \\
\hline Total & $100 \%$ & $100 \%$ & $\mathbf{- 2 , 6 4 \%}$ \\
\hline
\end{tabular}

Fonte: Relatórios Gestão da Resex Canutama - adaptado pela autora.

A começar pela castanha, produto mais vendido da Resex, que em 2020 teve perda de participação na ordem de 13,10\%, em relação a 2019. Diferentemente do pescado fresco, cuja participação nas vendas totais da Resex, aumentou mais que o dobro, tendo crescimento de 98,15\%. Entre os produtos mais cultivados (não necessariamente os mais vendidos), sobressaí a melancia, que tiveram crescimento positivo de $101,06 \%$.

Observe-se que, enquanto a participação da castanha nas vendas de 2020 foi menor que em 2019 (29,9\% contra 33,5\%), a farinha e o pescado fresco tiveram resultado positivo, com crescimento de $9,17 \%$ e $98,15 \%$, respectivamente A venda de pescado fresco em 2020 aumentou mais que o dobro com relação à 2019, passou de $10 \%$ para $21 \%$ de participação. A farinha representou 17\% das vendas em 2020, contra 15\%, em 2019.

Ainda que não anotados na Tabela 11 em referência, registre-se que os demais produtos que compõem a cesta da produção da Resex Canutama já tinham participação irrisória nas vendas totais (menos de 1\%) e mantiveram o patamar, sendo que grande parte perdeu participação, tendo resultado negativo em 2020 (em comparação a 2019), o que leva a crer que, nesse caso, a prioridade foi o sustento das famílias - são produtos originados predominantemente de pequenas lavouras (feijão, batata doce, pupunha, entre outros) e da criação de animais e aves (boi, porco, galinha). Mesmo assim, se comparados aos próprios resultados, alguns produtos se destacaram, por exemplo, produtos que não tiveram colheita em 2019 e passaram a vender em 2020, como o óleo de copaíba (APÊNDICE B - Produtos Vendidos na Resex Canutama (2019-2020).

O carvão vegetal, que tinha ensaiado aumentos de produção/venda em 2018 e 2019 (vide Tabela 5), em 2020 teve queda brusca, com perda de 87,44\% de participação nas vendas totais da Resex. 
A Resex Canutama possui 38 espaços territoriais, sendo 16 Comunidades e 22 Localidades, a Tabela 12 traz os resultados gerais das vendas da Resex nos dois últimos anos contabilizados, revelando que, em 2020, o crescimento foi negativo $(-2,64 \%)$, em comparação a 2019 .

Tabela 12 - Resultados das Vendas da Resex Canutama (2019/2020)

\begin{tabular}{lcc|cc|c}
\hline \multirow{2}{*}{$\begin{array}{l}\text { Local da } \\
\text { Produção }\end{array}$} & \multicolumn{2}{c|}{ Resultado em 2019 } & \multicolumn{2}{|c|}{ Resultado em 2020 } & Crescimento \\
\cline { 2 - 6 } Comunidades & $2.680 .132,00$ & $89,25 \%$ & $1.872 .297,94$ & $64,04 \%$ & $\mathbf{- 3 0 , 1 4 \%}$ \\
Localidades & $322.820,00$ & $10,75 \%$ & $1.051 .291,42$ & $35,96 \%$ & $\mathbf{2 2 5 , 6 6 \%}$ \\
\hline Produção Total & $\mathbf{3 . 0 0 2 . 9 5 2 , 0 0}$ & $\mathbf{1 0 0} \%$ & $\mathbf{2 . 9 2 3 . 5 8 9 , 3 6}$ & $\mathbf{1 0 0 \%}$ & $\mathbf{- 2 , 6 4 \%}$ \\
\hline
\end{tabular}

Fonte: Relatórios Gestão da Resex Canutama - adaptado pela autora

Tal cenário reflete o resultado das comunidades, cujas vendas, no mesmo período, também foram negativas, fechando em $-30,14 \%$, embora o histórico tenha se mantido, com as comunidades permanecendo à frente das localidades, ou seja, participação nas vendas de $64,04 \%$ contra 35,96\%, respectivamente. (Ver os dados de produção e vendas de todas as comunidades e localidades no APÊNDICE A - Produção na Resex Canutama 2019-2020)

Ao mesmo tempo, há que se ressaltar o vertiginoso crescimento do volume de vendas totais das localidades $(225,66 \%)$, não há dados suficientes para explicar a situação.

Logo abaixo a Tabela 13 apresenta os percentuais de participação de cada uma das 16 Comunidades nas vendas de 2019 e 2020, assim como a taxa de crescimento verificada em 2020, em comparação a 2019.

Pelo que se constata, apesar de um número maior de comunidades terem tido resultado positivo, eles foram modestos. Ao contrário dos resultados negativos, que mostraram perdas acentuadas.

A começar pela Comunidade Nova Vista, destaque da Resex em produção e vendas, que em 2020, ainda que tenha mantido o primeiro lugar entre as demais, operou com desempenho 61,26\% negativo, em relação a 2019. Esse fato demonstra a alta dependência da comunidade em relação à castanha, em 2019 e 2020 o produto representou 85,52\% e 64,25\% de seu volume de produção, respectiamente. 
Tabela 13 - Participação percentual da produção realizada nas Comunidades, em relação ao total da produção na Resex Canutama (2019-2020)

\begin{tabular}{lcc|c}
\hline Comunidades & $\mathbf{2 0 1 9}$ & $\mathbf{2 0 2 0}$ & Crescimento \\
\hline Nova Vista & $27,7 \%$ & $11,0 \%$ & $\mathbf{- 6 1 , 3 \%}$ \\
Bacadaru & $6,5 \%$ & $8,2 \%$ & $\mathbf{2 4 , 3 \%}$ \\
Santa Bárbara & $14,1 \%$ & $6,3 \%$ & $\mathbf{- 5 6 , 6 \%}$ \\
Açaituba & $7,7 \%$ & $5,0 \%$ & $\mathbf{- 3 7 , 7 \%}$ \\
Fortaleza & $8,3 \%$ & $4,6 \%$ & $\mathbf{- 4 5 , 4 \%}$ \\
Glória II & $2,4 \%$ & $4,3 \%$ & $\mathbf{7 9 , 5 \%}$ \\
Sacado & $3,4 \%$ & $3,8 \%$ & $\mathbf{9 , 3 \%}$ \\
Irajá & $2,3 \%$ & $3,2 \%$ & $\mathbf{3 8 , 4 \%}$ \\
Santa Maria & $2,2 \%$ & $2,8 \%$ & $\mathbf{2 5 , 5 \%}$ \\
Forte Veneza N. Colônia & $3,6 \%$ & $2,4 \%$ & $\mathbf{- 3 3 , 6 \%}$ \\
Santo Antônio do Apituã & $1,8 \%$ & $2,4 \%$ & $\mathbf{3 0 , 5 \%}$ \\
São Jerônimo & $1,7 \%$ & $2,3 \%$ & $\mathbf{3 2 , 5 \%}$ \\
Carmo & $2,1 \%$ & $2,2 \%$ & $\mathbf{2 , 2 \%}$ \\
Boca do Gavião & $2,2 \%$ & $2,1 \%$ & $\mathbf{- 5 , 5 \%}$ \\
São Tomé & $1,5 \%$ & $2,0 \%$ & $\mathbf{3 1 , 9 \%}$ \\
Capoeirinha & $2,0 \%$ & $1,3 \%$ & $\mathbf{- 3 8 , 0 \%}$ \\
\hline Total & $\mathbf{8 9 , 2 5 \%}$ & $\mathbf{6 4 , 0 4 \%}$ & $\mathbf{- 3 0 , 1 4 \%}$ \\
\hline
\end{tabular}

Fonte: Relatórios Gestão da Resex Canutama - adaptado pela autora.

A Figura 15 abaixo revela a alta concentração da produção nas comunidades, pois considerando o valor monetário alcançado com a produção nas dezesseis comunidades em 2019, há uma forte concentração da produção em poucas comunidades, somente cinco comunidades conseguem atingir mais de $5 \%$ da produção da Resex, sendo uma única comunidade, Nova Vista, responsável por $31 \%$ de toda a produção, seguida da Comunidade Santa Bárbara (16\%); Fortaleza; Açaituba com 9\% e Comunidade Bacadaru com 7\%.

Essa forte concentração pode ser explicada pelo fato de que essas comunidades com maior volume de recursos financeiros concentrarem suas atividades econômicas nos produtos potenciais de maior procura na Resex, conforme explicitado a seguir:

- Comunidade Nova Vista: principal produto - Castanha.

- Comunidade Santa Bárbara: principal produto - Farinha, Pescado e Porco.

_ Comunidade Fortaleza: principal produto - Farinha, Castanha, Pescado.

_ Comunidade Açaituba: principal produto - Açaí.

_ Comunidade Bacadaru: principal produto - Castanha e Farinha. 
Figura 15 - Gráfico da participação da produção nas Comunidades-Resex Canutama (2020)

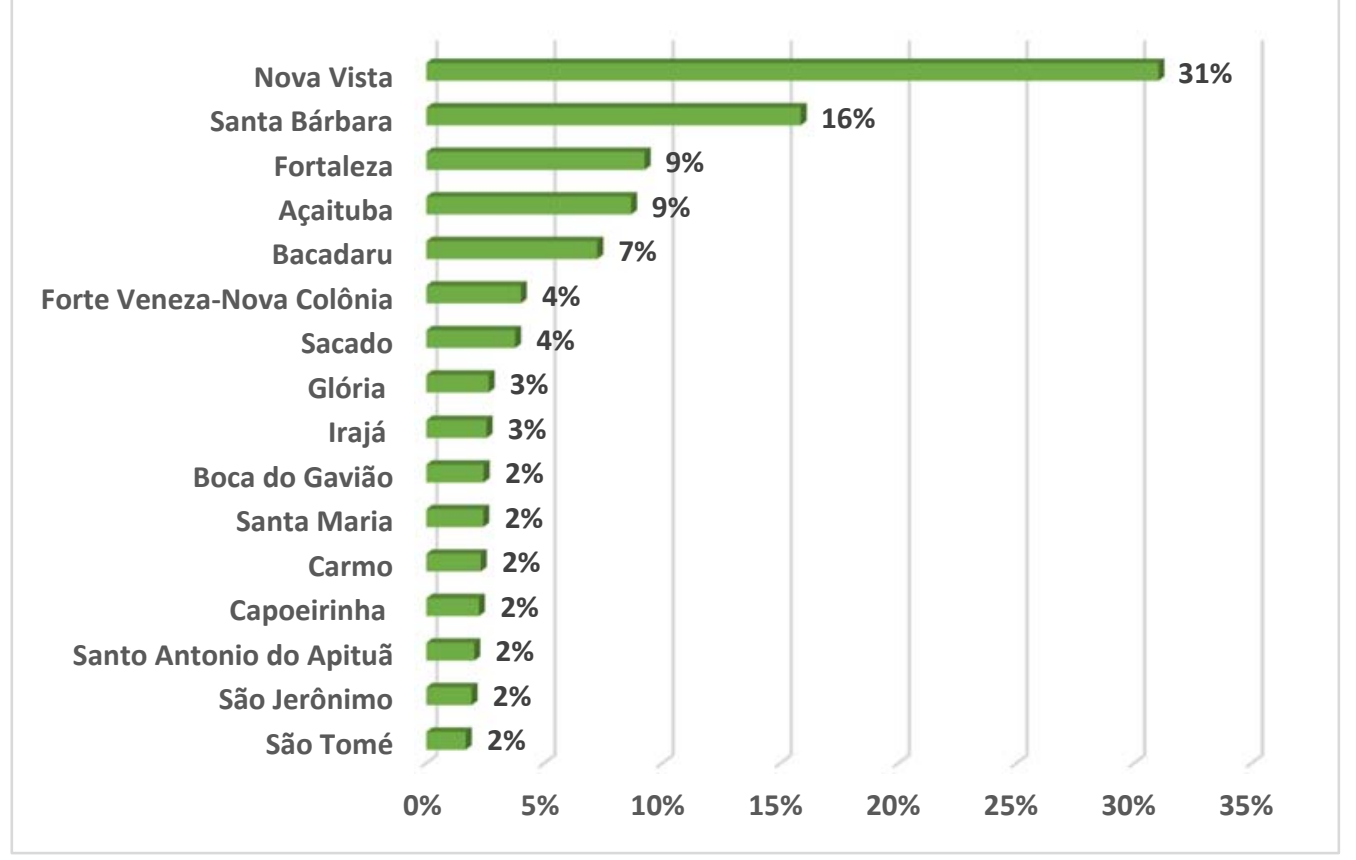

Fonte: Elaborado pela autora.

Por outro lado, a maioria das comunidades cuja performance costuma ser inferior em produção e vendas, apresentou resultados melhores em 2020 - por exemplo, a Comunidade Glória II teve crescimento de 79,48\% nas vendas, o que significa que sua participação nas vendas foi quase o dobro da alcançada em 2019. Contudo, não se pode dizer que esse é um resultado determinante para o resultado do conjunto da Resex, parece ter mais significado sobretudo financeiro - para a própria comunidade.

No caso das localidades, embora tenham tido resultado surpreendentemente positivo, atingindo crescimento de $225,70 \%$ em 2020 (mais que o triplo do ano anterior), para efeito de análise, optou-se por não apresentar os dados individuais, devido aos baixos índices de desempenho, com relação aos resultados totais da Resex.

A Tabela 14 abaixo apresenta os percentuais de participação de cada uma 22 Localidades nas vendas de 2019 e 2020, assim como a taxa de crescimento verificada em 2020, em comparação a 2019. 
Tabela 14 - Participação percentual da produção realizada nas Localidades, em relação ao total da produção na Resex Canutama (2019-2020)

\begin{tabular}{lcc|c}
\hline Localidades & $\mathbf{2 0 1 9}$ & $\mathbf{2 0 2 0}$ & Crescimento \\
\hline Tororó-Paissé & $0,56 \%$ & $7,89 \%$ & $\mathbf{1 . 2 7 8 , 9 4 \%}$ \\
Mapiciari & $0,36 \%$ & $6,84 \%$ & $\mathbf{1 . 7 3 8 , 2 4 \%}$ \\
Santana & $1,01 \%$ & $3,80 \%$ & $\mathbf{2 6 6 , 7 4 \%}$ \\
Vista Alegre & $2,90 \%$ & $1,69 \%$ & $\mathbf{- 4 3 , 1 5 \%}$ \\
Bom Sucesso & $2,75 \%$ & $1,78 \%$ & $\mathbf{- 3 6 , 9 0 \%}$ \\
Santa Eugênia & $1,93 \%$ & $1,21 \%$ & $\mathbf{- 3 8 , 9 1 \%}$ \\
Santa Cora & $1,24 \%$ & $1,35 \%$ & $\mathbf{5 , 8 6 \%}$ \\
Estirão do Açaituba & $0,00 \%$ & $2,43 \%$ & $\mathbf{1 0 0 \%}$ \\
São Francisco & $0,00 \%$ & $1,70 \%$ & $\mathbf{1 0 0 \%}$ \\
Moará & $0,00 \%$ & $1,66 \%$ & $\mathbf{1 0 0 \%}$ \\
Macacoã & $0,00 \%$ & $1,46 \%$ & $\mathbf{1 0 0 \%}$ \\
Paraíso & $0,00 \%$ & $1,19 \%$ & $\mathbf{1 0 0 \%}$ \\
Samaumeira & $0,00 \%$ & $1,01 \%$ & $\mathbf{1 0 0 \%}$ \\
Novo intento & $0,00 \%$ & $0,93 \%$ & $\mathbf{1 0 0 \%}$ \\
Nazaré & $0,00 \%$ & $0,66 \%$ & $\mathbf{1 0 0 \%}$ \\
Monte Sião & $0,00 \%$ & $0,21 \%$ & $\mathbf{1 0 0 \%}$ \\
Espírito Santo & $0,00 \%$ & $0,13 \%$ & $\mathbf{1 0 0 \%}$ \\
Arraial & $0,00 \%$ & $0,02 \%$ & $\mathbf{1 0 0 \%}$ \\
São José do Paraíso & $0,00 \%$ & $0,00 \%$ & $\mathbf{0 , 0 0 \%}$ \\
Sobradinho & $0,00 \%$ & $0,00 \%$ & $\mathbf{0 , 0 0 \%}$ \\
Concórdia & $0,00 \%$ & $0,00 \%$ & $\mathbf{0 , 0 0 \%}$ \\
Conceição-Paissé & $0,00 \%$ & $0,00 \%$ & $\mathbf{0 , 0 0 \%}$ \\
\hline Total & $\mathbf{1 0 , 7 5 \%}$ & $\mathbf{3 5 , 9 6 \%}$ & $\mathbf{2 2 5 , 6 6 \%}$ \\
\hline
\end{tabular}

Fonte: Relatórios Gestão da Resex Canutama - adaptado pela autora.

A taxa de crescimento elevada foi apurada em apenas três das vinte e duas localidades existentes (Santana, Tororó-Paissé e Mapiciari) - ainda que essas localidades tenham se destacado individualmente, sua participação nas vendas totais da Resex ficou abaixo dos $8 \%$.

A maior parte das localidades não atingiu 2\% de participação no total das vendas, sendo que algumas tiveram queda com relação a 2019. Nesse sentido, subentende-se que os números do crescimento têm maior significado para o resultado individual das próprias localidades.

\subsubsection{Excesso e escassez de produtos}

Os produtores reclamaram sobre o problema de excesso e escassez de produtos, revelando o impacto negativo do excesso de oferta de melancia em 2019 causou grande prejuízo às comunidades.

"Mas o plantio da melancia é assim, ... vamos supor que tem ano que dá muito, né, mas tem ano que dá pouco. Aí a pessoa aventura” (Produtor - Comunidade Santa Bárbara) 
Enquanto a produção de melancia quase sempre é alta, no caso da extração da castanha, há percepção de que está havendo redução da semente naquela região, bem como tem piorado a sua qualidade. Ambas as situações interferem na venda dos produtos: no caso de alta na oferta, o problema está na limitação do mercado comprador, que não absorve toda a produção, o que faz com que parte dos produtores não consiga vender seus produtos e tenha perda em dobro - do dinheiro esperado e do produto, que apodrece facilmente, principalmente em região de clima tão quente como o Amazonas. Por outro lado, a escassez de um produto ou a baixa da sua qualidade impacta sobremaneira nas condições de venda e, particularmente, em se tratando da castanha, que é bastante aceita e demandada pelo mercado interno e externo, a expectativa costuma ser alta.

Associado a isso, houve relatos de que alguns produtores tentam vender uma mistura de castanha de boa e má qualidade, o que, na opinião geral, prejudica ainda mais a venda, pois causa danos à reputação do produto e dos produtores.

Estudo de Maciel et al. (2018) também constatou que, na última década, a renda gerada pela extração da borracha e da castanha do Pará atingiram seu limite por falta de inovação. Com o prejuízo apresentado por essas atividades, os produtores estão buscando outras fontes de renda fora das Unidades de Conservação (inclusive trabalho assalariado).

“Tinha vinte e uma pessoa para cortar seringa lá. E agora não tem mais... Todo mundo deixou de cortar seringa pra ir pescar." (Produtor - Comunidade Santa Bárbara)

\subsubsection{Continuidade na atividade}

O mais comum entre as famílias entrevistadas é, com o passar do tempo, os filhos assumirem as tarefas dos pais, o que, na maior parte dos casos, não interrompe totalmente a atividade, mas sofre alguma perda, uma vez que significa menos mão de obra (quando os pais se aposentam), e até de eficiência, já que os que assumem, de acordo com relatos, têm menos experiência no ofício e precisam de tempo para alcançar o ritmo dos trabalhadores anteriores, apesar de o envolvimento com as atividades produtivas ter início ainda quando crianças (especialmente os homens, já que as mulheres, em sua maioria, tendem a se dedicar aos filhos e aos afazeres domésticos).

Os resultados mostram que, a depender da continuidade por parte dos filhos, a produção agrícola (para subsistência) e extrativista na Resex Canutama permanecerá, pois poucos dos jovens entrevistados têm intenção de deixar o local. Entretanto, há que se observar 
a insatisfação desse grupo (seguido por alguns pais) com relação às limitações do serviço educacional oferecido nas comunidades, que é a principal justificativa para a saída de jovens da Resex.

“Os filhos vão crescendo, vão casando, formando novas famílias... Pouca coisa mudou aqui. Mais, é por questão de saída para estudar... Então, [a saída] é questão de escola mesmo. Que na Resex não tem, só tem até o ensino fundamental, né, o médio, não tem”.

(Gestor da Resex)

\subsubsection{Impacto da Covid-19 na Produção}

Até o período de realização do estudo, não foram identificados relatos que algum morador da Resex Canutama tenha sido contaminado pelo Coronavírus, entretanto, para alguns, as restrições impostas pela doença potencializaram as dificuldades para a comercialização dos produtos, por conta do receio de sair da Resex visto que o vírus já havia se espalhado por Canutama e Lábrea, que são os municípios mais próximos da Reserva - e onde ocorre a venda dos produtos.

No entanto, outros moradores, mesmo temendo contaminação, estavam indo à cidade para vender seus produtos e, para esses, a pandemia não chegou a prejudicar as vendas, até porque a produção não era grande e, assim, não houve maiores dificuldades para vender tudo que foi colhido/extraído.

Opinião consensual era de que o vírus não chegou à Resex graças à barreira sanitária, situada à entrada da Unidade de Conservação, que fazia fiscalização e controle rígidos. Ademais, os moradores estavam seguindo as orientações dos agentes de saúde que visitaram as comunidades desde o início da pandemia.

"Até agora eu não sei de muitas coisas [sobre Covid-19]. Por causa que aqui é até difícil a gente ir pra cidade, né? Vê apenas o que passa no jornal. Veio a lancha de saúde, aí veio também um menino que participa da Reserva. Aí, veio, orientou a gente, deixou uns papel aí. E a gente vai levando, né? Do jeito que a gente vê no jornal, a gente vai fazendo do mesmo jeito". (Produtora - Comunidade Açaituba)

Em resumo, da análise de conteúdo referente às atividades produtivas da Resex Canutama podemos destacar que: a produção é determinada pela sazonalidade hídrica -, período de seca, agricultura, período de cheia, extrativismo; os alimentos cultivados servem primordialmente para a subsistência das famílias, mas parte deles é comercializada, junto com os produtos extraídos, que têm maior peso nas vendas totais da Resex. São várias as dificuldades para produção: sazonalidade hídrica; logística de escoamento da produção; 
escassez/excesso de produtos e relatam dificuldade de manter filhos na comunidade devido às limitações do serviço educacional.

\subsubsection{Renda}

As famílias têm consciência das limitações da sua situação financeira e, apesar dos desejos de melhorias de vida, como ter uma casa melhor, adquirir produtos de conforto (TV, painel solar, sinal de wifi), elas não extrapolam gastos.

Embora o extrativismo e o cultivo de alimentos sejam importantes fontes de renda para os comunitários (para alguns é o principal meio de sustento), essas atividades não podem ser consideradas suficientes para a sobrevivência das famílias que residem na Resex Canutama, levando em conta a irregularidade do volume da produção (depende do clima, do contingente de trabalhadores) e as dificuldades e custos da logística de venda. Por isso, parcela significativa dos entrevistados planta para o consumo próprio (há, inclusive, os que estão satisfeitos com essa situação e não comercializam o excedente da sua produção). Outros, têm uma renda fixa por serem funcionários públicos (professores, serviços gerais, na própria comunidade) ou porque têm contrato com a Prefeitura de Lábrea ou Canutama, para fornecimento de algum alimento que produzem. Como complemento, a maioria dos comunitários - ou algum membro da família -, recebe pagamento de programas assistenciais do governo federal, como o bolsa família e, durante a pandemia da Covid-19, recebeu também o auxílio emergencial.

Estudo de Camilotti et al. (2020) reforça esses dados, tendo concluído que não é possível sobreviver somente com a renda derivada dos produtos extraídos da floresta, devido ao fato de que as vendas não são regulares e apenas complementam as necessidades de consumo das famílias.

Embora as reclamações pelas dificuldades para comercialização dos seus produtos ou de que não há ajuda regular do Poder público sejam unânimes e frequentes, porém, não houve, por parte dos entrevistados, manifestações contundentes ou indicação de desespero pela situação. O que se viu foram lamentos e demonstração de insatisfação, mas, ao mesmo tempo, sem sinalização de disposição ou intenção de agir, eles mesmos, em busca de solução para os transtornos que os aflige. Não se sabe se a ausência de ação se dá por falta de conhecimento (não sabem o que fazer ou a quem recorrer) ou por falta de iniciativa própria (resignação com a vida atual). Paralelamente, não se pode desconsiderar as complicações impostas pela pandemia da Covid-19, que não depende dos produtores para serem solucionadas. 
Diante desse quadro, parece difícil que a condição financeira ou a renda dessas famílias sofra grandes transformações (positivas), pelo menos em curto prazo. Em consenso, Freitas et al. (2018) reforça que baixo investimento e equipe inexperiente para tratar questões complexas comprometem o bem-estar de famílias e a biodiversidade locais, o que pode levar ao insucesso e colocar em risco o futuro do modelo Resex.

"A gente também não vive assim tão aperreado. Porque a gente também sabe dos compromissos da gente. A gente também não vai querer comprar uma coisa que a gente sabe que não vai poder pagar. Também, para não se aperrear. Eu, pelo menos, tenho essa preocupação”. (Produtor - Comunidade São Jerônimo)

[Custo de vida] "Eu digo assim que não é tão caro [custo de vida], pelo fato de a gente, digamos assim, a gente sai daqui, não compra o peixe, praticamente a gente não compra o peixe, a gente compra as outras coisas: açúcar... É, essas coisas assim... Agora, esse rancho tudinho, assim, que a gente vai buscar na cidade, ele é um pouco caro”.

(Produtor - Comunidade São Jerônimo)

\subsubsection{Venda/Negociação}

Para garantir a venda e não perder o produto ou deixar de ganhar algum dinheiro (mesmo que considerado pouco ou "injusto"), os produtores recorrem a atravessadores. Apenas os que já tem compradores fixos, sobretudo nas comunidades vizinhas, cuidam, eles mesmos, da venda da sua produção.

Outro obstáculo decisivo que leva ao envolvimento de atravessadores é a dificuldade para se chegar à cidade, porque os gastos com tempo e dinheiro para o deslocamento praticamente inviabiliza a venda pelos próprios produtores. Já os atravessadores, estão preparados para arcar com a logística do transporte e costumam recolher a produção nas comunidades, às vezes, até na própria área de coleta - "Ele vem buscar aqui. Se for possível, ele vai pegar lá dentro [da floresta] mesmo".

Tal cenário causa insatisfação entre os produtores, não somente por não receberem valor considerado justo pelo seu produto, mas porque, para muitos, acaba levando à falta de motivação para produzir com objetivo de venda - "não vale a pena" -, fazendo com que optem por cultivar apenas para a subsistência da família. Além dos dificultadores logísticos, os produtores acrescentaram que quando a produção é farta, nem sempre há compradores suficientes para o grande número de vendedores (produtos).

No caso do extrativismo não é diferente, os empecilhos são os mesmos, com o agravante que, à exceção da pesca, esses produtos não estão próximos das residências dos comunitários, fazendo-os se deslocar para dentro da floresta, tendo que permanecer lá por alguns dias, até finalizar a coleta. 
Por isso a reclamação por ajuda do Poder público, no sentido de disponibilizar transporte adequado e viabilizar condições de comunicação entre a Resex e os municípios onde estão os compradores, de maneira a possibilitar que os produtores tenham informações da cotação de preços dos seus produtos, para, então, analisarem se os gastos para efetivar a venda (transporte, combustível, atravessador, às vezes ter que ficar na cidade por mais de um dia) valem a pena, quer dizer, se, no final, terão algum lucro com a venda, ao invés de prejuízo (que costuma ser frequente).

Baseado nesse contexto, vários comunitários têm refletido se vale a pena continuar comercializando seus produtos, tendo que arcar com altos custos da logística da venda, além de aceitar valor “injusto" (na opinião geral dos produtores) pela venda do produto.

A percepção de Capelari (2017) coincide com essa situação - para o autor, apesar de o extrativismo proporcionar muitos benefícios para seus adeptos e para a proteção das florestas, a realidade indica que a atividade estabelece relações de subsistência, sem contribuir para avanços significativos em melhoria de bem-estar e inclusão econômica das pessoas que a praticam.

“'[Produção] É pouca quantidade. A gente vai mais pra Lábrea, e lá, é uma dificuldade pra vender alguma coisa. É um sacrifício de vida. Aí é mais para o consumo mesmo. Por causa que aqui, pra nós, é muito difícil o transporte. Principalmente agora, que é tudo caro, né? Pra gente levar pouco, também não dá nada, somente pra despesa. Aí não adianta a gente levar”. (Produtora - Comunidade Açaituba)

“O negócio é que a zona rural não é muito a prioridade para esse povo [Poder público].

(Gestor da Resex)

\subsubsection{Dificuldades para manter a atividade}

Somadas às dificuldades de negociação e venda dos seus produtos, as complicações para acesso às comunidades, tais como transporte, clima (cheia/seca) e a própria condição dos locais de coleta da extração dos produtos (floresta densa) são outros problemas enfrentados pelos produtores para realizar sua atividade.

$\mathrm{Na}$ medida em que se adentra as comunidades constata-se precariedade em vários aspectos básicos para sobrevivência e dignidade dos residentes, desde energia, passando pela educação e saúde e, principalmente, das dificuldades para subsistência das famílias, que acabam afetando o seu trabalho na "roça" ou no extrativismo.

Geralmente, os produtos do extrativismo estão em locais afastados das moradias - em certos casos, há necessidade de um dia de deslocamento (de barco) para chegar às áreas onde 
estão a castanha ou o açaí - e é necessário ficar lá por até uma semana, colhendo o produto. $\mathrm{O}$ mais comum é uma safra de castanha por ano, que pode ser farta ou não, o que, às vezes, implica ter que fazer esse deslocamento (e permanência por lá) duas ou três vezes na mesma temporada, para garantir o mínimo de renda. A atividade pesqueira exige menos deslocamento, já que as comunidades estão localizadas à beira do rio.

Nesse sentido, repetem-se as reivindicações por ajuda do Poder público principalmente com relação à viabilização da logística de venda, que significa fazer os produtos chegarem aos compradores, de forma rápida e sem interferência de atravessadores.

A operação mais importante - e a que mais preocupa os produtores - é a venda dos seus produtos, ou seja, evitar situação em que não se obtém lucro devido as elevadas despesas logísticas inerentes ao processo de venda e, dessa forma, "não levar dinheiro para casa".

Em complemento, percebeu-se que, de maneira geral, a expectativa de lucro com a venda dos produtos é baixa. Primeiro, porque os produtores não têm poder de negociação, quem estabelece o valor de venda dos produtos são os atravessadores, que, pelos depoimentos, não costumam pagar valor “justo". Segundo, porque, com relação a vários produtos comercializados (melancia é um exemplo), quase sempre há excesso de produção (vendedores), para número incompatível de compradores existentes no mercado. Há forte demanda para os produtos mais potenciais: castanha e farinha.

Além das questões de precificação dos produtos, há outros dificultadores que, indiretamente, acabam encarecendo o processo de venda e diminuindo a chance de obtenção de lucro, a saber:

Transporte - há queixas recorrentes no que diz respeito ao "abandono" do Poder público (leia-se, sobretudo a Prefeitura dos municípios mais próximos Canutama e Lábrea) com relação à Resex, porque existe entendimento de que a Prefeitura local deve ajudar a Resex em todas as suas dificuldades, mas a expectativa é maior no que se refere à disponibilização (ou doação) de transporte adequado para escoamento da produção, a fim de que os produtores não precisem recorrer aos atravessadores. Havendo transporte adequado, prevê-se redução nos custos da venda e, consequentemente, maior lucro para os produtores.

"Como eu te falei naquele dia, muito se fala de ação e menos recurso. (Gestor da Resex)

Nesse contexto, a figura do atravessador tem papel importante - porque único agente efetivo - na logística, viabilização e concretização da venda da produção da Resex. Assim, os produtores entregam sua produção, sem direito a negociação de preço. Na tentativa de não perder a venda (a produção), ocorre de, por vezes, um comunitário assumir o papel de 
intermediário entre os produtores e os grandes atravessadores, o que, porém, não significa melhores condições de negociação.

Os produtores têm consciência de que o preço pago pelos atravessadores não é o mesmo pelo qual o produto é vendido para o mercado, já que, segundo eles, os principais compradores (grandes varejistas e distribuidores) estão na capital - Manaus - ou em outros estados do Brasil e, como ressaltam alguns, até em outros países.

Por isso que, no geral, moradores da floresta (em áreas protegidas ou não) consideram que esses recursos naturais têm pouca relevância para geração de renda, o que faz supor que somente quando a extração de recursos da floresta for economicamente compensadora, também refletirá positivamente na qualidade de vida da população dessas áreas, por meio do aumento de renda (CAMILOTTI et al., 2020).

Em resumo, a análise de conteúdo referente aos relatos que são vinculados à sustentabilidade financeira do morador/produtor revelou que os produtores já se acostumaram ao baixo lucro proveniente da venda de seus produtos; que a produção é concentrada em poucos produtos com potencial de vendas e que apesar de reclamarem das dificuldades para obter uma venda mais favorável, eles não demonstraram iniciativas para que a situação mude. Relatam dificuldades relativas às vendas; têm consciência que a atuação de atravessadores resulta em lucro baixo e ainda que a renda decorrente do extrativismo e/ou das pequenas lavouras não têm sido suficientes para manter a sustentabilidade financeira das famílias.

Assim como Capelari (2017) acredita na possibilidade de "novos caminhos institucionais", o SIW Resex Canutama, principal produto desta pesquisa, representa uma ferramenta de gestão que pode gerar sinais para o setor público e privado possibilitando a formulação de estratégias que permitam o fortalecimento e integração de mecanismos financeiros públicos e privados, direcionados para sustentabilidade financeira (ou viabilidade) das comunidades extrativistas das unidades de conservação do Bioma Amazônia.

\subsection{Mensuração da Sustentabilidade Financeira}

Este tópico analisa resultados que compõem aspectos da sustentabilidade financeira da Resex Canutama. Os dados fazem parte de registros / relatórios da gestão da Resex Canutama, que foram disponibilizados à pesquisadora. Além de exibir um panorama com o saldo das vendas entre os anos de 2010 e 2020, também analisa os mesmos dados comparativamente, com foco nos dois últimos anos contabilizados. 
Os dados se referem à produção comercializada. Não há registros sobre os produtos não vendidos, porém, é possível supor seu destino, pois, sabe-se que a maior parte das pequenas lavouras existentes na Resex é reservada para o sustento das famílias residentes.

Esses e outros dados (mais detalhados) podem ser consultados no site criado pela autora desta tese, no endereço https://izabel.rsmtecnologia.com.br/pages/principal.

Cada uma das comunidades e localidades da Resex Canutama foi avaliada dentro dos parâmetros apresentados no próximo item, os dados foram registrados no Sistema de Informações Web Resex Canutama, em que o Radar de Sustentabilidade Financeira é gerado automaticamente apresentando um resultado agregado em um indicador com valor percentual da mensuração que oscila entre $0 \%$ e $100 \%$.

Os parâmetros para mensuração da sustentabilidade financeira são apresentados a seguir.

\subsubsection{Modelo analítico - Radar de Sustentabilidade Financeira}

O tratamento dos dados primários e secundários coletados possibilitaram a construção de uma proposta de modelo para mensurar da sustentabilidade financeira das comunidades e localidades da Resex Canutama por meio de criação de indicadores ou parâmetros.

A Tabela 15 abaixo apresenta os parâmetros que foram inseridos nos SIW Resex Canutama para a mensuração de um índice agregado automático para cada comunidade: 
Tabela 15 - Resumo dos parâmetros de sustentabilidade financeira no SIW

\section{Parâmetros Avaliados}

[A comunidade possui...]
SIM

Referência Resultado

(1)

(1) Líder comunitário com perfil empreendedor

(2) Controle de castanhal e exploração de castanhal

(3) $\mathrm{N}^{\circ}$ mínimo de residentes $\geq 30$ pessoas

(4) Produção per capita da comunidade $\geq$ média do PIB per capita dos municípios Canutama e Lábrea

(5) Produção na Comunidade $\geq$ média da produção total na Resex Canutama

(6) Produção diversificada e contendo o produto potencial 'Farinha' com produção $\geq 10 \%$

(7) Produção diversificada e contendo o produto potencial 'Peixe Fresco' com produção $\geq 10 \%$

(8) Produção diversificada e contendo o produto potencial 'Peixe Seco' com produção $\geq 10 \%$

(9) Produção diversificada e contendo o produto potencial 'Porco' com produção $\geq 10 \%$

(10) Produção diversificada e contendo o produto potencial 'Açaí' com produção $\geq 10 \%$

(11) Produção diversificada e contendo o produto potencial 'Castanha' com produção $\geq$ $10 \%$

Índice de Sustentabilidade Financeira (resultado arredondado)

Legenda: Na Coluna [Referência]

[1] Sim, a comunidade atende o parâmetro

[0] Não, a comunidade não atende o parâmetro

Fonte: Elaborado pela autora.

Os parâmetros ou indicadores apresentados na Tabela 15 que serviram para identificar, avaliar e mensurar a sustentabilidade financeira em cada uma das comunidades/localidades da Resex Canutama são apresentados a seguir:

Parâmetro - Líder comunitário com perfil empreendedor

Avaliação qualitativa decorrente da percepção da pesquisadora especificamente nas entrevistas com a liderança comunitária em que ficou evidente o engajamento, a responsabilidade e a participação ativa voltados para a comunidade. O perfil 
empreendedor é compreendido como um fator para o desenvolvimento comunitário (BOSE, 2012).

Parâmetro - Controle e exploração de área de castanhal

Avaliação qualitativa decorrente das informações decorrentes dos relatos dos produtores ao afirmarem que o controle do castanhal permite vantagens financeiras, uma vez que a castanha é produto extrativista com maior potencial de vendas local.

> Parâmetro - Número de residentes

Avaliação quantitativa decorrente das informações coletadas nas entrevistas em que os produtores e líderes comunitários relataram a necessidade de as comunidades possuírem um mínimo necessário de 30 residentes para a execução das atividades de produção para o consumo e venda.

\section{> Parâmetro - Produção per capita}

Avaliação quantitativa decorrente da comparação entre o valor da Produção per capita alcançada na Resex é igual ou maior que a média da Renda per capita dos municípios de Canutama e Lábrea, uma vez que os municípios são os destinos mais comuns para os residentes na Resex. A Produção per capita das comunidades pode ser comparada com o PIB per capita divulgado pelo IBGE devido ausência de tributos e subsídios incidentes sobre a produção de bens in natura vendidos diretamente na comunidade, nesse contexto, o valor monetário da produção per capita da comunidade equivale ao Produto interno bruto per capita a preços de mercados divulgado pelo IBGE.

Conforme os dados do IBGE referentes ao ano de $2018^{8}$ o PIB per capita dos municípios de Canutama e Lábrea foram de $\mathrm{R} \$ 6.965,40$ e $\mathrm{R} \$ 10.841,94$ respectivamente. O PIB per capita médio dos municípios atingiu $\mathrm{R} \$ 8.953,67$ e servirá de parâmetro para comparar com a Produção per capita das comunidades e localidades.

\footnotetext{
${ }^{8}$ Dados coletados diretamente no site do IBGE no endereço https://cidades.ibge.gov.br/brasil/am
} 
$>$ Parâmetro - Produção média

Avaliação quantitativa decorrente da comparação entre o valor monetário da Produção total de cada comunidade/localidade comparado com a Produção média da Resex.

$>$ Parâmetro - Produção diversificada e com produtos potenciais

Avaliação quantitativa decorrente da verificação se a comunidade possui uma produção diversificada e contém produtos com maior potencial de vendas da Resex (Castanha, Farinha, Pescado Fresco, Pescado Seco, Açaí e Porco). Como indicador de análise, os produtos potenciais devem representar no mínimo $10 \%$ do volume de produção da comunidade.

Cada um dos parâmetros foi cadastrado no SIW Resex Canutama como um dado binário usando apenas dois algarismos para gerar informações ('Sim' representado pelo algarismo 1 e 'Não' representado pelo algarismo 0), cada avaliação positiva gera um percentual de 9,1\% no 'Radar de Sustentabilidade Financeira'.

Cada uma das comunidades e localidades da Resex Canutama foi avaliada dentro dos parâmetros apresentados na Tabela15, os dados foram registrados no SIW Resex Canutama, com o objetivo de gerar avaliação automática apresentando um resultado agregado em valor percentual da mensuração quantitativa da sustentabilidade financeira e ainda possibilitando agrupar em três dimensões que podem servir de 'alerta' para a gestão da Resex, conforme a Figura 16:

Figura 16 - Radar de Sustentabilidade Financeira

\begin{tabular}{|c|c|c|}
\hline Radar Vermelho & Radar Amarelo & Radar Verde \\
\hline $\begin{array}{c}\text { Resultado } \\
\text { agregado } \\
\leq 30 \%\end{array}$ & $\begin{array}{c}\text { Resultado } \\
\text { agregado } \\
>30 \% \mathrm{e}<65 \%\end{array}$ & $\begin{array}{c}\text { Resultado } \\
\text { agregado } \\
>65 \%\end{array}$ \\
\hline
\end{tabular}

Fonte: Elaborado pela autora.

Alertas gerados pelo Radar:

Radar com resultado agregado posicionado na área VERMELHA: comunidades e/ou localidades que alcançaram um baixo índice percentual de Sustentabilidade Financeira. 
Radar com resultado agregado posicionado na área AMARELA: comunidades e/ou localidades que alcançaram um moderado índice percentual de Sustentabilidade Financeira.

Radar com resultado agregado posicionado na área VERDE: comunidades e/ou localidades que alcançaram um alto índice percentual de Sustentabilidade Financeira.

O índice de sustentabilidade financeira da Resex Canutama será obtido a partir da média aritmética simples considerando todos os índices percentuais de cada uma das comunidades e localidades.

\subsubsection{Radar de Sustentabilidade Financeira Agregado da Resex}

O radar de sustentabilidade financeira da Resex Canutama é representado pela média do conjunto dos índices de sustentabilidade financeira apurados em cada uma das 16 comunidades e 22 localidades pertencentes a reserva. $\mathrm{O}$ índice de sustentabilidade financeira, representado por um índice percentual, foi mensurado a partir de parâmetros que avaliaram se a comunidade/localidade possuía as seguintes características:

(a) Liderança comunitária com perfil empreendedor;

(b) controle e exploração de área de castanhal;

(c) número de residentes $\geq 30$ habitantes;

(d) produção per capita $\geq$ a média da produção per capita dos municípios de Canutama e Lábrea;

(e) produção média $\geq$ a média da produção total da Resex;

(f) produção diversificada e contendo produtos com maior potencial de vendas (castanha, farinha, peixe, açaí, porco).

Pelos resultados desta pesquisa, a Resex Canutama ainda não alcançou a sustentabilidade financeira. Contudo, se a sustentabilidade financeira da Resex Canutama existe, ela é frágil e/ou inconstante, quer dizer, não se mantém com regularidade, além de excluir a maioria das comunidades e localidades que fazem parte daquela área protegida.

As justificativas para a falta de sustentabilidade financeira resumem-se, notadamente, em dois aspectos (que incluem outros tantos):

1) a gestão precária (sem representatividade ativa e ações sistemáticas) e o pouco, ou nenhum, envolvimento dos produtores, afora falta de suporte do Poder público; e

2) o fato de o desempenho nas vendas depender quase que somente da extração (oferta/disponibilidade) de, praticamente, um único produto - castanha -, que, 
segundo comentários, está em declínio, e não está disponível com a mesma abundância para todas as comunidades da Resex, o que causa desequilíbrio em termos de produção - e receita - nos resultados individuais, de cada comunidade e localidade.

Os resultados sumarizados obtidos no Radar de Sustentabilidade Financeira referente ao ano de 2019 e 2020 estão apresentados na Figura 17 a seguir:

Figura 17 - Radar de Sustentabilidade Financeira da Resex Canutama (2019-2020)

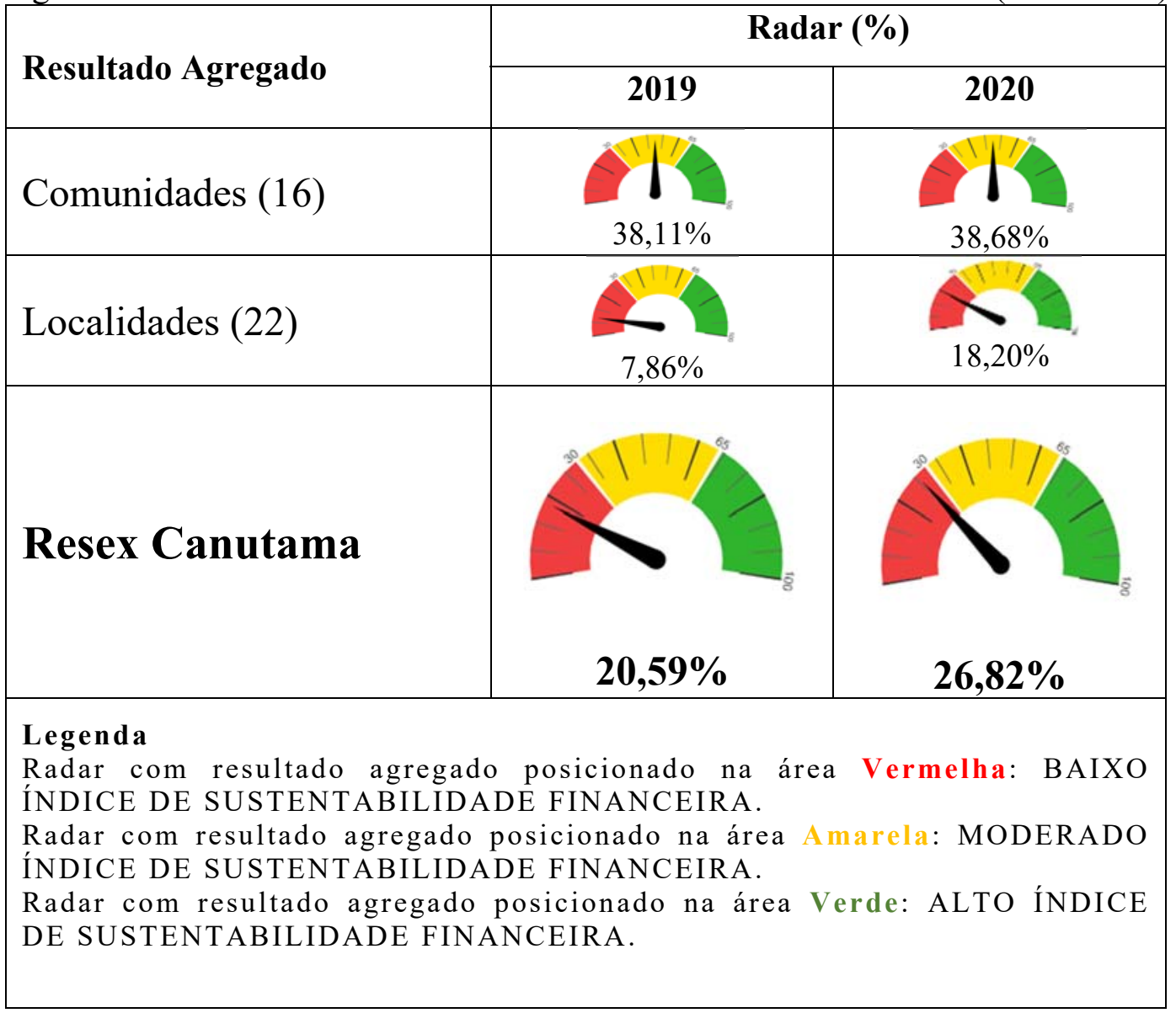

Fonte: Elaborado pela autora.

Com base nos resultados obtidos podemos observar que:

_ O índice de sustentabilidade é maior quando o indicador é deduzido da média dos indicadores das 16 comunidades, índice acima de $38 \%$ nos dois anos analisados, locais em que estão concentrados o maior volume de produção e de residentes na Resex;

- Maior vulnerabilidade financeira nas localidades, uma vez que, o índice deduzido da média dos indicadores das 22 localidades, ficou abaixo de $10 \%$ em 2019 e abaixo de $20 \%$ em 2020 ; 
_ O índice de sustentabilidade deduzido da média dos resultados das 16 comunidades e 22 localidades foi de 20,59\% em 2019 e de $26,82 \%$ em 2020.

\subsubsection{Radar de Sustentabilidade Financeira das Comunidades}

A pesquisa constatou grande disparidade entre as comunidades, que não se verifica apenas na oferta desigual (embora natural, pois o potencial extrativista é diferente ao longo do território da Resex) da castanha, principal produto, mas em todos os aspectos relacionados à produção, desde as condições de extração até o faturamento das famílias e o desenvolvimento e progresso das comunidade e localidades.

Importa conhecer o resultado sumarizado obtidos no Radar de Sustentabilidade Financeira em cada das 22 comunidades. A Figura 18 a seguir apresenta os dados:

Figura 18 - Radar de Sustentabilidade Financeira das Comunidades (2019-2020)

\begin{tabular}{|c|c|c|c|c|c|}
\hline \multirow{2}{*}{ Comunidades $^{9}$} & \multicolumn{2}{|c|}{ Radar (\%) } & \multirow{2}{*}{ Comunidades } & \multicolumn{2}{|c|}{ Radar (\%) } \\
\hline & 2019 & 2020 & & 2019 & 2020 \\
\hline$\underline{\text { Nova Vista }}$ & $54,60 \%$ & $54,60 \%$ & Açaituba & $36,40 \%$ & $36,40 \%$ \\
\hline$\underline{\text { Santa Bárbara }}$ & $54,60 \%$ & $54,60 \%$ & $\underline{\text { Carmo }}$ & $36,40 \%$ & $27,30 \%$ \\
\hline$\underline{\text { Bacadaru }}$ & $54,60 \%$ & $45,50 \%$ & $\begin{array}{l}\text { Forte Veneza } \\
\text { Nova Colônia }\end{array}$ & $36,40 \%$ & $27,30 \%$ \\
\hline Sacado & $54,60 \%$ & $45,50 \%$ & $\underline{\text { Santa Maria }}$ & $27,30 \%$ & $45,50 \%$ \\
\hline Fortaleza & $45,50 \%$ & $36,40 \%$ & $\underline{\text { São Tomé }}$ & $27,30 \%$ & $36,40 \%$ \\
\hline$\underline{\text { São Jerônimo }}$ & $45,50 \%$ & $36,40 \%$ & $\begin{array}{l}\text { Santo Antônio do } \\
\text { Apituã }\end{array}$ & ${ }_{27,30 \%}$ & $27,30 \%$ \\
\hline Irajá & $36,40 \%$ & $54,60 \%$ & $\underline{\text { Boca do Gavião }}$ & $18,20 \%$ & $18,20 \%$ \\
\hline Glória II & $36,40 \%$ & $54,60 \%$ & Capoeirinha & $18,20 \%$ & ${ }_{18,20 \%}$ \\
\hline
\end{tabular}

Fonte: Elaborado pela autora.

Com base nos resultados obtidos podemos observar que:

_ Em geral, nenhuma das comunidades conseguiu atingir um alto índice de sustentabilidade, ou seja, resultado agregado $>65 \%$, posição na área verde.

\footnotetext{
${ }^{9}$ Ctrl + Clique para seguir link para acessar o Apêndice contendo quadro com os dados gerais e a tabela de apuração do índice de sustentabilidade da comunidade.
} 
_ Onze comunidades em 2019 e nove em 2020, conseguiram atingir moderado índice de sustentabilidade (resultado agregado $>30 \%$ e $<65 \%$, posição na área amarela);

_ Em 2019, os maiores índices de sustentabilidade foram obtidos por 4 comunidades: Nova Vista, Santa Bárbara, Bacadaru e Sacado (54,60\%);

- Em 2020, os maiores índices de sustentabilidade foram obtidos por 4 comunidades: Nova Vista, Santa Bárbara, Glória II e Irajá (54,60\%);

Questões importantes interferem no desenvolvimento e prosperidade de algumas comunidades e localidades e que, em alguma medida, atingem toda a Reserva. A saber:

- Comunidade Nova Vista - É a comunidade mais bem sucedida da Resex Canutama e algumas situações podem estar fazendo com que os melhores resultados das vendas da Resex se concentre especialmente no Caixa da Nova Vista.

Não que esta Comunidade seja responsável pelas dificuldades da Resex Canutama na tentativa de alcançar melhor desempenho (geral), contemplando todas as famílias de forma equitativa. A questão é que, além de ter elevado potencial extrativista (está localizada em grande área de extração de castanha), o seu líder comunitário, que também é presidente da Associação dos Agroextrativistas Canutama -ASARC, atua como atravessador, e compra "toda a produção" de castanha da Reserva.

Ao mesmo tempo, a Comunidade Nova Vista costuma arrendar o castanhal de outras comunidades, o que, somado aos fatores já descritos, aponta para a destacada performance de participação nas vendas totais da Resex - em 2020, mesmo com forte queda nas vendas, a Nova Vista manteve o melhor desempenho, registrando $11,02 \%$ na participação geral, sendo que a segunda comunidade mais bem classificada alcançou $8,25 \%$ de participação, e os resultados das demais comunidades foram inferiores aos $8 \%$ de participação nas vendas da Resex Canutama.

Outros dados contrastantes ajudam a confirmar este cenário: a Comunidade Nova Vista, formada por apenas 8 famílias, tem infraestrutura acima da média (possui igreja, escola, gerador de energia próprio,várias casas com painel solar), é a mais próspera da Resex Canutama, inclusive, tendo recursos para arrendar castanhal de outras comunidades. Em contraponto, a Comunidade Irajá, formada por 12 famílias (52 pessoas, contra 42 pessoas da Nova Vista), não tem sequer escola em sua sede e vivia (à época deste estudo) declínio econômico. 
Importa indagar até que ponto a Comunidade Nova Vista 'inspira' (no sentido de incentivar, ser exemplo) ou 'canibaliza' (no sentido de prejudicar, tirar a chance/possibilidade e até desestimular) as demais comunidades, no que se refere ao desenvolvimento e à sustentabilidade financeira de cada comunidade e da própria Resex?

- Disputas internas - Manifestações pontuais, de moradores de algumas comunidades, declararam insatisfação com as respectivas gestões/lideranças e comentaram da necessidade de substituição. Os motivos variam, há reclamações por causa da diminuição da capacidade de gerir (idade avançada ou doença), ou por tomada de decisão (arrendamento do castanhal) que desagradou e, para alguns, acabou comprometendo o desempenho financeiro da comunidade.

- Falta de engajamento dos residentes / produtores na gestão da Resex - É evidente o distanciamento dos produtores com relação à gestão da Resex. Não houve relato referente a iniciativas regulares no sentido de incentivar a participação ou manter conexão entre gestor e produtores. Exemplo disso é que as reclamações (inclusive as do próprio gestor) e a responsabilização pela situação em que se encontra a Resex são dirigidas à Prefeitura de Canutama, quer dizer, os produtores não cogitam recorrer ao gestor ou acioná-lo como interlocutor. Da mesma forma, a relação entre gestor e produtores, assim como entre a Resex Canutama e o Poder público, as entidades representativas e as empresas apoiadoras, é inexistente ou precária e eventual. Esse distanciamento, somado à falta de conhecimento e acesso a procedimentos de funcionamento da Resex e ao perfil simples e passivo dos produtores, dificulta o engajamento e participação dos moradores nas decisões administrativas da Resex, bem como na defesa dos seus direitos e necessidades.

Junte-se a essas circunstâncias, as dificuldades externas, como a pandemia da Covid19 (restrições de circulação e comércio) e o aumento das ilegalidades ambientais nas terras protegidas (além da questão ambiental em si, aumentou o desequilíbrio nas condições de competitividade comercial), o que potencializa e prorroga o tempo para resolução dos problemas.

"Nós temo que tomar uma providência. Porque senão vai ficar pior pra nós, né?” E nós passemo um monte de dia lá dentro... Eu fui com os meus menino tudinho. Oh, esse daqui... A gente anda o varador, a gente carregava peixe pro varador, pra vê se a gente consegue um dinheirinho. Aí chega lá, os pessoal tão acabando com tudo". (Produtora - Comunidade Nova Vista) 
Dessa forma, parece difícil alcançar - ou manter - a sustentabilidade financeira, se os recursos naturais e financeiros estão concentrados em poucas comunidades, e/ou dependem da venda de, praticamente, um único produto para sustentar toda a Resex (688 pessoas, 191 famílias) e atender às suas necessidades.

\subsubsection{Radar de Sustentabilidade Financeira das Localidades}

O resultado sumarizado obtidos no Radar de Sustentabilidade Financeira em cada das 22 comunidades estão apresentados na Figura 19 a seguir:

Figura 19 - Radar de Sustentabilidade Financeira das Localidades (2019-2020)

\begin{tabular}{|c|c|c|c|c|c|}
\hline \multirow{2}{*}{ Localidades $^{10}$} & \multicolumn{2}{|c|}{ Radar (\%) } & \multirow{2}{*}{ Localidades } & \multicolumn{2}{|c|}{ Radar (\%) } \\
\hline & 2019 & 2020 & & 2019 & 2020 \\
\hline$\underline{\text { Bom Sucesso }}$ & $45,50 \%$ & $18,20 \%$ & Estirão do Açaituba & $0 \%$ & $18,20 \%$ \\
\hline$\underline{\text { Tororó-Paissé }}$ & $27,30 \%$ & $27,30 \%$ & $\underline{\text { São Francisco }}$ & $0 \%$ & ${ }_{18,20 \%}$ \\
\hline$\underline{\text { Santa Cora }}$ & $27,30 \%$ & $27,30 \%$ & Espírito Santo & $0 \%$ & ${ }_{18,20 \%}$ \\
\hline Vista Alegre & $27,30 \%$ & $18,20 \%$ & $\underline{\text { Macacoã }}$ & $\alpha_{0 \%}$ & $\alpha_{18,20 \%}$ \\
\hline$\underline{\text { Santana }}$ & $18,20 \%$ & $27,30 \%$ & $\underline{\text { Monte Sião }}$ & $\alpha_{0 \%}$ & $9,10 \%$ \\
\hline$\underline{\text { Mapiciari }}$ & $18,20 \%$ & $27,30 \%$ & $\underline{\text { Santa Eugênia }}$ & $\alpha_{0 \%}$ & $\alpha_{9,10 \%}$ \\
\hline$\underline{\text { Moará }}$ & $9,10 \%$ & ${ }_{27,30 \%}$ & $\underline{\text { Arraial }}$ & $\alpha_{0 \%}$ & $\alpha_{0 \%}$ \\
\hline$\underline{\text { Paraíso }}$ & $0 \%$ & $45,50 \%$ & $\underline{\text { São José do Paraíso }}$ & $\alpha_{0 \%}$ & $\alpha_{0 \%}$ \\
\hline$\underline{\text { Samaumeira }}$ & ${ }_{0 \%}$ & $27,30 \%$ & $\underline{\text { Sobradinho }}$ & R\% & $\alpha_{0 \%}$ \\
\hline$\underline{\text { Novo intento }}$ & ${ }_{0 \%}$ & $27,30 \%$ & $\underline{\text { Concórdia }}$ & $\alpha_{0 \%}$ & $\alpha_{0 \%}$ \\
\hline$\underline{\text { Nazaré }}$ & $\underset{0 \%}{\alpha}$ & $27,30 \%$ & Conceição-Paissé & ${ }_{0 \%}$ & ${ }_{0 \%}$ \\
\hline
\end{tabular}

Fonte: Elaborado pela autora.

Com base nos resultados obtidos podemos observar que:

_ Nenhuma das localidades conseguiu atingir alto índice de sustentabilidade, ou seja, resultado agregado $>65 \%$, posição na área verde;

${ }^{10} \mathrm{Ctrl}+$ Clique para seguir link para acessar o Apêndice contendo quadro com os dados gerais e a tabela de apuração do índice de sustentabilidade da localidade. 
_ Somente a Localidade Bom Sucesso em 2019 e a Localidade Paraíso, em 2020, conseguiram atingir moderado índice de sustentabilidade (resultado agregado $>30 \%$ e $<65 \%$, posição na área amarela);

- Há maior vulnerabilidade financeira nas localidades, uma vez que, 19 localidades, nos dois anos apurados, ficaram com resultado agregado $\leq 30 \%$ posição na área vermelha);

_ Quinze comunidades em 2019 e cinco em 2020, não possuem registros de produção, ficando com zero no indicador de sustentabilidade.

Entende-se que é importante promover a equidade na produção e nas vendas, abrangendo cada Comunidade e Localidade da Resex Canutama. Assim como é necessária a diversificação da cesta de produtos comercializados - alavancar a venda de produtos que não fazem parte do topo do ranking, ao mesmo tempo em que todas (ou mais) Comunidades e Localidades possam usufruir do sucesso daqueles produtos que geram maior resultado financeiro.

Em se tratando de potencialidades/possibilidades de mercado, destaque-se que, mesmo com oscilações na produção e venda, a melancia e o pescado fazem parte do portfólio de todas as comunidades e localidades da Resex, o que os habilita, em certa medida, a serem considerados produtos que oferecem garantia de retorno financeiro, maior ou menor, a depender das condições. Em alguns casos, estes, foram os produtos mais vendidos em 2020 (último ano contabilizado) - como na Localidade Santa Eugênia, em que a melancia representou, naquele ano, 56,44\% das vendas. Ou na Comunidade Santa Maria, que teve o pescado fresco ocupando o primeiro lugar nas suas vendas, com 30,78\% de participação.

Sobretudo a melancia, talvez seja um dos produtos 'alternativos' que mais tem potencial de produção e venda, por todas comunidades e localidades, pela facilidade de cultivo (apesar de o transporte exigir grandes embarcações, dado o peso e volume do produto). E pode ser um produto - combinado com as sementes e óleos que tiveram crescimento/demanda nos últimos anos - com possibilidade de alavancar a participação dos menores (com menor performance) nas vendas. De todo modo, esse produto, se não contribui para a sustentabilidade financeira da Resex, é importante componente para a subsistência das famílias residentes.

Além disso, há as localidades sem registro de vendas e as comunidades e localidades que não comercializam castanha. Se nesses locais há solo fértil/favorável ou potencial 
extrativista para algum outro produto, esta pode ser a alternativa para se juntarem às demais, a fim de aumentar, ou incrementar, a produção da Resex.

\subsubsection{Análise dos parâmetros em relação aos resultados apurados}

Do modelo proposto de mensurar a sustentabilidade financeira, a seguir serão apresentados os parâmetros gerais estalebecidos em correlação com os indicadores apurados:

\section{Parâmetro - Líder comunitário com perfil empreendedor}

O perfil empreendedor foi percebido somente nas comunidades Nova Vista; Santa Bárbara e São Jerônimo, conforme avaliação qualitativa decorrente da percepção da pesquisadora especificamente nas entrevistas com a liderança comunitária em que fícou evidente o engajamento, a responsabilidade e a participação ativa voltados para a comunidade.

\section{Parâmetro - Controle e exploração de área de castanhal}

Avaliação qualitativa das informações decorrentes dos relatos dos produtores ao afirmarem que o controle do castanhal permite vantagens financeiras, uma vez que a castanha é produto extrativista com maior potencial de vendas local. A comunidade que possui um residente como detentor/controlador do castanhal tem poder de negociação com os atravessadores e ainda age como empregador, contratando mão de obra para as atividades de extração da castanha.

As comunidades que detêm o controle do castanhal (Nova Vista; Bacadaru e São Tomé), possuem maior poder de negociação com o atravessador e dispõem de recursos financeiros para contratar mão-de-obra local para os trabalhos de extração da castanha. O que, de fato, pode ser a explicação (ou uma delas) para o destaque da Nova Vista entre as demais, já que além do seu próprio, essa Comunidade arrenda o castanhal de outras.

Especificamente as Comunidades Nova Vista e Bacadaru apresentam os maiores índices de sustentabilidade em 2019 (54,60\%), em contraposição da Comunidade São Tomé, que apresentou indicador de 27,30\%, situação que pode ser explicada pelo fato da comunidade não possuir número elevado de residentes e baixa diversificação na produção.

\section{Parâmetro - Número de residentes}

O modelo apresentou forte correlação entre o número de residentes em relação ao resultado apurados no índice de sustentabilidade, uma vez que: 
- As comunidades com residentes em número igual ou superior a 30 pessoas apresentaram índices de sustentabilidade superiores ao da média do índice de sustentabilidade da Resex, nos dois anos analisados: Comunidades Nova Vista, Santa Bárbara, Bacadaru, Fortaleza, Sacado, Glória II, Irajá, Carmo e São Jerônimo. A média dos índices de sustentabilidade dessas nove comunidades foram 47,52\% e 46,51\%, em 2019 e 2020, respectivamente. Índices superiores ao Resultado Agregado das Comunidades e da Resex (Figura 17 - Tópico 4.6.2).

- As localidades, que possuem em média 8 residentes por localidade, apresentaram índices de sustentabilidade menores do que a média do índice de sustentabilidade da Resex, nos dois anos analisados. A média dos índices de sustentabilidade das 21 localidades foram 7,80\% e 17,77\%, em 2019 e 2020, respectivamente. Somente a Localidade do Moará, possui mais de 30 residentes, com índice de sustentabilidade de 9,10\% e 27,30\%, em 2019 e 2020, portanto, valores acima do Resultado Agregado das Localidades, 7,86\% em 2019 e 18,20\% em 2020 (Figura 17 - Tópico 4.6.2).

\section{Parâmetro - Produção per capita}

Avaliação quantitativa decorrente da comparação se o valor da Produção per capita alcançada na Resex é igual ou maior que a média da Renda per capita dos municípios de Canutama e Lábrea, uma vez que os municípios são os destinos mais comuns para os residentes na Resex. Como valor de corte, o PIB per capita médio dos municípios atingiu R\$ 8.953,67 e serviu de parâmetro para comparar com a Produção per capita das comunidades e localidades.

Em 2019, somente duas comunidades atingiram o patamar de produção per capita superior ao critério estabelecido: Nova Vista e Açaituba.

Em 2020, somente a Comunidade Açaituba atingiu o patamar de produção per capita superior ao critério estabelecido. Quatro localidades apresentaram um valor muito superior ao valor do PIB per capita médio dos municípios de Canutama e Lábrea: Tororó-Paissé; Mapiciari; Santana e Nazaré, o que pode ser explicado pelo registro elevado da produção local em relação ao número de moradores.

\section{Parâmetro - Produção média}

Avaliação quantitativa decorrente da comparação entre o valor monetário da Produção total de cada comunidade/localidade comparado com a Produção média da Resex. 
Em 2019, sete comunidades e duas localidades atingiram valor igual ou superior a produção média da Resex (R\$ 79.025,05) - Comunidades: Nova Vista, Santa Bárbara, Bacadaru, Fortaleza, Açaituba, Sacado e Forte Veneza/Nova Colônia. Localidades: Vista Alegre e Bom Sucesso.

Em 2020, nove comunidades e três localidades atingiram valor igual ou superior a produção média da Resex (R\$ 76.936,56) - Comunidades: Nova Vista, Santa Bárbara, Bacadaru, Fortaleza, Açaituba, Sacado, Glória II, Irajá e Santa Maria. Localidades: TororóPaissé, Mapiciari e Santana.

\section{Parâmetro - Produção diversificada e com produtos potenciais}

Avaliação quantitativa decorrente da verificação se a comunidade possui uma produção diversificada e contém produtos com maior potencial de vendas da Resex (Castanha, Farinha, Pescado Fresco, Pescado Seco, Açaí e Porco). Como indicador de análise, os produtos potenciais devem representar no mínimo $10 \%$ do volume de produção da comunidade.

As comunidades que ofertam um portfólio de produtos com maior potencial de vendas, tais como castanha, farinha, pescado, porco, açaí, melancia e, mais recentemente, carvão vegetal, têm vantagem competitiva. Esses produtos podem formar a base de uma lista para ser trabalhada com o intuito de gerar maior diversificação da cesta de oferta da Resex, além de possibilitar maior abrangência de comunidades e localidades envolvidas e beneficiadas pelos resultados totais das vendas da Resex Canutama. 


\section{CONSIDERAÇÕES FINAIS}

\subsection{Consecução dos objetivos propostos}

Como forma de apresentação das considerações finais, os tópicos a seguir apresentam um resumo dos resultados em relação ao alcance de cada um dos objetivos específicos, as contribuições, limitações da pesquisa e sugestões para novos estudos.

$>$ Em relação ao objetivo: Levantar e analisar as características e dinâmicas das atividades produtivas desenvolvidas nos espaços territoriais produtivos de uma reserva extrativista do Bioma Amazônia

Decorridos mais de vinte anos da criação das Reservas Extrativistas, os produtores ainda sofrem com dificuldades para manter sua produção e, especialmente, suas condições de subsistência. Alguns poucos conseguem renda mais alta, por terem contratos fixos com a Prefeitura ou por destinarem parcela maior da sua produção para venda (em vez de somente destinarem o que excede do sustento próprio), mas a maioria das famílias pesquisadas convivem, constantemente, com as incertezas sobre seu sustento.

Ainda que haja empenho na produção, o processo de venda é dificultoso e de alto custo, o que acaba causando desânimo entre os comunitários e, talvez, esse seja o real motivo da falta de iniciativas (por parte deles) para mudar esse quadro, embora não se possa desconsiderar outras justificativas, tais como a evidente falta de conhecimento sobre seus direitos e sobre os mecanismos de gestão da Resex e, principalmente, a reclamada falta de apoio do Poder público. Além das próprias características dos comunitários, que são pessoas simples e mais afeitas a questões "da terra" ou da "roça", do que a processos de gestão ou modelos de negócios.

Independentemente do propósito da Resex (quando da sua criação), no que se refere ao meio ambiente e ao papel dos produtores nesse contexto, o que se constatou foi significativo desamparo aos comunitários, seja do Poder público, de entidades e empresas apoiadoras e da própria gestão da Reserva (incluídas a cooperativa e a associação local). 
O estudo revelou que os comunitários não recebem informação ou acompanham a gestão da Resex, o que pode ser a razão pela qual as demandas por assistência sejam direcionadas somente ao Poder público. Afinal, os moradores demonstraram não saber o que está ocorrendo (como está a gestão) ou quais as atribuições da gestão, no sentido de auxiliar e amparar os comunitários, como também não se pode reclamar ou reivindicar ações do gestor da Resex. Ainda, este pode ser o motivo do distanciamento e/ou falta de engajamento dos comunitários com relação às questões relacionadas à Resex.

Em contrapartida, o gestor se diz "abandonado" e, por isso, impossibilitado de agir, o que, adicionado à postura dos comunitários, dificulta bastante a resolução de problemas e implementação de iniciativas que promovam o desenvolvimento da Resex.

Dentre outros, a infraestrutura (leia-se embarcação, energia) insuficiente para a venda da produção, bem como a deficiência na oferta de serviço de educação, são os principais fatores de insatisfação dos entrevistados e é o que pode, pelos depoimentos, induzir ao abandono da Resex e/ou da atividade extrativista no local. O primeiro, atinge fortemente os mais velhos, que vivenciam essas mesmas dificuldades há muito tempo, enquanto o segundo problema, é preponderante entre os jovens, que, na maioria dos casos, gostam de morar na Resex, mas querem avançar nos estudos.

Para a maioria dos moradores, a continuidade da Reserva depende de iniciativas no que diz respeito ao processo logístico de escoamento da produção e das condições de venda dos produtos, do extrativismo ou das pequenas lavouras. Caso contrário, a tendência, segundo depoimentos, é de que as pessoas abandonem a região, em busca de alternativas que lhes garantam o sustento.

Alguns demonstraram desânimo quanto ao futuro da Resex Canutama, mas talvez esse seja o sentimento de um número maior de moradores - o perfil calmo dos comunitários pode mascarar certo abatimento. A aparente resignação pode ser, na realidade, sentimento de desânimo, que corrobora a falta de iniciativa para mudar o panorama atual.

$\mathrm{Na}$ questão ambiental, o crescimento dos índices de extração de carvão vegetal nos anos recentes pode ter relação com o aumento da produção de farinha na Resex Canutama, que necessita do carvão em etapa importante para finalização do produto. Todavia, mesmo considerando os danos causados à floresta e ao clima (se excedido ou não limite de proteção), os produtores não se mostraram preocupados. Tendo em vista a igual aceleração do desmatamento na Amazônia, esse panorama poderá provocar consequências mais graves e persistentes para todo aquele ecossistema, neste momento e no futuro (próximo). 
Sabe-se que a degradação da floresta amazônica está cada vez mais rápida, mas o cenário delineado acima ocorre há muito tempo, à margem desse problema estrutural e da gestão da Resex Canutama, cuja gravidade é semelhante, ou maior, que o desmatamento, uma vez que envolve diretamente a população local, que, em princípio, é a guardiã daquele território.

Portanto, entende-se que não é o desmatamento o causador dos transtornos vivenciados, repetidamente, pelos produtores, durante a realização da venda dos produtos da Resex, assim como das limitações financeiras das famílias. O produtor extrativista está fazendo o que lhe cabe e é permitido - plantando e extraindo produtos, seguindo as regras de restrições para as áreas protegidas. Contudo, a contrapartida dos governos e da gestão da Resex não está sendo concretizada. E a falta de conhecimento e inexperiência em negociação (porque foram acostumados a não ter que lidar com a questão), além da falta de recursos para implementar - eles próprios - a logística do escoamento de seus produtos, deixa os produtores de mãos atadas e entregues à atuação dos atravessadores.

Por isso, as demonstrações da expectativa de melhorias da vida na Resex, sobretudo nas questões necessitadas de ação pública (saneamento, energia, educação, logística de venda da produção), o que, para os moradores, consequentemente, se traduzirá em condições mais favoráveis para suas vidas, para a execução da atividade e para obtenção de maior lucro/receita.

No período de realização do estudo de caso, a Reserva Extrativista Canutama, assim como todo o ecossistema da Amazônia - e o Brasil, de modo geral -, sofria com os reflexos da pandemia da Covid-19, que limitou a circulação de pessoas e, para alguns, prejudicou a comercialização dos produtos locais. Mas não somente. Antes da pandemia do Coronavírus, a região amazônica já convivia com as consequências do "abandono" do Poder público, notadamente explicitado pela falta de estrutura para operacionalização da atividade de extração dos produtos e para a logística da venda da produção, o que, somado ao crescimento acelerado de ilegalidades ambientais, afetava a produção e comercialização dos produtos, repercutindo na vida dos residentes.

Com base nos relatos, foi possível destacar dois fatores desafiadores para as atividades produtivas: (a) o desafio da fonte de energia, principalmente para o escoamento da produção e para uso na comunidade, pois a maior parte da energia utilizada é obtida a partir de geradores doados pela Prefeitura de Canutama, que também fornece insuficiente quantidade de combustível (diesel); (b) o desafio do transporte: além das complicações geográficas e naturais para acesso à Resex Canutama (estão no meio da floresta, margeados por um rio), os 
comunitários sofrem com a falta de transporte adequado (em tamanho e potência do motor) para os trajetos entre a Reserva e os centros urbanos mais próximos, tanto para escoar a produção, quanto para compras de alimentos.

Embora o resultado deste estudo indica elevada satisfação dos comunitários em residir na Resex, há relatos de insatisfação em relação à sua condição financeira, que podem provocar a saída dos residentes, o que denota, em certa medida, falha na realização dos propósitos originais da criação das Unidades de Conservação, já que não está conseguindo manter a integridade da floresta nem a dignidade e subsistência das famílias locais.

A falta de apoio, incentivos e orientação técnica, associado a um ambiente com constantes investidas de infratores das restrições estabelecidas para áreas protegidas e por grandes empresas e proprietários de terras, além de ter o processo de comercialização dos produtos da Resex dominado por atravessadores, deixa os comunitários vulneráveis e suscetíveis a situações que, geralmente, causam prejuízo a todos que lá residem e dependem do bom desempenho econômico da Reserva Extrativista Canutama.

Em relação ao objetivo: Propor instrumento que permita a mensuração e o monitoramento da sustentabilidade financeira de reservas extrativistas do Bioma Amazônia.

Esta pesquisa, converge com a teoria que acredita na possibilidade de "novos caminhos institucionais", e apresenta como produto principal, o SIW Resex Canutama, uma ferramenta de gestão que pode gerar sinais para o setor público e privado direcionados a formulação de estratégias que permitam o fortalecimento e integração de mecanismos financeiros públicos e privados, direcionados para sustentabilidade financeira (ou viabilidade) das comunidades extrativistas das unidades de conservação do Bioma Amazônia.

O Sistema de Informações WEB construído, não foi uma proposta inicial do projeto de pesquisa, foi um produto decorrente do desenvolvimento da pesquisa, os parâmetros nasceram das observações, relatos e percepções da autora, derivado da necessidade de 'enxergar' as características das partes (comunidades e localidades) e do todo (reserva extrativista) de forma simultânea, para gerar dados para análises. O modelo foi concebido a partir da inquietude: como entender a situação atual e desenhar ações para fortalecer a sustentabilidade financeira sem ter parâmetros ou indicadores de sustentabilidade financeira da resex? 
O sistema de informações web (SIW), foi desenvolvido dentro do conceito de acesso universal, em que facilmente pode ser acessado de qualquer lugar ou plataforma, com usabilidade simples, sem a necessidade de um treinamento detalhado sobre como utilizar a aplicação.

O SIW Resex Canutama é um software de conteúdo hospedado na internet, onde foram inseridas informações gerais sobre cada uma das comunidades e localidades da Resex Canutama, para fins de gerar informações automáticas sobre a produção e a sustentabilidade financeira local, em que o usuário só necessita de um sistema operacional, um navegador e conexão com internet para acessar o sistema web, portanto, é um hardware de baixo custo.

O SIW Resex Canutama é o modelo proposto para mensurar a sustentabilidade financeira das comunidades e localidades da Resex Canutama por meio de parâmetros estabelecidos na pesquisa. Após a criação, ficou patente a possibilidade de contribuir para a gestão da Resex Canutama uma vez que oferece os seguintes módulos para inserção de dados:

_ Módulo 'Produtos': registrar os produtos vendidos na resex;

_ Módulo 'Comunidade': registrar os espaços territoriais produtivos (comunidade e localidade), inclusive inserindo a sua localização no mapa, por meio da latitude e longetude;

_ Módulo 'Produção': registrar a produção vendida em cada uma das comunidades, por ano, por produto e preço, por quantidade vendida, por destino da produção;

_ Módulo 'Relatórios': permite gerar informações da produção da Resex de forma automática: por produtos; por comunidades e por sustentabilidade.

O sistema de informações web é uma proposta de um modelo para a mensuração da sustentabilidade financeira, a partir de parâmetros qualitativos e quantitativos, que avalia com a mesma lente, todos os espaços territoriais produtivos (comunidades e localidades). O Radar de Sustentabilidade Financeira da Resex, é representado por um indicador com uma escala que varia de $0 \%$ a $100 \%$, e foi mensurado a partir de onze parâmetros que avaliaram as seguintes características de cada uma das 16 comunidades e 22 localidades:

[A comunidade possui...] (1) Líder comunitário com perfil empreendedor; (2) Controle de castanhal e exploração de castanhal; (3) $\mathrm{N}^{\circ}$ mínimo de residentes $\geq 30$ pessoas; (4) Produção per capita da comunidade $\geq$ média do PIB per capita dos municípios Canutama e Lábrea; (5) Produção na Comunidade $\geq$ média da produção total na Resex Canutama; (6) Produção diversificada e contendo o produto potencial 'Farinha' com produção $\geq 10 \%$; (7) 
Produção diversificada e contendo o produto potencial 'Peixe Fresco' com produção $\geq 10 \%$;

(8) Produção diversificada e contendo o produto potencial 'Peixe Seco' com produção $\geq 10 \%$;

(9) Produção diversificada e contendo o produto potencial 'Porco' com produção $\geq 10 \%$; (10)

Produção diversificada e contendo o produto potencial 'Açaí' com produção $\geq 10 \%$; (11)

Produção diversificada e contendo o produto potencial 'Castanha' com produção $\geq 10 \%$.

Em relação ao objetivo: Mensurar as condições de sustentabilidade financeira existentes em comunidades extrativistas de uma reserva extrativista do Bioma Amazônia a partir do modelo analítico proposto.

O modelo analítico proposto permitiu a mensuração das condições de sustentabilidade financeiras de todos os espaços territoriais ocupados por residentes: comunidades e localidades. As comunidades concentram o maior número de residentes ( $75 \%$ da população) e são responsáveis pelo maior volume de produção ( $80 \%$ da produção total da Resex).

O Radar de Sustentabilidade Financeira da Resex das comunidades apurou que mesmo não conseguindo atingir um alto índice de sustentabilidade (resultado agregado $>65 \%$, posição na área verde) esses espaços territoriais são mais 'sustentáveis', pois

_ Onze comunidades em 2019 e nove em 2020, conseguiram atingir moderado índice de sustentabilidade (resultado agregado $>30 \%$ e $<65 \%$, posição na área amarela);

_ Em 2019, os maiores índices de sustentabilidade foram obtidos em quatro comunidades: Nova Vista, Santa Bárbara, Bacadaru e Sacado (54,60\%);

_ Em 2020, os maiores índices de sustentabilidade foram obtidos em quatro comunidades: Nova Vista, Santa Bárbara, Glória II e Irajá (54,60\%).

O Radar de Sustentabilidade Financeira da Resex das localidades apurou que nenhuma localidade conseguiu atingir alto índice de sustentabilidade (resultado agregado $>65 \%$, posição na área verde). Somente a Localidade Bom Sucesso em 2019 e duas localidades, Santana e Paraíso, em 2020, conseguiram atingir moderado índice de sustentabilidade (resultado agregado $>30 \%$ e $<65 \%$, posição na área amarela), portanto, foi possível constatar:

_ Maior vulnerabilidade financeira nas localidades, uma vez que, 19 localidades, nos dois anos apurados, ficaram com resultado agregado $\leq 30 \%$ posição na área vermelha); 
_ Quinze comunidades em 2019 e cinco em 2020, não apresentarem registros de produção, portanto, ficaram com zero no indicador de sustentabilidade.

O Radar de Sustentabilidade Financeira da Resex Canutama é resultado da média do conjunto dos índices de sustentabilidade financeira apurados em cada um dos 38 espaços territoriais (comunidades e localidades). O resultado agregado para a Resex Canutama, de 20,59\% em 2019 e 26,82\% em 2020, indica que a Resex Canutama ainda não alcançou a sustentabilidade financeira. Contudo, se a sustentabilidade financeira da Resex Canutama existe, ela é frágil e/ou inconstante, quer dizer, não se mantém com regularidade, além de excluir a maioria das comunidades e localidades que fazem parte daquela área protegida.

A gestão precária; a falta de suporte do Poder público; a forte concentração das vendas na extração da castanha; a ausência de dados produtivos para dar suporte ao planejamento e tomadas de decisões provoca forte desequilíbrio em termos de produção - e receita - nos resultados individuais de cada comunidade e localidade.

As comunidades que ofertam um portfólio de produtos com maior potencial de vendas, tais como castanha, farinha, pescado, porco, açaí, melancia e, mais recentemente, carvão vegetal, têm vantagem competitiva e apresentaram maior percentual de sustentabilidade financeira. Esses produtos podem formar a base de uma lista para ser trabalhada com o intuito de gerar maior diversificação da cesta de oferta da Resex, além de possibilitar maior abrangência de comunidades e localidades envolvidas e beneficiadas pelos resultados totais das vendas da Resex Canutama.

Alerta-se ao fato de que este é o ponto de vista dos acontecimentos na Reserva Canutama, objeto deste estudo, o que revela a necessidade de novas pesquisas, abrangendo outras Reservas Extrativistas e Unidades de Conservação, a fim de elucidar a realidade da vida dos residentes, bem como o cumprimento (efetividade e adequação) dos propósitos de criação dessas áreas protegidas.

\subsection{Contribuições}

O objetivo geral proposto de 'estruturar mecanismo de mensuração e monitoramento da sustentabilidade financeira para o fortalecimento de reservas extrativistas do Bioma Amazônia' foi cumprido com a criação do SIW Resex Canutama como uma proposta de uma ferramenta de gestão que poderá fortalecer a governança da Resex, uma vez que: 
(a) para os órgãos de controle da Resex (SEMA e Gestor da Resex) disponibiliza um repositório de dados da produção com possibilidade de registrar novos dados de produção; acesso rápido e seguro a base dados; possibilidade de gerar informações essenciais para controle e coordenação da produção; possibilidade de identificar comunidades e/ou localidades em situação de excesso e/ou de escassez de produção;

(b) para os líderes comunitários, disponibiliza o acesso as características produtivas de todas as comunidades/localidades; possibilita o registro de dados primários da produção específica de cada espaço territorial produtivo (quantidade, preço de venda, volume e destino da produção); possibilita a disseminação de conhecimento das características produtivas de toda a Resex, permitindo conhecer a importância da comunidade em relação ao volume de recursos financeiros gerados na Resex.

Para a academia, a pesquisa contribui para a compreensão e aplicabilidade do conceito de Sustentabilidade Financeira, um conceito em construção e de difícil incorporação, pois associa concepções financeiras e o conceito de sustentabilidade ambiental. Ademais, o debate sobre sustentabilidade precisa se tornar operacional e superar o debate puramente teórico.

Para a prática gerencial, a pesquisa permite conhecer e mensurar as condições de sustentabilidade financeira das comunidades localizadas no bioma Amazônia, e com isso, gerar sinais para a adoção de políticas públicas e iniciativas privadas na economia local, que consigam frear o desmatamento, gerando benefícios ambientais para todo o planeta.

O modelo analítico, Radar de Sustentabilidade Financeira, pode servir de sinalizador para a adoção de ações públicas e privadas que visem elevar as condições de sustentabilidade financeira das comunidades e localidades. Os órgãos de controle, particularmente, a SEMA, poderão implementar programas para:

(a) oferecer capacitação para as lideranças comunitárias visando desenvolver técnicas de negociação e coordenação da produção local;

(b) promover parceria com a associação/cooperativa local para resgatar as atividades de beneficiamento da castanha, aumentando o valor agregado ao produto final;

(c) mapear as áreas de castanhais e adotar ações para distribuir equitativamente as áreas para exploração com uma parcela maior de comunitários, reduzindo a alta concentração atual;

(d) monitorar a adoção das práticas agrícolas e extrativistas previstas no Plano de Gestão; 
(e) prover as comunidades de informações sobre as atividades econômicas desenvolvidas na Resex, no sentido de sinalizar os produtos com maior potencial de vendas, para evitar graves oscilações em relação ao excesso/escassez de produtos;

(f) desenvolver parcerias com empresas que possam oferecer soluções alternativas para o desafio da comunicação, transporte e energia local.

O fortalecimento das condições socioeconômicas das reservas extrativistas pode contribuir para a identificação e adoção de mecanismos que possibilitem frear $o$ desmatamento e a degradação ambiental, além de reduzir a vulnerabilidade da população residente nessas comunidades.

É preciso eleger as comunidades e povos tradicionais e mais especificamente, a comunidade extrativista amazônica, como protagonista de um cenário econômico mundial, regional e local que discute, revisa e impõe a necessidade de um modelo viável de desenvolvimento sustentável que consiga, simultaneamente, atender as necessidades socioeconômicas da população residente em reserva extrativista e conservar os recursos naturais ameaçados pelo avanço do desmatamento florestal no Bioma Amazônia.

A visão sobre as Resex (ou áreas protegidas em geral) tem dois segmentos de manifestações, os críticos e os defensores. Os críticos se baseiam sobretudo na situação atual (após 2012) da Amazônia, que retrata o alto, descontrolado e indiscriminado grau de desmatamento ilegal na região, o que, para alguns, denota o "fracasso" das Resex, se considerados seus objetivos e metas iniciais. A autora, por sua vez, defende que, em alguma medida, as Resex conseguem proteger a floresta e inibem (em alguma medida) a ação de fazendeiros, pecuaristas, grileiros e afins. A pesquisa comprovou, que, os 'beiradeiros' autodenominação dos povos tradicionais residentes na Resex estudada -, mesmo com as dificuldades de sobrevivência/subsistência, ainda defendem e priorizam o bioma Amazônia, em vez de aderir aos dividendos atrativos da exploração ilegal da floresta.

\subsection{Limitações}

Decorrente das dificuldades impostas pela Pandemia da COVID-19, a pesquisa de campo, que originalmente previa visita e realização de entrevistas em, pelo menos, duas reservas extrativistas, não foi possível. Fato que impossibilitou gerar dados comparativos de comunidades/localidades localizadas em diferentes reservas extrativistas do Bioma Amazônia. 
Uma outra limitação da pesquisa foi a ausência da análise da demanda por produtos da floresta, e a ausência de entrevistas de outros atores que influenciam a dinâmica da cadeia produtiva, como por exemplo, as organizações da sociedade civil que ajudam no escoamento de produtos, as empresas compradoras de matéria-prima e os órgãos públicos.

\subsection{Sugestões}

As sugestões para pesquisas futuras são indicadas a seguir:

- Novas pesquisas que estudem outras Resex, e até um Bioma inteiro, relacionando a sobrevivência das populações residentes, em todos os sentidos, financeiro, social, a partir de parâmetros aderentes às características locais e/ou adaptando o modelo do 'Radar de Sustentabilidade Financeira' apresentado nesta pesquisa.

- Estudos que analisem as cadeias produtivas e formas de gerar maior valor socioambiental e valor econômico para as comunidades e localidades.

- Estudos que analisem a necessidade de permanência da nova geração de residentes para dar continuidade a ocupação dos espaços territoriais de uma reserva extrativista. 


\section{REFERÊNCIAS ${ }^{11}$}

ABRAMOVAY, Ricardo. Amazônia: por uma economia do conhecimento da natureza. São Paulo: Edições Terceira Via; Abong; Iser Assessoria, 2019.

ALEIXO, Josinaldo (Org.). Memorial da luta pela reserva extrativista do Médio Purus em Lábrea-AM: registro da mobilização social, organização comunitária e conquista de cidadania na Amazônia. Associação dos Trabalhadores Agroextrativistas do Médio Purus. Brasília: Instituto Internacional de Educação do Brasil (IEB), 2011.

ANTUNES, J., DO NASCIMENTO, V. S., DE QUEIROZ, Z. F. Narrativa crítica acerca do desenvolvimento sustentável: quais relações podemos estabelecer? REMEA-Revista Eletrônica do Mestrado em Educação Ambiental, 34(2), 57-75, 2017.

ARAÚJO, M. B. V. Informações contábeis e o risco de insolvência de cooperativas de crédito. Dissertação de Mestrado, Faculdade de Economia, Administração e Contabilidade, Universidade de São Paulo, São Paulo, 2011. doi:10.11606/D.12.2011.tde-21062011-141251. Disponível em: <www.teses.usp.br>. Acesso em: 18 abr. 2019.

ÁVILA, L. V., BARROS, I. C. F., MADRUGA, L. R. D. R. G., E JÚNIOR, V. F. S. Características das publicações sobre Empreendedorismo (Social) no Web of Science no período 2002-2011. Administração Pública e Gestão Social, 6(2), 88-100, 2014.

BANERJEE, Subhabrata B. Organizational strategies for sustainable development: developing a research agenda for the new Millennium. Australian Journal of Management, V. 27, Special Issue, 2002.

BARBIERI, José Carlos et al. Inovação e Sustentabilidade: novos modelos e proposições. Revista de Administração de Empresas (RAE). São Paulo, v. 50, n. 2, abr./jun. 2010, 146-154.

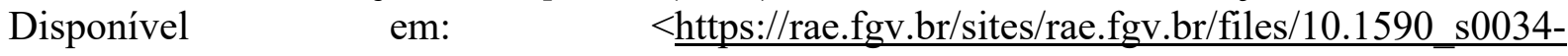
75902010000200002.pdf $>$. Acesso em: 18 abr. 2019.

BARDIN, Lawrence. Análise de Conteúdo. São Paulo, Edições 70 LDA, 1977.

BRASIL. INSTITUTO CHICO MENDES - ICMBio. Disponível em:

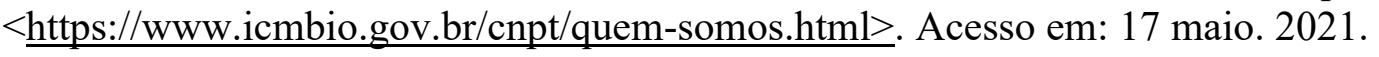

BODNAR, Z., PASSOS DE FREITAS, V., \& SILVA, K. A epistemologia interdisciplinar da sustentabilidade: por uma ecologia integral para a sustentação da casa comum. Revista

${ }^{11}$ De acordo com Diretrizes para apresentação de teses e dissertações da USP - Parte I (ABNT), 2020 
Brasileira de Direito, 12(2), 59-70, 2016. doi:https://doi.org/10.18256/22380604/revistadedireito.v12n2p59-70.

BOFF, L. História da sustentabilidade. Revista EA.ORG., 2005. Disponível em: < http://www.mobilizadores.org.br/wpcontent/uploads/2014/05/artigo_historia_da_sustentabilid ade.pdf. $>$. Acesso em 03 mar. 2019.

BRANCO, A. M. F. Sustentabilidade Financeira Empresarial no Brasil. 2013. 136 f. Dissertação (Mestrado em Administração de Organizações) - Faculdade de Economia, Administração e Contabilidade de Ribeirão Preto, Universidade de São Paulo, Ribeirão Preto, 2013. Disponível em: <www.teses.usp.br>. Acesso em: 20 nov. 2020.

BRIGHAM, E. F.; EHRHARDT, M. C. Administração financeira: teoria e prática. Tradução Noveritis do Brasil, Pólen Editorial, Solange Aparecida Visconti; Revisão técnica: James R. Hunter, Peter Edward Mr. Wilson. 3. ed. - São Paulo: Cengage Learning, 2016.

BRUNDTLAND, G. H., e KHALID, M. Nosso futuro comum. Comissão Mundial sobre Meio Ambiente, 2 ed. Fundação Getúlio Vargas: Rio de Janeiro, 1991.

CAKE PHP. Versão 4.X Online 2020. Tutorial. Cake Software Foundation, Inc. Disponível em: $<$ https://book.cakephp.org/4/pt/index.html.> Acessado em: 10 dez. 2020.

CAMILOTTI, Vagner L. et al. The Importance of Forest Extractive Resources for Income Generation and Subsistence among Caboclos and Colonists in the Brazilian Amazon. Human Ecology 48, 17-31. Springer Science+Business Media, LLC, part of Springer Nature, 2020.

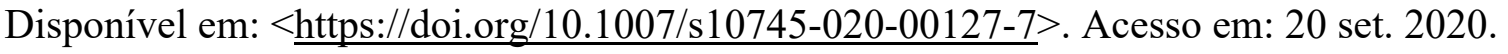

CAPELARI, M. G. M. Instituições para a governança: o papel das regras formais e informais no controle do desmatamento em Reservas Extrativistas da Amazônia. Tese (Doutorado em Administração Pública e Políticas Públicas), Universidade de Brasília PPGA/UnB. Brasília, 2017.

CARVALHO, F. L. Indicadores de avaliação de desempenho de cooperativas agropecuárias: um estudo em cooperativas paulistas. Dissertação (Mestrado) - Faculdade de Economia, Administração e Contabilidade de Ribeirão Preto, Universidade de São Paulo, Ribeirão Preto, 2008. Disponível em: <www.teses.usp.br>. Acesso em: 18 abr. 2018.

CASTELANI, S. A. Florestas e cidades: ensaios sobre crescimento urbano e desenvolvimento na Amazônia brasileira. São Paulo, 2013.

CHAGAS, F.; DE CARVALHO, C. L.; DA SILVA, J. C. Um estudo sobre os sistemas de gerenciamento de conteúdo de código aberto. Revista Telfract, v. 1, n. 1, 2018. Disponível em: $\quad<$ https://telematicafractal.com.br/revista/index.php/telfract/article/view/2/13.. . Acesso em: 14 jan. 2021.

COMINI, G. M. Negócios sociais e inovação social: um retrato de experiências brasileiras. Tese de Doutorado. Universidade de São Paulo, 2016. Disponível em: <www.teses.usp.br>. Acesso em: 28 set. 2017. 
COMISSÃO INTERMINISTERIAL PARA A PREPARAÇÃO DA CONFERÊNCIA DA ONU SOBRE MEIO AMBIENTE E DESENVOLVIMENTO (Brasil). O desafio do desenvolvimento sustentável. Brasília: Secretaria da Imprensa da Presidência da República. Brasília: CIMA, 1991.

CONWAY, GR. Análise participativa para o desenvolvimento agrícola sustentável. Rio de Janeiro: AS-PTA, $1993 . \quad$ Disponível em: $<$ http://aspta.redelivre.org.br/files/2016/09/An\%C3\%A1lise-participativa_Conway.pdf $>$.

Acessado em: 02 mai 2018

COOPER, N. A.; K. A. KAINER. To log or not to log: local perceptions of timber management and its implications for wellbeing within a sustainable - use protected area. Ecology and Society 23(2):4, 2018 Disponível em: <https://doi.org/10.5751/ES-09995230204 >. Acesso em: 16 set. 2020.

COSTANZA, R. Ecological economics: the science and management of sustainability. New York: Columbia Pres, 1991.

DEES, J. G. Enterprising Nonprofits. Harvard Business Review, v. 76, n. 1, p. 55+, jan./fev. 1998. Disponível em: $\quad<$ https://centers.fuqua.duke.edu/case/wpcontent/uploads/sites/7/2015/03/Article_Dees_EnterprisingNonprofits_1998.pdf. $>$. Acesso em: 29 abr. 2019.

EHLERS, E. O que é Agricultura sustentável. $1^{\text {a }}$ ed. eBook. São Paulo: Editora Brasiliense, 2017.

EISENHARDT, K. M. Building Theories from Case Study Research. Academy of Management Review, v. 14, n. 34, p. 532-550. 1989.

ELKINGTON, John. Green Swans: the coming boom in regenerative capitalism. New York: Fast Company Press, 2020.

ELKINGTON, John. Canibais com Garfo e Faca. São Paulo: Makron Books, 2001.

FERREIRA PIMENTA, M., e NARDELLI, A. Desenvolvimento sustentável: os avanços na discussão sobre os temas ambientais lançados pela conferência das Nações Unidas sobre o desenvolvimento sustentável, Rio +20 e os desafios para os próximos 20 anos. Perspectiva, 33(3), 1257-1277, 2016. Disponível em: <https://doi.org/10.5007/2175795X.2015v33n3p1257.>. Acessado em: 23 jun. 2019.

FERREIRA, M. A. M.; GONÇALVES, R. M. L.; BRAGA, M. J. Investigação do desempenho das Cooperativas de Crédito de Minas Gerais por meio da Análise Envoltória de Dados (DEA). Economia Aplicada, São Paulo, v. 11, n. 3, p. 425-445, julho-setembro, 2007. Disponível em: <https://dx.doi.org/10.1590/S1413-80502007000300006>. Acesso em: 12 nov. 2019.

FISCHER, R. M. Negócios Sociais. In: BOULlOSA, R. F (org.). Dicionário para a formação em gestão social. Salvador: CIAGS/UFBA, p. 125-127, 2014. Disponível para 
leitura online: $<$ https://issuu.com/carlosvilmar/docs/e-book dicionario de verbetes $>$. Acessado em: 15 jan. 2019.

FISCHER, R. M. e COMINI, G. M. Desenvolvimento sustentável: da responsabilidade ao empreendedorismo. Revista de Administração (São Paulo), 47 (3), 363-369. 2012. Disponível em: $<$ https://dx.doi.org/10.1590/S0080-21072012000300002>. Acesso em: 27 set. 2017.

FREITAS, M. D., e CASTRO JÚNIOR, W. E. D. Amazônia e desenvolvimento sustentável: um diálogo que todos os brasileiros deveriam conhecer. Com a colaboração de Walter Esteves de Castro Júnior. Petrópolis, RJ: Vozes, 2004

FREITAS, Marcílio de (Org.) Amazônia a natureza dos problemas e os problemas da natureza, v. 1. Universidade Federal do Amazonas. Manaus: EDUA, 2005.

FREITAS, M., SILVA, M. C., e MARMOZ, L. A ilusão da sustentabilidade. Universidade Federal do Amazonas. Manaus: EDUA, 2003.

FREITAS, J. S. et al. Reservas Extrativistas sem extrativismo: uma tendência em curso na Amazônia? Revista de Gestão Social e Ambiental - RGSA, São Paulo, v. 12, n. 1, p. 56-72, jan./abr. 2018.

FREITAS, J. S., e RIVAS, A. F. Unidades De Conservação Promovem Pobreza E Estimulam Agressão À Natureza Na Amazônia. Revista de Gestão Social e Ambiental, 8(3), 18, 2014.

FREITAS, J. S., MATHIS, A., FARIAS FILHO, M. C., HOMMA, A., e SILVA, D. Reservas extrativistas na Amazônia: modelo conservação ambiental e desenvolvimento social? Embrapa Amazônia Oriental-Artigo em periódico indexado (ALICE), 2017.

FROEHLICH, C. Sustentabilidade: dimensões e métodos de mensuração de resultados. Revista de Gestão do Unilasalle, 3(2), 151-168, 2014.

GIACOMIN, J., BOETLER, C., FIABANI, F., e SANDRI, O. Cooperativismo: uma análise da gestão de três cooperativas de Erechim/RS e dos indicadores econômico-financeiros de 2006 a 2015. Revista de Gestão e Organizações Cooperativas - RGC, Santa Maria, v.5, n.10, p.93-108, Jul./Dez. 2018. DOI: 10.5902/2359043229688.

GIL, A. C. Como elaborar projetos de pesquisa. São Paulo: Atlas, 2002.

GIL, A. C. Métodos e Técnicas de Pesquisa Social. 6.ed. São Paulo: Atlas, 2008.

GITMAN, L. J. Princípios de Administração Financeira. 12 ed. São Paulo: Pearson Prentice Hall, 2010.

GLADWIN, T. N.; KRAUSE, Tara-Shelomith; KENNELLY, J. J. Beyond eco-efficiency: toward socially sustainable business. Sustainable Development 3, 35-43, april. 1995. 
GOMES, C. V. A. et al. Extractive reserves in the Brazilian Amazon thirty years after Chico Mendes: social movement achievements, territorial expansion and continuing struggles. Desenvolvimento e Meio Ambiente, v. 48, Edição especial: 30 Anos do Legado de Chico Mendes, p. 74-98, novembro 2018.

GRIFFITHS, W., HILL, C., e JUDGE, G. Econometria. São Paulo: Editora Saraiva, 1999.

IIZUKA, E. S. Empreendedorismo Social. In: BOULLOSA, R. F (org.). Dicionário para a formação em gestão social. Salvador: CIAGS/UFBA, p. 57-59, 2014. Disponível para leitura online: < https://issuu.com/carlosvilmar/docs/e-book_dicionario_de verbetes $>$. Acessado em: 15 jan. 2019.

INSTITUTO BRASILEIRO DE GEOGRAFIA E ESTATÍSTICA (Brasil). Amazônia Legal. Portal de Mapas. IBGE, 2014. Disponível em: $<$ https://portaldemapas.ibge.gov.br/portal.php\#mapa206097>. Acesso em: 17 fev. 2019.

INSTITUTO BRASILEIRO DE GEOGRAFIA E ESTATÍSTICA (Brasil). Biomas e sistema costeiro-marinho do Brasil: compatível com a escala 1:250 000 / IBGE, Coordenação de Recursos Naturais e Estudos Ambientais. - Rio de Janeiro: IBGE, 2019. 168 p. - (Relatórios metodológicos, ISSN 0101-2843; v. 45). Disponível em: $<$ https://www.ibge.gov.br/geociencias/informacoes-ambientais/estudos-ambientais/15842biomas.html? $=\& \mathrm{t}=$ publicacoes $>$. Acesso em: 23 jun. 2021.

INSTITUTO BRASILEIRO DE GEOGRAFIA E ESTATÍSTICA (Brasil). Brasil em síntese: Território. Disponível em: < $\underline{\text { https://brasilemsintese.ibge.gov.br/territorio.html }>\text { Acesso em: }}$ 16 set. 2020 .

INSTITUTO BRASILEIRO DE GEOGRAFIA E ESTATÍSTICA (Brasil). In: Comissão Nacional de Classificação - CNAE. IBGE, 2019. Disponível em: $<\underline{\text { https://cnae.ibge.gov.br. }>}$ Acesso em: 02 fev. 2019.

INSTITUTO BRASILEIRO DE GEOGRAFIA E ESTATÍSTICA (Brasil). Monitoramento da cobertura e uso da terra do Brasil 2016 - 2018. Rio de Janeiro: IBGE, 2020. Disponível em: <https://biblioteca.ibge.gov.br/ visualizacao/livros/liv101703.pdf $>$ Acesso em: 16 set. 2020 .

INSTITUTO CHICO MENDES - ICMBio (Brasil). Avaliação das Gestão das unidades de conservação: método RAPPAM (2015) e SAMGE (2016). Ministério do Meio Ambiente. Brasília. MMA-ICMBio, 2017. Disponível em: <www.icmbio.gov.br>. Acesso em: 20 ago. 2018.

INSTITUTO DO HOMEM E MEIO AMBIENTE DA AMAZÔNIA (Brasil). Empreender com a floresta em pé. IMAZON, 2020. Disponível em: $<$ https://imazon.org.br/imprensa/empreender-com-a-floresta-em-pe/>. Acesso em: 16 out. 2020. 
INSTITUTO NACIONAL DE PESQUISAS ESPACIAIS (Brasil). PRODES: Monitoramento do Desmatamento da Floresta Amazônica Brasileira por Satélite. INPE, 2020a. Disponível em: $<$ http://www.inpe.br/noticias/noticia.php?Cod_Noticia=5465>. Acesso em: 21 nov. 2020.

INSTITUTO NACIONAL DE PESQUISAS ESPACIAIS (Brasil). Programa de Monitoramento ambiental. INPE, 2020b. Disponível em: $<$ http://terrabrasilis.dpi.inpe.br/app/dashboard/deforestation/biomes/amazon/increments $>$.

Acesso em: 02 out. 2020.

LEISMANN, E. L.; CARMONA, C. U. M. Sustentabilidade Financeira das Instituições de Microfinanças Brasileiras: Análise das Cooperativas de Crédito Singulares. Revista de Economia e Sociologia Rural, Piracicaba, SP, vol. 48, no 4, p. 635-672, out/dez 2010 Impressa em março, 2011. Disponível em: <https://dx.doi.org/10.1590/S0103$20032010000400007>$. Acesso em: 22 jan. 2019.

MACHADO, D.; Mello, G. R. Análise da Solvência das Cooperativas de Crédito Rural do Sistema Cresol. II Congresso Nacional de Pesquisa em Ciências Sociais Aplicadas - II CONAPE Francisco Beltrão/PR, 02, 03 e 04 de outubro de 2013.

MACIEL et al. The "Chico Mendes" extractive reserve and land governance in the Amazon: Some lessons from the two last decades. Journal of Environmental Management 223 (2018) 403-408. 2018. Elsevier Ltd. All rights reserved. DOI: $<$ https://doi.org/10.1016/j.jenvman.2018.06.064>. Acesso em: 10 dez. 2019.

MANUAL PHP. Versão Online 2020. Organizador Achour, Mehdi. Editado por Cowbur, Peter. PHP Documentation Group. Disponível em: $<$ https://www.php.net/manual/pt BR/copyright.php. $>$. Acessado em: 20 dez. 2020.

MEADOWS, D. H. The Limits to Growth. A report for the Club of Rome's project on the predicament of mankind., $1972 . \quad$ Disponível em: < http://www.clubderoma.net/memorias/cecor memoria 2002anexos.pdf $>$. Acesso em: 01 fev. 2019.

MEDEIROS, R.; YOUNG; C. E. F.; PAVESE, H. B. ARAÚJO, F. F. S. Contribuição das unidades de conservação brasileiras para a economia nacional: Sumário Executivo. Brasília: UNEP-WCMC, 44p., 2011. Disponível em: $<$ https://www.icmbio.gov.br/portal/images/stories/comunicacao/estudocontribuicao.pdf.> Acesso em: 05 set. 2020.

MEMORIAL CHICO MENDES. Reservas Extrativistas. 2018. Disponível em: $<$ http://memorialchicomendes.org/reservas-extrativistas $>$. Acesso em: 01.jan.2018.

MENEGÁRIO, A. H. Emprego de Indicadores socioeconômicos na avaliação financeira de cooperativas agropecuárias. Dissertação (Mestrado em Ciências) - Escola Superior de Agricultura "Luiz de Queiroz", Universidade de São Paulo, Piracicaba, 2000. Disponível em: $<$ www.teses.usp.br>. Acesso em: 21 abr. 2018. 
MEYER, R. Track Record of Financial Institutions in Assisting the Poor in Asia. ADB Institute Research Paper Series, n. 49. December 2002. Disponível em:

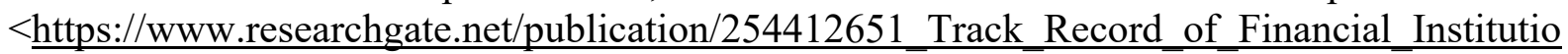
ns in Assisting the Poor in Asia.> Acesso em: 16 nov. 2020.

MINISTÉRIO DO MEIO AMBIENTE (Brasil). Investimentos Mínimos para Conservação. MMA， 2020. Disponível em: <https://www.mma.gov.br/areas-protegidas/unidades-deconservacao/sistema-nacional-de-ucs-snuc/sustentabilidade-financeira/investimentosminimos-para-conservacao.html. $>$ Acesso em: 02 nov. 2020.

MINISTÉRIO DO MEIO AMBIENTE (Brasil). CNUC - Cadastro Nacional de Unidades de Conservação, Painel das Unidades de Conservação Brasileiras. MMA, 2019. Última atualização Disponível em: $<$ https://app.powerbi.com/view?r=eyJrIjoiMjUxMTU0NWMtODkyNC00NzNiLWJiNTQtN GI3NTI2NjliZDkzIiwidCI6IjM5NTdhMzY3LTZkMzgtNGMxZi1hNGJhLTMzZThmM2M1 NTBlNyJ9>. Acesso em: 05 set. 2020.

MINISTÉRIO DO MEIO AMBIENTE (Brasil). Áreas Prioritárias para Conservação, Utilização Sustentável e Repartição dos Benefícios da Biodiversidade da Amazônia. 2 ${ }^{\mathrm{a}}$ Atualização. MMA, 2018. Disponível em: $<$ http://areasprioritarias.mma.gov.br $>$. Acesso em: 05 set. 2020.

MINISTÉRIO DO MEIO AMBIENTE (Brasil). Avaliação e identificação de áreas e ações prioritárias para a conservação, utilização sustentável e repartição dos benefícios da biodiversidade nos biomas brasileiros. Brasília: SBF/MMA, 2002. 404 p.

MINISTÉRIO DO MEIO AMBIENTE (Brasil). Biomas/Amazônia. MMA, 2019. Disponível em: $<$ http://www.mma.gov.br/biomas/amazônia $>$. Acesso em: 02 fev. 2019.

MINISTÉRIO DO MEIO AMBIENTE (Brasil). Cadastro Nacional de Unidades de Conservação - CNUC. MMA, 2021. Disponível em: <https://antigo.mma.gov.br/areasprotegidas/cadastro-nacional-de-ucs.html>. Acesso em: 01 jun. 2021.

MINISTÉRIO DO MEIO AMBIENTE (Brasil). Fortalecimento comunitário em unidade de conservação: desafios, avanços e lições aprendidas no Programa Áreas Protegidas da Amazônia (ARPA) [recurso eletrônico] / Ministério do Meio Ambiente, Secretaria de Biodiversidade, Programa Áreas Protegidas da Amazônia. - Brasília, DF: MMA, 2018. Disponível em: $<$ http://www.mma.gov.br/publicacoes-mma $>$. Acesso em: 23 ago. 2020.

MINISTÉRIO DO MEIO AMBIENTE (Brasil). Pilares para a Sustentabilidade Financeira do Sistema Nacional de Unidades de Conservação. Secretaria de Biodiversidade e Florestas. Departamento de Áreas Protegidas. Brasília: SBF/MMA, 2009. 72p. (Áreas Protegidas do Brasil, 7).

MINISTÉRIO DO MEIO AMBIENTE (Brasil). Responsabilidade Socioambiental / Agenda 21. MMA, 2019. Disponível em: <https://antigo.mma.gov.br/responsabilidadesocioambiental/agenda-21/agenda-21-global.html>. Acesso em: 9 mar.2019. 
MINISTÉRIO DO MEIO AMBIENTE (Brasil). Sistema Nacional de Unidades de Conservação. MMA, 2020. Disponível em: <https://www.mma.gov.br/areasprotegidas/unidades-de-conservacao/sistema-nacional-de-ucs-snuc.html > . Acesso em: 05 set. 2020.

MINISTÉRIO DO MEIO AMBIENTE (Brasil). Sustentabilidade Financeira. MMA, 2020. Disponível em: $\quad<$ https://www.mma.gov.br/areas-protegidas/unidades-deconservacao/sistema-nacional-de-ucs-snuc/sustentabilidade-financeira.html $>$. Acesso em: 05 set. 2020.

MINISTÉRIO DO MEIO AMBIENTE (Brasil). Unidades de Conservação. MMA, 2020. Disponível em: <https://www.mma.gov.br/areas-protegidas/unidades-de-conservacao.html $>$. Acesso em: 05 set. 2020.

MINISTÉRIO DO MEIO AMBIENTE (Brasil). Uso e Cobertura da Terra na Floresta amazônica. Subprojeto 106/2004, MMA-PROBIO, 2004. Disponível em: $<\underline{\text { http://mapas.mma.gov.br/geodados/brasil/vegetacao/vegetacao2002/amazonia/documentos/r }}$ elatorio final.pdf $>$. acesso em: 24 jun. 2021.

MORETTIN, P. A., \& BUSSAB, W. O. Estatística básica. São Paulo: Editora Saraiva, 2002.

MOROZINI, J. F., OLINQUEVITCH, J. L., e HEIN, N. Seleção de índices na análise de balanços: uma aplicação da técnica estatística 'ACP'. Revista Contabilidade \& Finanças, 17(41), 87-99, 2006. Disponível em: <www.revistas.usp.br>. Acesso em: 04 abr. 2018.

NAÇÕES UNIDAS BRASIL (Brasil). A ONU e o Meio Ambiente. ONU-Brasil, 2020. Disponível em: $<$ https://brasil.un.org/pt-br/91223-onu-e-o-meio-ambiente>. Acesso em: 02 dez. 2020.

NAÇÕES UNIDAS BRASIL (Brasil). Transformando Nosso Mundo: A Agenda 2030 para o Desenvolvimento Sustentável. ONU, 2015. Disponível em: $<$ https://nacoesunidas486780792.wpcomstaging.com/pos2015/agenda2030/>. Acesso em: 10 jan. 2019.

NAVES, C. F. B. A sustentabilidade financeira das cooperativas de crédito rural: um estudo de caso no estado de São Paulo. 2207. 145 f. Dissertação (Mestrado) - Faculdade de Economia, Administração e Contabilidade de Ribeirão Preto, Universidade de São Paulo, Ribeirão Preto, 2007. Disponível em: <www.teses.usp.br.>. Acesso em: 04 abr. 2019.

NORIEGA, Carlos Enrique López. Desenvolvimento de um programa computacional para avaliação postural de código aberto e gratuito. 2012. Tese de Doutorado. Universidade de São Paulo. Disponível em: <www.teses.usp.br.>. Acesso em: 02 mar. 2021.

OLIVEIRA, G. Developing Ecological and Enviromental Macromodels. Tese de Doutorado, Faculdade de Economia, Administração e Contabilidade, Universidade de São Paulo, São Paulo, 2016. Disponível em: <www.teses.usp.br. $>$. Acesso em: 24 out. 2018. 
OLIVEIRA, L. D. Os "Limites do Crescimento" 40 Anos Depois. Revista Continentes, (1), 72-96, 2012.

ORGANIZAÇÃO DAS COOPERATIVAS BRASILEIRAS (Brasil). O que é cooperativismo. OCB, 2020. Disponível em: $<$ https://www.ocb.org.br/o-que-ecooperativismo>. Acesso em: 02 nov. 2020.

PASCUCHI, P. M. Fundamentos jurídicos da zona de amortecimento em terra indígena. Manaus: UEA, 2007; Dissertação de Mestrado do Programa de Pós-Graduação em Direito Ambiental, Universidade do Estado do Amazonas, 2007.

PAWLOWSKI, A. How many dimensions does sustainable development have? Sustainable development, 16(2), 81-90, 2008.

PROJETO DE MAPEAMENTO ANUAL DO USO E COBERTURA DA TERRA NO BRASIL (MAPBIOMAS). Coleção 5.0 da Série Anual de Mapas de Cobertura e Uso de Solo do Brasil. MAPBIOMAS, 2019. Disponível em: $<$ https://plataforma.brasil.mapbiomas.org $>$. Acesso em: 22 jun. 2021.

RELATÓRIO ANUAL DE DESMATAMENTO. 2019 - São Paulo, SP - MapBiomas, 2020 - 49 páginas. Disponível em: http://alerta.mapbiomas.org . Acesso em: 01 dez. 2020.

RELATÓRIO BRUNDTLAND: Nosso Futuro Comum. 1987. Disponível em: https://documents-ddsny.un.org/doc/UNDOC/GEN/N87/184/67/IMG/N8718467.pdf?OpenElement. Acesso em: 02 set. 2020.

RIVAS, A; MOTA, J. A.; MACHADO, J. A. DA C. (organizadores). Instrumentos econômicos para a proteção da Amazônia: a experiência do Polo Industrial de Manaus. $1^{\mathrm{a}}$. ed. Curitiba: Editora CRV, 2009. Co-Editora: PIATAM. Disponível em:

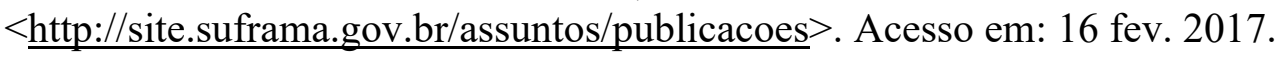

ROSS, S. A.; WESTERFIELD, R. W.; JORDAN, B. D.; LAMB, R. Fundamentos de administraçãa financeira [recurso eletrônico]. Tradução: Leonardo Zilio, Rafaela Guimarães Barbosa. - 9. ed. - Dados eletrônicos. Porto Alegre: AMGH, 2013.

SABADIN, A. L., HOELTGEBAUM, M., E SILVEIRA, A. Tendências de desempenho das cooperativas do estado do Paraná, Brasil, segundo a análise de indicadores contábeis. In Anais do Congresso Brasileiro de Custos-ABC, Curitiba - Paraná, Brasil, 2008.

SACHS, I. Estratégias de transição para o século XXI: desenvolvimento e meio ambiente. Studio Nobel, Fundação do Desenvolvimento Administrativo, 1993.

SACHS, I. Caminhos para o Desenvolvimento Sustentável. 2 ed. Rio de Janeiro: Garamond, 2002.

SACHS, I. Desenvolvimento: includente, sustentável, sustentado. Rio de Janeiro: Garamond, 2008. 
SANTOS, M. E. Desenvolvimento Sustentável e o fornecimento de produtos da biodiversidade nas comunidades tradicionais da Amazônia. (Tese de Doutorado) Faculdade de Economia, Administração e Contabilidade de Ribeirão Preto, Universidade de São Paulo. Ribeirão Preto, 2019. Disponível em: <www.teses.usp.br.>. Acesso em: 20 nov. 2020.

SAVITZ, A. W.; WEBER, K. A empresa sustentável: o verdadeiro sucesso é o lucro com responsabilidade social e ambiental. Rio de Janeiro: Elsevier, 2007.

SECRETARIA DE ESTADO DO MEIO AMBIENTE DO AMAZONAS-SEMA (Amazonas). CENTRO ESTADUAL DE UNIDADES DE CONSERVAÇÃO-CEUC. Plano de Gestão da Reserva Extrativista do Rio Gregório. Volumes I e II. Manaus - Amazonas: SEMA/CEUC, 2010.

SECRETARIA DE ESTADO DO MEIO AMBIENTE DO AMAZONAS-SEMA (Amazonas). CENTRO ESTADUAL DE UNIDADES DE CONSERVAÇÃO-CEUC. Plano de Gestão de Unidades de Conservação do Apuí - Resex Guariba. Volumes I e II. Apuí Amazonas: SEMA/CEUC, 2010.

SECRETARIA DE ESTADO DO MEIO AMBIENTE DO AMAZONAS-SEMA (Amazonas). CENTRO ESTADUAL DE UNIDADES DE CONSERVAÇÃO-CEUC. Plano de Gestão da Reserva Extrativista Catuá-Ipixuna. Volumes I e II. Tefé, Coari - Amazonas: SEMA/CEUC, 2010.

SECRETARIA DE ESTADO DO MEIO AMBIENTE DO AMAZONAS-SEMA (Amazonas). CENTRO ESTADUAL DE UNIDADES DE CONSERVAÇÃO-CEUC. Plano de Gestão da Reserva Extrativista Canutama. Volumes I e II. Canutama - Amazonas: SEMA/CEUC, 2014.

SILVA, Gimima B. M. da. Guardiões da Floresta: Retóricas e formas de controle da gestão ambiental e territorial. Rio de Janeiro: Letra Capital, 2015.

SUPERINTENDÊNCIA DO DESENVOLVIMENTO DA AMAZÔNIA-SUDAM (Brasil). Plano Regional de Desenvolvimento da Amazônia (PRDA): 2020-2023 / Superintendência do Desenvolvimento da Amazônia. - $1^{\mathrm{a}}$ ed. amp. - Belém: SUDAM, 2020. 235. Disponível em: $\quad<$ http://repositorio.sudam.gov.br/sudam/prda/publicacoes-institucionais/prda-20202023.pdf/view>. Acesso em: 23 jun. 2021.

UNIÃO INTERNACIONAL PARA CONSERVAÇÃO DA NATUREZA - UICN. Reservas Extrativistas. Editores: Julio Ruiz Murrieta e Manuel Pinzón Rueda. UICN, 1995; Glad, Suíça e Cambridge, Reino Unido. Disponível em: < $\underline{\text { https://www.iucn.org/content/extractive- }}$ reserves-0>. Acesso em: 22 ago. 2020.

UNITED NATIONS CONFERENCE ON TRADE AND DEVELOPMENT - UNCTAD. United Nations Conference on Trade and Development - Trade and Biodiversity Conservation. - Trade and Biodiversity Conservation. United Nations publication issued by the United Nations Conference on Trade and Development. UNCTAD: New York and Geneva, 2017. Disponível em: $<$ https://www.sipotra.it/wpcontent/uploads/2018/04/Trade-and-biodiversity-conservation.pdf>. Acesso em: 14 dez. 2020. 
UNITED NATIONS CONFERENCE ON TRADE AND DEVELOPMENT - UNCTAD. The business of biotrade: using biological resources sustainably and responsibly. Copyright (C) United Nations, UNCTAD, 2014. Disponível em: $<$ https://unctad.org/system/files/official-document/ditcbcc20094 en.pdf > Acesso em: 26 out. 2020.

UNITED NATIONS - UN. The future is now: science for achieving sustainable development. Global Sustainable Development Report. UN, 2019. United Nations publication issued by the Department of Economic and Social Affairs. Disponível em:

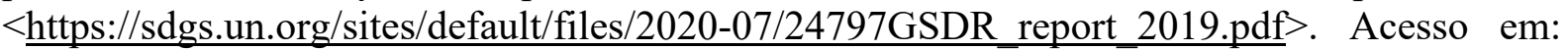
02 set. 2020.

UNITED NATIONS - UN. United Nations Conference on Sustainable Development, Rio+20. Rio de Janeiro, UN: Brazil. 20-22. June, 2012. Disponível em: $<$ https://sustainabledevelopment.un.org/rio20>. Acesso em: 02 dez. 2020.

UNIVERSIDADE DE SÃO PAULO -USP. Agência USP de Gestão da Informação Acadêmica. Diretrizes para apresentação de dissertações e teses da USP: parte I (ABNT). Vânia Martins Bueno de Oliveira Funaro, coordenadora; Vânia Martins Bueno de Oliveira Funaro [et al.]. 4. ed. - São Paulo: AGUIA, 2020. 76p.: il. (Cadernos de estudos; 9). Disponível em $\quad<$ https://web.icmc.usp.br/SCATUSU/Normalizacao/ Diretrizes ABNT 2020.pdf.> Acesso em: 27 ago. 2020.

VAN BELLEN, H. M. Desenvolvimento sustentável: uma descrição das principais ferramentas de avaliação. Ambiente \& Sociedade, 7(1), 67-88, 2004.

VIANA, C. L.; VACCARO, G. L. R.; VENZKE, C. S. Sustentabilidade e os diferenciais Cooperativos: Um estudo em um Sistema Cooperativo de Crédito. Revista de Gestão e Organizações Cooperativas - RGC. Santa Maria, v.5, n.9, Págs. 163-180, Jan./Jun. 2018. DOI: $10.5902 / 2359043230627$.

WORLDWIDE FUND FOR NATURE - WWF. The Impact of the ARPA Program on the Management Effectiveness of Amazon Protected Areas. WWF, 2017. Disponível em: < https://wwfbr.awsassets.panda.org/downloads/wwf folder ingles paginas 2.pdf $>$. Acesso em: 31 out. 2020.

YIN, Robert K. Estudo de caso: planejamento e métodos. 2. ed. Porto Alegre: Bookman, 2001.

YIN, Robert K. Pesquisa Qualitativa do Início ao Fim. E-PUB [recurso eletrônico]. Porto Alegre: Editora Penso, 2016.

YOUNG, C. E. F.; MEDEIROS, R. (Organizadores). Quanto vale o verde: a importância econômica das unidades de conservação brasileiras. Rio de Janeiro: Conservação Internacional, 2018. 


\section{Leis e Decretos}

BRASIL. Decreto $\mathrm{n}^{0}$ 6.040, de 07 de fevereiro de 2007. Institui a Política Nacional de Desenvolvimento Sustentável dos Povos e Comunidades Tradicionais. Brasília. 2007. Disponível em: <http://www.planalto.gov.br/ccivil_03/_ato2007-2010/2007/ decreto/d6040.htm>. Acesso em: 17 mar. 2019.

BRASIL. Decreto $n^{0}$ 9.580, de 22 de novembro de 2018. Regulamenta a tributação, a fiscalização, a arrecadação e a administração do Imposto sobre a Renda e Proventos de Qualquer Natureza. Brasília. 2018. Disponível em: $<$ http://www.planalto.gov.br/ccivil_03/_ato2015-2018/2018/decreto/D9580.htm>. Acesso em 06 mai. 2019.

BRASIL. Decreto n ${ }^{\circ}$ 98.897, de 30 de janeiro de 1990. Dispõe sobre as Reservas Extrativistas e dá outras providências. Disponível em: <https://www.planalto.gov.br/ccivil 03/decreto/antigos/d98897.htm>. Acesso em: 25 ago. 2020.

BRASIL. Lei Complementar $n^{\circ}$ 124, de 3 de janeiro de 2007. Institui, na forma do art. 43 da Constituição Federal, a Superintendência do Desenvolvimento da Amazônia - SUDAM; dispõe sobre o Fundo de Desenvolvimento da Amazônia - FDA; altera a Medida Provisória no 2.157-5, de 24 de agosto de 2001; revoga a Lei Complementar no 67/1991; e dá outras providências. $\quad$ Brasília. $2007 . \quad$ Disponível em: $<$ http://www.planalto.gov.br/ccivil_03/leis/lcp/Lcp124.htm>. Acesso em: 17 mar. 2019.

BRASIL. Lei $\mathrm{n}^{\circ}$ 10.406, de 10 de janeiro de 2002. Institui Código Civil. Capítulo II, Artigos 53-61: Das Associações. Disponível em: $<$ http://www.planalto.gov.br/ccivil03/leis/2002/ L10406compilada.htm>. Acesso em: 03 nov. 2020.

BRASIL. Lei $\mathrm{n}^{\mathrm{o}}$ 5.764, de 16 de dezembro de 1971. Define a Política Nacional de Cooperativismo, institui o regime jurídico das sociedades cooperativas, e dá outras providências. Disponível em: <http://www.planalto.gov.br/ccivil 03/Leis/L5764.htm>. Acesso em: 04 out. 2020.

BRASIL. Lei ${ }^{0}$ 6.938, de 31 de agosto de 1981. Dispõe sobre a Política Nacional do Meio Ambiente, seus fins e mecanismos de formulação e aplicação, e dá outras providências. Brasília. 1981. Disponível em: <http://www.planalto.gov.br/ccivil_03/leis/16938.htm>. Acesso em: 17 mar. 2019.

BRASIL. Lei $\mathrm{n}^{\circ}$ 9.008, de 21 de março de 1995. Cria, na estrutura organizacional do Ministério da Justiça, o Conselho Federal Gestor do Fundo de Defesa dos Direitos Difusos CFDD. 1995. Disponível em: < http://www.planalto.gov.br/ccivil_03/leis/19008.htm>. Acesso em: 04 out. 2020.

BRASIL. Lei $n^{\circ}$ 9.985, de 10 de julho de 2000. Regulamenta o artigo 225, $\S 1^{\circ}$, incisos I, II, III e VII da Constituição Federal, institui o Sistema Nacional de Unidades de Conservação da Natureza e dá outras providências. Disponível em: < $\underline{\mathrm{http}}$ ://www.planalto.gov.br/ccivil 03/leis/L9985.htm>. Acesso em: 05 set. 2020. 
AMAZONAS-BRASIL. Decreto $\mathrm{n}^{0}$ 28.421, de 27 de março de 2009. Cria a Reserva Extrativista Canutama, localizada no Município de Canutama e dá outras providências. Disponível em:

https://documentacao.socioambiental.org/ato_normativo/UC/442_20101014_155509.pdf $>$. Acesso em: 05 set. 2020.

O acervo das referências para acesso no Drive da USP. Disponível para acesso pelo link abaixo (Ctrl + clique para seguir o link):

https://drive.google.com/drive/folders/1z-

jVTIgj8jxRwLBVFCNQpJsxMi6LHEgn?usp=sharing 


\section{APÊNDICES}

APÊNDICE A - Produção na Resex Canutama (2019-2020)................................................................. 166

APÊNDICE B - Produtos Vendidos na Resex Canutama (2019-2020) ...................................................... 167

APÊNDICE C - Dados Gerais e Índice de Sustentabilidade das 16 Comunidades.................................... 168

APÊNDICE D - Dados Gerais e Índice de Sustentabilidade das 22 Localidades .................................... 201

APÊNDICE E - Roteiro das Entrevistas de Campo ……...................................................................... 242

APÊNDICE F - Termo de Consentimento Livre e Esclarecido e Pós-Esclarecido ..................................... 244

APÊNDICE G - Acervo Fotográfico da Pesquisa …...................................................................... 245

APÊNDICE H - Instruções para acesso ao SIW Resex Canutama.......................................................... 257 


\section{APÊNDICE A - Produção na Resex Canutama (2019-2020)}

Tabela 16 - Valor e Participação percentual por local de produção na Resex Canutama (20192020)

\begin{tabular}{|c|c|c|c|c|c|}
\hline \multirow{3}{*}{ Local da Produção } & \multicolumn{2}{|c|}{ Produção ano 2019} & \multicolumn{2}{|c|}{ Produção ano 2020} & \multirow{3}{*}{$\begin{array}{c}\text { Cresciment } \\
\text { o } \\
(\%) \\
\end{array}$} \\
\hline & \multicolumn{2}{|c|}{ Valor Participação } & \multicolumn{2}{|c|}{ Valor Participação } & \\
\hline & $(\mathbf{R} \$)$ & $(\%)$ & $(\mathbf{R} \$)$ & $(\%)$ & \\
\hline Comunidade Nova Vista & $831.676,00$ & $27,70 \%$ & $322.203,20$ & $11,02 \%$ & $-61,26 \%$ \\
\hline Comunidade Santa Bárbara & $424.914,00$ & $14,15 \%$ & $184.591,96$ & $6,31 \%$ & $-56,56 \%$ \\
\hline Comunidade Bacadaru & $194.030,00$ & $6,46 \%$ & $241.170,00$ & $8,25 \%$ & $24,30 \%$ \\
\hline Comunidade Fortaleza & $247.877,00$ & $8,25 \%$ & $135.249,00$ & $4,63 \%$ & $-45,44 \%$ \\
\hline Comunidade Açaituba & $232.415,00$ & $7,74 \%$ & $144.893,96$ & $4,96 \%$ & $-37,66 \%$ \\
\hline Localidade Tororó - Paissé & $16.735,00$ & $0,56 \%$ & $230.765,00$ & $7,89 \%$ & $1.278,94 \%$ \\
\hline Comunidade Sacado & $100.936,00$ & $3,36 \%$ & $110.337,64$ & $3,77 \%$ & $9,31 \%$ \\
\hline Localidade Mapiciari & $10.880,00$ & $0,36 \%$ & $200.000,00$ & $6,84 \%$ & $1.738,24 \%$ \\
\hline Comunidade Glória II & $70.755,00$ & $2,36 \%$ & $126.990,00$ & $4,34 \%$ & $79,48 \%$ \\
\hline Comunidade Forte Veneza & $107.200,00$ & $3,57 \%$ & $71.141,00$ & $2,43 \%$ & $-33,64 \%$ \\
\hline Comunidade Irajá & $68.380,00$ & $2,28 \%$ & $94.626,00$ & $3,24 \%$ & $38,38 \%$ \\
\hline Comunidade Santa Maria & $64.701,00$ & $2,15 \%$ & $81.230,00$ & $2,78 \%$ & $25,55 \%$ \\
\hline Localidade Santana & $30.254,00$ & $1,01 \%$ & $110.953,00$ & $3,80 \%$ & $266,74 \%$ \\
\hline Localidade Vista Alegre & $87.085,00$ & $2,90 \%$ & $49.510,00$ & $1,69 \%$ & $-43,15 \%$ \\
\hline Localidade Bom Sucesso & $82.500,00$ & $2,75 \%$ & $52.059,80$ & $1,78 \%$ & $-36,90 \%$ \\
\hline Comunidade Boca do Gavião & $65.162,00$ & $2,17 \%$ & $61.552,92$ & $2,11 \%$ & $-5,54 \%$ \\
\hline Comunidade S. Ant. do Apituã & $54.441,00$ & $1,81 \%$ & $71.041,26$ & $2,43 \%$ & $30,49 \%$ \\
\hline Comunidade Carmo & $61.810,00$ & $2,06 \%$ & $63.169,00$ & $2,16 \%$ & $2,20 \%$ \\
\hline Comunidade São Jerônimo & $51.370,00$ & $1,71 \%$ & $68.042,00$ & $2,33 \%$ & $32,45 \%$ \\
\hline Comunidade São Tomé & $44.760,00$ & $1,49 \%$ & $59.060,00$ & $2,02 \%$ & $31,95 \%$ \\
\hline Comunidade Capoeirinha & $59.705,00$ & $1,99 \%$ & $37.000,00$ & $1,27 \%$ & $-38,03 \%$ \\
\hline Localidade Santa Eugênia & $58.006,00$ & $1,93 \%$ & $35.436,00$ & $1,21 \%$ & $-38,91 \%$ \\
\hline Localidade Santa Cora & $37.360,00$ & $1,24 \%$ & $39.550,00$ & $1,35 \%$ & $5,86 \%$ \\
\hline Localidade Estirão do Açaituba & - & $0,00 \%$ & $71.138,62$ & $2,43 \%$ & $100 \%$ \\
\hline Localidade São Francisco & - & $0,00 \%$ & $49.630,00$ & $1,70 \%$ & $100 \%$ \\
\hline Localidade Moará & - & $0,00 \%$ & $48.396,00$ & $1,66 \%$ & $100 \%$ \\
\hline Localidade Macacoã & - & $0,00 \%$ & $42.800,00$ & $1,46 \%$ & $100 \%$ \\
\hline Localidade Paraíso & - & $0,00 \%$ & $34.830,00$ & $1,19 \%$ & $100 \%$ \\
\hline Localidade Samaumeira & - & $0,00 \%$ & $29.496,00$ & $1,01 \%$ & $100 \%$ \\
\hline Localidade Novo Intento & - & $0,00 \%$ & $27.122,00$ & $0,93 \%$ & $100 \%$ \\
\hline Localidade Nazaré & - & $0,00 \%$ & $19.200,00$ & $0,66 \%$ & $100 \%$ \\
\hline Localidade Monte Sião & - & $0,00 \%$ & $6.080,00$ & $0,21 \%$ & $100 \%$ \\
\hline Localidade Espírito Santo & - & $0,00 \%$ & $3.725,00$ & $0,13 \%$ & $100 \%$ \\
\hline Localidade Arraial & - & $0,00 \%$ & 600,00 & $0,02 \%$ & $100 \%$ \\
\hline Localidade São José do Paraíso & - & $0,00 \%$ & - & $0,00 \%$ & - \\
\hline Localidade Sobradinho & - & $0,00 \%$ & - & $0,00 \%$ & - \\
\hline Localidade Concórdia & - & $0,00 \%$ & - & $0,00 \%$ & - \\
\hline Localidade Conceição-Paissé & - & $0,00 \%$ & - & $0,00 \%$ & - \\
\hline Total & $3.002 .952,00$ & $100 \%$ & $2.923 .589,36$ & $100 \%$ & $2,64 \%$ \\
\hline
\end{tabular}

Fonte: Relatórios Gestão da Resex Canutama - adaptado pela autora. 


\section{APÊNDICE B - Produtos Vendidos na Resex Canutama (2019-2020)}

Tabela 17 - Valor e Participação percentual por produtos na produção da Resex Canutama

(2019-2020)

\begin{tabular}{|c|c|c|c|c|c|}
\hline \multirow{2}{*}{$\begin{array}{l}\text { Produto } \\
\text { (Unidade de Medida) }\end{array}$} & \multicolumn{2}{|c|}{ Produção ano 2019} & \multicolumn{2}{|c|}{ Produção ano 2020} & \multirow{2}{*}{$\begin{array}{c}\text { Cresciment } \\
\text { o } \\
(\%)\end{array}$} \\
\hline & (R\$) & $(\%)$ & (R\$) & $(\%)$ & \\
\hline Castanha (Hectolitro; 100 litros) & $1.006 .250,00$ & $33,51 \%$ & $874.400,00$ & $29,91 \%$ & $-13,10 \%$ \\
\hline Farinha (Saca de 50Kg) & $455.090,00$ & $15,15 \%$ & $496.800,00$ & $16,99 \%$ & $9,17 \%$ \\
\hline Pescado Fresco $(\mathrm{Kg})$ & $309.312,00$ & $10,30 \%$ & $612.900,00$ & $20,96 \%$ & $98,15 \%$ \\
\hline Pescado Seco $(\mathrm{Kg})$ & $307.090,00$ & $10,23 \%$ & $272.364,00$ & $9,32 \%$ & $-11,31 \%$ \\
\hline Porco (Unidade) & $285.600,00$ & $9,51 \%$ & 816,00 & $0,03 \%$ & $-99,71 \%$ \\
\hline Açaí Fruto (Lata 18Kg) & $148.140,00$ & $4,93 \%$ & $147.635,00$ & $5,05 \%$ & $-0,34 \%$ \\
\hline Melancia (Unidade) & $108.650,00$ & $3,62 \%$ & $218.448,00$ & $7,47 \%$ & $101,06 \%$ \\
\hline Carvão Vegetal (Saco 50Kg) & $103.500,00$ & $3,45 \%$ & $13.000,00$ & $0,44 \%$ & $-87,44 \%$ \\
\hline Galinha Caipira (Unidade) & $31.875,00$ & $1,06 \%$ & $4.450,00$ & $0,15 \%$ & $-86,04 \%$ \\
\hline Andiroba semente (Lata $20 \mathrm{Kg}$ ) & $31.570,00$ & $1,05 \%$ & $44.490,00$ & $1,52 \%$ & $40,92 \%$ \\
\hline Feijão $(\mathrm{Kg})$ & $26.605,00$ & $0,89 \%$ & $26.328,00$ & $0,90 \%$ & $-1,04 \%$ \\
\hline Macaxeira (Kg) & $24.420,00$ & $0,81 \%$ & $6.940,00$ & $0,24 \%$ & $-71,58 \%$ \\
\hline Banana (Cacho) & $22.275,00$ & $0,74 \%$ & $67.890,00$ & $2,32 \%$ & $204,78 \%$ \\
\hline Goma da Mandioca (Lata 20Kg) & $20.640,00$ & $0,69 \%$ & - & $0,00 \%$ & $-100,00 \%$ \\
\hline Jerimum (Unidade) & $19.635,00$ & $0,65 \%$ & $4.455,00$ & $0,15 \%$ & $-77,31 \%$ \\
\hline Boi (Unidade) & $19.550,00$ & $0,65 \%$ & - & $0,00 \%$ & $-100,00 \%$ \\
\hline Maxixe $(\mathrm{Kg})$ & $14.100,00$ & $0,47 \%$ & - & $0,00 \%$ & $-100,00 \%$ \\
\hline Melão (Unidade) & $13.250,00$ & $0,44 \%$ & $5.100,00$ & $0,17 \%$ & $-61,51 \%$ \\
\hline Murumuru semente (Lata 20Kg) & $13.200,00$ & $0,44 \%$ & $61.400,36$ & $2,10 \%$ & $365,15 \%$ \\
\hline Açaí Beneficiado (Litro) & $11.480,00$ & $0,38 \%$ & $10.000,00$ & $0,34 \%$ & $-12,89 \%$ \\
\hline Pato (Unidade) & $7.960,00$ & $0,27 \%$ & 330,00 & $0,01 \%$ & $-95,85 \%$ \\
\hline Milho Verde (Mão-50 espigas) & $5.250,00$ & $0,17 \%$ & $8.575,00$ & $0,29 \%$ & $63,33 \%$ \\
\hline Batata-doce $(\mathrm{Kg})$ & $5.160,00$ & $0,17 \%$ & $1.788,00$ & $0,06 \%$ & $-65,35 \%$ \\
\hline Limão (Kg) & $3.000,00$ & $0,10 \%$ & 420,00 & $0,01 \%$ & $-86,00 \%$ \\
\hline Milho Seco (Kg) & $2.850,00$ & $0,09 \%$ & 255,00 & $0,01 \%$ & $-91,05 \%$ \\
\hline Cará $(\mathrm{Kg})$ & $1.900,00$ & $0,06 \%$ & $2.750,00$ & $0,09 \%$ & $44,74 \%$ \\
\hline Pimenta de Cheiro (Kg) & $1.500,00$ & $0,05 \%$ & 520,00 & $0,02 \%$ & $-65,33 \%$ \\
\hline Cebolinha (maço) & $1.410,00$ & $0,05 \%$ & 300,00 & $0,01 \%$ & $-78,72 \%$ \\
\hline Cupuaçu (Kg) & 780,00 & $0,03 \%$ & - & $0,00 \%$ & $-100,00 \%$ \\
\hline Pupunha (Cacho) & 510,00 & $0,02 \%$ & - & $0,00 \%$ & $-100,00 \%$ \\
\hline Farinha Tapioca (Litro) & 400,00 & $0,01 \%$ & - & $0,00 \%$ & $-100,00 \%$ \\
\hline Boi $(\mathrm{Kg})$ & - & $0,00 \%$ & $13.712,00$ & $0,47 \%$ & $100 \%$ \\
\hline Porco $(\mathrm{Kg})$ & - & $0,00 \%$ & $12.160,00$ & $0,42 \%$ & $100 \%$ \\
\hline Copaíba Óleo (Kg) & - & $0,00 \%$ & $7.140,00$ & $0,24 \%$ & $100 \%$ \\
\hline Canoa (Unidade) & - & $0,00 \%$ & $6.000,00$ & $0,21 \%$ & $100 \%$ \\
\hline Remo (Unidade) & - & $0,00 \%$ & $2.000,00$ & $0,07 \%$ & $100 \%$ \\
\hline Tucumã (Dúzia) & - & $0,00 \%$ & 168,00 & $0,01 \%$ & $100 \%$ \\
\hline Andiroba Óleo (Litro) & - & $0,00 \%$ & 55,00 & $0,00 \%$ & $100 \%$ \\
\hline Total & $3.002 .952,00$ & $100 \%$ & 2.923.589,36 & $100 \%$ & $2,64 \%$ \\
\hline
\end{tabular}

Fonte: Relatórios Gestão da Resex Canutama - adaptado pela autora. 


\section{APÊNDICE C - Dados Gerais e Índice de Sustentabilidade das 16 Comunidades}

A apresentação das comunidades está em ordem decrescente de volume de produção do ano de 2019. Todos os dados da produção 2019 e 2020 foram extraídos dos relatórios de gestão da Resex Canutama e adaptados pela autora.

\section{Índice}

Comunidade Nova Vista

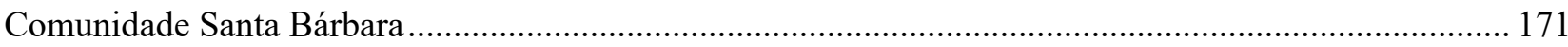

Comunidade Bacadaru ..................................................................................................... 173

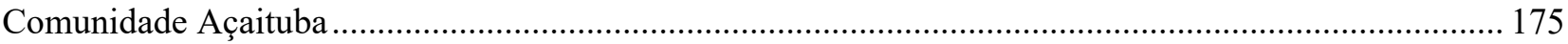

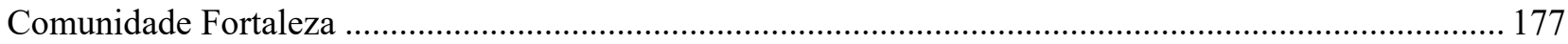

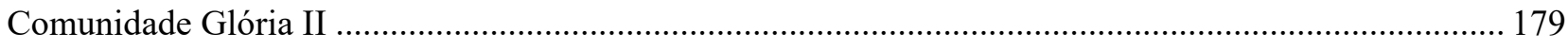

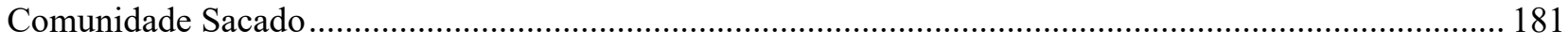

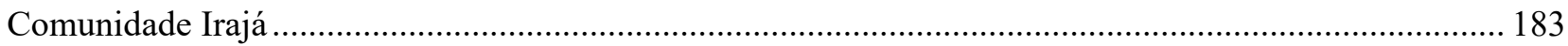

Comunidade Santa Maria .................................................................................................. 185

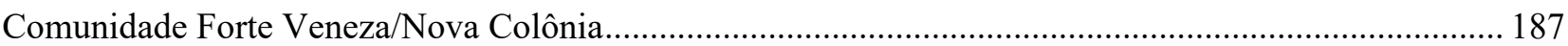

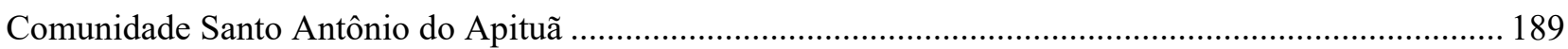

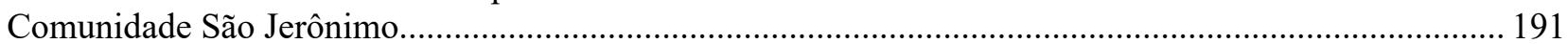

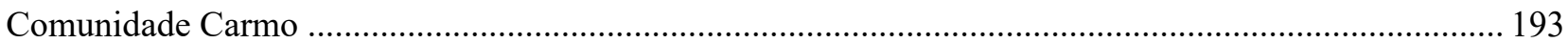

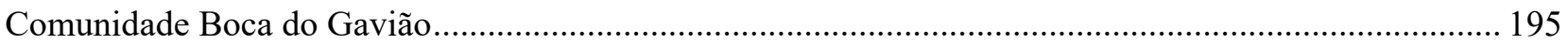

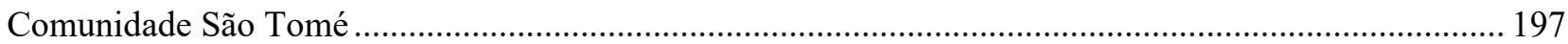

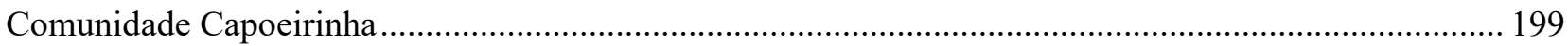




\section{Comunidade Nova Vista}

Quadro 11 - Dados gerais para Avaliação da Comunidade Nova Vista (2019-2020)

\begin{tabular}{|c|c|c|}
\hline Informações & Ano 2019 & Ano 2020 \\
\hline Valor da Produção na Resex Canutama & $\mathrm{R} \$ 3.002 .952,00$ & $\mathrm{R} \$ 2.923 .589,36$ \\
\hline Média da Produção na Resex Canutama & $\mathrm{R} \$ 79.025,05$ & $\mathrm{R} \$ 76.936,56$ \\
\hline $\mathrm{N}^{\mathrm{o}}$ de residentes na Comunidade & 42 & 42 \\
\hline $\mathrm{N}^{\circ}$ de produtos vendidos & 24 & 13 \\
\hline Valor da Produção na Comunidade & $\mathrm{R} \$ 831.676,00$ & $\mathrm{R} \$ 322.203,20$ \\
\hline Produção Per capita da Comunidade & $\mathrm{R} \$ 19.801,81$ & $\mathrm{R} \$ 7.671,50$ \\
\hline $\begin{array}{l}\text { Média do PIB per capita dos municípios de Canutama } \\
\text { e Lábrea* }\end{array}$ & $\mathrm{R} \$ 8.953,67$ & $\mathrm{R} \$ 8.953,67$ \\
\hline
\end{tabular}

(*) Média com base no ano de 2018: PIB per capita de Lábrea (R\$ 10.941,94) e PIB per capita de Canutama (R \$ $6.965,40)$ - Último ano divulgado conforme dados do IBGE.

Tabela 18 - Sustentabilidade Financeira da Comunidade Nova Vista (2019-2020)

\section{Parâmetros Avaliados}

[A comunidade possui...]

\begin{tabular}{|c|c|c|c|}
\hline \multicolumn{2}{|c|}{ Avaliação 2019} & \multicolumn{2}{|c|}{ Avaliação 2020} \\
\hline $\begin{array}{c}\text { Referência } \\
\text { (1 ou 0) }\end{array}$ & $\begin{array}{c}\text { Resultado } \\
(\%) \\
\end{array}$ & $\begin{array}{c}\text { Referência } \\
\text { (1 ou 0) }\end{array}$ & $\begin{array}{c}\text { Resultado } \\
(\%) \\
\end{array}$ \\
\hline 1 & $9,09091 \%$ & 1 & $9,0909 \%$ \\
\hline 1 & $9,09091 \%$ & 1 & $9,0909 \%$ \\
\hline 1 & $9,09091 \%$ & 1 & $9,0909 \%$ \\
\hline 1 & $9,09091 \%$ & 0 & $0,0000 \%$ \\
\hline 1 & $9,09091 \%$ & 1 & $9,0909 \%$ \\
\hline 0 & $0,00000 \%$ & 1 & $9,0909 \%$ \\
\hline 0 & $0,00000 \%$ & 0 & $0,0000 \%$ \\
\hline 0 & $0,00000 \%$ & 0 & $0,0000 \%$ \\
\hline 0 & $0,00000 \%$ & 0 & $0,0000 \%$ \\
\hline 0 & $0,00000 \%$ & 0 & $0,0000 \%$ \\
\hline 1 & $9,09091 \%$ & 1 & $9,0909 \%$ \\
\hline 6 & $54,60 \%$ & 6 & $54,60 \%$ \\
\hline
\end{tabular}

(1) Líder comunitário com perfil empreendedor

(2) Controle de castanhal e exploração de castanhal

(3) $\mathrm{N}^{\circ}$ mínimo de residentes $\geq 30$ pessoas

(4) Produção per capita da comunidade $\geq$ média do PIB per capita dos municípios Canutama e Lábrea

(5) Produção na Comunidade $\geq$ média da produção total na Resex Canutama

(6) Produção diversificada e contendo o produto potencial 'Farinha' com produção $\geq 10 \%$

(7) Produção diversificada e contendo o produto potencial 'Peixe Fresco' com produção $\geq 10 \%$

(8) Produção diversificada e contendo o produto potencial 'Peixe Seco' com produção $\geq 10 \%$

(9) Produção diversificada e contendo o produto potencial 'Porco' com produção $\geq 10 \%$

(10) Produção diversificada e contendo o produto potencial 'Açaí' com produção $\geq 10 \%$

(11) Produção diversificada e contendo o produto potencial 'Castanha' com produção $\geq 10 \%$

Índice de Sustentabilidade Financeira (resultado arredondado)

Legenda: Na Coluna [Resultado]

Legenda: Na Coluna [Referência]

[1] Sim, a comunidade atende o parâmetro

[0] Não, a comunidade não atende o parâmetro

Fonte: Elaborado pela autora.
[1] Avaliação positiva gera um percentual de 9,09091\%

[0] Avaliação negativa gera percentual de $0,0000 \%$ 
Tabela 19 - Produção na Comunidade Nova Vista (2019)

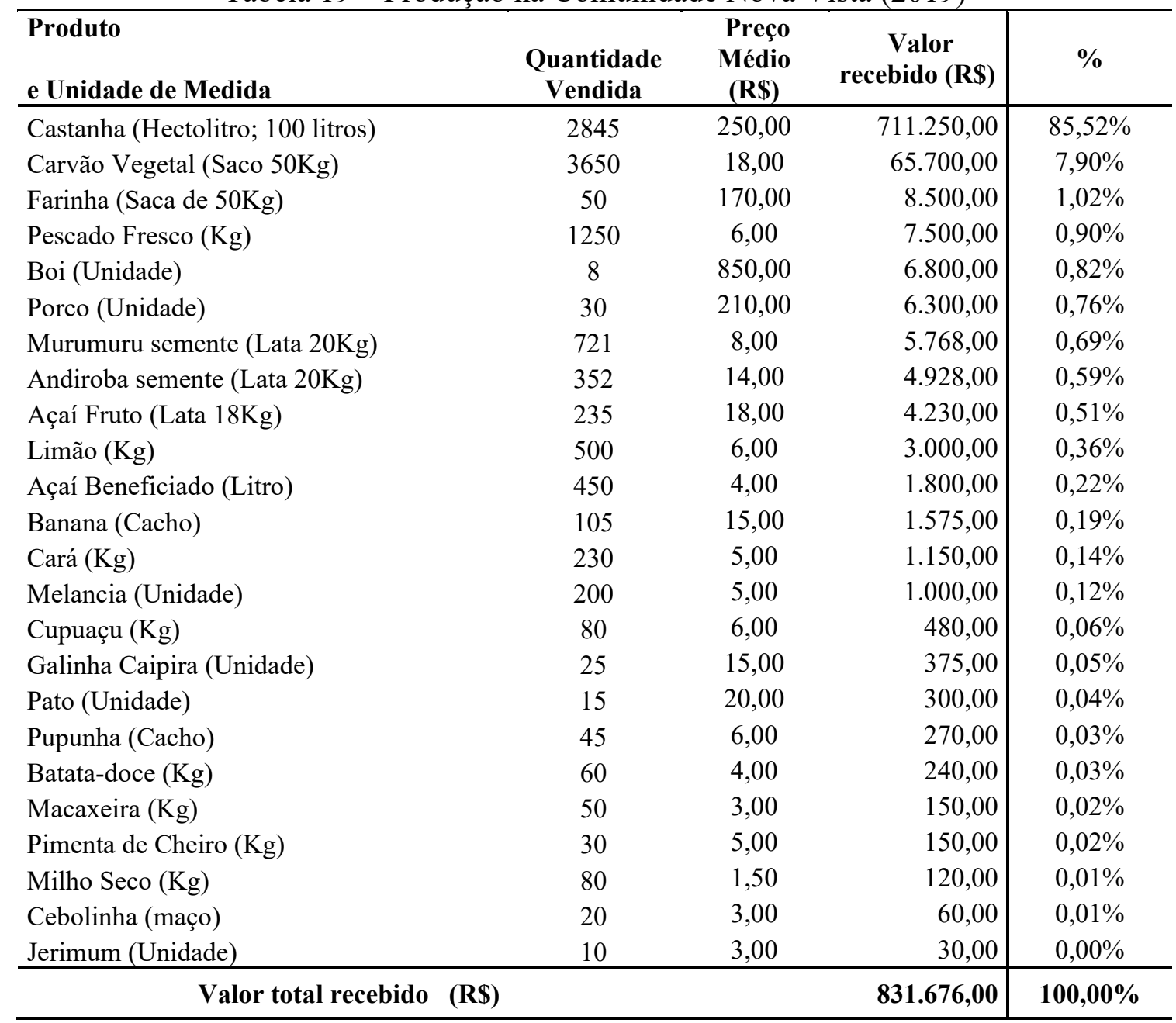

Tabela 20 - Produção na Comunidade Nova Vista (2020)

\begin{tabular}{|c|c|c|c|c|}
\hline $\begin{array}{l}\text { Produto } \\
\text { e Unidade de Medida }\end{array}$ & $\begin{array}{c}\text { Quantidade } \\
\text { Vendida }\end{array}$ & $\begin{array}{l}\text { Preço } \\
\text { Médio } \\
\text { (R\$) }\end{array}$ & $\begin{array}{c}\text { Valor } \\
\text { recebido (RS) }\end{array}$ & $\%$ \\
\hline Castanha (Hectolitro; 100 litros) & 1.035 & 200,00 & $207.000,00$ & $64,25 \%$ \\
\hline Farinha (Saca de $50 \mathrm{Kg})$ & 221 & 200,00 & $44.200,00$ & $13,72 \%$ \\
\hline Pescado Fresco $(\mathrm{Kg})$ & 4.000 & 5,00 & $20.000,00$ & $6,21 \%$ \\
\hline Carvão Vegetal (Saco 50Kg) & 650 & 20,00 & $13.000,00$ & $4,03 \%$ \\
\hline Murumuru semente (Lata $20 \mathrm{Kg}$ ) & 860 & 14,42 & $12.401,20$ & $3,85 \%$ \\
\hline Pescado Seco $(\mathrm{Kg})$ & 1.750 & 6,00 & $10.500,00$ & $3,26 \%$ \\
\hline Andiroba semente (Lata $20 \mathrm{Kg}$ ) & 778 & 10,00 & $7.780,00$ & $2,41 \%$ \\
\hline Copaíba Óleo (Kg) & 150 & 35,00 & $5.250,00$ & $1,63 \%$ \\
\hline Banana (Cacho) & 30 & 30,00 & 900,00 & $0,28 \%$ \\
\hline Melancia (Unidade) & 100 & 8,00 & 800,00 & $0,25 \%$ \\
\hline Feijão (Kg) & 40 & 6,00 & 240,00 & $0,07 \%$ \\
\hline Batata-doce (Kg) & 18 & 4,00 & 72,00 & $0,02 \%$ \\
\hline Melão (Unidade) & 10 & 6,00 & 60,00 & $0,02 \%$ \\
\hline Valor total recebido (R\$) & & & $322.203,20$ & $100,00 \%$ \\
\hline
\end{tabular}




\section{Comunidade Santa Bárbara}

Quadro 12 - Dados gerais para Avaliação da Comunidade Santa Bárbara (2019-2020)

\begin{tabular}{|c|c|c|}
\hline Informações & Ano 2019 & Ano 2020 \\
\hline Valor da Produção na Resex Canutama & $\mathrm{R} \$ 3.002 .952,00$ & $\mathrm{R} \$ 2.923 .589,36$ \\
\hline Média da Produção na Resex Canutama & $\mathrm{R} \$ 79.025,05$ & $R \$ 76.936,56$ \\
\hline $\mathrm{N}^{\circ}$ de residentes na Comunidade & 52 & 52 \\
\hline $\mathrm{N}^{\circ}$ de produtos vendidos & 14 & 15 \\
\hline Valor da Produção na Comunidade & $\mathrm{R} \$ 8.171,42$ & $\mathrm{R} \$ 3.549,85$ \\
\hline Produção Per capita da Comunidade & $\mathrm{R} \$ 424.914,00$ & $\mathrm{R} \$ 184.591,96$ \\
\hline $\begin{array}{l}\text { Média do PIB per capita dos municípios de Canutama } \\
\text { e Lábrea* }\end{array}$ & $\mathrm{R} \$ 8.953,67$ & $\mathrm{R} \$ 8.953,67$ \\
\hline
\end{tabular}

(*) Média com base no ano de 2018: PIB per capita de Lábrea (R \$ 10.941,94) e PIB per capita de Canutama (R\$ $6.965,40)$ - Último ano divulgado conforme dados do IBGE.

Tabela 21 - Sustentabilidade Financeira da Comunidade Santa Bárbara (2019-2020)

\begin{tabular}{|c|c|c|c|c|}
\hline \multirow[b]{2}{*}{$\begin{array}{l}\text { Parâmetros Avaliados } \\
\text { [A comunidade possui...] }\end{array}$} & \multicolumn{2}{|c|}{ Avaliação 2019} & \multicolumn{2}{|c|}{ Avaliação 2020} \\
\hline & $\begin{array}{c}\text { Referência } \\
\text { (1 ou 0) }\end{array}$ & $\begin{array}{c}\text { Resultado } \\
(\%)\end{array}$ & $\begin{array}{c}\text { Referência } \\
\text { (1 ou 0) }\end{array}$ & $\begin{array}{c}\text { Resultado } \\
(\%) \\
\end{array}$ \\
\hline (1) Líder comunitário com perfil empreendedor & 1 & $9,09091 \%$ & 1 & $9,0909 \%$ \\
\hline (2) Controle de castanhal e exploração de castanhal & 0 & $0,00000 \%$ & 0 & $0,0000 \%$ \\
\hline (3) $\mathrm{N}^{\circ}$ mínimo de residentes $\geq 30$ pessoas & 1 & $9,09091 \%$ & 1 & $9,0909 \%$ \\
\hline $\begin{array}{l}\text { (4) Produção per capita da comunidade } \geq \text { média do PIB } \\
\text { per capita dos municípios Canutama e Lábrea }\end{array}$ & 0 & $0,00000 \%$ & 0 & $0,0000 \%$ \\
\hline $\begin{array}{l}\text { (5) Produção na Comunidade } \geq \text { média da produção total } \\
\text { na Resex Canutama }\end{array}$ & 1 & $9,09091 \%$ & 1 & $9,0909 \%$ \\
\hline $\begin{array}{l}\text { (6) Produção diversificada e contendo o produto potencial } \\
\text { 'Farinha' com produção } \geq 10 \%\end{array}$ & 1 & $9,09091 \%$ & 1 & $9,0909 \%$ \\
\hline $\begin{array}{l}\text { (7) Produção diversificada e contendo o produto potencial } \\
\text { 'Peixe Fresco' com produção } \geq 10 \%\end{array}$ & 0 & $0,00000 \%$ & 1 & $9,0909 \%$ \\
\hline $\begin{array}{l}\text { (8) Produção diversificada e contendo o produto potencial } \\
\text { 'Peixe Seco' com produção } \geq 10 \%\end{array}$ & 1 & $9,09091 \%$ & 0 & $0,0000 \%$ \\
\hline $\begin{array}{l}\text { (9) Produção diversificada e contendo o produto potencial } \\
\text { 'Porco' com produção } \geq 10 \%\end{array}$ & 1 & $9,09091 \%$ & 0 & $0,0000 \%$ \\
\hline $\begin{array}{l}\text { (10) Produção diversificada e contendo o produto } \\
\text { potencial 'Açaí' com produção } \geq 10 \%\end{array}$ & 0 & $0,00000 \%$ & 0 & $0,0000 \%$ \\
\hline $\begin{array}{l}\text { (11) Produção diversificada e contendo o produto } \\
\text { potencial 'Castanha' com produção } \geq 10 \%\end{array}$ & 0 & $0,00000 \%$ & 1 & $9,0909 \%$ \\
\hline $\begin{array}{l}\text { Índice de Sustentabilidade Financeira } \\
\text { (resultado arredondado) }\end{array}$ & 6 & $54,60 \%$ & 6 & $54,60 \%$ \\
\hline $\begin{array}{l}\text { Legenda: Na Coluna [Referência] } \\
\text { [1] Sim, a comunidade atende o parâmetro } \\
\text { [0] Não, a comunidade não atende o parâmetro } \\
\text { Fonte: Elaborado pela autora. }\end{array}$ & [1] Avaliação & Cariva & $\begin{array}{l}\text { do] } \\
\text { n percen }\end{array}$ & $\begin{array}{l}9,09091 \% \\
0000 \%\end{array}$ \\
\hline
\end{tabular}


Tabela 22 - Produção na Comunidade Santa Bárbara (2019)

\begin{tabular}{lccc|c}
\hline Produto & Preço & $\begin{array}{c}\text { Valor } \\
\text { Quantidade } \\
\text { Vendida }\end{array}$ & $\begin{array}{c}\text { Médio } \\
\text { (R\$) }\end{array}$ & $\begin{array}{c}\text { (R\$) } \\
\text { e Unidade de Medida }\end{array}$ \\
\hline Porco (Unidade) & 1000 & 210,00 & $210.000,00$ & $49,42 \%$ \\
Farinha (Saca de 50Kg) & 500 & 170,00 & $85.000,00$ & $20,00 \%$ \\
Pescado Seco (Kg) & 8000 & 7,00 & $56.000,00$ & $13,18 \%$ \\
Pescado Fresco (Kg) & 5000 & 6,00 & $30.000,00$ & $7,06 \%$ \\
Castanha (Hectolitro; 100 litros) & 120 & 250,00 & $30.000,00$ & $7,06 \%$ \\
Galinha Caipira (Unidade) & 500 & 15,00 & $7.500,00$ & $1,77 \%$ \\
Açaí Beneficiado (Litro) & 500 & 4,00 & $2.000,00$ & $0,47 \%$ \\
Melancia (Unidade) & 200 & 5,00 & $1.000,00$ & $0,24 \%$ \\
Jerimum (Unidade) & 300 & 3,00 & 900,00 & $0,21 \%$ \\
Murumuru semente (Lata 20Kg) & 108 & 8,00 & 864,00 & $0,20 \%$ \\
Melão (Unidade) & 100 & 5,00 & 500,00 & $0,12 \%$ \\
Feijão (Kg) & 100 & 5,00 & 500,00 & $0,12 \%$ \\
Maxixe (Kg) & 70 & 5,00 & 350,00 & $0,08 \%$ \\
Macaxeira (Kg) & 100 & 3,00 & 300,00 & $0,07 \%$ \\
\hline Valor total recebido (R\$) & & & $\mathbf{4 2 4 . 9 1 4 , 0 0}$ & $\mathbf{1 0 0 , 0 0 \%}$ \\
\hline
\end{tabular}

Tabela 23 - Produção na Comunidade Santa Bárbara (2020)

\begin{tabular}{|c|c|c|c|c|}
\hline e Unidade de Medida & $\begin{array}{c}\text { Quantidade } \\
\text { Vendida }\end{array}$ & $\begin{array}{c}\text { Preço } \\
\text { Médio } \\
\text { (R\$) }\end{array}$ & $\begin{array}{c}\text { Valor } \\
\text { recebido } \\
\text { (R\$) }\end{array}$ & $\%$ \\
\hline Farinha (Saca de $50 \mathrm{Kg}$ ) & 159 & 200,00 & $31.800,00$ & $17,23 \%$ \\
\hline Pescado Fresco (Kg) & 6.000 & 5,00 & $30.000,00$ & $16,25 \%$ \\
\hline Melancia (Unidade) & 3.553 & 8,00 & $28.424,00$ & $15,40 \%$ \\
\hline Murumuru semente (Lata $20 \mathrm{Kg}$ ) & 1.688 & 14,42 & $24.340,96$ & $13,19 \%$ \\
\hline Castanha (Hectolitro; 100 litros) & 96 & 200,00 & $19.200,00$ & $10,40 \%$ \\
\hline Andiroba semente (Lata $20 \mathrm{Kg}$ ) & 1.817 & 10,00 & $18.170,00$ & $9,84 \%$ \\
\hline Pescado Seco (Kg) & 3.000 & 6,00 & $18.000,00$ & $9,75 \%$ \\
\hline Açaí Fruto (Lata 18Kg) & 1.000 & 5,00 & $5.000,00$ & $2,71 \%$ \\
\hline Açaí Beneficiado (Litro) & 1.000 & 5,00 & $5.000,00$ & $2,71 \%$ \\
\hline Porco $(\mathrm{Kg})$ & 410 & 10,00 & $4.100,00$ & $2,22 \%$ \\
\hline Feijão (Kg) & 50 & 6,00 & 300,00 & $0,16 \%$ \\
\hline Batata-doce (Kg) & 25 & 4,00 & 100,00 & $0,05 \%$ \\
\hline Melão (Unidade) & 12 & 6,00 & 72,00 & $0,04 \%$ \\
\hline Andiroba Óleo (Litro) & 1 & 55,00 & 55,00 & $0,03 \%$ \\
\hline Porco (Unidade) & 5 & 6,00 & 30,00 & $0,02 \%$ \\
\hline Valor total recebido (R\$) & & & $184.591,96$ & $100,00 \%$ \\
\hline
\end{tabular}




\section{Comunidade Bacadaru}

Quadro 13 - Dados gerais para Avaliação da Comunidade Bacadaru (2019-2020)

\begin{tabular}{|c|c|c|}
\hline Informações & Ano 2019 & Ano 2020 \\
\hline Valor da Produção na Resex Canutama & $\mathrm{R} \$ 3.002 .952,00$ & $\mathrm{R} \$ 2.923 .589,36$ \\
\hline Média da Produção na Resex Canutama & $\mathrm{R} \$ 79.025,05$ & $\mathrm{R} \$ 76.936,56$ \\
\hline $\mathrm{N}^{o}$ de residentes na Comunidade & 56 & 56 \\
\hline $\mathrm{N}^{\circ}$ de produtos vendidos & 23 & 23 \\
\hline Valor da Produção na Comunidade & $\mathrm{R} \$ 194.030,00$ & $\mathrm{R} \$ 241.170,00$ \\
\hline Produção Per capita da Comunidade & $\mathrm{R} \$ 3.464,82$ & $\mathrm{R} \$ 4.306,61$ \\
\hline $\begin{array}{l}\text { Média do PIB per capita dos municípios de Canutama } \\
\text { e Lábrea* }\end{array}$ & $\mathrm{R} \$ 8.953,67$ & $\mathrm{R} \$ 8.953,67$ \\
\hline
\end{tabular}

(*) Média com base no ano de 2018: PIB per capita de Lábrea (R\$ 10.941,94) e PIB per capita de Canutama (R\$ $6.965,40)$ - Último ano divulgado conforme dados do IBGE.

Tabela 24 - Sustentabilidade Financeira da Comunidade Bacadaru (2019-2020)

\begin{tabular}{|c|c|c|c|c|}
\hline \multirow{2}{*}{$\begin{array}{l}\text { Parâmetros Avaliados } \\
\text { [A comunidade possui....] }\end{array}$} & \multicolumn{2}{|c|}{ Avaliação 2019} & \multicolumn{2}{|c|}{ Avaliação 2020} \\
\hline & $\begin{array}{c}\text { Referência } \\
\text { (1 ou 0) }\end{array}$ & $\begin{array}{c}\text { Resultado } \\
(\%)\end{array}$ & $\begin{array}{l}\text { Referência } \\
\text { (1 ou 0) }\end{array}$ & $\begin{array}{c}\text { Resultado } \\
(\%)\end{array}$ \\
\hline (1) Líder comunitário com perfil empreendedor & 0 & $0,00000 \%$ & 0 & $0,0000 \%$ \\
\hline (2) Controle de castanhal e exploração de castanhal & 0 & $0,00000 \%$ & 0 & $0,0000 \%$ \\
\hline (3) $\mathrm{N}^{\circ}$ mínimo de residentes $\geq 30$ pessoas & 0 & $0,00000 \%$ & 0 & $0,0000 \%$ \\
\hline $\begin{array}{l}\text { (4) Produção per capita da comunidade } \geq \text { média do PIB } \\
\text { per capita dos municípios Canutama e Lábrea }\end{array}$ & 1 & $9,09091 \%$ & 1 & $9,0909 \%$ \\
\hline $\begin{array}{l}\text { (5) Produção na Comunidade } \geq \text { média da produção total } \\
\text { na Resex Canutama }\end{array}$ & 1 & $9,09091 \%$ & 1 & $9,0909 \%$ \\
\hline $\begin{array}{l}\text { (6) Produção diversificada e contendo o produto } \\
\text { potencial 'Farinha' com produção } \geq 10 \%\end{array}$ & 0 & $0,00000 \%$ & 0 & $0,0000 \%$ \\
\hline $\begin{array}{l}\text { (7) Produção diversificada e contendo o produto } \\
\text { potencial 'Peixe Fresco' com produção } \geq 10 \%\end{array}$ & 0 & $0,00000 \%$ & 1 & $9,0909 \%$ \\
\hline $\begin{array}{l}\text { (8) Produção diversificada e contendo o produto } \\
\text { potencial 'Peixe Seco' com produção } \geq 10 \%\end{array}$ & 0 & $0,00000 \%$ & 0 & $0,0000 \%$ \\
\hline $\begin{array}{l}\text { (9) Produção diversificada e contendo o produto } \\
\text { potencial 'Porco' com produção } \geq 10 \%\end{array}$ & 0 & $0,00000 \%$ & 0 & $0,0000 \%$ \\
\hline $\begin{array}{l}\text { (10) Produção diversificada e contendo o produto } \\
\text { potencial 'Açaí' com produção } \geq 10 \%\end{array}$ & 1 & $9,09091 \%$ & 1 & $9,0909 \%$ \\
\hline $\begin{array}{l}\text { (11) Produção diversificada e contendo o produto } \\
\text { potencial 'Castanha' com produção } \geq 10 \%\end{array}$ & 1 & $9,09091 \%$ & 0 & $0,0000 \%$ \\
\hline $\begin{array}{l}\text { Índice de Sustentabilidade Financeira } \\
\text { (resultado arredondado) }\end{array}$ & 4 & $36,4 \%$ & 4 & $36,4 \%$ \\
\hline $\begin{array}{l}\text { Legenda: Na Coluna [Referência] } \\
\text { [1] Sim, a comunidade atende o parâmetro } \\
\text { [0] Não, a comunidade não atende o parâmetro }\end{array}$ & $\begin{array}{l}\text { 1] Avaliação } \\
, 09091 \% \\
\text { 0] Avaliação 1 }\end{array}$ & $\begin{array}{l}\text { oluna [Resu } \\
\text { positiva } \\
\text { negativa ger }\end{array}$ & $\begin{array}{l}\text { tado] } \\
\text { pera um pe } \\
\text { percentual de }\end{array}$ & $\begin{array}{l}\text { centual de } \\
0,0000 \%\end{array}$ \\
\hline
\end{tabular}

Fonte: Elaborado pela autora. 
Tabela 25 - Produção na Comunidade Bacadaru (2019)

\begin{tabular}{|c|c|c|c|c|}
\hline $\begin{array}{l}\text { Produto } \\
\text { e Unidade de Medida }\end{array}$ & $\begin{array}{c}\text { Quantidade } \\
\text { Vendida } \\
\end{array}$ & $\begin{array}{c}\text { Preço } \\
\text { Médio } \\
\text { (R\$) }\end{array}$ & $\begin{array}{c}\text { Valor } \\
\text { recebido (R\$) }\end{array}$ & $\%$ \\
\hline Castanha (Hectolitro; 100 litros) & 254 & 250,00 & $63.500,00$ & $32,73 \%$ \\
\hline Pescado Seco $(\mathrm{Kg})$ & 8000 & 7,00 & $56.000,00$ & $28,86 \%$ \\
\hline Farinha (Saca de $50 \mathrm{Kg}$ ) & 125 & 170,00 & $21.250,00$ & $10,95 \%$ \\
\hline Pescado Fresco $(\mathrm{Kg})$ & 2000 & 6,00 & $12.000,00$ & $6,18 \%$ \\
\hline Goma da Mandioca (Lata 20Kg) & 123 & 80,00 & $9.840,00$ & $5,07 \%$ \\
\hline Banana (Cacho) & 520 & 15,00 & $7.800,00$ & $4,02 \%$ \\
\hline Melancia (Unidade) & 1500 & 5,00 & $7.500,00$ & $3,87 \%$ \\
\hline Melão (Unidade) & 530 & 5,00 & $2.650,00$ & $1,37 \%$ \\
\hline Galinha Caipira (Unidade) & 150 & 15,00 & $2.250,00$ & $1,16 \%$ \\
\hline Milho Verde (Mão-50 espigas) & 80 & 25,00 & $2.000,00$ & $1,03 \%$ \\
\hline Feijão $(\mathrm{Kg})$ & 250 & 5,00 & $1.250,00$ & $0,64 \%$ \\
\hline Pimenta de Cheiro (Kg) & 220 & 5,00 & $1.100,00$ & $0,57 \%$ \\
\hline Cebolinha (Maço) & 350 & 3,00 & $1.050,00$ & $0,54 \%$ \\
\hline Pato (Unidade) & 50 & 20,00 & $1.000,00$ & $0,52 \%$ \\
\hline Maxixe (Kg) & 200 & 5,00 & $1.000,00$ & $0,52 \%$ \\
\hline Jerimum (Unidade) & 320 & 3,00 & 960,00 & $0,49 \%$ \\
\hline Macaxeira $(\mathrm{Kg})$ & 310 & 3,00 & 930,00 & $0,48 \%$ \\
\hline Cará $(\mathrm{Kg})$ & 150 & 5,00 & 750,00 & $0,39 \%$ \\
\hline Batata-doce (Kg) & 150 & 4,00 & 600,00 & $0,31 \%$ \\
\hline Farinha Tapioca (Litro) & 80 & 5,00 & 400,00 & $0,21 \%$ \\
\hline Açaí Beneficiado (Litro) & 50 & 4,00 & 200,00 & $0,10 \%$ \\
\hline Valor total recebido (R\$) & & & $194.030,00$ & $100,00 \%$ \\
\hline
\end{tabular}

Tabela 26 - Produção na Comunidade Bacadaru (2020)

\begin{tabular}{|c|c|c|c|c|}
\hline $\begin{array}{l}\text { Produto } \\
\text { e Unidade de Medida }\end{array}$ & $\begin{array}{l}\text { Quantidade } \\
\text { Vendida }\end{array}$ & $\begin{array}{l}\text { Preço } \\
\text { Médio } \\
\text { (R\$) }\end{array}$ & $\begin{array}{c}\text { Valor } \\
\text { recebido (RS) }\end{array}$ & $\%$ \\
\hline \multirow{2}{*}{$\begin{array}{l}\text { Farinha (Saca de } 50 \mathrm{Kg}) \\
\text { Castanha (Hectolitro; } 100 \text { litros) }\end{array}$} & 350 & 200,00 & $70.000,00$ & $29,03 \%$ \\
\hline & 350 & 200,00 & $70.000,00$ & $29,03 \%$ \\
\hline Pescado Fresco $(\mathrm{Kg})$ & 10.560 & 5,00 & $52.800,00$ & $21,89 \%$ \\
\hline Melancia (Unidade) & 2.080 & 8,00 & $16.640,00$ & $6,90 \%$ \\
\hline Pescado Seco (Kg) & 2.000 & 6,00 & $12.000,00$ & $4,98 \%$ \\
\hline Açaí Beneficiado (Litro) & 1.000 & 5,00 & $5.000,00$ & $2,07 \%$ \\
\hline Porco $(\mathrm{Kg})$ & 400 & 10,00 & $4.000,00$ & $1,66 \%$ \\
\hline Feijão (Kg) & 460 & 6,00 & $2.760,00$ & $1,14 \%$ \\
\hline Banana (Cacho) & 80 & 30,00 & $2.400,00$ & $1,00 \%$ \\
\hline Jerimum (Unidade) & 280 & 5,00 & $1.400,00$ & $0,58 \%$ \\
\hline Macaxeira $(\mathrm{Kg})$ & 200 & 4,00 & 800,00 & $0,33 \%$ \\
\hline Cará $(\mathrm{Kg})$ & 150 & 5,00 & 750,00 & $0,31 \%$ \\
\hline Açaí Fruto (Lata 18Kg) & 50 & 15,00 & 750,00 & $0,31 \%$ \\
\hline Pimenta de Cheiro (Kg) & 130 & 4,00 & 520,00 & $0,22 \%$ \\
\hline Cebolinha (maço) & 100 & 3,00 & 300,00 & $0,12 \%$ \\
\hline Melão (Unidade) & 40 & 6,00 & 240,00 & $0,10 \%$ \\
\hline Galinha Caipira (Unidade) & 8 & 25,00 & 200,00 & $0,08 \%$ \\
\hline Batata-doce $(\mathrm{Kg})$ & 48 & 4,00 & 192,00 & $0,08 \%$ \\
\hline Tucumã (Dúzia) & 42 & 4,00 & 168,00 & $0,07 \%$ \\
\hline Limão (Kg) & 20 & 6,00 & 120,00 & $0,05 \%$ \\
\hline \multirow{2}{*}{$\begin{array}{l}\text { Milho Verde (Mão-50 espigas) } \\
\text { Porco (Unidade) }\end{array}$} & 2 & 25,00 & 50,00 & $0,02 \%$ \\
\hline & 8 & 6,00 & 48,00 & $0,02 \%$ \\
\hline Boi $(\mathrm{Kg})$ & 2 & 16,00 & 32,00 & $0,01 \%$ \\
\hline \multicolumn{3}{|l|}{ Valor total recebido $(\mathrm{R} \$)$} & $241.170,00$ & $100,00 \%$ \\
\hline
\end{tabular}




\section{Comunidade Açaituba}

Quadro 14 - Dados gerais para Avaliação da Comunidade Açaituba (2019-2020)

\begin{tabular}{|c|c|c|}
\hline Informações & Ano 2019 & Ano 2020 \\
\hline Valor da Produção na Resex Canutama & $\mathrm{R} \$ 3.002 .952,00$ & $\mathrm{R} \$ 2.923 .589,36$ \\
\hline Média da Produção na Resex Canutama & $\mathrm{R} \$ 79.025,05$ & $R \$ 76.936,56$ \\
\hline $\mathrm{N}^{\circ}$ de residentes na Comunidade & 16 & 16 \\
\hline $\mathrm{N}^{\circ}$ de produtos vendidos & 15 & 12 \\
\hline Valor da Produção na Comunidade & $\mathrm{R} \$ 232.415,00$ & $\mathrm{R} \$ 144.893,96$ \\
\hline Produção Per capita da Comunidade & $\mathrm{R} \$ 14.525,94$ & $\mathrm{R} \$ 9.055,87$ \\
\hline $\begin{array}{l}\text { Média do PIB per capita dos municípios de Canutama } \\
\text { e Lábrea* }\end{array}$ & $\mathrm{R} \$ 8.953,67$ & $\mathrm{R} \$ 8.953,67$ \\
\hline
\end{tabular}

(*) Média com base no ano de 2018: PIB per capita de Lábrea (R\$10.941,94) e PIB per capita de Canutama (R\$ $6.965,40)$ - Último ano divulgado conforme dados do IBGE.

Tabela 27 - Sustentabilidade Financeira da Comunidade Açaituba (2019-2020)

\begin{tabular}{|c|c|c|c|c|}
\hline \multirow[b]{2}{*}{$\begin{array}{l}\text { Parâmetros Avaliados } \\
\text { [A comunidade possui...] }\end{array}$} & \multicolumn{2}{|c|}{ Avaliação 2019} & \multicolumn{2}{|c|}{ Avaliação 2020} \\
\hline & $\begin{array}{c}\text { Referência } \\
\text { (1 ou 0) }\end{array}$ & $\begin{array}{c}\text { Resultado } \\
(\%)\end{array}$ & $\begin{array}{l}\text { Referência } \\
\text { (1 ou 0) }\end{array}$ & $\begin{array}{c}\text { Resultado } \\
(\%)\end{array}$ \\
\hline (1) Líder comunitário com perfil empreendedor & 0 & $0,00000 \%$ & 0 & $0,0000 \%$ \\
\hline (2) Controle de castanhal e exploração de castanhal & 0 & $0,00000 \%$ & 0 & $0,0000 \%$ \\
\hline (3) $\mathrm{N}^{\circ}$ mínimo de residentes $\geq 30$ pessoas & 0 & $0,00000 \%$ & 0 & $0,0000 \%$ \\
\hline $\begin{array}{l}\text { (4) Produção per capita da comunidade } \geq \text { média do PIB } \\
\text { per capita dos municípios Canutama e Lábrea }\end{array}$ & 1 & $9,09091 \%$ & 1 & $9,0909 \%$ \\
\hline $\begin{array}{l}\text { (5) Produção na Comunidade } \geq \text { média da produção total } \\
\text { na Resex Canutama }\end{array}$ & 1 & $9,09091 \%$ & 1 & $9,0909 \%$ \\
\hline $\begin{array}{l}\text { (6) Produção diversificada e contendo o produto potencial } \\
\text { 'Farinha' com produção } \geq 10 \%\end{array}$ & 0 & $0,00000 \%$ & 0 & $0,0000 \%$ \\
\hline $\begin{array}{l}\text { (7) Produção diversificada e contendo o produto potencial } \\
\text { 'Peixe Fresco' com produção } \geq 10 \%\end{array}$ & 0 & $0,00000 \%$ & 1 & $9,0909 \%$ \\
\hline $\begin{array}{l}\text { (8) Produção diversificada e contendo o produto potencial } \\
\text { 'Peixe Seco' com produção } \geq 10 \%\end{array}$ & 0 & $0,00000 \%$ & 0 & $0,0000 \%$ \\
\hline $\begin{array}{l}\text { (9) Produção diversificada e contendo o produto potencial } \\
\text { 'Porco' com produção } \geq 10 \%\end{array}$ & 0 & $0,00000 \%$ & 0 & $0,0000 \%$ \\
\hline $\begin{array}{l}\text { (10) Produção diversificada e contendo o produto } \\
\text { potencial 'Açaí' com produção } \geq 10 \%\end{array}$ & 1 & $9,09091 \%$ & 1 & $9,0909 \%$ \\
\hline $\begin{array}{l}\text { (11) Produção diversificada e contendo o produto } \\
\text { potencial 'Castanha' com produção } \geq 10 \%\end{array}$ & 1 & $9,09091 \%$ & 0 & $0,0000 \%$ \\
\hline $\begin{array}{l}\text { Índice de Sustentabilidade Financeira } \\
\text { (resultado arredondado) }\end{array}$ & 4 & $36,4 \%$ & 4 & $36,4 \%$ \\
\hline $\begin{array}{l}\text { Legenda: Na Coluna [Referência] } \\
\text { [1] Sim, a comunidade atende o parâmetro } \\
\text { [0] Não, a comunidade não atende o parâmetro }\end{array}$ & 1] Avaliação 1 & $\begin{array}{l}\text { luna [Resul } \\
\text { ositiva gera } \\
\text { egativa gera }\end{array}$ & $\begin{array}{l}\text { do] } \\
\text { a percentual } \\
\text { ercentual de } 0\end{array}$ & $\begin{array}{l}9,09091 \% \\
0000 \%\end{array}$ \\
\hline
\end{tabular}

Fonte: Elaborado pela autora. 
Tabela 28 - Produção na Comunidade Açaituba (2019)

\begin{tabular}{|c|c|c|c|c|}
\hline $\begin{array}{l}\text { Produto } \\
\text { e Unidade de Medida } \\
\end{array}$ & $\begin{array}{c}\text { Quantidade } \\
\text { Vendida } \\
\end{array}$ & $\begin{array}{l}\text { Preço } \\
\text { Médio } \\
\text { (R\$) }\end{array}$ & $\begin{array}{l}\text { Valor } \\
\text { recebido } \\
(\mathbf{R} \$)\end{array}$ & $\%$ \\
\hline Açaí Fruto (Lata 18Kg) & 6495 & 18,00 & $116.910,00$ & $50,30 \%$ \\
\hline Castanha (Hectolitro; 100 litros) & 100 & 250,00 & $25.000,00$ & $10,76 \%$ \\
\hline Melancia (Unidade) & 5000 & 5,00 & $25.000,00$ & $10,76 \%$ \\
\hline Farinha (Saca de $50 \mathrm{Kg})$ & 120 & 170,00 & $20.400,00$ & $8,78 \%$ \\
\hline Boi (Unidade) & 15 & 850,00 & $12.750,00$ & $5,49 \%$ \\
\hline Pescado Fresco (Kg) & 2000 & 6,00 & $12.000,00$ & $5,16 \%$ \\
\hline Pescado Seco (Kg) & 1000 & 7,00 & $7.000,00$ & $3,01 \%$ \\
\hline Feijão $(\mathrm{Kg})$ & 1000 & 5,00 & $5.000,00$ & $2,15 \%$ \\
\hline Murumuru semente (Lata 20Kg) & 510 & 8,00 & $4.080,00$ & $1,76 \%$ \\
\hline Macaxeira $(\mathrm{Kg})$ & 600 & 3,00 & $1.800,00$ & $0,77 \%$ \\
\hline Galinha Caipira (Unidade) & 80 & 15,00 & $1.200,00$ & $0,52 \%$ \\
\hline Maxixe $(\mathrm{Kg})$ & 100 & 5,00 & 500,00 & $0,22 \%$ \\
\hline Açaí Beneficiado (Litro) & 100 & 4,00 & 400,00 & $0,17 \%$ \\
\hline Banana (Cacho) & 15 & 15,00 & 225,00 & $0,10 \%$ \\
\hline Melão (Unidade) & 30 & 5,00 & 150,00 & $0,06 \%$ \\
\hline Valor total recebido (R\$) & & & $232.415,00$ & $100,00 \%$ \\
\hline \multicolumn{5}{|c|}{ Tabela 29 - Produção na Comunidade Açaituba (2020) } \\
\hline $\begin{array}{l}\text { Produto } \\
\text { e Unidade de Medida }\end{array}$ & $\begin{array}{c}\text { Quantidade } \\
\text { Vendida }\end{array}$ & $\begin{array}{l}\text { Preço } \\
\text { Médio } \\
\text { (R\$) }\end{array}$ & $\begin{array}{c}\text { Valor } \\
\text { recebido } \\
(\mathbf{R} \$) \\
\end{array}$ & $\%$ \\
\hline Açaí Fruto (Lata 18Kg) & 4.000 & 15,00 & $60.000,00$ & $41,41 \%$ \\
\hline Melancia (Unidade) & 4.500 & 8,00 & $36.000,00$ & $24,85 \%$ \\
\hline Pescado Fresco (Kg) & 3.000 & 5,00 & $15.000,00$ & $10,35 \%$ \\
\hline Pescado Seco $(\mathrm{Kg})$ & 2.000 & 6,00 & $12.000,00$ & $8,28 \%$ \\
\hline Castanha (Hectolitro; 100 litros) & 30 & 200,00 & $6.000,00$ & $4,14 \%$ \\
\hline Macaxeira $(\mathrm{Kg})$ & 1.500 & 4,00 & $6.000,00$ & $4,14 \%$ \\
\hline Murumuru semente (Lata 20Kg) & 338 & 14,42 & $4.873,96$ & $3,36 \%$ \\
\hline Farinha (Saca de $50 \mathrm{Kg})$ & 20 & 200,00 & $4.000,00$ & $2,76 \%$ \\
\hline Melão (Unidade) & 60 & 6,00 & 360,00 & $0,25 \%$ \\
\hline Galinha Caipira (Unidade) & 10 & 25,00 & 250,00 & $0,17 \%$ \\
\hline Feijão (Kg) & 35 & 6,00 & 210,00 & $0,14 \%$ \\
\hline Batata-doce $(\mathrm{Kg})$ & 50 & 4,00 & 200,00 & $0,14 \%$ \\
\hline Valor total recebido (RS) & & & $144.893,96$ & $100,00 \%$ \\
\hline
\end{tabular}




\section{Comunidade Fortaleza}

Quadro 15 - Dados gerais para Avaliação da Comunidade Fortaleza (2019-2020)

\begin{tabular}{|c|c|c|}
\hline Informações & Ano 2019 & Ano 2020 \\
\hline Valor da Produção na Resex Canutama & $\mathrm{R} \$ 3.002 .952,00$ & $\mathrm{R} \$ 2.923 .589,36$ \\
\hline Média da Produção na Resex Canutama & $\mathrm{R} \$ 79.025,05$ & $\mathrm{R} \$ 76.936,56$ \\
\hline $\mathrm{N}^{\mathrm{o}}$ de residentes na Comunidade & 46 & 46 \\
\hline $\mathrm{N}^{\circ}$ de produtos vendidos & 18 & 18 \\
\hline Valor da Produção na Comunidade & $\mathrm{R} \$ 247.877,00$ & $\mathrm{R} \$ 135.249,00$ \\
\hline Produção Per capita da Comunidade & $\mathrm{R} \$ 5.388,63$ & $\mathrm{R} \$ 2.840,20$ \\
\hline $\begin{array}{l}\text { Média do PIB per capita dos municípios de Canutama } \\
\text { e Lábrea* }\end{array}$ & $\mathrm{R} \$ 8.953,67$ & $\mathrm{R} \$ 8.953,67$ \\
\hline
\end{tabular}

(*) Média com base no ano de 2018: PIB per capita de Lábrea (R \$ 10.941,94) e PIB per capita de Canutama (R\$ $6.965,40)$ - Último ano divulgado conforme dados do IBGE.

Tabela 30 - Sustentabilidade Financeira da Comunidade Fortaleza (2019-2020)

\begin{tabular}{|c|c|c|c|c|}
\hline \multirow{2}{*}{$\begin{array}{l}\text { Parâmetros Avaliados } \\
\text { [A comunidade possui...] }\end{array}$} & \multicolumn{2}{|c|}{ Avaliação 2019} & \multicolumn{2}{|c|}{ Avaliação 2020} \\
\hline & $\begin{array}{l}\text { Referência } \\
\text { (1 ou 0) }\end{array}$ & $\begin{array}{c}\text { Resultado } \\
(\%)\end{array}$ & $\begin{array}{l}\text { Referência } \\
\text { (1 ou 0) }\end{array}$ & $\begin{array}{c}\text { Resultado } \\
(\%)\end{array}$ \\
\hline (1) Líder comunitário com perfil empreendedor & 0 & $0,00000 \%$ & 0 & $0,0000 \%$ \\
\hline (2) Controle de castanhal e exploração de castanhal & 0 & $0,00000 \%$ & 0 & $0,0000 \%$ \\
\hline (3) $\mathrm{N}^{\circ}$ mínimo de residentes $\geq 30$ pessoas & 1 & $9,09091 \%$ & 1 & $9,0909 \%$ \\
\hline $\begin{array}{l}\text { (4) Produção per capita da comunidade } \geq \text { média do PIB } \\
\text { per capita dos municípios Canutama e Lábrea }\end{array}$ & 0 & $0,00000 \%$ & 0 & $0,0000 \%$ \\
\hline $\begin{array}{l}\text { (5) Produção na Comunidade } \geq \text { média da produção total } \\
\text { na Resex Canutama }\end{array}$ & 1 & $9,09091 \%$ & 1 & $9,0909 \%$ \\
\hline $\begin{array}{l}\text { (6) Produção diversificada e contendo o produto } \\
\text { potencial 'Farinha' com produção } \geq 10 \%\end{array}$ & 1 & $9,09091 \%$ & 1 & $9,0909 \%$ \\
\hline $\begin{array}{l}\text { (7) Produção diversificada e contendo o produto } \\
\text { potencial 'Peixe Fresco' com produção } \geq 10 \%\end{array}$ & 1 & $9,09091 \%$ & 0 & $0,0000 \%$ \\
\hline $\begin{array}{l}\text { (8) Produção diversificada e contendo o produto } \\
\text { potencial 'Peixe Seco' com produção } \geq 10 \%\end{array}$ & 1 & $9,09091 \%$ & 0 & $0,0000 \%$ \\
\hline $\begin{array}{l}\text { (9) Produção diversificada e contendo o produto } \\
\text { potencial 'Porco' com produção } \geq 10 \%\end{array}$ & 0 & $0,00000 \%$ & 0 & $0,0000 \%$ \\
\hline $\begin{array}{l}\text { (10) Produção diversificada e contendo o produto } \\
\text { potencial 'Açaí' com produção } \geq 10 \%\end{array}$ & 0 & $0,00000 \%$ & 0 & $0,0000 \%$ \\
\hline $\begin{array}{l}\text { (11) Produção diversificada e contendo o produto } \\
\text { potencial 'Castanha' com produção } \geq 10 \%\end{array}$ & 0 & $0,00000 \%$ & 1 & $9,0909 \%$ \\
\hline $\begin{array}{l}\text { Índice de Sustentabilidade Financeira } \\
\text { (resultado arredondado) }\end{array}$ & 5 & $45,5 \%$ & 4 & $36,4 \%$ \\
\hline
\end{tabular}

Legenda: Na Coluna [Referência]

[1] Sim, a comunidade atende o parâmetro

[0] Não, a comunidade não atende o parâmetro

Fonte: Elaborado pela autora.
Legenda: Na Coluna [Resultado]

[1] Avaliação positiva gera um percentual de 9,09091\%

[0] Avaliação negativa gera percentual de $0,0000 \%$ 
Tabela 31 - Produção na Comunidade Fortaleza (2019)

\begin{tabular}{lccr|c}
\hline Produto & $\begin{array}{c}\text { Puantidade } \\
\text { Vendida }\end{array}$ & $\begin{array}{c}\text { Médio } \\
\text { (R\$) }\end{array}$ & $\begin{array}{c}\text { Vacebr } \\
\text { (R\$) }\end{array}$ & $\%$ \\
\hline Farinha (Saca de 50Kg) & 750 & 170,00 & $127.500,00$ & $51,44 \%$ \\
Pescado Fresco (Kg) & 8000 & 6,00 & $48.000,00$ & $19,36 \%$ \\
Pescado Seco (Kg) & 4000 & 7,00 & $28.000,00$ & $11,30 \%$ \\
Castanha (Hectolitro; 100 litros) & 73 & 250,00 & $18.250,00$ & $7,36 \%$ \\
Macaxeira (Kg) & 3000 & 3,00 & $9.000,00$ & $3,63 \%$ \\
Goma da Mandioca (Lata 20Kg) & 55 & 80,00 & $4.400,00$ & $1,78 \%$ \\
Galinha Caipira (Unidade) & 200 & 15,00 & $3.000,00$ & $1,21 \%$ \\
Andiroba semente (Lata 20Kg) & 166 & 14,00 & $2.324,00$ & $0,94 \%$ \\
Feijão (Kg) & 400 & 5,00 & $2.000,00$ & $0,81 \%$ \\
Jerimum (Unidade) & 500 & 3,00 & $1.500,00$ & $0,61 \%$ \\
Maxixe (Kg) & 200 & 5,00 & $1.000,00$ & $0,40 \%$ \\
Murumuru semente (Lata 20Kg) & 111 & 8,00 & 888,00 & $0,36 \%$ \\
Banana (Cacho) & 50 & 15,00 & 750,00 & $0,30 \%$ \\
Melão (Unidade) & 100 & 5,00 & 500,00 & $0,20 \%$ \\
Açaí Beneficiado (Litro) & 100 & 4,00 & 400,00 & $0,16 \%$ \\
Pato (Unidade) & 10 & 20,00 & 200,00 & $0,08 \%$ \\
Milho Verde (Mão-50 espigas) & 6 & 25,00 & 150,00 & $0,06 \%$ \\
Milho Seco (Kg) & 10 & 1,50 & 15,00 & $0,01 \%$ \\
\hline Valor total recebido (R\$) & & & $\mathbf{2 4 7 . 8 7 7 , 0 0}$ & $\mathbf{1 0 0 , 0 0 \%}$ \\
\hline
\end{tabular}

Tabela 32 - Produção na Comunidade Fortaleza (2020)

\begin{tabular}{l|ccr|c}
\hline Produto & $\begin{array}{c}\text { Quantidade } \\
\text { Q Unidade de Medida }\end{array}$ & $\begin{array}{c}\text { Preço } \\
\text { (Rédio }\end{array}$ & $\begin{array}{c}\text { Valor } \\
\text { recebido } \\
\text { (R\$) }\end{array}$ & \% \\
\hline Farinha (Saca de 50Kg) & 240 & 200,00 & $48.000,00$ & $35,49 \%$ \\
Castanha (Hectolitro; 100 litros) & 196 & 200,00 & $39.200,00$ & $28,98 \%$ \\
Melancia (Unidade) & 1.730 & 8,00 & $13.840,00$ & $10,23 \%$ \\
Pescado Fresco (Kg) & 1.900 & 5,00 & $9.500,00$ & $7,02 \%$ \\
Pescado Seco (Kg) & 1.430 & 6,00 & $8.580,00$ & $6,34 \%$ \\
Feijão (Kg) & 1.050 & 6,00 & $6.300,00$ & $4,66 \%$ \\
Canoa (Unidade) & 20 & 300,00 & $6.000,00$ & $4,44 \%$ \\
Remo (Unidade) & 100 & 20,00 & $2.000,00$ & $1,48 \%$ \\
Jerimum (Unidade) & 90 & 5,00 & 450,00 & $0,33 \%$ \\
Galinha Caipira (Unidade) & 15 & 25,00 & 375,00 & $0,28 \%$ \\
Melão (Unidade) & 55 & 6,00 & 330,00 & $0,24 \%$ \\
Milho Seco (Kg) & 51 & 5,00 & 255,00 & $0,19 \%$ \\
Açaí Fruto (Lata 18Kg) & 10 & 15,00 & 150,00 & $0,11 \%$ \\
Banana (Cacho) & 3 & 30,00 & 90,00 & $0,07 \%$ \\
Milho Verde (Mão-50 espigas) & 3 & 25,00 & 75,00 & $0,06 \%$ \\
Batata-doce (Kg) & 18 & 4,00 & 72,00 & $0,05 \%$ \\
Macaxeira (Kg) & 5 & 4,00 & 20,00 & $0,01 \%$ \\
Porco (Unidade) & 2 & 6,00 & 12,00 & $0,01 \%$ \\
\hline Valor total recebido (R\$) & & & $\mathbf{1 3 5 . 2 4 9 , 0 0}$ & $\mathbf{1 0 0 , 0 0 \%}$ \\
\hline & & &
\end{tabular}




\section{Comunidade Glória II}

Quadro 16 - Dados gerais para Avaliação da Comunidade Glória II (2019-2020)

\begin{tabular}{|c|c|c|}
\hline Informações & Ano 2019 & Ano 2020 \\
\hline Valor da Produção na Resex Canutama & $\mathrm{R} \$ 3.002 .952,00$ & $\mathrm{R} \$ 2.923 .589,36$ \\
\hline Média da Produção na Resex Canutama & $\mathrm{R} \$ 79.025,05$ & $R \$ 76.936,56$ \\
\hline $\mathrm{N}^{\circ}$ de residentes na Comunidade & 53 & 53 \\
\hline $\mathrm{N}^{\circ}$ de produtos vendidos & 16 & \\
\hline Valor da Produção na Comunidade & $\mathrm{R} \$ 70.755,00$ & $\mathrm{R} \$ 126.990,00$ \\
\hline Produção Per capita da Comunidade & $\mathrm{R} \$ 1.335,00$ & $\mathrm{R} \$ 2.396,04$ \\
\hline $\begin{array}{l}\text { Média do PIB per capita dos municípios de Canutama } \\
\text { e Lábrea* }\end{array}$ & $\mathrm{R} \$ 8.953,67$ & $\mathrm{R} \$ 8.953,67$ \\
\hline
\end{tabular}

(*) Média com base no ano de 2018: PIB per capita de Lábrea (R\$ 10.941,94) e PIB per capita de Canutama (R\$ $6.965,40)$ - Último ano divulgado conforme dados do IBGE.

Tabela 33 - Sustentabilidade Financeira da Comunidade Glória II (2019-2020)

\begin{tabular}{|c|c|c|c|c|}
\hline \multirow{2}{*}{$\begin{array}{l}\text { Parâmetros Avaliados } \\
\text { [A comunidade possui...] }\end{array}$} & \multicolumn{2}{|c|}{ Avaliação 2019} & \multicolumn{2}{|c|}{ Avaliação 2020} \\
\hline & $\begin{array}{l}\text { Referência } \\
(1 \text { ou } 0)\end{array}$ & $\begin{array}{c}\text { Resultado } \\
(\%)\end{array}$ & $\begin{array}{l}\text { Referência } \\
\text { (1 ou 0) }\end{array}$ & $\begin{array}{c}\text { Resultado } \\
(\%)\end{array}$ \\
\hline (1) Líder comunitário com perfil empreendedor & 0 & $0,00000 \%$ & 0 & $0,0000 \%$ \\
\hline (2) Controle de castanhal e exploração de castanhal & 0 & $0,00000 \%$ & 0 & $0,0000 \%$ \\
\hline (3) $\mathrm{N}^{\circ}$ mínimo de residentes $\geq 30$ pessoas & 1 & $9,09091 \%$ & 1 & $9,0909 \%$ \\
\hline $\begin{array}{l}\text { (4) Produção per capita da comunidade } \geq \text { média do PIB } \\
\text { per capita dos municípios Canutama e Lábrea }\end{array}$ & 0 & $0,00000 \%$ & 0 & $0,0000 \%$ \\
\hline $\begin{array}{l}\text { (5) Produção na Comunidade } \geq \text { média da produção total } \\
\text { na Resex Canutama }\end{array}$ & 0 & $0,00000 \%$ & 1 & $9,0909 \%$ \\
\hline $\begin{array}{l}\text { (6) Produção diversificada e contendo o produto } \\
\text { potencial 'Farinha' com produção } \geq 10 \%\end{array}$ & 1 & $9,09091 \%$ & 1 & $9,0909 \%$ \\
\hline $\begin{array}{l}\text { (7) Produção diversificada e contendo o produto } \\
\text { potencial 'Peixe Fresco' com produção } \geq 10 \%\end{array}$ & 1 & $9,09091 \%$ & 1 & $9,0909 \%$ \\
\hline $\begin{array}{l}\text { (8) Produção diversificada e contendo o produto } \\
\text { potencial 'Peixe Seco' com produção } \geq 10 \%\end{array}$ & 0 & $0,00000 \%$ & 1 & $9,0909 \%$ \\
\hline $\begin{array}{l}\text { (9) Produção diversificada e contendo o produto } \\
\text { potencial 'Porco' com produção } \geq 10 \%\end{array}$ & 0 & $0,00000 \%$ & 0 & $0,0000 \%$ \\
\hline $\begin{array}{l}\text { (10) Produção diversificada e contendo o produto } \\
\text { potencial 'Açaí' com produção } \geq 10 \%\end{array}$ & 0 & $0,00000 \%$ & 0 & $0,0000 \%$ \\
\hline $\begin{array}{l}\text { (11) Produção diversificada e contendo o produto } \\
\text { potencial 'Castanha' com produção } \geq 10 \%\end{array}$ & 1 & $9,09091 \%$ & 1 & $9,0909 \%$ \\
\hline $\begin{array}{l}\text { Índice de Sustentabilidade Financeira } \\
\text { (resultado arredondado) }\end{array}$ & 4 & $36,4 \%$ & 6 & $54,6 \%$ \\
\hline $\begin{array}{l}\text { Legenda: Na Coluna [Referência] } \\
\text { [1] Sim, a comunidade atende o parâmetro } \\
\text { [0] Não, a comunidade não atende o parâmetro }\end{array}$ & $\begin{array}{l}\text { egenda: } \mathrm{Na} \\
\text { 1] Avaliaç } \\
\text {,09091\% } \\
\text { 0] Avaliaçãc }\end{array}$ & $\begin{array}{l}\text { Dluna }[\text { Resu } \\
\text { positiva }\end{array}$ & $\begin{array}{l}\text { tado] } \\
\text { gera um }\end{array}$ & $\begin{array}{l}\text { rcentual de } \\
0,0000 \%\end{array}$ \\
\hline
\end{tabular}

Fonte: Elaborado pela autora. 
Tabela 34- Produção na Comunidade Glória II (2019)

\begin{tabular}{|c|c|c|c|c|}
\hline $\begin{array}{l}\text { Produto } \\
\text { e Unidade de Medida }\end{array}$ & $\begin{array}{c}\text { Quantidade } \\
\text { Vendida }\end{array}$ & $\begin{array}{c}\text { Preço } \\
\text { Médio } \\
\text { (R\$) }\end{array}$ & $\begin{array}{c}\text { Valor } \\
\text { recebido } \\
(\mathbf{R} \$)\end{array}$ & $\%$ \\
\hline Farinha (Saca de 50Kg) & 125 & 170,00 & $21.250,00$ & $30,03 \%$ \\
\hline Castanha (Hectolitro; 100 litros) & 56 & 250,00 & $14.000,00$ & $19,79 \%$ \\
\hline Pescado Seco (Kg) & 2000 & 7,00 & $14.000,00$ & $19,79 \%$ \\
\hline Porco (Unidade) & 15 & 210,00 & $3.150,00$ & $4,45 \%$ \\
\hline Melancia (Unidade) & 600 & 5,00 & $3.000,00$ & $4,24 \%$ \\
\hline Jerimum (Unidade) & 1000 & 3,00 & $3.000,00$ & $4,24 \%$ \\
\hline Feijão $(\mathrm{Kg})$ & 600 & 5,00 & $3.000,00$ & $4,24 \%$ \\
\hline Maxixe $(\mathrm{Kg})$ & 500 & 5,00 & $2.500,00$ & $3,53 \%$ \\
\hline Galinha Caipira (Unidade) & 100 & 15,00 & $1.500,00$ & $2,12 \%$ \\
\hline Melão (Unidade) & 300 & 5,00 & $1.500,00$ & $2,12 \%$ \\
\hline Goma da Mandioca (Lata 20Kg) & 15 & 80,00 & $1.200,00$ & $1,70 \%$ \\
\hline Banana (Cacho) & 40 & 15,00 & 600,00 & $0,85 \%$ \\
\hline Macaxeira (Kg) & 200 & 3,00 & 600,00 & $0,85 \%$ \\
\hline Milho Seco (Kg) & 400 & 1,50 & 600,00 & $0,85 \%$ \\
\hline Milho Verde (Mão-50 espigas) & 23 & 25,00 & 575,00 & $0,81 \%$ \\
\hline Açaí Beneficiado (Litro) & 70 & 4,00 & 280,00 & $0,40 \%$ \\
\hline Valor total recebido (RS) & & & $70.755,00$ & $100,00 \%$ \\
\hline
\end{tabular}

Tabela 35 - Produção na Comunidade Glória II (2020)

\begin{tabular}{|c|c|c|c|c|}
\hline $\begin{array}{l}\text { Produto } \\
\text { e Unidade de Medida }\end{array}$ & $\begin{array}{c}\text { Quantidade } \\
\text { Vendida }\end{array}$ & $\begin{array}{c}\text { Preço } \\
\text { Médio } \\
\text { (R\$) }\end{array}$ & $\begin{array}{c}\text { Valor } \\
\text { recebido } \\
(\mathrm{R} \$)\end{array}$ & $\%$ \\
\hline Pescado Fresco $(\mathrm{Kg})$ & 7.220 & 5,00 & $36.100,00$ & $28,43 \%$ \\
\hline Pescado Seco (Kg) & 4.350 & 6,00 & $26.100,00$ & $20,55 \%$ \\
\hline Castanha (Hectolitro; 100 litros) & 100 & 200,00 & $20.000,00$ & $15,75 \%$ \\
\hline Melancia (Unidade) & 2.400 & 8,00 & $19.200,00$ & $15,12 \%$ \\
\hline Farinha (Saca de $50 \mathrm{Kg}$ ) & 86 & 200,00 & $17.200,00$ & $13,54 \%$ \\
\hline Feijão $(\mathrm{Kg})$ & 515 & 6,00 & $3.090,00$ & $2,43 \%$ \\
\hline Açaí Fruto (Lata 18Kg) & 100 & 15,00 & $1.500,00$ & $1,18 \%$ \\
\hline Galinha Caipira (Unidade) & 30 & 25,00 & 750,00 & $0,59 \%$ \\
\hline Milho Verde (Mão-50 espigas) & 30 & 25,00 & 750,00 & $0,59 \%$ \\
\hline Jerimum (Unidade) & 150 & 5,00 & 750,00 & $0,59 \%$ \\
\hline Melão (Unidade) & 120 & 6,00 & 720,00 & $0,57 \%$ \\
\hline Banana (Cacho) & 20 & 30,00 & 600,00 & $0,47 \%$ \\
\hline Porco (Unidade) & 15 & 6,00 & 90,00 & $0,07 \%$ \\
\hline Porco $(\mathrm{Kg})$ & 8 & 10,00 & 80,00 & $0,06 \%$ \\
\hline Batata-doce (Kg) & 10 & 4,00 & 40,00 & $0,03 \%$ \\
\hline Macaxeira $(\mathrm{Kg})$ & 5 & 4,00 & 20,00 & $0,02 \%$ \\
\hline Valor total recebido (RS) & & & $126.990,00$ & $100,00 \%$ \\
\hline
\end{tabular}




\section{Comunidade Sacado}

Quadro 17 - Dados gerais para Avaliação da Comunidade Sacado (2019-2020)

\begin{tabular}{|c|c|c|}
\hline Informações & Ano 2019 & Ano 2020 \\
\hline Valor da Produção na Resex Canutama & $\mathrm{R} \$ 3.002 .952,00$ & $\mathrm{R} \$ 2.923 .589,36$ \\
\hline Média da Produção na Resex Canutama & $\mathrm{R} \$ 79.025,05$ & $\mathrm{R} \$ 76.936,56$ \\
\hline $\mathrm{N}^{o}$ de residentes na Comunidade & 35 & 35 \\
\hline $\mathrm{N}^{\circ}$ de produtos vendidos & 20 & 14 \\
\hline Valor da Produção na Comunidade & $\mathrm{R} \$ 100.936,00$ & $\mathrm{R} \$ 110.337,64$ \\
\hline Produção Per capita da Comunidade & $\mathrm{R} \$ 2.883,89$ & $\mathrm{R} \$ 3.152,50$ \\
\hline $\begin{array}{l}\text { Média do PIB per capita dos municípios de Canutama } \\
\text { e Lábrea* }\end{array}$ & $\mathrm{R} \$ 8.953,67$ & $\mathrm{R} \$ 8.953,67$ \\
\hline
\end{tabular}

(*) Média com base no ano de 2018: PIB per capita de Lábrea (R\$ 10.941,94) e PIB per capita de Canutama (R\$ $6.965,40)$ - Último ano divulgado conforme dados do IBGE.

Tabela 36 - Sustentabilidade Financeira da Comunidade Sacado (2019-2020)

\begin{tabular}{|c|c|c|c|c|}
\hline \multirow[b]{2}{*}{$\begin{array}{l}\text { Parâmetros Avaliados } \\
\text { [A comunidade possui...] }\end{array}$} & \multicolumn{2}{|c|}{ Avaliação 2019} & \multicolumn{2}{|c|}{ Avaliação 2020} \\
\hline & $\begin{array}{l}\text { Referência } \\
(1 \text { ou } 0)\end{array}$ & $\begin{array}{c}\text { Resultado } \\
(\%)\end{array}$ & $\begin{array}{l}\text { Referência } \\
(1 \text { ou } 0)\end{array}$ & $\begin{array}{c}\text { Resultado } \\
(\%)\end{array}$ \\
\hline (1) Líder comunitário com perfil empreendedor & 0 & $0,00000 \%$ & 0 & $0,0000 \%$ \\
\hline (2) Controle de castanhal e exploração de castanhal & 0 & $0,00000 \%$ & 0 & $0,0000 \%$ \\
\hline (3) $\mathrm{N}^{\circ}$ mínimo de residentes $\geq 30$ pessoas & 1 & $9,09091 \%$ & 1 & $9,0909 \%$ \\
\hline $\begin{array}{l}\text { (4) Produção per capita da comunidade } \geq \text { média do PIB } \\
\text { per capita dos municípios Canutama e Lábrea }\end{array}$ & 0 & $0,00000 \%$ & 0 & $0,0000 \%$ \\
\hline $\begin{array}{l}\text { (5) Produção na Comunidade } \geq \text { média da produção total } \\
\text { na Resex Canutama }\end{array}$ & 1 & $9,09091 \%$ & 1 & $9,0909 \%$ \\
\hline $\begin{array}{l}\text { (6) Produção diversificada e contendo o produto } \\
\text { potencial 'Farinha' com produção } \geq 10 \%\end{array}$ & 1 & $9,09091 \%$ & 0 & $0,0000 \%$ \\
\hline $\begin{array}{l}\text { (7) Produção diversificada e contendo o produto } \\
\text { potencial 'Peixe Fresco' com produção } \geq 10 \%\end{array}$ & 1 & $9,09091 \%$ & 1 & $9,0909 \%$ \\
\hline $\begin{array}{l}\text { (8) Produção diversificada e contendo o produto } \\
\text { potencial 'Peixe Seco' com produção } \geq 10 \%\end{array}$ & 1 & $9,09091 \%$ & 1 & $9,0909 \%$ \\
\hline $\begin{array}{l}\text { (9) Produção diversificada e contendo o produto } \\
\text { potencial 'Porco' com produção } \geq 10 \%\end{array}$ & 0 & $0,00000 \%$ & 0 & $0,0000 \%$ \\
\hline $\begin{array}{l}\text { (10) Produção diversificada e contendo o produto } \\
\text { potencial 'Açaí' com produção } \geq 10 \%\end{array}$ & 0 & $0,00000 \%$ & 0 & $0,0000 \%$ \\
\hline $\begin{array}{l}\text { (11) Produção diversificada e contendo o produto } \\
\text { potencial 'Castanha' com produção } \geq 10 \%\end{array}$ & 1 & $9,09091 \%$ & 1 & $9,0909 \%$ \\
\hline $\begin{array}{l}\text { Índice de Sustentabilidade Financeira } \\
\text { (resultado arredondado) }\end{array}$ & 6 & $54,6 \%$ & 5 & $45,5 \%$ \\
\hline
\end{tabular}

Legenda: Na Coluna [Referência]

[1] Sim, a comunidade atende o parâmetro

[0] Não, a comunidade não atende o parâmetro

Fonte: Elaborado pela autora.
Legenda: Na Coluna [Resultado]

[1] Avaliação positiva gera um percentual de 9,09091\%

[0] Avaliação negativa gera percentual de $0,0000 \%$ 
Tabela 37 - Produção na Comunidade Sacado (2019)

\begin{tabular}{|c|c|c|c|c|}
\hline $\begin{array}{l}\text { Produto } \\
\text { e Unidade de Medida }\end{array}$ & $\begin{array}{c}\text { Quantidade } \\
\text { Vendida } \\
\end{array}$ & $\begin{array}{c}\text { Preço } \\
\text { Médio } \\
\text { (RS) }\end{array}$ & $\begin{array}{c}\text { Valor } \\
\text { recebido } \\
(\mathrm{R} \$)\end{array}$ & $\%$ \\
\hline Pescado Fresco (Kg) & 3000 & 6,00 & $18.000,00$ & $17,83 \%$ \\
\hline Castanha (Hectolitro; 100 litros) & 72 & 250,00 & $18.000,00$ & $17,83 \%$ \\
\hline Farinha (Saca de 50Kg) & 89 & 170,00 & $15.130,00$ & $14,99 \%$ \\
\hline Pescado Seco $(\mathrm{Kg})$ & 2000 & 7,00 & $14.000,00$ & $13,87 \%$ \\
\hline Melancia (Unidade) & 2000 & 5,00 & $10.000,00$ & $9,91 \%$ \\
\hline Andiroba semente (Lata $20 \mathrm{Kg}$ ) & 519 & 14,00 & $7.266,00$ & $7,20 \%$ \\
\hline Pato (Unidade) & 200 & 20,00 & $4.000,00$ & $3,96 \%$ \\
\hline Açaí Fruto (Lata $18 \mathrm{Kg}$ ) & 150 & 18,00 & $2.700,00$ & $2,67 \%$ \\
\hline Batata-doce $(\mathrm{Kg})$ & 600 & 4,00 & $2.400,00$ & $2,38 \%$ \\
\hline Açaí Beneficiado (Litro) & 400 & 4,00 & $1.600,00$ & $1,59 \%$ \\
\hline Galinha Caipira (Unidade) & 100 & 15,00 & $1.500,00$ & $1,49 \%$ \\
\hline Macaxeira $(\mathrm{Kg})$ & 500 & 3,00 & $1.500,00$ & $1,49 \%$ \\
\hline Porco (Unidade) & 5 & 210,00 & $1.050,00$ & $1,04 \%$ \\
\hline Goma da Mandioca (Lata 20Kg) & 13 & 80,00 & $1.040,00$ & $1,03 \%$ \\
\hline Jerimum (Unidade) & 300 & 3,00 & 900,00 & $0,89 \%$ \\
\hline Banana (Cacho) & 35 & 15,00 & 525,00 & $0,52 \%$ \\
\hline Maxixe $(\mathrm{Kg})$ & 100 & 5,00 & 500,00 & $0,50 \%$ \\
\hline Melão (Unidade) & 90 & 5,00 & 450,00 & $0,45 \%$ \\
\hline Feijão $(\mathrm{Kg})$ & 50 & 5,00 & 250,00 & $0,25 \%$ \\
\hline Milho Verde (Mão-50 espigas) & 5 & 25,00 & 125,00 & $0,12 \%$ \\
\hline Valor total recebido (R\$) & & & $100.936,00$ & $100,00 \%$ \\
\hline
\end{tabular}

Tabela 38 - Produção na Comunidade Sacado (2020)

\begin{tabular}{|c|c|c|c|c|}
\hline $\begin{array}{l}\text { Produto } \\
\text { e Unidade de Medida }\end{array}$ & $\begin{array}{c}\text { Quantidade } \\
\text { Vendida }\end{array}$ & $\begin{array}{l}\text { Preço } \\
\text { Médio } \\
\text { (R\$) }\end{array}$ & \begin{tabular}{|c|} 
Valor \\
recebido \\
$(\mathbf{R} \$)$ \\
\end{tabular} & $\%$ \\
\hline Pescado Fresco (Kg) & 8.000 & 5,00 & $40.000,00$ & $36,25 \%$ \\
\hline Pescado Seco (Kg) & 3.740 & 6,00 & $22.440,00$ & $20,34 \%$ \\
\hline Castanha (Hectolitro; 100 litros) & 102 & 200,00 & $20.400,00$ & $18,49 \%$ \\
\hline Farinha (Saca de 50Kg) & 45 & 200,00 & $9.000,00$ & $8,16 \%$ \\
\hline Melancia (Unidade) & 820 & 8,00 & $6.560,00$ & $5,95 \%$ \\
\hline Murumuru semente (Lata 20Kg) & 342 & 14,42 & $4.931,64$ & $4,47 \%$ \\
\hline Andiroba semente (Lata 20Kg) & 482 & 10,00 & $4.820,00$ & $4,37 \%$ \\
\hline Feijão (Kg) & 132 & 6,00 & 792,00 & $0,72 \%$ \\
\hline Açaí Fruto (Lata 18Kg) & 25 & 15,00 & 375,00 & $0,34 \%$ \\
\hline Jerimum (Unidade) & 73 & 5,00 & 365,00 & $0,33 \%$ \\
\hline Melão (Unidade) & 50 & 6,00 & 300,00 & $0,27 \%$ \\
\hline Galinha Caipira (Unidade) & 8 & 25,00 & 200,00 & $0,18 \%$ \\
\hline Pato (Unidade) & 3 & 30,00 & 90,00 & $0,08 \%$ \\
\hline Batata-doce $(\mathrm{Kg})$ & 16 & 4,00 & 64,00 & $0,06 \%$ \\
\hline Valor total recebido (R\$) & & & $110.337,64$ & $100,00 \%$ \\
\hline
\end{tabular}




\section{Comunidade Irajá}

Quadro 18 - Dados gerais para Avaliação da Comunidade Irajá (2019-2020)

\begin{tabular}{|c|c|c|}
\hline Informações & Ano 2019 & Ano 2020 \\
\hline Valor da Produção na Resex Canutama & $\mathrm{R} \$ 3.002 .952,00$ & $\mathrm{R} \$ 2.923 .589,36$ \\
\hline Média da Produção na Resex Canutama & $\mathrm{R} \$ 79.025,05$ & $R \$ 76.936,56$ \\
\hline $\mathrm{N}^{\circ}$ de residentes na Comunidade & 58 & 58 \\
\hline $\mathrm{N}^{\circ}$ de produtos vendidos & 19 & 14 \\
\hline Valor da Produção na Comunidade & $\mathrm{R} \$ 68.380,00$ & $\mathrm{R} \$ 94.626,00$ \\
\hline Produção Per capita da Comunidade & $\mathrm{R} \$ 1.178,97$ & $\mathrm{R} \$ 1.631,48$ \\
\hline $\begin{array}{l}\text { Média do PIB per capita dos municípios de Canutama } \\
\text { e Lábrea* }\end{array}$ & $\mathrm{R} \$ 8.953,67$ & $\mathrm{R} \$ 8.953,67$ \\
\hline
\end{tabular}

(*) Média com base no ano de 2018: PIB per capita de Lábrea (R\$ 10.941,94) e PIB per capita de Canutama (R\$ $6.965,40)$ - Último ano divulgado conforme dados do IBGE.

Tabela 39 - Sustentabilidade Financeira da Comunidade Irajá (2019-2020)

\begin{tabular}{|c|c|c|c|c|}
\hline \multirow{2}{*}{$\begin{array}{l}\text { Parâmetros Avaliados } \\
\text { [A comunidade possui...] }\end{array}$} & \multicolumn{2}{|c|}{ Avaliação 2019} & \multicolumn{2}{|c|}{ Avaliação 2020} \\
\hline & $\begin{array}{c}\text { Referência } \\
(1 \text { ou } 0)\end{array}$ & $\begin{array}{c}\text { Resultado } \\
(\%)\end{array}$ & $\begin{array}{c}\text { Referência } \\
(1 \text { ou } 0)\end{array}$ & $\begin{array}{c}\text { Resultado } \\
(\%) \\
\end{array}$ \\
\hline (1) Líder comunitário com perfil empreendedor & 0 & $0,00000 \%$ & 0 & $0,0000 \%$ \\
\hline (2) Controle de castanhal e exploração de castanhal & 0 & $0,00000 \%$ & 0 & $0,0000 \%$ \\
\hline (3) $\mathrm{N}^{\circ}$ mínimo de residentes $\geq 30$ pessoas & 1 & $9,09091 \%$ & 1 & $9,0909 \%$ \\
\hline $\begin{array}{l}\text { (4) Produção per capita da comunidade } \geq \text { média do } \\
\text { PIB per capita dos municípios Canutama e Lábrea }\end{array}$ & 0 & $0,00000 \%$ & 0 & $0,0000 \%$ \\
\hline $\begin{array}{l}\text { (5) Produção na Comunidade } \geq \text { média da produção } \\
\text { total na Resex Canutama }\end{array}$ & 0 & $0,00000 \%$ & 1 & $9,0909 \%$ \\
\hline $\begin{array}{l}\text { (6) Produção diversificada e contendo o produto } \\
\text { potencial 'Farinha' com produção } \geq 10 \%\end{array}$ & 1 & $9,09091 \%$ & 0 & $0,0000 \%$ \\
\hline $\begin{array}{l}\text { (7) Produção diversificada e contendo o produto } \\
\text { potencial 'Peixe Fresco' com produção } \geq 10 \%\end{array}$ & 1 & $9,09091 \%$ & 1 & $9,0909 \%$ \\
\hline $\begin{array}{l}\text { (8) Produção diversificada e contendo o produto } \\
\text { potencial 'Peixe Seco' com produção } \geq 10 \%\end{array}$ & 1 & $9,09091 \%$ & 1 & $9,0909 \%$ \\
\hline $\begin{array}{l}\text { (9) Produção diversificada e contendo o produto } \\
\text { potencial 'Porco' com produção } \geq 10 \%\end{array}$ & 0 & $0,00000 \%$ & 0 & $0,0000 \%$ \\
\hline $\begin{array}{l}\text { (10) Produção diversificada e contendo o produto } \\
\text { potencial 'Açaí' com produção } \geq 10 \%\end{array}$ & 0 & $0,00000 \%$ & 1 & $9,0909 \%$ \\
\hline $\begin{array}{l}\text { (11) Produção diversificada e contendo o produto } \\
\text { potencial 'Castanha' com produção } \geq 10 \%\end{array}$ & 0 & $0,00000 \%$ & 1 & $9,0909 \%$ \\
\hline $\begin{array}{l}\text { Índice de Sustentabilidade Financeira } \\
\text { (resultado arredondado) }\end{array}$ & 4 & $36,4 \%$ & 6 & $54,6 \%$ \\
\hline
\end{tabular}

Legenda: Na Coluna [Referência]

[1] Sim, a comunidade atende o parâmetro

[0] Não, a comunidade não atende o parâmetro

Fonte: Elaborado pela autora.
Legenda: Na Coluna [Resultado]

[1] Avaliação positiva gera um percentual de 9,09091\%

[0] Avaliação negativa gera percentual de $0,0000 \%$ 
Tabela 40 - Produção na Comunidade Irajá (2019)

\begin{tabular}{lccc|c}
\hline Produto & $\begin{array}{c}\text { Preço } \\
\text { Quantidade } \\
\text { Vendida }\end{array}$ & $\begin{array}{c}\text { Médio } \\
\text { (R\$) }\end{array}$ & $\begin{array}{c}\text { Valor } \\
\text { recebido } \\
\text { (R\$) }\end{array}$ & Unidade de Medida \\
\hline Pescado Fresco (Kg) & 3000 & 6,00 & $18.000,00$ & $26,32 \%$ \\
Farinha (Saca de 50Kg) & 100 & 170,00 & $17.000,00$ & $24,86 \%$ \\
Pescado Seco (Kg) & 2000 & 7,00 & $14.000,00$ & $20,47 \%$ \\
Castanha (Hectolitro; 100 litros) & 26 & 250,00 & $6.500,00$ & $9,51 \%$ \\
Açaí Fruto (Lata 18Kg) & 150 & 18,00 & $2.700,00$ & $3,95 \%$ \\
Galinha Caipira (Unidade) & 120 & 15,00 & $1.800,00$ & $2,63 \%$ \\
Melancia (Unidade) & 350 & 5,00 & $1.750,00$ & $2,56 \%$ \\
Macaxeira (Kg) & 400 & 3,00 & $1.200,00$ & $1,75 \%$ \\
Banana (Cacho) & 60 & 15,00 & 900,00 & $1,32 \%$ \\
Melão (Unidade) & 120 & 5,00 & 600,00 & $0,88 \%$ \\
Pato (Unidade) & 30 & 20,00 & 600,00 & $0,88 \%$ \\
Açaí Beneficiado (Litro) & 150 & 4,00 & 600,00 & $0,88 \%$ \\
Jerimum (Unidade) & 200 & 3,00 & 600,00 & $0,88 \%$ \\
Maxixe (Kg) & 100 & 5,00 & 500,00 & $0,73 \%$ \\
Feijão (Kg) & 80 & 5,00 & 400,00 & $0,58 \%$ \\
Goma da Mandioca (Lata 20Kg) & 5 & 80,00 & 400,00 & $0,58 \%$ \\
Milho Verde (Mão-50 espigas) & 15 & 25,00 & 375,00 & $0,55 \%$ \\
Batata-doce (Kg) & 80 & 4,00 & 320,00 & $0,47 \%$ \\
Milho Seco (Kg) & 90 & 1,50 & 135,00 & $0,20 \%$ \\
\hline Valor total recebido (R\$) & & & $\mathbf{6 8 . 3 8 0 , 0 0}$ & $\mathbf{1 0 0 , 0 0 \%}$ \\
\hline
\end{tabular}

Tabela 41 - Produção na Comunidade Irajá (2020)

\begin{tabular}{|c|c|c|c|c|}
\hline $\begin{array}{l}\text { Produto } \\
\text { e Unidade de Medida }\end{array}$ & $\begin{array}{c}\text { Quantidade } \\
\text { Vendida }\end{array}$ & $\begin{array}{l}\text { Preço } \\
\text { Médio } \\
\text { (R\$) }\end{array}$ & $\begin{array}{c}\text { Valor } \\
\text { recebido } \\
(\mathbf{R} \$) \\
\end{array}$ & $\%$ \\
\hline Pescado Fresco (Kg) & 5.000 & 5,00 & $25.000,00$ & $26,42 \%$ \\
\hline Pescado Seco (Kg) & 3.004 & 6,00 & $18.024,00$ & $19,05 \%$ \\
\hline Castanha (Hectolitro; 100 litros) & 73 & 200,00 & $14.600,00$ & $15,43 \%$ \\
\hline Melancia (Unidade) & 1.770 & 8,00 & $14.160,00$ & $14,96 \%$ \\
\hline Açaí Fruto (Lata 18Kg) & 766 & 15,00 & $11.490,00$ & $12,14 \%$ \\
\hline Farinha (Saca de 50Kg) & 42 & 200,00 & $8.400,00$ & $8,88 \%$ \\
\hline Copaíba Óleo (Kg) & 30 & 35,00 & $1.050,00$ & $1,11 \%$ \\
\hline Porco $(\mathrm{Kg})$ & 65 & 10,00 & 650,00 & $0,69 \%$ \\
\hline Batata-doce (Kg) & 100 & 4,00 & 400,00 & $0,42 \%$ \\
\hline Limão (Kg) & 50 & 6,00 & 300,00 & $0,32 \%$ \\
\hline Melão (Unidade) & 40 & 6,00 & 240,00 & $0,25 \%$ \\
\hline Pato (Unidade) & 5 & 30,00 & 150,00 & $0,16 \%$ \\
\hline Feijão (Kg) & 20 & 6,00 & 120,00 & $0,13 \%$ \\
\hline Porco (Unidade) & 7 & 6,00 & 42,00 & $0,04 \%$ \\
\hline Valor total recebido (RS) & & & $94.626,00$ & $100,00 \%$ \\
\hline
\end{tabular}




\section{Comunidade Santa Maria}

Quadro 19 - Dados gerais para Avaliação da Comunidade Santa Maria (2019-2020)

\begin{tabular}{|c|c|c|}
\hline Informações & Ano 2019 & Ano 2020 \\
\hline Valor da Produção na Resex Canutama & $\mathrm{R} \$ 3.002 .952,00$ & $\mathrm{R} \$ 2.923 .589,36$ \\
\hline Média da Produção na Resex Canutama & $\mathrm{R} \$ 79.025,05$ & $\mathrm{R} \$ 76.936,56$ \\
\hline $\mathrm{N}^{\mathrm{o}}$ de residentes na Comunidade & 16 & 16 \\
\hline $\mathrm{N}^{\circ}$ de produtos vendidos & 19 & 10 \\
\hline Valor da Produção na Comunidade & $\mathrm{R} \$ 64.701,00$ & $\mathrm{R} \$ 81.230,00$ \\
\hline Produção Per capita da Comunidade & $\mathrm{R} \$ 4.043,81$ & $\mathrm{R} \$ 5.076,88$ \\
\hline $\begin{array}{l}\text { Média do PIB per capita dos municípios de Canutama } \\
\text { e Lábrea* }\end{array}$ & $\mathrm{R} \$ 8.953,67$ & $\mathrm{R} \$ 8.953,67$ \\
\hline
\end{tabular}

(*) Média com base no ano de 2018: PIB per capita de Lábrea (R \$ 10.941,94) e PIB per capita de Canutama (R\$ $6.965,40)$ - Último ano divulgado conforme dados do IBGE.

Tabela 42 - Sustentabilidade Financeira da Comunidade Santa Maria (2019-2020)

\begin{tabular}{|c|c|c|c|c|}
\hline \multirow[b]{2}{*}{$\begin{array}{l}\text { Parâmetros Avaliados } \\
\text { [A comunidade possui...] }\end{array}$} & \multicolumn{2}{|c|}{ Avaliação 2019} & \multicolumn{2}{|c|}{ Avaliação 2020} \\
\hline & $\begin{array}{l}\text { Referência } \\
(1 \text { ou } 0)\end{array}$ & $\begin{array}{c}\text { Resultado } \\
(\%)\end{array}$ & $\begin{array}{c}\text { Referência } \\
\text { (1 ou 0) }\end{array}$ & $\begin{array}{c}\text { Resultado } \\
(\%) \\
\end{array}$ \\
\hline (1) Líder comunitário com perfil empreendedor & 0 & $0,00000 \%$ & 0 & $0,0000 \%$ \\
\hline (2) Controle de castanhal e exploração de castanhal & 0 & $0,00000 \%$ & 0 & $0,0000 \%$ \\
\hline (3) $\mathrm{N}^{\circ}$ mínimo de residentes $\geq 30$ pessoas & 0 & $0,00000 \%$ & 0 & $0,0000 \%$ \\
\hline $\begin{array}{l}\text { (4) Produção per capita da comunidade } \geq \text { média do PIB } \\
\text { per capita dos municípios Canutama e Lábrea }\end{array}$ & 0 & $0,00000 \%$ & 0 & $0,0000 \%$ \\
\hline $\begin{array}{l}\text { (5) Produção na Comunidade } \geq \text { média da produção total } \\
\text { na Resex Canutama }\end{array}$ & 0 & $0,00000 \%$ & 1 & $9,0909 \%$ \\
\hline $\begin{array}{l}\text { (6) Produção diversificada e contendo o produto } \\
\text { potencial 'Farinha' com produção } \geq 10 \%\end{array}$ & 0 & $0,00000 \%$ & 1 & $9,0909 \%$ \\
\hline $\begin{array}{l}\text { (7) Produção diversificada e contendo o produto } \\
\text { potencial 'Peixe Fresco' com produção } \geq 10 \%\end{array}$ & 1 & $9,09091 \%$ & 1 & $9,0909 \%$ \\
\hline $\begin{array}{l}\text { (8) Produção diversificada e contendo o produto } \\
\text { potencial 'Peixe Seco' com produção } \geq 10 \%\end{array}$ & 1 & $9,09091 \%$ & 1 & $9,0909 \%$ \\
\hline $\begin{array}{l}\text { (9) Produção diversificada e contendo o produto } \\
\text { potencial 'Porco' com produção } \geq 10 \%\end{array}$ & 0 & $0,00000 \%$ & 0 & $0,0000 \%$ \\
\hline $\begin{array}{l}\text { (10) Produção diversificada e contendo o produto } \\
\text { potencial 'Açaí' com produção } \geq 10 \%\end{array}$ & 0 & $0,00000 \%$ & 0 & $0,0000 \%$ \\
\hline $\begin{array}{l}\text { (11) Produção diversificada e contendo o produto } \\
\text { potencial 'Castanha' com produção } \geq 10 \%\end{array}$ & 1 & $9,09091 \%$ & 1 & $9,0909 \%$ \\
\hline $\begin{array}{l}\text { Índice de Sustentabilidade Financeira } \\
\text { (resultado arredondado) }\end{array}$ & 3 & $27,3 \%$ & 5 & $45,0 \%$ \\
\hline
\end{tabular}

Legenda: Na Coluna [Referência]

[1] Sim, a comunidade atende o parâmetro

[0] Não, a comunidade não atende o parâmetro

Fonte: Elaborado pela autora.
Legenda: Na Coluna [Resultado]

[1] Avaliação positiva gera um percentual de 9,09091\%

[0] Avaliação negativa gera percentual de $0,0000 \%$ 
Tabela 43 - Produção na Comunidade Santa Maria (2019)

\begin{tabular}{lccc|c}
\hline Produto & Preço & $\begin{array}{c}\text { Valor } \\
\text { Quantidade } \\
\text { Vendida }\end{array}$ & $\begin{array}{c}\text { Médio } \\
\text { (R\$) }\end{array}$ & $\begin{array}{c}\text { (R\$) } \\
\text { e Unidade de Medida }\end{array}$ \\
\hline Pescado Fresco (Kg) & 3000 & 6,00 & $18.000,00$ & \% \\
Pescado Seco (Kg) & 2000 & 7,00 & $14.000,00$ & $21,64 \%$ \\
Castanha (Hectolitro; 100 litros) & 55 & 250,00 & $13.750,00$ & $21,25 \%$ \\
Farinha (Saca de 50Kg) & 36 & 170,00 & $6.120,00$ & $9,46 \%$ \\
Melancia (Unidade) & 1000 & 5,00 & $5.000,00$ & $7,73 \%$ \\
Andiroba semente (Lata 20Kg) & 154 & 14,00 & $2.156,00$ & $3,33 \%$ \\
Feijão (Kg) & 200 & 5,00 & $1.000,00$ & $1,55 \%$ \\
Galinha Caipira (Unidade) & 60 & 15,00 & 900,00 & $1,39 \%$ \\
Macaxeira (Kg) & 300 & 3,00 & 900,00 & $1,39 \%$ \\
Maxixe (Kg) & 100 & 5,00 & 500,00 & $0,77 \%$ \\
Açaí Beneficiado (Litro) & 100 & 4,00 & 400,00 & $0,62 \%$ \\
Melão (Unidade) & 70 & 5,00 & 350,00 & $0,54 \%$ \\
Jerimum (Unidade) & 100 & 3,00 & 300,00 & $0,46 \%$ \\
Cebolinha (maço) & 100 & 3,00 & 300,00 & $0,46 \%$ \\
Pato (Unidade) & 13 & 20,00 & 260,00 & $0,40 \%$ \\
Pimenta de Cheiro (Kg) & 50 & 5,00 & 250,00 & $0,39 \%$ \\
Goma da Mandioca (Lata 20Kg) & 3 & 80,00 & 240,00 & $0,37 \%$ \\
Milho Seco (Kg) & 100 & 1,50 & 150,00 & $0,23 \%$ \\
Milho Verde (Mão-50 espigas) & 25,00 & 125,00 & $0,19 \%$ \\
\hline Valor total recebido (R\$) & 5 & & $\mathbf{6 4 . 7 0 1 , 0 0}$ & $\mathbf{1 0 0 , 0 0 \%}$ \\
\hline
\end{tabular}

Tabela 44 - Produção na Comunidade Santa Maria (2020)

\begin{tabular}{|c|c|c|c|c|}
\hline $\begin{array}{l}\text { Produto } \\
\text { e Unidade de Medida }\end{array}$ & $\begin{array}{c}\text { Quantidade } \\
\text { Vendida }\end{array}$ & $\begin{array}{l}\text { Preço } \\
\text { Médio } \\
\text { (R\$) }\end{array}$ & $\begin{array}{c}\text { Valor } \\
\text { recebido } \\
(\mathrm{R} \$) \\
\end{array}$ & $\%$ \\
\hline Pescado Fresco (Kg) & 5.000 & 5,00 & $25.000,00$ & $30,78 \%$ \\
\hline Castanha (Hectolitro; 100 litros) & 115 & 200,00 & $23.000,00$ & $28,31 \%$ \\
\hline Pescado Seco (Kg) & 3.000 & 6,00 & $18.000,00$ & $22,16 \%$ \\
\hline Farinha (Saca de $50 \mathrm{Kg}$ ) & 65 & 200,00 & $13.000,00$ & $16,00 \%$ \\
\hline Feijão $(\mathrm{Kg})$ & 130 & 6,00 & 780,00 & $0,96 \%$ \\
\hline Melancia (Unidade) & 95 & 8,00 & 760,00 & $0,94 \%$ \\
\hline Jerimum (Unidade) & 80 & 5,00 & 400,00 & $0,49 \%$ \\
\hline Melão (Unidade) & 20 & 6,00 & 120,00 & $0,15 \%$ \\
\hline Pato (Unidade) & 3 & 30,00 & 90,00 & $0,11 \%$ \\
\hline Batata-doce $(\mathrm{Kg})$ & 20 & 4,00 & 80,00 & $0,10 \%$ \\
\hline Valor total recebido (R\$) & & & $81.230,00$ & $100,00 \%$ \\
\hline
\end{tabular}




\section{Comunidade Forte Veneza/Nova Colônia}

Quadro 20 - Dados gerais para Avaliação da Comunidade Forte Veneza/Nova Colônia (20192020)

\begin{tabular}{|l|c|c|}
\hline \multicolumn{1}{|c|}{ Informaçães } & Ano 2019 & Ano 2020 \\
\hline Valor da Produção na Resex Canutama & $\mathrm{R} \$ 3.002 .952,00$ & $\mathrm{R} \$ 2.923 .589,36$ \\
\hline Média da Produção na Resex Canutama & $\mathrm{R} \$ 79.025,05$ & $\mathrm{R} \$ 76.936,56$ \\
\hline $\mathrm{N}^{\circ}$ de residentes na Comunidade & 16 & 16 \\
\hline $\mathrm{N}^{\circ}$ de produtos vendidos & 17 & 15 \\
\hline Valor da Produção na Comunidade & $\mathrm{R} \$ 107.200,00$ & $\mathrm{R} \$ 71.141,00$ \\
\hline Produção Per capita da Comunidade & $\mathrm{R} \$ 6.700,00$ & $\mathrm{R} \$ 4.446,31$ \\
\hline $\begin{array}{l}\text { Média do PIB per capita dos municípios de Canutama } \\
\text { e Lábrea* }\end{array}$ & $\mathrm{R} \$ 8.953,67$ & $\mathrm{R} \$ 8.953,67$ \\
\hline
\end{tabular}

(*) Média com base no ano de 2018: PIB per capita de Lábrea (R\$ 10.941,94) e PIB per capita de Canutama (R\$ $6.965,40)$ - Último ano divulgado conforme dados do IBGE.

Tabela 45 - Sustentabilidade Financeira da Comunidade Forte Veneza/Nova Colônia (20192020)

Parâmetros Avaliados

[A comunidade possui....]

(1) Líder comunitário com perfil empreendedor

(2) Controle de castanhal e exploração de castanhal

(3) $\mathrm{N}^{\circ}$ mínimo de residentes $\geq 30$ pessoas

(4) Produção per capita da comunidade $\geq$ média do PIB per capita dos municípios Canutama e Lábrea

(5) Produção na Comunidade $\geq$ média da produção total na Resex Canutama

(6) Produção diversificada e contendo o produto potencial 'Farinha' com produção $\geq 10 \%$

(7) Produção diversificada e contendo o produto potencial 'Peixe Fresco' com produção $\geq 10 \%$

(8) Produção diversificada e contendo o produto potencial 'Peixe Seco' com produção $\geq 10 \%$

(9) Produção diversificada e contendo o produto potencial 'Porco' com produção $\geq 10 \%$

(10) Produção diversificada e contendo o produto potencial 'Açaí' com produção $\geq 10 \%$

(11) Produção diversificada e contendo o produto potencial 'Castanha' com produção $\geq 10 \%$

Índice de Sustentabilidade Financeira (resultado arredondado)

Legenda: Na Coluna [Referência]

[1] Sim, a comunidade atende o parâmetro

[0] Não, a comunidade não atende o parâmetro

Fonte: Elaborado pela autora.

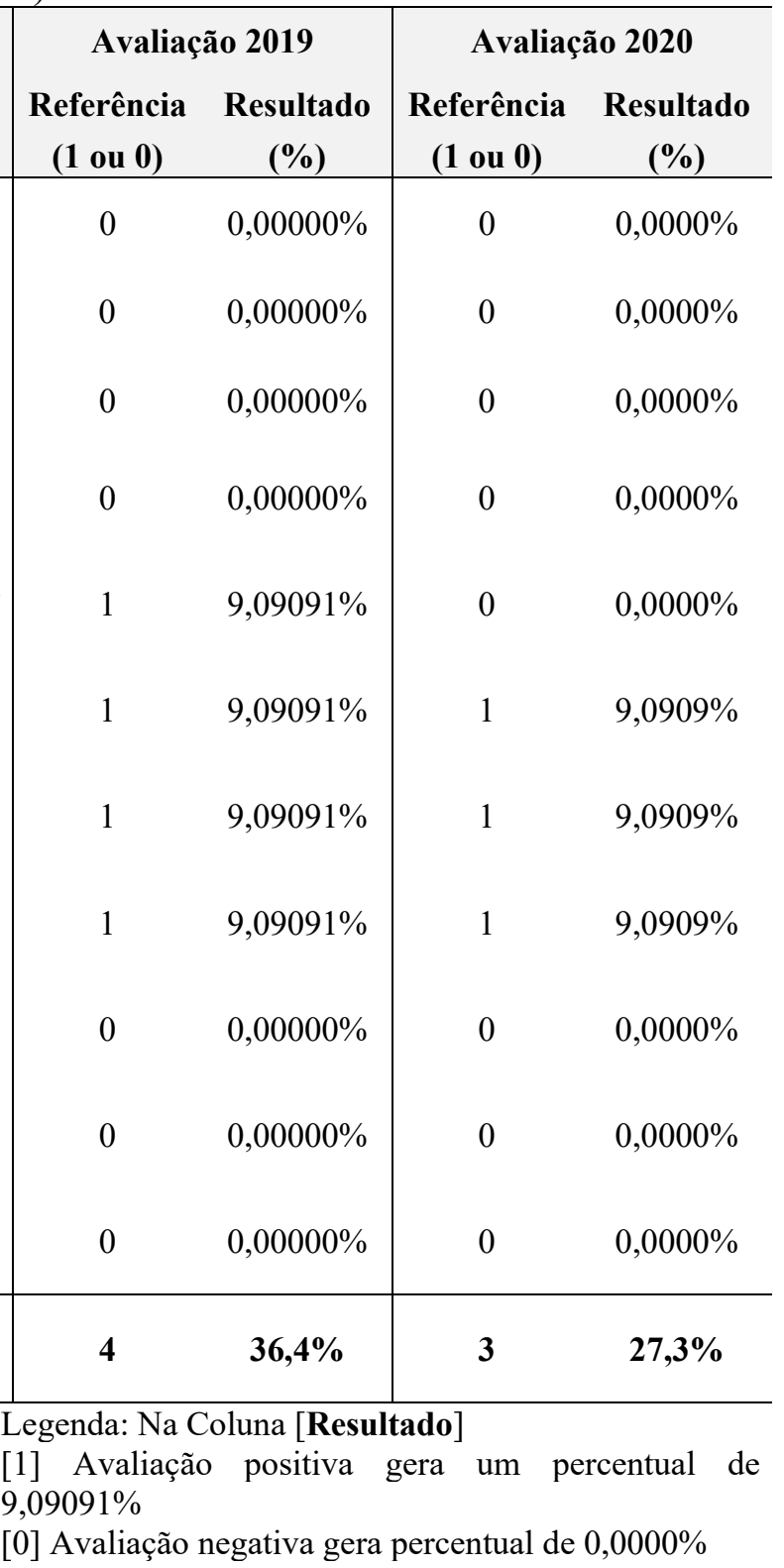


Tabela 46 - Produção na Comunidade Forte Veneza/Nova Colônia (2019)

\begin{tabular}{lccr|c}
\hline Produto & $\begin{array}{c}\text { Preço } \\
\text { Quantidade } \\
\text { e Unididade de Medida }\end{array}$ & $\begin{array}{c}\text { Valor } \\
\text { (R\$) }\end{array}$ & $\begin{array}{c}\text { recebido } \\
\text { (R\$) }\end{array}$ & \% \\
\hline Farinha (Saca de 50Kg) & 200 & 170,00 & $34.000,00$ & $31,72 \%$ \\
Pescado Fresco (Kg) & 5000 & 6,00 & $30.000,00$ & $27,99 \%$ \\
Pescado Seco (Kg) & 3000 & 7,00 & $21.000,00$ & $19,59 \%$ \\
Castanha (Hectolitro; 100 litros) & 35 & 250,00 & $8.750,00$ & $8,16 \%$ \\
Porco (Unidade) & 25 & 210,00 & $5.250,00$ & $4,90 \%$ \\
Banana (Cacho) & 90 & 15,00 & $1.350,00$ & $1,26 \%$ \\
Macaxeira (Kg) & 400 & 3,00 & $1.200,00$ & $1,12 \%$ \\
Melão (Unidade) & 200 & 5,00 & $1.000,00$ & $0,93 \%$ \\
Maxixe (Kg) & 200 & 5,00 & $1.000,00$ & $0,93 \%$ \\
Goma da Mandioca (Lata 20Kg) & 10 & 80,00 & 800,00 & $0,75 \%$ \\
Melancia (Unidade) & 150 & 5,00 & 750,00 & $0,70 \%$ \\
Batata-doce (Kg) & 150 & 4,00 & 600,00 & $0,56 \%$ \\
Feijão (Kg) & 110 & 5,00 & 550,00 & $0,51 \%$ \\
Pato (Unidade) & 15 & 20,00 & 300,00 & $0,28 \%$ \\
Jerimum (Unidade) & 100 & 3,00 & 300,00 & $0,28 \%$ \\
Açaí Beneficiado (Litro) & 50 & 4,00 & 200,00 & $0,19 \%$ \\
Galinha Caipira (Unidade) & 10 & 15,00 & 150,00 & $0,14 \%$ \\
\hline Valor total recebido (R\$) & & & $\mathbf{1 0 7 . 2 0 0 , 0 0}$ & $\mathbf{1 0 0 , 0 0 \%}$ \\
\hline
\end{tabular}

Tabela 47 - Produção na Comunidade Forte Veneza/Nova Colônia (2020)

\begin{tabular}{l|ccr|c}
\hline Produto & $\begin{array}{c}\text { Puantidade } \\
\text { Vendida }\end{array}$ & $\begin{array}{c}\text { Médio } \\
\text { (R\$) }\end{array}$ & $\begin{array}{c}\text { Valor } \\
\text { recebido } \\
\text { (R\$) }\end{array}$ & \% \\
\hline Pescado Fresco (Kg) & 5.400 & 5,00 & $27.000,00$ & $37,95 \%$ \\
Pescado Seco (Kg) & 3.550 & 6,00 & $21.300,00$ & $29,94 \%$ \\
Farinha (Saca de 50Kg) & 41 & 200,00 & $8.200,00$ & $11,53 \%$ \\
Melancia (Unidade) & 640 & 8,00 & $5.120,00$ & $7,20 \%$ \\
Castanha (Hectolitro; 100 litros) & 20 & 200,00 & $4.000,00$ & $5,62 \%$ \\
Feijão (Kg) & 310 & 6,00 & $1.860,00$ & $2,61 \%$ \\
Banana (Cacho) & 40 & 30,00 & $1.200,00$ & $1,69 \%$ \\
Jerimum (Unidade) & 150 & 5,00 & 750,00 & $1,05 \%$ \\
Melão (Unidade) & 120 & 6,00 & 720,00 & $1,01 \%$ \\
Açaí Fruto (Lata 18Kg) & 30 & 15,00 & 450,00 & $0,63 \%$ \\
Porco (Unidade) & 46 & 6,00 & 276,00 & $0,39 \%$ \\
Galinha Caipira (Unidade) & 5 & 25,00 & 125,00 & $0,18 \%$ \\
Porco (Kg) & 8 & 10,00 & 80,00 & $0,11 \%$ \\
Macaxeira (Kg) & 10 & 4,00 & 40,00 & $0,06 \%$ \\
Batata-doce (Kg) & 5 & 4,00 & 20,00 & $0,03 \%$ \\
\hline Valor total recebido (R\$) & & & $\mathbf{7 1 . 1 4 1 , 0 0}$ & $\mathbf{1 0 0 , 0 0 \%}$ \\
\hline & & & &
\end{tabular}




\section{Comunidade Santo Antônio do Apituã}

Quadro 21 - Dados gerais para Avaliação da Comunidade Santo Antônio do Apituã (20192020)

\begin{tabular}{|l|c|c|}
\hline \multicolumn{1}{|c|}{ Informaçães } & Ano 2019 & Ano 2020 \\
\hline Valor da Produção na Resex Canutama & $\mathrm{R} \$ 3.002 .952,00$ & $\mathrm{R} \$ 2.923 .589,36$ \\
\hline Média da Produção na Resex Canutama & $\mathrm{R} \$ 79.025,05$ & $\mathrm{R} \$ 76.936,56$ \\
\hline $\mathrm{N}^{\circ}$ de residentes na Comunidade & 18 & 18 \\
\hline $\mathrm{N}^{\circ}$ de produtos vendidos & 15 & $\mathrm{R} \$ 71.041,26$ \\
\hline Valor da Produção na Comunidade & $\mathrm{R} \$ 54.441,00$ & $\mathrm{R} \$ 3.946,74$ \\
\hline Produção Per capita da Comunidade & $\mathrm{R} \$ 3.024,50$ & $\mathrm{R} \$ 8.953,67$ \\
\hline $\begin{array}{l}\text { Média do PIB per capita dos municípios de Canutama } \\
\text { e Lábrea* }\end{array}$ & $\mathrm{R} \$ 8.953,67$ & \\
\hline
\end{tabular}

(*) Média com base no ano de 2018: PIB per capita de Lábrea (R\$ 10.941,94) e PIB per capita de Canutama (R\$ $6.965,40)$ - Último ano divulgado conforme dados do IBGE.

Tabela 48 - Sustentabilidade Financeira da Comunidade Santo Antônio do Apituã (20192020)

\begin{tabular}{|c|c|c|c|c|}
\hline \multirow[b]{2}{*}{$\begin{array}{l}\text { Parâmetros Avaliados } \\
\text { [A comunidade possui....] }\end{array}$} & \multicolumn{2}{|c|}{ Avaliação 2019} & \multicolumn{2}{|c|}{ Avaliação 2020} \\
\hline & $\begin{array}{l}\text { Referência } \\
(1 \text { ou } 0)\end{array}$ & $\begin{array}{c}\text { Resultado } \\
(\%)\end{array}$ & $\begin{array}{l}\text { Referência } \\
(1 \text { ou } 0)\end{array}$ & $\begin{array}{c}\text { Resultado } \\
(\%)\end{array}$ \\
\hline (1) Líder comunitário com perfil empreendedor & 0 & $0,00000 \%$ & 0 & $0,0000 \%$ \\
\hline (2) Controle de castanhal e exploração de castanhal & 0 & $0,00000 \%$ & 0 & $0,0000 \%$ \\
\hline (3) $\mathrm{N}^{\circ}$ mínimo de residentes $\geq 30$ pessoas & 0 & $0,00000 \%$ & 0 & $0,0000 \%$ \\
\hline $\begin{array}{l}\text { (4) Produção per capita da comunidade } \geq \text { média do PIB } \\
\text { per capita dos municípios Canutama e Lábrea }\end{array}$ & 0 & $0,00000 \%$ & 0 & $0,0000 \%$ \\
\hline $\begin{array}{l}\text { (5) Produção na Comunidade } \geq \text { média da produção total } \\
\text { na Resex Canutama }\end{array}$ & 0 & $0,00000 \%$ & 0 & $0,0000 \%$ \\
\hline $\begin{array}{l}\text { (6) Produção diversificada e contendo o produto } \\
\text { potencial 'Farinha' com produção } \geq 10 \%\end{array}$ & 1 & $9,09091 \%$ & 0 & $0,0000 \%$ \\
\hline $\begin{array}{l}\text { (7) Produção diversificada e contendo o produto } \\
\text { potencial 'Peixe Fresco' com produção } \geq 10 \%\end{array}$ & 1 & $9,09091 \%$ & 1 & $9,0909 \%$ \\
\hline $\begin{array}{l}\text { (8) Produção diversificada e contendo o produto } \\
\text { potencial 'Peixe Seco' com produção } \geq 10 \%\end{array}$ & 1 & $9,09091 \%$ & 1 & $9,0909 \%$ \\
\hline $\begin{array}{l}\text { (9) Produção diversificada e contendo o produto } \\
\text { potencial 'Porco' com produção } \geq 10 \%\end{array}$ & 0 & $0,00000 \%$ & 0 & $0,0000 \%$ \\
\hline $\begin{array}{l}\text { (10) Produção diversificada e contendo o produto } \\
\text { potencial 'Açaí' com produção } \geq 10 \%\end{array}$ & 0 & $0,00000 \%$ & 0 & $0,0000 \%$ \\
\hline $\begin{array}{l}\text { (11) Produção diversificada e contendo o produto } \\
\text { potencial 'Castanha' com produção } \geq 10 \%\end{array}$ & 0 & $0,00000 \%$ & 1 & $9,0909 \%$ \\
\hline $\begin{array}{l}\text { Índice de Sustentabilidade Financeira } \\
\text { (resultado arredondado) }\end{array}$ & 3 & $27,3 \%$ & 3 & $27,3 \%$ \\
\hline
\end{tabular}

Legenda: Na Coluna [Referência]

[1] Sim, a comunidade atende o parâmetro

[0] Não, a comunidade não atende o parâmetro

Fonte: Elaborado pela autora.
Legenda: Na Coluna [Resultado]

[1] Avaliação positiva gera um percentual de 9,09091\%

[0] Avaliação negativa gera percentual de 0,0000\% 
Tabela 49 - Produção na Comunidade Santo Antônio do Apituã (2019)

\begin{tabular}{|c|c|c|c|c|}
\hline $\begin{array}{l}\text { Produto } \\
\text { e Unidade de Medida }\end{array}$ & $\begin{array}{c}\text { Quantidade } \\
\text { Vendida } \\
\end{array}$ & $\begin{array}{l}\text { Preço } \\
\text { Médio } \\
\text { (R\$) }\end{array}$ & $\begin{array}{l}\text { Valor } \\
\text { recebido } \\
\text { (R\$) }\end{array}$ & $\%$ \\
\hline Pescado Fresco $(\mathrm{Kg})$ & 3000 & 6,00 & $18.000,00$ & $33,06 \%$ \\
\hline Farinha (Saca de $50 \mathrm{Kg}$ ) & 75 & 170,00 & $12.750,00$ & $23,42 \%$ \\
\hline Pescado Seco $(\mathrm{Kg})$ & 1300 & 7,00 & $9.100,00$ & $16,72 \%$ \\
\hline Melancia (Unidade) & 800 & 5,00 & $4.000,00$ & $7,35 \%$ \\
\hline Castanha (Hectolitro; 100 litros) & 15 & 250,00 & $3.750,00$ & $6,89 \%$ \\
\hline Jerimum (Unidade) & 500 & 3,00 & $1.500,00$ & $2,76 \%$ \\
\hline Andiroba semente (Lata $20 \mathrm{Kg}$ ) & 89 & 14,00 & $1.246,00$ & $2,29 \%$ \\
\hline Açaí Beneficiado (Litro) & 200 & 4,00 & 800,00 & $1,47 \%$ \\
\hline Maxixe (Kg) & 150 & 5,00 & 750,00 & $1,38 \%$ \\
\hline Macaxeira $(\mathrm{Kg})$ & 200 & 3,00 & 600,00 & $1,10 \%$ \\
\hline Banana (Cacho) & 35 & 15,00 & 525,00 & $0,96 \%$ \\
\hline Feijão (Kg) & 100 & 5,00 & 500,00 & $0,92 \%$ \\
\hline Pato (Unidade) & 20 & 20,00 & 400,00 & $0,73 \%$ \\
\hline Melão (Unidade) & 80 & 5,00 & 400,00 & $0,73 \%$ \\
\hline Murumuru semente (Lata $20 \mathrm{Kg}$ ) & 15 & 8,00 & 120,00 & $0,22 \%$ \\
\hline Valor total recebido $(\mathrm{R} \$)$ & & & $54.441,00$ & $100,00 \%$ \\
\hline
\end{tabular}

Tabela 50 - Produção na Comunidade Santo Antônio do Apituã (2020)

\begin{tabular}{|c|c|c|c|c|}
\hline $\begin{array}{l}\text { Produto } \\
\text { e Unidade de Medida }\end{array}$ & $\begin{array}{l}\text { Quantidade } \\
\text { Vendida }\end{array}$ & $\begin{array}{c}\text { Preço } \\
\text { Médio } \\
\text { (R\$) }\end{array}$ & $\begin{array}{c}\text { Valor } \\
\text { recebido } \\
\text { (R\$) }\end{array}$ & $\%$ \\
\hline Pescado Fresco (Kg) & 6.000 & 5,00 & $30.000,00$ & $42,23 \%$ \\
\hline Pescado Seco (Kg) & 2.570 & 6,00 & $15.420,00$ & $21,71 \%$ \\
\hline Castanha (Hectolitro; 100 litros) & 72 & 200,00 & $14.400,00$ & $20,27 \%$ \\
\hline Melancia (Unidade) & 430 & 8,00 & $3.440,00$ & $4,84 \%$ \\
\hline Murumuru semente (Lata $20 \mathrm{Kg}$ ) & 153 & 14,42 & $2.206,26$ & $3,11 \%$ \\
\hline Andiroba semente (Lata 20Kg) & 189 & 10,00 & $1.890,00$ & $2,66 \%$ \\
\hline Farinha (Saca de 50Kg) & 8 & 200,00 & $1.600,00$ & $2,25 \%$ \\
\hline Banana (Cacho) & 30 & 30,00 & 900,00 & $1,27 \%$ \\
\hline Copaíba Óleo (Kg) & 20 & 35,00 & 700,00 & $0,99 \%$ \\
\hline Feijão (Kg) & 30 & 6,00 & 180,00 & $0,25 \%$ \\
\hline Melão (Unidade) & 20 & 6,00 & 120,00 & $0,17 \%$ \\
\hline Jerimum (Unidade) & 15 & 5,00 & 75,00 & $0,11 \%$ \\
\hline Batata-doce $(\mathrm{Kg})$ & 15 & 4,00 & 60,00 & $0,08 \%$ \\
\hline Galinha Caipira (Unidade) & 2 & 25,00 & 50,00 & $0,07 \%$ \\
\hline Valor total recebido (R\$) & & & $71.041,26$ & $100,00 \%$ \\
\hline
\end{tabular}




\section{Comunidade São Jerônimo}

Quadro 22 - Dados gerais para Avaliação da Comunidade São Jerônimo (2019-2020)

\begin{tabular}{|l|c|c|}
\hline \multicolumn{1}{|c|}{ Informações } & Ano 2019 & Ano 2020 \\
\hline Valor da Produção na Resex Canutama & $\mathrm{R} \$ 3.002 .952,00$ & $\mathrm{R} \$ 2.923 .589,36$ \\
\hline Média da Produção na Resex Canutama & $\mathrm{R} \$ 79.025,05$ & $\mathrm{R} \$ 76.936,56$ \\
\hline $\mathrm{N}^{\circ}$ de residentes na Comunidade & 30 & 30 \\
\hline $\mathrm{N}^{\circ}$ de produtos vendidos & 13 & $\mathrm{R} \$ 68.042,00$ \\
\hline Valor da Produção na Comunidade & $\mathrm{R} \$ 51.370,00$ & $\mathrm{R} \$ 2.268,07$ \\
\hline Produção Per capita da Comunidade & $\mathrm{R} \$ 1.712,33$ & $\mathrm{R} \$ 8.953,67$ \\
\hline $\begin{array}{l}\text { Média do PIB per capita dos municípios de Canutama } \\
\text { e Lábrea* }\end{array}$ & $\mathrm{R} \$ 8.953,67$ & \\
\hline
\end{tabular}

(*) Média com base no ano de 2018: PIB per capita de Lábrea (R\$ 10.941,94) e PIB per capita de Canutama (R\$ $6.965,40)$ - Último ano divulgado conforme dados do IBGE.

Tabela 51 - Sustentabilidade Financeira da Comunidade São Jerônimo (2019-2020)

\begin{tabular}{|c|c|c|c|c|}
\hline \multirow{2}{*}{$\begin{array}{l}\text { Parâmetros Avaliados } \\
\text { [A comunidade possui...] }\end{array}$} & \multicolumn{2}{|c|}{ Avaliação 2019} & \multicolumn{2}{|c|}{ Avaliação 2020} \\
\hline & $\begin{array}{l}\text { Referência } \\
(1 \text { ou } 0)\end{array}$ & $\begin{array}{c}\text { Resultado } \\
(\%)\end{array}$ & $\begin{array}{l}\text { Referência } \\
\text { (1 ou 0) }\end{array}$ & $\begin{array}{c}\text { Resultado } \\
(\%)\end{array}$ \\
\hline (1) Líder comunitário com perfil empreendedor & 1 & $9,09091 \%$ & 1 & $9,0909 \%$ \\
\hline (2) Controle de castanhal e exploração de castanhal & 0 & $0,00000 \%$ & 0 & $0,0000 \%$ \\
\hline (3) $\mathrm{N}^{\circ}$ mínimo de residentes $\geq 30$ pessoas & 1 & $9,09091 \%$ & 1 & $9,0909 \%$ \\
\hline $\begin{array}{l}\text { (4) Produção per capita da comunidade } \geq \text { média do PIB } \\
\text { per capita dos municípios Canutama e Lábrea }\end{array}$ & 0 & $0,00000 \%$ & 0 & $0,0000 \%$ \\
\hline $\begin{array}{l}\text { (5) Produção na Comunidade } \geq \text { média da produção total } \\
\text { na Resex Canutama }\end{array}$ & 0 & $0,00000 \%$ & 0 & $0,0000 \%$ \\
\hline $\begin{array}{l}\text { (6) Produção diversificada e contendo o produto } \\
\text { potencial 'Farinha' com produção } \geq 10 \%\end{array}$ & 1 & $9,09091 \%$ & 0 & $0,0000 \%$ \\
\hline $\begin{array}{l}\text { (7) Produção diversificada e contendo o produto } \\
\text { potencial 'Peixe Fresco' com produção } \geq 10 \%\end{array}$ & 1 & $9,09091 \%$ & 1 & $9,0909 \%$ \\
\hline $\begin{array}{l}\text { (8) Produção diversificada e contendo o produto } \\
\text { potencial 'Peixe Seco' com produção } \geq 10 \%\end{array}$ & 0 & $0,00000 \%$ & 0 & $0,0000 \%$ \\
\hline $\begin{array}{l}\text { (9) Produção diversificada e contendo o produto } \\
\text { potencial 'Porco' com produção } \geq 10 \%\end{array}$ & 1 & $9,09091 \%$ & 0 & $0,0000 \%$ \\
\hline $\begin{array}{l}\text { (10) Produção diversificada e contendo o produto } \\
\text { potencial 'Açaí' com produção } \geq 10 \%\end{array}$ & 0 & $0,00000 \%$ & 0 & $0,0000 \%$ \\
\hline $\begin{array}{l}\text { (11) Produção diversificada e contendo o produto } \\
\text { potencial 'Castanha' com produção } \geq 10 \%\end{array}$ & 0 & $0,00000 \%$ & 1 & $9,0909 \%$ \\
\hline $\begin{array}{l}\text { Índice de Sustentabilidade Financeira } \\
\text { (resultado arredondado) }\end{array}$ & 5 & $45,5 \%$ & 4 & $36,4 \%$ \\
\hline $\begin{array}{l}\text { Legenda: Na Coluna [Referência] } \\
\text { [1] Sim, a comunidade atende o parâmetro } \\
\text { [0] Não, a comunidade não atende o parâmetro }\end{array}$ & $\begin{array}{l}\text { egenda: } \mathrm{NaC} \text { C } \\
\text { 1] Avaliaçã } \\
\text {,09091\% } \\
\text { 0] Avaliação }\end{array}$ & $\begin{array}{l}\text { oluna [Resu } \\
\text { positiva }\end{array}$ & percentual de & centual de \\
\hline
\end{tabular}

Fonte: Elaborado pela autora. 
Tabela 52 - Produção na Comunidade São Jerônimo (2019)

\begin{tabular}{lccc|c}
\hline Produto e & Preço & $\begin{array}{c}\text { Valor } \\
\text { Quantidade } \\
\text { Vendida }\end{array}$ & $\begin{array}{c}\text { Médio } \\
\text { (R\$) }\end{array}$ & $\begin{array}{c}\text { (R\$) } \\
\text { Unidade de Medida }\end{array}$ \\
\hline Porco (Unidade) & 70 & 210,00 & $14.700,00$ & $28,62 \%$ \\
Pescado Fresco (Kg) & 2000 & 6,00 & $12.000,00$ & $23,36 \%$ \\
Farinha (Saca de 50Kg) & 45 & 170,00 & $7.650,00$ & $14,89 \%$ \\
Melancia (Unidade) & 1300 & 5,00 & $6.500,00$ & $12,65 \%$ \\
Castanha (Hectolitro; 100 litros) & 20 & 250,00 & $5.000,00$ & $9,73 \%$ \\
Galinha Caipira (Unidade) & 100 & 15,00 & $1.500,00$ & $2,92 \%$ \\
Banana (Cacho) & 100 & 15,00 & $1.500,00$ & $2,92 \%$ \\
Jerimum (Unidade) & 300 & 3,00 & 900,00 & $1,75 \%$ \\
Macaxeira (Kg) & 200 & 3,00 & 600,00 & $1,17 \%$ \\
Goma da Mandioca (Lata 20Kg) & 5 & 80,00 & 400,00 & $0,78 \%$ \\
Feijão (Kg) & 70 & 5,00 & 350,00 & $0,68 \%$ \\
Maxixe (Kg) & 30 & 5,00 & 150,00 & $0,29 \%$ \\
Açaí Beneficiado (Litro) & 30 & 4,00 & 120,00 & $0,23 \%$ \\
\hline Valor total recebido (R\$) & & & $\mathbf{5 1 . 3 7 0 , 0 0}$ & $\mathbf{1 0 0 , 0 0 \%}$ \\
\hline
\end{tabular}

Tabela 53 - Produção na Comunidade São Jerônimo (2020)

\begin{tabular}{|c|c|c|c|c|}
\hline $\begin{array}{l}\text { Produto e } \\
\text { Unidade de Medida }\end{array}$ & $\begin{array}{c}\text { Quantidade } \\
\text { Vendida } \\
\end{array}$ & $\begin{array}{c}\text { Preço } \\
\text { Médio } \\
\text { (R\$) }\end{array}$ & $\begin{array}{c}\text { Valor } \\
\text { recebido } \\
(\mathbf{R} \$) \\
\end{array}$ & $\%$ \\
\hline Melancia (Unidade) & 2.225 & 8,00 & $17.800,00$ & $26,16 \%$ \\
\hline Pescado Fresco (Kg) & 2.000 & 5,00 & $10.000,00$ & $14,70 \%$ \\
\hline Castanha (Hectolitro; 100 litros) & 48 & 200,00 & $9.600,00$ & $14,11 \%$ \\
\hline Boi (Kg) & 600 & 16,00 & $9.600,00$ & $14,11 \%$ \\
\hline Milho Verde (Mão-50 espigas) & 300 & 25,00 & $7.500,00$ & $11,02 \%$ \\
\hline Farinha (Saca de 50Kg) & 20 & 200,00 & $4.000,00$ & $5,88 \%$ \\
\hline Açaí Fruto (Lata 18Kg) & 240 & 15,00 & $3.600,00$ & $5,29 \%$ \\
\hline Porco (Kg) & 250 & 10,00 & $2.500,00$ & $3,67 \%$ \\
\hline Banana (Cacho) & 50 & 30,00 & $1.500,00$ & $2,20 \%$ \\
\hline Pescado Seco $(\mathrm{Kg})$ & 200 & 6,00 & $1.200,00$ & $1,76 \%$ \\
\hline Porco (Unidade) & 43 & 6,00 & 258,00 & $0,38 \%$ \\
\hline Galinha Caipira (Unidade) & 10 & 25,00 & 250,00 & $0,37 \%$ \\
\hline Melão (Unidade) & 35 & 6,00 & 210,00 & $0,31 \%$ \\
\hline Batata-doce (Kg) & 6 & 4,00 & 24,00 & $0,04 \%$ \\
\hline Valor total recebido (R\$) & & & $68.042,00$ & $100,00 \%$ \\
\hline
\end{tabular}




\section{Comunidade Carmo}

Quadro 23 - Dados gerais para Avaliação da Comunidade Carmo (2019-2020)

\begin{tabular}{|l|c|c|}
\hline \multicolumn{1}{|c|}{ Informações } & Ano 2019 & Ano 2020 \\
\hline Valor da Produção na Resex Canutama & $\mathrm{R} \$ 3.002 .952,00$ & $\mathrm{R} \$ 2.923 .589,36$ \\
\hline Média da Produção na Resex Canutama & $\mathrm{R} \$ 79.025,05$ & $\mathrm{R} \$ 76.936,56$ \\
\hline $\mathrm{N}^{\circ}$ de residentes na Comunidade & 35 & 35 \\
\hline $\mathrm{N}^{\circ}$ de produtos vendidos & 16 & 11 \\
\hline Valor da Produção na Comunidade & $\mathrm{R} \$ 61.810,00$ & $\mathrm{R} \$ 63.169,00$ \\
\hline Produção Per capita da Comunidade & $\mathrm{R} \$ 1.766,00$ & $\mathrm{R} \$ 1.804,83$ \\
\hline $\begin{array}{l}\text { Média do PIB per capita dos municípios de Canutama } \\
\text { e Lábrea* }\end{array}$ & $\mathrm{R} \$ 8.953,67$ & $\mathrm{R} \$ 8.953,67$ \\
\hline
\end{tabular}

(*) Média com base no ano de 2018: PIB per capita de Lábrea (R\$ 10.941,94) e PIB per capita de Canutama (R\$ $6.965,40)$ - Último ano divulgado conforme dados do IBGE.

Tabela 54 - Sustentabilidade Financeira da Comunidade Carmo (2019-2020)

\begin{tabular}{|c|c|c|c|c|}
\hline \multirow{2}{*}{$\begin{array}{l}\text { Parâmetros Avaliados } \\
\text { [A comunidade possui...] }\end{array}$} & \multicolumn{2}{|c|}{ Avaliação 2019} & \multicolumn{2}{|c|}{ Avaliação 2020} \\
\hline & $\begin{array}{l}\text { Referência } \\
(1 \text { ou 0) }\end{array}$ & $\begin{array}{c}\text { Resultado } \\
(\%) \\
\end{array}$ & $\begin{array}{c}\text { Referência } \\
\text { (1 ou 0) }\end{array}$ & $\begin{array}{c}\text { Resultado } \\
(\%)\end{array}$ \\
\hline (1) Líder comunitário com perfil empreendedor & 0 & $0,00000 \%$ & 0 & $0,0000 \%$ \\
\hline (2) Controle de castanhal e exploração de castanhal & 0 & $0,00000 \%$ & 0 & $0,0000 \%$ \\
\hline (3) $\mathrm{N}^{\circ}$ mínimo de residentes $\geq 30$ pessoas & 1 & $9,09091 \%$ & 1 & $9,0909 \%$ \\
\hline $\begin{array}{l}\text { (4) Produção per capita da comunidade } \geq \text { média do PIB } \\
\text { per capita dos municípios Canutama e Lábrea }\end{array}$ & 0 & $0,00000 \%$ & 0 & $0,0000 \%$ \\
\hline $\begin{array}{l}\text { (5) Produção na Comunidade } \geq \text { média da produção total } \\
\text { na Resex Canutama }\end{array}$ & 0 & $0,00000 \%$ & 0 & $0,0000 \%$ \\
\hline $\begin{array}{l}\text { (6) Produção diversificada e contendo o produto potencial } \\
\text { 'Farinha' com produção } \geq 10 \%\end{array}$ & 1 & $9,09091 \%$ & 0 & $0,0000 \%$ \\
\hline $\begin{array}{l}\text { (7) Produção diversificada e contendo o produto potencial } \\
\text { 'Peixe Fresco' com produção } \geq 10 \%\end{array}$ & 1 & $9,09091 \%$ & 1 & $9,0909 \%$ \\
\hline $\begin{array}{l}\text { (8) Produção diversificada e contendo o produto potencial } \\
\text { 'Peixe Seco' com produção } \geq 10 \%\end{array}$ & 0 & $0,00000 \%$ & 1 & $9,0909 \%$ \\
\hline $\begin{array}{l}\text { (9) Produção diversificada e contendo o produto potencial } \\
\text { 'Porco' com produção } \geq 10 \%\end{array}$ & 0 & $0,00000 \%$ & 0 & $0,0000 \%$ \\
\hline $\begin{array}{l}\text { (10) Produção diversificada e contendo o produto } \\
\text { potencial 'Açaí' com produção } \geq 10 \%\end{array}$ & 1 & $9,09091 \%$ & 0 & $0,0000 \%$ \\
\hline $\begin{array}{l}\text { (11) Produção diversificada e contendo o produto } \\
\text { potencial 'Castanha' com produção } \geq 10 \%\end{array}$ & 0 & $0,00000 \%$ & 0 & $0,0000 \%$ \\
\hline $\begin{array}{l}\text { Índice de Sustentabilidade Financeira } \\
\text { (resultado arredondado) }\end{array}$ & 4 & $36,4 \%$ & 3 & $27,3 \%$ \\
\hline
\end{tabular}

Legenda: Na Coluna [Referência]

[1] Sim, a comunidade atende o parâmetro

[0] Não, a comunidade não atende o parâmetro

Fonte: Elaborado pela autora.
Legenda: Na Coluna [Resultado]

[1] Avaliação positiva gera um percentual de 9,09091\%

[0] Avaliação negativa gera percentual de $0,0000 \%$ 
Tabela 55 - Produção na Comunidade Carmo (2019)

\begin{tabular}{lccr|c}
\hline Produto & $\begin{array}{c}\text { Quantidade } \\
\text { Vendida }\end{array}$ & $\begin{array}{c}\text { Preço } \\
\text { Médio } \\
\text { (R\$) }\end{array}$ & $\begin{array}{c}\text { Valor } \\
\text { recebido } \\
\text { (R\$) }\end{array}$ & \%nidade de Medida \\
\hline Açaí Fruto (Lata 18Kg) & 1200 & 18,00 & $21.600,00$ & $34,95 \%$ \\
Farinha (Saca de 50Kg) & 76 & 170,00 & $12.920,00$ & $20,90 \%$ \\
Pescado Fresco (Kg) & 2000 & 6,00 & $12.000,00$ & $19,41 \%$ \\
Galinha Caipira (Unidade) & 200 & 15,00 & $3.000,00$ & $4,85 \%$ \\
Feijão (Kg) & 500 & 5,00 & $2.500,00$ & $4,04 \%$ \\
Castanha (Hectolitro; 100 litros) & 8 & 250,00 & $2.000,00$ & $3,24 \%$ \\
Melancia (Unidade) & 250 & 5,00 & $1.250,00$ & $2,02 \%$ \\
Macaxeira (Kg) & 400 & 3,00 & $1.200,00$ & $1,94 \%$ \\
Jerimum (Unidade) & 400 & 3,00 & $1.200,00$ & $1,94 \%$ \\
Maxixe (Kg) & 200 & 5,00 & $1.000,00$ & $1,62 \%$ \\
Melão (Unidade) & 200 & 5,00 & $1.000,00$ & $1,62 \%$ \\
Milho Verde (Mão-50 espigas) & 30 & 25,00 & 750,00 & $1,21 \%$ \\
Batata-doce (Kg) & 150 & 4,00 & 600,00 & $0,97 \%$ \\
Pato (Unidade) & 20 & 20,00 & 400,00 & $0,65 \%$ \\
Goma da Mandioca (Lata 20Kg) & 3 & 80,00 & 240,00 & $0,39 \%$ \\
Milho Seco (Kg) & 100 & 1,50 & 150,00 & $0,24 \%$ \\
\hline Valor total recebido (R\$) & & & $\mathbf{6 1 . 8 1 0 , 0 0}$ & $\mathbf{1 0 0 , 0 0 \%}$ \\
\hline
\end{tabular}

Tabela 56 - Produção na Comunidade Carmo (2020)

\begin{tabular}{l|ccr|c}
\hline Produto & $\begin{array}{c}\text { Preço } \\
\text { Quantidade } \\
\text { Vendida }\end{array}$ & $\begin{array}{c}\text { Médio } \\
\text { (R\$) }\end{array}$ & $\begin{array}{c}\text { Valor } \\
\text { recebido } \\
\text { (R\$) }\end{array}$ & \% \\
\hline Pescado Fresco (Kg) & 7.000 & 5,00 & $35.000,00$ & $55,41 \%$ \\
Pescado Seco (Kg) & 1.500 & 6,00 & $9.000,00$ & $14,25 \%$ \\
Açaí Fruto (Lata 18Kg) & 350 & 15,00 & $5.250,00$ & $8,31 \%$ \\
Farinha (Saca de 50Kg) & 23 & 200,00 & $4.600,00$ & $7,28 \%$ \\
Feijão (Kg) & 720 & 6,00 & $4.320,00$ & $6,84 \%$ \\
Melancia (Unidade) & 393 & 8,00 & $3.144,00$ & $4,98 \%$ \\
Castanha (Hectolitro; 100 litros) & 6 & 200,00 & $1.200,00$ & $1,90 \%$ \\
Galinha Caipira (Unidade) & 15 & 25,00 & 375,00 & $0,59 \%$ \\
Melão (Unidade) & 25 & 6,00 & 150,00 & $0,24 \%$ \\
Batata-doce (Kg) & 20 & 4,00 & 80,00 & $0,13 \%$ \\
Porco (Kg) & 5 & 10,00 & 50,00 & $0,08 \%$ \\
\hline Valor total recebido (R\$) & & & $\mathbf{6 3 . 1 6 9 , 0 0}$ & $\mathbf{1 0 0 , 0 0 \%}$ \\
\hline
\end{tabular}




\section{Comunidade Boca do Gavião}

Quadro 24 - Dados gerais para Avaliação da Comunidade Boca do Gavião (2019-2020)

\begin{tabular}{|l|c|c|}
\hline \multicolumn{1}{|c|}{ Informaç̃̃es } & Ano 2019 & Ano 2020 \\
\hline Valor da Produção na Resex Canutama & $\mathrm{R} \$ 3.002 .952,00$ & $\mathrm{R} \$ 2.923 .589,36$ \\
\hline Média da Produção na Resex Canutama & $\mathrm{R} \$ 79.025,05$ & $\mathrm{R} \$ 76.936,56$ \\
\hline $\mathrm{N}^{\circ}$ de residentes na Comunidade & 25 & 25 \\
\hline $\mathrm{N}^{\circ}$ de produtos vendidos & 11 & 11 \\
\hline Valor da Produção na Comunidade & $\mathrm{R} \$ 65.162,00$ & $\mathrm{R} \$ 61.552,92$ \\
\hline Produção Per capita da Comunidade & $\mathrm{R} \$ 2.606,48$ & $\mathrm{R} \$ 2.462,12$ \\
\hline $\begin{array}{l}\text { Média do PIB per capita dos municípios de Canutama } \\
\text { e Lábrea* }\end{array}$ & $\mathrm{R} \$ 8.953,67$ & $\mathrm{R} \$ 8.953,67$ \\
\hline
\end{tabular}

(*) Média com base no ano de 2018: PIB per capita de Lábrea (R\$10.941,94) e PIB per capita de Canutama (R\$ $6.965,40)$ - Último ano divulgado conforme dados do IBGE.

Tabela 57 - Sustentabilidade Financeira da Comunidade Boca do Gavião (2019-2020)

\begin{tabular}{|c|c|c|c|c|}
\hline \multirow[b]{2}{*}{$\begin{array}{l}\text { Parâmetros Avaliados } \\
\text { [A comunidade possui....] }\end{array}$} & \multicolumn{2}{|c|}{ Avaliação 2019} & \multicolumn{2}{|c|}{ Avaliação 2020} \\
\hline & $\begin{array}{l}\text { Referência } \\
(1 \text { ou } 0)\end{array}$ & $\begin{array}{c}\text { Resultado } \\
(\%)\end{array}$ & $\begin{array}{c}\text { Referência } \\
\text { (1 ou 0) }\end{array}$ & $\begin{array}{c}\text { Resultado } \\
(\%)\end{array}$ \\
\hline (1) Líder comunitário com perfil empreendedor & 0 & $0,00000 \%$ & 0 & $0,0000 \%$ \\
\hline (2) Controle de castanhal e exploração de castanhal & 0 & $0,00000 \%$ & 0 & $0,0000 \%$ \\
\hline (3) $\mathrm{N}^{\circ}$ mínimo de residentes $\geq 30$ pessoas & 0 & $0,00000 \%$ & 0 & $0,0000 \%$ \\
\hline $\begin{array}{l}\text { (4) Produção per capita da comunidade } \geq \text { média do PIB } \\
\text { per capita dos municípios Canutama e Lábrea }\end{array}$ & 0 & $0,00000 \%$ & 0 & $0,0000 \%$ \\
\hline $\begin{array}{l}\text { (5) Produção na Comunidade } \geq \text { média da produção total } \\
\text { na Resex Canutama }\end{array}$ & 0 & $0,00000 \%$ & 0 & $0,0000 \%$ \\
\hline $\begin{array}{l}\text { (6) Produção diversificada e contendo o produto } \\
\text { potencial 'Farinha' com produção } \geq 10 \%\end{array}$ & 0 & $0,00000 \%$ & 0 & $0,0000 \%$ \\
\hline $\begin{array}{l}\text { (7) Produção diversificada e contendo o produto } \\
\text { potencial 'Peixe Fresco' com produção } \geq 10 \%\end{array}$ & 0 & $0,00000 \%$ & 1 & $9,0909 \%$ \\
\hline $\begin{array}{l}\text { (8) Produção diversificada e contendo o produto } \\
\text { potencial 'Peixe Seco' com produção } \geq 10 \%\end{array}$ & 1 & $9,09091 \%$ & 1 & $9,0909 \%$ \\
\hline $\begin{array}{l}\text { (9) Produção diversificada e contendo o produto } \\
\text { potencial 'Porco' com produção } \geq 10 \%\end{array}$ & 1 & $9,09091 \%$ & 0 & $0,0000 \%$ \\
\hline $\begin{array}{l}\text { (10) Produção diversificada e contendo o produto } \\
\text { potencial 'Açaí' com produção } \geq 10 \%\end{array}$ & 0 & $0,00000 \%$ & 0 & $0,0000 \%$ \\
\hline $\begin{array}{l}\text { (11) Produção diversificada e contendo o produto } \\
\text { potencial 'Castanha' com produção } \geq 10 \%\end{array}$ & 0 & $0,00000 \%$ & 0 & $0,0000 \%$ \\
\hline $\begin{array}{l}\text { Índice de Sustentabilidade Financeira } \\
\text { (resultado arredondado) }\end{array}$ & 2 & $18,2 \%$ & 2 & $18,2 \%$ \\
\hline
\end{tabular}

Legenda: Na Coluna [Referência]

[1] Sim, a comunidade atende o parâmetro

[0] Não, a comunidade não atende o parâmetro

Fonte: Elaborado pela autora.
Legenda: Na Coluna [Resultado]

[1] Avaliação positiva gera um percentual de 9,09091\%

[0] Avaliação negativa gera percentual de 0,0000\% 
Tabela 58 - Produção na Comunidade Boca do Gavião (2019)

\begin{tabular}{|c|c|c|c|c|}
\hline Produto e Unidade de Medida & $\begin{array}{l}\text { Quantidade } \\
\text { Vendida }\end{array}$ & $\begin{array}{c}\text { Preço } \\
\text { Médio } \\
\text { (R\$) }\end{array}$ & $\begin{array}{c}\text { Valor } \\
\text { recebido (R\$) }\end{array}$ & $\%$ \\
\hline Porco (Unidade) & 150 & 210,00 & $31.500,00$ & $48,34 \%$ \\
\hline Pescado Seco (Kg) & 2500 & 7,00 & $17.500,00$ & $26,86 \%$ \\
\hline Melancia (Unidade) & 2000 & 5,00 & $10.000,00$ & $15,35 \%$ \\
\hline Farinha (Saca de 50Kg) & 15 & 170,00 & $2.550,00$ & $3,91 \%$ \\
\hline Jerimum (Unidade) & 300 & 3,00 & 900,00 & $1,38 \%$ \\
\hline Galinha Caipira (Unidade) & 50 & 15,00 & 750,00 & $1,15 \%$ \\
\hline Feijão (Kg) & 150 & 5,00 & 750,00 & $1,15 \%$ \\
\hline Açaí Beneficiado (Litro) & 150 & 4,00 & 600,00 & $0,92 \%$ \\
\hline Milho Verde (Mão-50 espigas) & 20 & 25,00 & 500,00 & $0,77 \%$ \\
\hline Melão (Unidade) & 20 & 5,00 & 100,00 & $0,15 \%$ \\
\hline Pescado Fresco $(\mathrm{Kg})$ & 2 & 6,00 & 12,00 & $0,02 \%$ \\
\hline Valor total recebido $(\mathrm{R} \$)$ & & & $65.162,00$ & $100,00 \%$ \\
\hline
\end{tabular}

Tabela 59 - Produção na Comunidade Boca do Gavião (2020)

\begin{tabular}{l|ccr|c}
\hline Produto e & $\begin{array}{c}\text { Preço } \\
\text { Quantidade } \\
\text { Vendidade de Medida }\end{array}$ & $\begin{array}{c}\text { Médio } \\
\text { (R\$) }\end{array}$ & $\begin{array}{c}\text { Valor } \\
\text { recebido } \\
\text { (R\$) }\end{array}$ & $\%$ \\
\hline Pescado Fresco (Kg) & 6.000 & 5,00 & $30.000,00$ & $48,74 \%$ \\
Pescado Seco (Kg) & 2.000 & 6,00 & $12.000,00$ & $19,50 \%$ \\
Farinha (Saca de 50Kg) & 30 & 200,00 & $6.000,00$ & $9,75 \%$ \\
Andiroba semente (Lata 20Kg) & 448 & 10,00 & $4.480,00$ & $7,28 \%$ \\
Melancia (Unidade) & 500 & 8,00 & $4.000,00$ & $6,50 \%$ \\
Murumuru semente (Lata 20Kg) & 276 & 14,42 & $3.979,92$ & $6,47 \%$ \\
Porco (Kg) & 50 & 10,00 & 500,00 & $0,81 \%$ \\
Feijão (Kg) & 40 & 6,00 & 240,00 & $0,39 \%$ \\
Melão (Unidade) & 30 & 6,00 & 180,00 & $0,29 \%$ \\
Galinha Caipira (Unidade) & 5 & 25,00 & 125,00 & $0,20 \%$ \\
Batata-doce (Kg) & 12 & 4,00 & 48,00 & $0,08 \%$ \\
\hline Valor total recebido (R\$) & & & $\mathbf{6 1 . 5 5 2 , 9 2}$ & $\mathbf{1 0 0 , 0 0 \%}$ \\
\hline & & &
\end{tabular}




\section{Comunidade São Tomé}

Quadro 25 - Dados gerais para Avaliação da Comunidade São Tomé (2019-2020)

\begin{tabular}{|c|c|c|}
\hline Informações & Ano 2019 & Ano 2020 \\
\hline Valor da Produção na Resex Canutama & $\mathrm{R} \$ 3.002 .952,00$ & $\mathrm{R} \$ 2.923 .589,36$ \\
\hline Média da Produção na Resex Canutama & $\mathrm{R} \$ 79.025,05$ & $\mathrm{R} \$ 76.936,56$ \\
\hline $\mathrm{N}^{o}$ de residentes na Comunidade & 11 & 11 \\
\hline $\mathrm{N}^{\circ}$ de produtos vendidos & 15 & 9 \\
\hline Valor da Produção na Comunidade & $\mathrm{R} \$ 44.760,00$ & $\mathrm{R} \$ 59.060,00$ \\
\hline Produção Per capita da Comunidade & $\mathrm{R} \$ 2.606,48$ & $\mathrm{R} \$ 5.369,09$ \\
\hline $\begin{array}{l}\text { Média do PIB per capita dos municípios de Canutama } \\
\text { e Lábrea* }\end{array}$ & $\mathrm{R} \$ 8.953,67$ & $\mathrm{R} \$ 8.953,67$ \\
\hline
\end{tabular}

(*) Média com base no ano de 2018: PIB per capita de Lábrea (R\$ 10.941,94) e PIB per capita de Canutama (R\$ $6.965,40)$ - Último ano divulgado conforme dados do IBGE.

Tabela 60 - Sustentabilidade Financeira da Comunidade São Tomé (2019-2020)

\begin{tabular}{|c|c|c|c|c|}
\hline \multirow[b]{2}{*}{$\begin{array}{l}\text { Parâmetros Avaliados } \\
\text { [A comunidade possui...] }\end{array}$} & \multicolumn{2}{|c|}{ Avaliação 2019} & \multicolumn{2}{|c|}{ Avaliação 2020} \\
\hline & $\begin{array}{c}\text { Referência } \\
\text { (1 ou 0) }\end{array}$ & $\begin{array}{c}\text { Resultado } \\
(\%)\end{array}$ & $\begin{array}{c}\text { Referência } \\
\text { (1 ou 0) }\end{array}$ & $\begin{array}{c}\text { Resultado } \\
(\%)\end{array}$ \\
\hline (1) Líder comunitário com perfil empreendedor & 0 & $0,00000 \%$ & 0 & $0,0000 \%$ \\
\hline (2) Controle de castanhal e exploração de castanhal & 1 & $9,09091 \%$ & 1 & $9,0909 \%$ \\
\hline (3) $\mathrm{N}^{\circ}$ mínimo de residentes $\geq 30$ pessoas & 0 & $0,00000 \%$ & 0 & $0,0000 \%$ \\
\hline $\begin{array}{l}\text { (4) Produção per capita da comunidade } \geq \text { média do PIB } \\
\text { per capita dos municípios Canutama e Lábrea }\end{array}$ & 0 & $0,00000 \%$ & 0 & $0,0000 \%$ \\
\hline $\begin{array}{l}\text { (5) Produção na Comunidade } \geq \text { média da produção total } \\
\text { na Resex Canutama }\end{array}$ & 0 & $0,00000 \%$ & 0 & $0,0000 \%$ \\
\hline $\begin{array}{l}\text { (6) Produção diversificada e contendo o produto } \\
\text { potencial 'Farinha' com produção } \geq 10 \%\end{array}$ & 0 & $0,00000 \%$ & 1 & $9,0909 \%$ \\
\hline $\begin{array}{l}\text { (7) Produção diversificada e contendo o produto } \\
\text { potencial 'Peixe Fresco' com produção } \geq 10 \%\end{array}$ & 1 & $9,09091 \%$ & 1 & $9,0909 \%$ \\
\hline $\begin{array}{l}\text { (8) Produção diversificada e contendo o produto } \\
\text { potencial 'Peixe Seco' com produção } \geq 10 \%\end{array}$ & 0 & $0,00000 \%$ & 0 & $0,0000 \%$ \\
\hline $\begin{array}{l}\text { (9) Produção diversificada e contendo o produto } \\
\text { potencial 'Porco' com produção } \geq 10 \%\end{array}$ & 0 & $0,00000 \%$ & 0 & $0,0000 \%$ \\
\hline $\begin{array}{l}\text { (10) Produção diversificada e contendo o produto } \\
\text { potencial 'Açaí' com produção } \geq 10 \%\end{array}$ & 0 & $0,00000 \%$ & 0 & $0,0000 \%$ \\
\hline $\begin{array}{l}\text { (11) Produção diversificada e contendo o produto } \\
\text { potencial 'Castanha' com produção } \geq 10 \%\end{array}$ & 1 & $9,09091 \%$ & 1 & $9,0909 \%$ \\
\hline $\begin{array}{l}\text { Índice de Sustentabilidade Financeira } \\
\text { (resultado arredondado) }\end{array}$ & 3 & $27,3 \%$ & 4 & $36,4 \%$ \\
\hline $\begin{array}{l}\text { Legenda: Na Coluna [Referência] } \\
\text { [1] Sim, a comunidade atende o parâmetro } \\
\text { [0] Não, a comunidade não atende o parâmetro }\end{array}$ & $\begin{array}{l}\text { Legenda: } \mathrm{NaC} \\
\text { [1] Avaliaçã } \\
9,09091 \% \\
\text { [0] Avaliação }\end{array}$ & $\begin{array}{l}\text { luna }[\text { Rest } \\
\text { positiva }\end{array}$ & $\begin{array}{l}\text { ado] } \\
\text { era um p }\end{array}$ & $\begin{array}{l}\text { centual de } \\
0000 \%\end{array}$ \\
\hline
\end{tabular}

Fonte: Elaborado pela autora. 
Tabela 61 - Produção na Comunidade São Tomé (2019)

\begin{tabular}{lccc|c}
\hline Produto & $\begin{array}{c}\text { Preço } \\
\text { Quantidade } \\
\text { Vendida }\end{array}$ & $\begin{array}{c}\text { Médio } \\
\text { (R\$) }\end{array}$ & $\begin{array}{c}\text { Valor } \\
\text { recebido } \\
\text { (R\$) }\end{array}$ & \% \\
\hline Castanha (Hectolitro; 100 litros) & 120 & 250,00 & $30.000,00$ & $67,02 \%$ \\
Pescado Fresco (Kg) & 900 & 6,00 & $5.400,00$ & $12,06 \%$ \\
Farinha (Saca de 50Kg) & 25 & 170,00 & $4.250,00$ & $9,50 \%$ \\
Macaxeira (Kg) & 400 & 3,00 & $1.200,00$ & $2,68 \%$ \\
Galinha Caipira (Unidade) & 68 & 15,00 & $1.020,00$ & $2,28 \%$ \\
Feijão (Kg) & 100 & 5,00 & 500,00 & $1,12 \%$ \\
Maxixe (Kg) & 100 & 5,00 & 500,00 & $1,12 \%$ \\
Batata-doce (Kg) & 100 & 4,00 & 400,00 & $0,89 \%$ \\
Melancia (Unidade) & 80 & 5,00 & 400,00 & $0,89 \%$ \\
Banana (Cacho) & 20 & 15,00 & 300,00 & $0,67 \%$ \\
Milho Verde (Mão-50 espigas) & 10 & 25,00 & 250,00 & $0,56 \%$ \\
Jerimum (Unidade) & 60 & 3,00 & 180,00 & $0,40 \%$ \\
Açaí Beneficiado (Litro) & 40 & 4,00 & 160,00 & $0,36 \%$ \\
Milho Seco (Kg) & 100 & 1,50 & 150,00 & $0,34 \%$ \\
Melão (Unidade) & 10 & 5,00 & 50,00 & $0,11 \%$ \\
\hline Valor total recebido & (R\$) & & $\mathbf{4 4 . 7 6 0 , 0 0}$ & $\mathbf{1 0 0 , 0 0 \%}$ \\
\hline
\end{tabular}

Tabela 62 - Produção na Comunidade São Tomé (2020)

\begin{tabular}{l|ccr|c}
\hline Produto & $\begin{array}{c}\text { Quantidade } \\
\text { Vendida }\end{array}$ & $\begin{array}{c}\text { Preço } \\
\text { Médio } \\
\text { e Unidade de Medida }\end{array}$ & $\begin{array}{c}\text { Valor } \\
\text { recebido } \\
\text { (R\$) }\end{array}$ & \% \\
\hline Castanha (Hectolitro; 100 litros) & 186 & 200,00 & $37.200,00$ & $62,99 \%$ \\
Pescado Fresco (Kg) & 2.000 & 5,00 & $10.000,00$ & $16,93 \%$ \\
Farinha (Saca de 50Kg) & 38 & 200,00 & $7.600,00$ & $12,87 \%$ \\
Pescado Seco (Kg) & 300 & 6,00 & $1.800,00$ & $3,05 \%$ \\
Melancia (Unidade) & 200 & 8,00 & $1.600,00$ & $2,71 \%$ \\
Feijão (Kg) & 80 & 6,00 & 480,00 & $0,81 \%$ \\
Galinha Caipira (Unidade) & 10 & 25,00 & 250,00 & $0,42 \%$ \\
Melão (Unidade) & 15 & 6,00 & 90,00 & $0,15 \%$ \\
Batata-doce (Kg) & 10 & 4,00 & 40,00 & $0,07 \%$ \\
\hline Valor total recebido (R\$) & & & $\mathbf{5 9 . 0 6 0 , 0 0}$ & $\mathbf{1 0 0 , 0 0 \%}$ \\
\hline
\end{tabular}




\section{Comunidade Capoeirinha}

Quadro 26 - Dados gerais para Avaliação da Comunidade Capoeirinha (2019-2020)

\begin{tabular}{|c|c|c|}
\hline Informações & Ano 2019 & Ano 2020 \\
\hline Valor da Produção na Resex Canutama & $\mathrm{R} \$ 3.002 .952,00$ & $\mathrm{R} \$ 2.923 .589,36$ \\
\hline Média da Produção na Resex Canutama & $\mathrm{R} \$ 79.025,05$ & $\mathrm{R} \$ 76.936,56$ \\
\hline $\mathrm{N}^{o}$ de residentes na Comunidade & 10 & 10 \\
\hline $\mathrm{N}^{\circ}$ de produtos vendidos & 15 & 3 \\
\hline Valor da Produção na Comunidade & $\mathrm{R} \$ 59.705,00$ & $\mathrm{R} \$ 37.000,00$ \\
\hline Produção Per capita da Comunidade & $\mathrm{R} \$ 2.606,48$ & $\mathrm{R} \$ 3.700,00$ \\
\hline $\begin{array}{l}\text { Média do PIB per capita dos municípios de Canutama } \\
\text { e Lábrea* }\end{array}$ & $\mathrm{R} \$ 8.953,67$ & $\mathrm{R} \$ 8.953,67$ \\
\hline
\end{tabular}

(*) Média com base no ano de 2018: PIB per capita de Lábrea (R\$10.941,94) e PIB per capita de Canutama (R\$ $6.965,40)$ - Último ano divulgado conforme dados do IBGE.

Tabela 63 - Sustentabilidade Financeira da Comunidade Capoeirinha (2019-2020)

\begin{tabular}{|c|c|c|c|c|}
\hline \multirow[b]{2}{*}{$\begin{array}{l}\text { Parâmetros Avaliados } \\
\text { [A comunidade possui...] }\end{array}$} & \multicolumn{2}{|c|}{ Avaliação 2019} & \multicolumn{2}{|c|}{ Avaliação 2020} \\
\hline & $\begin{array}{c}\text { Referência } \\
\text { (1 ou 0) }\end{array}$ & $\begin{array}{c}\text { Resultado } \\
(\%) \\
\end{array}$ & $\begin{array}{c}\text { Referência } \\
(1 \text { ou } 0)\end{array}$ & $\begin{array}{c}\text { Resultado } \\
(\%) \\
\end{array}$ \\
\hline (1) Líder comunitário com perfil empreendedor & 0 & $0,00000 \%$ & 0 & $0,0000 \%$ \\
\hline (2) Controle de castanhal e exploração de castanhal & 0 & $0,00000 \%$ & 0 & $0,0000 \%$ \\
\hline (3) $\mathrm{N}^{\circ}$ mínimo de residentes $\geq 30$ pessoas & 0 & $0,00000 \%$ & 0 & $0,0000 \%$ \\
\hline $\begin{array}{l}\text { (4) Produção per capita da comunidade } \geq \text { média do PIB } \\
\text { per capita dos municípios Canutama e Lábrea }\end{array}$ & 0 & $0,00000 \%$ & 0 & $0,0000 \%$ \\
\hline $\begin{array}{l}\text { (5) Produção na Comunidade } \geq \text { média da produção total } \\
\text { na Resex Canutama }\end{array}$ & 0 & $0,00000 \%$ & 0 & $0,0000 \%$ \\
\hline $\begin{array}{l}\text { (6) Produção diversificada e contendo o produto } \\
\text { potencial 'Farinha' com produção } \geq 10 \%\end{array}$ & 1 & $9,09091 \%$ & 0 & $0,0000 \%$ \\
\hline $\begin{array}{l}\text { (7) Produção diversificada e contendo o produto } \\
\text { potencial 'Peixe Fresco' com produção } \geq 10 \%\end{array}$ & 0 & $0,00000 \%$ & 1 & $9,0909 \%$ \\
\hline $\begin{array}{l}\text { (8) Produção diversificada e contendo o produto } \\
\text { potencial 'Peixe Seco' com produção } \geq 10 \%\end{array}$ & 1 & $9,09091 \%$ & 0 & $0,0000 \%$ \\
\hline $\begin{array}{l}\text { (9) Produção diversificada e contendo o produto } \\
\text { potencial 'Porco' com produção } \geq 10 \%\end{array}$ & 0 & $0,00000 \%$ & 0 & $0,0000 \%$ \\
\hline $\begin{array}{l}\text { (10) Produção diversificada e contendo o produto } \\
\text { potencial 'Açaí' com produção } \geq 10 \%\end{array}$ & 0 & $0,00000 \%$ & 0 & $0,0000 \%$ \\
\hline $\begin{array}{l}\text { (11) Produção diversificada e contendo o produto } \\
\text { potencial 'Castanha' com produção } \geq 10 \%\end{array}$ & 0 & $0,00000 \%$ & 1 & $9,0909 \%$ \\
\hline $\begin{array}{l}\text { Índice de Sustentabilidade Financeira } \\
\text { (resultado arredondado) }\end{array}$ & 2 & $18,2 \%$ & 2 & $18,2 \%$ \\
\hline $\begin{array}{l}\text { Legenda: Na Coluna [Referência] } \\
\text { [1] Sim, a comunidade atende o parâmetro } \\
\text { [0] Não, a comunidade não atende o parâmetro }\end{array}$ & Legenda: $\mathrm{Na}$ & gativa gera & entual d & $\begin{array}{l}\text { e } 9,09091 \\
0000 \%\end{array}$ \\
\hline
\end{tabular}

Fonte: Elaborado pela autora. 
Tabela 64 - Produção na Comunidade Capoeirinha (2019)

\begin{tabular}{|c|c|c|c|c|}
\hline $\begin{array}{l}\text { Produto e } \\
\text { Unidade de Medida }\end{array}$ & $\begin{array}{c}\text { Quantidade } \\
\text { Vendida }\end{array}$ & $\begin{array}{c}\text { Preço } \\
\text { Médio } \\
\text { (R\$) }\end{array}$ & $\begin{array}{c}\text { Valor } \\
\text { recebido (RS) }\end{array}$ & $\%$ \\
\hline Farinha (Saca de $50 \mathrm{Kg}$ ) & 125 & 170,00 & $21.250,00$ & $35,59 \%$ \\
\hline Pescado Seco $(\mathrm{Kg})$ & 2000 & 7,00 & $14.000,00$ & $23,45 \%$ \\
\hline Feijão (Kg) & 1200 & 5,00 & $6.000,00$ & $10,05 \%$ \\
\hline Porco (Unidade) & 15 & 210,00 & $3.150,00$ & $5,28 \%$ \\
\hline Melancia (Unidade) & 600 & 5,00 & $3.000,00$ & $5,02 \%$ \\
\hline Jerimum (Unidade) & 1000 & 3,00 & $3.000,00$ & $5,02 \%$ \\
\hline Maxixe $(\mathrm{Kg})$ & 500 & 5,00 & $2.500,00$ & $4,19 \%$ \\
\hline Galinha Caipira (Unidade) & 100 & 15,00 & $1.500,00$ & $2,51 \%$ \\
\hline Melão (Unidade) & 300 & 5,00 & $1.500,00$ & $2,51 \%$ \\
\hline Milho Seco $(\mathrm{Kg})$ & 800 & 1,50 & $1.200,00$ & $2,01 \%$ \\
\hline Goma da Mandioca (Lata 20Kg) & 10 & 80,00 & 800,00 & $1,34 \%$ \\
\hline Banana (Cacho) & 40 & 15,00 & 600,00 & $1,00 \%$ \\
\hline Macaxeira $(\mathrm{Kg})$ & 200 & 3,00 & 600,00 & $1,00 \%$ \\
\hline Milho Verde (Mão-50 espigas) & 13 & 25,00 & 325,00 & $0,54 \%$ \\
\hline Açaí Beneficiado (Litro) & 70 & 4,00 & 280,00 & $0,47 \%$ \\
\hline Valor total recebido $(\mathrm{R} \$)$ & & & $59.705,00$ & $100,00 \%$ \\
\hline
\end{tabular}

Tabela 65 - Produção na Comunidade Capoeirinha (2020)

\begin{tabular}{l|ccc|c}
\hline $\begin{array}{l}\text { Produto e } \\
\text { Unidade de Medida }\end{array}$ & $\begin{array}{c}\text { Quantidade } \\
\text { Vendida }\end{array}$ & $\begin{array}{c}\text { Preço } \\
\text { (RS) }\end{array}$ & $\begin{array}{c}\text { Valor } \\
\text { recebido } \\
\text { (R\$) }\end{array}$ & \% \\
\hline Castanha (Hectolitro; 100 litros) & 150 & 200,00 & $30.000,00$ & $81,08 \%$ \\
Pescado Fresco (Kg) & 1.000 & 5,00 & $5.000,00$ & $13,51 \%$ \\
Farinha (Saca de 50Kg) & 10 & 200,00 & $2.000,00$ & $5,41 \%$ \\
\hline Valor total recebido (R\$) & & & $\mathbf{3 7 . 0 0 0 , 0 0}$ & $\mathbf{1 0 0 , 0 0 \%}$ \\
\hline
\end{tabular}




\section{APÊNDICE D - Dados Gerais e Índice de Sustentabilidade das 22 Localidades}

A apresentação das comunidades está em ordem decrescente de volume de produção do ano de 2019. Todos os dados da produção 2019 e 2020 foram extraídos dos relatórios de gestão da Resex Canutama e adaptados pela autora.

\section{Índice}

Localidade Tororó-Paissé

Localidade Mapiciari.

Localidade Santana ....

Localidade Vista Alegre

Localidade Bom Sucesso

Localidade Santa Eugênia

Localidade Santa Cora

Localidade Estirão do Açaitub

Localidade São Francisco

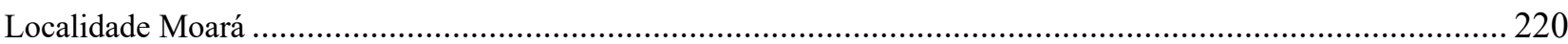

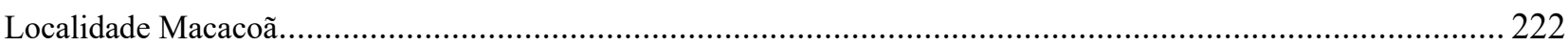

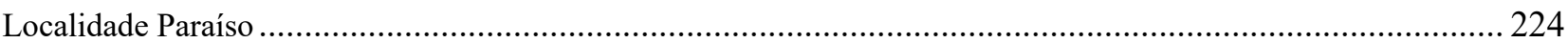

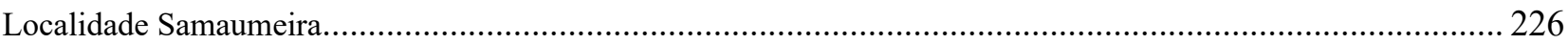

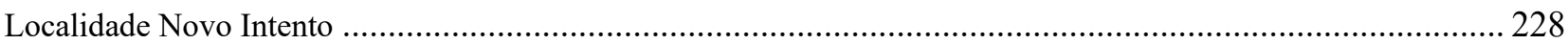

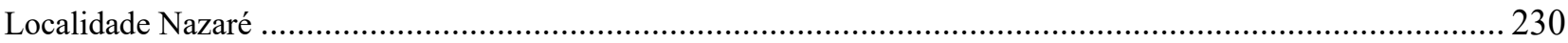

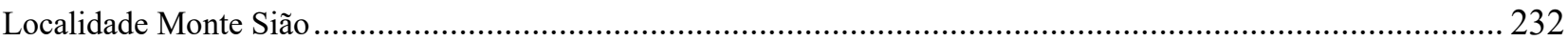

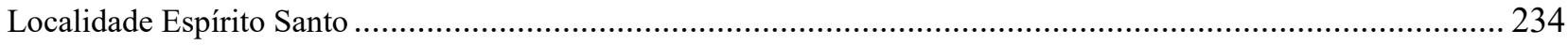

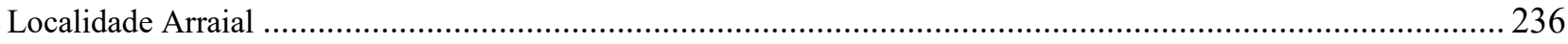

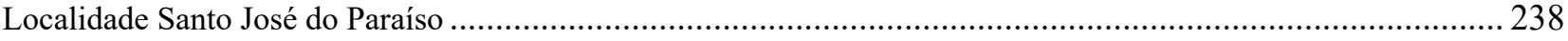

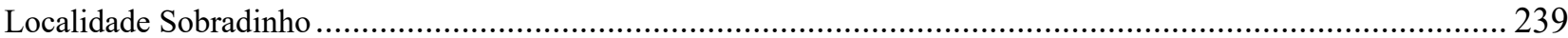

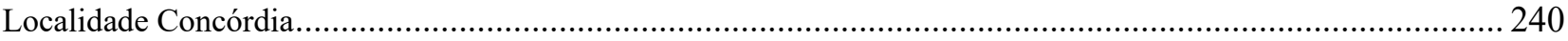

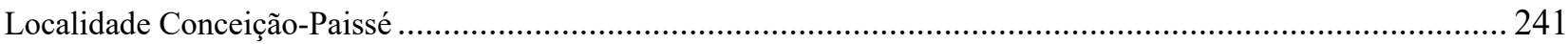




\section{Localidade Tororó-Paissé}

Quadro 27 - Dados gerais para Avaliação da Localidade Tororó-Paissé (2019-2020)

\begin{tabular}{|c|c|c|}
\hline Informações & Ano 2019 & Ano 2020 \\
\hline Valor da Produção na Resex Canutama & $\mathrm{R} \$ 3.002 .952,00$ & $\mathrm{R} \$ 2.923 .589,36$ \\
\hline Média da Produção na Resex Canutama & $\mathrm{R} \$ 79.025,05$ & $\mathrm{R} \$ 76.936,56$ \\
\hline $\mathrm{N}^{\circ}$ de residentes na Comunidade & 9 & 9 \\
\hline $\mathrm{N}^{\circ}$ de produtos vendidos & 7 & 9 \\
\hline Valor da Produção na Comunidade & $\mathrm{R} \$ 16.735,00$ & $\mathrm{R} \$ 230.765,00$ \\
\hline Produção Per capita da Comunidade & $\mathrm{R} \$ 1.859,44$ & $\mathrm{R} \$ 25.640,56$ \\
\hline $\begin{array}{l}\text { Média do PIB per capita dos municípios de Canutama } \\
\text { e Lábrea* }\end{array}$ & $\mathrm{R} \$ 8.953,67$ & $\mathrm{R} \$ 8.953,67$ \\
\hline
\end{tabular}

(*) Média com base no ano de 2018: PIB per capita de Lábrea (R\$10.941,94) e PIB per capita de Canutama (R\$ $6.965,40)$ - Último ano divulgado conforme dados do IBGE.

Tabela 66 - Sustentabilidade Financeira da Localidade Tororó-Paissé (2019-2020)

\begin{tabular}{|c|c|c|c|c|}
\hline \multirow[b]{2}{*}{$\begin{array}{l}\text { Parâmetros Avaliados } \\
\text { [A comunidade possui...] }\end{array}$} & \multicolumn{2}{|c|}{ Avaliação 2019} & \multicolumn{2}{|c|}{ Avaliação 2020} \\
\hline & $\begin{array}{l}\text { Referência } \\
\text { (1 ou 0) }\end{array}$ & $\begin{array}{c}\text { Resultado } \\
(\%)\end{array}$ & $\begin{array}{l}\text { Referência } \\
\text { (1 ou 0) }\end{array}$ & $\begin{array}{c}\text { Resultado } \\
(\%)\end{array}$ \\
\hline (1) Líder comunitário com perfil empreendedor & 0 & $0,00000 \%$ & 0 & $0,0000 \%$ \\
\hline (2) Controle de castanhal e exploração de castanhal & 0 & $0,00000 \%$ & 0 & $0,0000 \%$ \\
\hline (3) $\mathrm{N}^{\circ}$ mínimo de residentes $\geq 30$ pessoas & 0 & $0,00000 \%$ & 0 & $0,0000 \%$ \\
\hline $\begin{array}{l}\text { (4) Produção per capita da comunidade } \geq \text { média do PIB } \\
\text { per capita dos municípios Canutama e Lábrea }\end{array}$ & 0 & $0,00000 \%$ & 1 & $9,0909 \%$ \\
\hline $\begin{array}{l}\text { (5) Produção na Comunidade } \geq \text { média da produção total } \\
\text { na Resex Canutama }\end{array}$ & 0 & $0,00000 \%$ & 1 & $9,0909 \%$ \\
\hline $\begin{array}{l}\text { (6) Produção diversificada e contendo o produto potencial } \\
\text { 'Farinha' com produção } \geq 10 \%\end{array}$ & 1 & $9,09091 \%$ & 1 & $9,0909 \%$ \\
\hline $\begin{array}{l}\text { (7) Produção diversificada e contendo o produto potencial } \\
\text { 'Peixe Fresco' com produção } \geq 10 \%\end{array}$ & 1 & $9,09091 \%$ & 0 & $0,0000 \%$ \\
\hline $\begin{array}{l}\text { (8) Produção diversificada e contendo o produto potencial } \\
\text { 'Peixe Seco' com produção } \geq 10 \%\end{array}$ & 1 & $9,09091 \%$ & 0 & $0,0000 \%$ \\
\hline $\begin{array}{l}\text { (9) Produção diversificada e contendo o produto potencial } \\
\text { 'Porco' com produção } \geq 10 \%\end{array}$ & 0 & $0,00000 \%$ & 0 & $0,0000 \%$ \\
\hline $\begin{array}{l}\text { (10) Produção diversificada e contendo o produto } \\
\text { potencial 'Açaí' com produção } \geq 10 \%\end{array}$ & 0 & $0,00000 \%$ & 0 & $0,0000 \%$ \\
\hline $\begin{array}{l}\text { (11) Produção diversificada e contendo o produto } \\
\text { potencial 'Castanha' com produção } \geq 10 \%\end{array}$ & 0 & $0,00000 \%$ & 0 & $0,0000 \%$ \\
\hline $\begin{array}{l}\text { Índice de Sustentabilidade Financeira } \\
\text { (resultado arredondado) }\end{array}$ & 3 & $27,30 \%$ & 3 & $27,30 \%$ \\
\hline $\begin{array}{l}\text { Legenda: Na Coluna [Referência] } \\
\text { [1] Sim, a comunidade atende o parâmetro } \\
\text { [0] Não, a comunidade não atende o parâmetro }\end{array}$ & Avaliação & $\begin{array}{l}\text { luna [Resı } \\
\text { sitiva gers } \\
\text { gativa ger }\end{array}$ & do] & $\begin{array}{l}9,09091 \% \\
0000 \%\end{array}$ \\
\hline
\end{tabular}

Fonte: Elaborado pela autora. 
Tabela 67 - Produção na Localidade Tororó-Paissé (2019)

\begin{tabular}{|c|c|c|c|c|}
\hline $\begin{array}{l}\text { Produto } \\
\text { e Unidade de Medida }\end{array}$ & $\begin{array}{l}\text { Quantidade } \\
\text { Vendida }\end{array}$ & $\begin{array}{c}\text { Preço } \\
\text { Médio } \\
\text { (R\$) }\end{array}$ & $\begin{array}{c}\text { Valor } \\
\text { recebido (R\$) }\end{array}$ & $\%$ \\
\hline Farinha (Saca de 50Kg) & 45 & 170,00 & $7.650,00$ & $45,71 \%$ \\
\hline Pescado Seco (Kg) & 720 & 7,00 & $5.040,00$ & $30,12 \%$ \\
\hline Pescado Fresco (Kg) & 500 & 6,00 & $3.000,00$ & $17,93 \%$ \\
\hline Melancia (Unidade) & 100 & 5,00 & 500,00 & $2,99 \%$ \\
\hline Banana (Cacho) & 25 & 15,00 & 375,00 & $2,24 \%$ \\
\hline Feijão (Kg) & 25 & 5,00 & 125,00 & $0,75 \%$ \\
\hline Jerimum (Unidade) & 15 & 3,00 & 45,00 & $0,27 \%$ \\
\hline Valor total recebido (R\$) & & & $16.735,00$ & $100,00 \%$ \\
\hline
\end{tabular}

Tabela 68 - Produção na Localidade Tororó-Paissé (2020)

\begin{tabular}{l|ccr|c}
\hline Produto & $\begin{array}{c}\text { Quantidade } \\
\text { Vendida }\end{array}$ & $\begin{array}{c}\text { Preço } \\
\text { Médio } \\
\text { (R\$) }\end{array}$ & $\begin{array}{c}\text { Valor } \\
\text { recebido (R\$) }\end{array}$ & \% \\
\hline Farinha (Saca de 50Kg) & 800 & 200,00 & $160.000,00$ & $69,33 \%$ \\
Banana (Cacho) & 1.200 & 30,00 & $36.000,00$ & $15,60 \%$ \\
Castanha (Hectolitro; 100 litros) & 65 & 200,00 & $13.000,00$ & $5,63 \%$ \\
Pescado Fresco (Kg) & 2.500 & 5,00 & $12.500,00$ & $5,42 \%$ \\
Pescado Seco (Kg) & 1.000 & 6,00 & $6.000,00$ & $2,60 \%$ \\
Cará (Kg) & 400 & 5,00 & $2.000,00$ & $0,87 \%$ \\
Açá Fruto (Lata 18Kg) & 50 & 15,00 & 750,00 & $0,33 \%$ \\
Galinha Caipira (Unidade) & 15 & 25,00 & 375,00 & $0,16 \%$ \\
Copaíba Óleo (Kg) & 4 & 35,00 & 140,00 & $0,06 \%$ \\
\hline Valor total recebido (R\$) & & & $\mathbf{2 3 0 . 7 6 5 , 0 0}$ & $\mathbf{1 0 0 , 0 0 \%}$ \\
\hline
\end{tabular}




\section{Localidade Mapiciari}

Quadro 28 - Dados gerais para Avaliação da Localidade Mapiciari (2019-2020)

\begin{tabular}{|c|c|c|}
\hline Informações & Ano 2019 & Ano 2020 \\
\hline Valor da Produção na Resex Canutama & $\mathrm{R} \$ 3.002 .952,00$ & $\mathrm{R} \$ 2.923 .589,36$ \\
\hline Média da Produção na Resex Canutama & $\mathrm{R} \$ 79.025,05$ & $\mathrm{R} \$ 76.936,56$ \\
\hline $\mathrm{N}^{\mathrm{o}}$ de residentes na Comunidade & 7 & 7 \\
\hline $\mathrm{N}^{\circ}$ de produtos vendidos & 9 & 1 \\
\hline Valor da Produção na Comunidade & $\mathrm{R} \$ 10.880,00$ & $\mathrm{R} \$ 200.000,00$ \\
\hline Produção Per capita da Comunidade & $\mathrm{R} \$ 1.554,29$ & $\mathrm{R} \$ 28,571,43$ \\
\hline $\begin{array}{l}\text { Média do PIB per capita dos municípios de Canutama } \\
\text { e Lábrea* }\end{array}$ & $\mathrm{R} \$ 8.953,67$ & $\mathrm{R} \$ 8.953,67$ \\
\hline
\end{tabular}

(*) Média com base no ano de 2018: PIB per capita de Lábrea (R\$ 10.941,94) e PIB per capita de Canutama (R \$ $6.965,40)$ - Último ano divulgado conforme dados do IBGE.

Tabela 69 - Sustentabilidade Financeira da Localidade Mapiciari (2019-2020)

\begin{tabular}{|c|c|c|c|c|}
\hline \multirow[b]{2}{*}{$\begin{array}{l}\text { Parâmetros Avaliados } \\
\text { [A comunidade possui...] }\end{array}$} & \multicolumn{2}{|c|}{ Avaliação 2019} & \multicolumn{2}{|c|}{ Avaliação 2020} \\
\hline & $\begin{array}{c}\text { Referência } \\
\text { (1 ou 0) }\end{array}$ & $\begin{array}{c}\text { Resultado } \\
(\%)\end{array}$ & $\begin{array}{c}\text { Referência } \\
\text { (1 ou 0) }\end{array}$ & $\begin{array}{c}\text { Resultado } \\
(\%) \\
\end{array}$ \\
\hline (1) Líder comunitário com perfil empreendedor & 0 & $0,00000 \%$ & 0 & $0,0000 \%$ \\
\hline (2) Controle de castanhal e exploração de castanhal & 0 & $0,00000 \%$ & 0 & $0,0000 \%$ \\
\hline (3) $\mathrm{N}^{\circ}$ mínimo de residentes $\geq 30$ pessoas & 0 & $0,00000 \%$ & 0 & $0,0000 \%$ \\
\hline $\begin{array}{l}\text { (4) Produção per capita da comunidade } \geq \text { média do PIB } \\
\text { per capita dos municípios Canutama e Lábrea }\end{array}$ & 0 & $0,00000 \%$ & 1 & $9,0909 \%$ \\
\hline $\begin{array}{l}\text { (5) Produção na Comunidade } \geq \text { média da produção total } \\
\text { na Resex Canutama }\end{array}$ & 0 & $0,00000 \%$ & 1 & $9,0909 \%$ \\
\hline $\begin{array}{l}\text { (6) Produção diversificada e contendo o produto } \\
\text { potencial 'Farinha' com produção } \geq 10 \%\end{array}$ & 1 & $9,09091 \%$ & 0 & $0,0000 \%$ \\
\hline $\begin{array}{l}\text { (7) Produção diversificada e contendo o produto } \\
\text { potencial 'Peixe Fresco' com produção } \geq 10 \%\end{array}$ & 1 & $9,09091 \%$ & 0 & $0,0000 \%$ \\
\hline $\begin{array}{l}\text { (8) Produção diversificada e contendo o produto } \\
\text { potencial 'Peixe Seco' com produção } \geq 10 \%\end{array}$ & 0 & $0,00000 \%$ & 0 & $0,0000 \%$ \\
\hline $\begin{array}{l}\text { (9) Produção diversificada e contendo o produto } \\
\text { potencial 'Porco' com produção } \geq 10 \%\end{array}$ & 0 & $0,00000 \%$ & 0 & $0,0000 \%$ \\
\hline $\begin{array}{l}\text { (10) Produção diversificada e contendo o produto } \\
\text { potencial 'Açaí' com produção } \geq 10 \%\end{array}$ & 0 & $0,00000 \%$ & 0 & $0,0000 \%$ \\
\hline $\begin{array}{l}\text { (11) Produção diversificada e contendo o produto } \\
\text { potencial 'Castanha' com produção } \geq 10 \%\end{array}$ & 0 & $0,00000 \%$ & 1 & $9,0909 \%$ \\
\hline $\begin{array}{l}\text { Índice de Sustentabilidade Financeira } \\
\text { (resultado arredondado) }\end{array}$ & 2 & $18,20 \%$ & 3 & $27,30 \%$ \\
\hline $\begin{array}{l}\text { Legenda: Na Coluna [Referência] } \\
\text { [1] Sim, a comunidade atende o parâmetro } \\
\text { [0] Não, a comunidade não atende o parâmetro } \\
\text { Fonte: Elaborado pela autora. }\end{array}$ & 1] Avaliação 1 & $\begin{array}{l}\text { luna }[\text { Resul } \\
\text { sitiva gera } \iota \\
\text { gativa gera }\end{array}$ & $\begin{array}{l}\text { do] } \\
\text { n percentual } \\
\text { ercentual de }\end{array}$ & $\begin{array}{l}9,09091 \% \\
0000 \%\end{array}$ \\
\hline
\end{tabular}

Fonte: Elaborado pela autora. 
Tabela 70 - Produção na Localidade Mapiciari (2019)

\begin{tabular}{lccr|c}
\hline Produto & $\begin{array}{c}\text { Quantidade } \\
\text { Vendida }\end{array}$ & $\begin{array}{c}\text { Preço } \\
\text { Médio } \\
\text { (R\$) }\end{array}$ & $\begin{array}{c}\text { Valor } \\
\text { recebido (R\$) }\end{array}$ & \% \\
\hline Pescado Fresco (Kg) & 1000 & 6,00 & $6.000,00$ & $55,15 \%$ \\
Farinha (Saca de 50Kg) & 8 & 170,00 & $1.360,00$ & $12,50 \%$ \\
Melancia (Unidade) & 200 & 5,00 & $1.000,00$ & $9,19 \%$ \\
Melão (Unidade) & 200 & 5,00 & $1.000,00$ & $9,19 \%$ \\
Murumuru semente (Lata 20Kg) & 60 & 8,00 & 480,00 & $4,41 \%$ \\
Maxixe (Kg) & 90 & 5,00 & 450,00 & $4,14 \%$ \\
Galinha Caipira (Unidade) & 20 & 15,00 & 300,00 & $2,76 \%$ \\
Açaí Beneficiado (Litro) & 50 & 4,00 & 200,00 & $1,84 \%$ \\
Jerimum (Unidade) & 30 & 3,00 & 90,00 & $0,83 \%$ \\
\hline Valor total recebido (R\$) & & & $\mathbf{1 0 . 8 8 0 , 0 0}$ & $\mathbf{1 0 0 , 0 0 \%}$ \\
\hline
\end{tabular}

Tabela 71 - Produção na Localidade Mapiciari (2020)

\begin{tabular}{|c|c|c|c|c|}
\hline $\begin{array}{l}\text { Produto } \\
\text { e Unidade de Medida }\end{array}$ & $\begin{array}{l}\text { Quantidade } \\
\text { Vendida }\end{array}$ & $\begin{array}{c}\text { Preço } \\
\text { Médio } \\
\text { (R\$) }\end{array}$ & $\begin{array}{c}\text { Valor } \\
\text { recebido }(\mathbf{R} \$)\end{array}$ & $\%$ \\
\hline Castanha (Hectolitro; 100 litros) & 1.000 & 200,00 & $200.000,00$ & $100,00 \%$ \\
\hline Valor total recebido (R\$) & & & $200.000,00$ & $100,00 \%$ \\
\hline
\end{tabular}




\section{Localidade Santana}

Quadro 29 - Dados gerais para Avaliação da Localidade Santana (2019-2020)

\begin{tabular}{|c|c|c|}
\hline Informações & Ano 2019 & Ano 2020 \\
\hline Valor da Produção na Resex Canutama & $\mathrm{R} \$ 3.002 .952,00$ & $\mathrm{R} \$ 2.923 .589,36$ \\
\hline Média da Produção na Resex Canutama & $\mathrm{R} \$ 79.025,05$ & $\mathrm{R} \$ 76.936,56$ \\
\hline $\mathrm{N}^{\circ}$ de residentes na Comunidade & 10 & 10 \\
\hline $\mathrm{N}^{\mathrm{o}}$ de produtos vendidos & 11 & 11 \\
\hline Valor da Produção na Comunidade & $\mathrm{R} \$ 30.254,00$ & $\mathrm{R} \$ 110.953,00$ \\
\hline Produção Per capita da Comunidade & $\mathrm{R} \$ 3.025,40$ & $\mathrm{R} \$ 11.095,30$ \\
\hline $\begin{array}{l}\text { Média do PIB per capita dos municípios de Canutama } \\
\text { e Lábrea* }\end{array}$ & $\mathrm{R} \$ 8.953,67$ & $\mathrm{R} \$ 8.953,67$ \\
\hline
\end{tabular}

(*) Média com base no ano de 2018: PIB per capita de Lábrea (R\$ 10.941,94) e PIB per capita de Canutama (R\$ $6.965,40)$ - Último ano divulgado conforme dados do IBGE.

Tabela 72 - Sustentabilidade Financeira da Localidade Santana (2019-2020)

\begin{tabular}{|c|c|c|c|c|}
\hline \multirow[b]{2}{*}{$\begin{array}{l}\text { Parâmetros Avaliados } \\
\text { [A comunidade possui....] }\end{array}$} & \multicolumn{2}{|c|}{ Avaliação 2019} & \multicolumn{2}{|c|}{ Avaliação 2020} \\
\hline & $\begin{array}{c}\text { Referência } \\
(1 \text { ou } 0)\end{array}$ & $\begin{array}{c}\text { Resultado } \\
(\%)\end{array}$ & $\begin{array}{l}\text { Referência } \\
(1 \text { ou } 0)\end{array}$ & $\begin{array}{c}\text { Resultado } \\
(\%) \\
\end{array}$ \\
\hline (1) Líder comunitário com perfil empreendedor & 0 & $0,00000 \%$ & 0 & $0,0000 \%$ \\
\hline (2) Controle de castanhal e exploração de castanhal & 0 & $0,00000 \%$ & 0 & $0,0000 \%$ \\
\hline (3) $\mathrm{N}^{\circ}$ mínimo de residentes $\geq 30$ pessoas & 0 & $0,00000 \%$ & 0 & $0,0000 \%$ \\
\hline $\begin{array}{l}\text { (4) Produção per capita da comunidade } \geq \text { média do PIB } \\
\text { per capita dos municípios Canutama e Lábrea }\end{array}$ & 0 & $0,00000 \%$ & 1 & $9,0909 \%$ \\
\hline $\begin{array}{l}\text { (5) Produção na Comunidade } \geq \text { média da produção total } \\
\text { na Resex Canutama }\end{array}$ & 0 & $0,00000 \%$ & 1 & $9,0909 \%$ \\
\hline $\begin{array}{l}\text { (6) Produção diversificada e contendo o produto potencial } \\
\text { 'Farinha' com produção } \geq 10 \%\end{array}$ & 0 & $0,00000 \%$ & 0 & $0,0000 \%$ \\
\hline $\begin{array}{l}\text { (7) Produção diversificada e contendo o produto potencial } \\
\text { 'Peixe Fresco' com produção } \geq 10 \%\end{array}$ & 1 & $9,09091 \%$ & 1 & $9,0909 \%$ \\
\hline $\begin{array}{l}\text { (8) Produção diversificada e contendo o produto potencial } \\
\text { 'Peixe Seco' com produção } \geq 10 \%\end{array}$ & 1 & $9,09091 \%$ & 0 & $0,0000 \%$ \\
\hline $\begin{array}{l}\text { (9) Produção diversificada e contendo o produto potencial } \\
\text { 'Porco' com produção } \geq 10 \%\end{array}$ & 0 & $0,00000 \%$ & 0 & $0,0000 \%$ \\
\hline $\begin{array}{l}\text { (10) Produção diversificada e contendo o produto } \\
\text { potencial 'Açaí' com produção } \geq 10 \%\end{array}$ & 0 & $0,00000 \%$ & 0 & $0,0000 \%$ \\
\hline $\begin{array}{l}\text { (11) Produção diversificada e contendo o produto } \\
\text { potencial 'Castanha' com produção } \geq 10 \%\end{array}$ & 0 & $0,00000 \%$ & 1 & $9,0909 \%$ \\
\hline $\begin{array}{l}\text { Índice de Sustentabilidade Financeira } \\
\text { (resultado arredondado) }\end{array}$ & 2 & $18,20 \%$ & 4 & $36,40 \%$ \\
\hline $\begin{array}{l}\text { Legenda: Na Coluna [Referência] } \\
\text { [1] Sim, a comunidade atende o parâmetro } \\
\text { [0] Não, a comunidade não atende o parâmetro }\end{array}$ & $\begin{array}{l}\text { egenda: } \mathrm{NaC} \\
\text { 1] Avaliação } \\
\text { 0] Avaliação }\end{array}$ & $\begin{array}{l}\text { luna [Resul } \\
\text { ositiva gera } \\
\text { egativa gera }\end{array}$ & $\begin{array}{l}\text { do] } \\
\text { n percentual } \\
\text { ercentual de }\end{array}$ & $\begin{array}{l}9,09091 \% \\
0000 \%\end{array}$ \\
\hline
\end{tabular}

Fonte: Elaborado pela autora. 
Tabela 73 - Produção na Localidade Santana (2019)

\begin{tabular}{lccr|c}
\hline $\begin{array}{l}\text { Produto } \\
\text { e Unidade de Medida }\end{array}$ & $\begin{array}{c}\text { Quantidade } \\
\text { Vendida }\end{array}$ & $\begin{array}{c}\text { Preço } \\
\text { Médio } \\
\text { (R\$) }\end{array}$ & $\begin{array}{c}\text { Valor } \\
\text { recebido } \\
\text { (R\$) }\end{array}$ & \% \\
\hline Pescado Seco (Kg) & 1300 & 7,00 & $9.100,00$ & $30,08 \%$ \\
Melancia (Unidade) & 1300 & 5,00 & $6.500,00$ & $21,48 \%$ \\
Pescado Fresco (Kg) & 1000 & 6,00 & $6.000,00$ & $19,83 \%$ \\
Andiroba semente (Lata 20Kg) & 243 & 14,00 & $3.402,00$ & $11,24 \%$ \\
Farinha (Saca de 50Kg) & 13 & 170,00 & $2.210,00$ & $7,30 \%$ \\
Jerimum (Unidade) & 500 & 3,00 & $1.500,00$ & $4,96 \%$ \\
Murumuru semente (Lata 20Kg) & 104 & 8,00 & 832,00 & $2,75 \%$ \\
Macaxeira (Kg) & 100 & 3,00 & 300,00 & $0,99 \%$ \\
Goma da Mandioca (Lata 20Kg) & 3 & 80,00 & 240,00 & $0,79 \%$ \\
Açaí Beneficiado (Litro) & 30 & 4,00 & 120,00 & $0,40 \%$ \\
Melão (Unidade) & 10 & 5,00 & 50,00 & $0,17 \%$ \\
\hline Valor total recebido (R\$) & & & $\mathbf{3 0 . 2 5 4 , 0 0}$ & $\mathbf{1 0 0 , 0 0 \%}$ \\
\hline
\end{tabular}

Tabela 74 - Produção na Localidade Santana (2020)

\begin{tabular}{l|ccr|c}
\hline $\begin{array}{l}\text { Produto } \\
\text { e Unidade de Medida }\end{array}$ & $\begin{array}{c}\text { Quantidade } \\
\text { Vendida }\end{array}$ & $\begin{array}{c}\text { Preço } \\
\text { Médio } \\
\text { (R\$) }\end{array}$ & $\begin{array}{c}\text { Valor } \\
\text { recebido (R\$) }\end{array}$ & \% \\
\hline Castanha (Hectolitro; 100 litros) & 326 & 200,00 & $65.200,00$ & $58,76 \%$ \\
Pescado Fresco (Kg) & 3.000 & 5,00 & $15.000,00$ & $13,52 \%$ \\
Pescado Seco (Kg) & 1.500 & 6,00 & $9.000,00$ & $8,11 \%$ \\
Murumuru semente (Lata 20Kg) & 450 & 14,42 & $6.489,00$ & $5,85 \%$ \\
Farinha (Saca de 50Kg) & 25 & 200,00 & $5.000,00$ & $4,51 \%$ \\
Melancia (Unidade) & 600 & 8,00 & $4.800,00$ & $4,33 \%$ \\
Andiroba semente (Lata 20Kg) & 376 & 10,00 & $3.760,00$ & $3,39 \%$ \\
Feijão (Kg) & 160 & 6,00 & 960,00 & $0,87 \%$ \\
Banana (Cacho) & 20 & 30,00 & 600,00 & $0,54 \%$ \\
Melão (Unidade) & 20 & 6,00 & 120,00 & $0,11 \%$ \\
Batata-doce (Kg) & 6 & 4,00 & 24,00 & $0,02 \%$ \\
\hline Valor total recebido (R\$) & & & $\mathbf{1 1 0 . 9 5 3 , 0 0}$ & $\mathbf{1 0 0 , 0 0 \%}$ \\
\hline
\end{tabular}




\section{Localidade Vista Alegre}

Quadro 30 - Dados gerais para Avaliação da Localidade Vista Alegre (2019-2020)

\begin{tabular}{|l|c|c|}
\hline \multicolumn{1}{|c|}{ Informações } & Ano 2019 & Ano 2020 \\
\hline Valor da Produção na Resex Canutama & $\mathrm{R} \$ 3.002 .952,00$ & $\mathrm{R} \$ 2.923 .589,36$ \\
\hline Média da Produção na Resex Canutama & $\mathrm{R} \$ 79.025,05$ & $\mathrm{R} \$ 76.936,56$ \\
\hline $\mathrm{N}^{\circ}$ de residentes na Comunidade & 12 & 12 \\
\hline $\mathrm{N}^{\circ}$ de produtos vendidos & 19 & 9 \\
\hline Valor da Produção na Comunidade & $\mathrm{R} \$ 87.085,00$ & $\mathrm{R} \$ 49.510,00$ \\
\hline Produção Per capita da Comunidade & $\mathrm{R} \$ 7.257,08$ & $\mathrm{R} \$ 4.125,83$ \\
\hline $\begin{array}{l}\text { Média do PIB per capita dos municípios de Canutama } \\
\text { e Lábrea* }\end{array}$ & $\mathrm{R} \$ 8.953,67$ & $\mathrm{R} \$ 8.953,67$ \\
\hline
\end{tabular}

(*) Média com base no ano de 2018: PIB per capita de Lábrea (R\$ 10.941,94) e PIB per capita de Canutama (R \$ $6.965,40)$ - Último ano divulgado conforme dados do IBGE.

Tabela 75 - Sustentabilidade Financeira da Localidade Vista Alegre (2019-2020)

\begin{tabular}{|c|c|c|c|c|}
\hline \multirow[b]{2}{*}{$\begin{array}{l}\text { Parâmetros Avaliados } \\
\text { [A comunidade possui....] }\end{array}$} & \multicolumn{2}{|c|}{ Avaliação 2019} & \multicolumn{2}{|c|}{ Avaliação 2020} \\
\hline & $\begin{array}{l}\text { Referência } \\
\text { (1 ou 0) }\end{array}$ & $\begin{array}{c}\text { Resultado } \\
(\%)\end{array}$ & $\begin{array}{l}\text { Referência } \\
\text { (1 ou 0) }\end{array}$ & $\begin{array}{c}\text { Resultado } \\
(\%)\end{array}$ \\
\hline (1) Líder comunitário com perfil empreendedor & 0 & $0,00000 \%$ & 0 & $0,0000 \%$ \\
\hline (2) Controle de castanhal e exploração de castanhal & 0 & $0,00000 \%$ & 0 & $0,0000 \%$ \\
\hline (3) $\mathrm{N}^{\circ}$ mínimo de residentes $\geq 30$ pessoas & 0 & $0,00000 \%$ & 0 & $0,0000 \%$ \\
\hline $\begin{array}{l}\text { (4) Produção per capita da comunidade } \geq \text { média do PIB } \\
\text { per capita dos municípios Canutama e Lábrea }\end{array}$ & 0 & $0,00000 \%$ & 0 & $0,0000 \%$ \\
\hline $\begin{array}{l}\text { (5) Produção na Comunidade } \geq \text { média da produção total } \\
\text { na Resex Canutama }\end{array}$ & 1 & $9,09091 \%$ & 0 & $0,0000 \%$ \\
\hline $\begin{array}{l}\text { (6) Produção diversificada e contendo o produto potencial } \\
\text { 'Farinha' com produção } \geq 10 \%\end{array}$ & 0 & $0,00000 \%$ & 0 & $0,0000 \%$ \\
\hline $\begin{array}{l}\text { (7) Produção diversificada e contendo o produto potencial } \\
\text { 'Peixe Fresco' com produção } \geq 10 \%\end{array}$ & 1 & $9,09091 \%$ & 1 & $9,0909 \%$ \\
\hline $\begin{array}{l}\text { (8) Produção diversificada e contendo o produto potencial } \\
\text { 'Peixe Seco' com produção } \geq 10 \%\end{array}$ & 0 & $0,00000 \%$ & 0 & $0,0000 \%$ \\
\hline $\begin{array}{l}\text { (9) Produção diversificada e contendo o produto potencial } \\
\text { 'Porco' com produção } \geq 10 \%\end{array}$ & 0 & $0,00000 \%$ & 0 & $0,0000 \%$ \\
\hline $\begin{array}{l}\text { (10) Produção diversificada e contendo o produto } \\
\text { potencial 'Açaí' com produção } \geq 10 \%\end{array}$ & 0 & $0,00000 \%$ & 0 & $0,0000 \%$ \\
\hline $\begin{array}{l}\text { (11) Produção diversificada e contendo o produto } \\
\text { potencial 'Castanha' com produção } \geq 10 \%\end{array}$ & 1 & $9,09091 \%$ & 1 & $9,0909 \%$ \\
\hline $\begin{array}{l}\text { Índice de Sustentabilidade Financeira } \\
\text { (resultado arredondado) }\end{array}$ & 3 & $27,30 \%$ & 2 & $18,20 \%$ \\
\hline $\begin{array}{l}\text { Legenda: Na Coluna [Referência] } \\
\text { [1] Sim, a comunidade atende o parâmetro } \\
\text { [0] Não, a comunidade não atende o parâmetro }\end{array}$ & $\begin{array}{l}\text { Legenda: } \mathrm{Na}( \\
\text { 1] Avaliação } \\
\text { 0] Avaliação }\end{array}$ & $\begin{array}{l}\text { luna [Resul } \\
\text { ositiva gera } \\
\text { egativa gera }\end{array}$ & $\begin{array}{l}\text { ado] } \\
\text { n percentual } \\
\text { ercentual de }(\end{array}$ & $\begin{array}{l}9,09091 \% \\
0000 \%\end{array}$ \\
\hline
\end{tabular}

Fonte: Elaborado pela autora. 
Tabela 76 - Produção na Localidade Vista Alegre (2019)

\begin{tabular}{|c|c|c|c|c|}
\hline $\begin{array}{l}\text { Produto } \\
\text { e Unidade de Medida }\end{array}$ & $\begin{array}{c}\text { Quantidade } \\
\text { Vendida }\end{array}$ & $\begin{array}{l}\text { Preço } \\
\text { Médio } \\
\text { (R\$) }\end{array}$ & $\begin{array}{c}\text { Valor } \\
\text { recebido } \\
\text { (R\$) }\end{array}$ & $\%$ \\
\hline Pescado Fresco (Kg) & 7000 & 6,00 & $42.000,00$ & $48,23 \%$ \\
\hline Castanha (Hectolitro; 100 litros) & 86 & 250,00 & $21.500,00$ & $24,69 \%$ \\
\hline Farinha (Saca de 50Kg) & 40 & 170,00 & $6.800,00$ & $7,81 \%$ \\
\hline Pescado Seco $(\mathrm{Kg})$ & 650 & 7,00 & $4.550,00$ & $5,22 \%$ \\
\hline Melancia (Unidade) & 600 & 5,00 & $3.000,00$ & $3,44 \%$ \\
\hline Galinha Caipira (Unidade) & 170 & 15,00 & $2.550,00$ & $2,93 \%$ \\
\hline Banana (Cacho) & 120 & 15,00 & $1.800,00$ & $2,07 \%$ \\
\hline Macaxeira (Kg) & 400 & 3,00 & $1.200,00$ & $1,38 \%$ \\
\hline Feijão (Kg) & 116 & 5,00 & 580,00 & $0,67 \%$ \\
\hline Melão (Unidade) & 100 & 5,00 & 500,00 & $0,57 \%$ \\
\hline Maxixe $(\mathrm{Kg})$ & 100 & 5,00 & 500,00 & $0,57 \%$ \\
\hline Andiroba semente (Lata $20 \mathrm{Kg}$ ) & 30 & 14,00 & 420,00 & $0,48 \%$ \\
\hline Jerimum (Unidade) & 110 & 3,00 & 330,00 & $0,38 \%$ \\
\hline Milho Seco $(\mathrm{Kg})$ & 200 & 1,50 & 300,00 & $0,34 \%$ \\
\hline Cupuaçu (Kg) & 50 & 6,00 & 300,00 & $0,34 \%$ \\
\hline Goma da Mandioca (Lata 20Kg) & 3 & 80,00 & 240,00 & $0,28 \%$ \\
\hline Pupunha (Cacho) & 40 & 6,00 & 240,00 & $0,28 \%$ \\
\hline Açaí Beneficiado (Litro) & 50 & 4,00 & 200,00 & $0,23 \%$ \\
\hline Milho Verde (Mão-50 espigas) & 3 & 25,00 & 75,00 & $0,09 \%$ \\
\hline Valor total recebido (R\$) & & & $87.085,00$ & $100,00 \%$ \\
\hline
\end{tabular}

Tabela 77 - Produção na Localidade Vista Alegre (2020)

\begin{tabular}{l|ccr|c}
\hline $\begin{array}{l}\text { Produto } \\
\text { e Unidade de Medida }\end{array}$ & $\begin{array}{c}\text { Quantidade } \\
\text { Vendida }\end{array}$ & $\begin{array}{c}\text { Preço } \\
\text { Médio } \\
\text { (R\$) }\end{array}$ & $\begin{array}{c}\text { Valor } \\
\text { recebido } \\
\text { (R\$) }\end{array}$ & \% \\
\hline Pescado Fresco (Kg) & 5.000 & 5,00 & $25.000,00$ & $50,49 \%$ \\
Castanha (Hectolitro; 100 litros) & 50 & 200,00 & $10.000,00$ & $20,20 \%$ \\
Melancia (Unidade) & 600 & 8,00 & $4.800,00$ & $9,70 \%$ \\
Farinha (Saca de 50Kg) & 20 & 200,00 & $4.000,00$ & $8,08 \%$ \\
Pescado Seco (Kg) & 500 & 6,00 & $3.000,00$ & $6,06 \%$ \\
Feijão (Kg) & 300 & 6,00 & $1.800,00$ & $3,64 \%$ \\
Galinha Caipira (Unidade) & 30 & 25,00 & 750,00 & $1,51 \%$ \\
Melão (Unidade) & 20 & 6,00 & 120,00 & $0,24 \%$ \\
Batata-doce (Kg) & 10 & 4,00 & 40,00 & $0,08 \%$ \\
\hline Valor total recebido (R\$) & & & $\mathbf{4 9 . 5 1 0 , 0 0}$ & $\mathbf{1 0 0 , 0 0 \%}$ \\
\hline
\end{tabular}




\section{Localidade Bom Sucesso}

Quadro 31 - Dados gerais para Avaliação da Localidade Bom Sucesso (2019-2020)

\begin{tabular}{|c|c|c|}
\hline Informações & Ano 2019 & Ano 2020 \\
\hline Valor da Produção na Resex Canutama & $\mathrm{R} \$ 3.002 .952,00$ & $\mathrm{R} \$ 2.923 .589,36$ \\
\hline Média da Produção na Resex Canutama & $\mathrm{R} \$ 79.025,05$ & $\mathrm{R} \$ 76.936,56$ \\
\hline $\mathrm{N}^{\circ}$ de residentes na Comunidade & 13 & 13 \\
\hline $\mathrm{N}^{\circ}$ de produtos vendidos & 17 & 13 \\
\hline Valor da Produção na Comunidade & $\mathrm{R} \$ 82.500,00$ & $\mathrm{R} \$ 52.059,80$ \\
\hline Produção Per capita da Comunidade & $\mathrm{R} \$$ & $\mathrm{R} \$ 4.004,60$ \\
\hline $\begin{array}{l}\text { Média do PIB per capita dos municípios de Canutama } \\
\text { e Lábrea* }\end{array}$ & $\mathrm{R} \$ 8.953,67$ & $\mathrm{R} \$ 8.953,67$ \\
\hline
\end{tabular}

(*) Média com base no ano de 2018: PIB per capita de Lábrea (R\$ 10.941,94) e PIB per capita de Canutama (R\$ $6.965,40)$ - Último ano divulgado conforme dados do IBGE.

Tabela 78 - Sustentabilidade Financeira da Localidade Bom Sucesso (2019-2020)

\begin{tabular}{|c|c|c|c|c|}
\hline \multirow[b]{2}{*}{$\begin{array}{l}\text { Parâmetros Avaliados } \\
\text { [A comunidade possui...] }\end{array}$} & \multicolumn{2}{|c|}{ Avaliação 2019} & \multicolumn{2}{|c|}{ Avaliação 2020} \\
\hline & $\begin{array}{l}\text { Referência } \\
\text { (1 ou 0) }\end{array}$ & $\begin{array}{l}\text { Resultado } \\
\text { (\%) }\end{array}$ & $\begin{array}{l}\text { Referência } \\
\text { (1 ou 0) }\end{array}$ & $\begin{array}{c}\text { Resultado } \\
\text { (\%) }\end{array}$ \\
\hline (1) Líder comunitário com perfil empreendedor & 0 & $0,00000 \%$ & 0 & $0,0000 \%$ \\
\hline (2) Controle de castanhal e exploração de castanhal & 0 & $0,00000 \%$ & 0 & $0,0000 \%$ \\
\hline (3) $\mathrm{N}^{\circ}$ mínimo de residentes $\geq 30$ pessoas & 0 & $0,00000 \%$ & 0 & $0,0000 \%$ \\
\hline $\begin{array}{l}\text { (4) Produção per capita da comunidade } \geq \text { média do PIB } \\
\text { per capita dos municípios Canutama e Lábrea }\end{array}$ & 0 & $0,00000 \%$ & 0 & $0,0000 \%$ \\
\hline $\begin{array}{l}\text { (5) Produção na Comunidade } \geq \text { média da produção total } \\
\text { na Resex Canutama }\end{array}$ & 1 & $9,09091 \%$ & 0 & $0,0000 \%$ \\
\hline $\begin{array}{l}\text { (6) Produção diversificada e contendo o produto potencial } \\
\text { 'Farinha' com produção } \geq 10 \%\end{array}$ & 1 & $9,09091 \%$ & 1 & $9,0909 \%$ \\
\hline $\begin{array}{l}\text { (7) Produção diversificada e contendo o produto potencial } \\
\text { 'Peixe Fresco' com produção } \geq 10 \%\end{array}$ & 0 & $0,00000 \%$ & 0 & $0,0000 \%$ \\
\hline $\begin{array}{l}\text { (8) Produção diversificada e contendo o produto potencial } \\
\text { 'Peixe Seco' com produção } \geq 10 \%\end{array}$ & 1 & $9,09091 \%$ & 0 & $0,0000 \%$ \\
\hline $\begin{array}{l}\text { (9) Produção diversificada e contendo o produto potencial } \\
\text { 'Porco' com produção } \geq 10 \%\end{array}$ & 1 & $9,09091 \%$ & 0 & $0,0000 \%$ \\
\hline $\begin{array}{l}\text { (10) Produção diversificada e contendo o produto } \\
\text { potencial 'Açaí' com produção } \geq 10 \%\end{array}$ & 0 & $0,00000 \%$ & 0 & $0,0000 \%$ \\
\hline $\begin{array}{l}\text { (11) Produção diversificada e contendo o produto } \\
\text { potencial 'Castanha' com produção } \geq 10 \%\end{array}$ & 1 & $9,09091 \%$ & 1 & $9,0909 \%$ \\
\hline $\begin{array}{l}\text { Índice de Sustentabilidade Financeira } \\
\text { (resultado arredondado) }\end{array}$ & 5 & $45,50 \%$ & 2 & $18,20 \%$ \\
\hline $\begin{array}{l}\text { Legenda: Na Coluna [Referência] } \\
\text { [1] Sim, a comunidade atende o parâmetro } \\
\text { [0] Não, a comunidade não atende o parâmetro }\end{array}$ & $\begin{array}{l}\text { egenda: } \mathrm{NaC} \\
\text { 1] Avaliação } 1 \\
\text { 0] Avaliação } 1\end{array}$ & $\begin{array}{l}\text { luna [Resul } \\
\text { ositiva gera } \\
\text { egativa gera }\end{array}$ & $\begin{array}{l}\text { ido] } \\
\text { n percentual } \\
\text { ercentual de }\end{array}$ & $\begin{array}{l}9,09091 \% \\
0000 \%\end{array}$ \\
\hline
\end{tabular}

Fonte: Elaborado pela autora. 
Tabela 79 - Producão na Localidade Bom Sucesso (2019)

\begin{tabular}{lcc|c|c}
\hline Produto & $\begin{array}{c}\text { Quantidade } \\
\text { Vendida }\end{array}$ & $\begin{array}{c}\text { Preço } \\
\text { Médio } \\
\text { (R\$) }\end{array}$ & $\begin{array}{c}\text { Valor } \\
\text { recebido } \\
\text { (R\$) }\end{array}$ & \% \\
\hline Pescado Seco (Kg) & 2800 & 7,00 & $19.600,00$ & $23,76 \%$ \\
Castanha (Hectolitro; 100 litros) & 75 & 250,00 & $18.750,00$ & $22,73 \%$ \\
Farinha (Saca de 50Kg) & 70 & 170,00 & $11.900,00$ & $14,42 \%$ \\
Porco (Unidade) & 50 & 210,00 & $10.500,00$ & $12,73 \%$ \\
Pescado Fresco (Kg) & 1200 & 6,00 & $7.200,00$ & $8,73 \%$ \\
Melancia (Unidade) & 1000 & 5,00 & $5.000,00$ & $6,06 \%$ \\
Andiroba semente (Lata 20Kg) & 325 & 14,00 & $4.550,00$ & $5,52 \%$ \\
Feijão (Kg) & 200 & 5,00 & $1.000,00$ & $1,21 \%$ \\
Açaí Beneficiado (Litro) & 200 & 4,00 & 800,00 & $0,97 \%$ \\
Galinha Caipira (Unidade) & 40 & 15,00 & 600,00 & $0,73 \%$ \\
Pato (Unidade) & 25 & 20,00 & 500,00 & $0,61 \%$ \\
Melão (Unidade) & 100 & 5,00 & 500,00 & $0,61 \%$ \\
Macaxeira (Kg) & 150 & 3,00 & 450,00 & $0,55 \%$ \\
Goma da Mandioca (Lata 20Kg) & 5 & 80,00 & 400,00 & $0,48 \%$ \\
Maxixe (Kg) & 60 & 5,00 & 300,00 & $0,36 \%$ \\
Jerimum (Unidade) & 100 & 3,00 & 300,00 & $0,36 \%$ \\
Banana (Cacho) & 10 & 15,00 & 150,00 & $0,18 \%$ \\
\hline Valor total recebido (R\$) & & & $\mathbf{8 2 . 5 0 0 , 0 0}$ & $\mathbf{1 0 0 , 0 0 \%}$ \\
\hline
\end{tabular}

Tabela 80 - Produção na Localidade Bom Sucesso (2020)

\begin{tabular}{l|cc|r|c}
\hline Produto & $\begin{array}{c}\text { Quantidade } \\
\text { Vendida }\end{array}$ & $\begin{array}{c}\text { Preço } \\
\text { e Unidio } \\
\text { (R\$) }\end{array}$ & $\begin{array}{c}\text { Valor } \\
\text { recebido } \\
\text { (R\$) }\end{array}$ & \% \\
\hline Castanha (Hectolitro; 100 litros) & 117 & 200,00 & $23.400,00$ & $44,95 \%$ \\
Farinha (Saca de 50Kg) & 60 & 200,00 & $12.000,00$ & $23,05 \%$ \\
Melancia (Unidade) & 600 & 8,00 & $4.800,00$ & $9,22 \%$ \\
Pescado Seco (Kg) & 700 & 6,00 & $4.200,00$ & $8,07 \%$ \\
Pescado Fresco (Kg) & 600 & 5,00 & $3.000,00$ & $5,76 \%$ \\
Andiroba semente (Lata 20Kg) & 214 & 10,00 & $2.140,00$ & $4,11 \%$ \\
Murumuru semente (Lata 20Kg) & 140 & 14,42 & $2.018,80$ & $3,88 \%$ \\
Feijão (Kg) & 20 & 6,00 & 120,00 & $0,23 \%$ \\
Melão (Unidade) & 20 & 6,00 & 120,00 & $0,23 \%$ \\
Porco (Kg) & 10 & 10,00 & 100,00 & $0,19 \%$ \\
Galinha Caipira (Unidade) & 4 & 25,00 & 100,00 & $0,19 \%$ \\
Batata-doce (Kg) & 9 & 4,00 & 36,00 & $0,07 \%$ \\
Jerimum (Unidade) & 5 & 5,00 & 25,00 & $0,05 \%$ \\
\hline Valor total recebido (R\$) & & & $\mathbf{5 2 . 0 5 9 , 8 0}$ & $\mathbf{1 0 0 , 0 0 \%}$ \\
\hline
\end{tabular}




\section{Localidade Santa Eugênia}

Quadro 32 - Dados gerais para Avaliação da Localidade Santa Eugênia (2019-2020)

\begin{tabular}{|c|c|c|}
\hline Informações & Ano 2019 & Ano 2020 \\
\hline Valor da Produção na Resex Canutama & $\mathrm{R} \$ 3.002 .952,00$ & $\mathrm{R} \$ 2.923 .589,36$ \\
\hline Média da Produção na Resex Canutama & $\mathrm{R} \$ 79.025,05$ & $\mathrm{R} \$ 76.936,56$ \\
\hline $\mathrm{N}^{\circ}$ de residentes na Comunidade & 7 & 7 \\
\hline $\mathrm{N}^{\circ}$ de produtos vendidos & 12 & 11 \\
\hline Valor da Produção na Comunidade & $\mathrm{R} \$ 58.006,00$ & $\mathrm{R} \$ 35.436,00$ \\
\hline Produção Per capita da Comunidade & $\mathrm{R} \$ 8.286,57$ & $\mathrm{R} \$ 5.062,29$ \\
\hline $\begin{array}{l}\text { Média do PIB per capita dos municípios de Canutama } \\
\text { e Lábrea* }\end{array}$ & $\mathrm{R} \$ 8.953,67$ & $\mathrm{R} \$ 8.953,67$ \\
\hline
\end{tabular}

(*) Média com base no ano de 2018: PIB per capita de Lábrea (R\$ 10.941,94) e PIB per capita de Canutama (R \$ $6.965,40)$ - Último ano divulgado conforme dados do IBGE.

Tabela 81 - Sustentabilidade Financeira da Localidade Santa Eugênia (2019-2020)

\begin{tabular}{|c|c|c|c|c|}
\hline \multirow[b]{2}{*}{$\begin{array}{l}\text { Parâmetros Avaliados } \\
\text { [A comunidade possui....] }\end{array}$} & \multicolumn{2}{|c|}{ Avaliação 2019} & \multicolumn{2}{|c|}{ Avaliação 2020} \\
\hline & $\begin{array}{l}\text { Referência } \\
\text { (1 ou 0) }\end{array}$ & $\begin{array}{c}\text { Resultado } \\
(\%)\end{array}$ & $\begin{array}{l}\text { Referência } \\
\text { (1 ou 0) }\end{array}$ & $\begin{array}{c}\text { Resultado } \\
(\%)\end{array}$ \\
\hline (1) Líder comunitário com perfil empreendedor & 0 & $0,00000 \%$ & 0 & $0,0000 \%$ \\
\hline (2) Controle de castanhal e exploração de castanhal & 0 & $0,00000 \%$ & 0 & $0,0000 \%$ \\
\hline (3) $\mathrm{N}^{\circ}$ mínimo de residentes $\geq 30$ pessoas & 0 & $0,00000 \%$ & 0 & $0,0000 \%$ \\
\hline $\begin{array}{l}\text { (4) Produção per capita da comunidade } \geq \text { média do PIB } \\
\text { per capita dos municípios Canutama e Lábrea }\end{array}$ & 0 & $0,00000 \%$ & 0 & $0,0000 \%$ \\
\hline $\begin{array}{l}\text { (5) Produção na Comunidade } \geq \text { média da produção total } \\
\text { na Resex Canutama }\end{array}$ & 0 & $0,00000 \%$ & 0 & $0,0000 \%$ \\
\hline $\begin{array}{l}\text { (6) Produção diversificada e contendo o produto potencial } \\
\text { 'Farinha' com produção } \geq 10 \%\end{array}$ & 0 & $0,00000 \%$ & 1 & $9,0909 \%$ \\
\hline $\begin{array}{l}\text { (7) Produção diversificada e contendo o produto potencial } \\
\text { 'Peixe Fresco' com produção } \geq 10 \%\end{array}$ & 0 & $0,00000 \%$ & 0 & $0,0000 \%$ \\
\hline $\begin{array}{l}\text { (8) Produção diversificada e contendo o produto potencial } \\
\text { 'Peixe Seco' com produção } \geq 10 \%\end{array}$ & 0 & $0,00000 \%$ & 0 & $0,0000 \%$ \\
\hline $\begin{array}{l}\text { (9) Produção diversificada e contendo o produto potencial } \\
\text { 'Porco' com produção } \geq 10 \%\end{array}$ & 0 & $0,00000 \%$ & 0 & $0,0000 \%$ \\
\hline $\begin{array}{l}\text { (10) Produção diversificada e contendo o produto } \\
\text { potencial 'Açaí' com produção } \geq 10 \%\end{array}$ & 0 & $0,00000 \%$ & 0 & $0,0000 \%$ \\
\hline $\begin{array}{l}\text { (11) Produção diversificada e contendo o produto } \\
\text { potencial 'Castanha' com produção } \geq 10 \%\end{array}$ & 0 & $0,00000 \%$ & 0 & $0,0000 \%$ \\
\hline $\begin{array}{l}\text { Índice de Sustentabilidade Financeira } \\
\text { (resultado arredondado) }\end{array}$ & $\mathbf{0}$ & $0,00 \%$ & 1 & $9,10 \%$ \\
\hline $\begin{array}{l}\text { Legenda: Na Coluna [Referência] } \\
\text { [1] Sim, a comunidade atende o parâmetro } \\
\text { [0] Não, a comunidade não atende o parâmetro }\end{array}$ & $\begin{array}{l}\text { Legenda: } \mathrm{Na}( \\
\text { 1] Avaliação } \\
\text { 0] Avaliação }\end{array}$ & $\begin{array}{l}\text { luna [Resul } \\
\text { ositiva gera } \\
\text { egativa gera }\end{array}$ & $\begin{array}{l}\text { ado] } \\
\text { n percentual } \\
\text { ercentual de }(\end{array}$ & $\begin{array}{l}9,09091 \% \\
0000 \%\end{array}$ \\
\hline
\end{tabular}

Fonte: Elaborado pela autora. 
Tabela 82 - Produção na Localidade Santa Eugênia (2019)

\begin{tabular}{|c|c|c|c|c|}
\hline $\begin{array}{l}\text { Produto } \\
\text { e Unidade de Medida }\end{array}$ & $\begin{array}{l}\text { Quantidade } \\
\text { Vendida }\end{array}$ & $\begin{array}{l}\text { Preço } \\
\text { Médio } \\
\text { (R\$) }\end{array}$ & $\begin{array}{c}\text { Valor } \\
\text { recebido }(\mathbf{R} \$)\end{array}$ & $\%$ \\
\hline Carvão Vegetal (Saco 50Kg) & 2.100 & 18,00 & $37.800,00$ & $65,17 \%$ \\
\hline Melancia (Unidade) & 2.000 & 5,00 & $10.000,00$ & $17,24 \%$ \\
\hline Pescado Fresco (Kg) & 700 & 6,00 & $4.200,00$ & $7,24 \%$ \\
\hline Farinha (Saca de $50 \mathrm{Kg}$ ) & 20 & 170,00 & $3.400,00$ & $5,86 \%$ \\
\hline Andiroba semente (Lata $20 \mathrm{Kg}$ ) & 89 & 14,00 & $1.246,00$ & $2,15 \%$ \\
\hline Jerimum (Unidade) & 100 & 3,00 & 300,00 & $0,52 \%$ \\
\hline Feijão (Kg) & 50 & 5,00 & 250,00 & $0,43 \%$ \\
\hline Açaí Beneficiado (Litro) & 60 & 4,00 & 240,00 & $0,41 \%$ \\
\hline Melão (Unidade) & 40 & 5,00 & 200,00 & $0,34 \%$ \\
\hline Galinha Caipira (Unidade) & 12 & 15,00 & 180,00 & $0,31 \%$ \\
\hline Maxixe $(\mathrm{Kg})$ & 20 & 5,00 & 100,00 & $0,17 \%$ \\
\hline Macaxeira $(\mathrm{Kg})$ & 30 & 3,00 & 90,00 & $0,16 \%$ \\
\hline Valor total recebido (RS) & & & $58.006,00$ & $100,00 \%$ \\
\hline
\end{tabular}

Tabela 83 - Produção na Localidade Santa Eugênia (2020)

\begin{tabular}{|c|c|c|c|c|}
\hline $\begin{array}{l}\text { Produto } \\
\text { e Unidade de Medida }\end{array}$ & $\begin{array}{l}\text { Quantidade } \\
\text { Vendida }\end{array}$ & $\begin{array}{l}\text { Preço } \\
\text { Médio } \\
\text { (R\$) }\end{array}$ & $\begin{array}{c}\text { Valor } \\
\text { recebido }(\mathrm{R} \$)\end{array}$ & $\%$ \\
\hline Melancia (Unidade) & 2.500 & 8,00 & $20.000,00$ & $56,44 \%$ \\
\hline Farinha (Saca de $50 \mathrm{Kg}$ ) & 29 & 200,00 & $5.800,00$ & $16,37 \%$ \\
\hline Boi $(\mathrm{Kg})$ & 250 & 16,00 & $4.000,00$ & $11,29 \%$ \\
\hline Castanha (Hectolitro; 100 litros) & 10 & 200,00 & $2.000,00$ & $5,64 \%$ \\
\hline Pescado Fresco $(\mathrm{Kg})$ & 300 & 5,00 & $1.500,00$ & $4,23 \%$ \\
\hline Pescado Seco $(\mathrm{Kg})$ & 200 & 6,00 & $1.200,00$ & $3,39 \%$ \\
\hline Feijão $(\mathrm{Kg})$ & 80 & 6,00 & 480,00 & $1,35 \%$ \\
\hline Milho Verde (Mão-50 espigas) & 8 & 25,00 & 200,00 & $0,56 \%$ \\
\hline Melão (Unidade) & 20 & 6,00 & 120,00 & $0,34 \%$ \\
\hline Jerimum (Unidade) & 20 & 5,00 & 100,00 & $0,28 \%$ \\
\hline Batata-doce $(\mathrm{Kg})$ & 9 & 4,00 & 36,00 & $0,10 \%$ \\
\hline Valor total recebido (RS) & & & $35.436,00$ & $100,00 \%$ \\
\hline
\end{tabular}




\section{Localidade Santa Cora}

Quadro 33 - Dados gerais para Avaliação da Localidade Santa Cora (2019-2020)

\begin{tabular}{|c|c|c|}
\hline Informações & Ano 2019 & Ano 2020 \\
\hline Valor da Produção na Resex Canutama & $\mathrm{R} \$ 3.002 .952,00$ & $\mathrm{R} \$ 2.923 .589,36$ \\
\hline Média da Produção na Resex Canutama & $\mathrm{R} \$ 79.025,05$ & $\mathrm{R} \$ 76.936,56$ \\
\hline $\mathrm{N}^{\mathrm{o}}$ de residentes na Comunidade & 10 & 10 \\
\hline $\mathrm{N}^{\circ}$ de produtos vendidos & 15 & 9 \\
\hline Valor da Produção na Comunidade & $\mathrm{R} \$ 37.360,00$ & $\mathrm{R} \$ 39.550,00$ \\
\hline Produção Per capita da Comunidade & $\mathrm{R} \$ 3.736,00$ & $\mathrm{R} \$ 3.955,00$ \\
\hline $\begin{array}{l}\text { Média do PIB per capita dos municípios de Canutama } \\
\text { e Lábrea* }\end{array}$ & $\mathrm{R} \$ 8.953,67$ & $\mathrm{R} \$ 8.953,67$ \\
\hline
\end{tabular}

(*) Média com base no ano de 2018: PIB per capita de Lábrea (R\$ 10.941,94) e PIB per capita de Canutama (R \$ $6.965,40)$ - Último ano divulgado conforme dados do IBGE.

Tabela 84 - Sustentabilidade Financeira da Localidade Santa Cora (2019-2020)

\begin{tabular}{|c|c|c|c|c|}
\hline \multirow[b]{2}{*}{$\begin{array}{l}\text { Parâmetros Avaliados } \\
\text { [A comunidade possui....] }\end{array}$} & \multicolumn{2}{|c|}{ Avaliação 2019} & \multicolumn{2}{|c|}{ Avaliação 2020} \\
\hline & $\begin{array}{c}\text { Referência } \\
(1 \text { ou } 0)\end{array}$ & $\begin{array}{c}\text { Resultado } \\
(\%)\end{array}$ & $\begin{array}{l}\text { Referência } \\
(1 \text { ou } 0)\end{array}$ & $\begin{array}{c}\text { Resultado } \\
(\%) \\
\end{array}$ \\
\hline (1) Líder comunitário com perfil empreendedor & 0 & $0,00000 \%$ & 0 & $0,0000 \%$ \\
\hline (2) Controle de castanhal e exploração de castanhal & 0 & $0,00000 \%$ & 0 & $0,0000 \%$ \\
\hline (3) $\mathrm{N}^{\circ}$ mínimo de residentes $\geq 30$ pessoas & 0 & $0,00000 \%$ & 0 & $0,0000 \%$ \\
\hline $\begin{array}{l}\text { (4) Produção per capita da comunidade } \geq \text { média do PIB } \\
\text { per capita dos municípios Canutama e Lábrea }\end{array}$ & 0 & $0,00000 \%$ & 0 & $0,0000 \%$ \\
\hline $\begin{array}{l}\text { (5) Produção na Comunidade } \geq \text { média da produção total } \\
\text { na Resex Canutama }\end{array}$ & 0 & $0,00000 \%$ & 0 & $0,0000 \%$ \\
\hline $\begin{array}{l}\text { (6) Produção diversificada e contendo o produto potencial } \\
\text { 'Farinha' com produção } \geq 10 \%\end{array}$ & 1 & $9,09091 \%$ & 1 & $9,0909 \%$ \\
\hline $\begin{array}{l}\text { (7) Produção diversificada e contendo o produto potencial } \\
\text { 'Peixe Fresco' com produção } \geq 10 \%\end{array}$ & 0 & $0,00000 \%$ & 0 & $0,0000 \%$ \\
\hline $\begin{array}{l}\text { (8) Produção diversificada e contendo o produto potencial } \\
\text { 'Peixe Seco' com produção } \geq 10 \%\end{array}$ & 1 & $9,09091 \%$ & 1 & $9,0909 \%$ \\
\hline $\begin{array}{l}\text { (9) Produção diversificada e contendo o produto potencial } \\
\text { 'Porco' com produção } \geq 10 \%\end{array}$ & 0 & $0,00000 \%$ & 0 & $0,0000 \%$ \\
\hline $\begin{array}{l}\text { (10) Produção diversificada e contendo o produto } \\
\text { potencial 'Açaí' com produção } \geq 10 \%\end{array}$ & 0 & $0,00000 \%$ & 0 & $0,0000 \%$ \\
\hline $\begin{array}{l}\text { (11) Produção diversificada e contendo o produto } \\
\text { potencial 'Castanha' com produção } \geq 10 \%\end{array}$ & 1 & $9,09091 \%$ & 1 & $9,0909 \%$ \\
\hline $\begin{array}{l}\text { Índice de Sustentabilidade Financeira } \\
\text { (resultado arredondado) }\end{array}$ & 3 & $27,30 \%$ & 3 & $27,30 \%$ \\
\hline $\begin{array}{l}\text { Legenda: Na Coluna [Referência] } \\
\text { [1] Sim, a comunidade atende o parâmetro } \\
\text { [0] Não, a comunidade não atende o parâmetro }\end{array}$ & $\begin{array}{l}\text { egenda: } \mathrm{NaC} \\
\text { 1] Avaliação } \\
\text { 0] Avaliação }\end{array}$ & $\begin{array}{l}\text { luna [Resul } \\
\text { ositiva gera } \\
\text { egativa gera }\end{array}$ & $\begin{array}{l}\text { do] } \\
\text { n percentual } \\
\text { ercentual de }\end{array}$ & $\begin{array}{l}9,09091 \% \\
0000 \%\end{array}$ \\
\hline
\end{tabular}

Fonte: Elaborado pela autora. 
Tabela 85 - Produção na Localidade Santa Cora (2019)

\begin{tabular}{lccc|c}
\hline Produto & $\begin{array}{c}\text { Quantidade } \\
\text { Vendida }\end{array}$ & $\begin{array}{c}\text { Preço } \\
\text { Médio } \\
\text { (R\$) }\end{array}$ & $\begin{array}{c}\text { Valor } \\
\text { recebido } \\
\text { (R\$) }\end{array}$ & \% \\
\hline Castanha (Hectolitro; 100 litros) & 65 & 250,00 & $16.250,00$ & $43,50 \%$ \\
Farinha (Saca de 50Kg) & 25 & 170,00 & $4.250,00$ & $11,38 \%$ \\
Pescado Seco (Kg) & 600 & 7,00 & $4.200,00$ & $11,24 \%$ \\
Andiroba semente (Lata 20Kg) & 288 & 14,00 & $4.032,00$ & $10,79 \%$ \\
Banana (Cacho) & 220 & 15,00 & $3.300,00$ & $8,83 \%$ \\
Melancia (Unidade) & 500 & 5,00 & $2.500,00$ & $6,69 \%$ \\
Jerimum (Unidade) & 300 & 3,00 & 900,00 & $2,41 \%$ \\
Macaxeira (Kg) & 200 & 3,00 & 600,00 & $1,61 \%$ \\
Goma da Mandioca (Lata 20Kg) & 5 & 80,00 & 400,00 & $1,07 \%$ \\
Galinha Caipira (Unidade) & 20 & 15,00 & 300,00 & $0,80 \%$ \\
Melão (Unidade) & 50 & 5,00 & 250,00 & $0,67 \%$ \\
Murumuru semente (Lata 20Kg) & 21 & 8,00 & 168,00 & $0,45 \%$ \\
Feijão (Kg) & 20 & 5,00 & 100,00 & $0,27 \%$ \\
Açaí Beneficiado (Litro) & 20 & 4,00 & 80,00 & $0,21 \%$ \\
Milho Seco (Kg) & 20 & 1,50 & 30,00 & $0,08 \%$ \\
\hline Valor total recebido (R\$) & & & $\mathbf{3 7 . 3 6 0 , 0 0}$ & $\mathbf{1 0 0 , 0 0 \%}$ \\
\hline
\end{tabular}

Tabela 86 - Produção na Localidade Santa Cora (2020)

\begin{tabular}{|c|c|c|c|c|}
\hline $\begin{array}{l}\text { Produto } \\
\text { e Unidade de Medida }\end{array}$ & $\begin{array}{l}\text { Quantidade } \\
\text { Vendida }\end{array}$ & $\begin{array}{l}\text { Preço } \\
\text { Médio } \\
\text { (R\$) }\end{array}$ & $\begin{array}{l}\text { Valor } \\
\text { recebido } \\
(\mathbf{R} \$)\end{array}$ & $\%$ \\
\hline Banana (Cacho) & 550 & 30,00 & $16.500,00$ & $41,72 \%$ \\
\hline Farinha (Saca de $50 \mathrm{Kg}$ ) & 35 & 200,00 & $7.000,00$ & $17,70 \%$ \\
\hline Castanha (Hectolitro; 100 litros) & 33 & 200,00 & $6.600,00$ & $16,69 \%$ \\
\hline Pescado Seco $(\mathrm{Kg})$ & 1.000 & 6,00 & $6.000,00$ & $15,17 \%$ \\
\hline Melancia (Unidade) & 200 & 8,00 & $1.600,00$ & $4,05 \%$ \\
\hline Pescado Fresco (Kg) & 300 & 5,00 & $1.500,00$ & $3,79 \%$ \\
\hline Melão (Unidade) & 30 & 6,00 & 180,00 & $0,46 \%$ \\
\hline Feijão (Kg) & 25 & 6,00 & 150,00 & $0,38 \%$ \\
\hline Batata-doce (Kg) & 5 & 4,00 & 20,00 & $0,05 \%$ \\
\hline Valor total recebido (RS) & & & $39.550,00$ & $100,00 \%$ \\
\hline
\end{tabular}




\section{Localidade Estirão do Açaituba}

Quadro 34 - Dados gerais para Avaliação da Localidade Estirão do Açaituba (2019-2020)

\begin{tabular}{|c|c|c|}
\hline Informações & Ano 2019 & Ano 2020 \\
\hline Valor da Produção na Resex Canutama & $\mathrm{R} \$ 3.002 .952,00$ & $\mathrm{R} \$ 2.923 .589,36$ \\
\hline Média da Produção na Resex Canutama & $\mathrm{R} \$ 79.025,05$ & $\mathrm{R} \$ 76.936,56$ \\
\hline $\mathrm{N}^{\mathrm{o}}$ de residentes na Comunidade & 13 & 13 \\
\hline $\mathrm{N}^{\circ}$ de produtos vendidos & 0 & 11 \\
\hline Valor da Produção na Comunidade & $\mathrm{R} \$ 0,00$ & $\mathrm{R} \$ 71.138,62$ \\
\hline Produção Per capita da Comunidade & $\mathrm{R} \$ 00,00$ & $\mathrm{R} \$ 5.472,20$ \\
\hline $\begin{array}{l}\text { Média do PIB per capita dos municípios de Canutama } \\
\text { e Lábrea* }\end{array}$ & $\mathrm{R} \$ 8.953,67$ & $\mathrm{R} \$ 8.953,67$ \\
\hline
\end{tabular}

(*) Média com base no ano de 2018: PIB per capita de Lábrea (R\$ 10.941,94) e PIB per capita de Canutama (R\$ $6.965,40)$ - Último ano divulgado conforme dados do IBGE.

Tabela 87 - Sustentabilidade Financeira da Localidade Estirão do Açaituba (2019-2020)

\begin{tabular}{|c|c|c|c|c|}
\hline \multirow[b]{2}{*}{$\begin{array}{l}\text { Parâmetros Avaliados } \\
\text { [A comunidade possui...] }\end{array}$} & \multicolumn{2}{|c|}{ Avaliação 2019} & \multicolumn{2}{|c|}{ Avaliação 2020} \\
\hline & $\begin{array}{c}\text { Referência } \\
\text { (1 ou 0) }\end{array}$ & $\begin{array}{c}\text { Resultado } \\
(\%)\end{array}$ & $\begin{array}{l}\text { Referência } \\
\text { (1 ou 0) }\end{array}$ & $\begin{array}{c}\text { Resultado } \\
(\%)\end{array}$ \\
\hline (1) Líder comunitário com perfil empreendedor & 0 & $0,00000 \%$ & 0 & $0,0000 \%$ \\
\hline (2) Controle de castanhal e exploração de castanhal & 0 & $0,00000 \%$ & 0 & $0,0000 \%$ \\
\hline (3) $\mathrm{N}^{\circ}$ mínimo de residentes $\geq 30$ pessoas & 0 & $0,00000 \%$ & 0 & $0,0000 \%$ \\
\hline $\begin{array}{l}\text { (4) Produção per capita da comunidade } \geq \text { média do PIB } \\
\text { per capita dos municípios Canutama e Lábrea }\end{array}$ & 0 & $0,00000 \%$ & 0 & $0,0000 \%$ \\
\hline $\begin{array}{l}\text { (5) Produção na Comunidade } \geq \text { média da produção total } \\
\text { na Resex Canutama }\end{array}$ & 0 & $0,00000 \%$ & 0 & $0,0000 \%$ \\
\hline $\begin{array}{l}\text { (6) Produção diversificada e contendo o produto potencial } \\
\text { 'Farinha' com produção } \geq 10 \%\end{array}$ & 0 & $0,00000 \%$ & 0 & $0,0000 \%$ \\
\hline $\begin{array}{l}\text { (7) Produção diversificada e contendo o produto potencial } \\
\text { 'Peixe Fresco' com produção } \geq 10 \%\end{array}$ & 0 & $0,00000 \%$ & 1 & $9,0909 \%$ \\
\hline $\begin{array}{l}\text { (8) Produção diversificada e contendo o produto potencial } \\
\text { 'Peixe Seco' com produção } \geq 10 \%\end{array}$ & 0 & $0,00000 \%$ & 0 & $0,0000 \%$ \\
\hline $\begin{array}{l}\text { (9) Produção diversificada e contendo o produto potencial } \\
\text { 'Porco' com produção } \geq 10 \%\end{array}$ & 0 & $0,00000 \%$ & 0 & $0,0000 \%$ \\
\hline $\begin{array}{l}\text { (10) Produção diversificada e contendo o produto } \\
\text { potencial 'Açaí' com produção } \geq 10 \%\end{array}$ & 0 & $0,00000 \%$ & 1 & $9,0909 \%$ \\
\hline $\begin{array}{l}\text { (11) Produção diversificada e contendo o produto } \\
\text { potencial 'Castanha' com produção } \geq 10 \%\end{array}$ & 0 & $0,00000 \%$ & 0 & $0,0000 \%$ \\
\hline $\begin{array}{l}\text { Índice de Sustentabilidade Financeira } \\
\text { (resultado arredondado) }\end{array}$ & $\mathbf{0}$ & $00,00 \%$ & 2 & $18,20 \%$ \\
\hline $\begin{array}{l}\text { Legenda: Na Coluna [Referência] } \\
\text { [1] Sim, a comunidade atende o parâmetro } \\
\text { [0] Não, a comunidade não atende o parâmetro }\end{array}$ & 1] Avaliação & $\begin{array}{l}\text { luna [Result } \\
\text { ositiva gera } u \\
\text { egativa gera }\end{array}$ & $\begin{array}{l}\text { do] } \\
\text { percentual } \\
\text { reentual de }\end{array}$ & $\begin{array}{l}9,09091 \% \\
0000 \%\end{array}$ \\
\hline
\end{tabular}


Tabela 88 - Produção na Localidade Estirão do Açaituba (2020)

\begin{tabular}{l|c|r|r|c}
\hline $\begin{array}{l}\text { Produto } \\
\text { e Unidade de Medida }\end{array}$ & $\begin{array}{c}\text { Quantidade } \\
\text { Vendida }\end{array}$ & $\begin{array}{c}\text { Preço } \\
\text { Médio } \\
\text { (R\$) }\end{array}$ & $\begin{array}{c}\text { Valor } \\
\text { recebido (R\$) }\end{array}$ & \% \\
\hline Açaí Fruto (Lata 18Kg) & 3.500 & 15,00 & $52.500,00$ & $73,80 \%$ \\
\hline Pescado Fresco (Kg) & 2.000 & 5,00 & $10.000,00$ & $14,06 \%$ \\
Melancia (Unidade) & 320 & 8,00 & $2.560,00$ & $3,60 \%$ \\
\hline Farinha (Saca de 50Kg) & 12 & 200,00 & $2.400,00$ & $3,37 \%$ \\
Pescado Seco (Kg) & 300 & 6,00 & $1.800,00$ & $2,53 \%$ \\
Banana (Cacho) & 40 & 30,00 & $1.200,00$ & $1,69 \%$ \\
\hline Andiroba semente (Lata 20Kg) & 30 & 10,00 & 300,00 & $0,42 \%$ \\
Murumuru semente (Lata 20Kg) & 11 & 14,42 & 158,62 & $0,22 \%$ \\
Melão (Unidade) & 18 & 6,00 & 108,00 & $0,15 \%$ \\
\hline Feijão (Kg) & 10 & 6,00 & 60,00 & $0,08 \%$ \\
\hline Batata-doce (Kg) & 13 & 4,00 & 52,00 & $0,07 \%$ \\
\hline Valor total recebido (R\$) & & & $\mathbf{7 1 . 1 3 8 , 6 2}$ & $\mathbf{1 0 0 , 0 0 \%}$ \\
\hline
\end{tabular}




\section{Localidade São Francisco}

Quadro 35 - Dados gerais para Avaliação da Localidade São Francisco (2019-2020)

\begin{tabular}{|l|c|c|}
\hline \multicolumn{1}{|c|}{ Informações } & Ano 2019 & Ano 2020 \\
\hline Valor da Produção na Resex Canutama & $\mathrm{R} \$ 3.002 .952,00$ & $\mathrm{R} \$ 2.923 .589,36$ \\
\hline Média da Produção na Resex Canutama & $\mathrm{R} \$ 79.025,05$ & $\mathrm{R} \$ 76.936,56$ \\
\hline $\mathrm{N}^{\circ}$ de residentes na Comunidade & 7 & 7 \\
\hline $\mathrm{N}^{\circ}$ de produtos vendidos & 0 & $\mathrm{R} \$ 49.630,00$ \\
\hline Valor da Produção na Comunidade & $\mathrm{R} \$ 0,00$ & $\mathrm{R} \$ 7.090,00$ \\
\hline Produção Per capita da Comunidade & $\mathrm{R} \$ 0,00$ & $\mathrm{R} \$ 8.953,67$ \\
\hline $\begin{array}{l}\text { Média do PIB per capita dos municípios de Canutama } \\
\text { e Lábrea* }\end{array}$ & $\mathrm{R} \$ 8.953,67$ & \\
\hline
\end{tabular}

(*) Média com base no ano de 2018: PIB per capita de Lábrea (R\$ 10.941,94) e PIB per capita de Canutama (R\$ $6.965,40)$ - Último ano divulgado conforme dados do IBGE.

Tabela 89 - Sustentabilidade Financeira da Localidade São Francisco (2019-2020)

\begin{tabular}{|c|c|c|c|c|}
\hline \multirow[b]{2}{*}{$\begin{array}{l}\text { Parâmetros Avaliados } \\
\text { [A comunidade possui...] }\end{array}$} & \multicolumn{2}{|c|}{ Avaliação 2019} & \multicolumn{2}{|c|}{ Avaliação 2020} \\
\hline & $\begin{array}{l}\text { Referência } \\
\text { (1 ou 0) }\end{array}$ & $\begin{array}{l}\text { Resultado } \\
\text { (\%) }\end{array}$ & $\begin{array}{l}\text { Referência } \\
\text { (1 ou 0) }\end{array}$ & $\begin{array}{c}\text { Resultado } \\
\text { (\%) }\end{array}$ \\
\hline (1) Líder comunitário com perfil empreendedor & 0 & $0,00000 \%$ & 0 & $0,0000 \%$ \\
\hline (2) Controle de castanhal e exploração de castanhal & 0 & $0,00000 \%$ & 0 & $0,0000 \%$ \\
\hline (3) $\mathrm{N}^{\circ}$ mínimo de residentes $\geq 30$ pessoas & 0 & $0,00000 \%$ & 0 & $0,0000 \%$ \\
\hline $\begin{array}{l}\text { (4) Produção per capita da comunidade } \geq \text { média do PIB } \\
\text { per capita dos municípios Canutama e Lábrea }\end{array}$ & 0 & $0,00000 \%$ & 0 & $0,0000 \%$ \\
\hline $\begin{array}{l}\text { (5) Produção na Comunidade } \geq \text { média da produção total } \\
\text { na Resex Canutama }\end{array}$ & 0 & $0,00000 \%$ & 0 & $0,0000 \%$ \\
\hline $\begin{array}{l}\text { (6) Produção diversificada e contendo o produto potencial } \\
\text { 'Farinha' com produção } \geq 10 \%\end{array}$ & 0 & $0,00000 \%$ & 0 & $0,0000 \%$ \\
\hline $\begin{array}{l}\text { (7) Produção diversificada e contendo o produto potencial } \\
\text { 'Peixe Fresco' com produção } \geq 10 \%\end{array}$ & 0 & $0,00000 \%$ & 1 & $9,0909 \%$ \\
\hline $\begin{array}{l}\text { (8) Produção diversificada e contendo o produto potencial } \\
\text { 'Peixe Seco' com produção } \geq 10 \%\end{array}$ & 0 & $0,00000 \%$ & 0 & $0,0000 \%$ \\
\hline $\begin{array}{l}\text { (9) Produção diversificada e contendo o produto potencial } \\
\text { 'Porco' com produção } \geq 10 \%\end{array}$ & 0 & $0,00000 \%$ & 0 & $0,0000 \%$ \\
\hline $\begin{array}{l}\text { (10) Produção diversificada e contendo o produto } \\
\text { potencial 'Açaí' com produção } \geq 10 \%\end{array}$ & 0 & $0,00000 \%$ & 0 & $0,0000 \%$ \\
\hline $\begin{array}{l}\text { (11) Produção diversificada e contendo o produto } \\
\text { potencial 'Castanha' com produção } \geq 10 \%\end{array}$ & 0 & $0,00000 \%$ & 1 & $9,0909 \%$ \\
\hline $\begin{array}{l}\text { Índice de Sustentabilidade Financeira } \\
\text { (resultado arredondado) }\end{array}$ & 0 & $0,00 \%$ & 2 & $18,20 \%$ \\
\hline $\begin{array}{l}\text { Legenda: Na Coluna [Referência] } \\
\text { [1] Sim, a comunidade atende o parâmetro } \\
\text { [0] Não, a comunidade não atende o parâmetro }\end{array}$ & $\begin{array}{l}\text { egenda: } \mathrm{NaC} \\
\text { 1] Avaliação } 1 \\
\text { 0] Avaliação } 1\end{array}$ & $\begin{array}{l}\text { luna [Resul } \\
\text { ositiva gera } \\
\text { egativa gera }\end{array}$ & $\begin{array}{l}\text { ido] } \\
\text { n percentual } \\
\text { ercentual de }\end{array}$ & $\begin{array}{l}9,09091 \% \\
0000 \%\end{array}$ \\
\hline
\end{tabular}

Fonte: Elaborado pela autora. 
Tabela 90 - Produção na Localidade São Francisco (2020)

\begin{tabular}{|c|c|c|c|c|}
\hline $\begin{array}{l}\text { Produto } \\
\text { e Unidade de Medida }\end{array}$ & $\begin{array}{l}\text { Quantidade } \\
\text { Vendida }\end{array}$ & $\begin{array}{l}\text { Preço } \\
\text { Médio } \\
\text { (R\$) }\end{array}$ & $\begin{array}{c}\text { Valor } \\
\text { recebido (R\$) }\end{array}$ & $\%$ \\
\hline Pescado Fresco (Kg) & 6.000 & 5,00 & $30.000,00$ & $60,45 \%$ \\
\hline Castanha (Hectolitro; 100 litros) & 58 & 200,00 & $11.600,00$ & $23,37 \%$ \\
\hline Pescado Seco $(\mathrm{Kg})$ & 800 & 6,00 & $4.800,00$ & $9,67 \%$ \\
\hline Farinha (Saca de $50 \mathrm{Kg})$ & 10 & 200,00 & $2.000,00$ & $4,03 \%$ \\
\hline Melancia (Unidade) & 150 & 8,00 & $1.200,00$ & $2,42 \%$ \\
\hline Feijão (Kg) & 5 & 6,00 & 30,00 & $0,06 \%$ \\
\hline Valor total recebido (R\$) & & & $49.630,00$ & $100,00 \%$ \\
\hline
\end{tabular}




\section{Localidade Moará}

Quadro 36 - Dados gerais para Avaliação da Localidade Moará (2019-2020)

\begin{tabular}{|c|c|c|}
\hline Informações & Ano 2019 & Ano 2020 \\
\hline Valor da Produção na Resex Canutama & $\mathrm{R} \$ 3.002 .952,00$ & $\mathrm{R} \$ 2.923 .589,36$ \\
\hline Média da Produção na Resex Canutama & $\mathrm{R} \$ 79.025,05$ & $\mathrm{R} \$ 76.936,56$ \\
\hline $\mathrm{N}^{\circ}$ de residentes na Comunidade & 33 & 33 \\
\hline $\mathrm{N}^{\circ}$ de produtos vendidos & 0 & 12 \\
\hline Valor da Produção na Comunidade & $\mathrm{R} \$ 0,00$ & $\mathrm{R} \$ 48.396,00$ \\
\hline Produção Per capita da Comunidade & $\mathrm{R} \$ 0,00$ & $\mathrm{R} \$ 1.466,55$ \\
\hline $\begin{array}{l}\text { Média do PIB per capita dos municípios de Canutama } \\
\text { e Lábrea* }\end{array}$ & $\mathrm{R} \$ 8.953,67$ & $\mathrm{R} \$ 8.953,67$ \\
\hline
\end{tabular}

(*) Média com base no ano de 2018: PIB per capita de Lábrea (R\$ 10.941,94) e PIB per capita de Canutama (R\$ $6.965,40)$ - Último ano divulgado conforme dados do IBGE.

Tabela 91 - Sustentabilidade Financeira da Localidade Moará (2019-2020)

\begin{tabular}{|c|c|c|c|c|}
\hline \multirow[b]{2}{*}{$\begin{array}{l}\text { Parâmetros Avaliados } \\
\text { [A comunidade possui....] }\end{array}$} & \multicolumn{2}{|c|}{ Avaliação 2019} & \multicolumn{2}{|c|}{ Avaliação 2020} \\
\hline & $\begin{array}{l}\text { Referência } \\
\text { (1 ou 0) }\end{array}$ & $\begin{array}{c}\text { Resultado } \\
(\%)\end{array}$ & $\begin{array}{l}\text { Referência } \\
\text { (1 ou 0) }\end{array}$ & $\begin{array}{c}\text { Resultado } \\
(\%)\end{array}$ \\
\hline (1) Líder comunitário com perfil empreendedor & 0 & $0,00000 \%$ & 0 & $0,0000 \%$ \\
\hline (2) Controle de castanhal e exploração de castanhal & 0 & $0,00000 \%$ & 0 & $0,0000 \%$ \\
\hline (3) $\mathrm{N}^{\circ}$ mínimo de residentes $\geq 30$ pessoas & 1 & $0,00000 \%$ & 1 & $9,0909 \%$ \\
\hline $\begin{array}{l}\text { (4) Produção per capita da comunidade } \geq \text { média do PIB } \\
\text { per capita dos municípios Canutama e Lábrea }\end{array}$ & 0 & $0,00000 \%$ & 0 & $0,0000 \%$ \\
\hline $\begin{array}{l}\text { (5) Produção na Comunidade } \geq \text { média da produção total } \\
\text { na Resex Canutama }\end{array}$ & 0 & $0,00000 \%$ & 0 & $0,0000 \%$ \\
\hline $\begin{array}{l}\text { (6) Produção diversificada e contendo o produto potencial } \\
\text { 'Farinha' com produção } \geq 10 \%\end{array}$ & 0 & $0,00000 \%$ & 1 & $9,0909 \%$ \\
\hline $\begin{array}{l}\text { (7) Produção diversificada e contendo o produto potencial } \\
\text { 'Peixe Fresco' com produção } \geq 10 \%\end{array}$ & 0 & $0,00000 \%$ & 1 & $9,0909 \%$ \\
\hline $\begin{array}{l}\text { (8) Produção diversificada e contendo o produto potencial } \\
\text { 'Peixe Seco' com produção } \geq 10 \%\end{array}$ & 0 & $0,00000 \%$ & 0 & $0,0000 \%$ \\
\hline $\begin{array}{l}\text { (9) Produção diversificada e contendo o produto potencial } \\
\text { 'Porco' com produção } \geq 10 \%\end{array}$ & 0 & $0,00000 \%$ & 0 & $0,0000 \%$ \\
\hline $\begin{array}{l}\text { (10) Produção diversificada e contendo o produto } \\
\text { potencial 'Açaí' com produção } \geq 10 \%\end{array}$ & 0 & $0,00000 \%$ & 0 & $0,0000 \%$ \\
\hline $\begin{array}{l}\text { (11) Produção diversificada e contendo o produto } \\
\text { potencial 'Castanha' com produção } \geq 10 \%\end{array}$ & 0 & $0,00000 \%$ & 0 & $0,0000 \%$ \\
\hline $\begin{array}{l}\text { Índice de Sustentabilidade Financeira } \\
\text { (resultado arredondado) }\end{array}$ & 1 & $9,10 \%$ & 3 & $27,30 \%$ \\
\hline $\begin{array}{l}\text { Legenda: Na Coluna [Referência] } \\
\text { [1] Sim, a comunidade atende o parâmetro } \\
\text { [0] Não, a comunidade não atende o parâmetro } \\
\text { Fonte: Elaborado pela autora. }\end{array}$ & $\begin{array}{l}\text { Legenda: } \mathrm{Na} \text { C } \\
\text { [1] Avaliação } \\
\text { [0] Avaliação }\end{array}$ & $\begin{array}{l}\text { oluna [Resul } \\
\text { ositiva gera } \\
\text { egativa gera }\end{array}$ & $\begin{array}{l}\text { ado] } \\
\text { m percentual } \\
\text { ercentual de }\end{array}$ & $\begin{array}{l}9,09091 \% \\
0000 \%\end{array}$ \\
\hline
\end{tabular}


Tabela 92 - Produção na Localidade Moará (2020)

\begin{tabular}{|c|c|c|c|c|}
\hline $\begin{array}{l}\text { Produto } \\
\text { e Unidade de Medida }\end{array}$ & $\begin{array}{l}\text { Quantidade } \\
\text { Vendida }\end{array}$ & $\begin{array}{l}\text { Preço } \\
\text { Médio } \\
\text { (R\$) }\end{array}$ & $\begin{array}{c}\text { Valor } \\
\text { recebido (RS) }\end{array}$ & $\%$ \\
\hline Pescado Fresco (Kg) & 7.500 & 5,00 & $37.500,00$ & $77,49 \%$ \\
\hline Farinha (Saca de $50 \mathrm{Kg}$ ) & 30 & 200,00 & $6.000,00$ & $12,40 \%$ \\
\hline Pescado Seco $(\mathrm{Kg})$ & 400 & 6,00 & $2.400,00$ & $4,96 \%$ \\
\hline Melancia (Unidade) & 200 & 8,00 & $1.600,00$ & $3,31 \%$ \\
\hline Feijão (Kg) & 50 & 6,00 & 300,00 & $0,62 \%$ \\
\hline Galinha Caipira (Unidade) & 6 & 25,00 & 150,00 & $0,31 \%$ \\
\hline Melão (Unidade) & 20 & 6,00 & 120,00 & $0,25 \%$ \\
\hline Porco $(\mathrm{Kg})$ & 10 & 10,00 & 100,00 & $0,21 \%$ \\
\hline Porco (Unidade) & 10 & 6,00 & 60,00 & $0,12 \%$ \\
\hline Macaxeira (Kg) & 15 & 4,00 & 60,00 & $0,12 \%$ \\
\hline Batata-doce (Kg) & 14 & 4,00 & 56,00 & $0,12 \%$ \\
\hline Jerimum (Unidade) & 10 & 5,00 & 50,00 & $0,10 \%$ \\
\hline Valor total recebido $(\mathrm{R} \$)$ & & & $48.396,00$ & $100,00 \%$ \\
\hline
\end{tabular}




\section{Localidade Macacoã}

Quadro 37 - Dados gerais para Avaliação da Localidade Macacoã (2019-2020)

\begin{tabular}{|c|c|c|}
\hline Informações & Ano 2019 & Ano 2020 \\
\hline Valor da Produção na Resex Canutama & $\mathrm{R} \$ 3.002 .952,00$ & $\mathrm{R} \$ 2.923 .589,36$ \\
\hline Média da Produção na Resex Canutama & $\mathrm{R} \$ 79.025,05$ & $\mathrm{R} \$ 76.936,56$ \\
\hline $\mathrm{N}^{\circ}$ de residentes na Comunidade & 10 & 10 \\
\hline $\mathrm{N}^{\mathrm{o}}$ de produtos vendidos & 0 & 4 \\
\hline Valor da Produção na Comunidade & $\mathrm{R} \$ 0,00$ & $\mathrm{R} \$ 42.800,00$ \\
\hline Produção Per capita da Comunidade & $\mathrm{R} \$ 0,00$ & $\mathrm{R} \$ 4.280,00$ \\
\hline $\begin{array}{l}\text { Média do PIB per capita dos municípios de Canutama } \\
\text { e Lábrea* }\end{array}$ & $\mathrm{R} \$ 8.953,67$ & $\mathrm{R} \$ 8.953,67$ \\
\hline
\end{tabular}

(*) Média com base no ano de 2018: PIB per capita de Lábrea (R\$ 10.941,94) e PIB per capita de Canutama (R\$ $6.965,40)$ - Último ano divulgado conforme dados do IBGE.

Tabela 93 - Sustentabilidade Financeira da Localidade Macacoã (2019-2020)

\begin{tabular}{|c|c|c|c|c|}
\hline \multirow[b]{2}{*}{$\begin{array}{l}\text { Parâmetros Avaliados } \\
\text { [A comunidade possui....] }\end{array}$} & \multicolumn{2}{|c|}{ Avaliação 2019} & \multicolumn{2}{|c|}{ Avaliação 2020} \\
\hline & $\begin{array}{c}\text { Referência } \\
\text { (1 ou 0) }\end{array}$ & $\begin{array}{c}\text { Resultado } \\
(\%)\end{array}$ & $\begin{array}{l}\text { Referência } \\
\text { (1 ou 0) }\end{array}$ & $\begin{array}{c}\text { Resultado } \\
(\%)\end{array}$ \\
\hline (1) Líder comunitário com perfil empreendedor & 0 & $0,00000 \%$ & 0 & $0,0000 \%$ \\
\hline (2) Controle de castanhal e exploração de castanhal & 0 & $0,00000 \%$ & 0 & $0,0000 \%$ \\
\hline (3) $\mathrm{N}^{\circ}$ mínimo de residentes $\geq 30$ pessoas & 0 & $0,00000 \%$ & 0 & $0,0000 \%$ \\
\hline $\begin{array}{l}\text { (4) Produção per capita da comunidade } \geq \text { média do PIB } \\
\text { per capita dos municípios Canutama e Lábrea }\end{array}$ & 0 & $0,00000 \%$ & 0 & $0,0000 \%$ \\
\hline $\begin{array}{l}\text { (5) Produção na Comunidade } \geq \text { média da produção total } \\
\text { na Resex Canutama }\end{array}$ & 0 & $0,00000 \%$ & 0 & $0,0000 \%$ \\
\hline $\begin{array}{l}\text { (6) Produção diversificada e contendo o produto potencial } \\
\text { 'Farinha' com produção } \geq 10 \%\end{array}$ & 0 & $0,00000 \%$ & 0 & $0,0000 \%$ \\
\hline $\begin{array}{l}\text { (7) Produção diversificada e contendo o produto potencial } \\
\text { 'Peixe Fresco' com produção } \geq 10 \%\end{array}$ & 0 & $0,00000 \%$ & 1 & $9,0909 \%$ \\
\hline $\begin{array}{l}\text { (8) Produção diversificada e contendo o produto potencial } \\
\text { 'Peixe Seco' com produção } \geq 10 \%\end{array}$ & 0 & $0,00000 \%$ & 0 & $0,0000 \%$ \\
\hline $\begin{array}{l}\text { (9) Produção diversificada e contendo o produto potencial } \\
\text { 'Porco' com produção } \geq 10 \%\end{array}$ & 0 & $0,00000 \%$ & 0 & $0,0000 \%$ \\
\hline $\begin{array}{l}\text { (10) Produção diversificada e contendo o produto } \\
\text { potencial 'Açaí' com produção } \geq 10 \%\end{array}$ & 0 & $0,00000 \%$ & 0 & $0,0000 \%$ \\
\hline $\begin{array}{l}\text { (11) Produção diversificada e contendo o produto } \\
\text { potencial 'Castanha' com produção } \geq 10 \%\end{array}$ & 0 & $0,00000 \%$ & 1 & $9,0909 \%$ \\
\hline $\begin{array}{l}\text { Índice de Sustentabilidade Financeira } \\
\text { (resultado arredondado) }\end{array}$ & $\mathbf{0}$ & $0,00 \%$ & 2 & $18,20 \%$ \\
\hline $\begin{array}{l}\text { Legenda: Na Coluna [Referência] } \\
\text { [1] Sim, a comunidade atende o parâmetro } \\
\text { [0] Não, a comunidade não atende o parâmetro } \\
\text { Fonte: Elaborado pela autora. }\end{array}$ & $\begin{array}{l}\text { Legenda: } \mathrm{NaC} \\
\text { [1] Avaliação } 1 \\
\text { [0] Avaliação } 1\end{array}$ & $\begin{array}{l}\text { oluna [Resul } \\
\text { ositiva gera } \\
\text { egativa gera }\end{array}$ & $\begin{array}{l}\text { ado] } \\
\text { m percentual } \\
\text { ercentual de } 0\end{array}$ & $\begin{array}{l}9,09091 \% \\
0000 \%\end{array}$ \\
\hline
\end{tabular}


Tabela 94 - Produção na Localidade Macacoã (2020)

\begin{tabular}{l|ccr|c}
\hline $\begin{array}{l}\text { Produto } \\
\text { e Unidade de Medida }\end{array}$ & $\begin{array}{c}\text { Quantidade } \\
\text { Vendida }\end{array}$ & $\begin{array}{c}\text { Preço } \\
\text { Médio } \\
\text { (R\$) }\end{array}$ & $\begin{array}{c}\text { Valor } \\
\text { recebido (R\$) }\end{array}$ & \% \\
\hline Pescado Fresco (Kg) & 6.000 & 5,00 & $30.000,00$ & $70,09 \%$ \\
Castanha (Hectolitro; 100 litros) & 45 & 200,00 & $9.000,00$ & $21,03 \%$ \\
Farinha (Saca de 50Kg) & 10 & 200,00 & $2.000,00$ & $4,67 \%$ \\
Pescado Seco (Kg) & 300 & 6,00 & $1.800,00$ & $4,21 \%$ \\
\hline Valor total recebido & $(\mathbf{R S )}$ & & $\mathbf{4 2 . 8 0 0 , 0 0}$ & $\mathbf{1 0 0 , 0 0 \%}$ \\
\hline
\end{tabular}




\section{Localidade Paraíso}

Quadro 38 - Dados gerais para Avaliação da Localidade Paraíso (2019-2020)

\begin{tabular}{|c|c|c|}
\hline Informações & Ano 2019 & Ano 2020 \\
\hline Valor da Produção na Resex Canutama & $\mathrm{R} \$ 3.002 .952,00$ & $\mathrm{R} \$ 2.923 .589,36$ \\
\hline Média da Produção na Resex Canutama & $\mathrm{R} \$ 79.025,05$ & $\mathrm{R} \$ 76.936,56$ \\
\hline $\mathrm{N}^{\circ}$ de residentes na Comunidade & 6 & 6 \\
\hline $\mathrm{N}^{\mathrm{o}}$ de produtos vendidos & 0 & 7 \\
\hline Valor da Produção na Comunidade & $\mathrm{R} \$ 0,00$ & $\mathrm{R} \$ 34.830,00$ \\
\hline Produção Per capita da Comunidade & $\mathrm{R} \$ 0,00$ & $\mathrm{R} \$ 5.805,00$ \\
\hline $\begin{array}{l}\text { Média do PIB per capita dos municípios de Canutama } \\
\text { e Lábrea* }\end{array}$ & $\mathrm{R} \$ 8.953,67$ & $\mathrm{R} \$ 8.953,67$ \\
\hline
\end{tabular}

(*) Média com base no ano de 2018: PIB per capita de Lábrea (R\$ 10.941,94) e PIB per capita de Canutama (R\$ $6.965,40)$ - Último ano divulgado conforme dados do IBGE.

Tabela 95 - Sustentabilidade Financeira da Localidade Paraíso (2019-2020)

\begin{tabular}{|c|c|c|c|c|}
\hline \multirow[b]{2}{*}{$\begin{array}{l}\text { Parâmetros Avaliados } \\
\text { [A comunidade possui....] }\end{array}$} & \multicolumn{2}{|c|}{ Avaliação 2019} & \multicolumn{2}{|c|}{ Avaliação 2020} \\
\hline & $\begin{array}{c}\text { Referência } \\
(1 \text { ou } 0)\end{array}$ & $\begin{array}{c}\text { Resultado } \\
(\%)\end{array}$ & $\begin{array}{l}\text { Referência } \\
(1 \text { ou } 0)\end{array}$ & $\begin{array}{c}\text { Resultado } \\
(\%) \\
\end{array}$ \\
\hline (1) Líder comunitário com perfil empreendedor & 0 & $0,00000 \%$ & 0 & $0,0000 \%$ \\
\hline (2) Controle de castanhal e exploração de castanhal & 0 & $0,00000 \%$ & 0 & $0,0000 \%$ \\
\hline (3) $\mathrm{N}^{\circ}$ mínimo de residentes $\geq 30$ pessoas & 0 & $0,00000 \%$ & 0 & $0,0000 \%$ \\
\hline $\begin{array}{l}\text { (4) Produção per capita da comunidade } \geq \text { média do PIB } \\
\text { per capita dos municípios Canutama e Lábrea }\end{array}$ & 0 & $0,00000 \%$ & 0 & $0,0000 \%$ \\
\hline $\begin{array}{l}\text { (5) Produção na Comunidade } \geq \text { média da produção total } \\
\text { na Resex Canutama }\end{array}$ & 0 & $0,00000 \%$ & 0 & $0,0000 \%$ \\
\hline $\begin{array}{l}\text { (6) Produção diversificada e contendo o produto potencial } \\
\text { 'Farinha' com produção } \geq 10 \%\end{array}$ & 0 & $0,00000 \%$ & 1 & $9,0909 \%$ \\
\hline $\begin{array}{l}\text { (7) Produção diversificada e contendo o produto potencial } \\
\text { 'Peixe Fresco' com produção } \geq 10 \%\end{array}$ & 0 & $0,00000 \%$ & 1 & $9,0909 \%$ \\
\hline $\begin{array}{l}\text { (8) Produção diversificada e contendo o produto potencial } \\
\text { 'Peixe Seco' com produção } \geq 10 \%\end{array}$ & 0 & $0,00000 \%$ & 1 & $9,0909 \%$ \\
\hline $\begin{array}{l}\text { (9) Produção diversificada e contendo o produto potencial } \\
\text { 'Porco' com produção } \geq 10 \%\end{array}$ & 0 & $0,00000 \%$ & 0 & $0,0000 \%$ \\
\hline $\begin{array}{l}\text { (10) Produção diversificada e contendo o produto } \\
\text { potencial 'Açaí' com produção } \geq 10 \%\end{array}$ & 0 & $0,00000 \%$ & 1 & $9,0909 \%$ \\
\hline $\begin{array}{l}\text { (11) Produção diversificada e contendo o produto } \\
\text { potencial 'Castanha' com produção } \geq 10 \%\end{array}$ & 0 & $0,00000 \%$ & 1 & $9,0909 \%$ \\
\hline $\begin{array}{l}\text { Índice de Sustentabilidade Financeira } \\
\text { (resultado arredondado) }\end{array}$ & $\mathbf{0}$ & $0,00 \%$ & 5 & $45,50 \%$ \\
\hline $\begin{array}{l}\text { Legenda: Na Coluna [Referência] } \\
\text { [1] Sim, a comunidade atende o parâmetro } \\
\text { [0] Não, a comunidade não atende o parâmetro }\end{array}$ & $\begin{array}{l}\text { egenda: } \mathrm{NaC} \\
\text { 1] Avaliação } \\
\text { 0] Avaliação }\end{array}$ & $\begin{array}{l}\text { luna [Resul } \\
\text { ositiva gera } \\
\text { egativa gera }\end{array}$ & $\begin{array}{l}\text { do] } \\
\text { n percentual } \\
\text { ercentual de }\end{array}$ & $\begin{array}{l}9,09091 \% \\
0000 \%\end{array}$ \\
\hline
\end{tabular}

Fonte: Elaborado pela autora. 
Tabela 96 - Produção na Localidade Paraíso (2020)

\begin{tabular}{|c|c|c|c|c|}
\hline $\begin{array}{l}\text { Produto } \\
\text { e Unidade de Medida }\end{array}$ & $\begin{array}{l}\text { Quantidade } \\
\text { Vendida }\end{array}$ & $\begin{array}{c}\text { Preço } \\
\text { Médio } \\
\text { (R\$) }\end{array}$ & $\begin{array}{c}\text { Valor } \\
\text { recebido (RS) }\end{array}$ & $\%$ \\
\hline Pescado Fresco (Kg) & 3.000 & 5,00 & $15.000,00$ & $43,07 \%$ \\
\hline Farinha (Saca de $50 \mathrm{Kg}$ ) & 32 & 200,00 & $6.400,00$ & $18,37 \%$ \\
\hline Açaí Fruto (Lata 18Kg) & 348 & 15,00 & $5.220,00$ & $14,99 \%$ \\
\hline Castanha (Hectolitro; 100 litros) & 20 & 200,00 & $4.000,00$ & $11,48 \%$ \\
\hline Pescado Seco $(\mathrm{Kg})$ & 600 & 6,00 & $3.600,00$ & $10,34 \%$ \\
\hline Andiroba semente (Lata $20 \mathrm{Kg}$ ) & 55 & 10,00 & 550,00 & $1,58 \%$ \\
\hline Feijão (Kg) & 10 & 6,00 & 60,00 & $0,17 \%$ \\
\hline Valor total recebido (R\$) & & & $34.830,00$ & $100,00 \%$ \\
\hline
\end{tabular}




\section{Localidade Samaumeira}

Quadro 39 - Dados gerais para Avaliação da Localidade Samaumeira (2019-2020)

\begin{tabular}{|l|c|c|}
\hline \multicolumn{1}{|c|}{ Informações } & Ano 2019 & Ano 2020 \\
\hline Valor da Produção na Resex Canutama & $\mathrm{R} \$ 3.002 .952,00$ & $\mathrm{R} \$ 2.923 .589,36$ \\
\hline Média da Produção na Resex Canutama & $\mathrm{R} \$ 79.025,05$ & $\mathrm{R} \$ 76.936,56$ \\
\hline $\mathrm{N}^{\circ}$ de residentes na Comunidade & 6 & 6 \\
\hline $\mathrm{N}^{\circ}$ de produtos vendidos & 0 & 5 \\
\hline Valor da Produção na Comunidade & $\mathrm{R} \$ 0,00$ & $\mathrm{R} \$ 29.496,00$ \\
\hline Produção Per capita da Comunidade & $\mathrm{R} 0,00$ & $\mathrm{R} \$ 4.916,00$ \\
\hline $\begin{array}{l}\text { Média do PIB per capita dos municípios de Canutama } \\
\text { e Lábrea* }\end{array}$ & $\mathrm{R} \$ 8.953,67$ & $\mathrm{R} \$ 8.953,67$ \\
\hline
\end{tabular}

(*) Média com base no ano de 2018: PIB per capita de Lábrea (R\$ 10.941,94) e PIB per capita de Canutama (R \$ $6.965,40)$ - Último ano divulgado conforme dados do IBGE.

Tabela 97 - Sustentabilidade Financeira da Localidade Samaumeira (2019-2020)

\begin{tabular}{|c|c|c|c|c|}
\hline \multirow[b]{2}{*}{$\begin{array}{l}\text { Parâmetros Avaliados } \\
\text { [A comunidade possui...] }\end{array}$} & \multicolumn{2}{|c|}{ Avaliação 2019} & \multicolumn{2}{|c|}{ Avaliação 2020} \\
\hline & $\begin{array}{l}\text { Referência } \\
\text { (1 ou 0) }\end{array}$ & $\begin{array}{c}\text { Resultado } \\
(\%) \\
\end{array}$ & $\begin{array}{l}\text { Referência } \\
\text { (1 ou 0) }\end{array}$ & $\begin{array}{c}\text { Resultado } \\
\text { (\%) }\end{array}$ \\
\hline (1) Líder comunitário com perfil empreendedor & 0 & $0,00000 \%$ & 0 & $0,0000 \%$ \\
\hline (2) Controle de castanhal e exploração de castanhal & 0 & $0,00000 \%$ & 0 & $0,0000 \%$ \\
\hline (3) $\mathrm{N}^{\circ}$ mínimo de residentes $\geq 30$ pessoas & 0 & $0,00000 \%$ & 0 & $0,0000 \%$ \\
\hline $\begin{array}{l}\text { (4) Produção per capita da comunidade } \geq \text { média do PIB } \\
\text { per capita dos municípios Canutama e Lábrea }\end{array}$ & 0 & $0,00000 \%$ & 0 & $0,0000 \%$ \\
\hline $\begin{array}{l}\text { (5) Produção na Comunidade } \geq \text { média da produção total } \\
\text { na Resex Canutama }\end{array}$ & 0 & $0,00000 \%$ & 0 & $0,0000 \%$ \\
\hline $\begin{array}{l}\text { (6) Produção diversificada e contendo o produto potencial } \\
\text { 'Farinha' com produção } \geq 10 \%\end{array}$ & 0 & $0,00000 \%$ & 0 & $0,0000 \%$ \\
\hline $\begin{array}{l}\text { (7) Produção diversificada e contendo o produto potencial } \\
\text { 'Peixe Fresco' com produção } \geq 10 \%\end{array}$ & 0 & $0,00000 \%$ & 1 & $9,0909 \%$ \\
\hline $\begin{array}{l}\text { (8) Produção diversificada e contendo o produto potencial } \\
\text { 'Peixe Seco' com produção } \geq 10 \%\end{array}$ & 0 & $0,00000 \%$ & 1 & $9,0909 \%$ \\
\hline $\begin{array}{l}\text { (9) Produção diversificada e contendo o produto potencial } \\
\text { 'Porco' com produção } \geq 10 \%\end{array}$ & 0 & $0,00000 \%$ & 0 & $0,0000 \%$ \\
\hline $\begin{array}{l}\text { (10) Produção diversificada e contendo o produto } \\
\text { potencial 'Açaí' com produção } \geq 10 \%\end{array}$ & 0 & $0,00000 \%$ & 0 & $0,0000 \%$ \\
\hline $\begin{array}{l}\text { (11) Produção diversificada e contendo o produto } \\
\text { potencial 'Castanha' com produção } \geq 10 \%\end{array}$ & 0 & $0,00000 \%$ & 1 & $9,0909 \%$ \\
\hline $\begin{array}{l}\text { Índice de Sustentabilidade Financeira } \\
\text { (resultado arredondado) }\end{array}$ & $\mathbf{0}$ & $0,00 \%$ & 3 & $27,30 \%$ \\
\hline $\begin{array}{l}\text { Legenda: Na Coluna [Referência] } \\
\text { [1] Sim, a comunidade atende o parâmetro } \\
\text { [0] Não, a comunidade não atende o parâmetro }\end{array}$ & $\begin{array}{l}\text { egenda: } \mathrm{Na} \mathrm{C} \\
\text { 1] Avaliação } \\
\text { 0] Avaliacão }\end{array}$ & $\begin{array}{l}\text { luna [Result } \\
\text { psitiva gera } u \\
\text { egativa gera } 1\end{array}$ & $\begin{array}{l}\text { do] } \\
\text { percentual } \\
\text { reentual de } 0\end{array}$ & $\begin{array}{l}9,09091 \% \\
0000 \%\end{array}$ \\
\hline
\end{tabular}


Tabela 98 - Produção na Localidade Samaumeira (2020)

\begin{tabular}{|c|c|c|c|c|}
\hline $\begin{array}{l}\text { Produto } \\
\text { e Unidade de Medida }\end{array}$ & $\begin{array}{l}\text { Quantidade } \\
\text { Vendida }\end{array}$ & $\begin{array}{l}\text { Preço } \\
\text { Médio } \\
\text { (R\$) }\end{array}$ & $\begin{array}{c}\text { Valor } \\
\text { recebido (R\$) }\end{array}$ & $\%$ \\
\hline Pescado Fresco (Kg) & 3.000 & 5,00 & $15.000,00$ & $50,85 \%$ \\
\hline Pescado Seco (Kg) & 1.500 & 6,00 & $9.000,00$ & $30,51 \%$ \\
\hline Castanha (Hectolitro; 100 litros) & 19 & 200,00 & $3.800,00$ & $12,88 \%$ \\
\hline Melancia (Unidade) & 200 & 8,00 & $1.600,00$ & $5,42 \%$ \\
\hline Feijão $(\mathrm{Kg})$ & 16 & 6,00 & 96,00 & $0,33 \%$ \\
\hline Valor total recebido (RS) & & & $29.496,00$ & $100,00 \%$ \\
\hline
\end{tabular}




\section{Localidade Novo Intento}

Quadro 40 - Dados gerais para Avaliação da Localidade Novo Intento (2019-2020)

\begin{tabular}{|l|c|c|}
\hline \multicolumn{1}{|c|}{ Informações } & Ano 2019 & Ano 2020 \\
\hline Valor da Produção na Resex Canutama & $\mathrm{R} \$ 3.002 .952,00$ & $\mathrm{R} \$ 2.923 .589,36$ \\
\hline Média da Produção na Resex Canutama & $\mathrm{R} \$ 79.025,05$ & $\mathrm{R} \$ 76.936,56$ \\
\hline $\mathrm{N}^{\circ}$ de residentes na Comunidade & 5 & 5 \\
\hline $\mathrm{N}^{\circ}$ de produtos vendidos & 0 & 11 \\
\hline Valor da Produção na Comunidade & $\mathrm{R} \$ 0,00$ & $\mathrm{R} \$ 27.122,00$ \\
\hline Produção Per capita da Comunidade & $\mathrm{R} \$ 0,00$ & $\mathrm{R} \$ 5.424,40$ \\
\hline $\begin{array}{l}\text { Média do PIB per capita dos municípios de Canutama } \\
\text { e Lábrea* }\end{array}$ & $\mathrm{R} \$ 8.953,67$ & $\mathrm{R} \$ 8.953,67$ \\
\hline
\end{tabular}

(*) Média com base no ano de 2018: PIB per capita de Lábrea (R\$ 10.941,94) e PIB per capita de Canutama (R\$ $6.965,40)$ - Último ano divulgado conforme dados do IBGE.

Tabela 99 - Sustentabilidade Financeira da Localidade Novo Intento (2019-2020)

\begin{tabular}{|c|c|c|c|c|}
\hline \multirow[b]{2}{*}{$\begin{array}{l}\text { Parâmetros Avaliados } \\
\text { [A comunidade possui...] }\end{array}$} & \multicolumn{2}{|c|}{ Avaliação 2019} & \multicolumn{2}{|c|}{ Avaliação 2020} \\
\hline & $\begin{array}{l}\text { Referência } \\
\text { (1 ou 0) }\end{array}$ & $\begin{array}{l}\text { Resultado } \\
\text { (\%) }\end{array}$ & $\begin{array}{l}\text { Referência } \\
\text { (1 ou 0) }\end{array}$ & $\begin{array}{c}\text { Resultado } \\
\text { (\%) }\end{array}$ \\
\hline (1) Líder comunitário com perfil empreendedor & 0 & $0,00000 \%$ & 0 & $0,0000 \%$ \\
\hline (2) Controle de castanhal e exploração de castanhal & 0 & $0,00000 \%$ & 0 & $0,0000 \%$ \\
\hline (3) $\mathrm{N}^{\circ}$ mínimo de residentes $\geq 30$ pessoas & 0 & $0,00000 \%$ & 0 & $0,0000 \%$ \\
\hline $\begin{array}{l}\text { (4) Produção per capita da comunidade } \geq \text { média do PIB } \\
\text { per capita dos municípios Canutama e Lábrea }\end{array}$ & 0 & $0,00000 \%$ & 0 & $0,0000 \%$ \\
\hline $\begin{array}{l}\text { (5) Produção na Comunidade } \geq \text { média da produção total } \\
\text { na Resex Canutama }\end{array}$ & 0 & $0,00000 \%$ & 0 & $0,0000 \%$ \\
\hline $\begin{array}{l}\text { (6) Produção diversificada e contendo o produto potencial } \\
\text { 'Farinha' com produção } \geq 10 \%\end{array}$ & 0 & $0,00000 \%$ & 1 & $9,0909 \%$ \\
\hline $\begin{array}{l}\text { (7) Produção diversificada e contendo o produto potencial } \\
\text { 'Peixe Fresco' com produção } \geq 10 \%\end{array}$ & 0 & $0,00000 \%$ & 1 & $9,0909 \%$ \\
\hline $\begin{array}{l}\text { (8) Produção diversificada e contendo o produto potencial } \\
\text { 'Peixe Seco' com produção } \geq 10 \%\end{array}$ & 0 & $0,00000 \%$ & 1 & $9,0909 \%$ \\
\hline $\begin{array}{l}\text { (9) Produção diversificada e contendo o produto potencial } \\
\text { 'Porco' com produção } \geq 10 \%\end{array}$ & 0 & $0,00000 \%$ & 0 & $0,0000 \%$ \\
\hline $\begin{array}{l}\text { (10) Produção diversificada e contendo o produto } \\
\text { potencial 'Açaí' com produção } \geq 10 \%\end{array}$ & 0 & $0,00000 \%$ & 0 & $0,0000 \%$ \\
\hline $\begin{array}{l}\text { (11) Produção diversificada e contendo o produto } \\
\text { potencial 'Castanha' com produção } \geq 10 \%\end{array}$ & 0 & $0,00000 \%$ & 0 & $0,0000 \%$ \\
\hline $\begin{array}{l}\text { Índice de Sustentabilidade Financeira } \\
\text { (resultado arredondado) }\end{array}$ & 0 & $0,00 \%$ & 3 & $27,30 \%$ \\
\hline $\begin{array}{l}\text { Legenda: Na Coluna [Referência] } \\
\text { [1] Sim, a comunidade atende o parâmetro } \\
\text { [0] Não, a comunidade não atende o parâmetro }\end{array}$ & $\begin{array}{l}\text { egenda: } \mathrm{NaC} \\
\text { 1] Avaliação } 1 \\
\text { 0] Avaliação } 1\end{array}$ & $\begin{array}{l}\text { luna [Resul } \\
\text { ositiva gera } \\
\text { egativa gera }\end{array}$ & $\begin{array}{l}\text { ido] } \\
\text { n percentual } \\
\text { ercentual de }\end{array}$ & $\begin{array}{l}9,09091 \% \\
0000 \%\end{array}$ \\
\hline
\end{tabular}

Fonte: Elaborado pela autora. 
Tabela 100 - Produção na Localidade Novo Intento (2020)

\begin{tabular}{|c|c|c|c|c|}
\hline $\begin{array}{l}\text { Produto } \\
\text { e Unidade de Medida }\end{array}$ & $\begin{array}{l}\text { Quantidade } \\
\text { Vendida }\end{array}$ & $\begin{array}{l}\text { Preço } \\
\text { Médio } \\
\text { (R\$) }\end{array}$ & $\begin{array}{c}\text { Valor } \\
\text { recebido (R\$) }\end{array}$ & $\%$ \\
\hline Banana (Cacho) & 200 & 30,00 & $6.000,00$ & $22,12 \%$ \\
\hline Pescado Seco (Kg) & 900 & 6,00 & $5.400,00$ & $19,91 \%$ \\
\hline Farinha (Saca de $50 \mathrm{Kg}$ ) & 23 & 200,00 & $4.600,00$ & $16,96 \%$ \\
\hline Pescado Fresco (Kg) & 800 & 5,00 & $4.000,00$ & $14,75 \%$ \\
\hline Melancia (Unidade) & 500 & 8,00 & $4.000,00$ & $14,75 \%$ \\
\hline Castanha (Hectolitro; 100 litros) & 10 & 200,00 & $2.000,00$ & $7,37 \%$ \\
\hline Feijão (Kg) & 100 & 6,00 & 600,00 & $2,21 \%$ \\
\hline Melão (Unidade) & 50 & 6,00 & 300,00 & $1,11 \%$ \\
\hline Galinha Caipira (Unidade) & 4 & 25,00 & 100,00 & $0,37 \%$ \\
\hline Jerimum (Unidade) & 18 & 5,00 & 90,00 & $0,33 \%$ \\
\hline Batata-doce (Kg) & 8 & 4,00 & 32,00 & $0,12 \%$ \\
\hline Valor total recebido (RS) & & & $27.122,00$ & $100,00 \%$ \\
\hline
\end{tabular}




\section{Localidade Nazaré}

Quadro 41 - Dados gerais para Avaliação da Localidade Nazaré (2019-2020)

\begin{tabular}{|c|c|c|}
\hline Informações & Ano 2019 & Ano 2020 \\
\hline Valor da Produção na Resex Canutama & $\mathrm{R} \$ 3.002 .952,00$ & $\mathrm{R} \$ 2.923 .589,36$ \\
\hline Média da Produção na Resex Canutama & $\mathrm{R} \$ 79.025,05$ & $\mathrm{R} \$ 76.936,56$ \\
\hline $\mathrm{N}^{\circ}$ de residentes na Comunidade & 1 & 1 \\
\hline $\mathrm{N}^{\mathrm{o}}$ de produtos vendidos & 0 & 4 \\
\hline Valor da Produção na Comunidade & $\mathrm{R} \$ 0,00$ & $\mathrm{R} \$ 19.200,00$ \\
\hline Produção Per capita da Comunidade & $\mathrm{R} \$ 0,00$ & $\mathrm{R} \$ 19.200,00$ \\
\hline $\begin{array}{l}\text { Média do PIB per capita dos municípios de Canutama } \\
\text { e Lábrea* }\end{array}$ & $\mathrm{R} \$ 8.953,67$ & $\mathrm{R} \$ 8.953,67$ \\
\hline
\end{tabular}

(*) Média com base no ano de 2018: PIB per capita de Lábrea (R\$10.941,94) e PIB per capita de Canutama (R\$ $6.965,40)$ - Último ano divulgado conforme dados do IBGE.

Tabela 101 - Sustentabilidade Financeira da Localidade Nazaré (2019-2020)

\begin{tabular}{|c|c|c|c|c|}
\hline \multirow[b]{2}{*}{$\begin{array}{l}\text { Parâmetros Avaliados } \\
\text { [A comunidade possui....] }\end{array}$} & \multicolumn{2}{|c|}{ Avaliação 2019} & \multicolumn{2}{|c|}{ Avaliação 2020} \\
\hline & $\begin{array}{c}\text { Referência } \\
\text { (1 ou 0) }\end{array}$ & $\begin{array}{c}\text { Resultado } \\
(\%)\end{array}$ & $\begin{array}{l}\text { Referência } \\
\text { (1 ou 0) }\end{array}$ & $\begin{array}{c}\text { Resultado } \\
(\%)\end{array}$ \\
\hline (1) Líder comunitário com perfil empreendedor & 0 & $0,00000 \%$ & 0 & $0,0000 \%$ \\
\hline (2) Controle de castanhal e exploração de castanhal & 0 & $0,00000 \%$ & 0 & $0,0000 \%$ \\
\hline (3) $\mathrm{N}^{\circ}$ mínimo de residentes $\geq 30$ pessoas & 0 & $0,00000 \%$ & 0 & $0,0000 \%$ \\
\hline $\begin{array}{l}\text { (4) Produção per capita da comunidade } \geq \text { média do PIB } \\
\text { per capita dos municípios Canutama e Lábrea }\end{array}$ & 0 & $0,00000 \%$ & 1 & $9,0909 \%$ \\
\hline $\begin{array}{l}\text { (5) Produção na Comunidade } \geq \text { média da produção total } \\
\text { na Resex Canutama }\end{array}$ & 0 & $0,00000 \%$ & 0 & $0,0000 \%$ \\
\hline $\begin{array}{l}\text { (6) Produção diversificada e contendo o produto potencial } \\
\text { 'Farinha' com produção } \geq 10 \%\end{array}$ & 0 & $0,00000 \%$ & 0 & $0,0000 \%$ \\
\hline $\begin{array}{l}\text { (7) Produção diversificada e contendo o produto potencial } \\
\text { 'Peixe Fresco' com produção } \geq 10 \%\end{array}$ & 0 & $0,00000 \%$ & 1 & $9,0909 \%$ \\
\hline $\begin{array}{l}\text { (8) Produção diversificada e contendo o produto potencial } \\
\text { 'Peixe Seco' com produção } \geq 10 \%\end{array}$ & 0 & $0,00000 \%$ & 0 & $0,0000 \%$ \\
\hline $\begin{array}{l}\text { (9) Produção diversificada e contendo o produto potencial } \\
\text { 'Porco' com produção } \geq 10 \%\end{array}$ & 0 & $0,00000 \%$ & 0 & $0,0000 \%$ \\
\hline $\begin{array}{l}\text { (10) Produção diversificada e contendo o produto } \\
\text { potencial 'Açaí' com produção } \geq 10 \%\end{array}$ & 0 & $0,00000 \%$ & 0 & $0,0000 \%$ \\
\hline $\begin{array}{l}\text { (11) Produção diversificada e contendo o produto } \\
\text { potencial 'Castanha' com produção } \geq 10 \%\end{array}$ & 0 & $0,00000 \%$ & 1 & $9,0909 \%$ \\
\hline $\begin{array}{l}\text { Índice de Sustentabilidade Financeira } \\
\text { (resultado arredondado) }\end{array}$ & $\mathbf{0}$ & $0,00 \%$ & 3 & $27,30 \%$ \\
\hline $\begin{array}{l}\text { Legenda: Na Coluna [Referência] } \\
\text { [1] Sim, a comunidade atende o parâmetro } \\
\text { [0] Não, a comunidade não atende o parâmetro } \\
\text { Fonte: Elaborado pela autora. }\end{array}$ & $\begin{array}{l}\text { Legenda: } \mathrm{NaC} \\
\text { [1] Avaliação } 1 \\
\text { [0] Avaliação } 1\end{array}$ & $\begin{array}{l}\text { oluna [Resul } \\
\text { ositiva gera } \\
\text { egativa gera }\end{array}$ & $\begin{array}{l}\text { ado] } \\
\text { m percentual } \\
\text { ercentual de } 0\end{array}$ & $\begin{array}{l}9,09091 \% \\
0000 \%\end{array}$ \\
\hline
\end{tabular}


Tabela 102 - Produção na Localidade Nazaré (2020)

\begin{tabular}{|c|c|c|c|c|}
\hline $\begin{array}{l}\text { Produto } \\
\text { e Unidade de Medida }\end{array}$ & $\begin{array}{l}\text { Quantidade } \\
\text { Vendida }\end{array}$ & $\begin{array}{l}\text { Preço } \\
\text { Médio } \\
\text { (R\$) }\end{array}$ & $\begin{array}{c}\text { Valor } \\
\text { recebido (R\$) }\end{array}$ & $\%$ \\
\hline Pescado Fresco (Kg) & 2.000 & 5,00 & $10.000,00$ & $52,08 \%$ \\
\hline Castanha (Hectolitro; 100 litros) & 40 & 200,00 & $8.000,00$ & $41,67 \%$ \\
\hline Açaí Fruto (Lata 18Kg) & 40 & 15,00 & 600,00 & $3,13 \%$ \\
\hline Pescado Seco $(\mathrm{Kg})$ & 100 & 6,00 & 600,00 & $3,13 \%$ \\
\hline Valor total recebido $(\mathrm{R} \$)$ & & & $19.200,00$ & $100,00 \%$ \\
\hline
\end{tabular}




\section{Localidade Monte Sião}

Quadro 42 - Dados gerais para Avaliação da Localidade Monte Sião (2019-2020)

\begin{tabular}{|c|c|c|}
\hline Informações & Ano 2019 & Ano 2020 \\
\hline Valor da Produção na Resex Canutama & $\mathrm{R} \$ 3.002 .952,00$ & $\mathrm{R} \$ 2.923 .589,36$ \\
\hline Média da Produção na Resex Canutama & $\mathrm{R} \$ 79.025,05$ & $\mathrm{R} \$ 76.936,56$ \\
\hline $\mathrm{N}^{\circ}$ de residentes na Comunidade & 4 & 4 \\
\hline $\mathrm{N}^{\mathrm{o}}$ de produtos vendidos & 0 & 2 \\
\hline Valor da Produção na Comunidade & $\mathrm{R} \$ 0,00$ & $\mathrm{R} \$ 6.080,00$ \\
\hline Produção Per capita da Comunidade & $\mathrm{R} \$ 0,00$ & $\mathrm{R} \$ 1.520,00$ \\
\hline $\begin{array}{l}\text { Média do PIB per capita dos municípios de Canutama } \\
\text { e Lábrea* }\end{array}$ & $\mathrm{R} \$ 8.953,67$ & $\mathrm{R} \$ 8.953,67$ \\
\hline
\end{tabular}

(*) Média com base no ano de 2018: PIB per capita de Lábrea (R\$ 10.941,94) e PIB per capita de Canutama (R\$ $6.965,40)$ - Último ano divulgado conforme dados do IBGE.

Tabela 103 - Sustentabilidade Financeira da Localidade Monte Sião (2019-2020)

\begin{tabular}{|c|c|c|c|c|}
\hline \multirow[b]{2}{*}{$\begin{array}{l}\text { Parâmetros Avaliados } \\
\text { [A comunidade possui...] }\end{array}$} & \multicolumn{2}{|c|}{ Avaliação 2019} & \multicolumn{2}{|c|}{ Avaliação 2020} \\
\hline & $\begin{array}{c}\text { Referência } \\
\text { (1 ou 0) }\end{array}$ & $\begin{array}{c}\text { Resultado } \\
(\%)\end{array}$ & $\begin{array}{c}\text { Referência } \\
\text { (1 ou 0) }\end{array}$ & $\begin{array}{c}\text { Resultado } \\
(\%)\end{array}$ \\
\hline (1) Líder comunitário com perfil empreendedor & 0 & $0,00000 \%$ & 0 & $0,0000 \%$ \\
\hline (2) Controle de castanhal e exploração de castanhal & 0 & $0,00000 \%$ & 0 & $0,0000 \%$ \\
\hline (3) $\mathrm{N}^{\circ}$ mínimo de residentes $\geq 30$ pessoas & 0 & $0,00000 \%$ & 0 & $0,0000 \%$ \\
\hline $\begin{array}{l}\text { (4) Produção per capita da comunidade } \geq \text { média do PIB } \\
\text { per capita dos municípios Canutama e Lábrea }\end{array}$ & 0 & $0,00000 \%$ & 0 & $0,0000 \%$ \\
\hline $\begin{array}{l}\text { (5) Produção na Comunidade } \geq \text { média da produção total } \\
\text { na Resex Canutama }\end{array}$ & 0 & $0,00000 \%$ & 0 & $0,0000 \%$ \\
\hline $\begin{array}{l}\text { (6) Produção diversificada e contendo o produto potencial } \\
\text { 'Farinha' com produção } \geq 10 \%\end{array}$ & 0 & $0,00000 \%$ & 0 & $0,0000 \%$ \\
\hline $\begin{array}{l}\text { (7) Produção diversificada e contendo o produto potencial } \\
\text { 'Peixe Fresco' com produção } \geq 10 \%\end{array}$ & 0 & $0,00000 \%$ & 1 & $9,0909 \%$ \\
\hline $\begin{array}{l}\text { (8) Produção diversificada e contendo o produto potencial } \\
\text { 'Peixe Seco' com produção } \geq 10 \%\end{array}$ & 0 & $0,00000 \%$ & 0 & $0,0000 \%$ \\
\hline $\begin{array}{l}\text { (9) Produção diversificada e contendo o produto potencial } \\
\text { 'Porco' com produção } \geq 10 \%\end{array}$ & 0 & $0,00000 \%$ & 0 & $0,0000 \%$ \\
\hline $\begin{array}{l}\text { (10) Produção diversificada e contendo o produto } \\
\text { potencial 'Açaí' com produção } \geq 10 \%\end{array}$ & 0 & $0,00000 \%$ & 0 & $0,0000 \%$ \\
\hline $\begin{array}{l}\text { (11) Produção diversificada e contendo o produto } \\
\text { potencial 'Castanha' com produção } \geq 10 \%\end{array}$ & 0 & $0,00000 \%$ & 0 & $0,0000 \%$ \\
\hline $\begin{array}{l}\text { Índice de Sustentabilidade Financeira } \\
\text { (resultado arredondado) }\end{array}$ & 0 & $\mathbf{0 , 0 0 \%}$ & 1 & $9,10 \%$ \\
\hline $\begin{array}{l}\text { Legenda: Na Coluna [Referência] } \\
\text { [1] Sim, a comunidade atende o parâmetro } \\
\text { [0] Não, a comunidade não atende o parâmetro }\end{array}$ & $\begin{array}{l}\text { Legenda: } \mathrm{Na}( \\
\text { 1] Avaliação } \\
\text { 0] Avaliação }\end{array}$ & $\begin{array}{l}\text { luna [Resul } \\
\text { ositiva gera } \\
\text { egativa gera }\end{array}$ & $\begin{array}{l}\text { do] } \\
\text { n percentual } \\
\text { ercentual de }(\end{array}$ & $\begin{array}{l}9,09091 \% \\
0000 \%\end{array}$ \\
\hline
\end{tabular}

Fonte: Elaborado pela autora. 
Tabela 104 - Produção na Localidade Monte Sião (2020)

\begin{tabular}{|c|c|c|c|c|}
\hline $\begin{array}{l}\text { Produto } \\
\text { e Unidade de Medida }\end{array}$ & $\begin{array}{l}\text { Quantidade } \\
\text { Vendida }\end{array}$ & $\begin{array}{l}\text { Preço } \\
\text { Médio } \\
\text { (R\$) }\end{array}$ & $\begin{array}{c}\text { Valor } \\
\text { recebido }(\mathrm{R} \$)\end{array}$ & $\%$ \\
\hline Pescado Seco $(\mathrm{Kg})$ & 1.000 & 6,00 & $6.000,00$ & $98,68 \%$ \\
\hline Boi $(\mathrm{Kg})$ & 5 & 16,00 & 80,00 & $1,32 \%$ \\
\hline Valor total recebido (R\$) & & & $6.080,00$ & $100,00 \%$ \\
\hline
\end{tabular}




\section{Localidade Espírito Santo}

Quadro 43 - Dados gerais para Avaliação da Localidade Espírito Santo (2019-2020)

\begin{tabular}{|l|c|c|}
\hline \multicolumn{1}{|c|}{ Informações } & Ano 2019 & Ano 2020 \\
\hline Valor da Produção na Resex Canutama & $\mathrm{R} \$ 3.002 .952,00$ & $\mathrm{R} \$ 2.923 .589,36$ \\
\hline Média da Produção na Resex Canutama & $\mathrm{R} \$ 79.025,05$ & $\mathrm{R} \$ 76.936,56$ \\
\hline $\mathrm{N}^{\circ}$ de residentes na Comunidade & 1 & 1 \\
\hline $\mathrm{N}^{\circ}$ de produtos vendidos & 0 & $\mathrm{R} \$ 3.725,00$ \\
\hline Valor da Produção na Comunidade & $\mathrm{R} \$ 0,00$ & $\mathrm{R} \$ 3.725,00$ \\
\hline Produção Per capita da Comunidade & $\mathrm{R} \$ 0,00$ & $\mathrm{R} \$ 8.953,67$ \\
\hline $\begin{array}{l}\text { Média do PIB per capita dos municípios de Canutama } \\
\text { e Lábrea* }\end{array}$ & $\mathrm{R} .953,67$ & \\
\hline
\end{tabular}

(*) Média com base no ano de 2018: PIB per capita de Lábrea (R\$ 10.941,94) e PIB per capita de Canutama (R \$ $6.965,40)$ - Último ano divulgado conforme dados do IBGE.

Tabela 105 - Sustentabilidade Financeira da Localidade Espírito Santo (2019-2020)

\begin{tabular}{|c|c|c|c|c|}
\hline \multirow[b]{2}{*}{$\begin{array}{l}\text { Parâmetros Avaliados } \\
\text { [A comunidade possui....] }\end{array}$} & \multicolumn{2}{|c|}{ Avaliação 2019} & \multicolumn{2}{|c|}{ Avaliação 2020} \\
\hline & $\begin{array}{c}\text { Referência } \\
\text { (1 ou 0) }\end{array}$ & $\begin{array}{c}\text { Resultado } \\
\text { (\%) }\end{array}$ & $\begin{array}{c}\text { Referência } \\
\text { (1 ou 0) }\end{array}$ & $\begin{array}{c}\text { Resultado } \\
(\%)\end{array}$ \\
\hline (1) Líder comunitário com perfil empreendedor & 0 & $0,00000 \%$ & 0 & $0,0000 \%$ \\
\hline (2) Controle de castanhal e exploração de castanhal & 0 & $0,00000 \%$ & 0 & $0,0000 \%$ \\
\hline (3) $\mathrm{N}^{\circ}$ mínimo de residentes $\geq 30$ pessoas & 0 & $0,00000 \%$ & 0 & $0,0000 \%$ \\
\hline $\begin{array}{l}\text { (4) Produção per capita da comunidade } \geq \text { média do PIB } \\
\text { per capita dos municípios Canutama e Lábrea }\end{array}$ & 0 & $0,00000 \%$ & 0 & $0,0000 \%$ \\
\hline $\begin{array}{l}\text { (5) Produção na Comunidade } \geq \text { média da produção total } \\
\text { na Resex Canutama }\end{array}$ & 0 & $0,00000 \%$ & 0 & $0,0000 \%$ \\
\hline $\begin{array}{l}\text { (6) Produção diversificada e contendo o produto potencial } \\
\text { 'Farinha' com produção } \geq 10 \%\end{array}$ & 0 & $0,00000 \%$ & 0 & $0,0000 \%$ \\
\hline $\begin{array}{l}\text { (7) Produção diversificada e contendo o produto potencial } \\
\text { 'Peixe Fresco' com produção } \geq 10 \%\end{array}$ & 0 & $0,00000 \%$ & 1 & $9,0909 \%$ \\
\hline $\begin{array}{l}\text { (8) Produção diversificada e contendo o produto potencial } \\
\text { 'Peixe Seco' com produção } \geq 10 \%\end{array}$ & 0 & $0,00000 \%$ & 1 & $9,0909 \%$ \\
\hline $\begin{array}{l}\text { (9) Produção diversificada e contendo o produto potencial } \\
\text { 'Porco' com produção } \geq 10 \%\end{array}$ & 0 & $0,00000 \%$ & 0 & $0,0000 \%$ \\
\hline $\begin{array}{l}\text { (10) Produção diversificada e contendo o produto } \\
\text { potencial 'Açaí' com produção } \geq 10 \%\end{array}$ & 0 & $0,00000 \%$ & 0 & $0,0000 \%$ \\
\hline $\begin{array}{l}\text { (11) Produção diversificada e contendo o produto } \\
\text { potencial 'Castanha' com produção } \geq 10 \%\end{array}$ & 0 & $0,00000 \%$ & 0 & $0,0000 \%$ \\
\hline $\begin{array}{l}\text { Índice de Sustentabilidade Financeira } \\
\text { (resultado arredondado) }\end{array}$ & $\mathbf{0}$ & $\mathbf{0 , 0 0 \%}$ & 2 & $18,20 \%$ \\
\hline $\begin{array}{l}\text { Legenda: Na Coluna [Referência] } \\
\text { [1] Sim, a comunidade atende o parâmetro } \\
\text { [0] Não, a comunidade não atende o parâmetro }\end{array}$ & $\begin{array}{l}\text { egenda: } \mathrm{NaC} \\
\text { 1] Avaliação } \\
\text { 0] Avaliação }\end{array}$ & $\begin{array}{l}\text { luna [Resul } \\
\text { ositiva gera } \\
\text { egativa gera }\end{array}$ & $\begin{array}{l}\text { do] } \\
\text { n percentual } \\
\text { ercentual de }\end{array}$ & $\begin{array}{l}9,09091 \% \\
0000 \%\end{array}$ \\
\hline
\end{tabular}

Fonte: Elaborado pela autora. 
Tabela 106 - Produção na Localidade Espírito Santo (2020)

\begin{tabular}{lccr|c}
\hline $\begin{array}{l}\text { Produto } \\
\text { e Unidade de Medida }\end{array}$ & $\begin{array}{c}\text { Quantidade } \\
\text { Vendida }\end{array}$ & $\begin{array}{c}\text { Preço } \\
\text { Médio } \\
\text { (R\$) }\end{array}$ & $\begin{array}{c}\text { Valor } \\
\text { recebido (R\$) }\end{array}$ & $\%$ \\
\hline Pescado Fresco (Kg) & 500 & 5,00 & $2.500,00$ & $67,11 \%$ \\
Pescado Seco (Kg) & 200 & 6,00 & $1.200,00$ & $32,21 \%$ \\
Galinha Caipira (Unidade) & 1 & 25,00 & 25,00 & $0,67 \%$ \\
\hline Valor total recebido (R\$) & & & $\mathbf{3 . 7 2 5 , 0 0}$ & $\mathbf{1 0 0 , 0 0 \%}$ \\
\hline
\end{tabular}




\section{Localidade Arraial}

Quadro 44 - Dados gerais para Avaliação da Localidade Arraial (2019-2020)

\begin{tabular}{|c|c|c|}
\hline Informações & Ano 2019 & Ano 2020 \\
\hline Valor da Produção na Resex Canutama & $\mathrm{R} \$ 3.002 .952,00$ & $\mathrm{R} \$ 2.923 .589,36$ \\
\hline Média da Produção na Resex Canutama & $\mathrm{R} \$ 79.025,05$ & $\mathrm{R} \$ 76.936,56$ \\
\hline $\mathrm{N}^{\circ}$ de residentes na Comunidade & 1 & 1 \\
\hline $\mathrm{N}^{\mathrm{o}}$ de produtos vendidos & 0 & 1 \\
\hline Valor da Produção na Comunidade & $\mathrm{R} \$ 0,00$ & $\mathrm{R} \$ 600,00$ \\
\hline Produção Per capita da Comunidade & $\mathrm{R} \$ 0,00$ & $\mathrm{R} \$ 600,00$ \\
\hline $\begin{array}{l}\text { Média do PIB per capita dos municípios de Canutama } \\
\text { e Lábrea* }\end{array}$ & $\mathrm{R} \$ 8.953,67$ & $\mathrm{R} \$ 8.953,67$ \\
\hline
\end{tabular}

(*) Média com base no ano de 2018: PIB per capita de Lábrea (R\$10.941,94) e PIB per capita de Canutama (R\$ $6.965,40)$ - Último ano divulgado conforme dados do IBGE.

Tabela 107 - Sustentabilidade Financeira da Localidade Arraial (2019-2020)

\begin{tabular}{|c|c|c|c|c|}
\hline \multirow{2}{*}{$\begin{array}{l}\text { Parâmetros Avaliados } \\
\text { [A comunidade possui....] }\end{array}$} & \multicolumn{2}{|c|}{ Avaliação 2019} & \multicolumn{2}{|c|}{ Avaliação 2020} \\
\hline & $\begin{array}{c}\text { Referência } \\
\text { (1 ou 0) }\end{array}$ & $\begin{array}{l}\text { Resultado } \\
\text { (\%) }\end{array}$ & $\begin{array}{c}\text { Referência } \\
\text { (1 ou 0) }\end{array}$ & $\begin{array}{c}\text { Resultado } \\
\text { (\%) }\end{array}$ \\
\hline (1) Líder comunitário com perfil empreendedor & 0 & $0,00000 \%$ & 0 & $0,00000 \%$ \\
\hline (2) Controle de castanhal e exploração de castanhal & 0 & $0,00000 \%$ & 0 & $0,00000 \%$ \\
\hline (3) $\mathrm{N}^{\circ}$ mínimo de residentes $\geq 30$ pessoas & 0 & $0,00000 \%$ & 0 & $0,00000 \%$ \\
\hline $\begin{array}{l}\text { (4) Produção per capita da comunidade } \geq \text { média do PIB } \\
\text { per capita dos municípios Canutama e Lábrea }\end{array}$ & 0 & $0,00000 \%$ & 0 & $0,00000 \%$ \\
\hline $\begin{array}{l}\text { (5) Produção na Comunidade } \geq \text { média da produção total } \\
\text { na Resex Canutama }\end{array}$ & 0 & $0,00000 \%$ & 0 & $0,00000 \%$ \\
\hline $\begin{array}{l}\text { (6) Produção diversificada e contendo o produto potencial } \\
\text { 'Farinha' com produção } \geq 10 \%\end{array}$ & 0 & $0,00000 \%$ & 0 & $0,00000 \%$ \\
\hline $\begin{array}{l}\text { (7) Produção diversificada e contendo o produto potencial } \\
\text { 'Peixe Fresco' com produção } \geq 10 \%\end{array}$ & 0 & $0,00000 \%$ & 0 & $0,00000 \%$ \\
\hline $\begin{array}{l}\text { (8) Produção diversificada e contendo o produto potencial } \\
\text { 'Peixe Seco' com produção } \geq 10 \%\end{array}$ & 0 & $0,00000 \%$ & 0 & $0,00000 \%$ \\
\hline $\begin{array}{l}\text { (9) Produção diversificada e contendo o produto potencial } \\
\text { 'Porco' com produção } \geq 10 \%\end{array}$ & 0 & $0,00000 \%$ & 0 & $0,00000 \%$ \\
\hline $\begin{array}{l}\text { (10) Produção diversificada e contendo o produto } \\
\text { potencial 'Açaí' com produção } \geq 10 \%\end{array}$ & 0 & $0,00000 \%$ & 0 & $0,00000 \%$ \\
\hline $\begin{array}{l}\text { (11) Produção diversificada e contendo o produto } \\
\text { potencial 'Castanha' com produção } \geq 10 \%\end{array}$ & 0 & $0,00000 \%$ & 0 & $0,00000 \%$ \\
\hline $\begin{array}{l}\text { Índice de Sustentabilidade Financeira } \\
\text { (resultado arredondado) }\end{array}$ & $\mathbf{0}$ & $\mathbf{0 , 0 0 \%}$ & $\mathbf{0}$ & $0,00 \%$ \\
\hline $\begin{array}{l}\text { Legenda: Na Coluna [Referência] } \\
\text { [1] Sim, a comunidade atende o parâmetro } \\
\text { [0] Não, a comunidade não atende o parâmetro }\end{array}$ & $\begin{array}{l}\text { Legenda: } \mathrm{NaC} \\
\text { 1] Avaliação } \\
\text { 0] Avaliação }\end{array}$ & $\begin{array}{l}\text { oluna [Resul } \\
\text { ositiva gera } \\
\text { egativa gera }\end{array}$ & $\begin{array}{l}\text { do] } \\
\text { n percentual } \\
\text { ercentual de }\end{array}$ & $\begin{array}{l}9,09091 \% \\
0000 \%\end{array}$ \\
\hline
\end{tabular}


Tabela 108 - Produção na Localidade Arraial (2020)

\begin{tabular}{lccc|c}
\hline $\begin{array}{l}\text { Produto } \\
\text { e Unidade de Medida }\end{array}$ & $\begin{array}{c}\text { Quantidade } \\
\text { Vendida }\end{array}$ & $\begin{array}{c}\text { Preço } \\
\text { Médio } \\
\text { (R\$) }\end{array}$ & $\begin{array}{c}\text { Valor } \\
\text { recebido (R\$) }\end{array}$ & $\%$ \\
\hline Andiroba semente (Lata 20Kg) & 60 & 10,00 & 600,00 & $100,00 \%$ \\
\hline Valor total recebido & $(\mathbf{R} \$)$ & & $\mathbf{6 0 0 , 0 0}$ & $\mathbf{1 0 0 , 0 0 \%}$ \\
\hline
\end{tabular}




\section{Localidade Santo José do Paraíso}

Quadro 45 - Dados gerais para Avaliação da Localidade São José do Paraíso (2019-2020)

\begin{tabular}{|c|c|c|}
\hline Informações & Ano 2019 & Ano 2020 \\
\hline Valor da Produção na Resex Canutama & $\mathrm{R} \$ 3.002 .952,00$ & $\mathrm{R} \$ 2.923 .589,36$ \\
\hline Média da Produção na Resex Canutama & $\mathrm{R} \$ 79.025,05$ & $\mathrm{R} \$ 76.936,56$ \\
\hline $\mathrm{N}^{\circ}$ de residentes na Comunidade & 6 & 6 \\
\hline $\mathrm{N}^{\circ}$ de produtos vendidos & 0 & 0 \\
\hline Valor da Produção na Comunidade & $\mathrm{R} \$ 0,00$ & $\mathrm{R} \$ 0,00$ \\
\hline Produção Per capita da Comunidade & $\mathrm{R} \$ 0,00$ & $\mathrm{R} \$ 0,00$ \\
\hline $\begin{array}{l}\text { Média do PIB per capita dos municípios de Canutama } \\
\text { e Lábrea* }\end{array}$ & $\mathrm{R} \$ 8.953,67$ & $\mathrm{R} \$ 8.953,67$ \\
\hline
\end{tabular}

(*) Média com base no ano de 2018: PIB per capita de Lábrea (R\$ 10.941,94) e PIB per capita de Canutama (R\$ $6.965,40)$ - Último ano divulgado conforme dados do IBGE.

Tabela 109 - Sustentabilidade Financeira da Localidade São José do Paraíso (2019-2020)

\begin{tabular}{|c|c|c|c|c|}
\hline \multirow[b]{2}{*}{$\begin{array}{l}\text { Parâmetros Avaliados } \\
\text { [A comunidade possui....] }\end{array}$} & \multicolumn{2}{|c|}{ Avaliação 2019} & \multicolumn{2}{|c|}{ Avaliação 2020} \\
\hline & $\begin{array}{c}\text { Referência } \\
\text { (1 ou 0) }\end{array}$ & $\begin{array}{c}\text { Resultado } \\
(\%)\end{array}$ & $\begin{array}{l}\text { Referência } \\
\text { (1 ou 0) }\end{array}$ & $\begin{array}{c}\text { Resultado } \\
(\%)\end{array}$ \\
\hline (1) Líder comunitário com perfil empreendedor & 0 & $0,00000 \%$ & 0 & $0,00000 \%$ \\
\hline (2) Controle de castanhal e exploração de castanhal & 0 & $0,00000 \%$ & 0 & $0,00000 \%$ \\
\hline (3) $\mathrm{N}^{\circ}$ mínimo de residentes $\geq 30$ pessoas & 0 & $0,00000 \%$ & 0 & $0,00000 \%$ \\
\hline $\begin{array}{l}\text { (4) Produção per capita da comunidade } \geq \text { média do PIB } \\
\text { per capita dos municípios Canutama e Lábrea }\end{array}$ & 0 & $0,00000 \%$ & 0 & $0,00000 \%$ \\
\hline $\begin{array}{l}\text { (5) Produção na Comunidade } \geq \text { média da produção total } \\
\text { na Resex Canutama }\end{array}$ & 0 & $0,00000 \%$ & 0 & $0,00000 \%$ \\
\hline $\begin{array}{l}\text { (6) Produção diversificada e contendo o produto potencial } \\
\text { 'Farinha' com produção } \geq 10 \%\end{array}$ & 0 & $0,00000 \%$ & 0 & $0,00000 \%$ \\
\hline $\begin{array}{l}\text { (7) Produção diversificada e contendo o produto potencial } \\
\text { 'Peixe Fresco' com produção } \geq 10 \%\end{array}$ & 0 & $0,00000 \%$ & 0 & $0,00000 \%$ \\
\hline $\begin{array}{l}\text { (8) Produção diversificada e contendo o produto potencial } \\
\text { 'Peixe Seco' com produção } \geq 10 \%\end{array}$ & 0 & $0,00000 \%$ & 0 & $0,00000 \%$ \\
\hline $\begin{array}{l}\text { (9) Produção diversificada e contendo o produto potencial } \\
\text { 'Porco' com produção } \geq 10 \%\end{array}$ & 0 & $0,00000 \%$ & 0 & $0,00000 \%$ \\
\hline $\begin{array}{l}\text { (10) Produção diversificada e contendo o produto } \\
\text { potencial 'Açaí' com produção } \geq 10 \%\end{array}$ & 0 & $0,00000 \%$ & 0 & $0,00000 \%$ \\
\hline $\begin{array}{l}\text { (11) Produção diversificada e contendo o produto } \\
\text { potencial 'Castanha' com produção } \geq 10 \%\end{array}$ & 0 & $0,00000 \%$ & 0 & $0,00000 \%$ \\
\hline $\begin{array}{l}\text { Índice de Sustentabilidade Financeira } \\
\text { (resultado arredondado) }\end{array}$ & $\mathbf{0}$ & $0,00 \%$ & 0 & $0,00 \%$ \\
\hline $\begin{array}{l}\text { Legenda: Na Coluna [Referência] } \\
\text { [1] Sim, a comunidade atende o parâmetro } \\
\text { [0] Não, a comunidade não atende o parâmetro } \\
\text { Fonte: Elaborado pela autora. }\end{array}$ & $\begin{array}{l}\text { Legenda: } \mathrm{NaCO} \\
\text { [1] Avaliação } 1 \\
\text { [0] Avaliação 1 }\end{array}$ & $\begin{array}{l}\text { oluna [Resul } \\
\text { ositiva gera } \\
\text { egativa gera }\end{array}$ & $\begin{array}{l}\text { ado] } \\
\text { m percentual } \\
\text { ercentual de } 0\end{array}$ & $\begin{array}{l}9,09091 \% \\
0000 \%\end{array}$ \\
\hline
\end{tabular}

Fonte: Elaborado pela autora. 


\section{Localidade Sobradinho}

Quadro 46 - Dados gerais para Avaliação da Localidade Sobradinho (2019-2020)

\begin{tabular}{|l|c|c|}
\hline \multicolumn{1}{|c|}{ Informações } & Ano 2019 & Ano 2020 \\
\hline Valor da Produção na Resex Canutama & $\mathrm{R} \$ 3.002 .952,00$ & $\mathrm{R} \$ 2.923 .589,36$ \\
\hline Média da Produção na Resex Canutama & $\mathrm{R} \$ 79.025,05$ & $\mathrm{R} \$ 76.936,56$ \\
\hline $\mathrm{N}^{\circ}$ de residentes na Comunidade & 4 & 4 \\
\hline $\mathrm{N}^{\circ}$ de produtos vendidos & 0 & 0 \\
\hline Valor da Produção na Comunidade & $\mathrm{R} \$ 0,00$ & $\mathrm{R} \$ 0,00$ \\
\hline Produção Per capita da Comunidade & $\mathrm{R} \$ 0,00$ & $\mathrm{R} \$ 0,00$ \\
\hline $\begin{array}{l}\text { Média do PIB per capita dos municípios de Canutama } \\
\text { e Lábrea* }\end{array}$ & $\mathrm{R} \$ 8.953,67$ & $\mathrm{R} \$ 8.953,67$ \\
\hline
\end{tabular}

(*) Média com base no ano de 2018: PIB per capita de Lábrea (R\$ 10.941,94) e PIB per capita de Canutama (R\$ $6.965,40)$ - Último ano divulgado conforme dados do IBGE.

Tabela 110 - Sustentabilidade Financeira da Localidade Sobradinho (2019-2020)

\begin{tabular}{|c|c|c|c|c|}
\hline \multirow[b]{2}{*}{$\begin{array}{l}\text { Parâmetros Avaliados } \\
\text { [A comunidade possui....] }\end{array}$} & \multicolumn{2}{|c|}{ Avaliação 2019} & \multicolumn{2}{|c|}{ Avaliação 2020} \\
\hline & $\begin{array}{l}\text { Referência } \\
\text { (1 ou 0) }\end{array}$ & $\begin{array}{c}\text { Resultado } \\
(\%) \\
\end{array}$ & $\begin{array}{c}\text { Referência } \\
\text { (1 ou 0) }\end{array}$ & $\begin{array}{c}\text { Resultado } \\
(\%) \\
\end{array}$ \\
\hline (1) Líder comunitário com perfil empreendedor & 0 & $0,00000 \%$ & 0 & $0,00000 \%$ \\
\hline (2) Controle de castanhal e exploração de castanhal & 0 & $0,00000 \%$ & 0 & $0,00000 \%$ \\
\hline (3) $\mathrm{N}^{\circ}$ mínimo de residentes $\geq 30$ pessoas & 0 & $0,00000 \%$ & 0 & $0,00000 \%$ \\
\hline $\begin{array}{l}\text { (4) Produção per capita da comunidade } \geq \text { média do PIB } \\
\text { per capita dos municípios Canutama e Lábrea }\end{array}$ & 0 & $0,00000 \%$ & 0 & $0,00000 \%$ \\
\hline $\begin{array}{l}\text { (5) Produção na Comunidade } \geq \text { média da produção total } \\
\text { na Resex Canutama }\end{array}$ & 0 & $0,00000 \%$ & 0 & $0,00000 \%$ \\
\hline $\begin{array}{l}\text { (6) Produção diversificada e contendo o produto potencial } \\
\text { 'Farinha' com produção } \geq 10 \%\end{array}$ & 0 & $0,00000 \%$ & 0 & $0,00000 \%$ \\
\hline $\begin{array}{l}\text { (7) Produção diversificada e contendo o produto potencial } \\
\text { 'Peixe Fresco' com produção } \geq 10 \%\end{array}$ & 0 & $0,00000 \%$ & 0 & $0,00000 \%$ \\
\hline $\begin{array}{l}\text { (8) Produção diversificada e contendo o produto potencial } \\
\text { 'Peixe Seco' com produção } \geq 10 \%\end{array}$ & 0 & $0,00000 \%$ & 0 & $0,00000 \%$ \\
\hline $\begin{array}{l}\text { (9) Produção diversificada e contendo o produto potencial } \\
\text { 'Porco' com produção } \geq 10 \%\end{array}$ & 0 & $0,00000 \%$ & 0 & $0,00000 \%$ \\
\hline $\begin{array}{l}\text { (10) Produção diversificada e contendo o produto } \\
\text { potencial 'Açaí' com produção } \geq 10 \%\end{array}$ & 0 & $0,00000 \%$ & 0 & $0,00000 \%$ \\
\hline $\begin{array}{l}\text { (11) Produção diversificada e contendo o produto } \\
\text { potencial 'Castanha' com produção } \geq 10 \%\end{array}$ & 0 & $0,00000 \%$ & 0 & $0,00000 \%$ \\
\hline $\begin{array}{l}\text { Índice de Sustentabilidade Financeira } \\
\text { (resultado arredondado) }\end{array}$ & $\mathbf{0}$ & $0,00 \%$ & 0 & $0,00 \%$ \\
\hline $\begin{array}{l}\text { Legenda: Na Coluna [Referência] } \\
\text { [1] Sim, a comunidade atende o parâmetro } \\
\text { [0] Não, a comunidade não atende o parâmetro } \\
\text { Fonte: Elaborado pela autora. }\end{array}$ & $\begin{array}{l}\text { Legenda: } \mathrm{Na} C \\
\text { [1] Avaliação } \\
\text { [0] Avaliação }\end{array}$ & $\begin{array}{l}\text { luna [Resul } \\
\text { ositiva gera } ~ \\
\text { egativa gera }\end{array}$ & $\begin{array}{l}\text { ado] } \\
\text { m percentual } \\
\text { ercentual de } 0\end{array}$ & $\begin{array}{l}\text { e } 9,09091 \% \\
0000 \%\end{array}$ \\
\hline
\end{tabular}




\section{Localidade Concórdia}

Quadro 47 - Dados gerais para Avaliação da Localidade Concórdia (2019-2020)

\begin{tabular}{|l|c|c|}
\hline \multicolumn{1}{|c|}{ Informações } & Ano 2019 & Ano 2020 \\
\hline Valor da Produção na Resex Canutama & $\mathrm{R} \$ 3.002 .952,00$ & $\mathrm{R} \$ 2.923 .589,36$ \\
\hline Média da Produção na Resex Canutama & $\mathrm{R} \$ 79.025,05$ & $\mathrm{R} \$ 76.936,56$ \\
\hline $\mathrm{N}^{\circ}$ de residentes na Comunidade & 3 & 3 \\
\hline $\mathrm{N}^{\circ}$ de produtos vendidos & 0 & 0 \\
\hline Valor da Produção na Comunidade & $\mathrm{R} \$ 0,00$ & $\mathrm{R} \$ 0,00$ \\
\hline Produção Per capita da Comunidade & $\mathrm{R} \$ 0,00$ & $\mathrm{R} \$ 0,00$ \\
\hline $\begin{array}{l}\text { Média do PIB per capita dos municípios de Canutama } \\
\text { e Lábrea* }\end{array}$ & $\mathrm{R} \$ 8.953,67$ & $\mathrm{R} \$ 8.953,67$ \\
\hline
\end{tabular}

(*) Média com base no ano de 2018: PIB per capita de Lábrea (R\$ 10.941,94) e PIB per capita de Canutama (R \$ $6.965,40)$ - Último ano divulgado conforme dados do IBGE.

Tabela 111 - Sustentabilidade Financeira da Localidade Concórdia (2019-2020)

\begin{tabular}{|c|c|c|c|c|}
\hline \multirow[b]{2}{*}{$\begin{array}{l}\text { Parâmetros Avaliados } \\
\text { [A comunidade possui...] }\end{array}$} & \multicolumn{2}{|c|}{ Avaliação 2019} & \multicolumn{2}{|c|}{ Avaliação 2020} \\
\hline & $\begin{array}{l}\text { Referência } \\
\text { (1 ou 0) }\end{array}$ & $\begin{array}{c}\text { Resultado } \\
\text { (\%) }\end{array}$ & $\begin{array}{l}\text { Referência } \\
\text { (1 ou 0) }\end{array}$ & $\begin{array}{c}\text { Resultado } \\
\text { (\%) }\end{array}$ \\
\hline (1) Líder comunitário com perfil empreendedor & 0 & $0,00000 \%$ & 0 & $0,00000 \%$ \\
\hline (2) Controle de castanhal e exploração de castanhal & 0 & $0,00000 \%$ & 0 & $0,00000 \%$ \\
\hline (3) $\mathrm{N}^{\circ}$ mínimo de residentes $\geq 30$ pessoas & 0 & $0,00000 \%$ & 0 & $0,00000 \%$ \\
\hline $\begin{array}{l}\text { (4) Produção per capita da comunidade } \geq \text { média do PIB } \\
\text { per capita dos municípios Canutama e Lábrea }\end{array}$ & 0 & $0,00000 \%$ & 0 & $0,00000 \%$ \\
\hline $\begin{array}{l}\text { (5) Produção na Comunidade } \geq \text { média da produção total } \\
\text { na Resex Canutama }\end{array}$ & 0 & $0,00000 \%$ & 0 & $0,00000 \%$ \\
\hline $\begin{array}{l}\text { (6) Produção diversificada e contendo o produto potencial } \\
\text { 'Farinha' com produção } \geq 10 \%\end{array}$ & 0 & $0,00000 \%$ & 0 & $0,00000 \%$ \\
\hline $\begin{array}{l}\text { (7) Produção diversificada e contendo o produto potencial } \\
\text { 'Peixe Fresco' com produção } \geq 10 \%\end{array}$ & 0 & $0,00000 \%$ & 0 & $0,00000 \%$ \\
\hline $\begin{array}{l}\text { (8) Produção diversificada e contendo o produto potencial } \\
\text { 'Peixe Seco' com produção } \geq 10 \%\end{array}$ & 0 & $0,00000 \%$ & 0 & $0,00000 \%$ \\
\hline $\begin{array}{l}\text { (9) Produção diversificada e contendo o produto potencial } \\
\text { 'Porco' com produção } \geq 10 \%\end{array}$ & 0 & $0,00000 \%$ & 0 & $0,00000 \%$ \\
\hline $\begin{array}{l}\text { (10) Produção diversificada e contendo o produto } \\
\text { potencial 'Açaí' com produção } \geq 10 \%\end{array}$ & 0 & $0,00000 \%$ & 0 & $0,00000 \%$ \\
\hline $\begin{array}{l}\text { (11) Produção diversificada e contendo o produto } \\
\text { potencial 'Castanha' com produção } \geq 10 \%\end{array}$ & 0 & $0,00000 \%$ & 0 & $0,00000 \%$ \\
\hline $\begin{array}{l}\text { Índice de Sustentabilidade Financeira } \\
\text { (resultado arredondado) }\end{array}$ & $\mathbf{0}$ & $0,00 \%$ & $\mathbf{0}$ & $0,00 \%$ \\
\hline $\begin{array}{l}\text { Legenda: Na Coluna [Referência] } \\
\text { [1] Sim, a comunidade atende o parâmetro } \\
\text { [0] Não, a comunidade não atende o parâmetro } \\
\text { Fonte: Elaborado pela autora. }\end{array}$ & $\begin{array}{l}\text { Legenda: } \mathrm{Na} \\
\text { [1] Avaliaçã̃ } \\
\text { [0] Avaliaçã }\end{array}$ & $\begin{array}{l}\text { oluna }[\text { Res } \\
\text { ositiva ger }\end{array}$ & do] & $\begin{array}{l}\text { e } 9,09091 \% \\
0000 \%\end{array}$ \\
\hline
\end{tabular}

Fonte: Elaborado pela autora. 


\section{Localidade Conceição-Paissé}

Quadro 48 - Dados gerais para Avaliação da Localidade Conceição-Paissé (2019-2020)

\begin{tabular}{|l|c|c|}
\hline \multicolumn{1}{|c|}{ Informações } & Ano 2019 & Ano 2020 \\
\hline Valor da Produção na Resex Canutama & $\mathrm{R} \$ 3.002 .952,00$ & $\mathrm{R} \$ 2.923 .589,36$ \\
\hline Média da Produção na Resex Canutama & $\mathrm{R} \$ 79.025,05$ & $\mathrm{R} \$ 76.936,56$ \\
\hline $\mathrm{N}^{\circ}$ de residentes na Comunidade & 1 & 1 \\
\hline $\mathrm{N}^{\circ}$ de produtos vendidos & 0 & 0 \\
\hline Valor da Produção na Comunidade & $\mathrm{R} \$ 0,00$ & $\mathrm{R} \$ 0,00$ \\
\hline Produção Per capita da Comunidade & $\mathrm{R} \$ 0,00$ & $\mathrm{R} \$ 0,00$ \\
\hline $\begin{array}{l}\text { Média do PIB per capita dos municípios de Canutama } \\
\text { e Lábrea* }\end{array}$ & $\mathrm{R} \$ 8.953,67$ & $\mathrm{R} \$ 8.953,67$ \\
\hline
\end{tabular}

(*) Média com base no ano de 2018: PIB per capita de Lábrea (R\$ 10.941,94) e PIB per capita de Canutama (R\$ $6.965,40)$ - Último ano divulgado conforme dados do IBGE.

Tabela 112 - Sustentabilidade Financeira da Localidade Conceição-Paissé (2019-2020)

\begin{tabular}{|c|c|c|c|c|}
\hline \multirow[b]{2}{*}{$\begin{array}{l}\text { Parâmetros Avaliados } \\
\text { [A comunidade possui....] }\end{array}$} & \multicolumn{2}{|c|}{ Avaliação 2019} & \multicolumn{2}{|c|}{ Avaliação 2020} \\
\hline & $\begin{array}{l}\text { Referência } \\
\text { (1 ou 0) }\end{array}$ & $\begin{array}{c}\text { Resultado } \\
(\%)\end{array}$ & $\begin{array}{l}\text { Referência } \\
\text { (1 ou 0) }\end{array}$ & $\begin{array}{c}\text { Resultado } \\
(\%)\end{array}$ \\
\hline (1) Líder comunitário com perfil empreendedor & 0 & $0,00000 \%$ & 0 & $0,00000 \%$ \\
\hline (2) Controle de castanhal e exploração de castanhal & 0 & $0,00000 \%$ & 0 & $0,00000 \%$ \\
\hline (3) $\mathrm{N}^{\circ}$ mínimo de residentes $\geq 30$ pessoas & 0 & $0,00000 \%$ & 0 & $0,00000 \%$ \\
\hline $\begin{array}{l}\text { (4) Produção per capita da comunidade } \geq \text { média do PIB } \\
\text { per capita dos municípios Canutama e Lábrea }\end{array}$ & 0 & $0,00000 \%$ & 0 & $0,00000 \%$ \\
\hline $\begin{array}{l}\text { (5) Produção na Comunidade } \geq \text { média da produção total } \\
\text { na Resex Canutama }\end{array}$ & 0 & $0,00000 \%$ & 0 & $0,00000 \%$ \\
\hline $\begin{array}{l}\text { (6) Produção diversificada e contendo o produto } \\
\text { potencial 'Farinha' com produção } \geq 10 \%\end{array}$ & 0 & $0,00000 \%$ & 0 & $0,00000 \%$ \\
\hline $\begin{array}{l}\text { (7) Produção diversificada e contendo o produto } \\
\text { potencial 'Peixe Fresco' com produção } \geq 10 \%\end{array}$ & 0 & $0,00000 \%$ & 0 & $0,00000 \%$ \\
\hline $\begin{array}{l}\text { (8) Produção diversificada e contendo o produto } \\
\text { potencial 'Peixe Seco' com produção } \geq 10 \%\end{array}$ & 0 & $0,00000 \%$ & 0 & $0,00000 \%$ \\
\hline $\begin{array}{l}\text { (9) Produção diversificada e contendo o produto } \\
\text { potencial 'Porco' com produção } \geq 10 \%\end{array}$ & 0 & $0,00000 \%$ & 0 & $0,00000 \%$ \\
\hline $\begin{array}{l}\text { (10) Produção diversificada e contendo o produto } \\
\text { potencial 'Açaí' com produção } \geq 10 \%\end{array}$ & 0 & $0,00000 \%$ & 0 & $0,00000 \%$ \\
\hline $\begin{array}{l}\text { (11) Produção diversificada e contendo o produto } \\
\text { potencial 'Castanha' com produção } \geq 10 \%\end{array}$ & 0 & $0,00000 \%$ & 0 & $0,00000 \%$ \\
\hline $\begin{array}{l}\text { Índice de Sustentabilidade Financeira } \\
\text { (resultado arredondado) }\end{array}$ & $\mathbf{0}$ & $0,00 \%$ & $\mathbf{0}$ & $0,00 \%$ \\
\hline $\begin{array}{l}\text { Legenda: Na Coluna [Referência] } \\
\text { [1] Sim, a comunidade atende o parâmetro } \\
\text { [0] Não, a comunidade não atende o parâmetro } \\
\text { Fonte: Elaborado pela autora. }\end{array}$ & $\begin{array}{l}\text { egenda: } \mathrm{N} \\
\text { 1] Avaliaç: } \\
\text { 0] Avaliaç: }\end{array}$ & egarva ger & $\begin{array}{l}\text { ado] } \\
\text { m percentual c } \\
\text { ercentual de } 0\end{array}$ & le $9,09091 \%$ \\
\hline
\end{tabular}




\section{APÊNDICE E - Roteiro das Entrevistas de Campo}

ROTEIRO PARA ENTREVISTA - PRODUTORES

Produtores residentes na Resex

\section{Identificação do Perfil do Produtor}

[Quero iniciar a 'nossa conversa', pedindo que me conte um pouco sobre sua vida, quem mora com você, se tem filhos...]

- Identificar nome, Idade; sexo; Escolaridade; Quanto tempo reside na Resex; Estado Civil; Quantidade de filhos (se os filhos ainda residem na Resex); Principal ocupação (coleta, extrai ou produz). Qual produto extrai/coleta.

\section{Entendimento da sua atividade (produção - produto - mercado)}

[Quero que me conte um pouco sobre o que você faz, como é seu trabalho, o que produz, para quem vende, se o preço que recebe está correto...]

- Identificar o entendimento da atividade para si, para sua família, para seu sustento, para meio ambiente (proteção da floresta, desmatamento, consequências X 'responsabilidade' para com o planeta).

- Identificar a visão do produtor sobre o mercado do seu produto - processo de produção, preço, aceitação, benefícios X dificuldades, como ocorre a negociação (responsáveis, satisfação/insatisfação, perspectivas), momento $\mathrm{X}$ futuro (diagnóstico e expectativas).

- Identificar o entendimento do produtor sobre o que pode ser feito para melhorar sua atividade (hoje) e sustentar a atividade/produção para os próximos anos (futuro).

- Identificar a relação com a associação e/ou cooperativa.

\section{Entendimento sobre sustentabilidade financeira (renda)}

[Quero que me conte um pouco sobre seu sustento, o que produz, seus ganhos com a sua atividade para você e sua família...]

- Identificar a percepção sobre o produto, produção e quantidade

- Identificar a percepção da rotina de trabalho

- Identificar a percepção de preço recebido

- Identificar a percepção de renda/sustento: o que ganha somente com o que produz é suficiente para sustentar você e sua família

- Identificar a percepção dos problemas/obstáculos/desafios para a sustentabilidade do seu produto/produção/negócio

\section{Entendimento sobre os mecanismos públicos/privado de sustentabilidade financeira}

[Quero que me conte a 'ajuda' que você, sua família, ou sua comunidade recebem do governo, de empresas, de pessoas]

- Identificar mecanismos públicos e/ou privados que atuam na Resex.

\section{Entendimento sobre os mecanismos públicos/privado de sustentabilidade financeira}

[Quero que me conte as 'ajudas' que você, sua família, ou sua comunidade recebem do governo, de empresas, de pessoas]

- Identificar se recebem Bolsa família, Bolsa Floresta, Auxílio Emergencial

- Identificar mecanismos públicos e/ou privados que atuam na Resex.

\section{Entendimento sobre a questão do desmatamento/degradação ambiental}

[Quero que me conte sobre o desmatamento da floresta, da reserva]

- Identificar a percepção sobre o que acham do desmatamento da floresta - atual e anterior (desde que começou)

- Identificar se percebem - e qual a opinião - sobre o aumento da degradação da floresta. Se a degradação afeta ou pode afetar sua atividade produtiva, sua vida e os rendimentos das famílias.

- Identificar se acham que sua atividade contribui para o desmatamento. O que pode ser feito? Percebe que isso pode afetar sua atividade/renda? 
- Identificar se a possibilidade de haver desmatamento, interfere na decisão de aderir/participar de alguma atividade extrativista legal (a atual ou alguma outra)? Já recusou/deixou de participar/aderir a algum projeto ou programa por conta disso?

6. Entendimento sobre as Reservas Extrativistas

[Quero que me conte se a Resex está funcionando. Já foi melhor/pior? O que aconteceu, está acontecendo?]

O que você acha que está faltando para dar certo a Resex? (Ou está dando certo?)

7. Percepção sobre a Pandemia pelo COVID-19

[Quero que você me conte qual a sua situação em relação à pandemia (doença) do Coronavírus]

- Identificar o que mais afetou: a produção, a venda, o valor do produto.

- Identificar se alguém da família contraiu o vírus. Se contraiu, conseguiu tratamento adequado. 


\title{
APÊNDICE F - Termo de Consentimento Livre e Esclarecido e Pós- Esclarecido
}

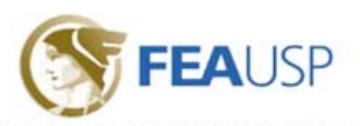

TERMO DE CONSENTIMENTO LIVRE E ESCLARECIDO E PÓS-ESCLARECIDO

\begin{abstract}
Prezado(a) participante,
IZABEL CRISTINA NOGUEIRA SEABRA, CPF 274.851.532-34, aluna de doutorado da Faculdade de Economia, Administração e Contabilidade da Universidade de São Paulo (FEA-USP) está desenvolvendo a pesquisa intitulada EMPREENDEDORISMO SOCIOAMBIENTAL E SUSTENTABILIDADE FINANCEIRA: Estudo de caso da Reserva Extrativista de Canutama - Bioma Amazônia, sob orientação da Prof "Graziella Maria Comini. O objetivo central deste trabalho é mapear e analisar estratégias para fortalecer e integrar mecanismos financeiros públicos e privados direcionados para sustentabilidade financeira em comunidades extrativistas do Bioma Amazônia.
\end{abstract}

Uma etapa do trabalho consiste em entrevistar pesquisadores envolvidos direta ou indiretamente com a temática Sustentabilidade; Empreendedorismo Social voltados para o Bioma Amazônia.

Por essa razão, o(a) convidamos a participar da pesquisa. Sua participação consistirá em participar de uma entrevista em profundidade, a ser gravada ou escrita. Sendo assim, solicito sua contribuição no sentido de responder questões relacionadas ao tema deste estudo. Sua participação é voluntária e você tem plena autonomia para decidir se quer ou não participar. A qualquer momento você poderá retirar seu consentimento em relação a informações coletadas parcial ou totalmente sem qualquer prejuizo a você e sua organização.

Asseguro o tratamento confidencial dos dados coletados e que serão utilizados exclusivamente para fins acadêmicos dentro do escopo deste trabalho. Fica a seu critério aprovar ou não a identificação de sua opinião declarando sua opção no Termo de Consentimento Pós-Esclarecido.

Agradeço a atenção e fico à disposição para informações complementares.

Pesquisadora responsável: Izabel Cristina Nogueira Seabra

E-mail: izabel.seabra@usp.br | Fone: (92) 98164-4187

Orientadora: Prof $^{\mathrm{a}}$ Graziella Maria Comini

E-mail: gcomini@usp.br | Fone: (11) 3091-5966 ou (11) 96368-6846

Caso esteja de acordo em participar da pesquisa, deve preencher e assinar o Termo de Consentimento Pós-Esclarecido que se segue, recebendo uma cópia do documento.

\section{TERMO DE CONSENTIMENTO PÓS-ESCLARECIDO}

Declaro que entendi os objetivos e condições de minha participação na pesquisa sobre EMPREENDEDORISMO SOCIOAMBIENTAL E SUSTENTABILIDADE FINANCEIRA: Estudo de Caso da Reserva Extrativista Canutama-Bioma Amazônia, e concordo em participar. [ ] Aprovo a identificação do meu nome.

[ ] Não provo a identificação do meu nome.

Assinatura:

Nome completo do(a) participante:

Local/Data: 


\section{APÊNDICE G - Acervo Fotográfico da Pesquisa}

Todas as fotos fazem parte do acervo da pesquisa. A apresentação das comunidades está na ordem da realização das visitas de campo realizadas em outubro de 2020. 
Figura 20 - Fotos dos Principais Produtos vendidos na Resex Canutama

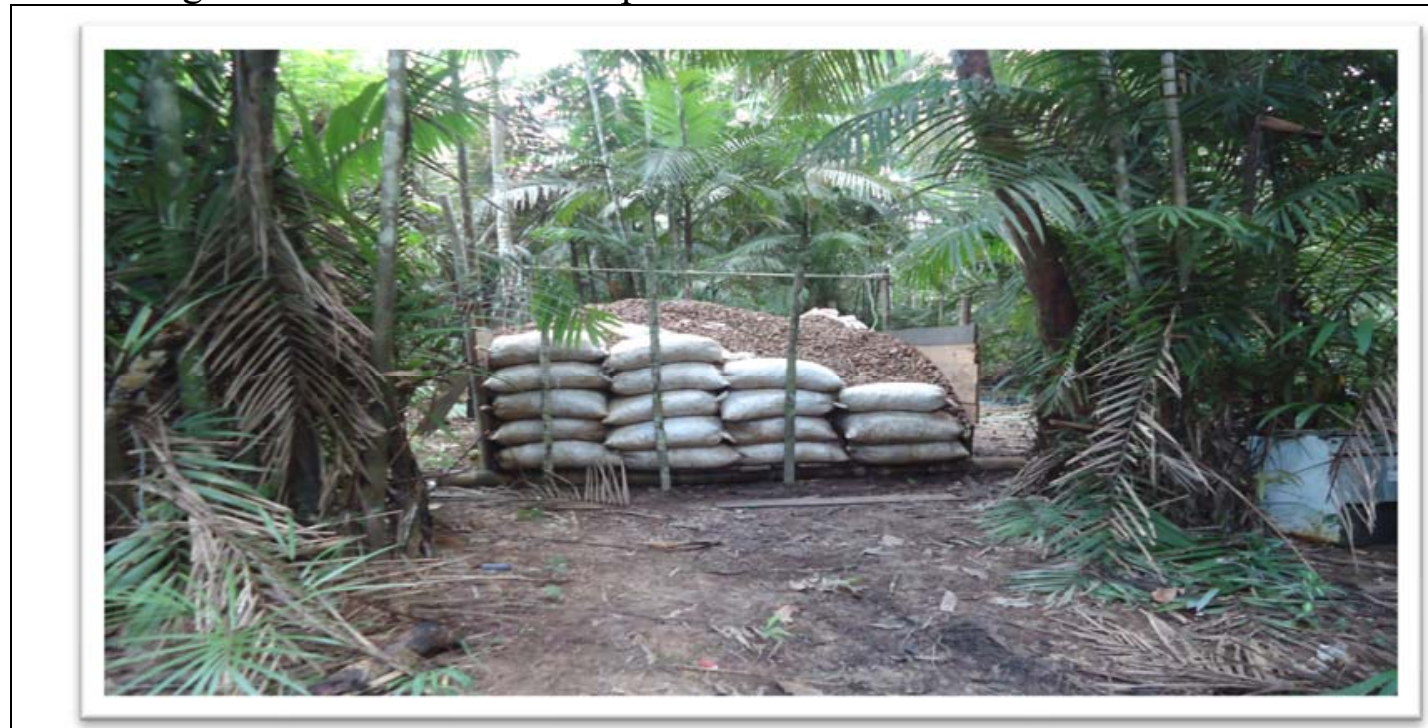

Castanha (vendida em sacas de 100 litros)

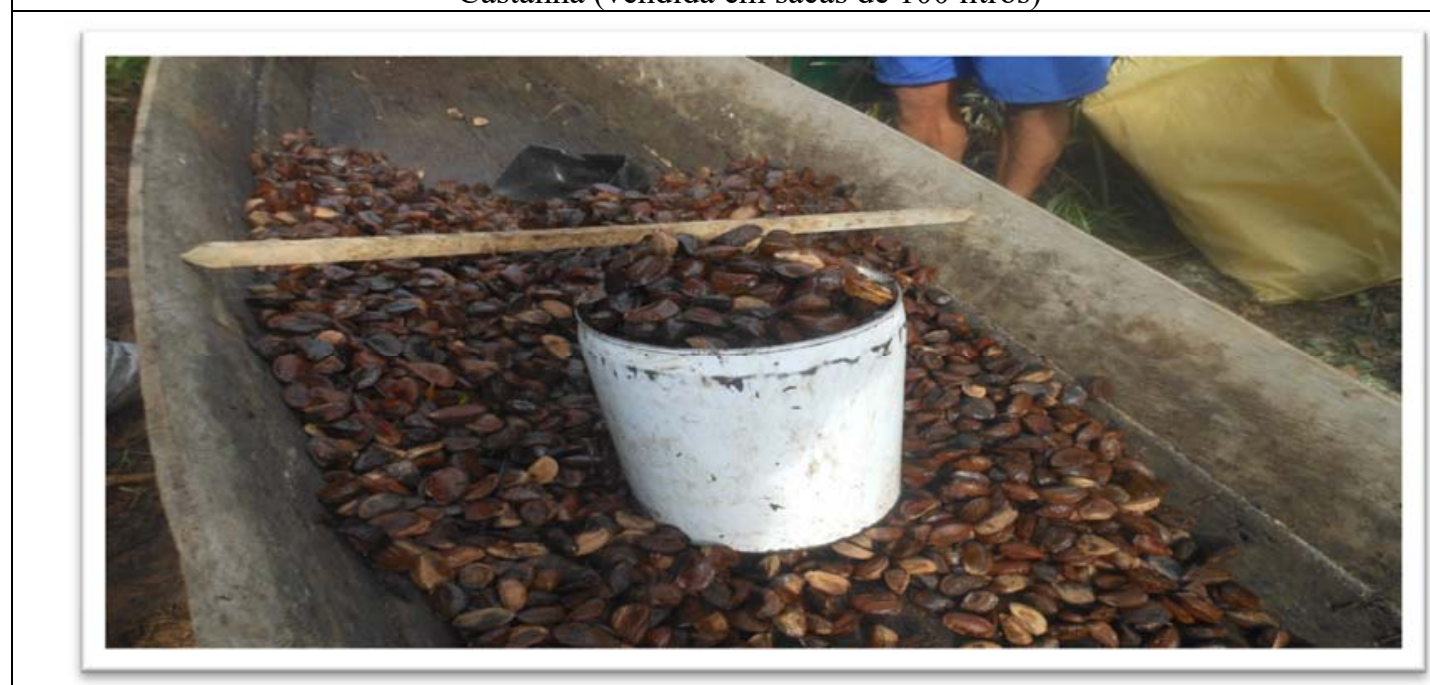

Castanha (consumo próprio)

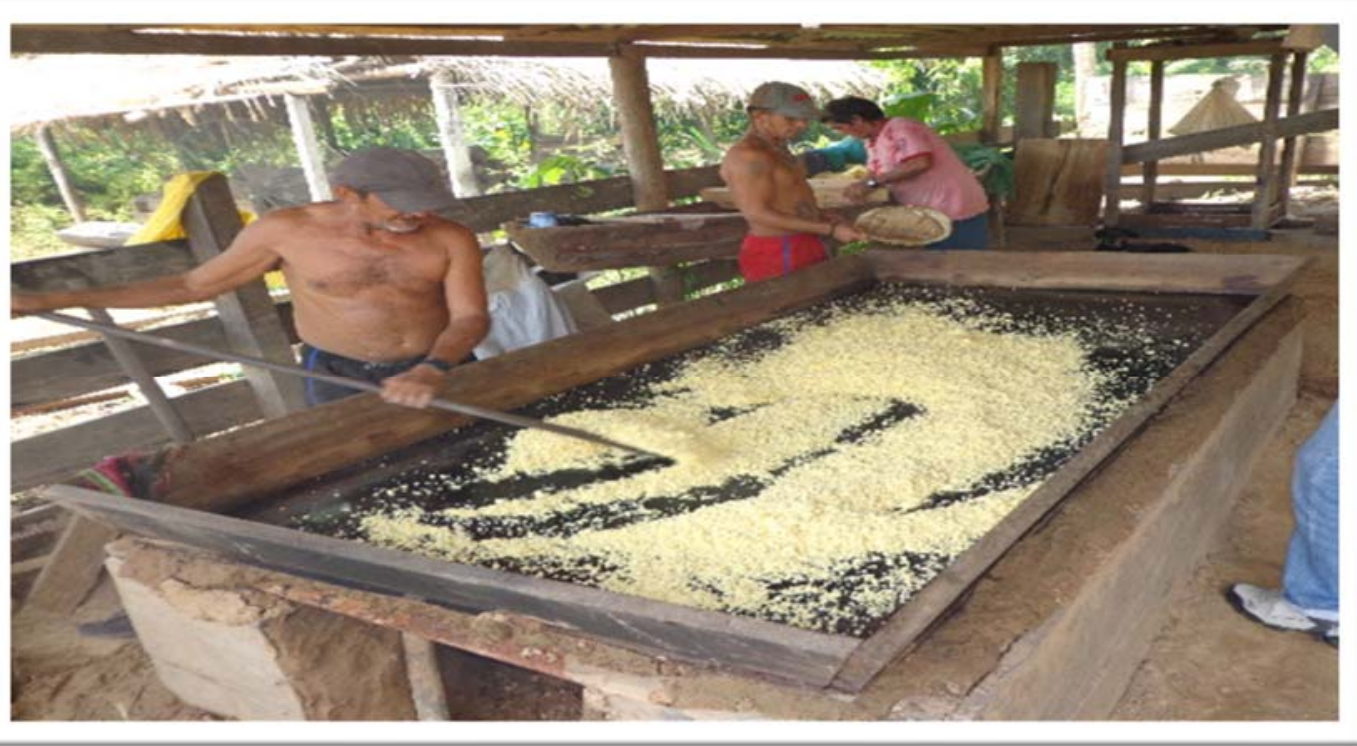

Casa de Farinha 


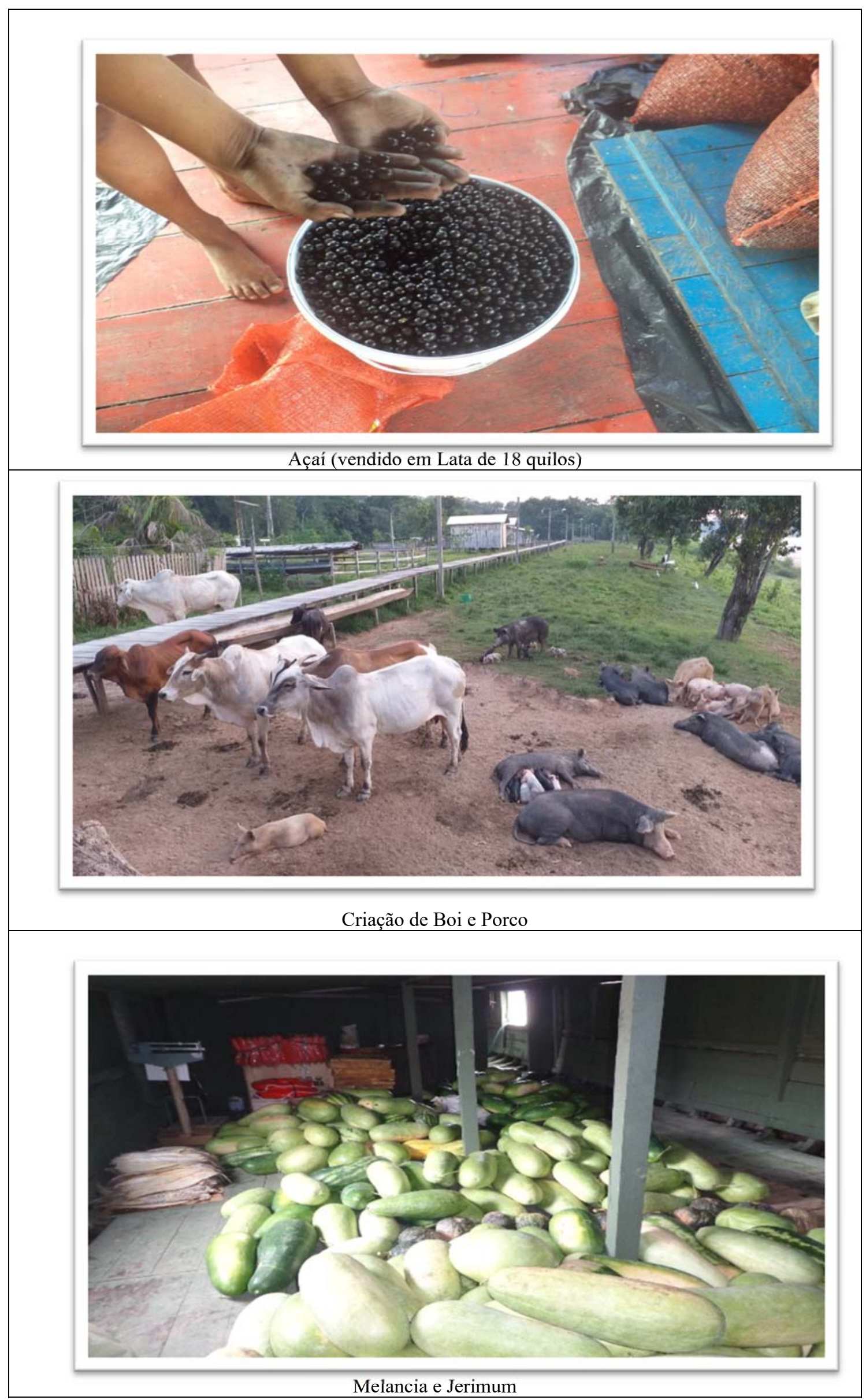


Figura 21 - Fotos da Comunidade São Jerônimo

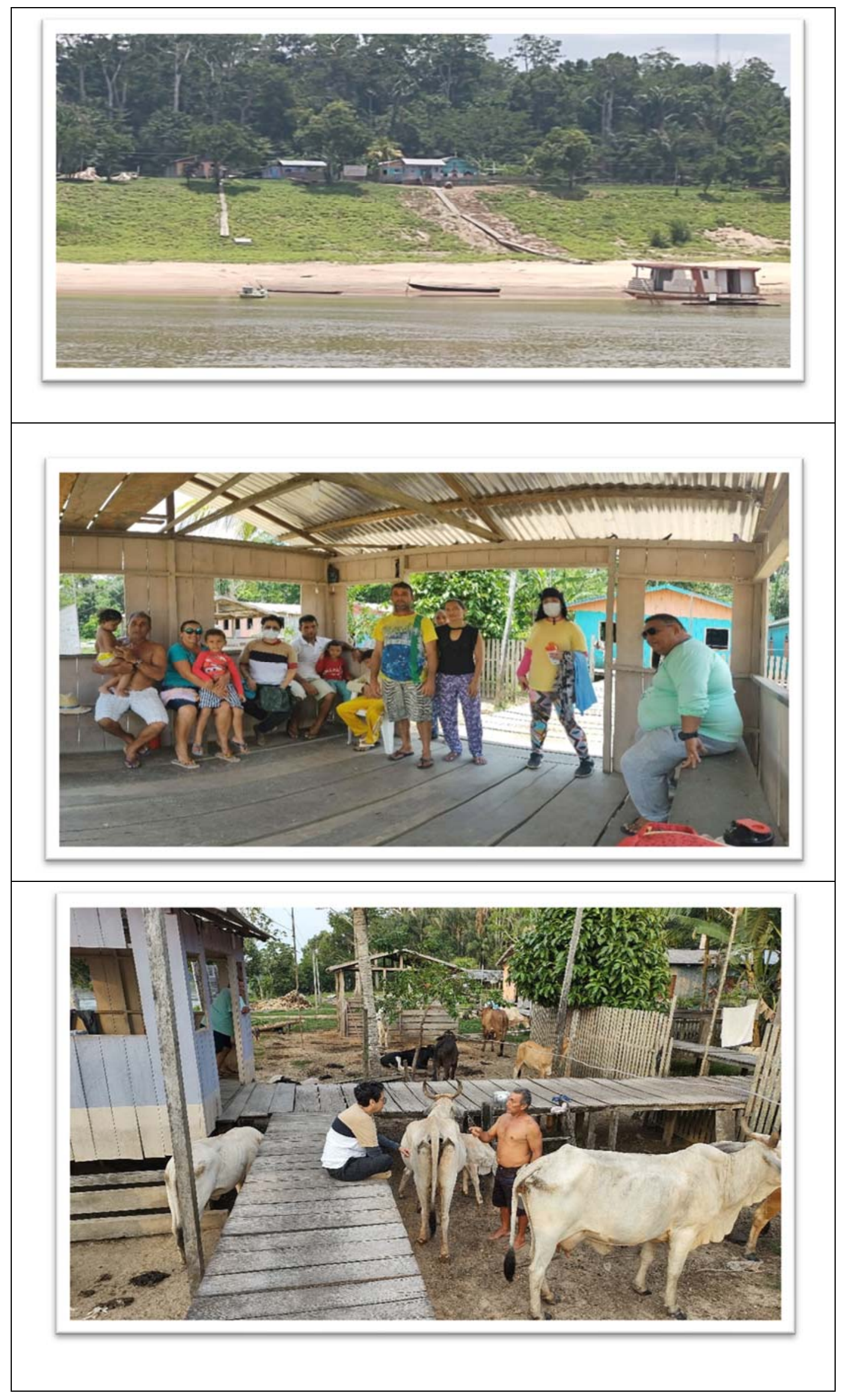


Figura 22 - Fotos da Comunidade Santa Bárbara

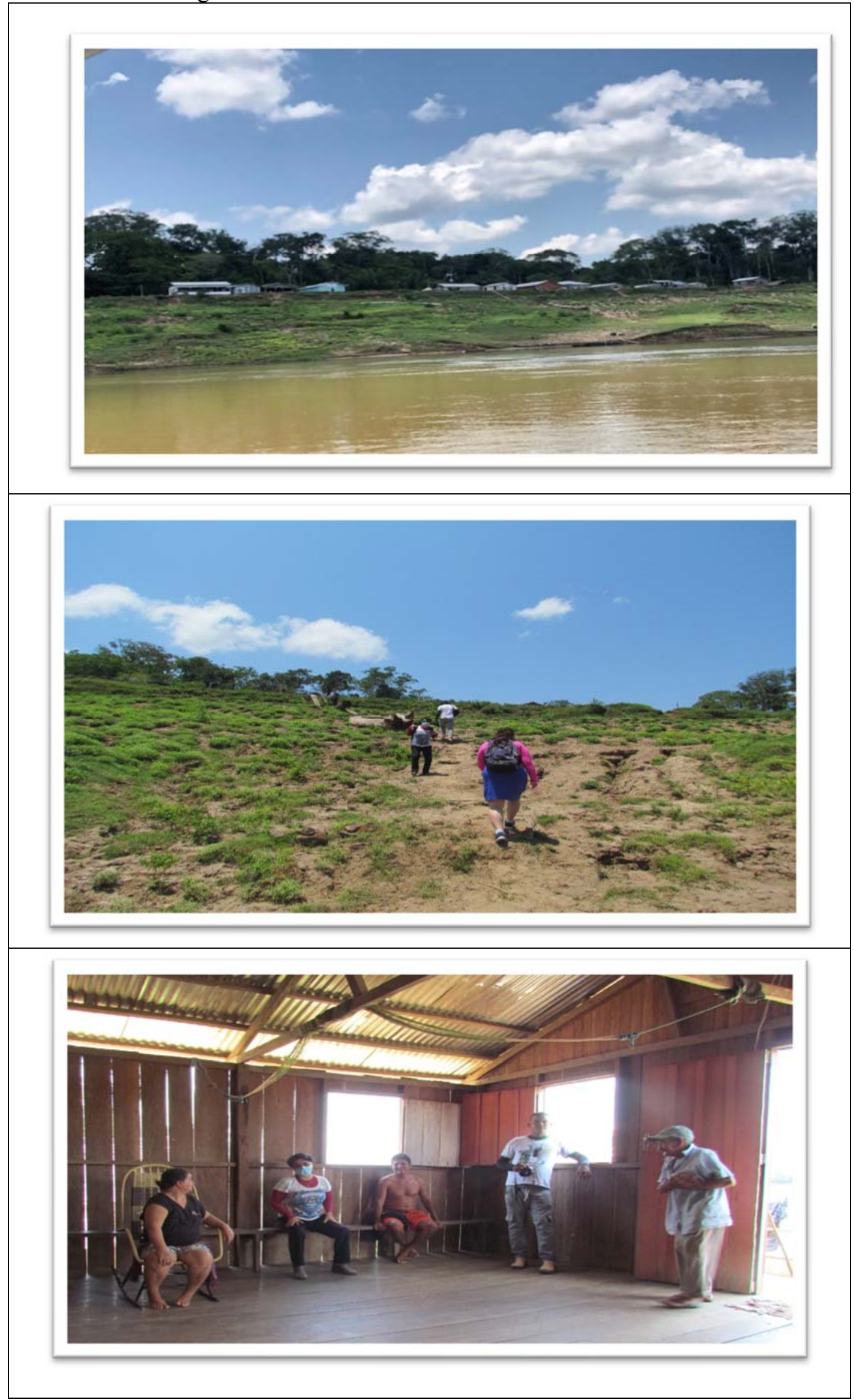


Figura 23 - Fotos da Comunidade Irajá
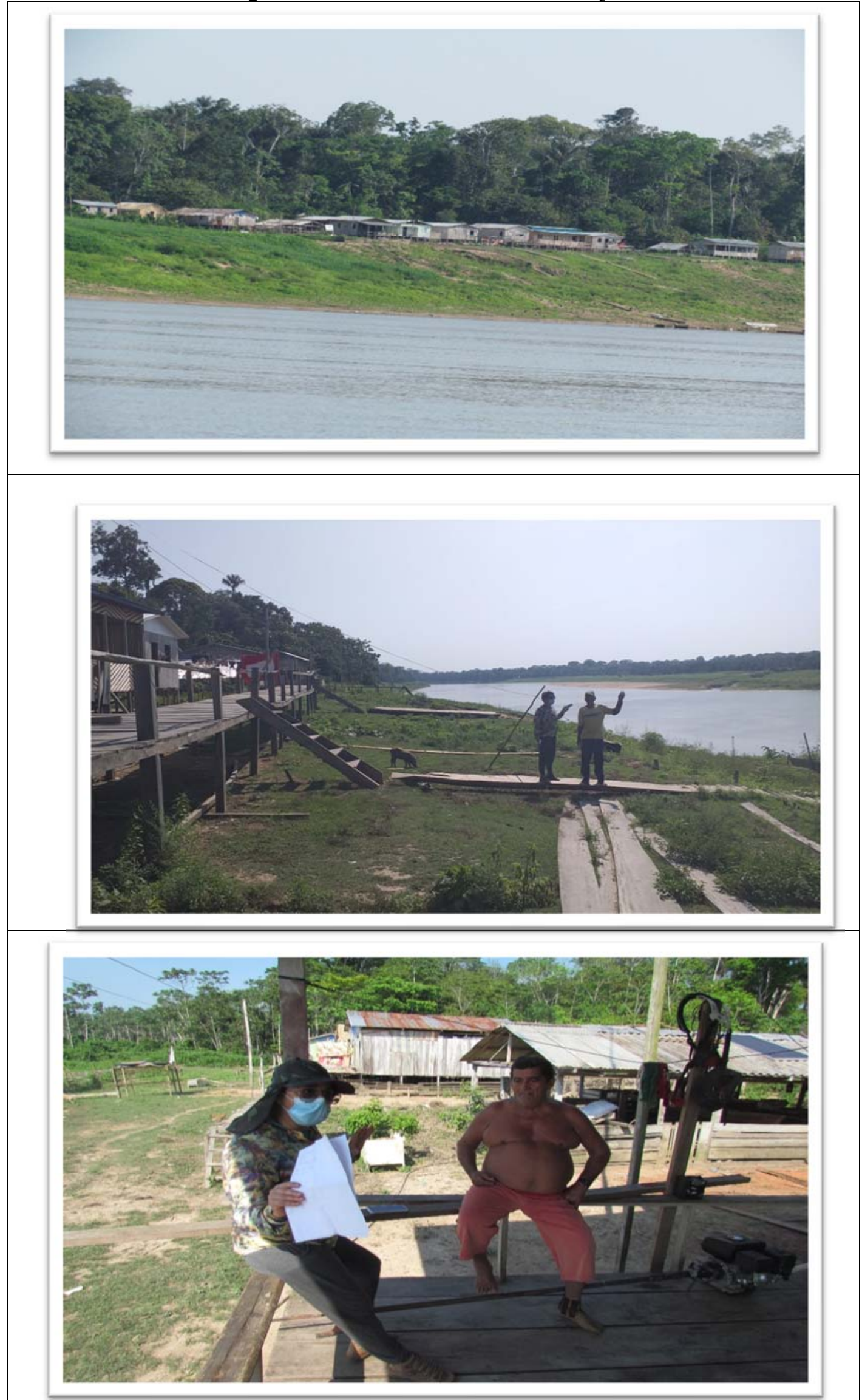
Figura 24 - Fotos da Comunidade Açaituba
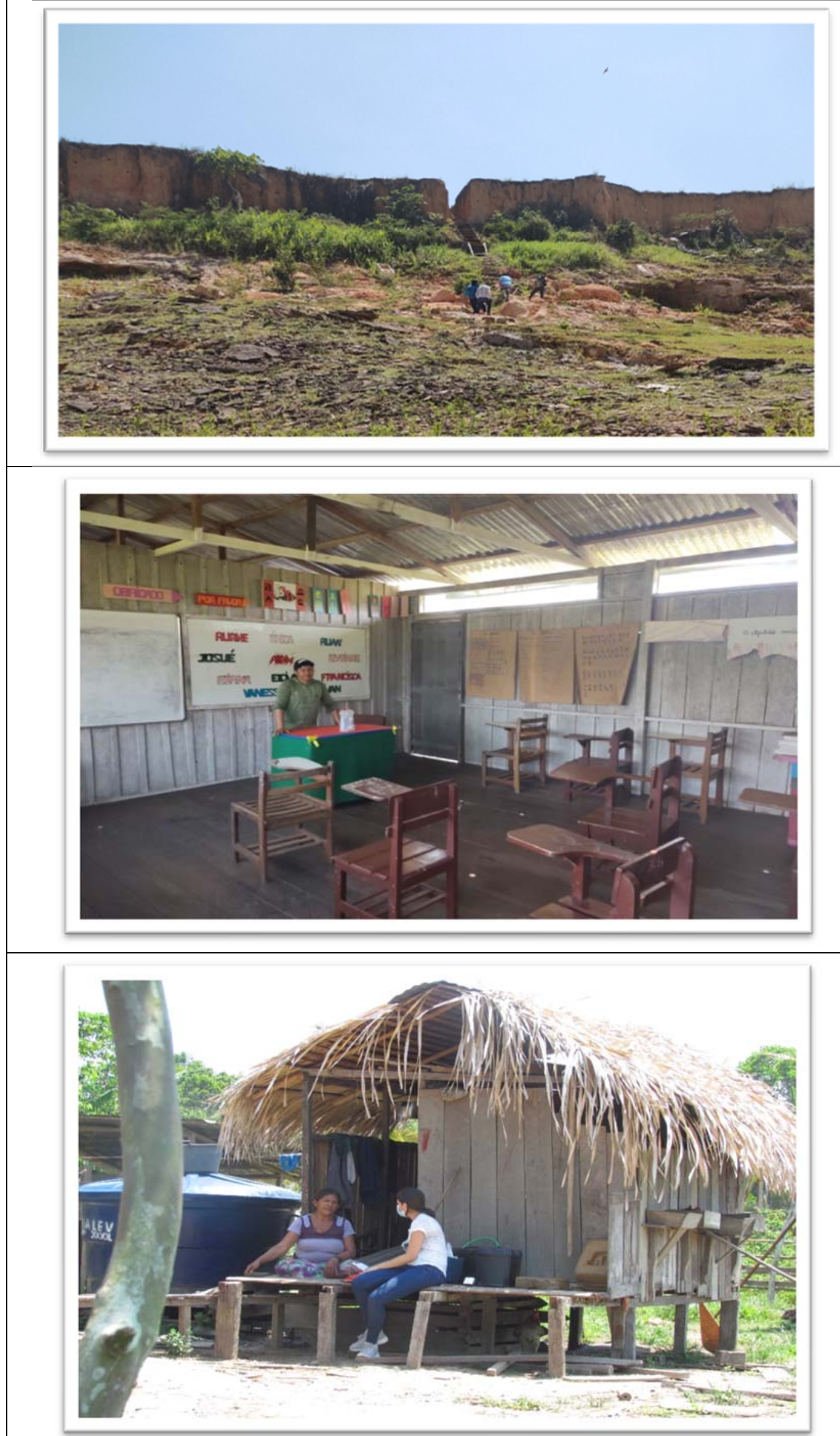
Figura 25 - Fotos da Comunidade Nova Vista

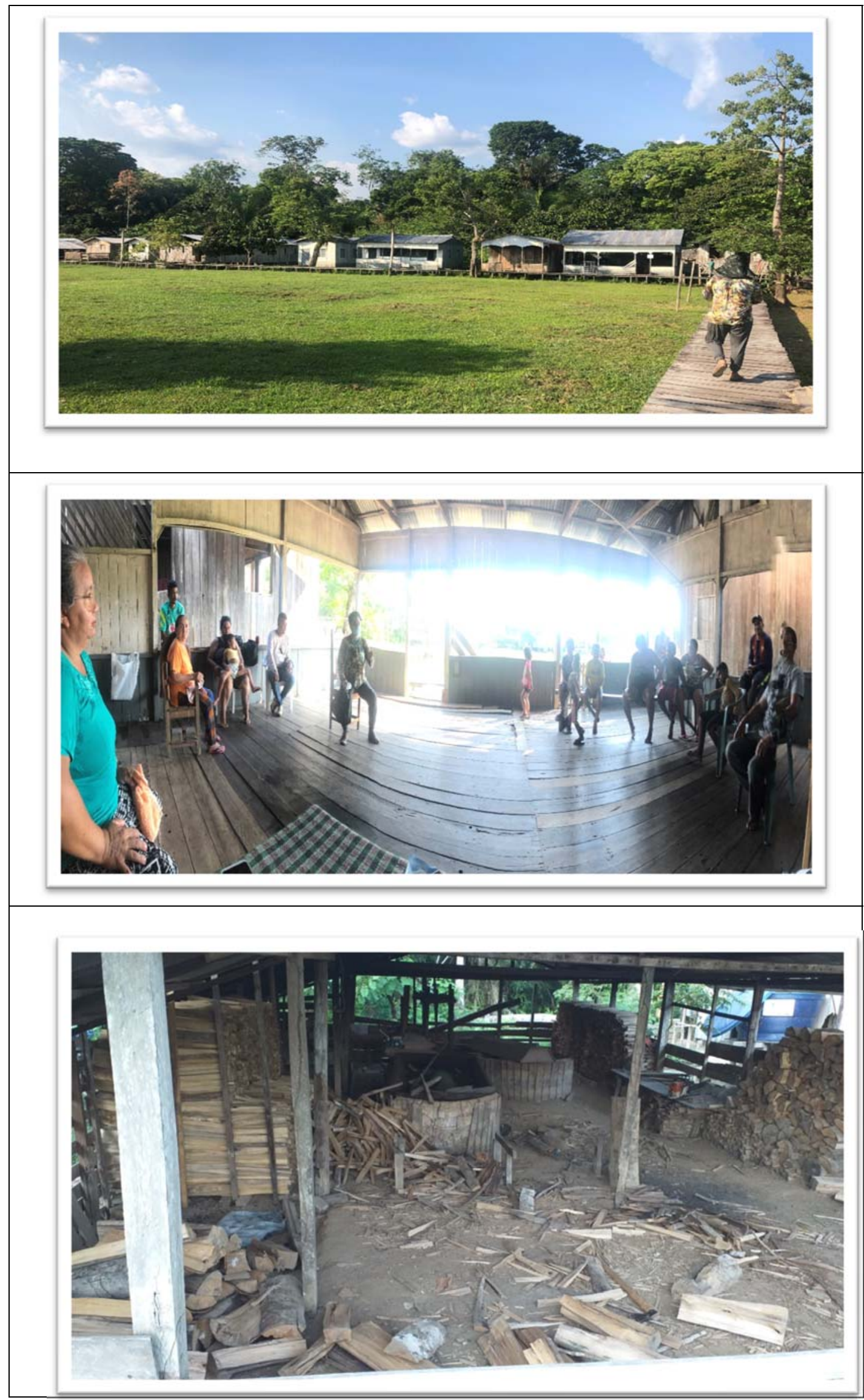


Figura 26 - Fotos da Comunidade Santa Maria
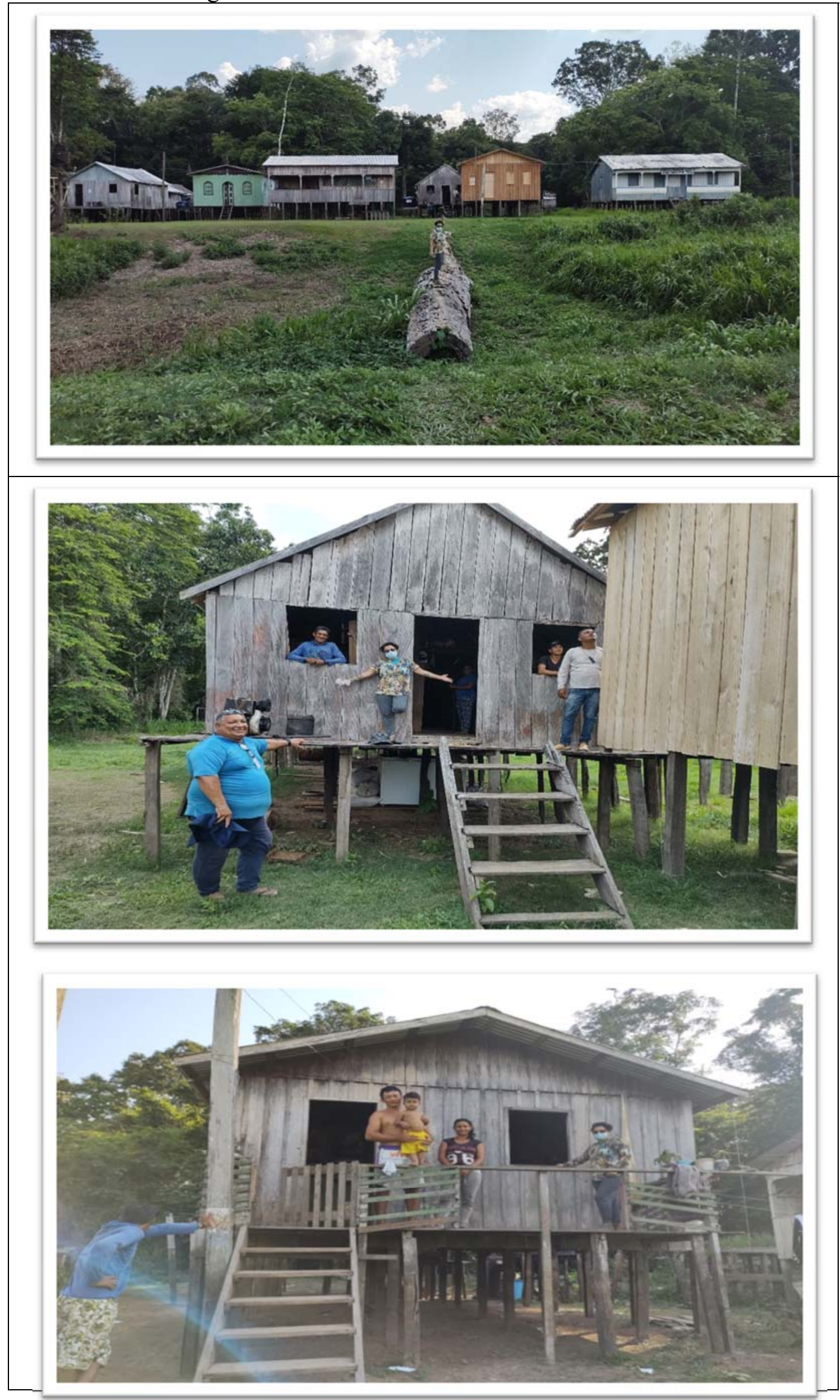
Figura 27 - Fotos da Comunidade São Tomé
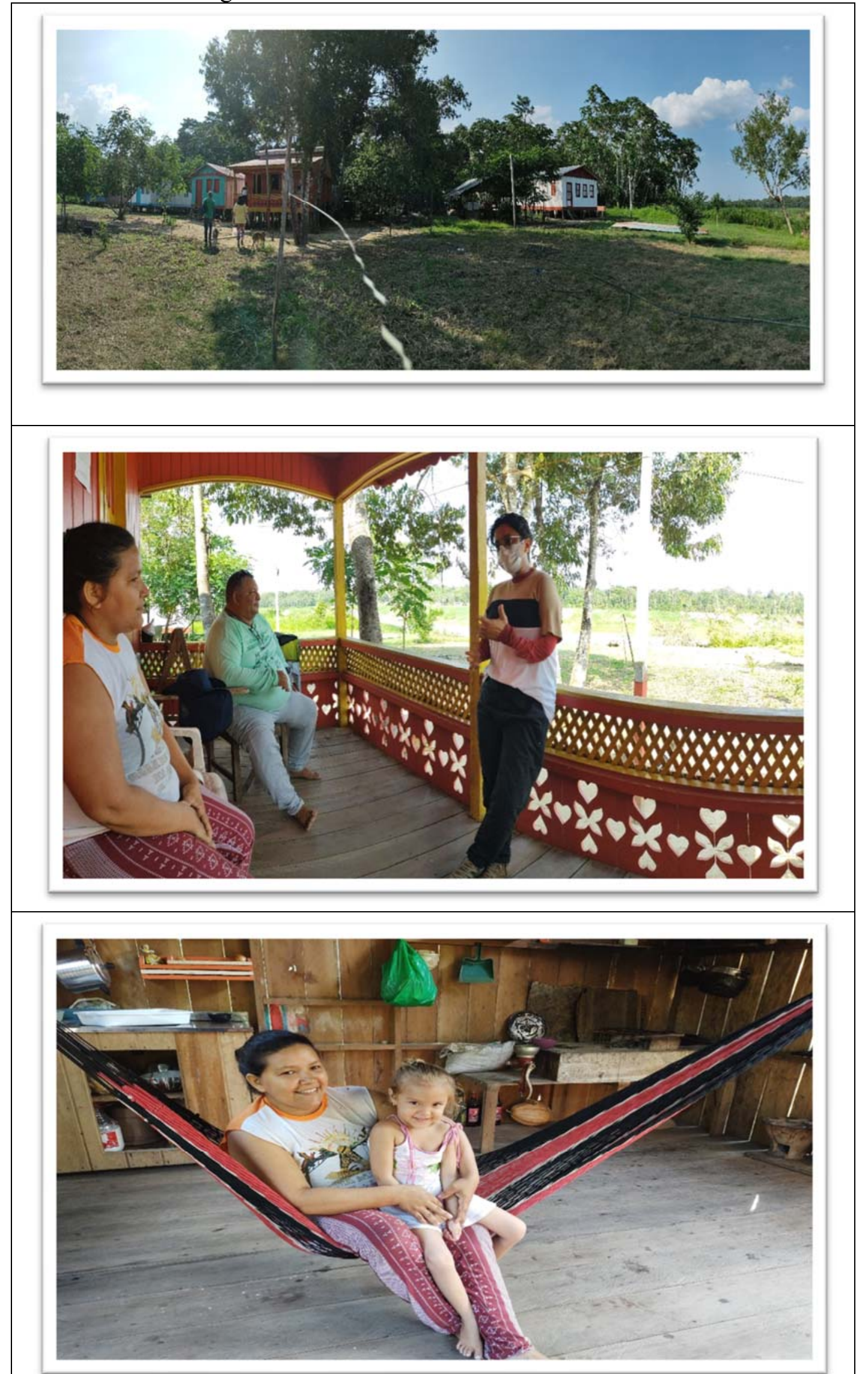
Figura 28 - Fotos da Comunidade Carmo
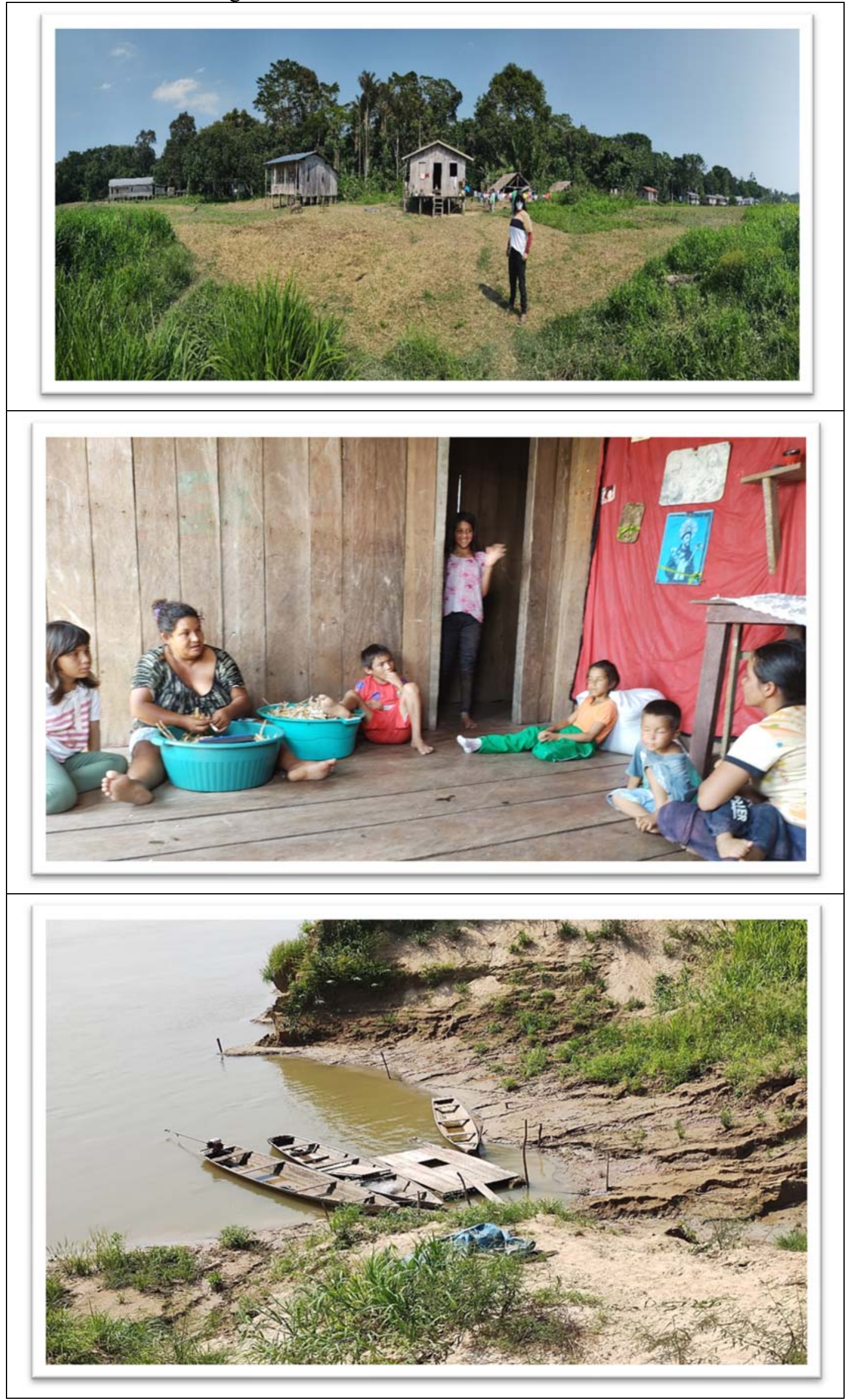
Figura 29 - Fotos da Equipe de Pesquisa

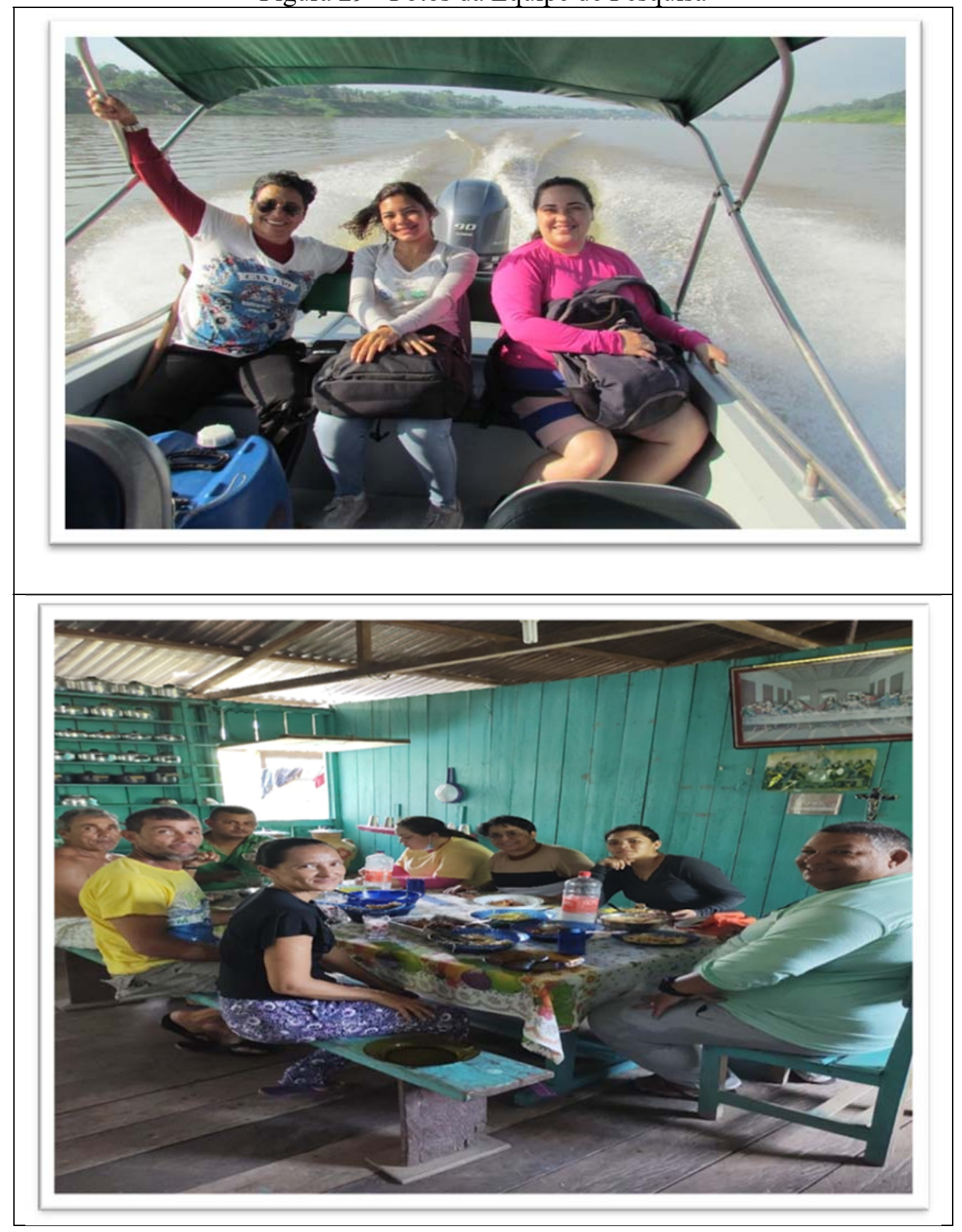




\section{APÊNDICE H - Instruções para acesso ao SIW Resex Canutama}

$1^{\mathrm{o}}$ - Acessar o endereço no link abaixo: $\mathrm{C} \operatorname{Trl}+$ Clique para seguir o link https://izabel.rsmtecnologia.com.br/usuarios/login

$2^{\circ}$ - Inserir no Nome do Usuário [usp@usp.br] e Senha [2021] e clicar [Acessar]

\section{Bem-vindo ao SIW+}

O Sistema de Informações Web Resex Canutama (SIW Resex Canutama) é produto da pesquisa apresentada no Programa de Pós-Graduação em Administração, Doutorado Interinstitucional entre a Universidade de São Paulo -USP e Universidade Estadual do Amazonas - UEA.

Nome de usuário

$$
\text { usp@usp.br }
$$

Senha

....

Você não está autorizado a acessar esse

$\times$ local.. 


\section{ANEXOS}

ANEXO A - Autorização ${ }^{\circ}$ 014/2020 - DEMUC/SEMA para realização da pesquisa de campo

ANEXO B - Contrato da Associação: fornecimento de gordura de Murumuru 263 ANEXO C - Relatórios extraídos do SIW Resex Canutama 


\section{ANEXO A - Autorização $n^{\circ} 014 / 2020$ - DEMUC/SEMA para realização da pesquisa de campo}

\section{AUTORIZAÇÃO N014/2020 - DEMUC/SEMA}

A Secretaria Estadual de Meio Ambiente do Amazonas (SEMA) por meio do Departamento de Mudanças Climáticas e Gestão de Unidades de Conservação (DEMUC). no âmbito de sua competência e considerando:

A Lei $n^{\circ}$ 53, de 05 de Junho de 2007, que institui o Sistema Estadual de Unidades de Conservação do Amazonas (SEUC/AM);

O Artigo 43 que trata do Capitulo VI da Lei do SEUC/AM, que trata das pesquisas cientificas em unidade de conservação.

AUTORIZA entrada e execução de pesquisa em Unidade de Conservação de Uso Sustentável, a saber:

\section{UNIDADES DE CONSERVAÇÃO CONTEMPLADAS:}

Reserva Extrativista Canutama

Reserva Extrativista Catuá-Ipixuna

Reserva Extrativista Rio Gregório

\section{AÇÄOIATIVIDADE:}

"Empreendorismo social e sustentabilidade financeira: uma analise das reservas extrativistas do Bioma Amazônia"

\section{PESQUISADORES AUTORIZADOS:}

\begin{tabular}{|l|l|l|l|l|}
\hline N & Nome & Cargo & Instituição & Documento \\
\hline 01 & Izabel Cristina Nogueira Seabra & Doutoranda & $\begin{array}{l}\text { Universidade do } \\
\text { Estado do } \\
\text { Amazonas (UEA) e } \\
\text { Universidade de } \\
\text { São Paulo }\end{array}$ & 274.851.532-34 \\
\hline
\end{tabular}

\section{PERIODO DE REALIZAÇÃo}

Março de 2020 a março de 2021

\section{CONSIDERAÇÕES}

- A Reserva Extrativista (RESEX) se constitui em área utilizada por comunidade tradicional, cuja subsistência se baseia no extrativismo e, complementarmente, na criação de animais em pequena escala, tendo por objetivos básicos proteger os meios 


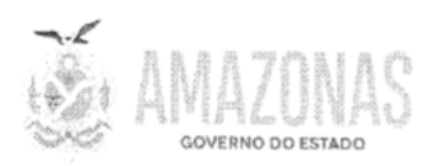

de vida e a cultura dessas populações, assegurando o uso sustentável dos recursos da Unidade (Art. 19 da Lei nº. 53, de 5 de junho de 2007).

- Os objetivos desta pesquisa são de relevante interesse para a conservação, pois visa "analisar a viabilidade financeira dos empreendimentos sociais de Resex e identificar estratégias para ampliação e integração de mecanismos financeiros públicos e privados voltados para as Reservas Extrativistas do Bioma Amazônia";

- A equipe técnica participante da atividade envolve profissionais aptos à execução da mesma:

- Os métodos a serem executados na atividade são apropriados aos objetivos propostos.

\section{RECOMENDAÇÕES TÉCNICAS}

- É obrigatória a apresentação dos objetivos da pesquisa aos moradores (líderes comunitários) e atores envolvidos da UC antes do início das atividades do projeto;

- O cronograma das visitas de campo deverá ser ajustado em conformidade e disponibilidade do gerente da UC para planejamento e esclarecimentos gerais sobre as UC, como informações sobre infraestrutura, ou acesso as áreas preteridas para execução das atividades;

RESERVA EXTRATIVISTA CANUTAMA

Gerente: Altemar Lopes

E-mail: altemarlopes@yahoo.com.br

RESERVA EXTRATIVISTA CATUÁ-IPIXUNA

Gerente: Erivan Moraes

E-mail: erivan_moraes@yahoo.com.br

RESERVA EXTRATIVISTA RIO GREGÓRIO

Gerente: Walben Junior

E-mail:walben.ceuc@gmail.com

- Recomenda-se a contratação de moradores locais para auxiliarem nas tarefas de campo,

\section{RECOMENDAÇÕES GERAIS (NORMAS)}

- O Comitê de Ética da UEA, assim como o Conselho de Gestão do Patrimônio Genético e Acesso ao Conhecimento Tradicional Associado (CGEN), quando for o caso, deverá

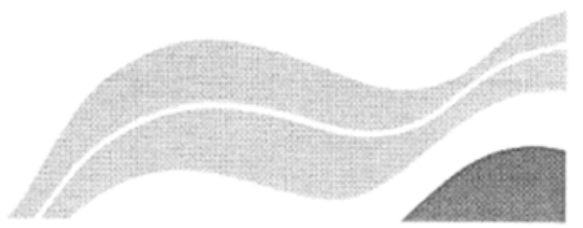




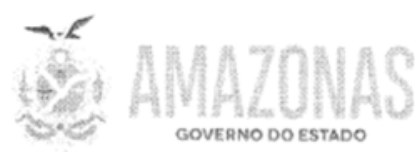

ser consultado a fim de se ter as devidas autorizações e/ou licenças que se façam necessárias:

- A SEMA autoriza o acesso às unidades de conservação estaduais, a coleta de material biológico de qualquer natureza deve haver o respaldo por autorização via SISBIO e termo de anuência do DEMUC;

- A SEMA mantém cooperação com o Instituto Nacional de Pesquisas da Amazônia (INPA) para depósito de material biológico originário das Unidades de Conservação (UC) estaduais. Assim, o material biológico coletado deverá ser depositado em instituições sediadas no Estado do Amazonas, realizando o contato prévio com a curadoria da coleção - Dra. Lúcia Rapp, lucia.rapp@gmail.com 3643-3226/ 3643-3341, a qual indicará os contatos das demais coleções para todos os grupos que serão coletados;

- Qualquer alteração no cronograma deverá ser comunicada à gerente da UC e a Assessoria de Pesquisas e Monitoramento Ambiental autorizacao.sema.am@gmail.com (3642-4607);

- Sendo assim, recomenda-se à pesquisa e a emissão de autorização podendo ser renovada, se necessário, mediante apresentação de relatório e justificativa.

- Em todas as divulgações, devem ser citadas a Secretaria de Estado de Meio Ambiente - SEMA, e de acordo com o art. 50 do Sistema Estadual de Unidades de Conservação - SEUC (Lei Complementar n 53/2007):

Art. 50. A comercialização de produtos florestais, subprodutos, recursos ambientais e o aproveitamento econômico de serviços ambientais e outros serviços obtidos ou desenvolvidos a partir de recursos naturais biológicos, cênicos, culturais ou da imagem de Unidade de Conservaçăo, exceto APA, RPPN e RPDS, dependerá de prévia autorizaçăo do Orgão Gestor e sujeitará o contratado ou o comprador a pagamento, conforme disposto em regulamentação especifica.

- A logomarca da SEMA e Governo do Amazonas devem ser solicitados para a assessoria de comunicação - ASSCOM (imprensasema.am@gmail.com), e de acordo com o parágrafo $1^{\circ}$ do Art. 51 do SEUC:

§1 $1^{\circ} \mathrm{A}$ utilização do nome da unidade de Conservação, da logomarca da Unidade de Conservação, do Orgâo Gestor e do Govemo do Amazonas, em produtos comerciais, sujeitará o usuário a pagamento, conforme contrato especifico.

- Após o término da pesquisa deverá ser encaminhado o relatório geral nos moldes do DEMUC no prazo de até $\mathbf{4 5}$ dias, e os demais resultados solicitados, no prazo de até 120 dias. Esta ação condicionará na emissão de novas autorizações ou sua renovação no nome de qualquer um dos participantes do projeto, seja como responsável ou não pelo mesmo.

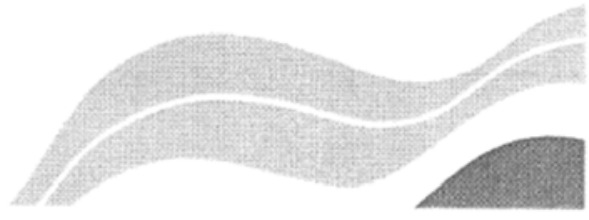




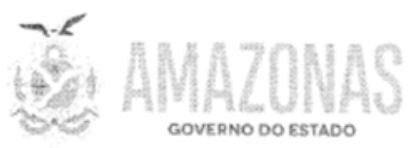

- Os resultados direcionados ao DEMUC estão abaixo e serão exigidos:

\begin{tabular}{|r|l|}
\hline 1 & Imagens (fotos) do desenvolvimento da pesquisa; \\
\hline 2 & Informações de entrevistas; \\
\hline 3 & Pontos georreferenciados; \\
\hline 4 & Relatório Geral, artigos, publicações; \\
\hline 5 & Relatório modelo DEMUC \\
\hline
\end{tabular}

Departamento de Mudanças Climáticas e Gestão de Unidades de Conservaçăo do Amazonas, em Manaus/AM, 03 de março de 2020.

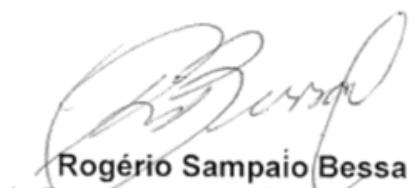

Chefe do Departamento de Mudanças Climáticas e

Gestão de Unidades de Conservaçăo - DEMUC/SEMA 


\title{
ANEXO B - Contrato da Associação: fornecimento de gordura de Murumuru
}

\section{INSTRUMENTO PARTICULAR DE CONTRATO DE FORNECIMENTO DE GORDURA DE MURUMURU}

\begin{abstract}
Pelo presente INSTRUMENTO PARTICULAR DE CONTRATO DE FORNECIMENTO DE GORDURA DE MURUMURU, as partes entre si, justas e contratadas, a saber:
\end{abstract}

De um lado, CHEMYUnion LTDA., pessoa juridica de direito privado, com sede na Av. Independência, 1.501, Iporanga - Sorocaba/SP, CEP 18.087101, inscrita no CNPJ sob n. ${ }^{\circ} 58.309 .709 / 0001-53$, neste ato representada por seu sócio e Diretor Industrial, Sr. MARCIO ANTONIO POLEZEL, brasileiro, casado, químico, RG sob o n. ${ }^{\circ}$ 10.537.609-7, CPF sob o n. ${ }^{\circ} 005.701 .498-19$, domiciliado no endereço supra, doravante denominada simplesmente CONTRATANTE; $e$

De outro lado, AsSOCIAÇÃo DOS PRODUTORES AGROEXTRATIVISTAS DA COLÔNIA DO SARDINHA - ASPACS, com sede na Rua Agostinho de Freitas Bairro Vila Falcão (Comunidade Sardinha), S/N - Zona Rural, Labrea/Amazonas, CEP 69830-000, inscrita no CNPJ sob o n. 02.369.784/0001-55, neste ato representada por sua Presidente, Sra. SANDRA BARROS MALA, brasileira, casada, empresária, RG sob o n. ${ }^{\circ} 0709043-9$, CPF sob o n. ${ }^{\circ}$ 166.824.162-53, domiciliada no endereço supra, doravante denominada simplesmente CONTRATADA;

CONSIDERANDO que a CONTRATANTE é empresa especializada na indústria e comércio de produtos químicos, especialmente para a indústria Farmacêutica, de Alimentos e Cosmética;

CONSIDERANDO que a CONTRATADA, tem expertise em extração de óleos e gorduras vegetais de espécim qs da flóra brasileira;
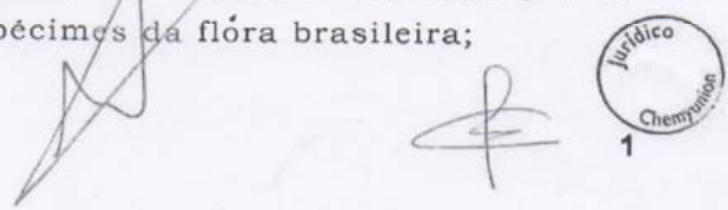
CONSIDERANDO que há interesse entre as PARTES de se estabelecer vinculo contratual, pelo qual a CONTRATADA se obriga a empregar esforços para promover a coleta do fruto murumuru, bem como a efetuar seu posterior processamento para obter a gordura do referido fruto, a fim de fornece-la à CONTRATANTE, sempre garantindo a qualidade e o padrão de utilização desta última, bem como sua rastreabilidade de origem;

RESOLVEM celebrar o presente instrumento conforme os termos e condiçōes adiante estabelecidas de comum acordo:

\section{- DO OBJETO}

1. O presente Contrato tem por objeto o fornecimento de 8.000 kg (oito mil quilos) de Gordura de Murumuru extraida dos frutos murumuru coletados durante o periodo da safra do ano de 2019 , bem como o acompanhamento do processo produtivo destes e a correta verificação de rastreabilidade de toda cadeia produtiva, compreendendo desde a coleta de frutos até a fabricação da Gordura de Murumuru a ser enviada para a

CONTRATANTE, sempre com o comprometimento de preservação do meio ambiente e observancia da época própria para coleta.

1.1 A CONTRATADA reconhece e concorda que a Gordura de Murumuru a ser fornecida à CONTRATANTE deverá obedecer estritamente às especificações indicadas no Anexo A deste Contrato.

1.2 Cada remessa deverá ser adequadamente embalada em tambores plásticos, com identificação de lote, data de fabricação e validade. Cada remessa deverá, ainda, ser
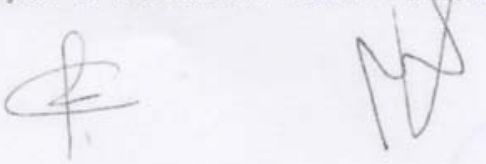
acompanhada de cópia dos recibos entregues à

CONTRATADA pelos ribeirinhos que tiverem fornecido os frutos usados para a fabricação da Gordura de Murumuru, conforme disposto na cláusula 2 abaixo.

1.3 Entregas que não atendam aos critérios estabelecidos nos itens 1.1 e 1.2 acima poderão ser recusadas pela CONTRATANTE, a critério desta, ficando a CONTRATADA, em tais casos, obrigada a efetuar as correspondentes reposições.

1.4 A cada compra de frutos junto as comunidades ribeirinhas, a CONTRATADA deverá obter recibo de entrega detalhado, devendo este conter todas as informações relevantes conforme modelo que integra o Anexo B deste Contrato, tais como: (i) nome completo do vendedor (ribeirinho ou representante da Comunidade Ribeirinha), (ii) R.G., (iii) endereço completo ou coordenadas geográficas que permitam sua geolocaliozação; (iv) quantidade adquirida; e (iv) valor pago. A CONTRATADA se compromete, ainda, a fornecer informaçōes adicionais referentes à rastreabilidade da cadeia produtiva, sempre que assim for razoavelmente solicitado pela CONTRATANTE.

1.5 A CONTRATADA se compromete a nāo adquirir matérias-primas de qualquer pessoa, fisica ou juridica, que demonstre ser negligente com a proteção, preservação e manutenção do meio ambiente, incluindo de quem praticar invasões, desmatamentos ilegais e/ou qualquer tipo de agressão contra a natureza, ou que sabidamente, adotẹn práticas que possam de alguma
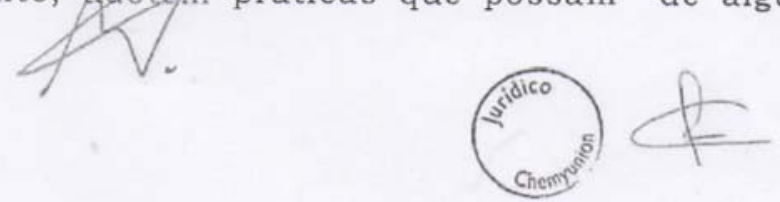
forma comprometer a imagem ou reputação da CONTRATANTE.

\section{DO PRAZO}

2. Este Contrato entrará em vigor na data de sua assinatura, assim permanecendo até o cumprimento integral do seu obejto contratual, respeitando-se o periodo de safra do murumuru, sendo 30/01/2020 a data limite para envio da quantidade total contratada de Gordura de Murumuru à Contratante. Qualquer evento que se enquadre, nos termos da lei, como caso fortuito ou de força maior, que possa de alguma forma impedir qualquer entrega ou, especialmente, o atendimento do prazo limite acima fixado, deverá ser prontamente comunicado à CONTRATANTE para que as Partes negociem a possibilidade de extensão do prazo.

2.1. Este contrato poderá ser resolvido de pleno direito pela CONTRATADA se a CONTRATANTE requerer ou tiver contra si requerido pedido de falência, recuperação judicial ou extrajudicial. Qualquer das partes poderá, ainda, resolver este contrato, também de pleno direito, em caso de insolvência da outra parte, ou ainda por descumprimento de cláusulas e responsabilidades aqui estabelecidas pela outra parte.

\section{DO REGISTRO DA CONTRATADA E DA FORMA DE TRABALHO}

3. Na vigência deste contrato a CONTRATADA deverá manter-se devidamente registrada e em dia perante os Órgãos Públicos inerentes, em função de súa atividade, bem como em dia com todos os tributos e demais dbrigaçōes sociais, decorrentes de
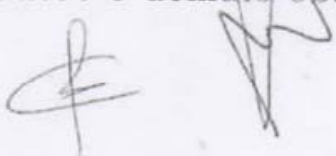
tal atividade, sendo certo que, havendo qualquer problema nesse âmbito, a CONTRATADA deverá comunicar a CONTRATANTE tão logo surja ou ocorra tal situação, facultando à ConTRATANTE optar pela resoluçāo plena e integral do presente instrumento, mediante simples aviso por escrito, com observância do cumprimento das obrigações pendentes até a data do aludido aviso.

\section{DAS OBRIGAÇÕES DA CONTRATADA}

4. Constituem obrigações da ConTratadA, sem exclusão das demais previstas neste contrato e das decorrentes de lei:

4.1 Prestar seus serviços com todo zelo, diligência, e honestidade, observados os termos deste contrato e a legislação vigente.

4.2 Manter absoluto sigilo e confidencialidade de toda e qualquer informação, e/ou dados que the sejam confiados pela CONTRATANTE, por conta de seu vinculo contratual com a empresa.

4.3 Garantir a todo tempo condições seguras e saudáveis de trabalho, bem como não permitir qualquer forma de trabalho forçado, compulsório, infantil ou em situações análogas;

4.4 Promover a não-discriminação e igualdade de gênero, tratando todos os trabalhadores de maneira justa durante o trabalho, respeitando e apoiando os direitos

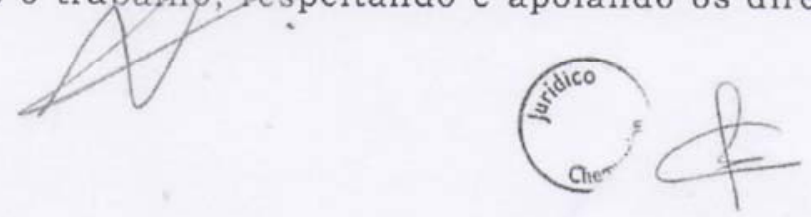


humanos, a fim de garantir um ambiente livre de discriminação e com igualdade de oportunidades.

4.5 Observar rigorosamente todas as disposições deste instrumento, principalmente as que se referem à preservação do meio ambiente e o manuseio sustentável das espécies de plantas e sementes.

4.6 Garantir a entrega do produto objeto deste contrato de acordo com especificaçōes constantes no Anexo A.

4.7 Comunicar a CONTRATANTE, imediatamente após quaisquer intercorrências e/ou incidentes relativos a eventuais problemas de safra ou de fornecimento, decorrentes ou não de caso fortuito ou força maior, de forma que que CONTRATANTE possa tomar medidas e firmar ações corretivas para a manutenção de seu estoque, a fim de que seus clientes não sejam afetados, ou o sejam minimamente.

\section{DA FORMA DE PAGAMENTO}

5. As partes acordam que, para a safra de 2019 , o preço a ser pago pela CONTRATANTE à CONTRATADA, pelo fornecimento da Gordura de Murumuru será de R\$40,00 por $K g$ de produto fornecido. O valor pago contempla a entrega do produto em transportadora a ser designada pela CONTRATANTE, na cidade de Porto Velho/RO, bem como inclui tributos e outros custos que a CONTRATADA tenha arcado para cumprimento do objeto contratual.
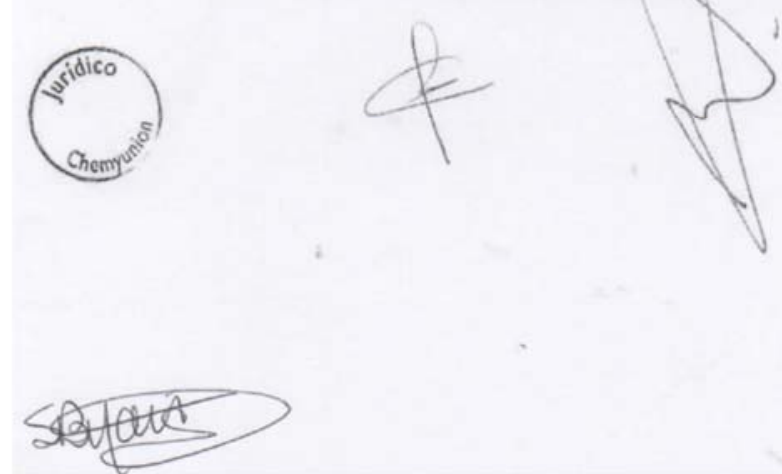
5.1. Mediante assinatura deste contrato, a CONTRATANTE fará um adiantamento, no valor de valor de $R \$ 30.000,00$ (trinta mil reais), a ser depositado na conta corrente da ContratadA, junto ao Banco do Brasil, a saber: conta corrente $n^{\circ}$ 7075-0, Agência $n^{\circ}$ 3317-0.

5.2. Fica ajustado que o adiantamento referido acima será deduzido do valor a ser pago quando da primeira entrega. Caso o contrato venha a ser rescindido em razão de descumprimento por parte da CONTRATADA ou por motivo a esta atribuivel, antes do envio da primeira remessa e consequente abatimento do adiantamento efetuado, referido adiantamento deverá ser reembolsado à CONTRATANTE tão logo seja comunicada a rescisão contratual.

5.3. Como condiçăo aos pagamentos, a CONTRATADA deverá apresentar à CONTRATANTE a respectiva Nota Fiscal que deverá acompanhar as cargas enviadas para a CONTRATANTE.

5.4. As Notas Fiscais deverão ser emitidas em inteira conformidade com as exigências regulamentares, especialmente as de natureza fiscal.

\section{DAS DISPOSIÇŌES GERAIS E FINAIS}

6. São disposições gerais e finais:

6.1. A tolerância das partes com relação a eventuais infrações da outra nấo será em hipótese alguma interpretada comglnoyação, remissão, desistência ou

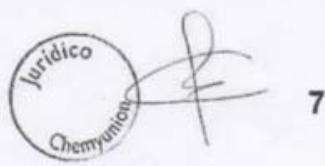


renúncia aos direitos que a lei e este instrumento the asseguram, consubtanciando-se em mera liberalidade.

6.2. Este contrato nảo poderá ser cedido em hipótese alguma, salvo se autorizado pela outra parte.

6.3 Qualquer modificação deste instrumento deverá ser efetuada por escrito, mediante comum acordo.

6.4 Casos omissos a este instrumento deverão ser resolvidos com base na Lei Civil, na boa-fé das partes e nos costumes do pleno desenvolvimento do presente contrato.

\section{DO FORO}

7. As partes elegem o foro da cidade e comarca de São Paulo, Capital do Estado de São Paulo, para dirimir eventuais conflitos de interesses porventura decorrentes do presente contrato, prevalecendo sobre qualquer outro, por mais privilegiado que seja.

E, por estarem assim justas e combinadas, firmam o presente instrumento, em 2 (duas) vias de igual teor e forma, juntamente com as testemunhas instrumentárias abaixo indicadas.

Sorocaba/SP, 10 de julho de 2019.
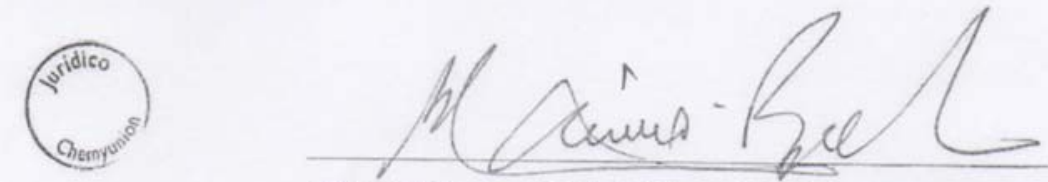

MARCIO A. POLEZEL - DIRETOR INDUSTRIAL CHEMYUNION LTDA. 


\section{Sandre Barros maia \\ ASSOCIAÇÃO DOS PRODUTORES AGROEXTRATIVISTAS DA \\ COLÔNIA DO SARDINHA - ASPACS \\ Sby al \\ Sandra Barros Maia \\ Presidente da ASPACS \\ RG: $0709043-9$}

TESTEMUNHAS:

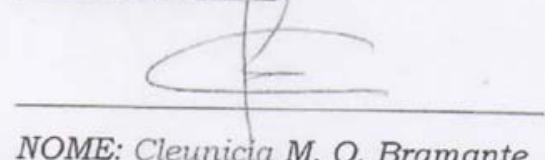

NOME: Cleunicia M. O. Bramante

NOME: José de Castro Correia

$R G: 32.057 .235-3$

RG: 358.132-9

CPF: $279.250 .498 / 63$

CPF: 052.444.712-87
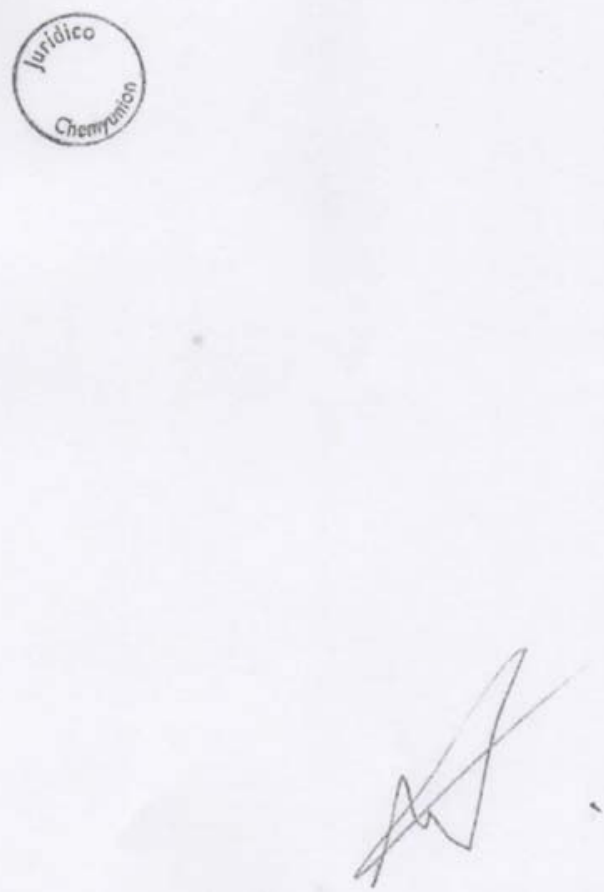


\section{ANEXO A \\ ESPECIFICAC̣ÕES}

1. Descriçăo Química: Gordura de Murumuru

2. Prazo de Validade: Minimo 12 meses

3. Requisitos da Qualidade:

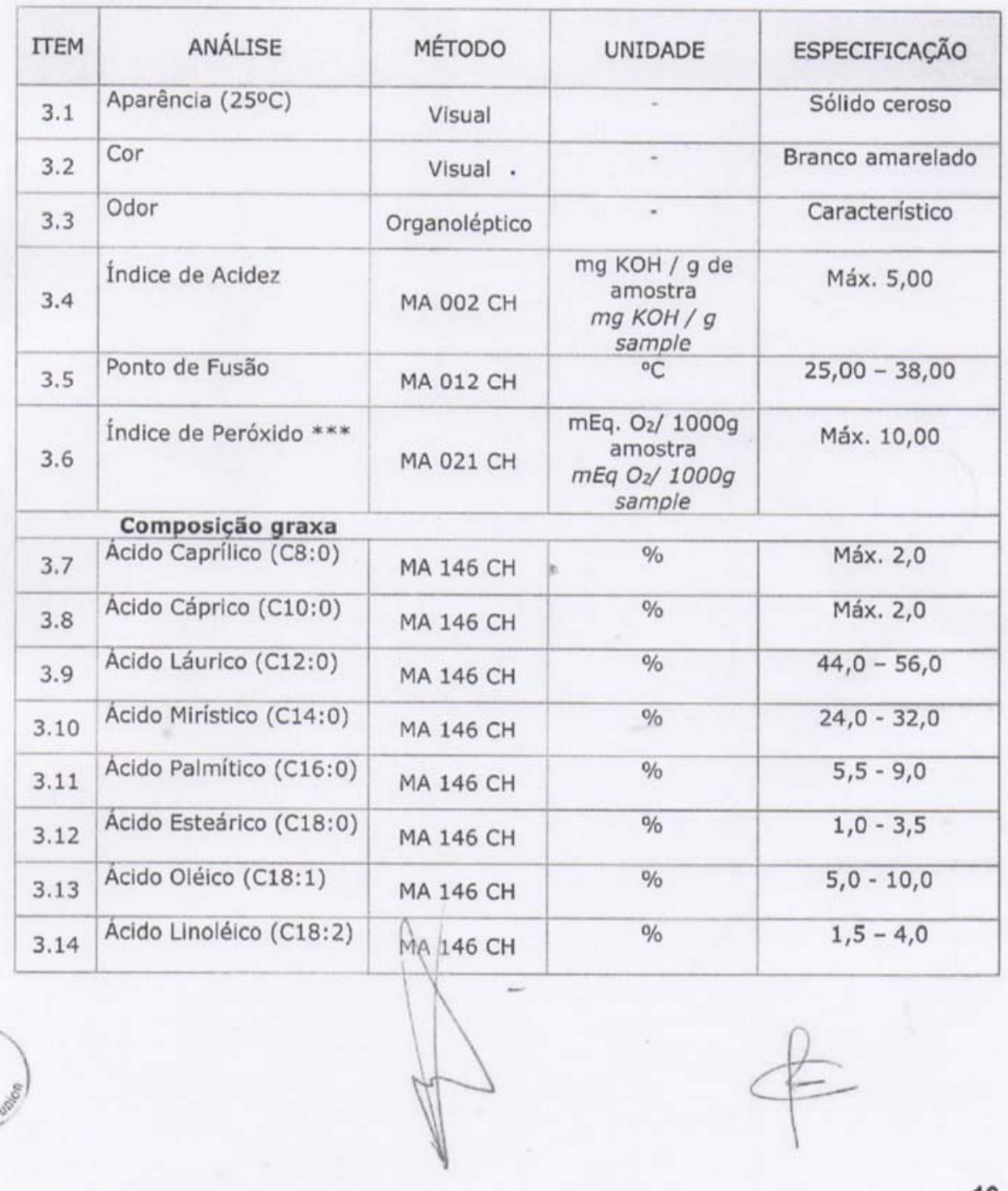


ANEXO B

MODELO DE RECIBO

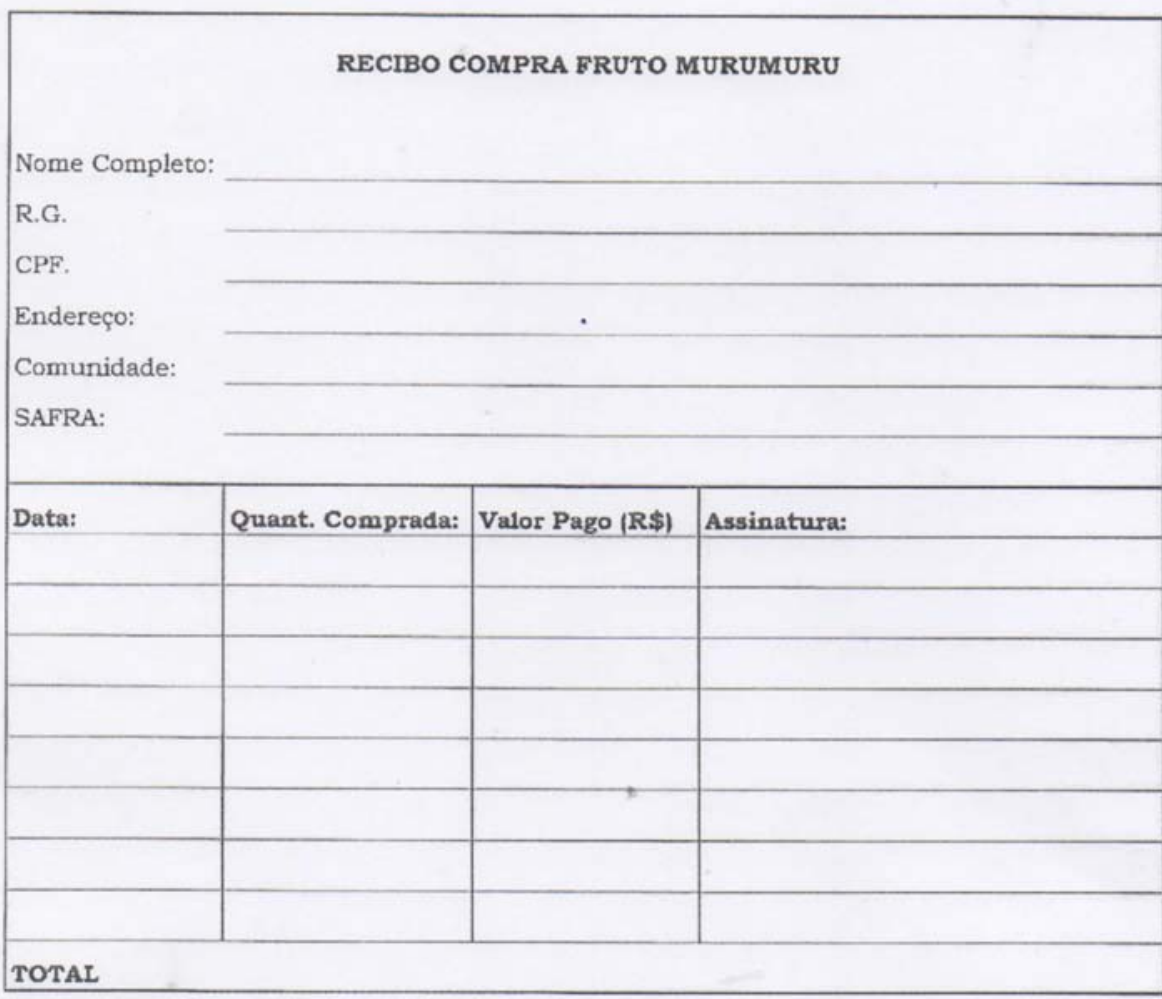<smiles>c1ccc2ccccc2c1</smiles> 


\section{ANEXO C - Relatório extraídos do SIW Resex Canutama}

\section{Relatório - Vendas Por Produtos}

\begin{tabular}{|c|c|c|c|c|c|c|}
\hline \# & Nome & $\$ 2019$ & $\%$ & $\$ 2020$ & $\%$ & $\%$ Crescimento \\
\hline 1 & Castanha (Hectolitro; 100 litros) & $1.006 .250,00$ & $33,51 \%$ & $874.400,00$ & $29,91 \%$ & $-13,10 \%$ \\
\hline 2 & Farinha (Saca de $50 \mathrm{Kg}$ ) & $455.090,00$ & $15,15 \%$ & $496.800,00$ & $16,99 \%$ & $9,17 \%$ \\
\hline 3 & Pescado Fresco (Kg) & $309.312,00$ & $10,30 \%$ & $612.900,00$ & $20,96 \%$ & $98,15 \%$ \\
\hline 4 & Pescado Seco (Kg) & $307.090,00$ & $10,23 \%$ & $272.364,00$ & $9,32 \%$ & $-11,31 \%$ \\
\hline 5 & Porco (Unidade) & $285.600,00$ & $9,51 \%$ & 816,00 & $0,03 \%$ & $-99,71 \%$ \\
\hline 6 & Açaí Fruto (Lata 18Kg) & $148.140,00$ & $4,93 \%$ & $147.635,00$ & $5,05 \%$ & $-0,34 \%$ \\
\hline 7 & Melancia (Unidade) & $108.650,00$ & $3,62 \%$ & $218.448,00$ & $7,47 \%$ & $101,06 \%$ \\
\hline 8 & Carvăo Vegetal (Saco 50Kg) & $103.500,00$ & $3,45 \%$ & $13.000,00$ & $0,44 \%$ & $-87,44 \%$ \\
\hline 9 & Galinha Caipira (Unidade) & $31.875,00$ & $1,06 \%$ & $4.450,00$ & $0,15 \%$ & $-86,04 \%$ \\
\hline 10 & Andiroba semente (Lata $20 \mathrm{Kg}$ ) & $31.570,00$ & $1,05 \%$ & $44.490,00$ & $1,52 \%$ & $40,92 \%$ \\
\hline 11 & Feijão (Kg) & $26.605,00$ & $0,89 \%$ & $26.328,00$ & $0,90 \%$ & $-1,04 \%$ \\
\hline 12 & Macaxeira $(\mathrm{Kg})$ & $24.420,00$ & $0,81 \%$ & $6.940,00$ & $0,24 \%$ & $-71,58 \%$ \\
\hline 13 & Banana (Cacho) & $22.275,00$ & $0,74 \%$ & $67.890,00$ & $2,32 \%$ & $204,78 \%$ \\
\hline 14 & Goma da Mandioca (Lata 20Kg) & $20.640,00$ & $0,69 \%$ & 0,00 & $0,00 \%$ & $-100,00 \%$ \\
\hline 15 & Jerimum (Unidade) & $19.635,00$ & $0,65 \%$ & $4.455,00$ & $0,15 \%$ & $-77,31 \%$ \\
\hline 16 & Boi (Unidade) & $19.550,00$ & $0,65 \%$ & 0,00 & $0,00 \%$ & $-100,00 \%$ \\
\hline 17 & Maxixe $(\mathrm{Kg})$ & $14.100,00$ & $0,47 \%$ & 0,00 & $0,00 \%$ & $-100,00 \%$ \\
\hline 18 & Melão (Unidade) & $13.250,00$ & $0,44 \%$ & $5.100,00$ & $0,17 \%$ & $-61,51 \%$ \\
\hline 19 & Murumuru semente (Lata $20 \mathrm{Kg}$ ) & $13.200,00$ & $0,44 \%$ & $61.400,36$ & $2,10 \%$ & $365,15 \%$ \\
\hline 20 & Açaí Beneficiado (Litro) & $11.480,00$ & $0,38 \%$ & $10.000,00$ & $0,34 \%$ & $-12,89 \%$ \\
\hline 21 & Pato (Unidade) & $7.960,00$ & $0,27 \%$ & 330,00 & $0,01 \%$ & $-95,85 \%$ \\
\hline 22 & Milho Verde (Mão-50 espigas) & $5.250,00$ & $0,17 \%$ & $8.575,00$ & $0,29 \%$ & $63,33 \%$ \\
\hline 23 & Batata-doce $(\mathrm{Kg})$ & $5.160,00$ & $0,17 \%$ & $1.788,00$ & $0,06 \%$ & $-65,35 \%$ \\
\hline 24 & Limão (Kg) & $3.000,00$ & $0,10 \%$ & 420,00 & $0,01 \%$ & $-86,00 \%$ \\
\hline 25 & Milho Seco (Kg) & $2.850,00$ & $0,09 \%$ & 255,00 & $0,01 \%$ & $-91,05 \%$ \\
\hline 26 & Cará (Kg) & $1.900,00$ & $0,06 \%$ & $2.750,00$ & $0,09 \%$ & $44,74 \%$ \\
\hline 27 & Pimenta de Cheiro (Kg) & $1.500,00$ & $0,05 \%$ & 520,00 & $0,02 \%$ & $-65,33 \%$ \\
\hline 28 & Cebolinha (maço) & $1.410,00$ & $0,05 \%$ & 300,00 & $0,01 \%$ & $-78,72 \%$ \\
\hline 29 & Cupuaçu $(\mathrm{Kg})$ & 780,00 & $0,03 \%$ & 0,00 & $0,00 \%$ & $-100,00 \%$ \\
\hline 30 & Pupunha (Cacho) & 510,00 & $0,02 \%$ & 0,00 & $0,00 \%$ & $-100,00 \%$ \\
\hline 31 & Farinha Tapioca (Litro) & 400,00 & $0,01 \%$ & 0,00 & $0,00 \%$ & $-100,00 \%$ \\
\hline 32 & Canoa (Unidade) & 0,00 & $0,00 \%$ & $6.000,00$ & $0,21 \%$ & $100 \%$ \\
\hline 33 & Copaíba Óleo (Kg) & 0,00 & $0,00 \%$ & $7.140,00$ & $0,24 \%$ & $100 \%$ \\
\hline 34 & Porco $(\mathrm{Kg})$ & 0,00 & $0,00 \%$ & $12.160,00$ & $0,42 \%$ & $100 \%$ \\
\hline 35 & Andiroba Óleo (Litro) & 0,00 & $0,00 \%$ & 55,00 & $0,00 \%$ & $100 \%$ \\
\hline 36 & Tucumã (Dúzia) & 0,00 & $0,00 \%$ & 168,00 & $0,01 \%$ & $100 \%$ \\
\hline
\end{tabular}


$11 / 08 / 2021$

\begin{tabular}{|c|c|c|c|c|c|c|}
\hline \# & Nome & $\$ 2019$ & $\%$ & $\$ 2020$ & $\%$ & $\%$ Crescimento \\
\hline 37 & Boi (Kg) & 0,00 & $0,00 \%$ & $13.712,00$ & $0,47 \%$ & $100 \%$ \\
\hline 38 & Remo (Unidade) & 0,00 & $0,00 \%$ & $2.000,00$ & $0,07 \%$ & $100 \%$ \\
\hline & Total & R\$ $3.002 .952,00$ & $100 \%$ & R\$ $2.923 .589,36$ & $100 \%$ & $-2,64 \%$ \\
\hline
\end{tabular}

https://izabel.rsmtecnologia.com.br/produtos/imprimir-relatorio 


\section{Relatório - Vendas Por Comunidades}

\begin{tabular}{|c|c|c|c|c|c|c|}
\hline \# & Nome & $\$ 2019$ & $\%$ & $\$ 2020$ & $\%$ & $\begin{array}{c}\% \\
\text { Crescimento }\end{array}$ \\
\hline 1 & COMUNIDADE NOVA VISTA & $831.676,00$ & $27,70 \%$ & $322.203,20$ & $11,02 \%$ & $-61,26 \%$ \\
\hline 2 & COMUNIDADE SANTA BÁRBARA & $424.914,00$ & $14,15 \%$ & $184.591,96$ & $6,31 \%$ & $-56,56 \%$ \\
\hline 3 & COMUNIDADE FORTALEZA & $247.877,00$ & $8,25 \%$ & $135.249,00$ & $4,63 \%$ & $-45,44 \%$ \\
\hline 4 & COMUNIDADE AÇAITUBA & $232.415,00$ & $7,74 \%$ & $144.893,96$ & $4,96 \%$ & $-37,66 \%$ \\
\hline 5 & COMUNIDADE BACADARU & $194.030,00$ & $6,46 \%$ & $241.170,00$ & $8,25 \%$ & $24,30 \%$ \\
\hline 6 & $\begin{array}{l}\text { COMUNIDADE FORTE VENEZA/NOVA } \\
\text { COLÔNIA }\end{array}$ & $107.200,00$ & $3,57 \%$ & $71.141,00$ & $2,43 \%$ & $-33,64 \%$ \\
\hline 7 & COMUNIDADE SACADO & $100.936,00$ & $3,36 \%$ & $110.337,64$ & $3,77 \%$ & $9,31 \%$ \\
\hline 8 & LOCALIDADE VISTA ALEGRE & $87.085,00$ & $2,90 \%$ & $49.510,00$ & $1,69 \%$ & $-43,15 \%$ \\
\hline 9 & LOCALIDADE BOM SUCESSO & $82.500,00$ & $2,75 \%$ & $52.059,80$ & $1,78 \%$ & $-36,90 \%$ \\
\hline 10 & COMUNIDADE GLÓRIA ॥ & $70.755,00$ & $2,36 \%$ & $126.990,00$ & $4,34 \%$ & $79,48 \%$ \\
\hline 11 & COMUNIDADE IRAJÁ & $68.380,00$ & $2,28 \%$ & $94.626,00$ & $3,24 \%$ & $38,38 \%$ \\
\hline 12 & COMUNIDADE BOCA DO GAVIÃO & $65.162,00$ & $2,17 \%$ & $61.552,92$ & $2,11 \%$ & $-5,54 \%$ \\
\hline 13 & COMUNIDADE SANTA MARIA & $64.701,00$ & $2,15 \%$ & $81.230,00$ & $2,78 \%$ & $25,55 \%$ \\
\hline 14 & COMUNIDADE CARMO & $61.810,00$ & $2,06 \%$ & $63.169,00$ & $2,16 \%$ & $2,20 \%$ \\
\hline 15 & COMUNIDADE CAPOEIRINHA & $59.705,00$ & $1,99 \%$ & $37.000,00$ & $1,27 \%$ & $-38,03 \%$ \\
\hline 16 & LOCALIDADE SANTA EUGÊNIA & $58.006,00$ & $1,93 \%$ & $35.436,00$ & $1,21 \%$ & $-38,91 \%$ \\
\hline 17 & COMUNIDADE SANTO ANTÔNIO DO APITUÃ & $54.441,00$ & $1,81 \%$ & $71.041,26$ & $2,43 \%$ & $30,49 \%$ \\
\hline 18 & COMUNIDADE SÃO JERÔNIMO & $51.370,00$ & $1,71 \%$ & $68.042,00$ & $2,33 \%$ & $32,45 \%$ \\
\hline 19 & COMUNIDADE SÃO TOMÉ & $44.760,00$ & $1,49 \%$ & $59.060,00$ & $2,02 \%$ & $31,95 \%$ \\
\hline 20 & LOCALIDADE SANTA CORA & $37.360,00$ & $1,24 \%$ & $39.550,00$ & $1,35 \%$ & $5,86 \%$ \\
\hline 21 & LOCALIDADE SANTANA & $30.254,00$ & $1,01 \%$ & $110.953,00$ & $3,80 \%$ & $266,74 \%$ \\
\hline 22 & LOCALIDADE TORORÓ - PAISSÉ & $16.735,00$ & $0,56 \%$ & $230.765,00$ & $7,89 \%$ & $1.278,94 \%$ \\
\hline 23 & LOCALIDADE MAPICIARI & $10.880,00$ & $0,36 \%$ & $200.000,00$ & $6,84 \%$ & $1.738,24 \%$ \\
\hline 24 & LOCALIDADE ESTIRÃO DO AÇAITUBA & 0,00 & $0,00 \%$ & $71.138,62$ & $2,43 \%$ & $100 \%$ \\
\hline 25 & LOCALIDADE MONTE SIÃO & 0,00 & $0,00 \%$ & $6.080,00$ & $0,21 \%$ & $100 \%$ \\
\hline 26 & LOCALIDADE MACACOÃ & 0,00 & $0,00 \%$ & $42.800,00$ & $1,46 \%$ & $100 \%$ \\
\hline 27 & LOCALIDADE SÃO FRANCISCO & 0,00 & $0,00 \%$ & $49.630,00$ & $1,70 \%$ & $100 \%$ \\
\hline 28 & LOCALIDADE SOBRADINHO & 0,00 & $0,00 \%$ & 0,00 & $0,00 \%$ & $100 \%$ \\
\hline 29 & LOCALIDADE CONCÓRDIA & 0,00 & $0,00 \%$ & 0,00 & $0,00 \%$ & $100 \%$ \\
\hline 30 & LOCALIDADE SAMAUMEIRA & 0,00 & $0,00 \%$ & $29.496,00$ & $1,01 \%$ & $100 \%$ \\
\hline 31 & LOCALIDADE PARAISO & 0,00 & $0,00 \%$ & $34.830,00$ & $1,19 \%$ & $100 \%$ \\
\hline 32 & LOCALIDADE NOVO INTENTO & 0,00 & $0,00 \%$ & $27.122,00$ & $0,93 \%$ & $100 \%$ \\
\hline 33 & LOCALIDADE NAZARÉ & 0,00 & $0,00 \%$ & $19.200,00$ & $0,66 \%$ & $100 \%$ \\
\hline 34 & LOCALIDADE ESPIRITO SANTO & 0,00 & $0,00 \%$ & $3.725,00$ & $0,13 \%$ & $100 \%$ \\
\hline 35 & LOCALIDADE CONCEIÇÃO - PAISSÉ & 0,00 & $0,00 \%$ & 0,00 & $0,00 \%$ & $100 \%$ \\
\hline \multicolumn{2}{|r|}{ Total } & $\begin{array}{r}\text { RS } \\
3.002 .952,00\end{array}$ & $100 \%$ & $\begin{array}{r}R S \\
2.923 .589,36\end{array}$ & $100 \%$ & $-2,64 \%$ \\
\hline
\end{tabular}


$11 / 08 / 2021$

https://izabel.rsmtecnologia.com.br/comunidades/imprimir-relatorio

\begin{tabular}{ccccccc}
\hline$\#$ & Nome & $\mathbf{\$ 2 0 1 9}$ & $\%$ & $\mathbf{\$ 2 0 2 0}$ & $\%$ & $\begin{array}{c}\% \\
\text { Crescimento }\end{array}$ \\
\hline 36 & LOCALIDADE SÃO JOSÉ DO PARAiso & 0,00 & $0,00 \%$ & 0,00 & $0,00 \%$ & $100 \%$ \\
\hline 37 & LOCALIDADE ARRAIAL & 0,00 & $0,00 \%$ & 600,00 & $0,02 \%$ & $100 \%$ \\
\hline 38 & LOCALIDADE MOARÁ & 0,00 & $0,00 \%$ & $48.396,00$ & $1,66 \%$ & $100 \%$ \\
\hline & Total & $\begin{array}{r}\text { RS } \\
\text { T.002.952,00 }\end{array}$ & $100 \%$ & $\mathbf{2 . 9 2 3 . 5 8 9 , 3 6}$ & $100 \%$ & $-2,64 \%$ \\
\hline
\end{tabular}


Relatório de sustentabilidade

Principal / Comunidades / Relatório de sustentabilidade

Dados da comunidade

Comunidade

Ano

Q Procurar

\begin{tabular}{|c|c|c|c|}
\hline Comunidade & Ano & Pontuaçăo & Status \\
\hline COMUNIDADE AÇAITUBA & 2019 & $36,40 \%$ & \\
\hline COMUNIDADE AÇAITUBA & 2020 & $36,40 \%$ & \\
\hline COMUNIDADE BACADARU & 2019 & $54,60 \%$ & \\
\hline COMUNIDADE BACADARU & 2020 & $45,50 \%$ & \\
\hline COMUNIDADE BOCA DO GAVIÃO & 2019 & $18,20 \%$ & \\
\hline COMUNIDADE BOCA DO GAVIÃO & 2020 & $18,20 \%$ & \\
\hline COMUNIDADE CAPOEIRINHA & 2019 & $18,20 \%$ & \\
\hline COMUNIDADE CAPOEIRINHA & 2020 & $18,20 \%$ & \\
\hline COMUNIDADE CARMO & 2019 & $36,40 \%$ & \\
\hline COMUNIDADE CARMO & 2020 & $27,30 \%$ & \\
\hline COMUNIDADE FORTALEZA & 2019 & $45,50 \%$ & \\
\hline COMUNIDADE FORTALEZA & 2020 & $36,40 \%$ & \\
\hline COMUNIDADE FORTE VENEZA/NOVA COLÔNIA & 2019 & $36,40 \%$ & \\
\hline COMUNIDADE FORTE VENEZA/NOVA COLÔNIA & 2020 & $27,30 \%$ & \\
\hline COMUNIDADE GLÓRIA $\|$ & 2019 & $36,40 \%$ & \\
\hline COMUNIDADE GLÓRIA $\|$ & 2020 & 54,6096 & \\
\hline COMUNIDADE IRAJÁ & 2019 & $36,40 \%$ & \\
\hline COMUNIDADE IRAJÁ & 2020 & $54,60 \%$ & \\
\hline COMUNIDADE NOVA VISTA & 2019 & $54,60 \%$ & \\
\hline COMUNIDADE NOVA VISTA & 2020 & $54,60 \%$ & \\
\hline COMUNIDADE SACADO & 2019 & $54,60 \%$ & \\
\hline COMUNIDADE SACADO & 2020 & $45,50 \%$ & \\
\hline COMUNIDADE SANTA BÁRBARA & 2019 & 54,6096 & \\
\hline COMUNIDADE SANTA BÁRBARA & 2020 & $54,60 \%$ & \\
\hline COMUNIDADE SANTA MARIA & 2019 & $27,30 \%$ & \\
\hline COMUNIDADE SANTA MARIA & 2020 & 45,5096 & \\
\hline COMUNIDADE SANTO ANTÔNIO DO APITUÃ & 2019 & $27,30 \%$ & \\
\hline COMUNIDADE SANTO ANTÔNIO DO APITUĀ & 2020 & $27,30 \%$ & \\
\hline COMUNIDADE SĀO JERÔNIMO & 2019 & $45,50 \%$ & \\
\hline COMUNIDADE SÃO JERÔNIMO & 2020 & $36,40 \%$ & \\
\hline COMUNIDADE SÃO TOMÉ & 2019 & $27,30 \%$ & \\
\hline COMUNIDADE SÃO TOMÉ & 2020 & $36,40 \%$ & \\
\hline LOCALIDADE ARRAIAL & 2019 & $0,00 \%$ & \\
\hline LOCALIDADE ARRAIAL & 2020 & $0,00 \%$ & \\
\hline
\end{tabular}




\begin{tabular}{|c|c|c|c|}
\hline & entabilidar & & \\
\hline Comunidade & Ano & Pontuaçāo & Status \\
\hline LOCALIDADE BOM SUCESSO & 2019 & $45,50 \%$ & \\
\hline LOCALIDADE BOM SUCESSO & 2020 & $18,20 \%$ & \\
\hline LOCALIDADE CONCEIÇĀO - PAISSÉ & 2019 & $0,00 \%$ & \\
\hline LOCALIDADE CONCEIÇÃO - PAISSÉ & 2020 & $0,00 \%$ & \\
\hline LOCALIDADE CONCÓRDIA & 2019 & $0,00 \%$ & \\
\hline LOCALIDADE CONCÓRDIA & 2020 & $0,00 \%$ & \\
\hline LOCALIDADE ESPÍRITO SANTO & 2019 & $0,00 \%$ & \\
\hline LOCALIDADE ESPIRITO SANTO & 2020 & $18,20 \%$ & \\
\hline LOCALIDADE ESTIRĀO DO AÇAITUBA & 2019 & $0,00 \%$ & \\
\hline LOCALIDADE ESTIRÃO DO AÇAITUBA & 2020 & $18,20 \%$ & \\
\hline LOCALIDADE MACACO $\AA \bar{~}$ & 2019 & $0,00 \%$ & \\
\hline LOCALIDADE MACACO $\AA$ & 2020 & $18,20 \%$ & \\
\hline LOCALIDADE MAPICIARI & 2019 & $18,20 \%$ & \\
\hline LOCALIDADE MAPICIARI & 2020 & $27,30 \%$ & \\
\hline LOCALIDADE MOARÁ & 2019 & $9,10 \%$ & \\
\hline LOCALIDADE MOARÁ & 2020 & $27,30 \%$ & \\
\hline LOCALIDADE MONTE SIÃO & 2019 & $0,00 \%$ & \\
\hline LOCALIDADE MONTE SIÃO & 2020 & $9,10 \%$ & \\
\hline LOCALIDADE NAZARÉ & 2019 & $0,00 \%$ & \\
\hline LOCALIDADE NAZARÉ & 2020 & $27,30 \%$ & \\
\hline LOCALIDADE NOVO INTENTO & 2019 & $0,00 \%$ & \\
\hline LOCALIDADE NOVO INTENTO & 2020 & $27,30 \%$ & \\
\hline LOCALIDADE PARAISO & 2020 & $45,50 \%$ & \\
\hline LOCALIDADE SAMAUMEIRA & 2019 & $0,00 \%$ & \\
\hline LOCALIDADE SAMAUMEIRA & 2020 & $27,30 \%$ & \\
\hline LOCALIDADE SANTA CORA & 2019 & $27,30 \%$ & \\
\hline LOCALIDADE SANTA CORA & 2020 & $27,30 \%$ & \\
\hline LOCALIDADE SANTA EUGÊNIA & 2019 & $0,00 \%$ & \\
\hline LOCALIDADE SANTA EUGÊNIA & 2020 & $9.10 \%$ & \\
\hline LOCALIDADE SANTANA & 2019 & $18,20 \%$ & \\
\hline LOCALIDADE SANTANA & 2020 & $36,40 \%$ & \\
\hline LOCALIDADE SÃO FRANCISCO & 2019 & $0,00 \%$ & \\
\hline LOCALIDADE SĀO FRANCISCO & 2020 & $18,20 \%$ & \\
\hline LOCALIDADE SÃO JOSÉ DO PARAISO & 2019 & $0,00 \%$ & \\
\hline LOCALIDADE SÃO JOSÉ DO PARAISO & 2020 & $0,00 \%$ & \\
\hline LOCALIDADE SOBRADINHO & 2019 & $0.00 \%$ & \\
\hline LOCALIDADE SOBRADINHO & 2020 & $0.00 \%$ & \\
\hline LOCALIDADE TORORÓ - PAISSÉ & 2019 & $27,30 \%$ & \\
\hline LOCALIDADE TORORÓ - PAISSÉ & 2020 & $27,30 \%$ & \\
\hline LOCALIDADE VISTA ALEGRE & 2019 & $27,30 \%$ & \\
\hline LOCALIDADE VISTA ALEGRE & 2020 & $18,20 \%$ & \\
\hline
\end{tabular}


Crédito da pesquisa

Principal/Créditos

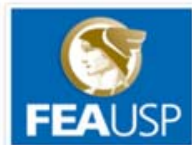

\section{Universidade de São Paulo \\ Universidade Estadual do Amazonas \\ Doutorado Institucional - DINTER}

o Sistema de Informações Web Resex Canutama (SIW Resex Canutama) é produto da pesquisa apresentada no Programa de Pós-Graduação em Administração, Doutorado Interinstitucional entre a Universidade de São Paulo -USP e Universidade Estadual do Amazonas - UEA.

\section{Pesquisa}

EMPREENDEDORISMO SOCIAL E SUSTENTABILIDADE FINANCEIRA EM COMUNIDADES EXTRATIVISTAS: ESTUdo de caso da Reserva Extrativista Canutama do Bioma Amazônia

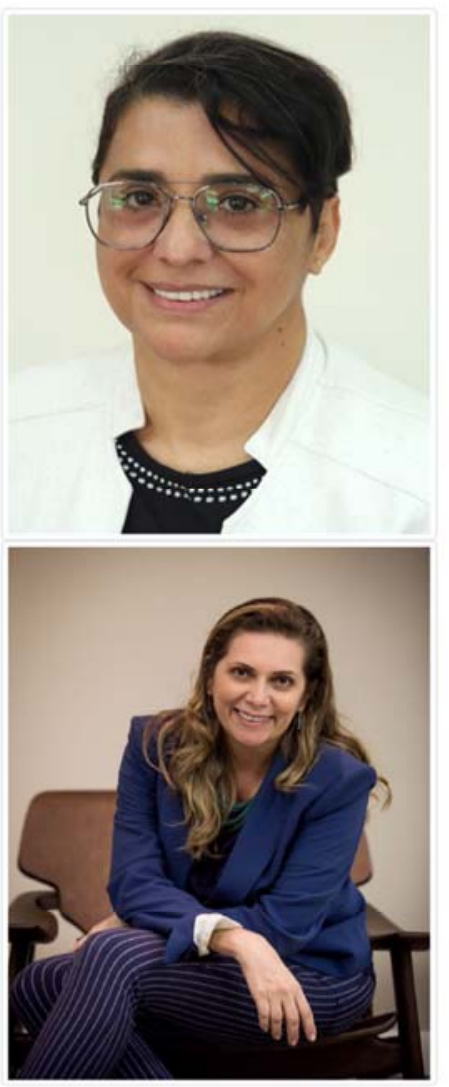

Pesquisadora Doutoranda

Prof Mestra Izabel Cristina Nogueira Seabra

Economista, graduada pela Universidade Federal do Amazonas (1994), pós-graduada em Metodologia da Pesquisa, Gestão Empresarial, Master Business Administration_MBA em Administraçăo e Diploma de Estudos Avançados_DEA pela Universidade de Marselle pelo projeto Brasil/FULLLP/Mercosul em Tecnologia da Informaçăo.

Mestra em Desenvolvimento Regional na PRODERE-UFAM.

Professora da Universidade do Estado do Amazonas-UEA (curso de Graduação e Pós graduaçăo). Experiência na área de Economia e Contabilidade, com ênfase em Auditoria Pública e Privada. Projetos, Administraçăo Financeira e Orçamentária; Finanças Pública e Privada.

Doutoranda em Administração no DINTER realizado entre a Universidade de São Paulo - USP e a Universidade do Amazonas- UEA.

Acesso ao Curriculum Lattes: http://lattes.cnpq.br/3855684494422277

SIW Resex Canutama foi criado a partir de dados primários e secundários gerados na pesquisa de campo.

- SIW Resex Canutama será doado para a SEMA (especificamente) para o gestor da Resex Canutama para contribuir como ferramenta de gestão.

Prof Doutora Graziella Maria Comini

Economista, com mestrado e doutorado em administraçăo pela Faculdade de Economia e Administração da Universidade de Săo Paulo, FEA/USP, especializaçăo na Harvard Business School e Universidade de Bologna.

Professora Associada do Departamento de Administração da FEA/USP, na área de Gestão de Pessoas.Coordenadora do Curso de Graduaçăo em Administraçăo da FEA/USP (2013-2017). ViceCoordenadora do Mestrado Profissional em Empreendedorismo e Inovação da FEA/USP desde 2017, Coordenadora do Centro de Empreendedorismo Social e Administraçăo do Terceiro Setor (CEATS) e Representante do Brasil no SEKN Social Enterprise Knowledge Network. Conselheira de empreendimentos socioambientais e negócios sociais no Brasil. Desenvolve projetos de pesquisa nos seguintes temas: organizaçōes híbridas, negócios sociais, inovação social, gestāo de pessoas e responsabilidade social.

Acesso ao Curriculum Lattes: http://lattes.cnpq.br/2121913529743968 